\title{
2009 年研究成果一覧
}

\section{生物学教室}

\section{〈研究概要〉}

○細胞運動の制御機構における $\mathrm{Ca}^{2+}$ の役割

研究対象にしてきたものは, 細胞内流動 (原形質流動), 大型アメーバや真正粘菌変形体の運動, ゾウリムシの㵶毛運 動, 各種動物卵の卵割などである. 特に真正粘菌変形体の往復流動は $\mathrm{Ca}^{2+}$ の周期的な変動によって阻害的に制御されて いることを明らかにした。またウ二卵，メダカ卵，ゼノパス卵では卵割時に $\mathrm{Ca}^{2+}$ 濃度が低下することによって収縮環の 収縮が進行するという，阻害的制御であることを明らかにした。ゾウリムシでは障害物に衝突した時，その部分で $\mathrm{Ca}^{2+}$ 濃度が急上昇し, 㵶毛運動が反転することが分かった。 これらのように筋肉運動以外では $\mathrm{Ca}^{2+}$ が阻害的に制御している 運動が多いことを，これからも明らかにしていきたい.

○各種 $\mathrm{Ca}^{2+}$ シグナルの映像化

クラゲの発光タンパクであるエクオリンと超高感度ビデオカメラを使って，ウニ卵，メダカ卵，ゼノパス卵，イモリ 卵, 八厶スター卵が受精する時に強い $\mathrm{Ca}^{2+}$ シグナルを発生することを明らかにし, さらにそれらの $\mathrm{Ca}^{2+}$ シグナルを $\mathrm{Ca}^{2+}$ 波として映像化することにも成功した．またアメーバ・プロテウスの運動に関しては，その尾部近くに存在する高 $\mathrm{Ca}^{2+}$ 領域を映像化して，アメーバ運動の制御に重要な働きをしていることを示した。 また真正粘菌変形体においても，その 運動モデルの一つであるカフェイン・ドロップの中に同じような高 $\mathrm{Ca}^{2+}$ 領域を見出すことができた．これからも $\mathrm{Ca}^{2+}$ グナルが関係しているさまざまな現象について，その映像化を試みたい.

○真正粘菌変形体に打ける流動りズムの発生機構

世界一速い細胞内流動を示すフィサルム変形体において，その流動りズムが主に变形体の先端部に発生して流動を制 御していることを明らかにした．今後はその流動りズムがなぜ先端部に局在しているのか，そのメカニズムを明らかに していきたい.

○概日時計の分子メカニズムについて

概日時計は地球環境に適応するために，ほとんどすべての生物が獲得しており，周期の安定性，外環境に対する同調 機構, 個体, 組織, 細胞などの多階層での制御・同調, 出力機構, 現象の生物種普遍性など, 解くべき課題の多い重要 な現象である. われわれは概日りズムを示すもっとも単純な生物であり, リズム研究のモデル生物であるシアノバクテ リアや，その他ウキクサなどの植物を材料として，概日時計の分子メカニズムを解明することを目標に研究を進めてい る.

\section{〈研究業績〉}

\section{原 著}

1. Oohata AA, Fukuzawa M, Hotta R, Nakagawa M, Niwa M and Takaya Y (2009) Differentiation inducing factors in Dictyostelium discoideum: A novel low molecular factor functions at an early stage(s) of differentiation Dev Growth Differ 51(9): 743-752

総 説

1. 吉本康明（2009）細胞内流動についてIV. 関西医大教 養部紀要 29: 41-56

2. 吉本康明（2009）細胞内流動についてIII. 関西医大教 養部紀要 29: $1-40$
学会発表

1. 村山依子, 今井圭子, 近藤孝男（2009）シアノバクテ リアの時計遺伝子 kaiC の多数の周期変異体の表現型 解析. ラン藻の分子生物学 2009, 千葉

2. Keiko Imai, Yoko Kitayama and Takao Kondo (2009) Effects of Clp proteases on the circadian rhythm in Synechococcus elongatus PCC 7942. 第 32 回日本分子生物 学会年会, 横浜

3. 村山依子, 今井圭子, 西脇妙子, 秋山修志, 近藤孝男 （2009）シアノバクテリア概日時計蛋白質 KaiC の ATPase 活性による周期決定機構と温度補償機構の解 析. 時間生物学会, 大阪 


\section{分子生物学教室}

\section{〈研究概要〉}

トランスポゾン（転移因子）と呼ばれるDNAは, 様々な生物のゲノム上で, ゲノム構造に変化をもたらすことにより 遺伝子の発現に大きな影響を与えている。 これまでトランスポゾンがゲノム上で引き起こす変化として, ゲノム構造を 大きく変化させるような, 検出しやすいケースについての研究は多数報告されている. 当教室では, トランスポゾンに よるゲノム上での不安定な小変化が，ゲノム上で隣接した遺伝子発現に影響を与えているという，これまで知られてい なかったタイプのトランスポゾンとゲノムとの間の関係について研究している.

IS (Insertion Sequence) 3ファミリーと呼ばれる大腸菌の一群の転移因子は, 数塩基（数はISの種類によって異なる） をはさんで2copyのISが tandem dimer構造を一時的に形成する場合があることが報告されている. この tandem dimer 構造 はIS3ファミリーに特有な転移反応の過程で生じる by-product と考元られ，その特異な構造が注目されているが，生物学 的な意義についてはこれまで不明であった。またこれまでの報告は全て plasmid 上での形成に限られ，このような IS の tandem dimer構造がバクテリアのゲノム上で安定して存在しているということは知られていなかった.

当研究室で単離した大腸菌MM1株ではゲノム上に打いて, IS3ファミリーの一つである転移因子IS2がcrp (cyclic AMP receptor protein）遺伝子のプロモーターと構造遺伝子の間に挿入したために, crp 遺伝子の発現がほとんどなくなってい る. ところがMM1株の培養液を保存しているうちにcrp遺伝子の発現が回復するようになった菌株が多数生じてきた。 そ のような菌株のゲノムを多数調べた結果, かなりの割合の菌株がゲノム上のこの部分で一塩基を挟んだ IS2 の tandem dimerを形成していることが判明した. IS2 tandem dimerのjunction部分の塩基配列を精查したところ，このIS2の両端が つながった junction 部分に強力な転写活性を有するハイブリッドなプロモーターが形成されているらしいことが予想で きた。

このハイブリッドプロモーターから始まった転写が, 後半のIS2 部分を通過して隣接する crp遺伝子を活性化させてい ることを in vivoで証明するため, 新たな cloning vectorシステムを開発した，転写活性を in vivoで測定するための既存の vectorのほとんどはmulti copy plasmidであり，遺伝子の転写活性を生理的条件（single gene/cell）で正確に測定できない. そこでlacZ 遺伝子をレポーターとして持つ，転写活性測定用の single copy plasmid を作製した．ところがこの vector で cloningした場合, 非常に強いプロモーターでないかぎり, 大腸菌での $\beta$-galactosidase活性測定の標準として用いられてい る Millerの方法では, 転写が ONの状態でも検出限界ぎりざりであることが判明した。 そこでMiller法の数百倍の検出感 度を示すような, ケミルミネッセンスを用いた $\beta$-galactosidase の in vivo での高感度活性測定法を開発し, single copy の vectorに cloning した, IS2 tandem dimer構造の junction部分に生じたプロモーターからの転写が, IS に隣接するcrp遺伝子 の発現を活性化していることを証明した.

\section{〈研究業績〉}

学会発表

1. Masayuki Morita (2009) Insertion sequence IS2 activates transcription of adjacent genes on E. coli chromosome by creating a novel dimer structure. 第 32 回日本分子生物 学会年会, 横浜

\section{心理学教室}

\section{〈研究概要〉}

当教室では, 以下の研究テーマを中心に行っている.

1. 医療に対する信頼感, および医師患者関係について, 質的および量的研究手法による分析. 今後, 医療面接分析技法 RIASを用いた分析もおこなっていく予定である.

2. 説得的コミュニケーション技法を応用した「健康増進ゲーム」を利用した行動科学的アプローチによる健康増進プロ グラムの開発と実践. これまで栄養士, 公衆衛生の専門家らと共に研究を進めてきたが, 今後さらに発展させる予定 である.

3. 健康りスク認知と健康行動抢よび特性不安などの性格特性との関連性の研究. 本研究は主に大学生を対象として行っ ている.

\section{〈研究業績〉}

その他

1. 西垣悦代（2009） 日本の患者の3タイプ.ヘルスサイ コロジスト $49: 4$
学会発表

1. Etsuyo Nishigaki (2009) Food education for university students:a comparison of two methods used to introduce Japanese Food Guide. 1st Asia-Pacific Conference on 
Health Promotiion and Education, Chiba

2. 西垣悦代（2009）説得と交渉のシミュレーション＆ ゲーミング. 日本シミュレーション\&ゲーミング学会 2009年度秋季全国大会, 横浜

3. 西垣悦代 (2009) 安全・安心から「信頼の医療」へ. 日本健康心理学会第 22 回大会, 東京

4. 西垣悦代（2009）医師患者間の信頼阻害要因の分析. 日本健康心理学会第 22 回大会, 東京
5. 西垣悦代（2009）ゲームを用いた大学生に対する食育 の効果. 日本心理学会第73回大会, 京都

著 書

1. 西垣悦代 (2009)「発達・社会からみる人間関係」（西 垣悦代編著） 10 章 健康増進のコミュニケーション 11章医療者 - 患者関係. 北大路書房

\section{化学教室}

\section{〈研究概要〉}

化学教室において行ったセリンパルミトイル転移酵素と細胞性粘菌に関する研究の主な成果について簡単に報告する.

セリンパルミトイル転移酵素（serine palmitoyltransferase; SPT）はピリドキサール -5'- リン酸（PLP）を補酵素とし， L-セリンとパルミトイル CoAを基質として, 脱炭酸を伴う縮合反応によって3-ケトジヒドロスフィンゴシン（KDS）を 生成する. この反応はスフィンゴ脂質生合成の初発反応であり，同時に経路全体の律速段階になっている。本酵素の活 性変化が細胞内のスフィンゴ脂質総量に直接影響することから, SPT の活性制御機構を明らかにすることはスフィンゴ 脂質のホメオスタシスを理解する上で必須の課題である.

初期のSPT研究によって，2つの対立する反応機構が提唱されてきた．1つは基質 L-セリンの脱炭酸反応によってキノ ノイド中間体が生じ，次にアシル化が起こるという機構Iであり，もう1つはL-セリンの $\alpha$ 位の脱プロトン反応によって キノノイド中間体が生じ, アシル化と脱炭酸反応がその後に続くという機構 II である. ラット肝ミクロソームを用いて 重水中でSPT 反応を行うと, 生成物 KDS の C2 位（L- セリンの $\alpha$ 位に相当）の軽水素が溶媒由来の重水素と置換される, という実験結果をもって機構 II を妥当とする報告があり，広く受け入れられている。しかしながら，KDSとPLP間で形 成されたアルジミン中間体に打いても KDSのC2 位へ重水素の導入が可能であることから，上述の実験結果は機構 $\mathrm{I}$ を否 定することにはならない. したがって，KDS生成がいずれの機構を経由するのかは未定のままである.

今回の細菌由来精製 SPT酵素標品を用いた実験結果はセリンパルミトイル転移反応に抏いて, SPT-L-セリン外アルジ ミンの $\alpha$ 位脱プロトン反応がClaisen型の炭素 - 炭素結合形成反応の前に起こることと,2つめの基質であるパルミトイル CoAの有無によって厳密に制御されていることを明らかに示した. さらに, SPT- 基質複合体の構造モデルの構築によっ て, 触媒部位に存在するHis159が本酵素の制御機構における重要な役割を果たしていることが強く示唆された.

細胞性粘菌のD. discoideum は, 単細胞から多細胞への分化に際して様々な因子を菌体外に分泌し, その分化を制御し ている。これまでに，予定胞子細胞へと分化を誘導する糖たんぱく質である prespore-inducing factor（psi-factor）を見出 し，その性質を明らかにした．しかし，そのpsi-factorをコードする遺伝子をノックアウトしたところ，胞子形成にいた るまでD. discoideumの形態上の変化は見出せなかった. そのことから psi-factor は予定胞子細胞への分化に重要ではある が, 分化誘導には別の経路も存在していることが示唆されていた. そしてpsi-factor と協調して作用していると見られる 低分子量の因子の存在が推測されたので，今回この低分子量因子について精製およびその性質を検討した。

D. discoideum V12M2 株の調製塩溶液 (conditioned medium, CM) から, XAD-2, Sephadex LH-20，逆相クロマトグラ フィーを用いて分化誘導活性を指標に精製を進めた．精製した因子は，ESI-LC/MSで分子量 208 と決定された．また，そ の紫外可視光領域での分光学的特長からポリケタイドであることが強く示唆されたため, この因子を Polyketide-like factor（PLF）と名づけた．このPLFは予定胞子細胞への分化に関係する遺伝子産物の発現を誘導するだけでなく，予定 柄細胞への分化誘導にも関与していることが明らかとなった.

\section{〈研究業績〉}

原 著

1. Oohata AA, Fukuzawa M, Hotta R, Nakagawa M, Niwa M and Takaya Y (2009) Differentiation inducing factors in Dictyostelium discoideum: A novel low molecular factor functions at an early stage(s) of differentiation. Dev Growth Differ 51(9): 743-752

2. Ikushiro H, Islam MM, Okamoto A, Hoseki J, Murakawa T, Fujii S, Miyahara I and Hayashi H (2009) Structural insights into the enzymatic mechanism of serine palmitoyltransferase from sphingobacterium multivorum. J Biochem 146(4): 549-562

学会発表

1. 中川 学, 東城博雅, 藤井 茂 (2009) D. discoideum の psi-factor 中に存在する糖鎖の新しい構造. 第 82 回 日本生化学会大会, 神戸 


\section{物理学教室}

\section{〈研究業績〉}

原 著

1. Kogo H, Takeuchi K, Inoue H, Kihara H, Kojima M and Takahashi K (2009) Urea-dependent unfolding of HIV-1 protease studied by circular dichroism and small-angle X-ray scattering. Biochim Biophys Acta-Proteins and Proteomics 1794: 70-74

2. Kim SJ, Matsumura Y, Dumont C, Kihara H and Gruebele M (2009) Slowing down downhill folding: a threeprobe study. Biophys J 97(1): 295-302

3. Bellgrove A, Kihara $\mathrm{H}$, Iwata A, Aoki $\mathrm{MN}$ and Heraud $\mathrm{P}$ (2009) Fourier transform infrared microspectroscopy as a tool to identify macroalgal propagules. J Phycol 45(3): 560-570

4. Yamamoto A, Takemoto K, Fukui T, Yoshimura Y, Okuno K, Namba H and Kihara H (2009) Observation of Immuno-Labeled Cells at High Resolution Using Soft XRay Microscope at Ritsumeikan University SR Center. 186: Article number 012099

5. Yamamoto A, Takemoto K, Komura I, Namba $\mathrm{H}$ and Kihara H (2009) Imaging of Chromosomes at Nanometer-Scale Resolution Using Soft X-Ray Microscope at Ritsumeikan University SR Center. 186: Article number 012098

6. Takemoto K, Ichise S, Ichikawa M, Namba $\mathrm{H}$ and Kihara H (2009) X-ray imaging of Picoplankton in Lake Biwa by Soft X-ray Microscope at Ritsumeikan University SR Center. 186: Article number 012097

7. Takemoto K, Narumi I, Satoh K, Namba H and Kihara H (2009) X-Ray Imaging of Radioresistant Deinococcus radiodurans. 186: Article number 012096

8. Takemoto K, Namba H, Mukai M, Okuno K, Ohta T and Kihara H (2009) Development of an Auto-focusing Imaging System in the Soft X-Ray Microscope Beamline of the SR Center in Ritsumeikan University. 186: Article number 012019

9. Fayard B, Salome M, Takemoto K, Kihara H and Susini J (2009) Some practical considerations about the effects of radiation damage on hydrated cells imaged by X-ray fluorescence microscopy. J Electron Spectros Relat Phenomena 170(1-3): 19-24

10. Takeda K, Sano Y, Ichikawa S, Hirata Y, Matsuki H and Kaneshina S (2009) Effect of a local anesthetic lidocaine hydrochloride on the bilayer structure of phospholipids. J Oleo Sci 58(7): 369-378

11. Takeda K, Hirata Y, Sano Y, Ichikawa S, Matsuki H and Kaneshina S (2009) Effect of a Local Anesthetic Lidocaine Hydrochloride on the Bilayer Structure of Phospholipids. J Oleo Sci 58(7): 36-377
12. Takemoto K, Kimura M, Kihara H, Ohigashi T, Fujii H, Aratame H, Ohashi Y, Nakanishi K and Namba H (2009) Recent Progress in Transmission Soft X-ray Microscope. Mem SR Cent Ritsumeikan Univ (11): 141-149

13. Tsukamoto S, Yamashita T, Yamada Y, Fujiwara K, Maki K, Kuwajima K, Matsumura Y, Kihara H, Tsuge H and Ikeguchi M (2009) Non-native $\alpha$-helix formation is not neccessary for folding of lipocalin: comparison of burstphase folding intermediates between tear lipocalin and $\beta$ lactoglobulin. Proteins 76(1): 226-236

14. Yasumoto M, Tamura S, Kamijo N, Uesugi K, Takeuchi A and Suzuki Y (2009) Observation of kinoform-style multilayer Fresnel zone plate by scanning ion microscopy. Vacuum 84(5): 669-671

15. Tamura S, Yasumoto M, Kamijo N, Takeuchi A, Uesugi K, Terada Y and Suzuki Y (2009) Quasi-blazed type multilayer zone plate for X-rays. Vacuum 84(5): 578-580

16. 小島正樹, 野中孝昌, 森本康幹, 中川隆司, 柳茂, 木原 裕 (2009) NMR とX線溶液散乱データから得ら れる構造情報の加算性, 呪長性, 相補性 (MS51)。 日 結晶学誌 51(1): 92-93

その他

1. Tamura S, Yasumoto M, Kamijo N, Uesugi K, Takeuchi A, Terada Y and Suzuki Y (2009) Quasi-kinoform type multilayer zone plate with high diffraction efficiency for high-energy X-rays. 186: Article number 012075

2. Ohigashi T, Fujii H, Aratame H, Namba H, Takemoto K, Kihara H, Inaba M and Kubokawa K (2009) Anatomical Observation of a Lancelet by a Full-Field Imaging Soft Xray Microscopy. Mem SR Cent Ritsumeikan Univ (11): 155-157

\section{学会発表}

1. Masaji Shinjo,Yoshitaka Matsumura, Xianju Jin and Hiroshi Kihara (2009) $\alpha$-helix-rich-states of $\beta$-lactoglobulin and src SH3, formed in high concentration of ethylene glycol and trifluoroethanol, are not either fully unfolded or compact. 日本生物物理学会, 徳島

2. Yoshitaka Matsumura, Masaji Shinjo, Nobuyuki Okishio and Hiroshi Kihara (2009) Structural change of PI3K SH3 domain at acidic pH. 日本生物物理学会, 徳島

3. Hiroshi Kihara, Yoshitaka Matsumura, Masaji Shinjo, Jinsong Li and Xinaju Jin (2009) Early Events of Protein Folding studied by cryo-stopped-flow method. International Symposium on Reaction Dynamics of Many-Body Chemical Systems, Kyoto

4. Fumiaki Kano and Hiroshi Kihara (2009) DENATURANT-INDUCED HELIX-COIL TRANSITION OF OLI- 
GOPEPTIDES. 摇らぎと生体機能, 岡崎

5. Hiroshi Kihara, Xianju Jin, Jinsong Li, Yoshitaka Matsumura and Masaji Shinjo (2009) VARIOUS ALPHAHELIX-RICH STRUCTURES OF SH3 DOMAIN PROTEINS. 摇らぎと生体機能, 岡崎

6. Masaji Shinjo, Fumiaki Kano, Zhijie Qin, Jinsong Li, Yoshitaka Matsumura, Akio Shimizu, Akio Teramoto and Hiroshi Kihara (2009) DENATURANT-INDUCED HELIX-COIL TRANSITION OF OLIGOPEPTIDES II, EQUILIBRIUM STUDY OF SHORT OLIGOPEPTIDES, C17 and AK16. 摇らぎと生体機能, 岡崎

7. 水谷治央, 大東㙇治, 藤井宏樹, 難波秀利, 竹本邦子, 木原 裕, 高木利久 (2009) 軟X線顕微鏡によるマウ ス大脳皮質の観察. 立命館大学オープンリサーチセン ターシンポジウム, 草津

8. 竹本邦子, 一瀬 諭, 大東玩治, 難波秀利, 木原 裕 （2009）軟 X 線顕微鏡による琵琶湖のピコ植物プラン クトンの観察. 立命館大学オープンリサーチセンター シンポジウム, 草津

9. 藤井宏樹, 臼井規真, 大東㙇治, 難波秀利, 竹本邦子, 木原 裕 (2009) SRセンター軟X線顕微鏡における高 度化の現状報告. 立命館大学オープンリサーチセン ターシンポジウム, 草津

10. 峯岸由紀子, 木下利彦, 木原 裕 (2009) 気功. 第25 回日本催眠学会学術大会, 枚方

11. Yoshitaka Matsumura, Masaji Shinjo, Anjali Mahajan, Ming-Daw Tsai and Hiroshi Kihara (2009) An observed $\alpha$-helical burst of FHA1 domain of Rad53 in the folding pathway. 日本生物物理学会, 徳島

12. 竹本邦子, 大東玩治, 藤井宏樹, 新田目啓敬, 水谷治 央, 一瀬 諭, 難波秀利, 木原 裕 (2009) 立命館大 学 SR センター軟 X 線顕微鏡による生物観察の最近の 成果. 日本バイオイメージング学会, 岡山

13. 竹本邦子, 木原 裕 (2009) 軟 X線顕微鏡による生き た生物のバイオイメージング. 日本バイオイメージン グ学会, 岡山

14. 竹本邦子, 藤井宏樹, 新田目啓敬, 神村伊緒, 山本章 嗣, 大東玩治, 難波秀利, 木原 裕 (2009) 軟X線顕 微鏡を用いた種々の方法で染色した染色体の観察. 日 本バイオイメージング学会, 岡山

15. 竹本邦子, 木原 裕 (2009) 軟 $\mathrm{X}$ 線顕微鏡のクライオ システムの開発. ナノネット報告会「ナノテクノロ

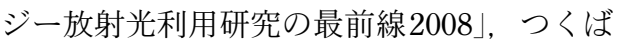

16. Yoshitaka Matsumura, Anjali Mahajan, Ming-Daw Tsai and Hiroshi Kihara (2009) Folding of beta structure proteins. FHA1 domain of Rad53 and Ki67 FHA domain. 日 本蛋白質科学会, 熊本

17. 中川香奈子, 山田好輝, 松村義隆, 藤原和夫, 池口雅 道（2009）ウマßラクトグロブリンの折れたたみ中間 体における分子の収縮と二次構造の関係性. 日本蛋白 質科学会, 熊本

18. Hiroshi Kihara, Xianju Jin, Jinsong Li, Yoshitaka Matsumura and Masaji Shinjo (2009) Early events of protein folding studied by cryo-stopped-flow x-ray scattering. PF symposium, 筑波

19. 木原 裕 (2009) X 線顕微鏡. X 線, 赤外線, マイク 口波研究会, 京阪奈

20. 大東㙇治, 藤井宏樹, 新田目啓敬, 稲葉真由美, 難波 秀利, 竹本邦子, 木原 裕, 窪川かおる (2009) 結像 型軟X線顕微鏡を用いたナメクジウオの器官の高分解 能観察. 日本放射光学会, 東京

21. 竹本邦子, 大東玩治，藤井宏樹，新田目啓敬，難波秀 利, 太田俊明, 木原 裕 (2009) 立命館大学軟X線顕 微鏡ビームライン I一自動観察システムと現状報告 一. 日本放射光学会, 東京

22. 宇野優衣，山本章嗣，新田目啓敬，神村伊緒，大東玩 治, 竹本邦子, 難波秀利, 木原 裕（2009）異なる染 色法を施した染色体の軟 X 線顕微鏡による観察. 立命 館大学オープンリサーチセンターシンポジウム, 草津

23. 大東玩治, 藤井宏樹, 稲葉真由美, 難波秀利, 竹本邦 子, 木原 裕, 窪川かおる (2009) 軟X線顕微鏡によ るナメジクジウオ内藏器官の観察. 立命館大学オープ ンリサーチセンターシンポジウム, 草津

24. 大東玩治, 藤井宏樹, 難波秀利, 竹本邦子, 木原 裕, 窪川かおる（2009）軟X線顕微鏡を用いたナメクジウ オ内臓器官の高分解能イメージグ. 日本バイオイメー ジング学会, 岡山

25. Seung Joong Kim, Yoshitaka Matsumura, Charles Dumont, Hiroshi Kihara and Martin Gruebele (2009) SLOWING DOWN DOWINHILL FOLDING: A THREEPROBE STUDY. 摇らぎと生体機能，岡崎

26. 竹本邦子, 木村光博, 大橋嘉雄, 中西康次, 大東玩治, 藤井宏樹，新田目啓敬，難波秀利，木原 裕 (2009) 立命館大学軟 X 線顕微鏡ビームライン II-クライオ装 置システムと冷却効果一. 日本放射光学会, 東京

\section{英語教室}

\section{〈研究概要〉}

大学は, 学問の中心として, 広く知識を授けるとともに, 深く専門の学芸を教授研究し, 知的, 道徳的及び応用的能 力を展開させることを目的とする。（学校教育法第五十二条 [大学の目的])

上の学校教育法にあるように，学問の場である大学においては，学術研究に資する英語教育を目指すべきであると考 
えられる。

特定目的の英語 (English for Specific purposes, ESP) 研究の視点から研究教育機関としての大学の英語教育目的を分類 すれば，学術目的の英語（English for Academic Purposes, EAP）を出発点とすべきである．そしてこのEAPはさらに，一 般学術目的の英語（English for General Academic Purposes, EGAP) と特定学術目的の英語（English for Specific Academic Purposes, ESAP）に大別される. 技能の観点から見れば, EGAPはあらゆる専門分野に共通する一般的な学術言語機能を 対象とするのに対し, ESAPは特定の専門分野に特化した学術的言語機能を対象としたものとなり, 本学の場合には, 医 学に特化した機能ということになる.

本教室では, 中高等学校英語教育の終着点ではなく, 学部専門教育への出発点として, EGAPからESAPへとスムーズ な移行を目指す英語教育のあり方を探っている.

\section{1 英語教育}

学術的言語機能の構成要素として，1）アカデミックリーディング (academic reading) 2) アカデミックライティング (academic writing) 3) 学術目的のスピーキング（speaking for academic purposes）4）文献/研究スキル（reference/research skills）の 4 分野を扱う.

academic readingでは，スキャニングとスキミングに, academic writingではproduct approachに限定して教育方法と教材 開発を行っている. speaking for academic purposes では, presentation skill だけでなく, participation skillsを重視した approach を, また, reference/research skills は学術研究では欠かせないが, 独自で扱える分野でないことから, academic reading と融合したapproachを研究している.

\section{2 言語学}

感情表現におけるメタファー表現を調査することにより，環状の概念構造を探り，さらに概念メタファーより原始的 で身体的・経験的基盤に根ざすとされる primary metaphorsの存在の可能性を考察している.

また，ジョークが frame shifting を端的に表現するものの好例であることから， 日本語でのジョークを観察することに より，日本人の持つフレームとフレームシフティングのあり方を考察する．また，その意味解釈において関連性理論が 提唱するような compositional approachをとるべきか, メンタルスペース理論が提唱するような constructive approachをと るべきか検証している.

教材開発を行っていることから，医学テキストに拈りメタファーおよびフレームも考察している.

\section{〈研究業績〉}

原 著

1. 斉藤里香, 中川 淳 (2009)「恐れ」, 「不安」一認知 言語学と脳科学の接点一. 言語文化学会論集 (33): 101-117

\section{学会発表}

1. 齋藤里香 (2009) 認知言語学からみた「基本情動」と 感情:「恐狆」「不安」「悲しみ」を中心に. 日本語用 論学会, 京都

\section{ドイツ語教室}

\section{〈研究概要〉}

1. 高齢者のナラティブに関する老年言語学研究

高齢者へのライフストーリー調査によって得られた言語コーパスを用いて, 老年言語学的観点から分析と考察を加え た. とくにナラティブデータの音声的・音響的特徵に焦点を当て, 発話数, 発話の長さ, 発話速度, 間（ポーズ）の分 析を行うとともに， 品詞と語彙の分布，更に主題分類を実施し，計量言語学的分析を加えた.

2. 高齢者介護現場のケアコミュニケーションに関する質的調査と日独比較研究

日本の介護付き有料老人ホーム 7 施設と特別養護老人ホーム 2 施設において実施した介護職員への質問紙調査, グルー プインタビュー調査の分析結果を踏まえ, 介護職員のケアコミュニケーション行動について考察した。また日本の介護 付き有料老人ホームとドイツの私立有料老人ホームでの参与観察調査データを基に, 介護現場の制度的コミュニケー ションについての日独対照分析を行い, 両国の言語活動とケアコミュニケーション上の相違点を明らかにした.

\section{3. 意味形態文法における修辞研究}

関口文法の修辞研究に関する言語コーパスを基礎にして，意味形態文法におけるレトリックの分類等を調査した。ま 
たこの修辞研究に関する調査結果を踏まえて, 意味形態文法の中心的テーマである主観性の問題と認知言語学との関係 について論及し，意味形態文法の可能性と方向性について検討した.

\section{〈研究業績〉}

原 著

1. 菅谷泰行 (2009)「いのち」を支えるケアコミュニケー ション.〈ゆうゆうの里〉研究発表会事例集 (8): 141156

学会発表

1. 菅谷泰行（2009）制度とケアとコミュニケーション.
ドイツ日本研究所主催ワークショップ, 東京

著 書

1. Yasuyuki Sugatani (2009) Rhetorische Aspekte in der Sprachforschung Tsugio Sekiguchis. Sekiguchi-Grammatik und die Linguistik von heute (K. Ezawa, K. Sato, H. Weydt eds) pp.101-106, Stauffenburg, T u bingen, Deutschland

\section{健康科学教室}

\section{〈研究業績〉}

原 著

1. 富樫健二，木村 穣，川田裕樹，井口光正（2009）家 庭用エクササイズ支援ゲーム機（Exergame）を用い た肥満小児の減量効果に関する研究. デサントスポー ツ科 30 : $172-180$

2. 田嶋佐和子, 木村 穣, 高尾奈那, 田部浩子, 中村伸 一，坂根直樹（2009）携帯電話を用いた生活習慣病予 防プログラムの検討一福井県お打い町を大阪から支 援する遠隔プログラムの試み一. 肥満と糖尿病 8 (別 冊8）:35-43

3. 堤 博美, 木村 穣 (2009) 形態, 強度の異なる運動 が血管スティフネスに及ぼす急性効果の検討. 29: 5772

総 説

1. 木村 穣 (2009) Successful Lifestyle Modification一実 践的なライフスタイル改善のノウハウ一No.3 特定 保健指導において認知行動療法をいかに実践するか. Life Style Med 3(3): 272-277

2. 木村 穣 (2009) 保健指導のための認知行動療法. 保 健の科学 51(9): 606-610

3. 木村 穣（2009）中高年における慢性期の運動・生活 指導の実際一スポーツ施設との連携一スポーツ施設 との連携一ジャパンメディカルフィットネスネット ワーク（JMFN）一. 臨スポーツ医２6(10): 1227-1233

その他

1. 佐藤由起子, 田嶋佐和子, 木村 穣 (2009) 交流分析 性格特性からみた IT 健康管理機器利用率の検討一保 健指導ツールの有効配布について一. 日遠隔医療会誌 5(2): 188-189
学会発表

1. 岡下さやか, 木村 穣, 堤 博美, 岩坂壽二（2009） 心肺運動負荷試験による加圧効果の検討. 第20回日本 臨床スポーツ医学会, 神戸

2. 堤 博美, 木村 穣, 岡下さやか, 岩坂壽二 (2009) 上肢加圧トレーニングが及ぼす形態, 筇力および生理 学的効果の検討. 第 20 回日本臨床スポーツ医学会, 神 戸

3. 中山英恵, 木村 譲, 高橋伯夫, 大倉ひろ枝, 岡下さ やか, 宮内卓史, 上田加奈子, 岩坂壽二（2009）減量 時の内藏脂肪に及ぼす対組成及び運動耐容能の評価. 第30回日本肥満学会, 浜松

4. 田嶋佐和子, 福田正子, 堤 博美, 浦上昌也, 木村 穣（2009）10代若年者のインスリン抵抗性と体組成と の関係．第30回日本肥満学会, 浜松

5. 福田正子, 田嶋佐和子, 堤 博美, 浦上昌也, 木村 穣（2009）若年者のインスリン抵抗性と生活習慣との 関係. 第30回日本肥満学会, 浜松

6. 中山英恵, 木村 穣, 高尾奈那, 宮内拓史, 堤 博美, 岩坂壽二 (2009) 高気圧酸素環境による脂肪燃焼効果 の検討，第23回日本体力医学会近畿地方会，大阪

\section{著 書}

1. Tamura T, Mizukura I, Tatsumi H, Kimura Y (2009) Is the home health care monitoring effective? Final Program and Abstract Book-9th International Conference on Information Technology and Applications in Biomedicine, ITAB 2009 (pp. 1-4 (Article number 5394357)) IEEE, Larnaca, Cyprus 


\section{解剖学第一講座}

\section{〈研究概要〉}

講座の中心的プロジェクトとして, 脳内における細胞新生とその後の分化過程を追究しているが, われわれはすでに, 正常成獣終脳皮質で，これまで知られていた部位とは異なる新たな神経系幹前駆細胞が脳内に広く存在していることを 突き止めている. この細胞は終脳皮質ニューロンに張り付いて存在するいわゆるサテライト細胞の一部であるところか ら，われわれは perineuronal germinal cells (PGC) と呼んでいる. PGC は，これまで未熟オリゴデンドロサイトのマー カーと考えられてきたプロテオグリカンNG2 を含有する. NG2 抗体を指標にこの幹前駆細胞から生まれた新生細胞がど のように分化していくのかを追究したところ, オリゴデンドロサイトやニューロン系細胞への分化が確認できた.

ところで，BrdUを取り込んだ分裂細胞は，ほぼNG2 陽性を示すものの一部はNG2 非陽性であることが判明している. NG2 をマーカーとして利用するためには, この非陽性細胞群の性質を明らかにすることが不可欠であり, 染色感度・標 識率や観察法などを工夫したところ, NG2 非陽性の分裂細胞は血管内皮細胞であって，それを除外するとNG2細胞と神 経系分裂細胞は完全一致すること, すなわちNG2がPGCのマーカーとなりうることが確認された (Acta Histochem Cytochem 42: 1-8, 2009).

一方この研究過程で，マーカーの持つ定義の摇らざやマーカーによる染色の多様性についても検討を加えている. 例 えば, ニューロンとマクログリア（オリゴデンドロサイト・アストロサイト）は神経系の細胞系譜であるが, 由来の異 なるミクログリアを標識して区別する必要があり，その点を検索したところ，これまで未分化細胞に発現し神経前駆の マーカーとされてきた中間径フィラメント分子 nestinがミクログリアの一部にも発現することが判明した（Brain Res 1270: 10-18, 2009)．別な分子マーカーとして用いている核膜タンパク質ラミンについての検討では, ラミンサブタイプ (A/C, B1, B2) とニューロンやグリアの分化の関係についても検索し, サブタイプ構成比が分化に従って変動することも 判明した.

他方, 立命館大学との共同により, 核-細胞質輸送やタンパク質遺伝子発現の転写後調節にかかわる研究もおこなって おり，成果を論文発表している (Med Mol Morphol 42: 70-81, 2009).

なお，外部研究資金として2009年に以下のものを獲得している.

1）基盤研究（C）「血管付き神経移植による視神経再生促進作用の解析」（代表＝若林）143万円（直接経費110万，間接 経費33万）

2）基盤研究（C）「マイクロサージェリーを駆使した新しい中枢神経軸索再生法の確立と分子生物学的評価」（分担=若 林）分担分 13 万円（直接経費 10 万，間接経費 3 万）

3）小林孫兵衛記念医学振興財団平成 21 年度助成金「てんかんの発症機序に関する細胞生物学的な基礎研究」(代表=森) 50 万円

\section{〈研究業績〉}

\section{原 著}

1. Mori T, Wakabayashi T, Takamori Y, Kitaya K and Yamada H (2009) Phenotype analysis and quantification of proliferating cells in the cortical gray matter of the adult rat. Acta Histochem Cytochem 42(1): 1-8

2. Takamori Y, Mori T, Wakabayashi T, Nagasaka Y, Matsuzaki T and Yamada H (2009) Nestin-positive microglia in adult rat cerebral cortex. Brain Res 1270: 10-18

3. Robel S, Mori T, Zoubaa S, Schlegel J, Sirko S, Faissner A, Goebbels S, Dimou L and Götz M (2009) Conditional deletion of $\beta 1$-integrin in astroglia causes partial reactive gliosis. Glia 57(15): 1630-1647

4. Kato K, Suzuki M, Kanno H, Sekino S, Kusakabe K, Okada T, Mori T, Yoshida K and Hirabayashi Y (2009) Distinct role of growth hormone on epilepsy progression in a model of temporal lobe epilepsy. J Neurochem 110(2): 509-519

5. Kimura T, Hashimoto I, Nishikawa $M$ and Yamada $H$ (2009) Nucleocytoplasmic transport of luciferase gene
mRNA requires CRM1/Exportin1 and RanGTPase. Med Mol Morphol 42(2): 70-81

総 説

1. 森 徹自, 山田久夫 (2009) 蛋白質, 核酸, カルシウ ムのイメージング 遺伝子改変手技と組織化学. 組織 細胞化学 2009: 107-118

その他

1. 井手貴広, 山田久夫 (2009) 関西医科大学における研 究業績データベース構築事例. 医図書館 56(2): 145150

学会発表

1. 北宅弘太郎, 安尾忠浩（2009） ヒト末梢血 CD16 陰性 ナチュラルキラー細胞の子宮微小血管内皮細胞から の選択的血管外遊走に打けるセレクチン $\mathrm{L} / \mathrm{CD} 44$ とデ ルマタン硫酸プロテオグリカンの相互作用の役割. 第 24 回日本生殖医学会, 金沢

2. 北宅弘太郎, 安尾忠浩 (2009) 分泌期子宮内膜におい 
て CD16 陰性 CD56 強陽性ナチュラルキラー細胞が増 加する機序. 第35回免疫カンファレンス, 京都

3. 北宅弘太郎, 安尾忠浩 (2009) ヒト末梢血 CD16 陰性 ナチュラルキラー細胞の子宮微小血管内皮細胞から の選択的血管外遊走に打けるセレクチン L/CD44 とデ ルマタン硫酸プロテオグリカンの相互作用の役割. 第 54 回日本生殖免疫学会, 東京

4. 高森康晴, 若林毅俊, 森 徹自, 北宅弘太郎, 小阪 淳, 山田久夫 (2009) 成獣フェレットの脳における ニューロン新生領域の組織学的解析. 第 32 回日本神経 科学大会, 名古屋

5. 森 徹自, 若林毅俊, 高森康晴, 北宅弘太郎, 山田久 夫（2009）成獣脳における新生ニューロンの神経伝達 物質表現型変化の試み. 第32回日本神経科学大会, 名 古屋

6. 山田久夫 (2009) 医学生命科学系学術情報の流通抢よ び活用に関する現状と今後一記念ワークショップ : 情 報化・競争社会において，オリジナリティを発揮する には一. 第50回日本組織細胞化学会・学術集会, 大津

7. 高森康晴, 森 徹自, 若林毅俊, 北宅弘太郎, 山田久 夫（2009）ラット終脳皮質におけるネスチン陽性ミク ログリア. 第 50 回日本組織細胞化学会総会・学術集
会, 大津

8. 若林毅俊, 小阪 淳, 森 徹自, 高森康晴, 北宅弘太 郎，三木友香理，山田久夫 (2009) 神経特異的分子 C 38 は神経成熟を促進する. 第50回日本組織細胞化学 会総会・学術集会, 大津

9. 森 徹自, 山田久夫 (2009) 遺伝子改変手技と組織化 学. 第34回組織細胞化学講習会, 徳島

10. 山田久夫 (2009) 医学図書館及び医学図書館協会の再 点検（基調講演）。第 80 回日本医学図書館協会総会, 埼玉

11. 高森康晴, 森 徹自, 若林毅俊, 山田久夫 (2009) ラッ 卜終脳皮質に打けるネスチン陽性ミクログリアの同 定. 第114回日本解剖学会総会 - 全国学術集会, 岡山

12. 若林毅俊, 小阪 淳, 山田久夫 (2009) 網膜神経細胞 の成熟を制御する分子の解析. 第 114 回日本解剖学会 総会・全国学術集会, 岡山

13. 北宅弘太郎, 森 徹自, 若林毅俊, 高森康晴, 仁平美 果, 山田久夫 (2009) 網羅的遺伝子発現解析による卵 巣ステロイドのヒト子宮微小血管内皮細胞への影響 の検討. 第 114 回日本解剖学会総会・全国学術集会, 岡山

\section{解剖学第二講座}

\section{〈研究概要〉}

マウス脳・春髄におけるコリン・アセチルトランスフェラーゼのスプライシング・バリアント発現に関する in situ八イ ブリダイゼーション法による研究

【はじめに】

コリン・アセチルトランスフェラーゼ（ChAT）はアセチルコリン合成のキーエンザイムとして，コリン神経系の機能 と生成様式を忠実に示すマーカーである。中枢内アセチルコリン神経系は学習・記憶・覚醒・睡眠・行動をはじめとす る基本的な脳機能の実行に重要な役割を果たしている. アルツハイマー病では前脳基底部コリンニューロンに捛いて選 択的にChAT mRNAが低值を示すことが知られている. 一方, 橋被蓋コリンニューロンに抄いては著しい低下を来たして いない．これらの所見は中枢内コリンニューロンの障害に対する多様性を物語っているが，その機構は不明である。

ChATは単一の遺伝子からコードされるが, この遺伝子は 3 種のnoncoding エクソンを有することから, 合計 7 種のChAT mRNA スプライシング・バリアントがそれぞれ異なるプロモーターサイトによって読み出される. 恐らくこのためにコ リンニューロンの部位とタイプにおける多様性が生じると思われる. 本研究では, ヒトとほぼ同様のChAT遺伝子構成を 有するマウスを用いてこれらの問題点を追究し, バリアント発現の多椂性を明らかにした.

【研究方法】

7 種のスプライシング・バリアントのうち, 組成の他と酷似する $\mathrm{M}$ タイプ, 中枢内発現の希少な $\mathrm{N} 2$ タイプを除き, 互 いに組成の酷似しない5種（R1，R2，R3，R4，N1）に関し，半定量的RT-PCR法を用いてマウス線条体と延䯣における 発現パターンを比較した.

5 種のバリアントの組織・細胞内発現をマウス脳・脊䯣においてin situハイブリダイゼーション法を用いて比較・観察 した.

\section{【結果と考察】}

半定量的 RT-PCR：線条体では R1， R2 高値， R3， R4， N1 低値，延䯣では R1， R2 高值， R3， R4， N1 が中等度値ない し高値を示した.

in situ ハイブリダイゼーション：R1，R2 は前脳, 脳幹, 脊髄の各コリンニューロンにおいて豊富に発現した。一方, R3 と R4 は脳幹, 脊䯣で中等度から高レベルに発現が認められたが, 前脳では低レベルないし中等度レベルの発現に留 まった．N1タイプもこれと同様のパターンを示したが，前脳での発現は極めて低レベルであった。 
以上より， R1， R2 タイプはいずれのコリンニューロンにも比較的豊富に発現していること， R3， R4， N1 タイプは前 脳に低く, 脳幹, 脊髄に高く発現していることがわかった. これらのバリアント発現の多様性はコリンニューロンの機 能・脆弱性・病態との関連性を考える上での基本的情報を提供するものと考察した.

\section{〈研究業績〉}

原 著

1. Maruyama M, Ishida K, Watanabe Y, Nishikawa M and Takakura Y (2009) Effects of methyl-beta-cyclodextrin treatment on secretion profile of interferon-beta and zonula occuludin-1 architecture in Madin-Darby canine kidney cell monolayers. Biol Pharm Bull 32(5): 910915

2. Maruyama M, Arisaka N, Goto $\mathrm{Y}$, Ohsawa $\mathrm{Y}$, Inoue H, Fujiwara H, Hattori A and Tsujimoto M (2009) Histidine 379 of human laeverin/aminopeptidase Q, a nonconserved residue within the exopeptidase motif, defines its distinctive enzymatic properties. J Biol Chem 284(50): 34692-34702

3. Trifonov S, Houtani T, Hamada S, Kase M, Maruyama M and Sugimoto T (2009) In situ hybridization study of the distribution of choline acetyltransferase mRNA and its splice variants in the mouse brain and spinal cord. Neuroscience 159(1): 344-357

4. 濱田聡子, 宝谷剛志, Trifonov Stefan, 丸山正人, 加 瀬政彦, 堤 俊之, 杉本哲夫, 友田幸一, 山下敏夫 (2009) 中枢聴覚路におけるコリン線維とムスカリン 性受容体サブタイプ発現の解析. 頭頸自律神 23: 7273

\section{学会発表}

1. Hattori A, Maruyama M, Arisaka N, Goto Y, Osawa Y, Inoue $\mathrm{H}$, Fujiwara $\mathrm{H}$ and Tsujimoto $\mathrm{M}$ (2009) Histidine379 of human laeverin/aminopeptidase $\mathrm{Q}$, a non-conserved residue within the exopeptidase motif, defines its distinctive enzymatic properties. 6th General Meeting of the International Proteolysis Society, Surfers Paradise, Australia
2. Trifonov S, Houtani T, Hamada S, Kase M, Maruyama M, Shimizu J and Sugimoto T (2009) Distinct regional differences in the expression pattern of the transcripts of the cholinergic gene locus. 第32 回日本神経科学大会, 名古 屋

3. Trifonov S, Houtani T, Hamada S, Kase M, Maruyama M and Sugimoto T (2009) Differential expression of ChAT mRNA splice variants in the mouse basal forebrain cholinergic neurons. Alzheimer's Association 2009 International Conference on Alzheimer's Disease, Vienna, Austria

4. Hamada S, Asako M, Tomoda K and Sugimoto T (2009) Cholinergic varicose fibers and muscarinic receptor subtypes: regional distribution in the mouse brainstem. 32nd MidWinter Meeting for the Association for Research in Otolaryngology, Baltimore, USA

5. Maruyama M, Houtani T, Trifonov S, Kase $M$ and Sugimoto T (2009) 薬剤選択を利用したマウス人工多 能性幹細胞由来神経幹細胞の効率的純化. 第 82 回日本 生化学大会, 神戸

6. Maruyama M, Houtani T, Trifonov S, Kase M and Sugimoto T (2009) マウス iPS 細胞から分化させた神 経幹細胞の効率的純化. 第 32 回日本神経科学大会, 名 古屋

7. Trifonov S, Houtani T, Hamada S, Kase M, Maruyama M and Sugimoto T (2009) Choline acetyltransferase mRNA splice variants-マウス脳・春髄での発現. 第114回日本 解剖学会総会・全国学術集会, 岡山

\section{著 書}

1. 杉本哲夫 (2009) 医学書院医学大辞典（伊藤正男, 井 村裕夫, 高久史麿編）2版1-3560頁，医学書院，東京

\section{生理学第一講座}

\section{〈研究概要〉}

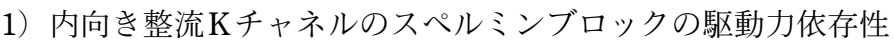

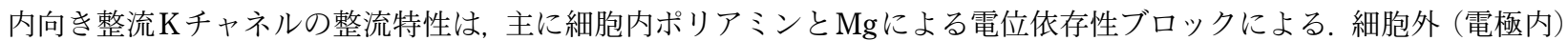

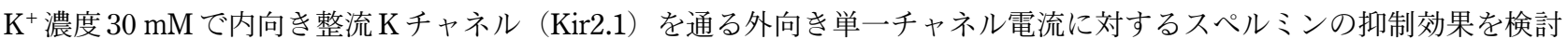
し, $150 \mathrm{mM}$ の場合（J Physiol 548: 361-371, 2003）と比較した. 10-100 nMのスペルミンによる抑制は, 逆転電位の移動 $(-37 \mathrm{mV})$ にともない負側に移動し，駆動力に依存した（同じ電位で見ると抑制は増強した）。同じ駆動力（+22 mV）で 求めたblocking rate constant と unblock rateはほぼ等しくなった. 細胞外 $\mathrm{K}^{+}$により，スペルミンや $\mathrm{K}^{+}$がチャネルポアを通 過する際の結合部位の親和性や障壁の高さが変わる結果, スペルミンブロックの駆動力依存性が生じることが示唆され た。 
2）新生ニューロンの神経活動補償作用

新生ニューロンの半数は一ヶ月以内に死滅し，神経活動がその選択に関与していると考えられているが，神経活動が どのように作用するかは不明である. モロニーレトロウイルスベクターを用いて, Kir2.1とそのドミナント・ネガティブ 体（Kir-DN）を海馬歯状回顆粒細胞に発現させ, 神経活動を人為的に増減させた. Kir-DNの過剩発現は, 新生ニューロ ンの生存率を上昇させたが, 意外なことに, Kir2.1の過剩発現は生存率を低下させず, 自発性発火頻度にも有意な低下は 認められなかった，全細胞電流記録を行うと, Kir2.1発現細胞に, $\mathrm{Na}$ 電流の増加, GABA入力の増加, 細胞内Cl-濃度上 昇によるGABAが興奮性に働く期間の延長という補償的変化が認められた。中枢神経系は,「子を千尋の谷に突き落とし て，その勢いを見る」だけではなく，内在性の興奮性と GABA 系入力によって，新生ニューロンを手厚く補償している ことが示唆された.

3）海馬での代謝型グルタミン酸受容体サブタイプについて

ラット海馬におけるI型代謝型グルタミン酸受容体のサブタイプ (mGluR1およびmGluR5) の発現を，スライス標品を 使用し, パッチクランプ法とカルシウムイメージング法を併用して調べている. 幼若期のCA 3 介在ニューロンは, I型代 謝型グルタミン酸受容体作動薬に反応し, 細胞内 $\mathrm{Ca}^{2+}$ 濃度の上昇が見られた。この $\mathrm{Ca}^{2+}$ 濃度上昇は, mGluR 1 サブタイプ の特異的遮断薬およびmGluR5サブタイプの特異的遮断薬によって抑制されたが, mGluR5遮断薬による抑制は, mGluR1 遮断薬による抑制に比べ弱かった。一方, 錐体細胞から記録した自発性 $\mathrm{GABA}_{\mathrm{A}}$ 受容体電流は, I 型受容体作動薬によっ て増強され，この増強は，大部分がmGluR1サブタイプの特異的遮断薬によって抑えられた. 以上の結果から, 幼若ラッ ト海馬でのmGluR1の機能発現が示された.

4）ミクロゾーム型アルデヒド脱水素酵素膜貫通部位の小胞体残留シグナル

$\mathrm{C}$ 末端アンカー型膜タンパク質のミクロゾーム型アルデヒド脱水素酵素（ALDH） は C 末端側の膜貫通部位（TMD）と 細胞質ドメインに小胞体残留シグナルを有する. これまでに緑色蛍光タンパク質 (GFP) とALDHのTMD（野生型および 変異型）とのキメラの $\mathrm{CHO}$ 細胞内局在を蛍光顕微鏡を用いて解析し, $\mathrm{TMD}$ 内の比較的疎水性の低いアミノ酸残基が小胞 体残留に関与することを明らかにした．今回，O型糖鎖付加配列を付けたGFPALDHキメラをCHO細胞に発現させ，その 糖鎖構造を調べた．野生型の GFPALDH キメラはO 型糖鎖は付加されなかったが，一つの疎水性の低いアミノ酸をロイシ ンに置換したシスゴルジに局在する変異体キメラにはO 型糖鎖（コア二糖）の修飾が見られた. また，複数のアミノ酸を ロイシンに置換したトランスゴルジおよび細胞膜に移行する変異体はさらにシアル酸がつくことが明らかになった.

\section{〈研究業績〉}

原 著

1. Sakaino M, Ishigaki M, Ohgari Y, Kitajima S, Masaki R, Yamamoto A and Taketani S (2009) Dual mitochondrial localization and different roles of the reversible reaction of mammalian ferrochelatase. FEBS J 276(19): 55595570

\section{学会発表}

1. Masayoshi Okada and Carlos Lois (2009) The compensation for the decreased activity in the hippocampal newborn neurons. Neuroscience 2009, Nagoya

2. Hayashi M and Matsuda H. (2009) $\mathrm{K}^{+}$channels on resting duct cells from rat pancreas. The 11th International Symposium on Exocrine Secretion (ISES), Tokushima
09, Tokushima

3. Taketo $\mathrm{M}$ and Matsuda $\mathrm{H}$ (2009) Intracellular $\mathrm{Ca}^{2+}$ elevation and GABAergic current facilitation by type I metabotropic glutamate receptors in newborn rat hippocampus. The 36th International Congress of Physiological Sciences, Kyoto

4. Hayashi M and Matsuda H (2009) Functional expression of $\mathrm{K}^{+}$channels in freshly isolated rat pancreatic duct cells. The 36th International Congress of Physiological Sciences, Kyoto

5. Masaki R and Yamamoto A (2009) Transmembranedependent sorting of tail-anchored proteins within the secretory pathway. The 61st Annual Meeting of the Japan Society for Cell Biology, Nagoya

\section{生理学第二講座}

\section{〈研究概要〉}

当講座では 2007 年から,「報酬獲得・嫌悪刺激回避行動の神経メカニズムの解明」を研究の主なテーマとしている. 報 酬に向かう行動は強化され, 嫌悪刺激にいたる行動は抑制される。これまで当教室の中村は, 報酬情報による行動の変 化のメカニズムが, 大脳基底核線条体に拈けるドパミンの作用であることを明らかにした. ドパミン細胞で記録される 信号は reward prediction error（得られた報酬と期待した報酬の差）であるとされるが，この信号がどのように生成され るのか不明である.そこでドパミン細胞に投射する以下の領域の信号処理機構を明らかにするため, 眼球運動課題を行っ 
ている霊長類を用いて, 単一神経細胞外記録を行っている.

(1) 背側縫線核における報酬・嫌悪情報処理機構

中村は同じモノアミン系神経伝達物質であるセロトニンを分泌する脳幹の背側縫線核の神経活動を行動課題遂行中の 霊長類から初めて記録し，背側縫線核細胞は報酬の情報をドパミンとは異なる時間スケールで計算していることを明ら かにした．現在さらに，背側縫線核細胞が嫌悪刺激情報をどのように処理しているかを中心に調べている．それによる と, 背側縫線核細胞には報酬にのみ反応するもの, 報酬と嫌悪刺激両方に反応するもの，嫌悪刺激のみに反応するもの， がそれぞれ発見された。 今後, セロトニンが嫌悪情報による行動変化にどのような役割を果たしているのか, 行動薬理 学的な方法で解明する予定である.

(2) 視床下部と腹側線条体の報酬・嫌悪情報処理機構

視床下部と腹側線条体は, 古くから情動に関係することが示唆されてきたが，実際の報酬獲得行動における神経活動 や嫌悪刺激に対する具体的な情報処理システムは驚くほどよくわかっていない. しかも，いずれの領域も，ドパミン細 胞への投射が非常に強く，ドパミン細胞で知られている報酬に関与した神経活動の「原料」になっている可能性がある. そこで, 霊長類に報酬量を操作した眼球運動課題および, 古典的条件付け課題を訓練し, これらの部位からの神経活動 記録を開始している.

以上の研究結果は日本神経科学会, 米国神経科学会にて発表した.

さらに, 2009年秋には human frontier science programに採択され, セロトニンの報酬・嫌悪刺激情報処理の神経メカニ ズムを, ヒトを対象とした fMRI実験, およびニューラルネットワークモデルの実験と, 我々の神経活動データと総合し て理解するプロジェクトを開始した.

\section{〈研究業績〉}

原 著

1. Ichikawa J and Gemba H (2009) Cell density-dependent changes in intracellular $\mathrm{Ca} 2+$ mobilization via the $\mathrm{P} 2 \mathrm{Y} 2$ receptor in rat bone marrow stromal cells. J Cell Physiol 219(2): 372-381

2. Noritake A, Uttl B, Terao M, Nagai M, Watanabe J and Yagi A (2009) Saccadic compression of rectangle and Kanizsa figures: now you see it, now you don' t. PLoS One 4(7): e6383

総 説

1. 中村加枝 (2009) ドパミン - セロトニン相互関係によ る衝動性のコントロールの神経機構. 中山科学振興財 団活動報告書 2008: 33-40

〈学会発表〉

1. 中村加枝 (2009) Coding of appetitive and aversive value in the primate dorsal raphe nucleus. 玉川大学国際シン ポジウム, 東京

2. Hayashi K and Ichitani Y (2009) Effects of NMDA and AMPA receptor blockade in the ventral hippocampus on spatial working memory in rats. The Annual meeting of Society for Neuroscience, Chicago

3. Nakao K, Matuzaki R, Noritake A, Okada O, Kobayashi Y and Nakamura K (2009) Positive and negative value coding in the primate dorsal raphe nucleus. The Annual meeting of Society for Neuroscience, Chicago

4. Kyuhou S, Amaya S, Nakao K and Matsuzak R (2009) Upregulation of neurotrophic factors in the motor cortex and functional recoveries after cerebellar lesion in mice. 36th International Congress of Physiological Sciences (IUPS2009), Kyoto

5. 林 和子（2009）ラットの空間的作業記憶におけるグ ルタミン酸受容体の役割. 第126回海馬研究会, 京都

6. 中村加枝 (2009) 報酬獲得行動におけるドパミンとセ ロトニンの役割. 東京都神経科学研究所 神経科学セ ミナー, 東京

7. 久璸真一 (2009) 茶葉成分テアニンによるパーキンソ ン病および本態性振戦の動物モデルに対する効果. 日 本予防医学会, 千葉

8. 久瓔真一 (2009) パーキンソン病の振戦モデルに対す る茶葉成分テアニンの効果について. 日本臨床神経生 理学会, 北九州

9. Matsuzaki R, Nakao K and Nakamura K (2009) Rewarddependent modulation of neuronal activity in the primate ventral striatum. 日本神経科学学会, 名古屋

10. Nakao K, Matsuzaki R, Okada O, Kobayashi Y and Nakamura K (2009) Reward coding by the primate dorsal raphe neurons is context dependent. 日本神経科学学 会, 名古屋

11. 中村加枝（2009）ドパミンとセロトニンによる報酬獲 得行動の制御のメカニズム. 第27回頭頝部自律神経研 究会, 大阪

12. 久寶真一 (2009) パーキンソン病に対するイソフラボ ンによる予防効果の実験的研究. 日本抗加歯医学会, 東京

13. 久寶真一 (2009) パーキンソン病に対する大豆イソフ ラボンの予防効果について. 第3 回Soy Nutrition Institute Japan (SNIJ) 学術集会, 国立健康 - 栄養研究所 (東京) 


\section{医化学講座}

\section{〈研究概要〉}

医化学講座のメインテーマは慢性疼痛, なかでも神経因性疼痛, の発症維持機構の解明である. 疼痛研究は1週間から 数ヶ月間もの長期にわたり, 分子から疼痛行動まで体系的に研究できる利点がある. 疼痛行動の神経可塑的変化は記憶・ 学習などの高次脳機能でみられる神経活動の長期増強と共通の分子基盤があることから, 疼痛研究の成果を脳研究の発 展に還元したいと考えている.

これまで，神経損傷に伴う神経因性疼痛は，上位中枢や脊䯣後角での神経回路網の再構築，脊髄後角の抑制系ニュー ロンの細胞死, 一次求心性線維の細胞体が存在する後根神経節（DRG）細胞での遺伝子発現の変化などの痛覚伝達経路 の器質的変化により難治性と考元られ, 多くの遺伝子産物や生理活性物質が慢性疼痛に関与することが報告されてきた。 さらに, 脊髄後角で産生されるプロスタグランジン $(\mathrm{PG}), \mathrm{ATP}$, サイトカインなど細胞間情報伝達物質が順行性, 逆行 性メッセンジャーとして関与することが示唆されてきた。これらの変化が慢性疼痛の原因なのか結果なのか, 慢性疼痛 に関与すると報告された情報伝達物質のカスケードが収束するのか，独立し平行であるのかすら不明であった．

基盤研究 $(\mathrm{S})$ (平成 17 年 21 年) において, 細胞内伝達カスケードに関与するさまざまな遺伝子改変マウスで神経因 性疼痛モデルを作製し，体系的に疼痛反応との関連を解析した，その結果，（1）〜（5）が明らかとなった．

（1）神経因性疼痛の維持は器質的変化ではなくグルタミン酸 NMDA 受容体 NR2B サブユニットのリン酸化など翻訳後 修飾による機能的変化により維持されていること

（2）機能的変化は $\mathrm{Ca}^{2+}$ カリモジュリンキナーゼII (CaMKII) や神経型一酸化窒素合成酵素 (nNOS) のシナプス膜への トランスロケーションなどNMDA受容体複合体のタンパク分子間の解離会合による動的変化によること

（3）慢性疼痛維持のカスケードがNMDA受容体—CaMKIIに収束すること

神経因性疼痛モデルの脊䯣では，末梢神経の活動によりシナプス膜上の NMDA受容体の活性化に伴う $\mathrm{Ca}^{2+}$ 流入によっ て Ca ${ }^{2+}$ 濃度の濃度勾配が脊䯣神経細胞内にでき，場の変化が生じる，海馬等の記憶・学習ではNMDA受容体一CaMKIIの 活性化は短期記憶（数時間）に関与し, 長期記憶（1日以上）には関与しないと考元られているが, 神経因性疼痛の 1 週 間以上の持続にNMDA受容体一CaMKIIの活性化が関与し収束するという新しい知見が得られた.

(4) 疼痛反応における反応の場としての脊䯣後角における $\mathrm{PGE}_{2}$ のつの $\mathrm{EP}$ 受容体を介する多彩な作用機構と NOによ る神経細胞一グリアのクロストーク

1 週間にも及ぶ神経因性疼痛の維持には一次求心性線維の細胞体が存在する DRG の遺伝子発現の変化やミクログリア の活性化など神経細胞一神経細胞, 神経細胞一グリア細胞間相互作用が加わり, 複雑になる. 我々は反応の場における 細胞間メッセンジャーの重要性と作用機序を明らかにした。

（5）in vivo神経再生モデルの確立と疼痛反応と神経再生への関連づけ

難治性神経因性疼痛の治療に向けたトランスレーショナル研究を推進するために, Thy1-YFPトランスジェニックマウ スに 4 週間持続的に薬物が注入可能なミニポンプを装着させるin vivo末梢神経再生モデルを確立した. 神経再生には, 場, 成長因子と細胞が必要であり，一次求心性線維の中枢端で神経因性疼痛を誘発・持続させ，行動を制限することが末梢 側の神経再生を促進させる可能性，神経細胞の軸索伸長に非神経細胞Schwann細胞が関与することを明らかにした.

疼痛研究に扔いて, 残された興味ある課題は次の 5 点である.

1）末梢組織からの侵害, 非侵害刺激は脊髄のどの部位に, どのように脊髄に伝達され, 触覚, 痛覚として認識される か（ゲートコントロール説の検証）

2) $\mathrm{PGE}_{2}, \mathrm{PGF}_{2 \alpha}$ が脊䯣後角でいつ，どこで産生され，慢性疼痛の発症・維持にどのように関与するか

3）慢性疼痛の持続にエピジェネティクスがどのように関与するのか

4）疼痛反応の客観的診断法が確立できるか

5）神経因性疼痛の治療として神経再生をどのように適用するのか

医化学講座はスタッフの他大学教授就任等により, 新たに矢尾育子講師 (三菱化学生命研究所), 下條正仁講師 (ケン タッキー大学医学部), 西田和彦助教 (大阪大学大学院生命機能研究科) が医化学講座に加わり, 最新の機器を駆使して 上記の疼痛研究の $5 つ$ 興味ある課題や新しいテーマにチャレンジしている.

\section{〈研究業績〉}

原 著

1. Yoshii S, Ito S, Shima M, Taniguchi A and Akagi M (2009) Functional restoration of rabbit spinal cord using collagen-filament scaffold. J Tissue Eng Regen Med 3(1): $19-25$
2. Unezaki S, Yoshii S, Mabuchi T, Saito A and Ito S (2009) Effects of neurotrophic factors on nerve regeneration monitored by in vivo imaging in thy1-YFP transgenic mice. J Neurosci Methods 178(2): 308-315

3. Lu J, Katano T, Okuda-Ashitaka E, Oishi Y, Urade Y and Ito $S$ (2009) Involvement of $S$-nitrosylation of actin in 
inhibition of neurotransmitter release by nitric oxide. Mol Pain 29(5): Article No. 58

4. Ohnishi T, Matsumura S and Ito S (2009) Translocation of neuronal nitric oxide synthase to the plasma membrane by ATP is mediated by P2X and P2Y receptors. Mol Pain 20(5): Article No. 40

5. Kunori S, Matsumura S, Mabuchi T, Tatsumi S, Sugimoto Y, Minami T and Ito S (2009) Involvement of prostaglandin $\mathrm{F}_{2 \alpha}$ receptor in ATP-induced mechanical allodynia. Neuroscience 163(1): 362-371

6. 稲田有史 (2009) 整形外傷; 治療における controversies 四肢筋区画症候群. 救急医 33(8): 895-899

総 説

1. 伊藤誠二（2009）【神経障害性疼痛の基礎と臨床】神 経障害性疼痛に関する基礎研究 慢性疼痛研究の最 近の進歩 機能的変化による慢性疼痛の維持機構. ペ インクリニック 30 (別冊春号) : S23-S32

2. 南 敏明, 伊藤誠二 (2009) 脊髄における痛みの伝達 機構. ペインクリニック 30(8): 1071-1098

3. 伊藤誠二 (2009) 細胞内トラッフィキングによる一酸 化窒素合成酵素の活性化機構の解明. 日応酵素協会誌 (43): 13-22

\section{学会発表}

1. Ito S, Kunori S, Mabuchi T, Tastumi S, Sugimoto Y, Matsumura S and Minami T (2009) Involvement of prostaglandin $\mathrm{F}_{2 \alpha}$ receptor in ATP-induced mechanical allodynia. The 39th Annual Meeting of the Society for Neuroscience, Chicago

2. Yao I, Kahyo T and Setou M (2009) Kinesin motor protein KIF1 is targeted by E3 ubiquitin ligase SCRAPPER. The 39th Annual Meeting of the Society for Neuroscience, Chicago

3. 矢尾育子, 杉浦悠毅, 瀬藤光利 (2009) 質量顕微鏡法 を用いたユビキチンリガーゼ SCRAPPER の解析. 第 32 回神経科学大会, 名古屋

4. 伊藤誠二 (2009) Prostaglandins as Intercellular Messengers in the Spinal Cord. 「痛み克服の国際的研究教 育拠点の形成」第1回国際シンポジウム，長崎

5. 大中誠之, 芦高恵美子, 金子志帆, 安藤 彰, 高橋寛 二, 伊藤誠二（2009）脳回転状脈絡網膜萎縮症の網膜 色素上皮細胞に打けるアルギナーゼIIの役割. 第 82 回 日本生化学会大会, 神戸
6. 矢尾育子, 杉浦悠毅, 瀬藤光利 (2009) 質量顕微鏡法 による遺伝子改変マウス組織の解析. 第34回日本医用 マススペクトル学会年会, 大阪

7. 矢尾育子 (2009) 高分子のイメージングマススペクト ロメトリー. 高分子分析研究懇談会 第 348 回例会, 神戸

8. 伊藤誠二 (2009) 痛みの発生維持機構と鎮痛薬の作用 点. 第39回日本ペインクリニック学会関西地方会, 大 阪

9. 芦高恵美子（2009）神経ペプチド・ノシスタチンによ る痛覚制御機構. 名古屋大学大学院生命農学研究科セ ミナ一, 名古屋

10. 芦高恵美子（2009）ノシスタチン結合タンパク質によ る疼痛制御. 科学技術振興機構第 2 回「情報と細胞 機能」研究会, 京都

11. 安藤 彰, 大中誠之, 金子志帆, 中内正志, 山田眞未, 伊藤誠二, 高橋寛二（2009）網脈絡膜変性疾患の in vitro モデルの確立および細胞変性機構におけるアミ ノ酸輸送の関与. 厚生労働省難治性疾患克服研究事 業, 網膜脈絡膜 - 視神経萎縮症調査研究班, 平成 20 年 度班会議, 名古屋

12. 安藤 彰, 大中誠之, 金子志帆, 中内正志, 山田眞未, 伊藤誠二（2009）網脈絡膜変性疾患のin vivo モデルの 確立および細胞変性機構におけるアミノ酸輸送の関 与. 第 13 回眼科分子生物研究会, 福岡

13. 陸 景珊, 片野泰代, 芦高恵美子, 大石 陽, 裏出良 博, 伊藤誠二 (2009) アクチンのS-ニトロシル化（SNO）を介した神経伝達物質の遊離調節機構 Involvement of $S$-nitrosylation of actin in inhibition of neurotransmitter release by nitric oxide. 第 82 回日本生化学 会大会, 神戸

14. 陸 景珊, 片野泰代, 伊藤誠二 (2009) 難治性疼痛に おける一酸化炭素 (NO) 標的分子の解析 A novel mechanism of nitric oxide in inflammatory pain. 筋 ・骨格系と 内臓の痛み研究会, 名古屋

\section{著 書}

1. 安藤 彰, 大中誠之, 金子志帆, 中内正志, 山田眞未, 伊藤誠二, 高橋寛二 (2009) 網脈絡膜変性疾患の in vitro モデルの確立および細胞変性機構におけるアミ ノ酸輸送の関与. 網膜脈絡膜・視神経萎縮症に関する 研究 平成 20 年度総括・分担研究報告書 146-149頁, 厚生労働省, 東京 


\section{薬理学講座}

\section{〈研究概要〉}

1）弾性線維形成の分子機構の研究

弾性線維は，伸び縮みする臓器・組織（動脈・肺・皮膚など）に多くあって，その弾性を担っている，老化による動 脈中膜の硬化, 肺気腫, 皮膚のたるみなどは弾性線維の劣化・断裂によるものであり, 弾性線維再生に向けて弾性線維 形成機構の解明は重要な課題である。我々は弾性線維形成に必須のインテグリンリガンド, fibulin-5（DANCEともいう） を発見した. fibulin-5 遺伝子欠損マウスは，全身の弾性線維形成異常のため，皮膚のたるみ，肺気腫，動脈の硬化など， ヒトの老化によく似た表現型を示した，一方，fibulin-5によく似たファミリー分子 fibulin-4の遺伝子欠損マウスも弾性線 維がほとんどできないという表現型を示し, fibulin-4,5 は弾性線維の形成過程に拈いて別々のメカニズムによって必須の 役割をはたしていることがわかった。今年度は, fibulin-4,5の作用様式の違いを明らかにし，それによって弾性線維形成 の分子機構の理解をすすめることを目的とした，fibulin-4の平滑筋特異的ノックアウトマウスを作成したところ，動脈弾 性板の形成異常をきたし上行大動脈瘤を発症した。 これに対して fibulin-5 ノックアウトマウスでは動脈弾性板の形成異常 はあるが大動脈瘤を発症しなかった. fibulin-4,5 の結合分子の違いを検索したところ, fibulin-4ではエラスチンをクロス リンクする酵素であるリシルオキシダーゼと結合するが fibulin-5は結合しないことを見出した. また，リシルオキシダー ゼはfibulin-4存在下でのみエラスチンと結合することができた。 このことはfibulin-4がリシルオキシダーゼをその基質で あるエラスチンにリクルートする働きをしていることを示唆している. 本研究の成果はProc Natl Acad Sci USA 106: 19029-34, 2009に発表した.

2）角膜組織における糖鎖の役割の研究

眼球組織の最前面に位置する角膜は, その大半が細胞外マトリックスと呼ばれる三次元構造体により構築されており 異物の侵入を防ぐのに充分な強度を持つと同時に非常に高い透明度を有する特殊な組織である. 我々は角膜細胞外マト リックスの主要な構成成分の一つであるケラタン硫酸という糖鎖の生合成経路解明とその角膜組織構築における機能を 明らかにするべく遺伝子変異マウスを用いて研究を進めている.

3）プロテアーゼシグナルを介する心不全形成の分子機構の研究

近年, 心筋梗塞に代表される虚血性心不全は起炎性物質（プロテアーゼやサイカイン等）が関わる炎症性疾患と指摘 されつつある. 特にプロテアーゼはその受容体（Protease-activated receptor; PAR）を介して慢性心不全の病態（心肥大， 心筋線維化）の形成に関わると考えられ，今年度は動物心筋細胞で検討した。 その結果，PAR刺激は細胞肥大を惹起し， その背景にはマトリックスメタロプロテアーゼ活性化に続くEGF受容体活性化とERK活性化という一連のシグナル伝達 機構が関わることを見出した。 この成果は 2010 年度日本薬理学会年会で発表し, 学術雑誌に投稿中である.

4) バソプレシン代謝産物の抗認知症薬としての作用機序の研究

AVP4-9 はバソプレシン（AVP）の代謝産物として生体内に存在するぺプチドで, 近年行動薬理学的な検討から学習記 憶改善作用を有することが明らかになってきた.AVP4-9 はAVPが有する抗利尿作用といったホルモン作用を殆ど持たな いことから, 副作用が少ない新規の抗認知症薬としての有用性が期待されるが, 作用機序については不明な点が多い. 我々は, ラット海馬粗膜標品て認められる [ $\left.{ }^{35} \mathrm{~S}\right]-\mathrm{AVP} 4-9$ の特異的結合が, AVP受容体を発現させた細胞から調整した粗膜 標品では認められないことから, 新しい受容体を認識している可能性を示した. さらにアルツハイマ一病の病因の一つ と考えられているアミロイド $\beta$ 蛋白負荷による神経細胞死が, AVP4-9処置によってAkt活性化を介して有意に減少する ことを明らかにした。

4) クロライド $\left(\mathrm{Cl}^{-}\right)$ポンプとアルツハイマー病治療薬の研究

我々は中枢神経細胞膜 $\mathrm{Cl}^{-}$ポンプの構成蛋白質 $55 \mathrm{kDa}$ 蛋白 (C1P55) をクローニングした. ラット海馬神経初代培養細胞 への ClP55 siRNA 導入によって神経細胞内Cl-濃度の上昇が見られ, ClP55 が $\mathrm{Cl}^{-}$ポンプの構成蛋白質であることを示した. 本研究は第 82 回日本薬理学会年会にて報告した。一方, アルツハイマー病 $(\mathrm{AD})$ の病原蛋白質アミロイド $\beta$ 蛋白（A $\beta$ ） が $\mathrm{Cl}^{-}$ポンプ活性に必須のホスファチジルイノシトール4-リン酸（PI4P） を生成する PI4 キナーゼ活性を直接抑制し，細 胞内 $\mathrm{Cl}^{-}$濃度の上昇とグルタミン酸神経興奮毒性の増悪化を明らかにしてきた. さらに毒性を示さない $\mathrm{A} \beta$ 部分ぺプチド (IGL) が上述の $\mathrm{A} \beta$ 毒性の抑制と $\mathrm{AD}$ モデルマウスへの $\mathrm{A} \beta$ 海馬内注入による学習障害を改善した. 本研究の成果はLife Sci 84: 132-138, 2009に発表した。

\section{〈研究業績〉}

原 著

1. Hattori N, Ishihara T and Saiki Y (2009) Macroprolactinaemia: prevalence and aetiologies in a large group of hospital workers. Clin Endocrinol 71(5): 702-705
2. Hattori N (2009) Expression, regulation and biological actions of growth hormone (GH) and ghrelin in the immune system. Growth Horm IGF Res 19(3): 187-197

3. Xiong ZM, Kitagawa K, Nishiuchi Y, Kimura T, Nakamura T and Inagaki C (2009) Acetyl-Ile-Gly-Leu protects 
neurons from Abeta(1-42)-induced toxicity in vitro and in V337M human tau-expressing mice. Life Sci 84(5-6): 132-138

4. Horiguchi M, Inoue T, Ohbayashi T, Hirai M, Noda K, Marmorstein LY, Yabe D, Takagi K, Akama TO, Kita T, Kimura T and Nakamura T. (2009) Fibulin-4 conducts proper elastogenesis via interaction with cross-linking enzyme lysyl oxidase. Proc Natl Acad Sci USA 45: 19029-19034

5. 中邨智之 (2009) 弾性線維形成におけるファイブリン (fibulin) ファミリータンパク質の役割. 生化学 81(1): $38-42$

総 説

1. 吉岡 慶, 大谷ひとみ, 中邨智之, 大谷 肇 (2009) ジストロフィンと心筋障害. 日薬理誌 134(2): 107

その他

1. Ikeda M, Naitoh M, Kubota H, Ishiko T, Yoshikawa K, Yamawaki S, Kurokawa M, Utani A, Nakamura T, Nagata $\mathrm{K}$ and Suzuki S. (2009) Elastic fiber assembly is disrupted by excessive accumulation of chondroitin sulfate in the human dermal fibrotic disease, keloid. Biochem Biophys Res Commun 390(4): 1221-1228

\section{学会発表}

1. Horiguchi, M., Inoue, T., Ohbayashi, T., Hirai, M., Noda, K., Marmorstein, L.Y., Akama, T.O., Kita, T., Kimura, T. and Nakamura, T (2009) The role of FIBULINs in elastogenesis. Gordon Research Conference on Elastin and Elastic Fiber, Biddeford, USA

2. Nakamura T (2009) What conditional knockout mice tell us: Fibulin-4 and LTBP2. Gordon Research Conference on Elastin and Elastic Fiber, Biddeford, USA

3. Akama $\mathrm{T}$ and Nakamura $\mathrm{T}$ (2009) Essential role of b3GnT7 for efficient KS-GAG production in cultured cells. 8th Pan Pacific Connective Tissue Societies Symposium, 横須賀
4. Horiguchi M, Inoue T, Noda K and Nakamura T (2009) The role of fibulins in elastic fiber assembly of mouse aorta. 8th Pan Pacific Connective Tissue Societies Symposium, 横須賀

5. 井上唯史, 大林徹也, 赤間智也, 中邨智之 (2009) LTBP2 遺伝子欠損マウスは緑内障を発症する. 第 82 回日本 生化学会, 神戸

6. 赤間智也, 北山和子, 福田道子, 中邨智之（2009）斑 状角膜ジストロフィータイプIIに見られる変異型硫 酸転移酵素のケラタン硫酸合成活性の測定. 第 82 回日 本生化学会, 神戸

7. 堀口真仁, 井上唯史, 野田和男, 中邨智之 (2009) マ ウス大動脈の弾性線維形成における Fibulinの役割. 第 82 回日本生化学会, 神戸

8. 中邨智之 (2009) 血管の伸縮性を生み出すしくみ. 脳 血管シンポジウム，東京

9. 中邨智之（2009）生体の弾性を生み出すしくみ，認識 と形成研究会, 北杜市, 山梨

10. 赤間智也, 中邨智之（2009）弾性線維形成における DANCE/fibulin-5の役割. 光老化研究会, 大阪

11. 中邨智之（2009）血管の弾性を生み出す仕組み，第 5 回 Vascular and Brain Conference-EAST, 東京

12. Horiguchi M and Nakamura T (2009) The role of fibulins in elastic fiber assembly of mouse aorta. 第 73 回日本循 環器学会学術集会, 大阪,

13. 大谷ひとみ, 吉岡 慶, 河合建蔵, 荒木宏昌, 中邨智 之（2009）プロテアーゼ活性化受容体を介する心筋細 胞肥大における $\mathrm{EGF}$ 受容体トランス活性化の関与. 第 82 回 日本薬理学会年会, 横浜

14. 中山靖久, 中邨智之 (2009) バゾプレシン代謝産物, AVP4-9，によるラット海馬培養細胞の軸索伸長作用. 第 82 回日本薬理学会年会, 横浜

15. 服部尚樹, 北川香織, 中邨智之 (2009) 薬物治療を要 さない高プロラクチン血漿の新たな原因「マクロプロ ラクチン血症」の一般人における基礎的, 臨床的検討. 第 82 回 日本薬理学会年会, 横浜

16. 北川香織, 熊 正梅, 中山靖久, 服部尚樹, 稲垣千代 子, 中邨智之 (2009) 塩素イオンポンプサブュニット (CpL55) の機能解析. 第82回日本薬理学会年会, 横浜

\section{病理学第一講座}

\section{〈研究概要〉}

全身性あるいは藏器特異的自己免疫疾患は“Stem cell disorders”として把握される疾病であり，正常骨髄細胞（ある いは骨髄細胞より精製した正常幹細胞）を移植することにより予防あるいは治療が可能である。ヒトにおいても骨髄移 植を施行された患者（自己免疫疾患を併発）では長期に渡り自己免疫疾患の再発が認められないことが報告されている.

自家骨髄移植に打いては骨䯣細胞の生着は容易であり一時的な疾病の軽減は認められるものの，長期的には自己免疫 疾患の再発の可能性が高い. またドナ一の選択範囲を考慮すると MHCの異なる同種（アロ）骨髄移植がヒトの臨床応用 において将来的に有望な方法と考えられる。 また, 骨髄移植を施行するに際して重要な点はレシピエントの負担を軽減 し，移植したドナ一骨髄細胞を効率よく生着させることである。 
これらの観点に立ち，我々は画期的な骨髄移植法として直接骨䯣内に骨髄細胞を注入する骨髄内骨髄移植（intra bone marrow bone marrow transplantation: IBM-BMT) を開発した. 従来の経静脈的骨髄移植（intravenous BMT: IV-BMT）に 比べ, IBM-BMT の利点として，1）ドナー造血前駆細胞の早期出現，2）各血液系細胞へ早期分化，3）速やかな免疫能 の回復，4）造血幹細胞の長期にわたる安定した維持，5）移植片対宿主反応（GvH反応）が軽微なこと，6）レシピエン 卜に対する前処置の軽減（放射線照射線量の低減，などが挙げられ，有効な骨髄移植法と考えられる．また，上に列挙 した項目に加え，IBM-BMTはドナー特異的免疫寛容（トレランス）の誘導を容易にすることが判明しており，レシピエ ントに対する前処置を軽減した条件で骨髄・臓器同時移植が可能である.

本年度はIBM-BMTにおけるこれらの利点・可能性を念頭におき研究を進め, 以下に示す研究成果が得られた.

1）骨髄内骨髄移植の際, カスパーゼ阻害剤ZVAD-fmkを用いることにより, 造血幹細胞のアポトーシスを抑制し, ドナー 由来細胞の生着を促進させることが可能になった.

2）ドナー末梢血，骨髄細胞あるいは末梢血幹細胞の頻回投与はアロ骨髄移植早期の白血球数の回復を促進した

3）磁気ビーズを結合させた骨髄細胞および磁場を用いることにより, 骨髄内骨髄移植後, 骨髄内に移植細胞を滞留させ ることが可能になり，造血促進効果が認められた．

4）骨髄内骨髄移植抢よび皮下ドナーリンパ球輸注はドナー骨髄細胞の生着を促進し, GVH病の軽減に著効を示した.

5）悪性腫瘍（癌, 肉腫等）の治療に関し, 樹状細胞とマウス線維肉腫との融合細胞を用いた抗腫瘍効果, および骨髄由 来樹状細胞の骨髄内投与による抗腫瘍効果を示し，また，進行担癌マウスに対して胎生期胸腺移植と骨髄内骨髄移植 の併用による延命効果や骨髄内骨髄移植と成体胸腺移植の併用によるマウス白血病の治療も検討した.

6）ストローマ細胞上の神経細胞接着分子（NCAM，CD56）が造血シグナルに重要であることをサルおよびヒト造血系 に掠いて検証した.

\section{〈研究業績〉}

原 著

1. Ikehara S (2009) A new bone marrow transplantation method for stem cell disorders. Ann N Y Acad Sci 1173: $774-780$

2. Tokuyama Y, Adachi Y, Minamino K, Shintaku H, Okigaki M, Hayashi K, Kitajima A, Takaki T, Koike N, Shima C, Imai Y, Shi M, Yanai S and Ikehara S (2009) Abnormal distribution of dendritic cells in (NZW x BXSB)F1 mice. Autoimmunity 42(5): 399-405

3. Shima C, Adachi Y, Shi M, Imai Y, Okigaki M, Yanai S, Minamino K, Takahashi K and Ikehara S (2009) The combination method using magnetic beads and a magnet helps sustain the number of donor BM cells after intra$\mathrm{BM}$ injection, resulting in rapid hematopoietic recovery. Bone Marrow Transplant Oct 5. [Epub ahead of print]

4. Nishida T, Hosaka N, Takaki T, Miyake T, Cui W, Inaba M, Kinoshita H, Matsuda T and Ikehara S (2009) Allogeneic intra-BM-BMT plus adult thymus transplantation from same donor has benefits for long-term survival even after sublethal irradiation or low-dose BM cell injection. Bone Marrow Transplant 43(11): 829-837

5. Ohnishi S, Ito H, Suzuki Y, Adachi Y, Wate R, Zhang J, Nakano S, Kusaka H and Ikehara S (2009) Intra-bone marrow-bone marrow transplantation slows disease progression and prolongs survival in G93A mutant SOD1 transgenic mice, an animal model mouse for amyotrophic lateral sclerosis. Brain Res 1296: 216-224

6. Honsho S, Nishikawa S, Amano K, Zen K, Adachi Y, Kishita E, Matsui A, Katsume A, Yamaguchi S, Nishikawa K, Isoda K, Riches DW, Matoba S, Okigaki M and
Matsubara H (2009) Pressure-Mediated Hypertrophy and Mechanical Stretch Induces IL-1 Release and Subsequent IGF-1 Generation to Maintain Compensative Hypertrophy by Affecting Akt and JNK Pathways. Circ Res 105(11): 1149-1158

7. Wang X, Hisha H, Mizokami T, Cui W, Cui Y, Shi A, Song C, Okazaki S, Li Q, Feng W, Kato J and Ikehara S (2009) Mouse Mesenchymal Stem Cells Can Support Human Hemopoiesis both In Vitro and In Vivo: Crucial Role of Neural Cell Adhesion Molecule (NCAM). Haematologica Dec 16. [Epub ahead of print]

8. Mizokami T, Hisha H, Okazaki S, Takaki T, Wang XL, Song CY, Li Q, Kato J, Hosaka N, Inaba M, Kanzaki H and Ikehara S (2009) Preferential expansion of human umbilical cord blood-derived CD34-positive cells on major histocompatibility complex-matched amnionderived mesenchymal stem cells. Haematologica 94(5): 618-628

9. Miyake T, Hosaka N, Cui W, Nishida T, Takaki T, Inaba M, Kamiyama Y and Ikehara S (2009) Adult Thymus Transplantation with Allogeneic Intra-Bone MarrowBone Marrow Transplantation from Same Donor Induces High Thymopoiesis, Mild Graft-Versus-Host Reaction and Strong Graft-Versus-Tumor Effects. Immunology 126(4): 552-564

10. Yanai S, Adachi Y, Fuijisawa J, Jiang S, Okigaki M, Shi M, Shima C, Imai Y, Kwon AH and Ikehara S (2009) Antitumor effects of fusion cells of type 1 dendritic cells and Meth A tumor cells using hemagglutinating virus of Japan-envelope. Int J Oncol 35(2): 249-255

11. Kushida T, Ueda Y, Umeda M, Oe K, Okamoto N, Iida H, 
Abraham NG, Gershwin ME and Ikehara S (2009) Allogeneic intra-bone marrow transplantation prevents rheumatoidarthritis in SKG/Jcl mice. J Autoimmun 32(3-4): 216-222

12. Matsunaga S, Okigaki M, Takeda M, Matsui A, Honsho S, Katsume A, Kishita E, Jishan C, Kurihara T, Adachi Y, Mansukhani A, Kobara M, Matoba Y, Tatsumi T and Matsubara H (2009) Endothelium-targeted overexpression of constitutively active FGF receptor induces cardioprotection in mice myocardial infarction (Corrigendum 47(3):419 2009). J Mol Cell Cardiol 46(5): 663-673

13. Umeda M, Kushida T, Sasai K, Asada T, Oe K, Sakai D, Mochida J, Ikehara S and Iida H (2009) Activation of rat nucleus pulposus cells by coculture with whole bone marrow cells collected by the perfusion method. J Orthop Res 27(2): 222-228

14. Irie N, Muraji T, Hosaka N, Takada Y, Sakamoto S and Tanaka K (2009) Maternal HLA ClassI Compatibility in Patients With Biliary Atresia. J Pediatr Gastroenterol Nutr 49(4): 488-492

15. Nakamichi N, Morii E, Ikeda JI, Qiu Y, Mamato S, Tian T, Fukuhara S and Aozasa K (2009) Synergistic effect of interleukin-6 and endoplasmic reticulum stress inducers on the high level of ABCG2 expression in plasma cells. Lab Invest 89(3): 327-336

16. Li M, Inaba M, Guo K, Abraham NG and Ikehara S (2009) Amelioration of cognitive ability in senescence-accelerated mouse prone 8 (SAMP8) by intra-bone marrowbone marrow transplantation. Neurosci Lett 465(1): 3640

17. Suzuki K, Iwai H, Kaneko T, Sakaguchi M, Hoshino S and Inaba M (2009) Induction of parotitis by fine-needle aspiration in parotid Warthin's tumor. Otolaryngol Head Neck Surg 141(2): 282-284

18. Imai Y, Adachi Y, Shi M, Shima C, Yanai S, Okigaki M, Yamashima T, Kaneko K and Ikehara S (2009) Caspase Inhibitor, ZVAD-fmk, Facilitates Engraftment of Donor Hematopoietic Stem Cells in Intra-Bone Marrow-Bone Marrow Transplantation. Stem Cells Dev 19(4): 461-468

19. Petrini M, Pacini S, Trombi L, Fazzi R, Montali M, Ikehara S and Abraham NG (2009) Identification and purification of mesodermal progenitor cells from human adult bone marrow. Stem Cells Dev 18(6): 857-866

20. 岩井 大, 鈴木健介, 星野勝一, 友田幸一, 稲葉宗夫 （2009）耳下腺術後唾液瘦に対する塩酸ミノサイクリ ン局所注入療法. 頭頸部外 19(3): 173-178

総 説

1. 池原 進 (2009)【細胞医療 Update】 造血幹細胞移植 の臨床 骨髄内幹細胞移植 次世代の移植方法. 医の あゆみ 229(9): 793-797
症例報告

1. 中出多子, 岩井 大, 金子敏彦, 河本光平, 星野勝一, 稲葉宗夫, 清水俊樹 (2009) 喉頭原発の混合型小細胞 癌例。耳鼻・頭頸外科 81(9): 633-637

2. 木下勇一, 山口直則, 有馬良一, 中山啓三, 安田迪之, 足立 靖, 鷹巣晃昌, 四方伸明 (2009) 子宮体部原発 神経内分泌癌の一例. 日臨細胞誌 48(3): 114-118

学会発表

1. Shima C, Adachi Y, Shi Ming,Yanai S, Imai Y, Takahashi K and Ikehara S (2009) Combination Method of Magnetic Beads and Magnet Helps Sustain Number of Donor Bone Marrow Cells after Intra-Bone Marrow Injection, Resulting in Rapid Hemopoietic Recovery マグネットビーズ とマグネットを用いた骨髄内骨髄移植の造血回復に おける効果. Japanese Society for Immunity第39回日本 免疫学会総会学術集会, 大阪

2. Zhang Y, Hosaka N, Takaki T, Inaba M and Ikehara S (2009) Effects of allogeneic hematopoietic stem cell transplantation + thymus transplantation on malignant tumor: Comparison between fetus, newborn, and adult mice. 第39回日本免疫会総会 - 学術集会, 大阪

3. Hosaka N and Ikehara S (2009) Prolonged Survival of Mice with Advanced Tumor after Syngeneic or Allogeneic IBM-BMT+Fetal Thymus Transplantation II. 第 68 回日本癌学会, 横浜

4. Baba S, Iwai H, Inaba M, Sakaguchi M, Lee S, Ikehara S and Tomoda K (2009) PREVENTIVE EFFECTS OF THYMUS GRAFT ON AGE-RELATED HEARING LOSS. 46th Inner Ear Biology Workshop, Utrecht, The Netherlands

5. Iwai H, Baba S, Inaba M, Sakaguchi M, Lee S, Ikehara S and Tomoda K (2009) INOCULATION OF HELPER T CELLS AS A STRATEGY FOR THE PREVENTION OF AGERELATED HEARING LOSS IN SAMP1 MICE. 46th Inner Ear Biology Workshop, Utrecht, The Netherlands

6. 李 清, 比舍弘子, 崔 文昊, 加藤順子, 池原 進 (2009) Repeated infusions of donor BMCs and PBSCs can restore early hematopoiesis after allogenic BMT. 第 98 回日本病理学会総会, 京都

7. 保坂直樹（2009）胸腺移植併用による次世代の骨髄移 植法の開発一T細胞の分化増殖・制御に向けて一，第 55 回日本病理学会秋期特別総会, 東京

8. 加藤順子, 西尾美保, 村社元美, 楠田沙織, 村田健司, 中澤孝夫, 保坂直樹, 足立 靖, 宋 寛之, 天野 殖 （2009）腹水検查で腸管型 T細胞リンパ腫と診断した 1 例. 第48回日本臨床細胞学会秋期大会, 福岡

9. 木下勇一, 松永志保, 市邊和男, 生田明子, 植村芳子, 坂井田紀子, 足立 靖, 圦 貴司, 鷹巣晃昌, 四方伸 明（2009）腹膜に進展した高分化乳頭型胸膜中皮腫の 
一例．第48回日本臨床細胞学会秋期大会, 福岡

10. 松岡雅人, 緒方奈保子, 高橋寛二, 足立 靖, 木下勇 一，西村哲哉（2009）硝子体細胞診が診断に有用で あったサルコイドーシスの 2 例（硝子体細胞診とサル コイドーシス)。第63回日本臨床眼科学会, 福岡

11. 加藤順子，西村昌子，西尾美保，村社元美，村田健司， 中澤孝夫，比舎弘子，足立 靖，池原 進，宋 寛之， 天野 殖 (2009) 腹水検査で腸管症型 $\mathrm{T}$ 細胞リンパ腫 と診断した1例. 第35回 日本臨床細胞学会近畿連合 会 学術集会, 京都

12. 保坂直樹, 高木孝士, 張玉明, 池原進 (2009) 骨髄内 骨髄移植法によるMRL/lpr マウスの自己免疫疾患治療 一骨髄細胞由来胸腺上皮細胞（TEC）の関与一. 第 41 回日本臨床分子形態学会総会・学術集会, 神戸

13. 足立 靖, 石 明, 池原 進 (2009) より効率的な 骨髄内骨髄移植の検討一コラーゲン・ゲル或いはマグ ネット・ビーズを用いて一. 第 45 回日本移植学会総 会, 東京

14. 木下勇一, 松永志保, 高畠 希, 市邊和夫, 生田明子, 植村芳子, 坂井田紀子, 足立 靖, 圦貴司, 鷹巣晃 昌, 四方伸明 (2009) 悪性胸膜 - 腹膜中皮腫が疑われ た 1例. 第十五回大阪病理研究会, 大阪

15. 足立 靖, 石 明, 矢内勢司, 嶋千絵子, 今井雄一 郎, 池原 進 (2009) Tie2 発現細胞特異的にFGFレセ プター 2 を発現させたトランスジェニックマウスにお ける造血系細胞の解析. 第98回日本病理学会総会, 京 都

16. 矢内勢司, 足立 靖, 石 明, 嶋千絵子, 今井雄一郎, 池原 進 (2009) 樹状細胞とマウス線維肉腫との融合 細胞を用いた抗腫瘍効果の検討. 第 98 回 日本病理学 会総会, 京都

17. 今井雄一郎, 足立 靖, 比舎弘子, 石 明, 矢内勢司, 嶋千絵子，金子一成，池原 進（2009）骨髄移植後の マウスに発生したドナー由来未熟白血病細胞株の樹 立とその解析. 第98回 日本病理学会総会, 京都

18. 石 明, 足立 靖, 矢内勢司, 嶋千絵子, 今井雄一郎, 池原 進 (2009) 骨髄内骨髄移植法に打けるコラーゲ ン・ゲルの有用性. 第98回 日本病理学会総会, 京都

19. 嶋千絵子, 足立 靖, 石 明, 矢内勢司, 今井雄一 郎，高橋寛二，池原 進（2009）骨髄由来樹状細胞の 骨䯣内投与による抗腫瘍効果の検討. 第98回 日本病 理学会総会, 京都
20. 加藤順子, 比舍弘子, 李 清, 池原 進 (2009) 神 経細胞接着分子（NCAM, CD56) のサルおよびヒト 造血系への関与. 第98回日本病理学会総会, 京都

21. 矢内勢司, 足立 靖, 權 雅憲, 池原 進 (2009) マ ウス線維肉腫に対する樹状細胞と腫瘍細胞との融合 細胞による抗腫瘍効果の検討. 第109回日本外科学会 定期学術集会, 福岡

22. 松岡雅人, 緒方奈保子, 高橋寛二, 足立 靖, 西村哲 哉（2009）硝子体生検が診断に有用であったサルコイ ドーシスの一例。第369回大阪眼科集談会，大阪

23. 木下勇一, 濱口記久子, 松永志保, 市邊和男, 李 重 煥, 鷹巣晃昌, 四方伸明, 足立 靖, 圦貴司, 生田 明子（2009）子宮体部原発明細胞腺癌の一例. 第34回

日本臨床細胞学会大阪府支部 学術集会, 大阪

24. 池原進 (2009) 難病の新しい治療法一呼吸器疾患を含 む一. 第40回北陸呼吸器シンポジウム (FITs), 金沢

25. 池原 進（2009）新しい骨髄移植法（灌流法十骨髄内 骨髄移植法）の最新知見. 第4 回 Annual Review Transplant Forum，東京

26. 池原 進（2009）“灌流法十骨髄内骨髄移植法” の有 用性一基礎加臨床へ一. 第 4 回骨髄内骨髄移植研究 会, 札幌

27. 池原 進（2009）灌流法と骨髄内骨骾移植法の臨床応 用に向けて. 厚労科学研究 6 研究合同公開シンポジウ 么, 東京

28. 池原 進（2009）新しい造血幹細胞移植技術（灌流法 十骨髄内骨髄移植法）の有用性一ウサギの haploidentical BMTの系を用いて一. 厚労科学研究造血幹細胞合 同班会議, 厚労科学研究 6 研究班合同公開シンポジウ 厶, 東京

\section{著 書}

1. 岡崎和一, 安藤祐吾, 坂口雄沢, 内田一茂, 松下光伸, 稲葉宗夫, 池原 進 (2009) 炎症性腸疾患の画期的治 療法に関する臨床研究 ラット皮下脂肪組織由来幹細 胞の粘膜下局所注入法による腸管粘膜再生. 炎症性腸 疾患の画期的治療法に関する臨床研究 平成 20 年度 総 括・分担研究報告書 36-38 頁, 厚生労働省, 東京

2. 池原 進 (2009) 新しい造血幹細胞移植技術の開発に 関する研究. 新しい造血幹細胞移植技術の開発に関す る研究平成 20 年度 総括・分担研究報告書 3-8頁, 厚 生労働省, 東京

\section{病理学第二講座}

\section{〈研究概要〉}

I. 乳癌発生におよぼす高齢妊娠の影響

若齢初産婦は未産婦に比して乳癌の発生の抑制をみるが, 逆に 35 歳以上の初回妊娠は, 未産婦よりも乳癌の危険性を 増す。しかし，実験的に高齢ラットにおける妊娠の乳癌発生におよぼす影響についての検討は困難である。ひとつには 動物を高齢で妊娠させる困難さがあげられるが, 我々は妊娠期ホルモン環境を短期有効なエストロゲンとプロゲステロ 
ン $(\mathrm{E} / \mathrm{P})$ 製剤により作出することにより検討した. すなわち, 7 週齢雌Lewis ラットに $50 \mathrm{mg} / \mathrm{kg} ・ \mathrm{~N}-\mathrm{methyl}-\mathrm{N}-n i t r o s o u r e a$

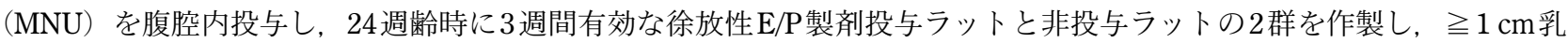
癌をみた個体を適宣屠殺し，48週齢時に実験を終了した。 その結果 $\geqq 1 \mathrm{~cm}$ 乳癌の発生率は $\mathrm{E} / \mathrm{P}$ 投与群では $60 \%$ と $/ \mathrm{P}$ 非 投与群の $44 \%$ よ上昇し, 潜状期間は短縮し, 微小乳癌も含めた全乳癌発生率で比較すると, E/P投与群では非投与群に 比してラット当たりの乳癌個数は有意に増加した（Tsukamoto et al., 2007）。しかし, 発癌刺激から $\mathrm{E} / \mathrm{P}$ 暴露までの期間が 延長すると遺伝子変異が重積して前癌状態となり, 腫瘤形成が起きやすいとも考えられる.よって, $\mathrm{E} / \mathrm{P}$ 暴露の時期を違 えても発癌刺激から $\mathrm{E} / \mathrm{P}$ 暴露までの期間を統一した実験系での検討が望まれる。 そこで, 若年 $\mathrm{E} / \mathrm{P}$ 群として 4 週齢時に $50 \mathrm{mg} / \mathrm{kg}$ ・ MNUを投与して 6 週齢時より 3 週間 $\mathrm{E} / \mathrm{P}$ 処置, 高齢 $\mathrm{E} / \mathrm{P}$ 群として 22 週と 23 週に各の $50 \mathrm{mg} / \mathrm{kg} ・ \mathrm{MNU}$ を投与し て 24 週齢時より 3 週間 $\mathrm{E} / \mathrm{P}$ 処置する実験系を作製した。 その結果，若年 $\mathrm{E} / \mathrm{P}$ 群の $\geqq 1 \mathrm{~cm}$ 乳癌発生率は $74 \%$ と対照群の 96 $\%$ に比して有意に減少したが，高齢 $\mathrm{E} / \mathrm{P}$ 群では $\mathrm{E} / \mathrm{P}$ 群の $\geqq 1 \mathrm{~cm}$ 乳癌発生率は $83 \%$ と対照群の $55 \%$ に比して有意ではない

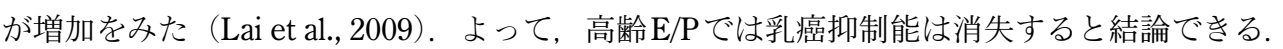

\section{II. 妊娠による乳癌抑制の機序解析}

経産ラット乳腺では発癌刺激後も細胞増殖関連酵素である ornithine decarboxylase (ODC) 遺伝子の発現誘導がほとん ど起こらない. c-Myc標的遺伝子である ODC 遺伝子はそのプロモーター領域に2つのE-box 配列 (CACGTG) をもってい る. E-boxに転写促進Myc-Max複合体が結合するとODC遺伝子の発現がオンに，転写抑制Mnt/Mad-Max 複合体が結合す ると発現がオフになると考えられていた。しかし， 発癌刺激後の経産乳腺において histone deacetylase 1(HDAC1)/c-Myc/ Mnt/Max複合体が形成され，この複合体がc-Myc標的遺伝子群の発現抑制因子として機能することで細胞増殖が抑制され ていることを証明した（Matsuoka et al., 2008). なお, 一連の検討から heterogenous nuclear ribonuclear protein U (hnRNP U）はC-Myc-Max複合体の転写共役因子として働くことが判明した（Matsuoka et al., 2009）.

\section{Paclitaxelによる新生仔眼毒性の検討}

Paclitaxel（PTX）は骨髄抑制や末梢神経傷害を惹起するが，新生仔の眼毒性についての検討はない。 そこで，出生 0 日 の雌雄のSprague-Dawlay ラットに $0,2,4,8 \mathrm{mg} / \mathrm{kg}$ ・PTXを単回復腔内投与し，投与後 1 日目と 7 日目に眼球を摘出して組 織検索をした。 また出生 14 日齢に $4 \mathrm{mg} / \mathrm{kg} ・ \mathrm{PTX}$ を投与し，投与 7 日目に眼球摘出し組織検索をした。 その結果，出生 0 日の $2 \mathrm{mg} / \mathrm{kg}$ ・PTX群では眼毒性はみられず，白内障は $4 \mathrm{mg} / \mathrm{kg} ・ \mathrm{PTX}$ 群の投与 1 日目で $80 \%, 7$ 日目で $56 \%$ ， $8 \mathrm{mg} / \mathrm{kg} ・$ PTX群の投与 1,7 日目とも $100 \%$ にみた. 網膜異形成は, $4 \mathrm{mg} / \mathrm{kg} ・ \mathrm{PTX}$ 群の投与 7 日目の $13 \%$ にた. $8 \mathrm{mg} / \mathrm{kg} ・ \mathrm{PTX}$ 群 では投与 1 日目の 100\%に神経芽細胞層の傷害がみられたが, 致死個体が増加した。但し出生 14 日目の $4 \mathrm{mg} / \mathrm{kg} ・ \mathrm{PTX}$ 投 与動物では眼毒性がなかった. 以上，出生直後の $4 \mathrm{mg} / \mathrm{kg} ・ \mathrm{PTX}$ 投与で白内障や網膜異形成を起こす危険があり，8 mg/ $\mathrm{kg} \cdot \mathrm{PTX}$ 投与では致死率が上昇する. 但し出生 14 日の $4 \mathrm{mg} / \mathrm{kg} ・ \mathrm{PTX}$ 投与では眼毒性は見られなかった (Kuwata et al., 2009).

\section{MNU誘発マウス網膜変性症における p53の役割}

MNUの単回投与は 7 日の経過で視細胞アポトーシスを介する網膜変性症を引き起こす. MNU網膜変性症における p53 の関与につき検討した. $60 \mathrm{mg} / \mathrm{kg} ・ \mathrm{MNU}$ を 8 週齢のp53+/+, +/-, -/-マウスに腹腔内投与し 7 日後に屠殺して網膜の状 態を形態的に比較した。 その結果, 7 日目ではいずれの群でも同等の網膜変性をみたことより, p53の関与はないと結論 づけられた（Yoshizawa et al., 2009）.

\section{〈研究業績〉}

原 著

1. Morioka T, Yamanaka K, Mori H, Omoto Y, Tokime K, Kakeda M, Kurokawa I, Gabazza E, Tsubura A, Yasutomi Y, Mizutani H. (2009) IL-4/IL-13 antagonist DNA vaccination successfully suppresses Thy 2 type chronic dermatitis. Br J Dermatol 160(6): 1172-1179

2. Senba Y, Kurokawa I, Kitagawa H, Omoto Y, Yamanaka K, Isoda K, Tsubura A, Mizutani H (2009) Folliculosebaceous cystic hamartoma differentiates toward the infundibulum, sebaceous duct and sebaceous cells: immunohistochemical study of keratins and filaggrin. $\mathrm{Br}$ J Dermatol 160(2): 454-456

3. Kurokawa I, Yamanaka K, Senba Y, Sugisaki H, Tsubura
A, Kimura T, Mizutani H. (2009) Pilomatricoma can differentiate not only towards hair matrix and hair cortex, but also follicular infundibulum, outer root sheath and hair bulge. Exp Dermatol 18(8): 734-737

4. Kuwata M, Yoshizawa K, Matsumura M, Takahashi K, Tsubura A (2009) Ocular toxicity caused by Paclitaxel in neonatal sprague-dawley rats. In Vivo 23(4): 555-560

5. Lai Y-C, Yuri T, Uehara N, Matsuoka Y, Kanemastu K, Tsubura A. (2009) Biphasic effect of short-term pregnancy hormone treatment on $\mathrm{N}$-methyl-N-nitrosoureainduced mammary carcinogenesis in young and old rats. Mol Med Rep 2(2): 213-220

6. Yoshizawa K, Kuwata M, Kawanaka A, Uehara N, Yuri T, Tsubura A. (2009) N-methyl-N-nitrosourea-induced reti- 
nal degeneration in mice is independent of the p53 gene. Mol Vis 15: 2919-2925

7. Matsuoka Y, Uehara N, Tsubura A (2009) hnRNP U interacts with the c-Myc-Max complex on the E-box promoter region inducing the ornithine decarboxylase gene. Oncol Rep 22(2): 249-255

8. Yoshizawa K, Jelezcova E, Brown AR, Foley JF, Nyska A, Cui X, Hofseth LJ, Maronpot RM, Wilson SH, Sepulveda AR, Sobol RW (2009) Gastrointestinal hyperplasia with altered expression of DNA polymerase $\beta$. PLoS ONE 4(8): Article number e6493

9. Yoshizawa K, Brix AE, Sells DM, Jokinen MP, Wyde M, Orzech DP, Kissling GE, Walker NJ, Nyska A. (2009) Reproductive lesions in female Harlan Sprague-Dawley rats following two-year oral treatment with dioxin and dioxin-like compounds. Toxicol Pathol 37(7): 921-937

\section{総 説}

1. Tsubura A, Yuri T, Yoshizawa K, Uehara N, Takada H. (2009) Role of fatty acids in malignancy and visual impairment: Epidemiological evidence and experimental studies. Histol Histopathol 24(2): 223-234

その他

1. 頼 彦長, 圦 貴司, 兼松清果, 桑田満喜, 螺良愛郎 . (2009) 若年と高齢での妊娠を模倣する短期エストロ ゲンとプロゲステロン処置による乳癌発生への影響 と乳腺脂肪織の役割。乳癌基礎研 18:23-27

\section{学会発表}

1. Nyska A, Yoshizawa K, Tani Y, Jokinen M. P, Lieuallen W and Dunnick J. (2009) Toxicologic pathology aspects of chemically induced cardiovascular toxicity, as seen in national toxicology program studies. The 7th Europ Cong Toxicol Pathol, Hague, The Netherlands

2. Kuwata M, Yoshizawa K, Matsumura M, Takahashi K and Tsubura A. (2009) Ocular toxicity caused by paclitaxel in neonatal Sprague-Dowley rats. The 28 th Soc Toxicol Pathol Annual Symp, Washington DC

3. 頼 彦長, 圦 貴司, 上原範久, 松岡洋一郎, 兼松清 果, 桑田満喜, 螺良愛郎 (2009) Biphasic effect of shortterm pregnancy hormone in young and old rats in MNUinduced mammary cancers. 第98回日本病理学会, 京都

4. 義澤克彦 (2009) 毒性評価とその概要「ダイオキシン の毒性」.2009年度「知の市場」, 東京

5. 岡島 愛, 是枝ちづ, 吉川恵史, 池田耕造, 関 寿人, 岡崎和一, 北出浩章, 四方伸明（2009）14年間の経過 観察にて進行が緩徐であったPBCの1例. 第38回日本 肝臓学会西部会, 鳥取県

6. 義澤克彦, 大石祐司, 螺良愛郎 (2009) 眼毒性 (網膜 毒性) 発症に打ける分子生物的変化. 第 10 回日本毒性
病理学会教育セミナー, 東京

7. 三城弥範, 常見幸三, 溝尻 岳, 大坪 大, 伊藤卓資, 中江史朗, 豊田昌夫, 仙崎英人, 螺良愛郎 (2009) 肝 囊胞としてフォローされていた胆管腔内乳頭状腫瘍 (IPNB) の 1 手術例. 第 71 回日本臨床外科学会総会, 京都

8. 木下勇一, 松永志保, 市邊和男, 生田明子, 植村芳子, 坂井田紀子, 足立 靖, 圦貴司, 鷹巣晃昌, 四方伸 明（2009）腹膜に進展した高分化乳頭型胸膜中皮腫の 一例. 第48回日本臨床細胞学会秋期大会, 福岡

9. Uehara $\mathrm{N}$ and Tsubura A. (2009) Role of p38MAPK in a cell-death pathway tviggered by suberoylanilide hydroxamic acid (SAHA) in human breast cancer cells. 日本癌 学会, 横浜

10. 義澤克彦 (2009) A critical comparison of murine pathology and epidemiological data of dioxins and PCBs. 第 41 回日本臨床分子形態学会, 神戸

11. 桑田満喜, 義澤克彦, 頼 彦長, 高橋寛二, 螺良愛郎 ．（2009）抗腫瘍薬 Paclitaxelによる新生仔ラットへの 眼毒性の検討. 第 41 回日本臨床分子形態学会, 神戸

12. 兼松清果, 上原範久, 三城弥範, 桑田満喜, 義澤克彦, 川中彩子, 圦 貴司, 螺良愛郎. (2009) Sulforaphane による乳癌細胞増殖抑制におけるアポトーシスと オートファジー誘導. 第 41 回日本臨床分子形態学会, 神戸

13. 三城弥範, 常見幸三, 溝尻 岳, 大坪 大, 高橋 毅, 伊藤卓資, 中江史朗, 豊田昌夫, 螺良愛郎, 仙崎英人, 橋本可成. (2009) 食道類基底細胞癌の一手術症例. 第 41 回日本臨床分子形態学会, 神戸

14. 上原範久, 螺良愛郎 (2009) 妊娠を契機とした乳腺発 癌耐性獲得の分子基盤. 第 41 回日本臨床分子形態学 会, 神戸

15. 川中彩子, 富永和也, 和唐雅博, 益野一哉, 西川哲成, 螺良愛郎, 田中昭男 (2009) ヒト歯根膜線維芽細胞に 対するエムドゲイン由来のペプチドの作用機序. 第 41 回日本臨床分子形態学会, 神戸

16. 螺良愛郎（2009）ヒト網膜色素変性症動物モデルの確 立と病態制御. 第 41 回日本臨床分子形態学会, 神戸

17. 頼 彦長, 兼松清果, 桑田満喜, 三城弥範, 川中彩子, 義澤克彦, 螺良愛郎 (2009) Short-term pregnancy hormones in young and old rats with MNU-induced mammary cancers. 第 41 回日本臨床分子形態学会, 神戸

18. 圦 貴司, 大石賢玄, 横井川規巨, 兼松清果, 頼 彦 長, 三城弥範, 高田秀穂, 螺良愛郎 (2009) 脾横行結 腸間膜巨大腫瘍の 1 例. 第 41 回日本臨床分子形態学会, 神戸

19. 兼松清果, 上原範久, 松岡洋一郎, 螺良愛郎 (2009) Sulforaphane の乳癌細胞増殖抑制とオートファジー. 第17回日本乳癌学会, 東京

20. 木下勇一, 松永志保, 高畠 希, 市邊和夫, 生田明子, 植村芳子, 坂井田紀子, 足立 靖, 块貴司, 鷹巣晃 
昌, 四方伸明 (2009）悪性胸膜 ・腹膜中皮腫が疑われ た 1 例. 第十五回大阪病理研究会, 大阪

21. 桑田満喜, 義澤克彦，頼 彦長，螺良愛郎 (2009) 新生仔ラットに対する Paclitaxel 誘発眼毒性. 第 98 回 日本病理学会, 京都

22. 兼松清果, 上原範久, 松岡洋一郎, 螺良愛郎 (2009) Sulforaphane による乳癌細胞増殖抑制におけるオート ファジー誘導の役割。第98回日本病理学会, 京都

23. 上原範久, 兼松清果, 松岡洋一郎, 螺良愛郎 (2009) ヒストン脱アセチル化酵素阻害剂による MAP キナー セシグナルを介した乳癌細胞死誘導機序. 第98回日本 病理学会, 京都

24. 圦 貴司, 頼 彦長, 兼松清果, 螺良愛郎 (2009) 短 期高用量エストロゲンによる乳腺分化促進と非浸潤 性乳癌発生抑制に関する実験的検討. 第98回日本病理 学会, 京都

25. 桑田満喜, 義澤克彦, 高橋寛二, 螺良愛郎 (2009) Pacli- taxelの新生仔ラットに対する眼毒性の検討．第113回 日本眼科学会総会, 東京

26. 木下勇一，濱口記久子，松永志保，市邊和男，李＼cjkstart重 煥, 鷹巣晃昌, 四方伸明, 足立 靖, 圦 貴司, 生田 明子（2009）子宮体部原発明細胞腺癌の一例. 第34回 日本臨床細胞学会大阪府支部 学術集会, 大阪

27. 黒川一郎, 鶴田大輔, 山本明美, 水野信之, 曽和順子, 石井正光, 水谷 仁, 螺良愛郎 (2009) Comedonal Darier' s disease におけるケラチン・フィラグリン発 現 免疫組織化学的研究. 第108回日本皮膚科学会, 福岡

\section{著 書}

1. 義澤克彦 (2009) 呼吸器毒性, 皮膚 - 粘膜毒性, 血 液・造血毒性, 免疫毒性. 第12回日本卜キシコロジー 学会基礎教育講習会 143-169 頁, 日本トキシコロ ジ一学会, 東京

\section{微生物学講座}

\section{〈研究概要〉}

ヒト T細胞白血病ウイルス（HTLV-1）は成人 T細胞白血病（ATL）に加え，難治性の脊髄疾患である HTLV-1関連脊髄 対麻痺（HAM; HTLV-1-associated myelopathy）等種々の自己免疫様疾患の原因となるヒトレトロウイルスである. 本邦 には約 108 万人の HTLV-1感染者が存在し，5～10\%の生涯発症率でATLを発症するが，ATLに対する治療法は未だに確 立されておらず，平均余命は 1 年に満たない，微生物学教室では，どのような機序で一部の感染者が白血病や神経疾患を

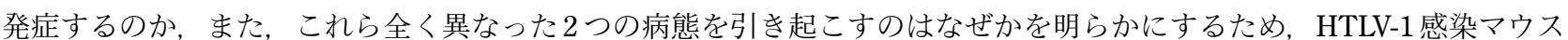
モデルの確立を試みている，これまでに，ヒト造血幹細胞を移植した重症免疫不全マウス（NOG-SCID; NOD-SCID/IL-2 receptor $\gamma$ chain knock-out)にHTLV-1を感染させることにより, ATL様の感染Tリンパ球の異常増殖とHAMに類似した感 染 $\mathrm{T}$ 細胞の脊髄浸潤を再現することに成功している. 現在, 同感染モデルマウスを中心に, ATLおよびHAMの発症機序 の解明と治療法の開発に向けて研究を進めている.

1）HTLV-1感染ヒト化マウスモデルを用いたATLおよびHAM発症機序の解明

HTLV-1 感染者の一部でのみ ATL やHAM が発症する要因として, 感染者体内の宿主免疫とウイルス感染細胞の動態の バランスが重要な役割を果たしていると考えられている。この関係を明らかにし，これをATL発症予防ワクチンの開発・ 評価に応用する目的で, NOG-SCID マウスの骨髄内にヒト臍帯血由来造血幹細胞を移植しヒ卜造血細胞系を再構築した マウス（ヒト化マウス, hu-NOG）を作製したうえ，この腹腔内に HTLV-1感染細胞を移入することで，マウス個体内の ヒトT細胞にHTLV-1を感染させることに成功した.

この HTLV-1感染ヒト化マウスは，感染数ヶ月で脾腫をきたし，ATLと同様な花弁様分葉核を持つHTLV-1感染 CD4陽 性 T 細胞の異常増殖が観察された。 また, 骨骾移植後早い時期に HTLV-1 感染させた場合, 約 1 ヶ月後に歩行困難を示 すマウスが出現したため, 剖検したところ, HAM で見られるのと同様に，脊䯣内に HTLV-1 感染細胞の浸潤が観察され た. 今後, 感染の時期や移入感染細胞の量等を検討することで, これら異なった 2 種類の HTLV-1関連疾患様の病態の発 生要因を明らかにしていきたいと考えている.

2) HTLV-1感染マウスを用いた HTLV-1感染細胞の動態解析

これまで，HTLV-1 はマウスに感染しないと考えられてきたが，野性型マウス腹腔内に HTLV-1 感染ヒト T 細胞株を移 入することで, マウスのTリンパ球にHTLV-1を感染させることに成功した。そこで, 同感染マウスを用いて, 感染T細 胞の経時的な増加や表面マーカーの変化を追跡することで，長い潜伏期における感染細胞の動態を解析している.

HTLV-1 感染マウス個体内の感染細胞は，感染初期においてはCD4(+)CD25(-)T 細胞を中心とする複数の T 細胞クロー ンであったが，感染後期では限られた数の CD4(+)CD25(+)T 細胞クローンであり，これは腫瘍細胞の選択過程を再現し ているものとして注目している，また，HTLV-1の感染が樹状細胞にも観察され，樹状細胞が感染のリザーバーとなる可 能性が示唆された. 
3）個体レベルでの HTLV-1遺伝子発現抑制機構の解析

HTLV-1の発現は感染者体内では可逆的に抑制されており，これがATL発症における長い潜伏期の原因のひとつと考え られている，そこで，この個体内特異的なウイルス発現抑制機構を明らかにするため, HTLV-1遺伝子を発現するように 改変したマウスリンパ腫細胞株（EL4）のマウス移植系を用いて, 個体内特異的な遺伝子発現抑制機構を再現し, これま でに，転写抑制における転写補助因子TORC2の関与，打よび抗Tax DNAワクチン投与による腫瘍増殖抑制効果を明らか にしてきた．現在，個体レベルで遺伝子発現が経時的に解析できる “in vivo イメージング”の手技を用いて，個体内に おけるウイルス感染細胞の動態解析を進めている.

4）In vivoイメージングを用いた同種骨髄移植によるATL治療法の検討

近年, 非骨髄破壊的同種骨髄移植を用いたATL 治療において抗 Tax CTLの再構築を伴う寛解例が報告されている. そ の際, GvHDの制御が大きな課題となっていることから, 本学, 病理学第一講座のグループによって開発された骨髄内骨 髄移植とリンパ球輸注の組み合わせによる，GvHD を伴わない抗がん治療法の応用を，上記，HTLV-1遺伝子発現マウス リンパ腫細胞のマウス移植系を用いて検討している.

そのために, HTLV-1遺伝子発現マウスEL4細胞にルシフェラーゼ遺伝子を導入し，ルシフェラーゼの発光活性を指標 に，in vivoイメージング装置を用いて体内での腫瘍増殖を経時的に計測する系を確立した。この系を用い，これまでに， 自家および他家骨髄移植とリンパ球輸注の併用により, HTLV-1遺伝子発現EL4 細胞の腫瘍増殖抑制を観察している. 今 後，腫瘍増殖抑制に関与する細胞成分の同定及びワクチン療法への応用等を検討中である.

\section{〈研究業績〉}

原 著

1. Murata M, Matsuzaki K, Yoshida K, Sekimoto G, Tahashi Y, Mori S, Uemura Y, Sakaida N, Fujisawa J, Seki T, Kobayashi K, Yokote K, Koike K and Okazaki K (2009) Hepatitis B virus X protein shifts human hepatic transforming growth factor (TGF)-beta signaling from tumor suppression to oncogenesis in early chronic hepatitis B. Hepatology 49(4): 1203-1217

2. Yanai S, Adachi Y, Fuijisawa J, Jiang S, Okigaki M, Shi M, Shima C, Imai Y, Kwon AH and Ikehara S (2009) Antitumor effects of fusion cells of type 1 dendritic cells and Meth A tumor cells using hemagglutinating virus of Japan-envelope. Int J Oncol 35(2): 249-255

3. Tanaka M, Nitta T, Yoshida T, Konishi T, Kawazu Y, Fujisawa J and Miwa M. (2009) Clonal proliferation of HTLV-1-infected cells is associated with spontaneous malignant tumor formation in mice. Int J Oncol 35(4): 701-707

4. Kimura T, Hashimoto I, Nishikawa $\mathrm{M}$ and Yamada $\mathrm{H}$ (2009) Nucleocytoplasmic transport of luciferase gene mRNA requires CRM1/Exportin1 and RanGTPase. Med Mol Morphol 42(2): 70-81

5. Jiang S, Inada T, Tanaka M, Furuta RA, Shingu K and Fujisawa J-I (2009) Involvement of TORC2, a CREB coactivator, in the in vivo-specific transcriptional control of HTLV-1. Retrovirology 6(ArticleNo. 73): 1-16

\section{学会発表}

1. Lu Zeng, Takahiro Fujii, Emi Ohta, Masakazu Tanaka, Satoshi Honjo, Petcharin Srivatanakul, Mantana Matharit, Chutiwan Viwatthanasittiphong, Dhiraphol Chenvidhya, Adisorn Jedpiyawongse and Masanao Miwa (2009) Polymorphisms of DNA repair-related genes and risk for cholangiocarcinoma in northeast Thailand. 20th Asia Pacific Cancer Conference, Tsukuba, Japan

2. 荀 潤澤, 手塚健太, 田中正和, 三輪正直, 竹之内徳 博, 藤澤順一（2009）HTLV-1 感染ヒト化マウス T 細 胞におけるCD25の活性化. 第57回日本ウイルス学会 学術集会, 東京

3. Lu Zeng, Akihiro Ueda, Emi Ohta, Masakazu Tanaka, Satoshi Honjo, Petcharin Srivatanakul, Mantana Matharit, Chutiwan Viwatthanasittiphong, Dhiraphol Chenvidhya, Adisorn Jedpiyawongse and Masanao Miwa (2009) Genetic and environmental risks for cholangiocarcinoma in Ubon Ratchathani, northeast Thailand. 9th Korea-Japan Symposium on Cancer and Ageing Research, DamYang Resort, Korea

4. Masanao Miwa, Masataka Tsuda, Masatoshi Mushiake, Masaki Yamada, Kouji Tanaka, Masakazu Tanaka, JunIchi Fujisawa and Emi Ohta (2009) Effect of inhibitor of poly(ADP-ribose) polymerases on centrosome amplification and chromosome number abnormality. 9th KoreaJapan Symposium on Cancer and Ageing Research, DamYang Resort, Korea

5. 木村富紀, 蒋 時文, 西澤幹雄, 西川正雄, 阿部紘平, 今別府勇介, 植野誠之, 鬼頭頼子, 玉置直也, 松崎典 子（2009） Natural antisense transcript stabilizes interferon-alpha1 mRNA and increases protein expression, which are induced upon viral infection. 第32 回日本分子 生物学会年会, 横浜

6. 木村富紀, 蒋 時文, 西澤幹雄, 西川正雄, 阿部紘平, 今別府勇介, 植野誠之, 鬼頭頼子, 玉置直也，松崎典 子（2009） Natural antisense transcript stabilizes interferon-alpha1 mRNA and increases protein expression, which are induced upon viral infection. 第32 回日本分子 生物学会年会, 横浜

7. 手塚健太, 荀 潤澤, 田中正和, 三輪正直, 竹之内徳 
博, 藤澤順一（2009）HTLV-1 感染ヒト化マウスモデ ルにおける感染 $\mathrm{T}$ 細胞の異常増殖とクローン選択. 第 62 回日本細菌学会関西支部総会, 泉佐野

8. 手塚健太, 荀 潤澤, 田中正和, 三輪正直, 竹之内徳 博, 藤澤順一（2009） ヒト化マウスモデルにおける HTLV-1感染CD25+T細胞のクローナル増殖. 第57回 日本ウイルス学会学術集会, 東京

9. 長谷川翔, 橋本岩雄, 田中正和, 足立 靖, 池原 進, 三輪正直，藤澤順一（2009）マウスモデルを用いた骨 髄移植ノリンパ球輸注による抗ATL治療法の検討. 第 57 回日本ウイルス学会学術集会, 東京

10. 鄭 真美, 田中正和, 長谷川翔, 手塚健太, 津田洋幸, 藤澤順一, 三輪正直（2009）ラクトフェリンによる個 体レベルでの HTLV-1感染抑制機構. 第57回日本ウイ ルス学会学術集会, 東京

11. 田中浩司, 田中正和, 津田雅貴, 藤澤順一, 三輪正直 （2009）DNA 修復阻害または DNA 損傷誘導により HTLV-1 感染細胞より産生されるウイルス粒子感染 性. 第57回日本ウイルス学会学術集会, 東京

12. 三輪正直, 山田真生, 津田雅貴, 虫明正敏, 中山敬子, 中山敬一，藤澤順一，田中正和（2009）DNA損傷で誘 導される中心体増幅の新しいシグナル経路. 第68回日 本癌学会学術総会, 横浜

13. 手塚健太, 田中正和, 孫 䰅蓮, 津田雅貴, 藤澤順一, 三輪正直（2009）HTLV-1 感染時に打けるシアル酸の 役割について．第68回日本癌学会学術総会, 横浜

14. 曽 路, 太田恵美, 藤井貴弘, 田中正和, 本荘 哲, 三 輪正直（2009）タイ王国での肝内胆管がんの発がんに おいての遺伝的要因. 第68回日本癌学会学術総会, 横 浜

15. 大谷 清, 岩永律子, 大園瑛子, 山岡昇司, 藤澤順一 (2009）HTLV-1 Taxの細胞種特異的な作用. 第68回日
本癌学会学術総会, 横浜

16. 虫明正敏, 津田雅貴, 田中正和, 藤澤順一，藤井貴弘， 三輪正直（2009）ポリADP-リボシル化の阻害が中心 体数と染色体数へ及ぼす影響. 第68回日本癌学会学術 総会, 横浜

17. 田中正和，荀 潤澤，手塚健太，巽 理恵，竹之内徳 博, 三輪正直, 藤澤順一 (2009) ヒト化学マウスモデ ルにおける HTLV-1感染CD4CD25陽性T細胞のクロー ナル増殖性と Tax 特異的な CTL検出について. 第68回 日本癌学会学術総会, 横浜

18. 田中浩司, 田中正和, 藤澤順一, 三輪正直 (2009) レ トロウイルス感染におけるポリADP-リボシル化酵素 (PARP) の関与について. 第82回日本生化学会大会, 神戸

19. 曽 路, 上田明弘, 太田恵美, 田中正和, 三輪正直, 本荘 哲, Petcharin Srivatanakul, Adisorn Jedpiyawongse, Mantana Mathrit, Chutiwan Viwatthanasittiphong, Dhiraphol Cehnvidhya（2009）タイの肝吸虫感 染関連胆管がん発がんにおける DNA 修復遺伝子 XRCC1 多型の予防効果. 「がん予防大会 2009 愛知」 第 16 回日本がん予防学会, 第 32 回日本がん疫学研究 会, 名古屋

20. 竹之内徳博，手塚健太，田中正和，荀＼cjkstart潤澤，三輪正 直, 藤澤順一（2009） ヒト免疫化 HAM マウスモデル における脊髄の解析. 第 50 回日本神経学会総会, 仙台

著 書

1. 田中正和, 鄭 真美, 小西智子, 河津祐介, 長谷川翔, 手塚健太, 津田洋幸, 藤澤順一, 三輪正直 (2009) 分 担執筆 ラクトフェリンによる HTLV-1 感染抑制効 果. ラクトフェリン 2009 (第3回ラクトフェリンフォー ラム実行委員会編) 55-62 頁, 日本医学館, 東京, 日本

\section{衛生学講座}

\section{〈研究概要〉}

衛生学講座は大学院医学研究科先端医療学専攻修復医療応用系で幹細胞生物学を担当している. このため幹細胞生物 学に基づいて, 主としてヒトの骨髄あるいは臍帯血に由来する組織幹細胞を用いるトランスレーショナルリサーチの展 開を目指している. さらに，これらの基礎的研究成果を近い将来に細胞治療・再生医療，免疫療法に応用することで予 防医学に貢献したいと考えている.

1）ヒト臍帯血由来CD34 抗原陰性造血幹細胞の同定とその幹細胞特性の解明に関する研究

最近, 私達の研究グループは, 独自に開発した骨髄腔内直接移植 (Intra-bome marrow injection, IBMI) 法を応用するこ とにより，非常に効率的なヒト未分化造血幹細胞（HSC）の同定法であるSCID-repopulating cell (SRC)測定系を開発した. 本法を用いることにより，ヒト臍帯血中に極めて少数存在するCD34抗原陰性造血幹細胞（CD34-HSC）の確実な同定に 世界に先駆けて成功した（Blood 101: 2924-2931, 2003）。さらに，このCD34-SRCが，in vivoに打り高い自己複製能と 増殖能・遊走能を保持していることを明らかにしている（Int J Hematol 79: 328-333, 2004）。重要な発見は, 従来, 未分 化な HSCに作用すると報告されていた stem cell factor, flt3 ligandのチロシンキナーゼ受容体であるc-kit, flt3が, われわれ が同定したCD34-SRCには発現していないことを明らかにしたことである（Blood 106(11): 235a, 2005). 以上の研究によ

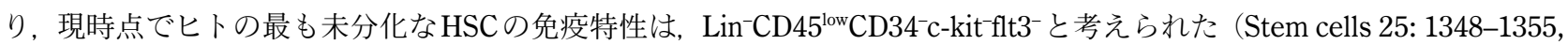
2007; J Autoimmunity 30: 136-144, 2008). 
その後の研究で, 従来未分化 HSC とされていたCD34 CD38-HSC とCD34-HSCの未分化性についてNOGマウスを用い る長期骨䯣再構築実験系で検討した，その結果，われわれが同定したCD34-HSC がより未分化であることが示唆された (Termis $2^{\text {nd }}$ World Congress Sep 2, 2009 発表, 投稿中).

当初開発したCD34-細胞の純化法では，臍帯血由来CD34-SRCの頻度は約 $1 / 25,000$ であった，われわれは，最近，各種 lineage 抗体を用いる negative selection 法を改良することにより, 臍带血由来 CD34-SRC の頻度を約 1/1,000 まで高めるこ とに成功している（第51回米国血液学会発表 (Blood 114: 336, 2009, 投稿中).

2）ヒト骨髄あるいは臍帯血に由来する組織幹細胞（TCSC）の同定とその機能解析に関する研究

ヒト骨䯣あるいは臍帯血中には，HSCだけでなく間葉系幹細胞（MSC）, あるいは多能性をもつ既知，未知のTCSCが 存在している，われわれは，磁気ビーズ法やFACS を駆使することにより，ヒトの骨䯣や臍帯血中に存在する多能性の TCSCの同定・純化法の開発・確立に取り組んできた。

その過程で，ヒト臍帯血由来単核細胞を type I コラーゲン処理した培養㿼中でEGM2 培地を加えて $1 \sim 2$ 週間培養し， cobblestone 様の late EPC (OEC) のコロニーを同定した. 本細胞は, CD31, KDR, CD34 抗原陽性で Dil-Ac-LDL-uptake, UEA-1 lectin 結合能を示したことから OEC と確認された. これまでの研究で, CXCL8（IL-8）が OECの migration 能や， matrigel中での tube formation等の機能を促進することを明らかにしている（投稿中）.

加えて, ヒト骨髄あるいは臍帯血中に存在する未知のTCSCの同定とその機能解析を目指す研究を継続している.

3）骨䯣腔内直接移植法による新規マウス造血幹細胞の探索研究

骨髄ニッチにおける造血幹細胞（HSC）の維持，増殖に必須の分子，c-kitおよびCXCR4の役割について検討を行った， 一般的にマウス HSC は，c-kitを高度に発現するc-kit(+)Sca-1(+)Lineage(-)（KSL）分画に存在すると考えられているが, c-kit(low) 分画にも頻度は低いがHSCが存在すること，およびc-kit(low)分画は強力な HSC 活性を有し, KSL細胞を産生す ることを明らかにした（第71回日本血液学会発表）。一方，CXCR4 は骨䯣 KSL 細胞の細胞表面には殆しど発現しないこ とを明らかにしている（The 7th Stem Cell Research Symposium及び第71回日本血液学会発表, Int J Hematol 90: 553-560, 2009). 現在，定常状態でCXCR4が発現しないメカニズムとその意義を検討中である.

4）樹状細胞によるTヘルパー応答制御機構の解明と免疫疾患新規治療法の開発研究

これまでNKT細胞機能，および免疫制御の中心的役割を担う樹状細胞の抗腫瘍拒絶応答，自己免疫応答，抢よびアレ ルギー応答における役割と獲得免疫系との連携メカニズムを明らかにしてきた。具体的には，(1)内分泌系が樹状細胞機 能に及ぼす影響の解析 (アレルギー応答), (2)妊娠維持における脱落膜NKT細胞の役割の解明 (移植拒絶制御), (3) NKT 細胞と樹状細胞の相互作用による免疫制御機構の解明（抗腫瘍・自己免疫制御）である. 特に(3に扑いて, ヒト NKT

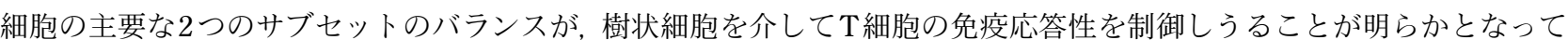
抢り（第71回日本血液学会発表, J Immunol 183: 201-208, 2009), 移植片対宿主病, 抗腫瘍拒絶応答, 炎症性晹疾患, 自 己免疫疾患を制御する新たな医療技術の開発へと発展させていきたい.

5）多能性歯髄幹細胞の探索と再生医療への応用

歯髄幹細胞（DPSC）の特性について検討した，歯髄細胞の多分化能について明らかにするため，骨，脂肪と骨格筋へ の分化を試みた。 その結果, 歯䯣中に骨, 脂肪へと分化可能な細胞が存在し, 5-aza-2'-deoxycytidine（5-aza）により骨格 筋への分化が認められた（第 8 回日本再生医療学会発表, 投稿中).さらにDPSC の純化を目的とし, 予期的分離と局在 の解析を行ったところ, 骨䯣間葉系幹細胞様の増殖能, 分化能を有する Sca-1, PDGFR-alpha 共陽性の DPSC がマウス切 歯に打ける幹細胞ニッチと考元られている常生歯形成端に存在することが示唆された（The 7th Stem Cell Research Symposium, 第32回日本分子生物学会発表).

6）食餌制限動物におけるストレス耐性增強機序の解明に関する研究

実験動物に打いて, 食䬣制限がストレス耐性の增強効果を示すことが知られている。これまでに, 48時間絶食したラッ 卜から調製した血清存在下で培養した細胞を用いた実験系を「食䭒制限の in vitro モデル」として確立し，絶食ラット血 清で培養した細胞において, 各種熱ショックたんぱく質遺伝子の熱ショックによる発現誘導率が自由摂取群ラット血清 で培養した細胞に比べて上昇し，それに伴い細胞の熱耐性が増強されることを見出した．絶食ラット血清においてイン スリン濃度の低下が認められたため, 絶食ラット血清にインスリンを添加して培養したところ, 熱ショックによる発現 誘導率の上昇が抑制された。 これらの結果, 短期絶食による各種熱ショックたんぱく質遺伝子の発現誘導率上昇に, イ ンスリン濃度の低下が関与する可能性が示唆された（第79回日本衛生学会発表）.

\section{〈研究業績〉}

原 著

1. Kouda K, Kohno H, Nakamura H, Ha-Kawa SK, Sonoda $\mathrm{Y}$ and Iki M (2009) Technetium-99m-GSA clearance in mice under long-term dietary restriction. Ann Nucl Med
23(2): $123-129$

2. Nishio N, Kouda K, Nishio J, Nakamura H, Sonoda Y and Takeshita T (2009) Smoking prevalence among dentists in Hyogo, Japan 2003. Ind Health 47(4): 431-435

3. Sasaki Y, Matsuoka Y, Hase M, Toyohara T, Murakami 
M, Takahashi M, Nakatsuka R, Uemura Y and Sonoda Y (2009) Marginal expression of CXCR4 on c-kit ${ }^{+}$Sca$1^{+}$Lineage $^{-}$hematopoietic stem/progenitor cells. Int $\mathrm{J}$ Hematol 90(5): 553-560

4. Uemura Y, Liu TY, Narita Y, Suzuki M, Nakatsuka R, Araki T, Matsumoto M, Iwai LK, Hirosawa N, Matsuoka Y, Murakami M, Kimura T, Hase M, Kohno H, Sasaki Y, Ichihara Y, Ishihara O, Kikuchi H, Sakamoto Y, Jiao SC, Senju S and Sonoda Y. (2009) Cytokine-dependent modification of IL-12p70 and IL-23 balance in dendritic cells by ligand activation of Valpha24 invariant NKT cells. J Immunol 183(1): 201-208

\section{学会発表}

1. Murakami M, Matsuoka Y, Nakatsuka R, Takahasi M, Nakamoto T, Yasuda K, Matsui K, Uemura Y, Sasaki Y, Tsuji T, Fukuhara S and Sonoda Y (2009) High Resolution Purification and Characterization of Human Cord Blood-Derived CD34-negative SCID-Repopulating Cells with a Very Immature Phenotype. 51th ASH Annual Meeting And Exposition, New Orleans, LA

2. 中塚隆介, 薗田精昭 (2009) Multipotent mouse Sca-1 and PDGER\&alpha; double positive DPSCs exist in tooth forming niche. 第32回日本分子生物学会総会, 横浜

3. Liu T, Uemura Y, Narita Y, Suzuki M, Senju S and Sonoda Y (2009) Cytokine-dependent modification of IL12 p70 and IL-23 balance in dendritic cells by ligand activation of V $\alpha 24$ invariant NKT cells. 第39回日本免疫学 会総会, 大坂

4. Uemura Y, Liu T, Narita Y, Suzuki M, Nakatsuka R, Hirosawa N, Matsuoka Y, Murakami M, Hase M, Kohno H, Sasaki Y, Sakamoto Y, Senju S and Sonoda Y (2009) Modification of IL-12p70 and IL-23 balance in dendritic cells by Valpha24 invariant NKT cells. 第 71 回日本血液 学会学術総会, 京都

5. Sonoda Y, Kimura T, Matsuoka Y, Murakami M, Nakamoto T, Yasuda K, Nakatsuka R, Uemura Y and sasaki Y (2009) In Vivo Dynamics of Human Cord Blood-derived CD34- SCID-Repopulating Cells(SRCs) in Comparison to CD34+CD38+ and CD34+CD38+SRCs Using IntraBone Marrow Injection. Seoul Stem Cell Symposium, Seoul

6. Nakatsuka R, Matsuoka Y, Uemura Y, Sasaki Y and Sonoda Y (2009) Isolation of mouse dental pulp-derived Sca$1+$ PDGFR $\alpha+$ tissue-committed stem cells. The 7 th Stem Cell Research Symposium, Izumi Garden Gallery

7. Sasaki Y, Matsuoka Y, Toyohara T, Hase M, Nakatsuka
R, Uemura Y and Sonoda Y (2009) Kinetics of CXCR4 expression on murine steady state KSL cells. The 7th Stem Cell Research Symposium, Izumi Garden Gallery

8. 村上真理, 松岡由和, 中塚隆介, 植村靖史, 佐々木豊, 福原資郎, 薗田精昭（2009） ヒト未分化 CD34 抗原陰 性造血幹細胞の純化とその特性解明. 第71回日本血液 学会学術集会, 京都

9. 佐々木豊, 松岡由和, 豊原貴之, 長谷 真, 中塚隆介, 植村靖史, 薗田精昭（2009）マウス骨髄造血幹/前駆 細胞は, CXCR4 低発現である. 第 71 回日本血液学会 学術総会, 京都

10. 松岡由和, 佐々木豊, 中塚隆介, 植村靖史, 㝨田精昭 （2009）マウス骨䯣由来 Lineage-Sca-1+c-kit low/- 細胞 の造血幹 (前駆) 細胞特製の解明. 第71回日本血液学 会学術総会, 京都

11. 植村靖史, 薗田精昭（2009）NKT細胞のアジュバント 効果と抗腫瘍免疫応答への応用. 第19回日本サイトメ トリー学会学術集会, 松江

12. 石原敬康, 河野比良夫, 甲田勝康, 西尾信宏, 中村晴 信, 伊木雅之, 薗田精昭（2009）間欠的短期絶食によ る遅延型アレルギー性皮膚炎の抑制機構. 第79回日本 衛生学会学術総会, 東京

13. 中塚隆介, 野崎中成, 松岡由和, 菅野渉平, 植村靖史, 佐々木豊, 薗田精昭（2009）CD45 陰性歯髄幹細胞 の探索と筋系譜細胞への分化転換. 第8 回日本再生医 療学会, 東京

14. 兼子裕人, 志村和穂, 大川原康夫, 薗田精昭, 大城宗 生, 山下美穂子, 堀池重夫, 横田昇平, 谷脇雅史 (2009) 再発・抵抗性悪性リンパ種に対する自己末梢血幹細胞 移植前の再導入療法の検討. 第31回日本造血細胞移植 学会総会, 札幌

15. 木村 卓, 松岡由和, 植村 靖, 佐々木豊, 福原資郎, 薗田精昭（2009）臍帯血由来血管内皮前駆細胞に対す るIL-8の作用について. 第31回日本造血細胞移植学会 総会, 札幌

\section{著 書}

1. 薗田精昭（2009）造血幹細胞の本体はどこまで解明さ れたのか. 造血器腫瘍アトラス 改訂第 4 (阿部達生 編）17-33頁，日本医事新報社，東京

2. 佐々木豊 (2009) 造血幹細胞ニッチ. 造血器腫瘍アト ラス 改訂第4 (阿部達生編) 34-36頁, 日本医事新報 社, 東京

3. 薗田精昭（2009）骨䯣内造血幹細胞移植．造血器腫瘍 アトラス 改訂第4 (阿部達生編) 538-543 頁, 日本医 事新報社, 東京 


\section{公衆衛生学講座}

\section{〈研究概要〉}

当講座が現在取り組んでいる研究テーマは，基礎医学から臨床まで多方面に渡っているが，予防医学に重点をおいた 研究が主である. 異なった研究分野の教員が様々な領域の研究を並行して行なうことにより, 広範囲にわたる公衆衛生 学の教育分野に対応できるよう日々研究を行っている.

1. 国際保健・感染症予防・渡航医学

感染症の疫学と予防に関する研究として国際保健医療として開発途上国における健康被害や健康管理に関する研究を 行っている. 特に熱帯感染症の診断と予防に関する研究では, ラオス人民民主共和国の僻地住民に対する健康実相調査 を行い様々な感染症に対する介入調査に取り組んでいる。 また，フィールドに扔けるタイ肝吸虫罹患患者の迅速診断法 の開発としてタイ肝吸虫は東南アジアを中心に生活する人々が生魚を食することにより感染する寄生虫疾患であり，こ の地域にかなりの罹患患者がいると推測される．この罹患患者をスクリーニングにより診断する迅速診断法は現在まで になく，この方法の確立が急務となっている，そこで，我々はタイ肝吸虫からスクリーニングに用いる特異抗原を探索 して, タイ肝吸虫患者を特異的に診断するキットの開発を試みている.

海外渡航者の健康管理に関する研究やそ扎に対する一次予防への取り組みの一環として, 附属滝井病院の海外渡航外 来に执いてワクチン接種や熱帯病の治療を行い，実戦的な臨床研究に取り組んでいる.

また, 在日外国人の医療に関して, 外国人が日本国内で医療機関を受診する際の障壁を減らすよう, 本年度は中国語 医療通訳のスキル向上並びに普及啓発を目的とした教科書を作成し，日本における制度化された医療通訳システム構築 を目指し医療通訳者の育成に取り組んでいる.

2. 難病治療のための再生医療

分子レベルでの再生医療への応用を図るために，現在話題となっている ES 細胞及び iPS 細胞などの万能細胞を用いて 神経細胞や内分泌細胞への分化誘導を試み, 難病治療への応用を検討することを目的としている. 具体的に体性幹細胞 の中でも組織に潜在する幹細胞についての非常に興味深い報告がある. これらの細胞は様々な器官や臟器でごく少数存

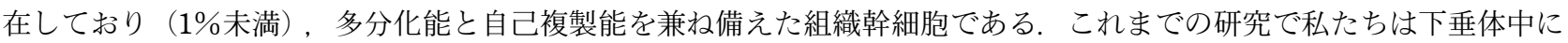
このような組織幹細胞の存在を確認し, かつHoechst33352を用いた染色により FACSでSide population（SP）細胞として 分取可能であることを明らかにした，その発現遺伝子をDNA arrayを用いて解析した結果, 幹細胞で高頻度に検出される 共通の遺伝子を強発現していることがわかった．さらに，下垂体幹細胞に存在する組織特異的な数種の遺伝子が強発現 していることが明らかとなった．これらの遺伝子が下垂体組織幹細胞のマーカー遺伝子となる可能性があり，その機能 解析を行うことを目的とする，具体的にこれらの遺伝子を肧性幹（ES）細胞または iPS 細胞に遺伝子導入し，その分化 誘導または未分化維持などを指標としてその機能を解析する。 これにより未知の組織特異幹細胞のマーカー遺伝子とし ての可能性並びに機能の詳細を知ることができると期待する.

3. 高齢者介護予防

高齢化社会に伴う健康の維持増進に関わる身体的機能の究明として身体機能低下を予防する運動療法や理学療法的な 面から介護予防と介護の労働の軽減について研究している. 特にオーストラリアと日本との比較から高齢者介護につい て検討を行い, 両国の施設高齢者の生活リズムを客観的に評価する為に, 腕時計型の小型高感度加速度センサー付き行 動計（アクチグラフ）を用いて測定した，その結果，オーストラリアの施設高齢者の $13 \sim 14$ 時では， 日本の施設高齢者 と比較して有意に活動量が多いことことが認められた．また，Wake after Onset Sleep（睡眠時の覚醒時間）においては， 日本の施設高齢者が最も長かった，オーストラリアで実践されている高齢者のコンプライアンスに合わせた支援である Diversional Therapy や自立支援を促す介護サービスが身体活動を高め，生活のリズムを適切に保つことが明らかになり， 行動計を用いた研究を他の方面にも活用し，高齢化社会に対する研究の施策になるように期待する.

また，高齢者の社会的孤立予防に着目し，郵便による介護予防情報誌を用いたコミュニケーションシステムの開発に 取り組み試験的な成果を得られ，広域な研究への取り組みとなった。

4. ヘルスツーリズム

旅行を活用したメタボリックシンドローム対策（ヘルスツーリズム）について研究している. 生活習慣病の予防には 健康生活を営むための食生活や運動習慣の定着が必要であるが, 非日常的な旅行行動から行動変容の効果と評価につい て継続して研究を行う.

\section{〈研究業績〉}

原 著

1. Hosomi R, Fukunaga $\mathrm{K}$, Arai $\mathrm{H}$, Nishiyama $\mathrm{T}$ and Yoshida M (2009) Effects of dietary fish protein on serum and liver lipid concentrations in rats and the expression of hepatic genes involved in lipid metabolism. J Agric Food Chem 57(19): 9256-9262

2. Okazaki K, Kawa S, Kamisawa T, Ito T, Inui K, Irie H, 
Irisawa A, Kubo K, Notohara K, Hasebe O, Fujinaga Y, Ohara H, Tanaka S, Nishino T, Nishimori I, Nishiyama T, Suda K, Shiratori K, Shimosegawa T and Tanaka M (2009) Japanese Clinical Guidelines for Autoimmune Pancreatitis. Pancreas 38(8): 849-866

3. Iharada A, Kaneko K, Tsuji S, Hasui M, Kanda S and Nishiyama T (2009) Increased nitric oxide production by $\mathrm{T}$ - and B-cells in idiopathic nephroticsyndrome. Pediatr Nephrol 24(5): 1033-1038

4. Hosomi R, Shimizu T, Fukunaga K, Kanda S, Nishiyama $\mathrm{T}$ and Yoshida M, (2009) Effect of Dietary L-Carnitine on Lipid Metabolism in Growing Rats. Trace Nutrients Res 26: 59-64

5. 三宅眞理, Anne Rock, 田近亜蘭, 保津真一郎, 仁木 稔, 平木宏児, 西山利正 (2009) オーストラリアと日 本の高齢者介護施設に打けるケアについての研究. オーストラリア研究 (22): 73-75

6. 濱田篤郎, 古賀才博, 福島慎二 (2009) 発展途上国に 長期滞在する日本人の予防接種状況の変化. 感染症誌 83(4): 375-379

7. 上田照子, 三宅真理, 西山利正, 田近亜蘭, 荒井由美 子（2009）要介護高齢者の息子による虐待の要因と多 発の背景. 厚生の指標 55(6): 19-26

8. 北川陽子, 起橋雅浩, 高取 聡, 岡本 葉, 福井直樹, 村田 弘, 住本建夫, 尾花裕孝（2009）GC/MS/MS を 用いた加工食品中の残留農薬一斉分析法の検討. 食品 衛生学雑誌 50(5): 243-252

9. 北川陽子, 起橋雅浩, 高取 聡, 岡本 葉, 福井直樹, 村田 弘，住本建夫，尾花裕孝（2009）GC/MSを用い た加工食品中の残留農薬一斉分析法の検討. 食品衛生 学雑誌 50(5): 198-207

10. 岡本 葉, 高取 聡, 北川陽子, 起橋雅浩, 福井直樹, 村田 弘, 住本建夫, 田中之雄, 尾花裕孝 (2009) LCMS/MS による餃子中の農薬一斉分析法の検討. 食品衛 生学雑誌 50(1): 10-15

11. 福島慎二, 大塚優子, 古賀才博, 奥沢英一, 津久井要, 安部慎治, 西川哲男, 濱田篤郎 (2009) 途上国に滞在 する日本人の自覚症状. 日本職業 - 災害医学会会誌 57(6): 319-325

12. 宮城 啓, 津守陽子, 中野貴司, 庵原俊昭, 石崎有澄 美, 市村 宏, 岩田 敏, 岡田賢司, 岡田純一, 金川 修造, 水野泰孝, 高山直秀, 西山利正, 三島伸介, 萩 原敏且，松本高明，濱田篤郎，福島慎二，春田恒和， 宮津光伸，渡邊 浩，尾内一信（2009）本邦に打ける 腸チフスワクチンと髄膜炎菌ワクチンの安全性と有 効性. 日渡航医学誌 2(1): 19-23

総 説

1. 古賀才博 (2009) パンデミックに備える一企業の新型 インフルエンザ対策一企業に求められる新型インフ ルエンザ対策．安全と健康 60(5): 436-439
2. 古賀才博 (2009) 企業のリスク管理者と産業医の先生 のための新型インフルエンザ対策. 海外赴任者, 海外 出張者のための対策 $17-18$

3. 西山利正, 三島伸介（2009）森の危険な生物たち 11 淡水魚介類から感染する寄生虫. 森林科学 (55): 3235

4. 福永健治, 細見亮太, 吉田宗弘 (2009) クックチルシ ステム。調理食品と技術 15(1): 27-32

5. 古賀才博 (2009) 発熱をもたらす感染症の鑑別 海外 渡航歴のあるとき。臨病理レビュー (143): 69-74

6. 古賀才博 (2009) 海外駐在員に対する新型インフルエ ンザ対策. 労政時報 (別冊) : 51-60

7. 小柳磨毅, 田中則子, 佐藤睦美, 中江徳彦, 木村佳記, 里田由美子, 森田裕介, 淵岡 聡 (2009) 膝のスポー ツ外傷・障害再発予防への理学療法の取り組み. 理学 療法 26(3): 417-424

\section{症例報告}

1. 三島伸介, 天野博之, 鈴木裕子, 神田靖士, 石田高明, 西山利正, 堀尾 修, 伊藤 誠, 木村英作 (2009) 末 梢血厚層塗抹法にてミクロフィラリアを検出したロ ア系状虫症の1例. Clinical Parasitology 19(1): 136-139

その他

1. 岡崎和一, 川茂 幸, 神澤輝実, 伊藤鉄英, 乾 和郎, 入江裕之, 入澤篤志, 久保惠嗣, 能登原憲司, 長谷部 修, 藤永康成, 大原弘隆, 田中滋城, 西野隆義, 西森 功, 西山利正, 須田耕一, 白鳥敬子, 下瀬川徹, 田中 雅夫（2009）自己免疫性膵炎診療ガイドライン 2009 . 膵臓 24(Supplment): S1-S54

学会発表

1. Hosomi R, Fukunaga K., Arai H, Nishiyama $\mathrm{T}$ and Yoshida M (2009) Effect of Dietary Fish Protein and Oil on Lipid Metabolism in Rats. 100th American Oil Chemists' Society Annual Meeting \& Expo, Orland Florida USA

2. Koga T, Fukushima S, Nishiyama $\mathrm{T}$ and Hamada A (2009) Three-year Follow-up Survey of Influenza Pandemic Preparedness Plans among Japanese Companies that Have Expanded their Business Overseas. 11th Conference of the International Society of Travel Medicine, Budapest, Hungary

3. Ooka H and Kanda S (2009) Identification of Tissue Specific Stem/Progenitor Cells in Auditory Pathway. 7departments joint meeting of otolaryngology 2009, hyogoken awajishima

4. Ooka H, Kanda S, Suzuki H, Nishiyama T and Tomoda K (2009) Identification of Tissue Specific Stem/Progenitor Cells in Auditory Pathway. Association for Research in Otolaryngology, Marylamd, USA 
5. 山中 裕, 三宅眞理, 櫻井一成, 戸祭達郎, 田中竜彦, 西山利正（2009）へルスツーリズムにおける森林セラ ピーの効果について-身体活動量計による運動の評価 と気分の変化. 日本行動療法学会 35 回大会, 千葉

6. 松下 寛, 山本 恵, 山中 裕, 三宅眞理 (2009) 特 別養護老人ホームにおける夜間排泄ケアに関する基 礎研究. 第10回日本認知症ケア学会大会, 東京

7. 三宅眞理, 上田照子, 渡邊完児, 田近亜蘭, 西山利正 （2009）介護老人福祉の介護作業における就業時間別 の身体活動の比較. 第68回日本公衆衛生学会総会, 奈 良

8. 細見亮太, 福永健治, 神田靖士, 西山利正, 吉田宗弘 （2009）コレステロール代謝に及ぼす魚肉タンパク質 給餌の影響. 第 82 回日本生化学会大会, 神戸

9. 細見亮太, 福永健治, 神田靖士, 西山利正, 吉田宗弘 （2009）ラットの脂質代謝に及ぼすプロタミン給餌の 影響. 平成 21 年度日本水産学会秋季大会, 岩手

10. 細見亮太, 福永健治, 神田靖士, 西山利正, 吉田宗弘 （2009）成長期ラットの脂質代謝に及ぼす L- カルニチ ン給餌の影響. 第48回日本油化学会, 名古屋市

11. 渡邊完児, 相澤徹, 渡辺一志, 弘原海剛, 米山冨士子, 三宅眞理，田中繁宏 (2009) 身体分節体積の簡易計測 法の検討. 第64回日本体力医学会大会, 新潟

12. 三島伸介, 西山利正, 天野博之, 宮城啓, 溝畑智子, 岡田千賀子, Phounsavath S, Phanmanivong V, Xaypangha T, Seuamlavanh S, 古賀康史, Lamaningao $\mathrm{P}$, Buonvatsana P (2009) ラオス人民民主共和国における 僻地住民に対する健康実相調査〜カムワン県マハサ イ郡にて. 第24回日本国際保健医療学会学術大会, 仙 台

13. 氏家無限，宮城啓，島崎貴冶，有吉紅也，三島伸介， 西山利正, 田之江崇文, 疋田直子, 森裕介, 原田早苗, 小野了代（2009）マラウィ共和国ンコヤコタ県ににお けるマラリア罹患率. 第24回日本国際保健医療学会学 術大会, 仙台

14. 大岡久司, 神田靖士, 岡崎はるか, 鈴木裕子, 西山利 正, 友田幸一 (2009) 聴覚伝導路における組織幹細胞 の同定および特徵付け. 第 27 回頭頸部自律神経研究 会, 大阪

15. 古賀才博, 福島慎二, 濱田篤郎（2009）海外派遣企業 のための新型インフルエンザ対策ガイドライン改定 に関して. 第13回日本渡航医学会学術集会, 福岡

16. 三島伸介, 田淵幸一郎, 神田靖士, 天野博之, 西山利 正 (2009) 妊婦における熱帯熱マラリアの一輸入症例. 第13回日本渡航医学会学術集会, 福岡

17. 田淵幸一郎, 三島伸介, 西山利正 (2009) 関西医科大 学附属滝井病院海外渡航外来のトラベルワクチン接 種情況. 第 13 回日本渡航医学会学術集会, 福岡

18. 福島慎二, 古賀才博, 濱田篤郎 (2009) 途上国に長期 滞在する日本人成人の健康問題. 第 13 回日本渡航医学 会学術集会, 福岡
19. 三島伸介，天野博之，西山利正（2009）メキシコで感 染したと思われる顎口虫症の疑診例. 第20回日本臨床 寄生虫学会, 大阪

20. 細見亮太, 志水崇法, 福永健治, 神田靖士, 西山利正, 吉田宗弘（2009）成長期ラットの脂質代謝に及ぼす Lカルニチン給餌の影響. 第26回日本微量栄養素学会学 術集会, 京都

21. 上田照子, 三宅真理, 荒井由美子（2009）在宅要介護 高齢者を介護する息子による虐待の実態と背景. 日本 老年社会科学会第 51 回大会, 横浜

22. 横田純子, 山田保隆, 佐野佑樹, 淵岡 聡, 河村廣幸, 佐々木力三, 渡邊 学, 洲鎌 亮, 小林章郎 (2009) 人工膝関節全置換術後の下肢腫脹と関節可動域の関 連について. 第44回日本理学療法学術大会, 東京

23. 崎田博之, 三井美紀子, 淵岡 聡 (2009) 健常青年に おける内側縦アーチと片脚立位バランスの関連につ いて. 第44回日本理学療法学術大会, 東京

24. 松本圭司, 隅田陽子, 淵岡 聡 (2009) 足趾外転運動 が片脚立位バランスに及ぼす即時効果. 第 44 回日本理 学療法学術大会, 東京

25. 淵岡 聡, 樋口由美, 奥田邦晴, 林 義孝（2009）介 護予防事業における介入方法の違いが転倒発生率に 及ぼす影響. 第44回日本理学療法学術大会, 東京

26. 野村卓生, 浅田史成, 中尾聡志, 伊藤健一, 淵岡 聡, 奥田邦晴, 田上光男, 宮下和幸, 野村 誠, 久保田昌 詞, 大橋 誠 (2009) 2 型糖尿病患者の下肢筋量と筋 力の関係 多発性神経障害の合併の有無による比較. 第44回日本理学療法学術大会, 東京

27. 細見亮太, 福永健治, 林 健太, 西山利正, 吉田宗弘 （2009）ラットの脂質代謝に及ぼす魚肉タンパク質お よび魚油給餌の影響. 第 63 回日本栄養・食糧学会大 会, 長崎

28. 古賀才博, 西山利正, 濱田篤郎 (2009) 海外進出企業 の新型インフルエンザ対策に関する 3 年間の追跡報 告. 第 82 回日本産業衛生学会, 福岡

29. 古賀才博 (2009) 産業現場における新型インフルエン ザ対策（海外勤務者対策を中心に）。日本産業衛生学 会関東地方会平成 21 年総会・第 245 回例会, 東京

30. 古賀才博, 西山利正, 濱田篤郎（2009）海外進出企業 の新型インフルエンザ対策に関する 3 年間の調査報 告. 第83回日本感染症学会総会, 東京

31. 福島慎二, 古賀才博, 丸井英二, 濱田篤郎（2009）途 上国に存在する日本人の $\mathrm{A}$ 型肝炎, 腸チフスワクチン の接種率. 第83回日本感染症学会総会, 東京

32. 大岡久司, 神田靖士, 鈴木裕子, 美島健二, 斉藤一郎, 西山利正（2009）聴覚伝導路（下丘）における組織幹 細胞の同定. 第8回日本再生医療学会総会, 東京

33. 細見亮太, 福永健治, 神田靖士, 西山利正, 吉田宗弘 （2009）ラットの脂質代謝に及ぼす食事性n-3 系高度不 飽和脂肪酸結合リン脂質給餌の影響. 第48回日本油化 学会, 名古屋 
著 書

1. 西山利正 (2009) その他の吸虫症（肺吸虫症, 肝吸虫 症, 横川吸虫症, 肝蛙症) . 今日の治療指針 51 (山 口 徹, 北原光夫, 福井次矢編) 195-196 頁, 医学書 院，東京

2. 西山利正 (2009) 旅の健康. 地球の歩き方 ラオス 226-227頁, ダイヤモンド社, 東京

3. 岡崎和一, 川茂 幸, 神澤輝実, 伊藤鉄英, 乾 和郎, 入江裕之, 西野隆義, 能登原憲司, 久保惠嗣, 大原弘 隆, 入澤篤志, 藤永康成, 長谷部修, 西森 功, 田中 滋城, 田中雅夫, 白鳥敬子, 須田耕一, 西山利正, 下 瀬川徹（2009）難治性膵疾患に関する調査研究 III.
自己免疫性膵炎 自己免疫性膵炎の診療ガイドライ ンの作成にむけて。難治性膵疾患に関する調査研究 平成 20 年度総括 - 分担研究報告書 204-208頁, 東北 大学大学院医学系研究科, 仙台

4. 吉本陽二, 淵岡 聡 (2009) テニス選手のコンディ ショニングス. 理学療法 MOOK9 スポーツ傷害の理 学療法 2(福井 勉, 小柳磨毅編) 296-313頁, 三輪 書店, 東京

5. 吉本陽二, 佐藤睦美 (2009) CRPS. 理学療法士 臨 床判断フローチャート（監修: 奈良 勲) 113-123頁, 文光堂, 東京

\section{法医学講座}

\section{〈研究概要〉}

（1）ミトコンドリアDNA rRNA遺伝子の解析による動物種判定法の開発

法科学鑑定で重要な人獣鑑別（動物種判定）法として，ユニバーサルプライマーを用いたミトコンドリア DNAの $16 \mathrm{~S}$ rRNA 領域の解析法の確立について検討した. 各動物種 250 種（脊索動物 150 種, 棘皮動物 5 種, 節足動物 65 種, 軟体動 物 29 種, 刺胞動物 1 種）の組織から抽出したDNAを試料として検討したところ, 多くの動物種の遺伝子を検出して識別 することが可能だった．この成果を国際学会で報告した．

(2) 高速液体クロマトグラフを用いた茹淫検査法の検討

茹淫検査の予備試験としてPhenolphthalein diphosphate試薬を用いた呈色反応が用いられているが，判定が主観的であ り, かつ, 血性（血液が混和した）試料では判定が困難である. そこで酸性フォスファターゼとの反応によって産生さ れるPhenolphthalein をHPLCで客観的に検出する方法を検討し, 数值化して血性試料でも判定を可能にした.

（3）揮発性成分による有機リン系農薬の簡易検査法の検討

市販されている有機リン系殺虫剂からエチルベンゼンやキシレン，1-メトキシ-2-プロパノール，エタノールあるいは メルカプタン系物質が検出される。 この成分をプラスチック（ポリスチレンとアクリル）の変質現象と検知管を用いて 間接的に証明する簡易検査法を検討した。プラスチック変質検查ではスミチオン乳剤とマラソン乳剤で溶解や白濁が認 められたが，オルトラン液剤は原液のみで生じた，検知管検査ではキシレン用とメルカプタン系物質用の検知管の併用 が有効と考えられた，対象となる検体が高濃度含まれる胃内容や腸内容であるが，剖検室などで簡便に検査できること から予備試験として有用と考えられた。

(4) HPLCによる農薬デス成分の同時分析法の検討

有機リン系農薬デスにはDDVPやキシレン, 乳化剤などが含まれており, 毒性評価にはこれらの成分を定量する必要 がある，そこで $\mathrm{NaCl}$-アセトニトリル抽出と高速液体クロマトグラフによる同時分析法を開発し，混合キシレンの同位体 を含めた各成分を分離・分析することができた，事例への応用では各成分が分離・検出され，吸収スペクトルも良く一 致した，対照血清からは妨害となるレベルの成分は認められず，迅速かつ簡便に分析が可能であった．

（5）混合キシレン含有検体の保存法の検討

農薬，塗料，印刷インキおよび接着剤などにキシレンとエチルベンゼンからなる混合キシレンが使用されている，そ こでキシレンが関与した事例を想定して, 検体の保存法について容器の材質や温度から検討した. 材質ではガラス製容 器が最適で, プラスチック製容器は顕著な濃度低下をもたらし不適当であった. 温度に関しては凍結保存する必要があっ た. $\mathrm{NaCl}$-アセトニトリル抽出処理して溶媒をアセトニトリルに置換すればポリプロピレン製容器でも濃度低下が軽減 し，抽出する意義があった，以上，毒性評価をする際に試料の保存法によっては定量値に誤差が生じるので注意する必 要があった

（6）脳波解析用ソフトウェアを用いた脳死患者の平坦脳波の検証

脳死診断時の脳波はもともと低電位であり，ノイズ等の影響を受けやすいことから，肉眼での脑波判読が困難であり， 従来よりDOS版で構築されている脳波自動解析システムを用いて脳波を定量的に解析してきた. 今日ではWindows OSが 主流であることから，市販されているアプリケーション（ATAMAP II for Windows）を従来のシステムと比較検討し，後 者でも同様に脳死診断の補助手段として利用できることを検証した. 
（7）溺死判定のためのプランクトン検査法における試料藏器の比較検討

プランクトン検査において肝, 腎からのプランクトンの検出数は肺に比べて少なく, 検出されない例も多い. そこで 他の藏器からの検出効率を検討し，心臟血，脾臟で効率的にプランクトンが検出できることを見出した．ただし腐敗溺 死体では心臓血が残存していない例が多いので，その時は心内膜を試料として用いると検出可能だった.

（8）食品中に混入している珪藻

食品中に混入している珪藻被殼がプランクトン検査に影響を与えて誤判定を起こす可能性が考えられたので, 動物性 食品に引き続いて植物性食品について検討したところ, 食品中に珪藻被殼が多数混入していることが判明した.

\section{〈研究業績〉}

原 著

1. Mitani T, Akane A, Tokiyasu T, Yoshimura S, Okii Y and Yoshida M (2009) Identification of animal species using the partial sequences in the mitochondrial 16S rRNA gene. Leg Med 11(Supplement 1): S449-S450

2. Okii Y, Akane A, Kawamoto K, Iwase M, Yoshida M, Mitani T, Yoshimura S, Tokiyasu T and Kobayashi T (2009) The proof of flat-line scalp EEGs of brain dead patients by an automatic EEG analysis system. Leg Med 11(Supplement 1): S401-S403

3. Yoshida M, Akane A, Mitani T, Kobayashi T and Okii Y (2009) Examination of seminal stain by HPLC assay of phenolphthalein. Leg Med 11(Supplement 1): S357-S359

4. 吉田 学, 赤根 敦 (2009) 揮発性成分の検出による 有機リン系殺虫剤の簡易検査. 法医の実際と研 52: 163-170

\section{学会発表}

1. 沖井 裕, 赤根 敦, 河本圭司, 岩瀬正顕, 時安太久 磨, 吉村澄孝, 吉田 学 (2009) 脳波解析用ソフト ウェア (ATAMAP II for Windows) の脳死判定への応 用. 日本法医学会学術近畿地方集会, 高梘
2. 吉田 学, 赤根 敦, 沖井 裕 (2009) 有機リン系農 薬の揮発性成分検出による簡易検査法の検討（II）事 例への応用. 日本法医学会学術近畿地方集会, 高槻

3. 吉田 学, 赤根 敦, 片木宗弘, 土橋 均 (2009) 混 合キシレン（エチルベンゼン, o-, m-, p- キシレン) 含有試料の保存法の検討. 日本法科学技術学会, 東京

4. 前田裕仁, 岩瀬正顕, 中谷壽男, 河本圭司, 赤根 敦, 池堂太一 (2009) 頭部打撲後 12 日目に急激な意識低下 をきたし 14 日目に死亡した外傷性脳腫脹の一剖検例. 第23回日本神経救急学会, 栃木

5. 吉村澄孝, 赤根 敦, 吉田 学, 沖井 裕, 時安太久 磨，三谷友亮，小林哲哉（2009）食品中に混入してい る珪藻 (第 2 報). 第 93 次日本法医学会学術全国集会, 豊中

6. 吉田 学, 赤根 敦, 沖井 裕, 吉村澄孝, 時安太久 磨，三谷友亮，小林哲哉（2009）HPLCによる農薬デ ス成分（DDVP抢よびキシレン）の同時分析法の検討. 第93次日本法医学会学術全国集会, 豊中

著 書

1. 赤根 敦（2009）中毒死体の見方. 死体検案ハンド ブック 2（的場梁次，近藤稔和編）141-165頁，金芳 堂, 京都

\section{分子遺伝学部門}

\section{〈研究概要〉}

リンパ球の生体内で最も活発に移動する細胞であり，脈管系とリンパ組織を再循環しながら，免疫監視を行っている. リンパ球の動態はリンパ組織内環境を構築している血管内皮, 抗原提示細胞, ストローマ細胞, リンパ管と相互作用を 介しており，ホーミング，抗原認識，組織内細胞移動や移出などの過程を調節している。この多様な細胞相互作用を基 盤とする動態過程で機能している接着分子インテグリンは刺激に応じてダイナミックに接着性が変化することが特徴で ある. 本講座では，この接着制御に低分子量 $\mathrm{G}$ タンパク質 Rap1シグナルが重要な役割を果たしていることを発見し，そ のシグナル伝達経路の解明とリンパ球の動態制御，および免度応答における機能を分子レベルから個体レべルにわたり 追及している。

最近の研究成果

Rap1のエフェクター分子RAPLに会合するSte20-likeキナーゼに属するMst1を同定し，Rap1のインテグリン調節と細 胞極性調節にRAPL/Mst1が関与していることを示した．また，in vivoでのMst1機能を調べるため，Mst1ノックアウトマ ウスを作成して解析した，その結果，末梢リンパ節，脾臟，パイエル板などのリンパ組織の低形成になり， T細胞， B 細 胞が減少していた。 また, 骨䯣や胸腺でのリンパ球産生は正常であるが, 骨䯣再循環 $\mathrm{B}$ 細胞や辺縁洞B細胞が著減してい た。胸腺では CD4 陽性, CD8 陽性胸腺細胞がやや増加しており, 胸腺細胞の移出低下が認められた。 これらの異常はり ンパ球の動態障害によっておこっていることがin vitroおよびin vivoの解析から明らかになった. Mst1 欠損T細胞拉よび 
B 細胞は, ケモカインによるLFA-1/ICAM-1や $\alpha 4$ インテグリン/VCAM-1の接着性や細胞極性誘導が低下し，末梢リンパ節 や脾蔵へのホーミングが障害されていた，末梢リンパ節へのホーミング過程を生体内顕微鏡を用いて解析すると，リン パ節高内皮細静脈（HEV）へのローリング接着や停止接着は正常であるが，接着が安定せず一過性の接着を示した，そ こでこの過程を詳細に検討するため, L-selectin によるローリングから LFA-1 による停止を再現する in vitro flow assay を 樹立した. Mst1 欠損 T 細胞を生理的流速下で灌流すると, ローリングから一過性の停止を示したが，大部分のリンパ球 の停止時間が 10 秒以内であった，RAPL 欠損リンパ球も同様の結果を示した。 したがって, RAPL/Mst1はリンパ球の安 定した接着に必要であることが明らかになった. 2 光子レーザー顕微鏡を用いた生体内観察によってリンパ節組織内のリ ンパ球移動を解析したところ, RAPL 欠損あるいはMst1 欠損 T, B リンパ球は移動速度が遅く, 移動距離が低下していた ことから, 組織内移動にもRAPL/Mst1が重要であることが判明した. 以上の研究により, Rap1-RAPLシグナルはMst1を 介して, リンパ球の細胞極性とLFA-1の局在を調節し, 血管内皮接着と組織内移動に重要な役割を果たしていることが明 らかになった。

現在, RAPL, Mst1の遺伝子改変マウスを用いて, リンパ球の増殖, 分化への影響, 自己免疫との関連を解析しており, インテグリン制御と細胞増殖・分化との協調的制御のメカニズムや自己免疫, リンホーマ発症に関与することを明らか にしつつある.

\section{〈研究業績〉}

原 著

1. Katagiri K, Katakai T, Ebisuno Y, Ueda Y, Okada T and Kinashi T (2009) Mst1 controls lymphocyte trafficking and interstitial motility within lymph nodes. EMBO J 28(9): 1319-1331

2. Suto H, Katakai T, Sugai M, Kinashi T and Shimizu A (2009) CXCL13 production by an established lymph node stromal cell line via lymphotoxin-beta receptor engagement involves the cooperation of multiple signaling pathways. Int Immunol 21(4): 467-476

\section{学会発表}

1. Kinashi T (2009) Regulation of lymphocyte trafficking by RAPL and Mst1 signaling. The 21st IUBMB and the 12th FAOBMB International Congress of Biochemistry and Molecular Biology, Shanghai,China

2. KInashi T (2009) Regulation of lymphocyte trafficking by RAPL and MST1 signaling. The 2009 FASEB (Federation of American Societies for Experimental Biol-
ogy)Summer Research Conference,Signal Transduction in The Immune System, Colorado, USA

3. Kinashi,T. (2009) RAPL signaling in regulation of immune cell traffic and proliferation. Clinical and Biological Implications for the role of the RASSF(the Ras association domain family) family of tumor suppressor proteins. First International Symposium, カナダ・バンフ

4. 植田祥啓, 片桐晃子, 安田鐘樹, 富山 尚, 片貝智哉, 羽廣克嘉, 池原 進, 木梨達雄（2009） T 細胞の恒常 性と免疫寛容に打ける Mst1 キナーゼの役割／The Ste20-loke kinase Mstlis essential for maintenance of $\mathrm{T}$ cell homeostasis and immunological tolerance. 第 39 回 日本免疫学会・学術集会, 大阪

5. 片貝智哉, 木梨達雄（2009）ICAM-1 に対する LFA-1 依存的接着はリンパ節より単離したストローマ細胞 上における $\mathrm{T}$ 細胞の高速移動に関与する／LFA1dependent adhesion to ICAM-1 contributes to highvelocity migration of primary $\mathrm{T}$ cells on stromal cells isolated from lymph nodes. 第39回 日本免疫学会・学術 集会, 大阪

\section{生体情報部門}

\section{〈研究概要〉}

外界からの病原体感染の脅威を排除するために，われわれの身体は自然免疫と獲得免疫の二つのシステムからなる免 疫系を進化させてきた。一方で, 免疫系の過剰な応答は, 自己免疫疾患・アレルギ一性疾患といった種々の免疫病態を 引き起す。したがって，われわれが健康な身体を維持する上で，体内に存在する免疫担当細胞が「適切」な活性制御を 受けることが大前提となる。われわれの研究室では, 自然免疫を司る樹状細胞やマクロファージ, ならびに獲得免疫を 司る T 細胞・B細胞を研究対象に, 細胞内シグナル伝達のキーコンポーネントである MAPK経路と PI3K経路の視点から, 個々の免疫担当細胞における「適切」な活性制御機構を明らかにすべく研究を推進している.

最近の研究成果

第一に, PI3K経路のうち, チロシンキナーゼの下流で活性化されるクラスIA PI3Kが, B細胞の増殖に必須の役割を果 たす NF- $\kappa \mathrm{B}$ 経路の発現調節に関与することを明らかにした。 これまで, 株化された培養細胞を対象に, wortmannin や LY294002 といったPI3K阻害剂を用いた解析を通して, PI3K経路はB 細胞の活性化シグナル伝達に必須なチロシンキナー ゼ・Btkの活性制御を行っているものと信じられてきた。しかし，上述したPI3K阻害剤は，PI3K以外にも DNA依存性夕 
ンパク質キナーゼやATM といった幅広い分子の活性を阻害することが知られており, クラス IA PI3Kの生理的な機能を 追求する上で，特異性に大きな問題があるものと考えられた。 そこでわれわれは，クラス IA PI $3 \mathrm{~K}$ の主要な制御サブユ ニットである $\mathrm{p} 85 \alpha$ を特異的に欠失した遺伝子改変マウス（以下， p $85 \alpha-\mathrm{KO}$ マウス）由来の B 細胞を用いて，B細胞にお けるクラスIA PI3K経路の真の生理機能の解明に取り組んだ。その結果, 従来の教科書的な記述と全く異なり, クラスIA PI3K 経路はBtkの活性制御には関与しておらず, 主要なNF-kBコンポーネントの一つであるc-Relのタンパク質レベルで の発現制御を介して，B細胞の増殖過程を制御していることが明らかとなった．PI3K経路によるc-Rel発現制御の分子機 構は未だ不明であるが, p $85 \alpha-K O$ マウス由来 B 細胞の増殖不全が恒常活性型 Akt の遺伝子導入により回復することから, Aktを介したリン酸化カスケードの関与が強く示唆されている. 現在, Aktの下流で機能する各種分子のc-Rel発現調節へ の関与の有無を検討中である.

また，B1-B 細胞と呼ばれる細胞に働きかけて自然抗体の産生に寄与するとともに寄生虫排除の過程で重要な役割を果 たす, 全く新規の免疫担当細胞を, 慶應義塾大学医学部の小安教授の研究グループと共同で発見・解析した。従来, B1$\mathrm{B}$ 細胞の活性化や, 寄生虫排除といった免疫応答は, 獲得免疫系の司令塔とも言えるへルパーT細胞によって制御されて いるものと考えられてきた. しかし, 今回発見された免疫担当細胞はT細胞・B細胞に見られるような抗原受容体を持た ず，自然免疫系に属する細胞であることが明らかとなり，その性状からナチュラルヘルパー細胞（NH細胞）と命名され た. 種々の遺伝子改変マウスを用いた解析から, この $\mathrm{NH}$ 細胞が非常に強力な $\mathrm{Th} 2$ 型サイトカインの産生細胞であること が明らかとなっている。

\section{〈研究業績〉}

原 著

1. Matsuda S, Mikami Y, Ohtani M, Fujiwara M, Hirata Y, Minowa A, Terauchi Y, Kadowaki T and Koyasu S (2009) Critical role of class IA PI3K for c-Rel expression in B lymphocytes. Blood 113(5): 1037-1044

総 説

1. 大谷真志, 松田達志, 小安重夫 (2009) 肝臓領域の樹 状細胞研究を極めるために樹状細胞の基礎を網羅す る樹状細胞のシグナル伝達. 肝・胆・膵５8(2): 185-192
学会発表

1. 松田達志 (2009) クラスIA PI3キナーゼはB 細胞にお ける NF-kBシグナルの活性化に必須である. 第5回血 液学若手研究者勉強会, 品川

2. 大谷真志 (2009) 自然免疫系における樹状細胞の IL12 産生に対する mTOR と GSK3 による異なる制御機 構. 第5 回血液学若手研究者勉強会, 品川

著 書

1. 松田達志 (2009) MAP kinase. 炎症 - 再生医学事典 （松島綱治, 西脇 徹編）100-102頁, 朝倉書店, 東京

\section{モデル動物部門}

\section{〈研究概要〉}

物理的刺激反応型人工プロモーターの開登; 遺伝子発現を開始するDNA配列シグナルであるプロモーターは, 刺激によっ て活性化される特定の転写因子が結合配列に結合し，遺伝子発現を制御すると考えられている．放射線，抗癌剂または 超音波等の物理的刺激により活性化する複数の転写因子の結合配列をランダムに組み合わせたDNA断片により，それら の刺激に敏感に反応して下流の遺伝子発現を元進するプロモーターを構築できることを見いだした. さらに，変異導入 型PCR法によりランダムに変異を入れることで, より反応性の高いプロモーターが構築できた (Journal of Gene Medicine, 10(3):316-324 (2008)). 物理的刺激に応答する人工的なプロモーターを利用した場合, 治療用遺伝子を標的領域に一旦導 入すれば, 刺激を与えた時のみ, 刺激を与えた部位でのみ遺伝子の発現が立進し, 従来のものよりも効率的な癌治療に 結びつくことを期待している.

組み換え $\mathrm{H}$ 鎖抗体を用いた抗インフルエンザウイルスの感染防御：抗体療法で幅広く研究されている抗腫瘍治療領域に おいて, 抗体の生物学的・生化学的不安定性, 腫瘍部位への到達性の問題, 特異性, 腫瘍抗原の多様性などが解決すべ き課題である. 一方, ラクダ科動物に存在する $\mathrm{H}$ 鎖のみで構成されている $\mathrm{H}$ 鎖抗体は, $\mathrm{L}$ 鎖がなく抗原認識部位が小さい ため, 通常の抗体が認識・結合不可能な部位の認識も可能であると考えられている. インフルエンザウイルス赤血球凝 集（HA）抗原を接種したラマからの H鎖抗体の抗原特異性と有用性を確認した. ファージディスプレイ法により有用の 抗体分子を探索し, 免疫原生が低く特異性の高い遺伝子組換え抗体の開発を進めている. 細胞のレセプター糖鎖への結 合・侵入に必須の HA 抗原に対する特異的 $\mathrm{H}$ 鎖抗体は, HA蛋白開裂部位へ結合し，機能阻害・感染防御を誘導すること は, 子孫ウイルスの感染力獲得を妨げ, ウイルスの感染拡大を抑制できると期待している. 


\section{〈研究業績〉}

原 著

1. Khatun MM, Islam MA, Baek BK and Lee SI. Cellular and humoral immune responses and antigen recognition in Sprague-Dawley rats experimentally infected with Brucella abortus biotype 1. Asian J Ani Vet Adv 4(6): 267277 (2009)

2. Khatun MM, Islam MA, Baek BK and Lee SI. Characteristics of the immune response during acute brucellosis in Sprague-Dawley rats. J Infect Dev Ctries 3(5): 392-397 (2009)

3. Islam MA, Khatun MM, Baek BK and Lee SI. Efficacy of strain RB51 vaccine in protecting infection and vertical transmission against Brucella abortus in Sprague-Dawley rats. J Vet Sci 10(3), 211-218 (2009)

4. Lee SI, Choi MJ, Khatun MM, Islam MA, Baek BK, Lee CS and Kakoma I. Analysis of human brucellosis sera using western blot assay. Kor J Vet Publ Hith 33 (1):3945 (2009)

5. Islam MA, Khatun MM, Baek BK and Lee SI. Effects of Brucella abortus biotype 1 infection on the reproductive performance of Sprague-Dawley rats. Pakistan J Biol Sci 12(4), 353-359 (2009)

6. Watanabe A, Kakutani S, Ogawa R, Lee SI, Yoshida T, Morii A, Kagiya G, Feril Jr, LB, Fuse H and Kondo T (2009) Construction of artificial promoters sensitively responsive to sonication in vitro. J Med Ultrasonic 36(1): $9-17$

\section{学術部}

\section{〈研究概要〉}

学術部は，業務部，医療情報部の協力の下，ネットワークおよび情報基盤サービスの提供や医学教材のインターネッ 卜公開等の日常業務に加え, 特に医療機関, 教育機関として求められている情報サービスに関し, 多面的なアプローチ を用いた研究を進めつつある.

2009年度の主要な研究課題は次のとおりである：

1） Medical Wave Form Encoding Rule（MFER）を用いた医用波形情報リポジトリの構築に関する研究

2) DICOM診療画像リポジトリの構築に関する研究

3）MFERおよびDICOMを用いた施設間診療情報相互参照基盤の構築と維持に関する研究

4）WAN-LAN接続部を中心としたネットワークセキュリティに関する研究

5）APMLを用いた隠蔽関係剖出と展開予測に関する研究

6）障害，災害，感染事故等に対する情報基盤の耐性向上に関する研究

7）コストパフォーマンスと環境に配慮した医療情報基盤の構築と維持に関する研究

8）映像音声データの中継，録画，オンデマンド配信に関する研究

1-3）世界初の試みとなった「MFER波形情報リポジトリを用いた施設間波形情報相互参照」は2009年度末に実証試験 をほぼ完了し，日常的に利用されるツールとして定着しつつある. 現在, 利用シーンの拡大に伴うプロシジャ追加策定 等を進めている。診療画像リポジトリはシステム構築をほぼ完了し，試験稼働を開始した。 2010 年夏に本格稼働に入る 予定である.

4-8）セキュリティおよび業務継続性に関する研究成果は, 2009年に連携先施設で発生したウイルス感染事故からの早 期復旧に反映されるとともに，演題「診療施設間連携におけるセキュリティ確保に関する問題点の検討」が第 29 回医療 情報学連合大会優秀ポスター賞に選定された. また, 情報基盤に関する研究成果は 2010 年開院の香里病院の設計および システム構築に, 映像音声中継/オンデマンド配信に関する研究成果は立命館大学との大学間戦略連携事業に, それぞれ 反映された.

\section{〈研究業績〉}

原 著

1. 渡辺 淳, 新貝欣久, 松本掲典, 仲野俊成, 畑森浩孝 （2009）APML を用いた隠蔽・暗黙関係の描出と展開 予測一SMTP snow一。医療情報学 29(Suppl.): 859864

2. 仲野俊成, 渡辺 淳, 竹花一哉, 小山武彦, 平井正明, 佐藤恵一，田中雅人（2009）MFERを用いた施設間波 形情報共有の有用性および事前需要予測の相互参照
実績に基づく検証. 医療情報学 29(Suppl.): 634-638

3. 渡辺 淳, 松本掲典, 新貝欣久, 平林江理夫, 山城美 智子，大西章夫，仲野俊成 (2009) 診療施設間連携に おけるセキュリティ確保に関する問題点の検討. 医療 情報学２9(Suppl.): 1149-1152

学会発表

1. 仲野俊成, 渡辺 淳, 竹花一哉, 小山武彦, 平井正明, 佐藤恵一，田中雅人（2009）MFERを用いた施設間波 
形情報共有の有用性および事前需要予測の相互参照 実績に基づく検証. 第29回医療情報学連合大会 (第10 回日本医療情報学会学術大会), 広島

2. 渡辺 淳, 松本掲典, 新貝欣久, 平林江理夫, 山城美 智子，大西章夫，仲野俊成 (2009) 診療施設間連携に おけるセキュリティ確保に関する問題点の検討. 第 29 回医療情報学連合大会 (第10回日本医療情報学会学術 大会)，広島

3. 渡辺 淳, 新貝欣久, 松本掲典, 仲野俊成, 畑森浩孝 （2009）APML を用いた隠蔽・暗黙関係の描出と展開
予測一SMTP snow一. 第29回医療情報学連合大会 (第 10 回日本医療情報学会学術大会), 広島

4. 渡辺 淳, 仲野俊成, 竹花一哉, 小山武彦, 平井正明 （2009）診療施設間波形情報連携への医用波形記述プ ロトコル (MFER) 導入の試み. 第13回日本医療情報 学会春季学術大会 (シンポジウム2009), 長崎

5. 仲野俊成, 渡辺 淳, 竹花一哉, 田中雅人, 平井正明 (2009) OS-26生体音の計測と解析 : 臨床診断への応用 電子カルテシステムに打ける波形情報管理. 第48回日 本生体医工学会大会, 東京

\section{医療情報部}

\section{〈研究概要〉}

医療情報部では，電子カルテをはじめとする病院情報システムの維持・運用および開発を継続的に行っている．枚方 病院の電子カルテシステムも 4 年目を迎え, 二次利用に供すべき診療情報も蓄積されてきている. Data Warehouse (DWH) を活用した研究としては, DWHやDPCデータ活用による統計解析へのアプローチを行った（DPCコード別コード比較）. また，2008年から開始しているがん登録であるが，電子カルテシステムDWHのみからの情報抽出で取得できる情報は限 られており，他部門システムからの情報も必要である，端末操作で可能とはいえ，各システムを駆使して情報収集する のは非常に煩雑であるため, 部門システムのDBアクセスも含めた情報収集ができるシステム開発を行った。これにより 効率的な情報収集が可能となり，予後調査の資料作成にも寄与することができた。

学術部1)で述べた波形情報データリポジトリは 2008年 7 月からサービスを開始しているが，この MFER心電図波形情 報サーバは 1 月から電子カルテシステムやオーダエントリーシステムと連携することにより本格運用に入った. 2009 年は サーバアクセスログや端末情報を解析し，予め想定していた事前重要予測および相互参照の実績について検証を行った.

看護師からの視点では，毎年新人教育をする中で，コンピュータリテラシーの違いによる新任看護師操作教育終了後 の心身の反応についてアンケートによる研究を行った.

なお，所属学会である日本医療情報学会が行っている医療情報技師育成事業では，研修幹事抢よび運営委員を委嘱さ れており，初級抢よび上級医療情報技師能力検定試験出題委員のほか，講習会の企画・運営にも参画している.

\section{〈研究業績〉}

\section{原 著}

1. 石原久美子，北村 臣，夜野敏明，西村泰典，仲野俊 成，井上健太郎，中根恭司，今村洋二（2009）院内が 儿登録症例の予後調査の試み. 医療情報学 29(Suppl.): 886-888

2. 夜野敏明，石原久美子，北村 臣，仲野俊成，今村洋 二（2009）独自開発の院内がん登録システムによる登 録状況改善の評価. 医療情報学 29(Suppl.): 882-885

3. 渡辺 淳, 新貝欣久, 松本掲典, 仲野俊成, 畑森浩孝 (2009) APML を用いた隠蔽・暗黙関係の描出と展開 予測一SMTP snow一. 医療情報学 29(Suppl.): 859864

4. 廣田美喜子, 安田照美, 夜野敏明, 西野典宏, 西村泰 典, 仲野俊成, 今村洋二 (2009) コンピューターリテ ラシーの違いによる新任看護師操作教育終了後の心 身の反応．医療情報学 29(Suppl.): 689-691

5. 仲野俊成, 渡辺 淳, 竹花一哉, 小山武彦, 平井正明, 佐藤恵一，田中雅人（2009）MFERを用いた施設間波 形情報共有の有用性および事前需要予測の相互参照 実績に基づく検証. 医療情報学 29(Suppl.): 634-638
6. 西野典宏, 仲野俊成, 北村 臣, 夜野敏明, 西村泰典, 山本康弘, 今村洋二 (2009) DWH やDPCデータ活用 による統計解析へのアプローチ (DPC疾患別コード比 較)。医療情報学 29(Suppl.): 452-455

7. 笹井浩介, 川上洋一, 三原直樹, 黒田知宏, 仲野俊成, 松村泰志, 宮本正喜（2009）症例オントロジーを応用 した画像診断支援システムの開発. 医療情報学 29(Suppl.): 1195-1196

8. 渡辺 淳, 松本掲典, 新貝欣久, 平林江理夫, 山城美 智子，大西章夫，仲野俊成（2009）診療施設間連携に おけるセキュリティ確保に関する問題点の検討. 医療 情報学２9(Suppl.): 1149-1152

9. 田中雅幸，鶴見由美子，打谷和記，西山徳人，廣田育 彦, 仲野俊成, 今村洋二 (2009) 抗腫瘍薬注射処方に おける監査支援システムの機能強化一投与前チェッ ク範囲の拡大による監査水準の向上一. 医療情報学 29(Suppl.): 1093-1097

10. 北村 臣, 石原久美子, 西村泰典, 仲野俊成, 里井壯 平, 宮崎浩彰（2009）電子カルテシステムにおけるク リニカルパス管理とその運用一診療情報管理士と医 療情報技師による医師・看護師のパスへの業務負担軽 
減の試み一。 日クリニカルパス会誌 11(2): 213-216

\section{学会発表}

1. 北村 臣（2009）シンポジウム 1 : パス作成・運用に おけるパラメディカルの役割一みんなで作る,使えて 役立つクリニカルパス一 当院でのパス作成・運用に おける診療情報管理士と医療情報技師の役割. 日本ク リニカルパス学会, 岐阜

2. 笹井浩介, 川上洋一, 三原直樹, 黒田知宏, 仲野俊成, 松村泰志，宮本正喜（2009）症例オントロジーを応用 した画像診断支援システムの開発. 第29回医療情報学 連合大会 (第 10 回日本医療情報学会学術大会), 広島

3. 西野典宏, 仲野俊成, 北村 臣, 夜野敏明, 西村泰典, 山本康弘，今村洋二（2009） DWHやDPCデータ活用 による統計解析へのアプローチ (DPC疾患別コード比 較)。第 29 回医療情報学連合大会（第10回日本医療情 報学会学術大会), 広島

4. 石原久美子, 北村 臣, 夜野敏明, 西村泰典, 仲野俊 成, 井上健太郎, 中根恭司, 今村洋二 (2009) 院内が 儿登録症例の予後調査の試み. 第29回医療情報学連合 大会 (第 10 回日本医療情報学会学術大会), 広島

5. 仲野俊成, 渡辺 淳, 竹花一哉, 小山武彦, 平井正明, 佐藤恵一, 田中雅人（2009）MFERを用いた施設間波 形情報共有の有用性抢よび事前需要予測の相互参照 実績に基づく検証. 第29回医療情報学連合大会 (第 10 回日本医療情報学会学術大会), 広島

6. 田中雅幸, 鶴見由美子, 打谷和記, 西山徳人, 廣田育 彦, 仲野俊成，今村洋二 (2009) 抗腫瘍薬注射処方に おける監査支援システムの機能強化一投与前チェッ ク範囲の拡大による監査水準の向上一. 第29回医療情 報学連合大会（第 10 回日本医療情報学会学術大会）, 広島

7. 渡辺 淳, 松本掲典, 新貝欣久, 平林江理夫, 山城美 智子，大西章夫，仲野俊成（2009）診療施設間連携に おけるセキュリティ確保に関する問題点の検討. 第 29 回医療情報学連合大会 (第 10 回日本医療情報学会学術 大会), 広島

8. 渡辺 淳, 新貝欣久, 松本掲典, 仲野俊成, 畑森浩孝 （2009）APML を用いた隠蔽・暗黙関係の描出と展開 予測一SMTP snow一. 第29回医療情報学連合大会（第 10 回日本医療情報学会学術大会), 広島

9. 夜野敏明, 石原久美子, 北村 臣, 仲野俊成, 今村洋
二 (2009) 独自開発の院内がん登録システムによる登 録状況改善の評価. 第 29 回医療情報学連合大会 (第 10 回日本医療情報学会学術大会), 広島

10. 廣田美喜子，安田照美，夜野敏明，西野典宏，西村泰 典, 仲野俊成, 今村洋二 (2009) コンピューターリテ ラシーの違いによる新任看護師操作教育終了後の心 身の反応. 第 29 回医療情報学連合大会（第 10 回日本 医療情報学会学術大会), 広島

11. 渡辺 淳, 仲野俊成, 竹花一哉, 小山武彦, 平井正明 （2009）診療施設間波形情報連携への医用波形記述プ ロトコル（MFER）導入の試み. 第13回日本医療情報 学会春季学術大会 (シンポジウム2009), 長崎

12. 北村 臣, 仲野俊成, 石原久美子, 和西晃寛, 夜野敏 明, 西野典宏, 廣田美貴子, 西村泰典, 宮嵪浩彰, 今 村洋二, 堀井俊洋 (2009) 電子クリニカルパスの現状 と課題. 第13回日本医療情報学会春季学術大会 (シン ポジウム2009), 長崎

13. 北村 臣（2009）データウエアハウスを用いた薬剤マ スタ整理の試み. 日本医療マネジメント学会, 長崎

14. 仲野俊成, 渡辺 淳, 竹花一哉, 田中雅人, 平井正明 （2009）OS-26 生体音の計測と解析：臨床診断への応 用 電子カルテシステムにおける波形情報管理. 第 48 回日本生体医工学会大会, 東京

\section{著 書}

1. 石川 澄（広島大）, 合地 明（岡山大）, 中川 肇 （富山大），宮本正喜（兵庫医大），八幡勝也（産業医 大），仲野俊成，他（2009）4. 医学・看護学 4.1 臨床医学 4.1.6 消化器系. 新版 医療情報 医学 医療編（日本医療情報学会医療情報技師育成部会部会 長 岡田美保子編) 185-188頁, 篠原出版新社, 東京

2. 松村泰志 (大阪大), 内藤道夫 (藤田保健衛生大), 仲 野俊成, 他 (2009） 2 病院情報システムの構成と機 能 2.2 病院情報システムの機能 2.2 .2 予約に関 するシステム 2.2.6 内視鏡検査・治療に関するシス テム 2.2 .7 病理検査に関するシステム 2.2 .11 血 液浄化に関するシステム 2.2 .15 食事に関するシス テム 2.2.16 入退院・病床管理に関するシステム 2.2.28 その他の病院情報システム．新版 医療情報 医療情報システム編（日本医療情報学会医療情報技師 育成部会部会長 岡田美保子編） 1，73-75，87-91, 99-100，106-109，152-155頁，篠原出版新社，東京

\section{内科学第一講座}

\section{〈研究概要〉}

樹状細胞は生体に広く分布し, 抗原特異的に $\mathrm{T}$ 細胞を活性化, 免疫応答を誘導する抗原提示細胞であり, 近年免疫ネッ トワークを多方面から統御する細胞として注目を浴びている，樹状細胞は，自然免疫賦活剂として，抗腫瘍免疫療法の 臨床試験も開始されてるが, 臨床疾患における樹状細胞の側面からの免疫学的アプローチは HIV 感染症等ごく限られた 疾患においてのみなされており, 樹状細胞と各臨床疾患との関わり, 特に免疫異常を来す病態においての樹状細胞の関 
わりは未解明のままである。樹状細胞は, その単離が難しいこと, 生体内各組織における分布細胞密度が必ずしも高く ないことなどにより，ヒトに扔いては正常状態での解析も十分になされていなかった．しかしながら，我々が確立した 方法により末梢血を循環する樹状細胞をそのままの状態で解析することが可能になり, これらを用いて, 我々は, 免疫 異常を呈する難治性疾患の病態を, 樹状細胞の性状と機能の面から解析することにより, これまで不明とされていた疾 患の病態を把握し,さらには治療に役立つ戦略の確立を目的とし現在研究を行っている.

血液部門：

同種造血幹細胞移植は，血液疾患の治療のみならず他の固形癌に対する治療戦略の一つとなりうることが示されつつ あり，今後ますます重要な治療法になると考えられる．同種造血幹細胞移植の中心理念はアロ抗原や腫瘍抗原に対する 免疫反応による腫瘍根絶（graft-versus-tumor effect）であるが, この免疫反応は両刃の剣であり hostの組織障害性に作用 し, しばしば致死的となる GVHD（graft-versus-hostdisease）が依然大きな問題となっている. 当教室では同種造血幹細 胞移植に関連して生じるこれらのダイナミックな免疫系の動態を多角的に解析することにより, graft-versus-tumor effect と GVHD の発生機序およびその相違を明らかにし，より効果的に前者を誘導し同時に後者を抑制する新しい治療戦略の 開発を目的として検討を行っている，同種造血幹細胞移植を受けた造血器腫瘍患者では急性 GVHD 発症時にはミエロイ ド系樹状細胞とリンパ系樹状細胞の双方が末梢血において著しく減少していることを明らかにした．GVHD 組織の免疫 染色により，この減少は組織への能動的な動員によることが示された．これはドナーの樹状細胞がアロ抗原を提示する ことにより急性GVHDを惹起する可能性を示唆している. 一方, 慢性GVHD発症時には急性GVHDでみられたような末 梢血樹状細胞の減少は認めなかった。しかしながら移植後慢性期にある患者では慢性 GVHD の発症の有無に関わらず IFN- $\gamma$ および TNF- $\alpha$ 産生性のエフェクターT 細胞の増加を認めた。これらの患者では腫瘍の再発を認めていないことょ り, これらのエフェクターT細胞が graft-versus-tumor effectを担っている可能性がある. また興味深いことに慢性 GVHD の発症時には IL-4 産生性の CD8 + T 細胞が必ず出現することが明らかとなった．すなわちこの IL-4 産生性の CD8 + T 細 胞は慢性GVHDの発症病態に深く関わっていることが示唆される.

呼吸器部門：

肺結核は高齢者のみならず, 多くの若年者にも発症者が報告されており, 現在最も重要視されている感染症のひとつ である．結核菌に対する感染防御機構については，現在までに多くの研究がなされてきているが，当教室では抗原提示 細胞として感染防御に重要である樹状細胞に焦点を当て検討を行っている. 私たちはこれまで, 肺結核患者では末梢血 のミエロイド系樹状細胞が減少し選択的に結核組織に移行しTh1応答を誘導していることを見いだした．また私たちは, 結核と同様の肉芽腫性疾患に属するサルコイドーシスに注目し, その発症・疾患の進展の機序を, 樹状細胞を含めた免 疫応答のシステムの観点から解析することを試みている. サルコイドーシス患者ではミエロイド系樹状細胞のみならず リンパ系樹状細胞も末梢血において著しく減少していることを突き止めている. すなわち, 同じ肉芽腫性疾患でも結核 とサルコイドーシスでは樹状細胞の動態が異なることが明らかにされた.

\section{免疫部門：}

近年における免疫学の進展は著しく, その中でも当科が注目し研究対象としている樹状細胞は, 生体免疫応答の要に 位置する極めて重要な細胞といえ, 各種感染症に対する防御免疫を担う中心的な存在として位置づけられる一方で, 炎 症性アレルギ一性疾患, 自己免疫疾患, 悪性腫瘍等の発症・進展のメカニズムにおいても重要な意味をもつことが明ら かにされつつある. また樹状細胞によって制御されているエフェクターT 細胞も Th1, Th2, regulatory T などの亜群に より様々な疾患病態に関与すると考えられている. 我々はヒト樹状細胞亜群ならびに制御性 $\mathrm{T}$ 細胞を含むエフェクターT 細胞亜群の解析を行っており, ヒトにおける免疫制御機構のデータを蓄積している. これらの結果から我々は免疫異常 を呈する難治性疾患の病態解明，さらには治療に役立つ戦略の確立を目的とし日々，研究を行っている.

\section{〈研究業績〉}

原 著

1. Sasaki Y, Matsuoka Y, Hase M, Toyohara T, Murakami M, Takahashi M, Nakatsuka R, Uemura Y and Sonoda Y (2009) Marginal expression of CXCR4 on c-kit+Sca$1+$ Lineage-hematopoietic stem/progenitor cells. Int $\mathrm{J}$ Hematol 90(5): 553-560

2. Shirasugi $Y$, Ando K, Hashino S, Nagasawa T, Kurata Y, Kishimoto Y, Iwato K, Ohtsu T and Berger DP (2009) A phase II, open-label, sequential-cohort, dose-escalation study of romiplostim in Japanese patients with chronic immune thrombocytopenic purpura. Int J Hematol 90(2): $157-165$

3. Uemura Y, Liu TY, Narita Y, Suzuki M, Nakatsuka R, Araki T, Matsumoto M, Iwai LK, Hirosawa N, Matsuoka Y, Murakami M, Kimura T, Hase M, Kohno H, Sasaki Y, Ichihara Y, Ishihara O, Kikuchi H, Sakamoto Y, Jiao SC, Senju S and Sonoda Y (2009) Cytokine-dependent modifi- 
cation of IL-12p70 and IL-23 balance in dendritic cells by ligand activation of Valpha24 invariant NKT cells. J Immunol 183(1): 201-208

4. Nakamichi N, Morii E, Ikeda JI, Qiu Y, Mamato S, Tian T, Fukuhara S and Aozasa K (2009) Synergistic effect of interleukin-6 and endoplasmic reticulum stress inducers on the high level of ABCG2 expression in plasma cells. Lab Invest 89(3): 327-336

5. 尾崎吉郎, 孫 瑛洙, 澤井宏和, 小室 元, 和田孝彦, 嶋元佳子, 安室秀樹, 伊藤量基, 福原資郎 (2009) 関 節リウマチの除痛に対する Diclofenac/Celecoxib 切り 替えの有用性に関する検討. Ther Res 30(9): 1499_ 1506

6. 伊藤量基（2009） TSLP で誘導されるアレルギー性炎 症の制御 27(20): 132-138

7. 和田孝彦, 尾崎吉郎, 小室 元, 孫 瑛洙, 飯田寛和 （2009）ロキソプロフェンナトリウム水和物含有貼付 剤（ロキソニンパップ）の使用感に関する患者調査一 アンケート調査における他剂貼付剂との比較検討一. 新薬と臨５8(7): 1250-1257

総 説

1. 伊藤量基 (2009) アレルギー疾患に関連するサイトカ イン群 6. TSLPで誘導されるアレルギー性炎症の制 御. 実験医 27(20): 3328-3334

2. 横井 崇, 清水俊樹, 米津精文, 福原資郎 (2009)【呼 吸器症候群（第 2 版） その他の呼吸器疾患を含めて】 腫瘍性疾患 上皮性（原発性）腫瘍 粘液産生性肺腺 癌. 日臨 別冊呼吸器症候群III: 65-67

3. 谷尻 力, 清水俊樹, 福原資郎 (2009) ホジキンリン パ腫におけるレギュラトリーT細胞の分化誘導. 臨免 疫・アレルギー科 51(1): 1-6

\section{症例報告}

1. Shimamoto Y, Nomura S, Ishii K, Shimizu M, Ozaki Y, Ito T, Urase F, Maeda Y and Fukuhara S (2009) Adult Tcell leukemia after immunosuppressive therapy for systemic lupus erythematosus. Int J Hematol 89(1): 128129

2. 中出多子, 岩井 大, 金子敏彦, 河本光平, 星野勝一, 稲葉宗夫, 清水俊樹 (2009) 喉頭原発の混合型小細胞 癌例. 耳鼻・頭頸外科 81(9): 633-637

その他

1. Wada N, Ikeda J, Kohara M, Ogawa H, Hino M, Fukuhara S, Kanamaru A, Sugiyama H, Kanakura Y, Morii E and Aozasa K (2009) Diffuse large B-cell lymphoma with a high number of epithelioid histiocytes (lymphoepithelioid B-cell lymphoma): a study of Osaka Lymphoma Study Group. Virchows Arch 455(3): 285-293

2. 谷尻 力, 米津精文, 鳥居芳太郎, 杉本博是, 横井
崇, 福原資郎（2009）喀痰・胸水中より虫卵を認めた ウエステルマン肺吸虫症の1例. 日呼吸会誌 47(12): 1131-1134

3. 山岡 学, 大西修司, 有元美代子, 市邊明美, 阿部 操, 館農美香, 大谷哲司, 森眞一郎, 福原資郎, 海堀 昌樹（2009）HLA抗体保有患者の生体肝移植症例. 日 輸血細胞治療会誌 55(6): 711-716

4. 藤田真也, 森眞一郎, 宮本理恵, 小笹亮太郎, 中道尚 人, 宮地理彦, 田嶋健一郎, 岸本裕司, 尼川龍一, 福 原資郎（2009）再発・治療抵抗性 DLBCLに対するRESHAP 療法 + 自家末梢血幹細胞移植併用大量化学療 法の後方視的検討 50(9): 1097

学会発表

1. Murakami M, Matsuoka Y, Nakatsuka R, Takahashi M, Nakamoto T, Yasuda K, Matsui K, Uemura Y, Sasaki U, Tsuji T, Fukuhara S and Sonoda Y (2009) High Resolution Purification and Characterization of Human Cord Blood-Derived CD34-negative SCID-Repopulating Cells with a very Immature Phenotype. ASH2009, NewOrleans, LA

2. Murakami N, Ito T, Inaba M, Amakawa R and Fukuhara S (2009) IL-33 enhances Th2 cell response by amplifying the function of OX40L. 11th International Workshop on Langerhans Cells, Funchal, Portugal

3. 金沢武哲, 安室秀樹, 杉本博是, 横井 崇, 小宮山豊, 正木浩哉, 尼川龍一, 高橋伯夫, 福原資郎（2009）血 漿交換に不応であった難治性の血栓性血小板減少性 紫斑病（TTP）の一例. 第 190 回日本内科学会近畿地 方会, 神戸

4. 兵晃, 尼川龍一, 安室秀樹, 尾形 誠, 中道尚人, 木村 卓, 杉本博是, 伊藤量基, 清水俊樹, 福原資郎 （2009）不明熱と縦隔リンパ節腫大を認め肝生検が確 定診断に有効であったサルコイドーシスの1例. 第190 回日本内科学会近畿地方会, 神戸

5. 村上直子, 伊藤量基, 宮本理恵, 嶋元佳子, 尼川龍一, 福原資郎（2009）IL-33 enhances Th2 cell response by amplifying the function of OX40L. 第39回日本免疫学会 総会・学術集会, 大阪

6. 小笹亮太郎, 岸本裕司, 藤田真也, 宮地理彦, 田嶋健 一郎, 森眞一郎, 福原資郎（2009）5年間の RAEB 期 を経て overt leukemiaへ進展したMDS. 第91回近畿血 液学地方会, 京都

7. 清水導臣, 石井一慶, 伊藤量基, 小宮山豊, 浦瀬文明, 前田裕弘, 野村昌作 (2009) 造血器腫瘍患者のDICに おけるケモカイン・可溶性分子の測定とトロンボモ ジュリンの治療効果. 第71回日本血液学会, 京都

8. 藤田真也, 森眞一郎, 宮本理恵, 小笹亮太郎, 中道尚 人, 宮地理彦, 田嶋健一郎, 岸本裕司, 尼川龍一, 福 原資郎（2009）再発・治療抵抗性 DLBCLに対する RESHAP 療法十自家末梢血幹細胞移植併用大量化学療 
法の後方視的検討. 第 71 回日本血液学会学術集会, 京 都

9. 中山英恵, 木村 譲, 高橋伯夫, 大倉ひろ枝, 岡下さ やか, 宮内卓史, 上田加奈子, 岩坂壽二（2009）減量 時の内臓脂肪に及ぼす対組成及び運動耐容能の評価. 第30回日本肥満学会, 浜松

10. 村上真理, 松岡由和, 中塚隆介, 植村靖史, 佐々木豊, 福原資郎，薗田精昭（2009） ヒト未分化 CD34 抗原陰 性造血幹細胞の純化とその特性解明. 第71回日本血液 学会学術集会, 京都

11. 山田晴彦, 二階堂潤, 星野 健, 高橋寛二, 尾崎吉郎 (2009) インフリキシマブ投与中の眼ベーチェット病 患者にトラベクレクトミーを施行した 2 例. スリーサ ム・イン なにわ（第43回眼炎症学会），大阪

12. 村上直子, 伊藤量基, 尾形 誠, 片芝雄一, 宮本理恵, 嶋元佳子，尼川龍一，福原資郎（2009）IL-33による CD4陽性細胞の分化制御. 第49回日本リンパ網内系学 会総会, 兵庫

13. 兵晃, 清水俊樹, 杉本博是, 鳥居芳太郎, 安室秀 樹，横井 崇，尼川龍一，岸本裕司，福原資郎 (2009)
レシピエントに抗 HLA 抗体を認めた遅発性輸血関連 肺傷害の剖検例の 1 例. 第 49 回日本呼吸器学会学術講 演会，東京

14. 小笹亮太郎, 森眞一郎, 藤田真也, 宮地理彦, 田嶋健 一郎, 岸本裕司, 福原資郎 (2009) 隆起型ポリープ状 病変を呈した濾胞性リンパにリツキシマブ単剤治療 を行った 1 例. 第91回近畿血液学地方会, 奈良

15. 鳥居芳太郎, 清水俊樹, 兵 晃, 杉本博是, 横井 崇, 福原資郎 (2009) 再発小細胞肺癌に対する塩酸ア ムルビシン単剤療法の用量一毒性相関の検討. 第7回 日本臨床腫瘍学会学術集会, 名古屋

16. 玉置岳史, 岡本三貴, 安藤性實, 谷尻 力, 今村麻衣 子，米津精文，福原資郎 (2009) Gefitinibにより奏功 がみられた肺粘表皮癌の 1 例. 第 89 回日本肺癌学会関 西支部会, 大阪

17. 安室秀樹, 嶋元佳子, 孫 瑛洙, 澤井宏和, 小室 元, 尾㠃吉郎，伊藤量基，和田孝彦，宮嶋茂雄，福原資郎 （2009）抗 IL-6 受容体抗体投与にて治療中に心膜炎の 悪化を認めた関節りウマチ患者の1例. 第53回日本リ ウマチ学会総会学術集会, 東京

\section{内科学第二講座}

\section{〈研究概要〉}

循環器

循環器学では, 心筋虚血, 心不全の病態解明についての基礎研究とともに, 虚血性心疾患や不整脈の患者予後に直接 還元できる臨床研究を主体としてきた. 同時に新しい再生医療として骨髄移植療法やNOGAシステムの臨床応用など, 今 後の新しい医療と，QOLを重視した臨床治療の確立を研究目標においている.

\section{動物実験モデルを用いた虚血，再潅流障害および心不全の病態生理と治療に関する研究}

我々は動物実験モデルを用いて心臓血管系に関わる種々の病態を解明し，その知見を臨床応用するというトランス レーショナルリサーチを推し進めている.

\section{1. 心筋特異的心筋保護法に関する研究}

分子生物学や細胞生物学の進歩に伴い低酸素や各種ストレスによって引き起こされる細胞死に関する研究は格段の進 歩を遂げた。それらの研究成果は急性心筋梗塞に対する再潅流療法, 開心術や心臓移植の成績向上に少なからず貢献し てきたが，未だ理想的な心筋保護法が確立されているとは言い難い。その原因は虚血，再潅流によって惹起される心筋 に特異的な病態生理を十分に解明できなかった点にあると考えられる. 虚血, 再潅流に伴う心筋細胞死の機序がその他 の細胞死と大きく異なる点は，心筋細胞では再潅流後の収縮再開に伴って細胞死が惹起される点にある. この心䇗特異 的細胞死の形態は古くから収縮帯壊死として知られているが，その根本にある分子生物学的機序は不明であった，我々 はかねてより心筋細胞に特異的に発現し，収縮に伴う機械的ストレスから細胞膜を保護する役割を果たしている dystrophin に着目し，研究を進めてきた。そして心筋再潅流障害はミトコンドリア機能低下とATP 産生の減少に伴い dystrophinが局在変化する結果, 細胞膜が脆弱化することにより惹起されるという仮説を支持する実験結果を得た．我々 はdystrophin遺伝子改変動物を用いて，心筋虚血，再潅流に際してdystrophinが局在変化する機序を解明し，心筋特異的 心筋保護法の開発を目指している.

我々はこの基礎研究と並行してブタの急性心筋梗塞モデルを用いた臨床前試験を行い, 超短時間作用性 $\beta$ - 遮断薬の再 潅流障害予防効果を証明し心筋特異的心筋保護法の概念が臨床応用可能であることを裏付けた。この実験結果に基づき 関西医科大学倫理委員会の承認を得て, 超短時間作用性 $\beta$-遮断薬の再潅流障害予防効果に関してST上昇型急性心筋梗塞 に対して一次的カテーテル治療を受ける患者を対象として前向き臨床試験を行っている. 


\section{2. 虚血, 再潅流障害および心不全における酸化ストレスの 2 面性に関する研究}

我々は高血圧, 糖尿病, 高脂血症, 心筋症といった酸化ストレス六進状態において施行される抗酸化療法の有用性と 危険性を酸化ストレスの二面性の観点から検討している. 酸化ストレスは心血管系の多くの病態において中心的な役割 を果たしている．種々の病的状態に際して過剰産生される活性酸素は心筋障害や動脈硬化の主たる原因であると考えら れてきた。しかし，活性酸素の分子生物学に関する最近の知見は酸化ストレスが細胞に対して単に障害的に作用するの みでなく, 非致死的な酸化ストレスが種々の致死的なストレスに対する防御機構を獲得させるうえで必須な生命現象で あることを示唆している，我々は食塩感受性高血圧ラット，糖尿病マウスおよび心筋症八ムスターを用いて虚血，再潅 流障害および心不全に対する抗酸化剂の効果を検討したが，無差別な酸化ストレスの排除は心筋保護的シグナルを減弱 させて有害な作用を抢よぼすことが示唆された。一方，これらの病的条件下で心筋保護作用を惹起するアンジオテンシ ンII 1型受容体拮抗薬はNADPH oxidase を選択的に阻害して有害な酸化ストレスのみを排除し, 心筋保護的なレドックス シグナルを温存することが明らかになった，現在これらの知見に基づいて病的心臓に対する新たな抗酸化療法の確立を 目指している.

\section{3. 虚血, 再潅流障害および心不全における窒素還元バランスの役割に関する研究}

窒素還元バランスとは一酸化窒素（NO）と酸化ストレスとの相互作用であり，心血管系の病態生理に重要な影響をお よぼしている．窒素還元バランスは一酸化窒素合成酵素（NOS）の共役状態と密接に関連している. 正常なNOSの共役 状態ではL-Arginine と酸素から主としてNOが合成されるが, 脱共役状態ではスーパーオキサイドの産生が増加する. NOS の共役状態を維持するために最も重要な因子はコファクターBH4である. 酸化ストレスに伴うBH4の減少はNOS脱共役 を惹起する結果, NO産生の低下とスーパーオキサイド産生の増加をもたらし, 窒素還元バランスを破綻させる. これま で，心蔵に打ける窒素還元バランスは主として内皮型NOS（eNOS）について検討されてきたが, 誘導型NOS（iNOS）の 役割に関しては不明な点が多い. eNOSが血管内皮細胞に恒常的に発現し, 健常状態においてリン酸化やカルシウムによ る活性調節を受けているのに対し, iNOSは健常状態では発現せず, 心不全や虚血等の病的状態において酸化ストレスに よって発現が誘導される. iNOS 脱共役の結果生じたスーパーオキサイドは二次的に eNOS脱共役を惹起し, さらなる窒 素還元バランスの悪化をもたらす可能性がある.したがって病的心筋ではiNOSを介した窒素還元バランスの異常が重要 な役割を果たすと考えられる。しかし敗血症でみられるような過剩な iNOSの発現六進, 活性化に伴う酸化/窒素ストレ スは心筋に対して有害な作用を示す反面, 遅発性ischemic preconditioningのように適度な窒素還元バランスは心筀保護的 に作用することが知られている。したがってiNOSの発現が心臓に有害に作用するか保護的に作用するかは窒素還元バラ ンスによって規定されていると考えられる. このような観点から我々は, 糖尿病モデル, 心筋梗塞モデルおよび圧負荷 モデルを用いてこれら病的心筋の虚血, 再潅流障害と心不全発症メカニズムにおける窒素還元バランスの役割を検討し, それを適切に維持するための治療法の確立を目指している.

\section{4. 急性心筋梗塞に対するサイトカイン療法の有効性に関する研究}

急性心筋梗塞の発症に伴い骨髄から種々の幹細胞が動員され, これが梗塞巣の修復に関わっていることが知られてい る. 骨髄細胞の末梢血中への動員を促すサイトカインとして granulocyte-colony stimulating factor (G-CSF) が存在し, こ れは化学療法に伴う顆粒球減少症の治療薬として確立されている. 近年, 心筋梗塞後の心筋修復を促進する目的でG-CSF を投与する試みが臨床的になされているが，その有効性に関しては議論が多い. 我々は緑色蛍光タンパク発現ラットの 骨髄を骨髄内移植したラットに心筋梗塞を作成して G-CSF の投与が骨䯣細胞の動員と心筋修復におよぼす影響を検討し た. その結果, G-CSF は造血幹細胞の末梢血中への動員を著明に増加させるが, 心筋梗塞巣への動員を増加させないこ とを明らかにした，その原因は，G-CSF 投与によって造血幹細胞に存在する stromal cell-derived factor-1 $\alpha(\mathrm{SDF}-1 \alpha)$ の 受容体である CXCR4 の発現を低下させることが示唆された. SDF-1 $\alpha$ は心筋梗塞巣で産生され, 骨髄から誘導された CXCR4陽性細胞と結合してこれを梗塞巣内に留める役割を担っている. したがって G-CSF投与によるCXCR4陽性細胞の 減少は末梢血中造血幹細胞の増加にも関わらず心筋梗塞巣において血管新生や心筋再生等の心筋修復に関与する造血幹 細胞数を増加させないことを意味している。一方, G-CSF は緑色蛍光タンパク発現マウスの骨䯣を骨䯣内移植した心筋 症マウスに拈いてイソプロテレノールによって誘導された心筋障害を軽減した。 これらの事実は G-CSFが骨髄造血幹細 胞の動員とは異なるメカニズムで心筋保護効果を発揮していることを示唆している. 我々は, そのメカニズムとして erythropoietin 等, 他のサイトカインの心筋保護効果に共通であるSTAT-3を介する心筋保護的シグナルに注目し, 新たな サイトカイン療法の確立を目指している.

\section{5. 薬剤徐放性ゲルを用いた心筋再生療法に関する研究}

急性心筋梗塞では発症後 24 時間以内に責任冠動脈領域に存在する心筋細胞の約 7 割が死滅し，その後も心筋細胞は一 定の割合で死滅することが知られている。この心筋細胞死を抑制することがその後進行する心室リモデリングと左室機 
能障害を予防するために重要である。 心筋梗塞巣では種々のケモカインや増殖因子が産生され血管新生や心筋再生に関 わっている. しかし，それらの多くは一過性に増加するのみであり，血管新生や心筋再生効果も一過性である. そこで 心筋梗塞後に血管新生や心筋再生に関わるケモカインや増殖因子を投与することが治療選択となるが，全身投与では多 臟器への悪影響が除外できない。この問題を克服するために我々は京都大学再生医科学研究所との共同研究により薬剤 徐放性ゲルにケモカインや血管新生促進因子を添加，これをシート状にして梗塞巣に貼付することによって心筋局所に のみ持続的に効果発現する治療法を考案した．現在，ケモカインであるSDF-1 $\alpha$, monocyte chemoattractant protein-1や血 管新生抑制性 microRNA に対する antagomir を用いてそれらの効果を検討している. この治療法は今後，心筋再生の局所 療法として発展していくことが期待される.

\section{動脈硬化，生活習慣病，心臓リハビリテーション領域での研究}

健康科学センターを中心に, 心疾患の再発予防, 治療㧍よび, 生活習慣病, 動脈硬化に関する多面的研究を行っている.

1）運動療法効果の機序に関する研究

上腕虚血再還流時の末梢血流変化より血管内皮機能を評価し, 運動療法効果, インスリン抵抗性, アディポネクチン 等サイトカインとの関連，内皮機能改善のための運動処方，薬剤等の介入方法の確立を目指している.

現在まで, 肥満例での6か月での運動療法により, 減量の有無にかかわらず, 血管内皮機能の改善抢よび各種サイトカ インの変化との関連を報告してきた，今後さらに血管皮機能と血管スティフネス，血圧，遺伝子レベルでの関連等を明 らかにしていく予定である.

2）心理的介入併用よるあらたな臨床治療効果の研究

認知行動療法は, うつ等の精神疾患に扔いてその治療効果が確立されているが, 肥満や生活習慣病における介入効果 に扔いては十分な検証がなされていない, 我々は, 同志社大学, 立命館大学心理学部との共同研究で, 従来の食事・運 動療法に加え, 心理的評価・介入を加えた新しいプログラムによる効果を認めており, 今後これら心理的介入の確立, 減 量後のリバウンドの予測等の研究を進めている. 特に高度肥満症における心理介入の併用は新たな肥満治療として注目 されており，臨床心理士との共同研究を行っている.

3）肥満症におけるエネルギー代謝からみた病態評価，治療法の研究

専門特殊外来として, 日本肥満学会認定の肥満症治療専門病院の認定を受け取り, 年間約 150 例の高度肥満の治療を 行っている. 同時に, 高度肥満に扔けるCT内臟脂肪, DEXA法等による精密体組成評価, 呼気ガス分析による脂肪燃焼 料等のエネルギー代謝機能，アディポネクチン等のサイトカイン，インスリン抵抗性等の総合的評価を行い，肥満症の 本質, 効果的介入方法の研究を行っている. 本年度から, 従来成人では消滅していると考えられていた褐色脂肪細胞の PETによる評価法を確立し, 新たな肥満症の評価, 介入方法につき研究を開始する予定である.

4）ITによる医療情報の最適化，共有化による医療効率の向上，医療費軽減効果の検証

サーバーシステム, クラウド化による医療情報の最適化, 共有抢よび生体情報収集デバイスの新規開発により, 医療 機関でのみ利用されてきた医療や健診結果を, 他の健康介入機関や時系列データとしてリアルタイムで評価可能となり, 個人の健康特性, 健康予測, 介入方法の開発等に大きな効果を上げてきている. 現在まで, 経産省, 総務省等の検証事 業により，PHR（Personal Health Record）システムの確立，減量プログラムの有用性につき報告している．今後より効 果的抢よび広域なデータベースの構築，健康增進機関との医療連携，医療レセプトデータによる費用対効果の検証など を行っていく予定である.

\section{慢性心不全における交感神経活動，圧受容体反射に関する研究}

心不全例において交感神経活動の充進, 圧受容体反射は予後を左右する上で重要な指標である. 交感神経活動の測定 は, 血中ノルアドレナリン，心拍変動スペクトラム，筋交感神経活動などを，圧受容体反射は動脈圧圧受容体反射を測 定している. 現在まで, ACE 阻害薬, ARB, 中枢交感神経抑制薬などの心不全症例に対する交感神経活動, 圧受容体反 射への影響について検討を重ねている. さらに, 最近では, 心不全症例に合併している糖尿病症例に対するピオグリタ ゾンの交感神経活動, 圧受容体反射の評価も行っている，今後は，重症心不全症例に対する両室ペーシング症例に対す る交感神経活動，圧受容体反射への影響への影響およびレスポンダー，ノンレスポンダーの機序の解明を検討していく 予定である.

\section{循環器画像診断を用いた心筋灌流・心筋変性に関する研究}

心臟核医学検査は血管造影では評価できない心筋の微小循環を評価するのみならず，心筋の変性についても非侵襲的 に評価可能な独立した検査法である。検查時に生じるバイアスが少ないことから，これまでに多くのエビデンスの蓄積 がなされ, 確立した予後評価法として認知されている。 また, 現在も糖尿病・慢性腎藏病など他の疾患と冠動脈疾患の 併存が予後に与える影響など，多くの検証がなされている，一方，近年循環器疾患への応用が急ピッチで行われている 
CT検査とのデータ共有により, 冠動脈の解剖学的狭窄と支配冠動脈領域の心筋血流を評価することが可能となった. 我々 は現在，その技術を応用することにより冠動脈石灰化と心筋虚血の関連，CT検査で認められる冠動脈狭窄部位の形状と 心筋虚血の関連等の評価を行い，その結果の一部を報告した，さらに冠動脈病変と血行再建の適応，患者予後との関連 を明らかにする検討を行う予定である。

\section{心臟カテーテル部門}

近年の我が国における，食生活の欧米化や高齢化社会の到来は，生活習慣病を基盤とする動脈硬化疾患の増加をもた らし, 循環器領域においては冠動脈硬化による狭心症, 心筋梗塞, 閉塞性動脈硬化症を始めとする末梢血管疾患が年々 増加の傾向にある.

カテーテルによる冠動脈形成術（PCI）は薬物溶出性ステント（Drug Eluting Stent: DES）の登場により，その治療成 績は飛躍的に向上した。 しかしながら, 左主幹部分岐部病変, 慢性完全閉塞病変, 膤漫性病変, 高度石灰化病変といっ た複雑冠動脈病変を有する患者に対するPCIの臨床成績は, BMS の時代に比較し改善されたとはいえ満足の行くもので はない．これら複雑冠動脈病変に対するPCI後の再狭窄の背景にあるのは糖尿病と維持透析である.

臨床研究 1 .

複雑冠動脈病変を有する糖尿病患者に対する塩酸ピオグリタゾンによる

第二世代のステント（Evalorimus Eluting Stent; EES）留置後の再狭窄予防効果

EESの登場により, 第一世代を淩ぐ臨床成績が期待されるなかで, これら複雑病変を有する糖尿病患者に対して, EES 留置後に, BMSの時代から再狭窄予防効果が期待されている. 塩酸ピオグリタゾンの効果を無作為試験により検討する. 臨床研究2.

OCTを用いた透析患者に対するEES留置後慢性期における再内皮化，内膜肥厚の評価

EES は従来のDES と比較し，金属量が少なく，ポリマーの生体適合性が高いことにから，血管壁に対する炎症性が低 減され，再内皮化率が高いことが基礎実験で明らかにされている，EESは，第一世代のDESでは高頻度に生じた透析例 の再狭窄をこれらの特性を以て抑制することが期待される. 光屈折波断層法（OCT）をステント留置後の慢性期に行い, ステント表面の内皮化率, 内膜肥厚の程度, 性状について, 従来の第一世代のDES と比較検討する.

臨床研究 3 .

透析患者に対するRotablator後EES留置例の臨床成績.

透析例ではカルシウム代謝異常から, 冠動脈の動脈硬化病変に高度の石灰化を高頻度で伴いその治療にはRotablatorに よる石灰切除後にStentを留置する方法が一般的である，上述のごとく透析例では再狭窄率が高く，EESの再狭窄抑制効 果が期待されるが, Rotablator後のDESを無作為に第一世代のSirolimus Eluting Stent と, EES留置例に分け, 慢性期の治 療成績について検討する.

臨床研究 4 .

Virtual Histology 用いたBMS と Silorimus Eluting Stent（SES）の再狭窄病変の解析.

DES 治療により，再狭窄は低減化されたが，一方で再内皮化の障害あるいは遅延が，血管壁の治癒過程を障害・遷延 化し，BMSの時代には見られなかった. Stent留置後 1 年以上を経過してから生じる超遅発性ステント血栓症 (VLST) が 重大な臨床課題として注目されている. その頻度は年率 $0.2 \%$ 程度と極めて低率ではあるが, 発症すれば, 半数以上がST 上昇型心筋梗塞のため死亡するとされる，その機序には，多因子が関連するが，主たる原因として，Stent表面の内皮化 が不十分なためその金属に対して生じる血栓，残存するポリマーによる炎症が惹起する内膜肥厚，あるいは新たに生じ る動脈硬化病変のプラークの破綻が上げられる.

Integrated backscattre 法は, 冠動脈内超音波検画像を解析しプラーク内の組織成分を可視化するものである. 即ち, BMS およびDES（SES）留置後, 遠隔期に生じたStent再狭窄病変の組織性状について比較検討し, その組織が内膜肥厚か新 規動脈硬化病変か血栓か，あるいはこれらの複合したものかを明らかにし，DESのVLSTの機序を解明する.

臨床研究 5 .

待機的PCI時におけるOCTを用いたplqque性状の評価と末梢塞栓の検討

待機的 PCI 時に CKが上昇する例は遠隔期予後が不良であることが知られており，その原因は，PCIによるプラーク破 壊によって生じたコレステリンなどの動脈硬化病変の内容物あるいはその表面に付着した血栓の末梢塞栓と考えられ る.

プラークの性状を解析する方法として，血管内超音波検査やCTAを用いるが，OCTに比較すればその分解能は $1 / 10$ 以 下であり，また待機例は急性冠症候群のごとき明らかな soft plaqueではないため, 両検查法から得られる性状を以てして 末梢塞栓を予測するのは困難である. OCTを用いたplaque性状の解析により, 未梢塞栓を予測することができれば, filter などを使用した塞栓予防が可能となる.

OCTによる plaque性状の解析と心筋障害の関係について検討する. 
臨床研究 6.

短時間作用型 $\beta$ 遮断薬による，再灌流障害の予防効果についての検討

急性心筋梗塞に対する PCI など再灌流療法後に梗塞心筋の過収縮による収縮帯壊死を生じることが病理学的に明らか にされているが，過収縮の予防は，再灌流療法による梗塞心筋の救済効果をさらに向上させる可能性がある.

これまで，急性心筋梗塞に対する $\beta$ 遮断薬治療は短期および遠隔期予後を改善することが知られているが，再灌流直後 に投与した $\beta$ 遮断薬の効果については明らかではない. 短時間作用型 $\beta$ 遮断薬は, 従来の $\beta$ 遮断薬に比較し血行動態の変 化に対応しながら容量調整することが可能で, 再灌流急性期の過収縮を抑制する効果が期待される. 発症早期の急性心 筋梗塞例に対するPCI患者に無作為に短時間作用型 $\beta$ 遮断薬を冠動脈内投与し,引き続き経静脈的に持続投与することで, 梗塞心筋の救済効果を検討する.

臨床研究7.

Statin はLDL cholesterolの低下作用とともに，血管保護作用など多面的効果を有することが知られており，特に急性冠 症候群において経皮的冠血管形成術（PCI）施行前のスタチンの大量投与はPCIに伴う心筋障害を抑制しMACEを改善す ることも知られている. その要因については血小板凝集抑制, 抗炎症, 接着因子の抑制等さまざまな報告があるが未だ 明らかでない，また慢性期に打ける血管内超音波（IVUS）を用いたプラークの退縮についての報告はされているが，急 性期（発症 2 週間以内）でのプラーク性状の变化については今まで報告がなされていない. 急性心筋梗塞発症時, 冠動脈 造影で自然再灌流がえら得た症例を対象に, virtual histolotyでプラーク性状を評価した後, ロスバスタチンを無作為に投 与し, 一週間後のPCI施行時に, virtual histolotyおよびpressure wireを用いて, plaque性状およびPCIによる微小循環障 害を評価し，その容量依存的効果を検討する.

臨床研究 8.

地域連携パスの冠動脈疾患二次予防における役割

冠動脈疾患の二次予防の主体は冠危険因子の厳格な管理にある.それぞれの冠危険因子について, 治療目標のガイド ラインが提唱されているが，その達成率は十分でないという報告が多い．枚方市，寝屋川市を中心とした北河内医療圏 東部におけて地域連携パスの運用を展開中であるが, 連携パス運用前後の冠危険因子の管理状況と心血管事故発生率に つき 3000 例を目標に観察研究を行う.

\section{心エコーを用いた左室拡張能の評価}

(1)左室拡張能による心房細動, 脳梗塞の予後と予測に関する検討

左室拡張能障害の臨床型とされる心房細動は持続性の不整脈のうち最も頻度の多い疾患で，心房細動を伴う群は，脳 梗塞や心不全などの合併に伴う入院の頻度・医療費が有意に高いことから，心房細動による経済的・社会的負担が今後 も増加することが予測され，心房細動の予防やその合併症の予防が重要とされている．我々は心エコ一検査を予定され た患者の経過を追い, 心房細動, 脳梗塞, 死亡の心血管系イベント発症の有無を前向きに調査している，現在までに， ベースラインの臨床データから, 肥満は左室拡張能障害に独立して関与する因子であること, 左室拡張能障害は慢性腎 蔵病に独立して関与する因子であることが判明し, 結果の一部を報告した. 今後, 研究対象患者を経過観察し, 心房細 動, 脳梗塞, 死亡が扢った群と, おこらなかった群間の, 臨床的, 血液生化学的, 心藏超音波的基礎データの比較検 討，また多変量解析で予後予測因子を検討する予定である.

(2)心房細動患者における左房容積の心不全予測における有用性の検討

心房細動は左室拡張能障害の臨床型とされる疾患である。 心房細動患者の心不全の合併頻度は脳梗塞に比し高く, 心 不全合併例では予後不良であるとされ，またその発症頻度は過去 20 年間に明らかな減少を認めていないことが判明して いる. 洞調律患者で，心不全の予測に左房容積の測定が有用とする報告があるが，心房細動患者における左房容積評価 の有用性や，リスクの層別化の有用性に関しては現在わかっていない. そこで心房細動患者を対象とした心不全の予測 に役立つ指標を検討する研究を計画中である. 本研究の結果から心力学的な面からの心不全の危険因子を理解すること ができ，今後我が国でも増加すると予測される年齢依存性心疾患の代表である心房細動における，心不全発症の予防達 成への重要な研究になることが期待される.

(3)肥満による血管内皮機能と左室拡張能への影響, その運動療法の効果に関する検討

肥満と左室拡張能障は共に将来の心血管系イベントの危険因子になると報告される。しかし，肥満は高血圧，糖尿病， 脂質異常などを伴うことが多く, 肥満が独立して左室拡張能障害や血管内皮機能障害の危険因子になりうるか否かは明 らかにされていない. 我々は, 肥満が独立して左室拡張能障害や血管内皮機能低下に関与するのか否か, 及び運動療法 が血管壁伸展性に及ぼす効果に関して検討している。その結果から，1）肥満は単独で左室拡張能と血管内皮機能に悪影 響を及ぼし，2）運動療法による減量療法で, 血管壁伸展性が改善を得られる可能性が示唆され, その結果の一部を報告 
した，今後は減量による肥満の改善により，血管機能の改善に加え，心血管系イベントを予防することが可能かどうか の研究を検討中である.

\section{(4) 3 次元心エコーによる左房容積評価に関する検討}

左室拡張能評価法の 1 つとして有用である左房の大きさは，心血管イベントの独立した危険因子とされている．心工 コーによる左房容積は，左房径と比較してょり正確な評価法であることが近年報告されてきた．しかし楕円形である左 房の形態から 2 次元エコーによる左房容積の評価には限界があるとされる. 近年, 心臟立体構築がより正確に観察可能な 3次元心エコーが利用可能となり臨床応用されてきている. 我々は, 心血管イベントの独立した危険因子である左房容積 の正確な評価方法を確立することを目的とし，3 次元心エコーによる左房容積とマルチスライスCTによる左房容積との 関係を調查し良好な相関を認め, 結果の一部を報告した.

\section{内分泌・代謝}

甲状腺疾患, 副腎疾患, 下垂体疾患など種々の内分泌疾患や，糖尿病の診療を行なうとともに，これらの臨床的なら びに基礎的研究を行なっている.

\section{1. 基礎的研究分野}

甲状腺から主に分泌される T4 は，5'の位置の脱ヨード反応により活性型ホルモンである T3 に転換される，一方，5の 位置の脱ヨード反応により不活性型ホルモンである reverse T3に変換される. 5 'の位置の脱ヨード反応を触媒する酵素に は, Type 1 及び Type 2 iodothyronine deiodinase（D1 及びD2）があり， 5 脱ヨード反応を触媒する酵素には, Type 3 iodothyronine deiodinase（D3）がある．D2 は，酵素が発現する局所での T3 産生を調節する重要な酵素である，D1，D2 及びD3の発現調節機構およびその生理的意義を明らかにし, 臨床応用することを目的として研究を行なっている.

従来，血中 T3濃度は，肝臓・腎臓などに発現するD1により調節されると考えられてきた。しかし，D1遺伝子を欠失 したマウスの血中 T3 濃度が野生型と差異を認めなかった。この結果より， D1を必要としない，血中 T3 濃度の調節機構 が存在すると考えられ，その解明に取り組んでいる.

（1）甲状腺組織には，D1及び D2 が発現している，T3 優位型バセドウ病や，著明な甲状腺腫を有する慢性甲状腺炎の甲 状腺組織を用いた研究より, 甲状腺組織に発現するD2活性が, 血中T3濃度調節に関与する可能性を明らかにした。

（2）ヒトの脂肪前駆細胞に，D2活性及びmRNAが発現すること, cAMPにより positiveにその発現が調節されることを明 らかにした．内臟脂肪由来の脂肪前駆細胞の D2 活性は, 皮下内臓脂肪由来の脂肪前駆細胞の D2 活性に比し高值である ことを明らかにした。

（3）血管中膜に D2 活性が発現し，その発現に日内リズムが存在することを明らかにした．血管中膜の D2 活性の日内リ ズムには，内因性グルココルチコイドの日内リズムが関与することを明らかにした.

\section{2. 臨床的研究分野}

1）バセドウ病の治療に関して：

（1）抗甲状腺剤は，バセドウ病の一般的な治療法であるが，寛解に至るまでの投与期間が長く，投与中止後の再発率が 高いなどの欠点がある. 抗甲状腺剤を用い，寛解に至るまでの期間が短く，中止後も再発率の少ない投与方法を研究し ている.

（2）1型自己免疫性糖尿病を合併するバセドウ病は，抗甲状腺剤では寛解に至り難く，難治性である，しかしながら，こ れまでに，1 型自己免疫性糖尿病を合併するバセドウ病が，難治性であるという evidence は報告されていない．この evidenceの構築を目指し, 1型自己免疫性糖尿病を合併するバセドウ病患者に適した, 治療法の確立を目指している.

（3）T3優位型バセドウ病は，抗甲状腺剤に難治性である．T3優位型を惹起する機序としては，甲状腺に発現する Type 2 iodothyronine deiodinase（D2）の関与が考えられる．D2活性の調節を介した，治療法を研究している.

2）血中T3濃度調節のメカニズム

（1）甲状腺全摘出後，T4製剂を投与されている患者さんが，血中T3濃度を調節するメカニズムを研究している.

（2）低 T3症候群において，血中T3濃度が低下する機序を研究している.

\section{糖尿病}

(1)基礎研究分野

糖尿病分野での基礎研究としては, 種々の糖尿病性合併症の成因を明らかにすることを目的に研究を打こなっている. これまで糖尿病性合併症の進展因子としてはポリオール系代謝，Cキナーゼ活性，糖化蛋白拉よび酸化ストレスなどの 関与が報告されている. 現在我々は糖化蛋白の受容体のひとつであるRAGE (receptor for advanced glycation endproducts) 
のシグナル伝達様式の解明および，その新規りガンドであるS100関連蛋白の糖尿病性合併症への関与を，分子生物学的 および発生工学的手法を用いて検討している.

(2)臨床研究分野

糖尿病は，それによる3大合併症である網膜症，神経障害，腎症のみならず，動脈硬化症の進展を基盤として，心筋梗 塞, 狭心症, 脳卒中など, 生命予後やQOLを規定する様々な病態を引き起こす危険因子の最も重要な疾患のひとつであ る. また，糖代謝異常はメタボリック症候群の中核を形成する病態である. これらを有機的に予防・治療するため, 当 科では糖尿病専門外来, 糖尿病教育を含む入院治療の連携で, きめ細かい診療を実施している. 糖尿病教室では, 医師・ 薬剂師・看護師・栄養士・心理士がそれぞれ協力して患者指導を行い糖尿病性合併症の予防と治療に力を注いでいる. ま た, 合併症発症後は当科心蔵・循環器や腎臓・透析グループおよび当院眼科と共にその管理治療を行っている. そして, これらの取り組みを基盤とした数々の臨床研究を行っている. 糖尿病治療の最近の特徵は, 種々のインスリン製剤や経 口血糖降下剂の開発により個々の病状に合わせた，よりオーダーメード的治療が可能となってきたことである。しかし 本邦に扔いて頻度の高い 2 型糖尿病の治療の基本は食事療法および運動療法であり, 日常診療においてはこれら生活習慣 の改善がでさない事による血糖コントロールの不良例も多数みられる. そこで, これらの血糖コントロールの不良例と その行動習慣, 性格, 情緒, 社会的要因などの関連性について調査し, それらへの行動科学的介入法を確立してゆく.

糖尿病性合併症の治療への新しい方法として, 糖尿病性末梢神経障害や慢性閉塞性動脈硬化症が明らかでない糖尿病 性足部潰瘍へ自家末梢血単核球細胞移植治療を進めていく予定である. 当科抏いてこれまで多数の下肢慢性閉塞性動 脈硬化症およびビュルガー病の方へ骨䯣および末梢血単核球細胞移植による血管新生治療が行われ良好な臨床成績が得 られている. 今後, 我々は下肢の微小血管障害に由来して発症または増悪すると考えられている糖尿病性末梢神経障害 や糖尿病性足部潰瘍への自家末梢血単核球細胞移植治療の有効性を検討してゆく. 更に, 糖尿病の種々血管合併症進展 における血中の骨髄前駆細胞の病態意義について研究を進めている.

\section{腎臓・高血圧}

\section{腎臟}

(1) 基礎研究分野

1）糖尿病性腎症（DMN）の発症・進展においてはレニン・アンジオテンシン系が重要な役割を担っている. アンジオ テンシンIIの受容体には幾つかのサブタイプが存在し, 最も重要とされる1型受容体の役割についてはこれまで数多くの 検討がなされてきた．しかし，2型受容体の役割については今な扔不明な点が多い，そこで，我々はDMNにおけるマウ スを用いてアンジオテンシン 2 型受容体の役割についての検討を行っている.

2）腹膜透析法は有効な維持透析療法として確立しているが, 腹膜機能の劣化の問題で実施できる期間に限りがあるとい う大きな問題がある. 我々はこの問題を解決する方法として, 自己骨䯣細胞を用いた腹膜再生法を検討している.

(2) 臨床研究分野

1）慢性腎臓病（CKD）においては心血管合併症のみならず腎障害進展抑制のため脂質管理が重要である. 我々は, CKD における小腸Choトランススポーター阻害剤エゼチミブの単独投与時およびスタチン系薬剤との併用投与時の動脈硬化 抑制作用抢よび腎保護作用について詳細な検討を行っている.

2）近年, メタボリック症候群による腎障害が注目を浴びている. 現在, メタボリック症候群による腎障害における腎内 レニン・アンジオテンシン系や酸化ストレスの役割についての検討を行っている.

3）血液透析患者ではエリスロポエチンの使用によりへモグロビン A1c（HbA1c）が見かけ上低值となるため, 血糖コン トロールの指標としてはグリコアルブミン（GA）の方が優れるとされる. 我々は, 保存期 CKD 患者において HbA1c と $\mathrm{GA}$ の測定意義を比較したところ, GA の方が動脈硬化との関連が強く, 血糖值の指標としては保存期 CKD に扔いても HbA1cよりもGAの方が優れている可能性を示した.

4）CKDでは心血管合併症発症のリスクが高いことが知られ，このことは心腎連関として注目されている．その機序の一 つとして, 血中ビタミンC 濃度の低下による酸化ストレス光進に起因する血管内皮機能障害が関与している可能性を見 出した．今後も心腎連関の機序について継続して検討を進めていく予定である.

5）血液透析患者では心血管合併症の罹患率や死亡率が高く，動脈硬化の正確な評価が重要である，我々は維持血液透析 患に打いて, 血管内皮機能 (血流依存性血管拡張反応), ankle-brachial index (ABI) 抢よびbrachial-ankle pulse wave velocity （baPWV）測定の予後推定における有用性を検討したところ，ABI と baPWV は有用であるが，FMD は予後を反映しない ことを確認し報告した.

6）メタボリック症候群では心血管合併症発症のリスクが高い，一方，維持血液透析患者は低栄養となることが多い．し かし, 我々は維持血液透析患者において内臟脂肪面積をCTを用いて測定したところ, 瘦せ型であっても腹部脂肪蓄積を 示す症例が高頻度で見られること, 抢よび腹部脂肪蓄積を認める患者では動脈壁硬化度が強いことを報告した. 現在, 内 蔵脂肪蓄積の予後に及ぼす影響などについての検討を行っているところである. 


\section{高血圧}

1）頭側延䯣腹外側野（rostral ventrolateral medulla, RVLM）は交感神経活動の制御中枢であり，血管運動中枢ともよばれ る領域である. 近年, RVLMへの動脈による圧迫と本態性高血圧の関連についての報告が散見されるようになった，我々 も本態性高血圧患者の一部では RVLM への動脈による圧迫が交感神経活動の六進を介して高血圧の成因に関与する可能 性，および圧迫解除術により交感神経活動が抑制され高血圧が治癒する症例が存在することを報告した．RVLMへの動 脈による圧迫を認める高血圧は本態性高血圧ではなく二次性高血圧に分類される可能性が考元られるが，このことは日 本高血圧学会の治療ガイドライン2009年版（JSH2009）に掲載され注目を浴びている.

このような高血圧に対する治療法としては，圧迫解除術を選択肢の一つとして考慮することができる．しかし，圧迫 解除術は侵襲性が高く圧迫を認める高血圧患者全例に適応を拡大することは困難であり, 有効な降圧薬治療手段を模索 すべきと考えられる，そこで，我々は交感神経抑制薬の有効性についての検討を行っている，また，同時に RVLMへの 動脈による圧迫の原因や病態生理の詳細についての検討も進めているところである.

2）安静時のみならずストレスによる交感神経活動の克進・心拍数の上昇は心事故発症のリスクを高めると考元られてい る. 従って降圧治療時には安静時のみならずストレスによる交感神経活動の克進・心拍数の上昇を抑制する薬剂の選択 が望ましい. カルシウム拮抗薬エホニジピンは血管平滑筋に存在するL型カルシウムチャネルのみならず洞房結節に存在 する $\mathrm{T}$ 型チャネルを阻害するため, 安静時に心拍数を低下させる効果を有する. 我々は精神的あるいは肉体的ストレス 負荷時の心拍数の上昇に及ぼすエヒニジピンの影響を検討したところ，同薬がこれらを抑制することを確認し報告した。

\section{〈研究業績〉}

原 著

1. Morimoto S, Yurugi T, Aota Y, Sakuma T, Jo F, Nishikawa M, Iwasaka T and Maki K (2009) Prognostic Significance of Ankle-Brachial Index, Brachial-Ankle Pulse Wave Velocity, Flow-Mediated Dilation, and Nitroglycerin-Mediated Dilation in End-Stage Renal Disease. Am J Nephrol 30(1): 55-63

2. Mori Y, Kosaki A, Kishimoto N, Kimura T, Iida K, Fukui M, Nakajima F, Nagahara M, Urakami M, Iwasaka T and Matsubara H (2009) Increased plasma S100A12 (ENRAGE) levels in hemodialysis patients with atherosclerosis. Am J Nephrol 29(1): 18-24

3. Yoshida S, Nakamura S, Sugiura T, Tsuka Y, Maeba H, Yuasa F, Senoo T, Takehana K, Baden M and Iwasaka T (2009) Factors associated with myocardial salvage immediately after emergent percutaneous coronary intervention in patients with ST-elevation acute myocardial infarction. Ann Nucl Med 23(4): 383-390

4. Otani H (2009) The Role of Nitric Oxide in Myocardial Repair and Remodeling. Antioxid Redox Signal 11(8): 1913-1928

5. Inami $\mathrm{N}$, Nomura $\mathrm{S}$, Inami O, Kimura $\mathrm{Y}$, Urase $\mathrm{F}$, Maeda Y and Iwasaka T (2009) Significance of soluble CD40 ligand, adiponectin and reactive oxygen metabolites in aging. Arch Gerontol Geriatr 49(1): 13-16

6. Tokuyama Y, Adachi Y, Minamino K, Shintaku H, Okigaki M, Hayashi K, Kitajima A, Takaki T, Koike N, Shima C, Imai Y, Shi M, Yanai S and Ikehara S (2009) Abnormal distribution of dendritic cells in (NZW x BXSB)F1 mice. Autoimmunity 42(5): 399-405

7. Shima C, Adachi Y, Shi M, Imai Y, Okigaki M, Yanai S, Minamino K, Takahashi K and Ikehara S (2009) The combination method using magnetic beads and a magnet helps sustain the number of donor BM cells after intra$\mathrm{BM}$ injection, resulting in rapid hematopoietic recovery. Bone Marrow Transplant Oct 5. [Epub ahead of print]

8. Honsho S, Nishikawa S, Amano K, Zen K, Adachi Y, Kishita E, Matsui A, Katsume A, Yamaguchi S, Nishikawa K, Isoda K, Riches DW, Matoba S, Okigaki M and Matsubara H (2009) Pressure-Mediated Hypertrophy and Mechanical Stretch Induces IL-1 Release and Subsequent IGF-1 Generation to Maintain Compensative Hypertrophy by Affecting Akt and JNK Pathways. Circ Res 105(11): 1149-1158

9. Morimoto S, Jo F, Maki K and Iwasaka T (2009) Effects of efonidipine hydrochloride on heart rate and circulatory changes due to stress. Clin Exp Hypertens 31(1): 83-91

10. Saito T, Matsumura K, Tsubota Y, Maniwa T, Kaneda H, Minami K, Sakaida N, Uemura Y, Kawa G, Yamamoto N, Fujii Y, Isobe K, Kawakami Y, Matsuda T, Saito Y and Takekoshi K (2009) Novel Mutation (L157X) in the Succinate Dehydrogenase B Gene (SDHB) in a Japanese Family with Abdominal Paraganglioma Following Lung Metastasis. Endocr J 56(3): 451-458

11. Shono A, Tsukaguchi H, Kitamura A, Hiramoto R, Qin XS, Doi T and Iijima K (2009) Predisposition to relapsing nephrotic syndrome by a nephrin mutation that interferes with assembly of functioning microdomains. Hum Mol Genet 18(16): 2943-2956

12. Aota Y, Morimoto S, Sakuma T, Morita T, Jo F, Takahashi N, Maehara M, Ikeda K, Sawada S and Iwasaka T (2009) Efficacy of an L- and N-type calcium channel blocker in hypertensive patients with neurovascular compression of the rostral ventrolateral medulla. Hypertens Res 32(8): 700-705

13. Morimoto S, Aota Y, Sakuma T, Ichibangase A, Ikeda K, Sawada S and Iwasaka T (2009) Efficacy of clonidine in a 
patient with refractory hypertension and chronic renal failure exhibiting neurovascular compression of the rostral ventrolateral medulla. Hypertens Res 32(3): 227-228

14. Ukita C, Miyazaki H, Toyoda N, Kosaki A, Nishikawa M and Iwasaka T (2009) Takotsubo Cardiomyopathy during Acute Adrenal Crisis due to Isolated Adrenocorticotropin Deficiency. Intern Med 48(5): 347-352

15. Ikeura T, Takaoka M, Shimatani M, Koyabu M, Kusuda T, Suzuki R, Sumimoto K and Okazaki K (2009) Xanthogranulomatous inflammation of the peripancreatic region mimicking pancreatic cystic neoplasm. Intern Med 48(21): 1881-1884

16. Yanai S, Adachi Y, Fuijisawa J, Jiang S, Okigaki M, Shi M, Shima C, Imai Y, Kwon AH and Ikehara S (2009) Antitumor effects of fusion cells of type 1 dendritic cells and Meth A tumor cells using hemagglutinating virus of Japan-envelope. Int J Oncol 35(2): 249-255

17. Park H, Otani H, Oishi C, Fujikawa M, Yamashita K, Okazaki T, Sato D, Ueyama T, Iwasaka J, Yamamoto Y and Iwasaka T (2009) Efficacy of intracoronary administration of a short-acting beta-blocker landiolol during reperfusion in pigs. Int J Cardiol Aug 24. [Epub ahead of print]

18. Yoshida S, Kamihata H, Nakamura S, Senoo T, Manabe K, Motohiro M, Sugiura T and Iwasaka T (2009) Prevention of contrast-induced nephropathy by chronic pravastatin treatment in patients with cardiovascular disease and renal insufficiency. J Cardiol 54(2): 192-198

19. Kawamura A, Yuasa F, Yokoe H, Masue Y, Sugiura T and Iwasaka T (2009) Augmented sympathoinhibitory effect of valsartan when added to angiotensin-converting enzyme inhibitor in patients with left ventricular dysfunction. J Cardiol 53(2): 171-178

20. Nomura S, Shouzu A, Omoto S, Inami N, Ueba T, Urase F and Maeda Y (2009) Effects of eicosapentaenoic acid on endothelial cell-derived microparticles, angiopoietins and adiponectin in patients with type 2 diabetes. J Atheroscler Thromb 16(2): 83-90

21. Matsunaga S, Okigaki M, Takeda M, Matsui A, Honsho S, Katsume A, Kishita E, Jishan C, Kurihara T, Adachi Y, Mansukhani A, Kobara M, Matoba Y, Tatsumi T and Matsubara H (2009) Endothelium-targeted overexpression of constitutively active FGF receptor induces cardioprotection in mice myocardial infarction (Corrigendum 47(3): 419 2009). J Mol Cell Cardiol 46(5): 663-673

22. Yoh M, Yuasa F, Mimura J, Yokoe H, Kawamura A, Sugiura T and Iwasaka T (2009) Resting muscle sympathetic nerve activity, cardiac metaiodobenzylguanidine uptake, and exercise tolerance in patients with left ventricular dysfunction. J Nucl Cardiol 16(2): 244-250

23. Hattori R, Oishi C, Iwasaka J, Iwasaka T, Okada T, Johno
H, Enoki C, Sumida T, Nakao Y and Imamura H (2009) Multiple papillary fibroelastoma with quadricuspid aortic valve. J Thorac Cardiovasc Surg 137(5): 1280-1282

24. Satoh D, Inami N, Shimazu T, Kajiura T, Yamada K, Iwasaka T and Nomura S (2009) Soluble TRAIL prevents RANTES-dependent restenosis after percutaneous coronary intervention in patients with coronary artery disease. J Thromb Thrombolysis 29(4): 471-476

25. Shimazu T, Inami N, Satoh D, Kajiura T, Yamada K, Iwasaka T and Nomura S (2009) Effect of acarbose on platelet-derived microparticles, soluble selectins, andadiponectin in diabetic patients. $\mathrm{J}$ Thromb Thrombolysis 28(4): 429-435

26. Yamahara H, Kishimoto N, Nakata M, Okazaki A, Kimura T, Sonomura K, Matsuoka E, Shiotsu Y, Adachi T, Matsubara H, Iwasaka T and Mori Y (2009) Direct Aldosterone Action as a Profibrotic Factor via ROS-Mediated SGK1 in Peritoneal Fibroblasts. Kidney Blood Press Res 32(3): 185-193

27. Fujitaka K, Nakamura S, Sugiura T, Hatada K, Tsuka Y, Umemura S, Fujikawa Y, Baden M and Iwasaka T (2009) Combined analysis of multislice computed tomography coronary angiography and stress-rest myocardial perfusion imaging in detecting patients with significant proximal coronary artery stenosis. Nucl Med Commun 30(10): 789-796

28. Koyanagi M, Iwasaki M, Haendeler J, Leitges M, Zeiher AM and Dimmeler S (2009) Wnt5a increases cardiac gene expressions of cultured human circulating progenitor cells via a PKC delta activation. PLoS ONE 4(6): e5765

29. Nomura S, Inami N, Shouzu A, Omoto S, Kimura Y, Takahashi N, Tanaka A, Urase F, Maeda Y, Ohtani H and Iwasaka $\mathrm{T}$ (2009) The effects of pitavastatin, eicosapentaenoic acid and combined therapy on platelet-derived microparticles and adiponectin in hyperlipidemic, diabetic patients. Platelets 20(1): 16-22

30. Bonauer A, Carmona G, Iwasaki M, Mione M, Koyanagi M, Fischer A, Burchfield J, Fox H, Doebele C, Ohtani K, Chavakis E, Potente M, Tjwa M, Urbich C, Zeiher AM and Dimmeler S (2009) MicroRNA-92a controls angiogenesis and functional recovery of ischemic tissues in mice. Science 324(5935): 1710-1713

31. Morimoto S, Nakajima F, Yurugi T, Morita T, Jo F, Nishikawa M, Iwasaka T and Maki K (2009) Risk factors of normal ankle-brachial index and low toe-brachial index in hemodialysis patients. Ther Apher Dial 13(2): 103-107

32. Toyoda N, Yasuzawa-Amano S, Nomura E, Yamauchi A, Nishimura K, Ukita C, Morimoto S, Kosaki A, Iwasaka T, Harney JW, Larsen PR and Nishikawa M (2009) Thyroid Hormone Activation in Vascular Smooth Muscle Cells Is 
Negatively Regulated by Glucocorticoid. Thyroid 19(7): 755-763

33. 朴 幸男, 岩坂壽二, 湯浅文雄, 大石千尋, 佐藤大祐, 岩坂潤二, 大谷肇 (2009) この心電図から何が読み取 れるか？ ハートナーシング 22(9): 86-89

34. 岩坂潤二, 山本克浩, 眞鍋憲市, 前羽宏史, 妹尾 健, 大石千尋, 吉田 進, 森口 暁, 佐藤大祐, 山本哲史, 湯浅文雄, 大谷 肇，岩坂壽二（2009）この心電図は 数時間後の突然死を予測できるか? ハートナーシ ング 22(1): 69-72

35. 大山恭夫, 阪口正博, 森本 聡 (2009) 2 型糖尿病に 対するピオグリタゾン投与前後における空腹時血中 インスリン濃度の変動について. Prog Med 29(3): 899-904

36. 西川光重, 豊田長興, 野村惠巳子 (2009) 甲状腺自己 免疫疾患の診断と治療 - 最近の話題甲状腺ホルモン の合成・分泌・代謝 甲状腺疾患を知るための基礎知 識. カレントテラピー 27(2): 183-188

37. 冨樫健二, 木村 穣, 川田裕樹, 井口光正 (2009) 家 庭用エクササイズ支援ゲーム機（Exergame）を用い た肥満小児の減量効果に関する研究. デサントスポー ツ科 30: 172-180

38. 菱川秀彦, 妹尾 健, 五十野剛, 真鍋憲市, 吉田 進, 森口 暁, 湯浅文雄, 岩坂壽二（2009）基礎から一歩 先へ! ケースに学ぶCCUの心電図 V3 誘導心電図で みられた変動する QRS 波形. ハートナーシング 22(7): 757-759

39. 岩坂壽二, 妹尾 健, 土手絹子, 森島景子, 宮坂陽子, 拝殿未央, 前羽宏史, 五十野剛, 横江洋之, 青田泰子, 万木孝富, 吉田 進, 野田哲平, 村川鉱介, 湯浅文雄 （2009）基礎から一歩先へ! ケースに学ぶCCUの心電 図【番外編】心室期外収縮の動悸はどうして起こるの か？ ハートナーシング 22(2): 200-201

40. 渡辺 淳, 仲野俊成, 竹花一哉, 小山武彦, 平井正明 （2009）診療施設間波形情報連携への医用波形記述プ ロトコル (MFER) 導入の試み. 医療情報学 29(Suppl): 1149-1152

41. 仲野俊成, 渡辺 淳, 竹花一哉, 小山武彦, 平井正明, 佐藤恵一, 田中雅人（2009）MFERを用いた施設間波 形情報共有の有用性および事前需要予測の相互参照 実績に基づく検証. 医療情報学 29 (Suppl.): 634-638

42. 堤 博美, 木村 穣 (2009) 形態, 強度の異なる運動 が血管スティフネスに及ぼす急性効果の検討 29 : 57-72

43. 岡本貴行, 太田裕美子, 北村哲也, 福井政慶, 中嶋章 貴, 森本 聡, 万木孝富, 本田由美子 (2009) 透析困 難症に対する血液透析 (HD) - 腹膜透析 (PD) 併用 療法の有用性について. 腎と透析 66 (別冊 : 腹膜透 析 2009) : 325-327

44. 西川光重, 豊田長興, 野村惠巳子（2009）【甲状腺疾 患をマスターする】甲状腺機能低下症 慢性甲状腺炎
（橋本病），甲状腺機能低下症. 綜合臨 58(7): 15571561

45. 種村直美, 宮野喜代子, 柴田清美, 大垣佳代, 尾崎珠 詠，大田千穂子，北空 幸，狭間信幸，衣川 大，高 橋延行, 森本 聡 (2009) 出口部ケア指導用 DVD の 作成および有用性の評価. 22: 8-11

46. 佐々木弘志, 北川佳奈, 木村 穣 (2009) マラソンの 記録を速度漸増テストの肺換気量応答から予測する。 大阪体育研 (47): 19-25

47. 石川浩史, 今田崇裕, 玉置由紀, 赤崎ゆり香, 加藤千 恵子, 坂口重子, 小杉 隆, 西谷義宏, 岡 敦子, 谷 川良子, 菊池早苗, 山原英樹, 河野啓子, 正木浩哉, 西川光重, 岩坂壽二（2009）透析用ダブルルーメンカ テーテルに打ける閉塞の実態調査と検討. 大阪透析研 会誌 27(2): 173-175

48. 大石千尋, 岩坂潤二, 高橋朋子, 上山敬直, 朴 幸男, 山本克浩, 大谷 肇, 岩坂壽二 (2009) 桂枝茯苓丸の 血管内皮機能における急性効果の検討. 日臨生理会誌 39(4): 215-218

総 説

1. 真鍋憲市, 神畠 宏, 岩坂壽二 (2009) 血管とアディ ポサイエンス 臨床 血管病の薬物療法一アディポ サイトカインの観点より. Adiposcience 6(2): 181-186

2. 大谷 肇 (2009) 予防医学からみたメタボリックシン ドロームメタボリックシンドロームと動物実験モ デル. Angiol Front 8(3): 288-294

3. 西川光重, 笠井喜久男, 重篤副作用別対応マニュアル 作成委員会 (2009)【甲状腺疾患の臨床 見逃されて いる疾患の最新の実地診療】甲状腺疾患の臨床・セミ ナー 薬剤誘発性甲状腺機能異常 増加している, 薬 が引き起こす甲状腺疾患とその臨床. Med Pract 26(1): 88-92

4. 原島典子, 矢澤 直, 友田雅己, 竹島秀美, 原 克子, 朴 幸男, 高橋伯夫, 上野 剛, 平山 哲, 三井田孝 (2009) 生化学検查. Med Technol 37(13): 1422-1483

5. 竹花一哉 (2009) マルチモダリティ画像診断の最前線 -Part3: MDCT と心臓核医学-MDCT時代の心臓核医 学の役割. Rad Fan 7(10): 16-19

6. 木村 穣, 門井文恵 (2009) ナースのための心蔵りハ ビリテーション完全ガイド 第 4 章 心臓リハビリ テーションチームづくり AtoZ 8 関西医科大学健康 科学センター. ハートナーシング (春季増刊) : 213-222

7. 朴 幸男, 岩坂壽二, 湯浅文雄, 大石千尋, 佐藤大祐, 岩坂潤二, 大谷 肇（2009）基礎から一歩先へ!ケー スに学ぶ CCUの心電図この心電図から何が読み取 れるか? 結講奥が深い! ハートナーシング 22(9): 958-961

8. 河本 慧, 宮坂陽子, 梅村茂雄, 妹尾 健, 菱川秀彦, 湯浅文雄, 岩坂壽二（2009）基礎から一歩先へ! ケー スに学ぶ CCUの心電図 労作時呼吸困難に伴って特 
徵的な心電図を示した1例. ハートナーシング 22(6): $626-629$

9. 岩坂潤二, 山本克浩, 眞鍋憲市, 前羽宏史, 妹尾 健, 大石千尋, 吉田 進, 森口 暁, 佐藤大祐, 山本哲史, 湯浅文雄，大谷 肇，岩坂壽二（2009）基礎から一歩 先へ! ケースに学ぶCCUの心電図【番外編】心室期外 収縮の動悸はどうして起こるのか？ ハートナーシ ング 22(1): 69-72

10. 森本 聡 (2009) 延髄血管運動中枢への動脈による圧 迫と高血圧の関連. 医薬の門 48(3): 259-262

11. 奥 真也, 松田恵雄, 竹花一哉, 尾川浩一, 河邊讓治, 對間博之，巽 光朗，長谷川雪憲，宮内 勉，神宮司 公二 (2009) 核医学情報の標準化: 核医学部門の情報 管理戦略ガイドラインの提案へむけて．核医 46(2): 107-108

12. 森本 聡（2009）動脈硬化対策一その治療と指針 3 CKD と高血圧. 循環plus 10(3): 2-6

13. 小系仁史（2009）肺高血圧症一基礎と臨床の最前線 CT/MRI． 綜合臨５8(11): 2259-2265

14. 西川光重, 豊田長興（2009）糖尿病療養指導に必要な 知識 内分泌疾患と糖尿病. 糖尿病の療養指導 : 糖尿 病の進歩 (43): 81-86

15. 塚口裕康（2009）【ネフローゼ症候群 診断と治療の 進歩】ネフローゼ症候群と遺伝子異常. 日内会誌 98(5): 1076-1083

16. 吉岡 慶, 大谷ひとみ, 中邨智之, 大谷 肇 (2009) ジストロフィンと心筋障害. 日薬理誌 134(2): 107

17. 森田龍頼, 森本 聡 (2009)【内科的疾患と多尿】尿 崩症について．排尿障害 17(2): 135-140

18. 木村 穣 (2009) 保健指導のための認知行動療法. 保 健の科学 51(9): 606-610

19. 木村 稕 (2009) 生活習慣病対策 保健指導のための 認知行動療法セミナー：第 7 回 実践編 保健指導に よる認知行動療法の具体的手順. 臨スポーツ医 26(4): 447-451

20. 木村 穣 (2009) 生活習慣病対策 保健指導のための 認知行動療法セミナー：第6回 実践編 運動指導と 認知行動療法．臨スポーツ医 26(3): 353-357

21. 木村 穣（2009）生活習慣病対策 保健指導のための 認知行動療法セミナー：第5回 実践編 食事指導と 認知行動療法. 臨スポーツ医 26(2): 225-230

22. 宮坂陽子, 辻本悟史, 吉田 進, 横江洋之, 前羽宏史, 土手絹子，湯浅文雄，岩坂壽二（2009）スポーツ・身 体活動と突然死 Brugada型心電図 : スポーツ参加を踏 まえた注意点. 臨スポーツ医 26(11): 1393-1399

23. 木村 穣 (2009) 中高年における慢性期の運動・生活 指導の実際一スポーツ施設との連携一ジャパンメ ディカルフィットネスネットワーク（JMFN）一。臨 スポーツ医 26(10): 1227-1233
症例報告

1. Hattori R, Sumida T, Okada T, Johno H, Enoki C, Nakao Y, Miyasaka Y, Haiden M, Dote K, Seno K, Iwasaka T and Imamura H (2009) Surgical treatment for right sided infective endocarditis with recurrent pulmonary infarction concurrent with a ventricular septal defect. 21: 339342

2. 西川光重 (2009) 内分泌疾患の検査と治療 副甲状腺 機能異常. 医と薬学 62(2): 179-184

3. 青田泰子, 森本 聡, 山内 梓, 森田龍頼, 佐久間孝 雄, 高橋延行, 岩坂壽二 (2009) 運動後急性腎不全を きたした腎性低尿酸血症の1例. 腎と透析 67(1): 103106

4. 岡本貴行, 北村哲也, 福井政慶, 中嶋章貴, 森本 聡, 森田龍頼, 万木孝富, 上田邦彦（2009）血液透析間体 重増加の著しい透析困難症に腹膜透析の併用が有効 であった1例。日透析医学会誌 42(4): 333-337

5. 北村哲也, 森本 聡, 万木孝富, 岩坂壽二, 岡本貴行, 福井政慶, 中嶋章貴, 来島泰秋（2009）腹部大動脈人 工血管の仮性動脈瘤破裂，および右大腿回旋動脈の仮 性動脈瘤破裂をきたした血液透析患者の1例. 日透析 医学会誌 42(12): 959-964

その他

1. Dote K, Miyasaka Y and Iwasaka T (2009) Endocarditis and giant mitral valve aneurysms. Acta Cardiol 64(6): 815-816

2. Qin XS, Tsukaguchi H, Shono A, Yamamoto A, Kurihara $\mathrm{H}$ and Doi T (2009) Phosphorylation of nephrin triggers its internalization by raft-mediated endocytosis. J Am Soc Nephrol 20(12): 2534-2545

3. 妹尾 健, 真鍋憲市, 吉田 進, 宮坂陽子, 竹花一哉, 湯浅文雄, 神畠 宏, 岩坂壽二（2009）基礎から一歩 先へ! ケースに学ぶ CCU の心電図 胸痛発作と巨大 陰性 T 波を示した一例。ハートナーシング 22(10): 1066-1069

4. 高橋朋子, 岩坂潤二, 大石千尋, 上山敬直, PARK Haengnam, 山本克浩, 大谷 肇, 岩坂壽二 (2009)「メ ガフード」とアカルボースが血管内皮機能に及ぼす急 性効果. 日臨生理会誌 39(6): 287-290

学会発表

1. Takeshi Senoo, Masayuki Motohiro, Hiroshi Kamihata, Kenichi Manabe, Satoshi Yamamoto, Susumu Yoshida, Tsuyoshi Isono, Takao Sakuma, Shigeo Umemura, Satoshi Tsujimoto, Yasuo Sutani and Toshiji Iwasaka (2009) Human atrial natriuretic peptide (hANP) can Prevent Contrast-induced Acute Kidney Injury For Patients with Chronic Kidney Disease. The 18th Annual Meeting of the Japanese Association of Cardiovascular Intervention and Therapeutics, Sapporo 
2. Kinuko Dote, Yoko Miyasaka, Mio Haiden, Satoshi Tsujimoto, Hirofumi Maeba and Toshiji Iwasaka (2009) Obesity as an Independent Risk for the Left Ventricular diastolic Dysfunction in 814 Japanese Adult Patients. American College of Cardiology 58th Scientific Seccion, Orland

3. Aota Y, Morimoto S, Sakuma T, Maehara M, Ikeda K, Sawada S and Iwasaka T (2009) Hypertensive Organ Damages in Essential Hypertension with Neurovascular Compression of the Rostral Ventrolateral Medulla. The 73th Annual Scientific Meeting of the Japanese Circulation Socity, Osaka

4. Sakuma T, Morimoto S, Aota Y, Maehara M, Ikeda K, Sawada S and Iwasaka T (2009) Incidnece of Neurovascular Compression of the Rostral Ventrolateral Medulla in Refractory Essential Hypertensive Patients. The 73th Annual Scientific Meeting of the Japanese Circulation Socity, Osaka

5. Haiden M, Miyasaka Y, Dote K, Senoo T, Aota Y, Yuasa F, Kimura Y and Iwasaka T (2009) Left atrial volume in obese subjects without cardiovascular comorbidities: comparison with non-obese healthy subjects. 第 73 回日 本循環器学会学術総会, Osaka

6. Miyasaka Y, Haiden M, Dote K, Tsujimoto S, Maeba H, Takehana K, Aota Y, Kimura Y and Iwasaka T (2009) Left atrial volume by real-time three-dimensional echocardiography: validation by 64 -slice multidetector computed tomography. 第73回日本循環器学会学術総会, Osaka

7. Masayoshi Iwasaki, Masamichi Koyanagi, Stefan Rupp, Janina Trauth, Jes-Niels Boeckel, Hans Kossman, Dietmar Schranz, Beatriz G Galvez, Giulio Cossu, Carmen Urbich, Andreas M. Zeiher and Stefanie Dimmeler (2009) Multipotent mesoangioblasts can be mobilized by hepatocyte growth factor. 第 73 回日本循環器学会総会, 大阪

8. Kinuko Dote, Yoko Miyasaka, Mio Haiden, Satoshi Tsujimoto, Hirofumi Maeba and Toshiji Iwasaka (2009) Obesity: an Independent risk for the Chronic Kidney Disease. 第73回日本循環器学会, 大阪

9. 森本 聡, 高橋延行, 染矢和則, 森田龍頼, 岩坂壽二 （2009）難治性ネフローゼ症候群に対して腹膜透析を 開始したが, 後に離脱可能となった 1 例. 第 23 回大阪 CAPD 研究会, 大阪市

10. 万木 孝富, 森本 聡, 染矢和則, 森田龍頼, 高橋延 行, 岩坂壽二 (2009) 維持血液透析患者における内蔵 脂肪面積と血清脂質プロファイル, 動脈硬化度との関 連. 第 14 回腎循環器病研究会, 東京

11. 種村直美, 宮野喜代子, 大垣佳代, 柴田清美, 尾崎珠 詠, 大田千穂子, 北空 幸, 衣川 大, 狭間信幸, 染 矢和則, 森田龍頼, 高橋延行, 森本 聡 (2009) 自作 の患者教育用 DVD・パンフレットを使用した新しい
$\mathrm{CKD}$ 外来開設の試み. 第 15 回日本腹膜透析研究会, 静 岡市

12. 住谷尚美, 森本 聡, 東真奈美, 高岸浩美, 城戸江利 花, 保井明泰 (2009) 婦人科検診及び胃内視鏡検査で 腹膜炎を発症した一例. 第 15 回日本腹膜透析研究会, 静岡市

13. 仲野俊成, 渡辺 淳, 竹花一哉, 小山武彦, 平井正明, 佐藤恵一, 田中雅人（2009）MFERを用いた施設間波 形情報共有の有用性および事前需要予測の相互参照 実績に基づく検証. 第29回医療情報学連合大会 (第 10 回日本医療情報学会学術大会), 広島

14. 藤高 啓祐, 長谷川隆正, 朴 正旭, 城 聡一, 城ひ ろみ, 野村惠巳子, 豊田長興, 小崎篤志, 西川光重, 岩坂壽二 (2009) ソフトドリンクケトーシスの発症で 発見された 1 型糖尿病の 1 例. 第 46 回日本糖尿病学会 近畿地方会, 京都

15. 野村惠巳子 ${ }^{1}$, 豊田長興 ${ }^{1}$, 伊藤 充 $^{2}$, 山内 梓 ${ }^{1}$, 西 村久美子 ${ }^{1}$, 浮田千津子 ${ }^{1}$, 岩坂壽二 ${ }^{1}$, 窪田純久 ${ }^{2}$, 宮 内 昭 ${ }^{2}$, 西川光重 ${ }^{1}$ 関西医科大学 第 2 内科 ${ }^{1}$, 隈病 院 $^{2}$ (2009) 橋本病甲状腺組織に発現する Type 2 iodothyronine deiodinaseに関する検討. 第52回 日本甲状 腺学会学術集会, 名古屋市

16. 森本 聡, 青田泰子, 森田龍頼, 城 聡一, 佐久間孝 雄, 高橋延行, 西川光重, 岩坂壽二（2009）慢性腎臓 病 (CKD) における血管内皮機能障害. 第 32 回日本 高血圧学会学術集会, 大津市

17. 青田泰子, 森本 聡, 佐久間孝雄, 城 聡一, 前原 稔, 池田耕士, 澤田 敏, 岩坂壽二 (2009) 頭側延䯣 腹外側野への動脈による接触を認める本態性高血圧 患者に打ける $\mathrm{L} ・ \mathrm{~N}$ 型カルシウム拮抗薬の有用性に関 する検討. 第32回日本高血圧学会学術集会, 大津市

18. 城 聡一, 森本 聡, 森田龍頼, 青田泰子, 佐久間孝 雄, 高橋延行, 西川光重, 岩坂壽二 (2009) 糖尿病性 腎症進展におけるアンジオテンシン 2 型受容体の役割 について. 第32回日本高血圧学会総会, 大津

19. 森田龍頼, 森本 聡, 染矢和則, 河野啓子, 高橋延行, 永田登志子, 梅田幸久, 西川光重, 岩坂壽二（2009） 急速な腎機能障害および高 $\mathrm{Ca}$ 血症を呈したサルコイ ドーシスの1例. 第39回日本腎臓学会西部学術集会総 会, 和歌山市

20. 森本 聡, 高橋延行, 瀬尾麻位子, 染矢和則, 森田龍 頼, 西川光重, 岩坂壽二 (2009) 慢性腎臓病患者の血 管内皮機能に関する検討. 第39回日本腎臓学会西部学 術集会総会，和歌山市

21. 染矢和則, 森本 聡, 瀬尾麻位子, 森田龍頼, 河野啓 子, 高橋延行, 永田登志子, 梅田幸久, 岩坂壽二 (2009) 足細胞陷入系球体症と考えられた全身性エリテマ トーデスの一例. 第39回日本腎蔵学会西部学術集会総 会, 和歌山市

22. 森本 聡, 高橋延行, 染矢和則, 森田龍頼, 岩坂壽二 （2009）慢性腎臓病（CKD）患者の血管内皮機能（EF） 
に関する検討. 第 46 回日本臨床生理学会学術集会総 会, 岩手市

23. 妹尾 健 (2009) 虚血性心疾患における地域連携パス. 第 31 回日本臨床栄養学会総会, 第 30 回日本臨床栄養 協会総会, 神戸

24. 柴田清美, 種村直美, 宮野喜代子, 大垣佳代, 大田千 穂子, 尾崎珠詠, 北空 幸, 衣川 大, 狭間信幸, 森 田龍頼, 高橋延行, 森本 聡 (2009) 患者教育用DVD を作成・使用した末期腎蔵病 (CKD) 外来の開設. 第 73 回大阪透析研究会, 大阪市

25. 大山恭夫, 阪口正博, 葛西宏一郎, 平山貴視, 森本 聡（2009）ピオグリタゾン効果不十分な 2 型糖尿病に 対するグリメピリドの併用効果一糖代謝および脂質 代謝異常の改善効果一. 第 189 回日本内科学会近畿地 方会, 大阪市

26. 森田龍頼, 高橋延行, 染矢和則, 森本 聡 (2009) 頻 回に蛋白尿を指摘され, 浮腫を主訴に紹介された 1 例. 第8回腎高血圧プライマリーケアセミナー, 守ロ市

27. 森田龍頼, 高橋延行, 瀬尾麻位子, 染矢和則, 森本 聡, 岩坂壽二 (2009) 血痰, 呼吸困難を訴え受診し, 胸部に浸潤影および高度腎機能障害を認めた症例.

Kansai Cardio-Renal Conference, 大阪市

28. 金沢武哲，妹尾 健，土手絹子，山本哲史，染矢和則， 岩坂壽二 (2009) 感染性心内膜炎による心不全で入院 し, 二弁置換術を施行した特発性血小板減少性紫斑病 の1例. 第 107 回日本循環器学会近畿地方会, 大阪

29. 渡辺 淳, 仲野俊成, 竹花一哉, 小山武彦, 平井正明 （2009）診療施設間波形情報連携への医用波形記述プ ロトコル (MFER) 導入の試み. 第13回日本医療情報 学会春季学術大会（シンポジウム2009), 長崎

30. 高橋延行, 森本 聡, 久保リ力, 諏訪恵信, 森田龍頼, 河野啓子，永田登志子，梅田幸久，岩坂壽二 (2009) 肺胞出血と高度腎機能障害を認め腎生検にて悪性腎 硬化症と診断した1例. 第52回日本腎蔵学会学術総会, 横浜市

31. 森田龍頼, 森本 聡, 奥田信昭, 西岡宏彰, 土手絹子, 宮坂陽子, 高橋延行, 西川光重, 岩坂壽二（2009）慢 性腎臓病（CKD）患者においてエゼチミブはコレステ ロール（Cho）低下打よび動脈硬化度低下作用を示す. 第52回日本腎臓学会学術総会, 横浜市

32. 森本 聡, 佐久間孝雄, 森田龍頼, 青田泰子, 万木孝 富, 城 聡一, 高橋延行, 西川光重, 岩坂壽二 (2009) 血管内皮機能障害（ED）と動脈硬化（AS）は慢性腎 蔵病（CKD）の早期から出現しステージ（S）の進行 とともに高度となる. 第52回日本腎臓学会学術総会, 横浜市

33. 瀬尾麻位子, 高橋延行, 森田龍頼, 森本 聡, 岩坂壽 二 (2009) Clostridium difficile 関連下痢症を発症した 腹膜透析患者の 1 例. 第 52 回日本腎臓学会学術総会, 横浜市

34. 染矢和則, 森本 伀, 森田龍頼, 城 聡一, 菊池早苗,
山原英樹, 今田崇裕, 河野啓子, 正木浩哉, 高橋延行, 西川光重, 岩坂壽二 (2009) 保存期慢性腎臓病患者に

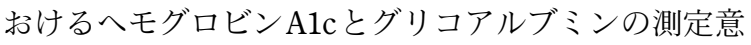
義の比較. 第5 2 回日本腎臓学会学術総会, 横浜市

35. 大山恭夫, 森本 聡, 阪口正博, 中嶋章貴, 万木孝富, 福井政慶 (2009) 尿アルブミン排泄量と血漿BNP值を 同時測定した分類表（Alb 尿・BNP 分類）の有効性の 検討. 第52回日本腎臓学会学術総会, 横浜市

36. 正木浩哉, 原 克子, 小宮山豊, 菊池早苗, 山原英樹, 今田崇裕, 河野啓子, 平川昭彦, 中谷壽男 (2009) 注 射用メシル酸ナファモスタット製剂における先発医 薬品と後発医薬品の比較分析. 第5 4 回日本透析医学会 学術集会・総会, 横浜

37. 衣川 大, 狭間信幸, 森田龍頼, 早川 敬, 森本 聡, 高橋延行 (2009) 医療機器安全管理業務の一環として の重症部門透析液浄化の取り組み. 第54回日本透析医 学会学術総会, 横浜市

38. 高橋延行, 森田龍頼, 瀬尾麻位子, 森本 聡, 岩坂壽 二（2009）診断に苦慮した血液透析患者に打ける Clostridium difficile(CD) 症の 1 例. 第 54 回日本透析医 学会学術総会, 横浜市

39. 今田崇裕, 森田龍頼, 菊池早苗, 山原秀樹, 早川 敬, 河野啓子, 森本 聡, 高橋延行, 正木浩哉, 西川光重, 岩坂壽二（2009）血液透析回路と血小板活性の検討. 第54回日本透析医学会学術総会, 横浜市

40. 山原秀樹, 今田崇裕, 森田龍頼, 菊池早苗, 早川 敬, 河野啓子, 森本 聡, 高橋延行, 正木浩哉, 西川光重, 岩坂壽二 (2009) 腹膜透析患者の味覚異常と体液量指 標に関する検討. 第 54 回日本透析医学会学術総会, 横 浜市

41. 柴田清美, 松澤美保, 大垣佳代, 大田千穂子, 種村直 美, 宮野喜代子, 北空 幸, 衣川大, 狭間信幸, 森 田龍頼, 高橋延行, 森本 聡 (2009) 自作の患者教育 用DVDを使用した慢性腎臓病（CKD）外来. 第54回 日本透析医学会学術総会, 横浜市

42. 住谷尚美, 城戸江利花, 東 奈美, 高岸浩美, 保井明 泰, 森本 聡 (2009) 婦人科受診および上部消化管内 視鏡検查後に腹膜炎を発症した腹膜透析の 1 例. 第 54 回日本透析医学会学術総会, 横浜市

43. 城戸江利花, 森本 聡, 住谷尚美, 高岸浩美, 鈴木憲 三，保井明泰（2009）PDから HDへの移行時に高血圧 脳症を呈した一例. 第54回日本透析医学会学術総会, 横浜市

44. 森田龍頼, 森本 聡, 高橋延行, 衣川 大, 狭間信幸, 柴田清美, 大垣佳代, 松澤美穂, 大田千穂子, 種村直 美, 宮野喜代子, 北空 幸（2009）患者指導効率の向 上を目指した慢性腎臓病（CKD）教育用DVDの作成. 第54回日本透析医学会学術総会, 横浜市

45. 森本 聡, 高橋延行, 森田龍頼, 万木孝富, 西川光重, 岩坂壽二（2009）維持血液透析（HD）患者の血管内 皮機能障害（ED）に対する寄与因子，第 54 回日本透 
析医学会学術総会, 横浜市

46. 村井潤一, 岡本貴行, 森本 聡, 奥上麻貴, 太田裕美 子, 万木孝富, 北村哲也, 福井政慶, 中嶋章貴 (2009) 無酢酸透析液カーボスターLのセントラルでの入院・ 通院透析における使用経験. 第54回日本透析医学会学 術総会, 横浜市

47. 中嶋章貴, 万木孝富, 福井政慶, 太田裕美子, 森本 聡（2009）LDL-Apheresis が透析患者の脳血流量に及 ぼす影響. 第54回日本透析医学会学術総会, 横浜市

48. 万木孝富, 森本 聡, 岩坂壽二, 岡本貴行, 福井政慶, 太田裕美子, 中嶋章貴, 川端和史, 岡博史 (2009) 維 持血液透析中にフルニエ症候群を発症したが緊急手 術にて救命し得た 1 例. 第54回日本透析医学会学術総 会, 横浜市

49. 万木孝富, 森本 聡, 森田龍頼, 高橋延行, 西川光重, 岩坂壽二, 岡本貴行, 太田裕美子, 福井政慶, 中嶋章 貴（2009）維持血液透析患者における内臓脂肪面積と 血清脂質值, 動脈硬化度との関連. 第54回日本透析医 学会学術総会, 横浜市

50. 野村惠巳子, 豊田長興, 長谷川隆正, 城 聡一, 城ひ ろみ, 藤高啓祐, 田代香織, 浮田千津子, 小崎篤志, 西川光重, 岩坂壽二 関西医科大学第 2 内科 (2009) 2 型糖尿病の経過中にACTH単独欠損症によると考えら れる著明な $\mathrm{HbA1c}$ 值の改善を認めた 1 例. 第 52 回日本 糖尿病学会年次学術総会, 大阪市

51. 藤高啓祐, 大谷 肇, 長谷川隆正, 城 聡一, 城ひろ み, 野村恵巳子, 田代香織, 浮田千津子, 豊田長興, 小㠃篤志, 西川光重, 岩坂壽二 (2009) メタボリック シンドロームを合併した糖尿病初期治療におけるピ オグリタゾンの効果に関する検討. 第 52 回日本糖尿病 学会年次学術集会, 大阪

52. 森本 聡 (2009) 動脈硬化性疾患治療における上腕一 足首間PWV (baPWV) 測定の有用性. 第9回臨床血圧 脈波研究会 ランチョンセミナー, 大阪市

53. 染矢和則, 森本 聡, 瀬尾麻位子, 森田龍頼, 河野啓 子, 高橋延行, 永田登志子, 梅田幸久（2009）尿蛋白 を呈したSLEの一例. 第 135 回新大阪腎疾患カンファ レンス, 大阪市

54. 仲野俊成, 渡辺 淳, 竹花一哉, 田中雅人, 平井正明 （2009）OS-26生体音の計測と解析 : 臨床診断への応用 電子カルテシステムに打ける波形情報管理. 第48回 日本生体医工学会大会, 東京

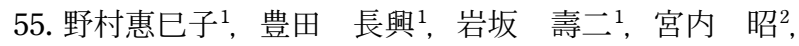
西川 光重 ${ }^{1}$ 関西医科大学 第 2 内科 ${ }^{1}$, 隈病院 ${ }^{2}$ （2009）甲状腺濾胞腺腫及び濾胞癌組織に発現する Type 1及びType 2 iodothyronine deiodinase活性に関す る検討. 第 82 回日本内分泌学会学術総会, 前橋市

56. Takeshi Senoo, Masayuki Motohiro, Hiroshi Kamihata, Kenichi Manabe, Satoshi Yamamoto, Tsuyoshi Isono, Takao Sakuma, Susumu Yoshida, Akira Moriguchi, Hiroshi Yokoe, Satoshi Tsujimoto, Yasuo Sutani and
Toshiji Iwasaka (2009) Carperitide can Prevent Acute Renal Failure from Contrast-media in Patients with Moderate Chronic Kidney disease. The 73rd Annual Scientific Meeting of the Japanese Circulation Socity, Osaka

57. Aota Y, Morimoto S, Sakuma T, Maehara M, Ikeda K, Sawada S and Iwasaka T (2009) Efficacy of L-and N-type Calcium Blocker in Essential Hypertension with Neurovascular Compression of the Rostral Ventrolateral Medulla. The 73th Annual Scientific Meeting of the Japanese Circulation Socity, Osaka

58. Satoshi Morimoto, Yasuko Aota, Takao Sakuma and Toshiji Iwasaka (2009) Relationship between Office Blood Pressure Reduction by Repeated Measurement and Flow-mediated Vasodilation. The 73th Annual Scientific Meeting of the Japanese Circulation Socity, Osaka

59. 森本 聡, 高橋延行, 森田龍頼, 万木孝富, 西川光重, 岩坂壽二（2009）維持血液透析（HD）患者の血管内 皮機能障害（ED）に影響する因子について．第 72 回 大阪透析研究会, 大阪市

60. 万木孝富, 森本 聡, 森田龍頼, 高橋延行, 西川光重, 岩坂壽二, 岡本貴行, 太田裕美子, 福井政慶, 中嶋章 貴（2009）維持血液透析患者における内臓脂肪面積と 血清脂質プロファイル, 動脈硬化との関連. 第72回大 阪透析研究会, 大阪市

61. 土手絹子, 宮坂陽子, 拝殿未央, 辻本悟史, 前羽宏史, 岩坂壽二（2009）慢性腎臓病に独立して関与する因 子: 成人 824 人における検討. 第 73 回日本循環器学会, 大阪

62. 大垣佳代, 宮野喜代子, 種村直美, 柴田清美, 大田千 穂子, 松澤美保, 北空 幸, 高橋延行, 森本 聡 (2009) $\mathrm{PD}$ 導入後維持期の継続看護〜出口部ケア DVD での教 育〜。第 24 回関西CAPDナースセミナー, 大阪

63. 大垣佳代, 宮野喜代子, 柴田清美, 松澤美穂, 大田千 穂子, 種村直美, 北空 幸, 高橋延行, 森本 聡 (2009) 患者指導における腹膜透析導入用電子クリニカルパ スの有用性に関する検討. 第24回関西CAPDナースセ ミナー, 大阪市

64. 森田龍頼, 森本 聡, 高橋延行, 万木孝富, 岩坂壽二 （2009）シクロスポリン・LDL アフェレーシス併用療 法が有用であったネフローゼ症候群の 1 例. 第 27 回日 本アフェレーシス学会関西地方会, 高松市

65. 森本 聡, 高橋延行, 草部牧子, 森田龍頼, 万木孝富, 岩坂壽二 (2009) コレステロール塞栓症による腎機能 障害に対してLDLアフェレーシス・ステロイド併用療 法が有用であった1例. 第27回日本アフェレーシス学 会関西地方会, 高松市

著 書

1. 西川光重 (2009) EMO 症候群. 医学大辞典 2（伊藤 正男, 井村裕夫, 高久史麿編) 102 頁, 医学書院, 東京

2. 西川光重 (2009) 腺腫様甲状腺腫. 医学大辞典 2(伊 
藤正男, 井村裕夫, 高久史麿編) 1621頁, 医学書院, 東京

3. 西川光重 (2009) 脱ヨード反応. 医学大辞典 2（伊 藤正男, 井村裕夫, 高久史麿編) 1775 頁, 医学書院, 東京

4. 西川光重 (2009) 中毒性多結節性甲状腺腫. 医学大辞 典 2 (医学大辞典) 1855頁, 医学書院, 東京

5. 西川光重 (2009) メルゼブルグ三徵. 医学大辞典 2 （伊藤正男, 井村裕夫, 高久史麿編） 2745 頁, 医学書 院, 東京

6. 西川光重 (2009) 濾胞性腺腫. 医学大辞典 2（伊藤 正男, 井村裕夫, 高久史麿編) 2959頁, 医学書院, 東京

7. 西川光重 (2009) 甲状腺悪性リンパ腫. 医学大辞典 2 (伊藤正男, 井村裕夫, 高久史麿編) 897-898頁, 医 学書院, 東京

8. 西川光重 (2009) 甲状腺アミロイドーシス. 医学大辞 典 2（伊藤正男, 井村裕夫, 高久史麿編) 898頁, 医 学書院, 東京

9. 西川光重 (2009) 甲状腺高分化型癌. 医学大辞典 2 （伊藤正男, 井村裕夫, 高久史麿編） 898 頁, 医学書 院, 東京

10. 西川光重 (2009) 甲状腺腫瘍. 医学大辞典 2 （伊藤 正男, 井村裕夫, 高久史麿編) 900 頁, 医学書院, 東京

11. 西川光重 (2009) 甲状腺腫誘発物質. 医学大辞典 2 （伊藤正男, 井村裕夫, 高久史麿編） 900 頁, 医学書 院, 東京

12. 西川光重 (2009) 甲状腺腺腫. 医学大辞典 2 (伊藤 正男, 井村裕夫, 高久史麿編) 901頁, 医学書院, 東京

13. 西川光重 (2009) 甲状腺乳頭癌 (1). 医学大辞典 2 （伊藤正男, 井村裕夫, 高久史麿編) 901-902頁, 医学 書院，東京

14. 西川光重 (2009) 甲状腺乳頭状濾胞状癌. 医学大辞典 2 (伊藤正男, 井村裕夫, 高久史麿編) 902頁, 医学 書院, 東京

15. 西川光重 (2009) 甲状腺囊胞. 医学大辞典 2 (伊藤 正男, 井村裕夫, 高久史麿編) 902 頁, 医学書院, 東京

16. 西川光重 (2009) 甲状腺扁平上皮癌. 医学大辞典 2 （伊藤正男, 井村裕夫, 高久史麿編） 902 頁, 医学書
院, 東京

17. 西川光重 (2009) 甲状腺未分化癌. 医学大辞典 2 (伊 藤正男, 井村裕夫, 高久史麿編） 902-903 頁, 医学書 院，東京

18. 西川光重 (2009) 甲状腺濾胞癌. 医学大辞典 2（伊 藤正男, 井村裕夫, 高久史麿編) 903 頁, 医学書院, 東京

19. 宮坂陽子（2009）バセドウ心. 医学大辞典 第 2 版改 変 2239 頁, 医学書院, 東京

20. 宮坂陽子（2009）脚気心. 医学大辞典 第 2 版改変 438頁, 医学書院, 東京

21. 西川光重 (2009) 日本甲状腺学会の取り組み. 甲状腺 疾患診療マニュアル（田上哲也, 西川光重, 伊藤公一, 成瀬光栄編）117頁，診断と治療社，東京

22. 西川光重 (2009) 甲状腺の診察の仕方. 甲状腺疾患診 療マニュアル（田上哲也, 西川光重, 伊藤公一, 成瀬 光栄編）21-23頁, 診断と治療社, 東京

23. 野村惠巳子（2009）第 2 章 臨床知識 C. 甲状腺機能 検査と読み方. 甲状腺疾患診療マニュアル（田上哲也, 西川光重, 伊藤公一, 成瀬光栄編) 24-26 頁, 診断と 治療社, 東京

24. 西川光重 (2009) Basedow病の診断. 甲状腺疾患診療 マニュアル（田上哲也, 西川光重, 伊藤公一, 成瀬光 栄編） 48-50頁, 診断と治療社, 東京

25. 西川光重 (2009) Basedow病の歴史的背景. 甲状腺疾 患診療マニュアル（田上哲也，西川光重，伊藤公一， 成瀬光栄編） 94 頁，診断と治療社，東京

26. 宮坂陽子, 神畠 宏, 岩坂壽二（2009）心電図まずは カタチで覚えよう一カードを使ってらくらく学習 第2版改変. メディカ出版, 大阪

27. 西川光重, 豊田長興, 野村惠巳子 (2009) 甲状腺機能 低下症. 内分泌代謝専門医ガイドブック 2 (成瀬光 栄, 平田結喜緒, 島津 章編) 129-132 頁, 診断と治 療社, 東京

28. 宮坂陽子 (2009) 粘液水腫心. 医学大辞典 第2 版改 変 2158 頁, 医学書院, 東京

\section{内科学第三講座}

\section{〈研究概要〉}

炎症と癌, 消化器免疫をキーワードに, 消化管では炎症性腸疾患, 肝では自己免疫性肝疾患, 胆膵では自己免疫性膵 炎, 硬化性胆管炎の病態解明と病態にもとづく新規治療法の開発を目指しています，炎症性腸疾患では，腸炎発症にお ける腸内細菌と自然免疫の関与について動物実験モデルを用いて検討を行うとともに, 厚生労働科学研究・難治性疾患 克服研究事業「難治性炎症性腸管障害に関する調査研究」,「炎症性腸疾患の画期的治療法に関する臨床研究」について, ドラッグデリバリーシステム（DDS）などの新しい治療法の開発と探索医療に取り組んでいる. 自己免疫性膵炎の発症 機序・IgG4 産生のメカニズムについて基礎的・臨床的に研究しており, 制御性 T 細胞との関連性について病態解明を進 めており, さらに新規の診断法や治療法も開発している. さらに, 炎症と癌では肝炎や潰瘍性大腸炎からの発癌機序に ついて, smadシグナルを中心に解析している. 


\section{〈研究業績〉}

1. Matsushita M, Ikeura T, Shimatani M, Uchida K, Takaoka M, Nishio A and Okazaki K (2009) Pancreatic cystic neoplasms: imaging surveillance for pancreatic and extra-pancreatic malignancy. Am J Gastroenterol 104(4): 1055-1056

2. Matsushita M, Yamagata H, Wakamatsu T, Danbara N, Kawamata S, Omiya M and Okazaki K (2009) Colonoscopy with a transparent hood: simple technique for improved quality of colonoscopy. Am J Gastroenterol 104(2): 527

3. Matsuzaki K, Kitano C, Murata M, Sekimoto G, Yoshida K, Uemura Y, Seki T, Taketani S, Fujisawa JI and Okazaki K (2009) Smad2 and Smad3 phosphorylated at both linker and $\mathrm{COOH}$-terminal regions transmit malignant TGF-beta signal in later stages of human colorectal cancer. Cancer Res 69(13): 5321-5330

4. Matsushita M, Uchida K, Nishio A and Okazaki K (2009) Larger short-axis length of llymph nodes: another predictor for malignant involvement. Dig Dis Sci 54(8): 18121813

5. Matsushita M, Danbara N, Kawamata S, Omiya M and Okazaki K (2009) Endoscopic removal of large colonic lipomas: difficult submucosal dissection or easy snare unroofing? Endoscopy 41: 475

6. Matsushita M, Shimatani M, Takaoka M and Okazaki K (2009) Effective device for peroral direct cholangioscopy: double-balloon enteroscope or ultra-slim gastroscope? Endoscopy 41(8): 730

7. Matsushita M, Mori S, Tahashi Y and Okazaki K (2009) Risky endoscopy for acute aortic dissection with hematemesis. Endoscopy 41(12): 1100

8. Matsushita M, Uchida K, Nishio A and Okazaki K (2009) Effective simple incision or partial snare resection for symptomatic duodenal cystic lesions, duplication cysts, and choledochoceles. Endoscopy 41(10): 918

9. Matsushita M, Takakuwa H, Uchida K, Nishio A and Okazaki K (2009) Techniques to facilitate ERCP with a conventional endoscope in patients with previous pancreatoduodenectomy. Endoscopy 41(10): 902-906

10. Shimatani M, Matsushita M, Takaoka M, Koyabu M, Ikeura T, Kato K, Fukui T, Uchida K and Okazaki K (2009) Effective "short" double-balloon enteroscope for diagnostic and therapeutic ERCP in patients with altered gastrointestinal anatomy: a large case series. Endoscopy 41(10): 849-854

11. Matsuzaki K (2009) Modulation of TGF-beta signaling during progression of chronic liver diseases. Front Biosci 14: 2923-2934

12. Moritoki Y, Zhang W, Tsuneyama K, Yoshida K, Wakabayashi K, Yang GX, Bowlus C, Ridgway WM, Ueno Y,
Ansari AA, Coppel RL, Mackay IR, Flavell RA, Gershwin ME and Lian ZX (2009) B cells suppress the inflammatory response in a mouse model of primary biliary cirrhosis. Gastroenterology 136(3): 1037-1047

13. Matsushita M, Danbara N, Omiya M and Okazaki K (2009) Initial diagnostic modality for superior mesenteric artery occlusion: risky colonoscopy or safe CT? Gastrointest Endosc 70(6): 1287

14. Matsushita M, Uchida K, Nishio A and Okazaki K (2009) Periampullary diverticulum: an indicator of easy or difficult cannulation? Gastrointest Endosc 70(5): 1049

15. Matsushita M, Shimatani M, Fukui Y and Okazaki K (2009) Patients in the prone position for preventing aspiration pneumonia after peroral double-balloon enteroscopy. Gastrointest Endosc 70(4): 816

16. Matsushita M, Shimatani M, Takaoka M and Okazaki K (2009) Double-balloon enteroscopyfor ERCP in patients with altered GI anatomy: front-viewing, a drawback forbiliary cannulation? Gastrointest Endosc 70(3): 601

17. Matsushita M, Mori S, Uchida K, Nishio A and Okazaki K (2009) "White opaque substance" and "light blue crest" within gastric flat tumors or intestinal metaplasia: same or different signs? Gastrointest Endosc 70(2): 402

18. Matsushita M, Shimatani M, Takaoka M and Okazaki K (2009) "Short" double-balloon enteroscope for ERCP with conventional accessories in patients with altered GI anatomy. Gastrointest Endosc 69(4): 981

19. Matsushita M, Shimatani M, Uchida K, Nishio A and Okazaki K (2009) Endoscopic removal of hollow colorectal foreign bodies with the use of a balloon catheter. Gastrointest Endosc 69(3): 604-605

20. Matsushita M, Uchida K, Nishio A and Okazaki K (2009) Larger short-axis length of lymph nodes predicts malignant involvement. Gastrointest Endosc 69(2): 387

21. Matsushita M, Omiya M, Uchida K, Nishio A and Okazaki $\mathrm{K}$ (2009) Narrow-band imaging in addition to a transparent hood for much more polyp detection. Gastrointest Endosc 69(1): 189-190

22. Matsushita M, Uchida K, Takaoka M, Nishio A and Okazaki K (2009) Malfunctioning covered biliary metallic stents: ineffective trimming or effective removal? Gastrointest Endosc 69(1): 189

23. Matsushita M, Uchida K, Nishio A and Okazaki K (2009) Endoscopic and EUS features of gastric inflammatory fibroid polyps. Gastrointest Endosc 69(1): 188

24. Matsushita M, Ando Y, Kawamata S, Omiya M, Uchida K, Nishio A and Okazaki K (2009) Appendix in ulcerative colitis: significant involvement and pathogenesis. Gastrointest Endosc 70: 821

25. Kamisawa T, Shimosegawa T, Okazaki K, Nishino T, Watanabe H, Kanno A, Okumura F, Nishikawa T, Koba- 
yashi K, Ichiya T, Takatori H, Yamakita K, Kubota K, Hamano H, Okamura K, Hirano K, Ito T, Ko SB and Omata M (2009) Standard steroid treatment for autoimmune pancreatitis. Gut 58(11): 1504-1507

26. Katsunori Yoshida, Guo-Xinag Yang, Weici Zhang, Masanobu Tsuda, Koichi Tsuneyama, Yuki Moritoki, Aftab A. Ansari, Kazuichi Okazaki, Zhe-Xiong Lian, Ross L. Coppel, Ian R. Mackay and M. Eric Gershwin (2009) Deletion of interleukin-12p40 suppresses autoimmune cholangitis in dominant negative transforming growth factor $\beta$ receptor type II mice. Hepatology 50(5): 14941500

27. Nagata H, Hatano E, Tada M, Murata M, Kitamura K, Asechi H, Narita M, Yanagida A, Tamaki N, Yagi S, Ikai I, Matsuzaki K and Uemoto S (2009) Inhibition of c-Jun NH2-terminal kinase switches Smad3 signaling from oncogenesis to tumor-suppression in rat hepatocellular carcinoma. Hepatology 49(6): 1944-1953

28. Murata M, Matsuzaki K, Yoshida K, Sekimoto G, Tahashi Y, Mori S, Uemura Y, Sakaida N, Fujisawa J, Seki T, Kobayashi K, Yokote K, Koike K and Okazaki K (2009) Hepatitis $\mathrm{B}$ virus $\mathrm{X}$ protein shifts human hepatic transforming growth factor (TGF)-beta signaling from tumor suppression to oncogenesis in early chronic hepatitis B. Hepatology 49(4): 1203-1217

29. Matsushita M, Ando Y, Omiya M, Uchida K, Nishio A and Okazaki K (2009) Association of "ulcerative appendicitis" and appendiceal adenocarcinoma. Inflamm Bowel Dis 15(9): 1283

30. Ikeura T, Takaoka M, Shimatani M, Koyabu M, Kusuda T, Suzuki R, Sumimoto K and Okazaki K (2009) Xanthogranulomatous inflammation of the peripancreatic region mimicking pancreatic cystic neoplasm. Intern Med 48(21): 1881-1884

31. Uchida K, Yazumi S, Nishio A, Kusuda T, Koyabu M, Fukata M, Miyoshi H, Sakaguchi Y, Fukui T, Matsushita M, Takaoka M and Okazaki K (2009) Long-term outcome of autoimmune pancreatitis. J Gastroenterol 44(7): 72632

32. Matsushita M, Takakuwa H, Shimeno N, Uchida K, Nishio A and Okazaki K (2009) Epinephrine sprayed on the papilla for prevention of post-ERCP pancreatitis. J Gastroenterol 44(1): 71-75

33. Okazaki K, Kawa S, Kamisawa T, Ito T, Inui K, Irie H, Irisawa A, Kubo K, Notohara K, Hasebe O, Fujinaga Y, Ohara H, Tanaka S, Nishino T, Nishimori I, Nishiyama T, Suda K, Shiratori K, Shimosegawa T and Tanaka M (2009) Japanese Clinical Guidelines for Autoimmune Pancreatitis. Pancreas 38(8): 849-866

34. Chen D, Lin Q, Box N, Roop D, Ishii S, Matsuzaki K, Fan T, Hornyak TJ, Reed JA, Stavnezer E, Timchenko NA and Medrano EE (2009) SKI knockdown inhibits human melanoma tumor growth in vivo. Pigment Cell Melanoma Res 22(6): 761-772

35. Matsushita M, Fukui T, Uchida K, Nishio A and Okazaki K (2009) Atypical retroperitoneal fibrosis associated with biliary stricture: IgG4-related sclerosing disease? Scand J Gastroenterol 44(9): 1146-1147

36. 島谷昌明, 松下光伸, 岡崎和一 (2009) ダブルバルー ン内視鏡における偶発症対策 167-172

37. 島谷昌明 (2009) 当院におけるダブルバルーン小腸内 視鏡検査のクリニカルパス 229-235

38. 高岡 亮, 島谷昌明, 池浦 司, 中島 淳, 富山 尚, 福井由里, 楠田武生, 小薮雅紀, 岡崎和一 (2009)【腹 腔鏡下胆囊摘出術・生体部分肝移植術後胆管狭窄の原 因と対策】術後胆管狭窄に対する内視鏡的治療の有用 性と問題点. 胆と膵 30(8): 883-888

39. 里井壯平, 豊川秀吉, 柳本泰明, 道浦 拓, 井上健太 郎, 松井陽一, 中根恭司, 權 雅憲, 宮崎浩彰, 北村

臣（2009）関西医科大学附属枚方病院に打ける消化 器癌診療と地域連携. 日クリニカルパス会誌 11(1): $85-87$

40. 藤井寿仁 (2009) 大腸腺腫と肥満, 食習慣との関連に ついての検討. 日大腸検会誌 25(2): 120-125

41. 是枝ちづ, 関 寿人, 岡崎和一 (2009) 総分岐鎖アミ ノ酸/チロシンモル比（BTR）。 日臨 67 (増刊号 8)： 634-637

42. 池浦 司, 高岡 亮, 島谷昌明, 内田一茂, 岡崎和一 （2009）新しい急性膵炎重症度判定基準の妥当性に関 する検討. 膵臓 24(4): 493-499

総 説

1. 岡崎和一, 深田憲将, 大宮美香, 川股聖二, 松下光伸 (2009) IBD ドラッグ\&マニピュレーション IBD治療 に打けるアミノサリチル酸製剂（5-ASA，サラゾスル ファピリジン）の使用. IBD Res 3(1): 60-67

2. 岡崎和一 (2009) 知っているようで知らない消化器疾 患 自己免疫性膵炎. Mebio 26(11): 97-105

3. 岡崎和一, 小藪雅紀, 内田一茂（2009）【膵炎のマネ ジメント 急性膵炎・慢性膵炎・自己免疫性萃炎】膵 炎をどう治療するか 自己免疫性膵炎のマネジメン トのポイントは? どんなときに自己免疫性膵炎を疑 うか? 一般医が行うべき検査は何か？ Medicina 46(3): 456-460

4. 松下光伸, 岡崎和一 (2009) 症状から考えられる疾患 の診断と治療 便秘. 医と薬学 61(6): 831-837

5. 岡崎和一, 内田一茂, 小藪雅紀, 楠田武生 (2009) 自 己免疫性肝胆膵疾患一最新知見 自己免疫性膵炎の 病態・診断・治療．医のあゆみ 228(9): 900-905

6. 岡崎和一, 内田一茂, 小藪雅紀, 楠田武生, 富山 尚 （2009）【膵石症】成因別特徵（膵石症の頻度・分布） 自己免疫性萃炎における膵石症. 肝・胆・膵 58(4): 
$477-483$

7. 岡崎和一, 川茂幸, 神澤輝実, 下瀬川徹, 田中雅夫 （2009）自己免疫性膵炎の最前線 わが国における自 己免疫性膵炎の診療ガイドラインの作成. 肝胆膵画像 11(6): 623-629

8. 木原康之, 原田 大, 神澤輝実, 岡崎和一, 大槻 眞 （2009）自己免疫性膵炎の最前線 自己免疫性膵炎の アジア診断基準. 肝胆膵画像 11(6): 617-621

9. 岡崎和一, 松下光伸 (2009) 消化管カルチノイド $425-427$

10. 島谷昌明, 高岡 亮, 松下光伸, 池浦 司, 小藪雅紀, 加藤孝太, 岡崎和一（2009）【Advanced Therapeutic Endoscopy】消化管再建術後例でのダブルバルーン内 視鏡を用いた内視鏡的乳頭括約筋切開術．消内視鏡 21(6): 896-902

11. 島谷昌明, 高岡 亮, 松下光伸, 池浦 司, 小藪雅紀, 宮本早知, 加藤孝太, 岡崎和一（2009）胆膵治療内視 鏡のエキスパートテクニック $\mathrm{ERCP}$ 関連手技：術後 胃（Billroth II, Roux-en-Y再建胃）に対するERCP術後 再建腸管を有する胆膵疾患例に対するダブルバルー ン内視鏡を用いた ERCP. 胆と膵 30 （臨時増刊）： 1213-1219

12. 松下光伸, 大宮美香, 岡崎和一（2009）空腸, 回腸, 盲腸, 結腸, 直腸 血行障害, 血管病变 虚血性腸炎.

日臨 別冊（消化管症候群 (下)）: 358-361

13. 関 寿人 (2009) 空腸, 回腸, 盲腸, 結腸, 直腸 炎 症性疾患 腸管吻合部潰瘍. 日臨 別冊（消化管症候 群 (下)）：318-320

14. 岡崎和一, 深田憲将, 大宮美香, 内田一茂, 松下光伸, 仲瀬裕志, 千葉 勉, 田畑泰彦 (2009) 炎症性腸疾患 の新規治療を探る ドラッグデリバリーシステムの 将来展望とは? 分子消化器病 6(2): 151-155

\section{症例報告}

1. Bando T, Matsushita M, Kitano M and Okazaki K (2009) Herpes simplex esophagitis in the elderly. Dig Endosc 21(3): 205-207

2. Matsushita M, Tahashi Y, Uchida K, Nishio A, Takakuwa $\mathrm{H}$ and Okazaki K (2009) White ball appearance: predictor of effective variceal ligation in massive bleeding with an obscure bleeding point. Dig Endosc 21(2): 131-133

3. Shimatani M, Matsushita M, Takaoka M, Kusuda T, Fukata N, Koyabu M, Uchida K and Okazaki K (2009) "Short" double balloon enteroscope for endoscopic retrograde cholangiopancreatography with conventional sphincterotomy and metallic stent placement after Billroth II gastrectomy. Endoscopy 41(Suppl.2): E19-E20

4. Takaoka M, Shimatani M, Ikeura T, Koyabu M, Kusuda T, Fukata N, Matsushita M and Okazaki K (2009) Diagnostic and therapeutic procedure with a short double-balloon enteroscope and cholangioscopy in a patient with acute cholangitis due to hepatolithiasis. Gastrointest Endosc 70(6): 1277-1279

5. Ando Y, Matsushita M, Kawamata S, Shimatani M, Fujii $\mathrm{T}$ and Okazaki K (2009) Infliximab for severe gastrointestinal bleeding in Crohn's disease. Inflamm Bowel Dis 15(3): 483-484

6. Fukui T, Nakayama S, Shimatani M, Uchida K, Matsushita M, Nishio A, Seki T and Okazaki K (2009) Endoscopic Biliary Plastic Stenting and Successful Intentional Stent Retrieval in a Benign Biliary Stricture with Mural Spherical Calcification and Porcelain Gallbladder. Intern Med 48(10): 809-813

7. 内山正三, 射出靖生, 福井 博, 生田英夫, 野口雅滋, 岡崎和一, 関 寿人 (2009) 魚骨肉芽腫の 1 例. Mod Physician 29(8): 1240-1242

8. 岡崎和一 (2009) Clinical Challenge この画像から何 が読めるか? 膵腫瘤. 肝胆膵画像 11(5): 580-582

9. 荒木吉朗, 吉岡和彦, 岩本慈能, 山木 壮, 岩井愛子, 中根恭司, 權 雅憲, 松下光伸, 岡崎和一, 植村芳子 （2009）極めて短い病悩期間で発症した Crohn 病に合 併した colitic cancerの1例. 日消器外誌 42(10): 15971602

10. 坂東具樹, 松下光伸, 北野元一, 岡崎和一（2009）高 齢者に発症した単純性へルペス食道炎の一例 51(9): 2522

11. 松下光伸, 田橋賢也, 内田一茂, 西尾彰功, 高鍬 博, 岡崎和一（2009）“白色球状外観”：出血点不明な食道 静脈瘤大量出血における効果的な内視鏡的静脈瘤結 紮術の確証像５1(6): 1485

その他

1. Hamajima H, Ozaki I, Zhang H, Iwane S, Kawaguchi Y, Eguchi Y, Matsuhashi S, Mizuta T, Matsuzaki K and Fujimoto K (2009) Modulation of the transforming growth factor- $\beta 1$-induced Smad phosphorylation by the extracellular matrix receptor $\beta 1$-integrin. Int $\mathrm{J}$ Oncol 35(6): 1441-1447

2. 岡崎和一, 内田一茂, 小藪雅紀, 楠田武生, 高岡 亮 （2009）自己免疫性膵炎の病態・診断・治療. Gastroenterol Endosc 51(6): 1403-1415

3. 高岡 亮, 岡崎和一 (2009) 内視鏡室の紹介 関西医 科大学附属枚方病院 内視鏡センター. Gastroenterol Endosc 51(2): 263-266

4. 岡崎和一, 金城福則, 平井郁仁, 余田 篤, 新井勝大 （2009）患者さんの立場に即した IBD 診療の更なる追 究 小児科との連携に向けて. IBD Res 3(2): 92-106

5. 川村梨那子, 永松良介, 大橋理奈, 伊藤 大 (2009) 門脈腫瘍栓合併進行肝癌に対してシスプラチン動注 化学療法が著効した1例. 肝臓 50(12): 731-735

6. 岡崎和一 (2009) 膵腫瘤一問題. 11(4): 366-367

7. 光山俊行, 坂尾将幸, 山口隆志, 柴谷伸行, 藤村和代, 
市島國雄, 内田一茂, 岡崎和一（2009）肝門部胆管癌 との鑑別困難な硬化性胆管炎に併発した肝炎症性偽 腫瘍の1例. 胆道 23(5): 789-796

8. 是枝ちづ, 谷野朋子, 村田美樹, 武田聖子, 梅原秀人, 池田耕造, 関 寿人, 岡崎和一, 河相吉 (2009) BMI 変化とレボビスト造影エコー／肝シンチグラフィに よる NASH の経過観察. 薬理と治療 37 (Suppl.1): S139-S145

9. 岡崎和一, 川茂幸, 神澤輝実, 伊藤鉄英, 乾 和郎, 入江裕之, 入澤篤志, 久保惠嗣, 能登原憲司, 長谷部 修, 藤永康成, 大原弘隆, 田中滋城, 西野隆義, 西森 功, 西山利正, 須田耕一, 白鳥敬子, 下瀬川徹, 田 中雅夫 (2009) 自己免疫性膵炎診療ガイドライン 2009 . 膵臓 24 (Supplment): S1-S54

\section{学会発表}

1. Kazushige Uchida, Hideaki Miyosi, Masanori Koyabu, Takeo Kusuda, Norimasa Fukata, Katsunori Yoshida, Yutaku Sakaguchi, Toshiro Fukui, Mitsunobu Matsushita, Makoto Takaoka, Akiyoshi Nishio and Kazuichi Okazkai (2009) Analysis of Regulatory T cells in Patients with Autoimmune pancreatitis. 40 th Anniversary Meeting of American Pancreatic Association and Japan Pancreatic Society, Honolulu

2. Sakaguchi Y, Kusuda T, Koyabu M, Fukata M, Miyoshi H, Fukui T, Uchida K, Matsushita M, Takaoka M, Nishio A and Okazaki K (2009) AN ANIMAL MODEL FOR ACUTE, CHRONIC, AND SEVERE PANCREATITIS WITH THE ANALYSES OF REGENERATION MECHANISMS. 40th Anniversary Joint Meeting of the American Pancreatic Association \& Japan Pancreas Society, Honolulu, USA

3. Shimatani M, Takaoka M, Matsushita M, Satoi S and Okazaki K (2009) Effective Shot Double Balloon Enteroscope for Diagnostic and Therapeutic ERCP in Patients with Aletered Gastrointestinal Anatomy for Pancreatic Diseases. 40th Anniversary Joint Meeting of the American Pancreatic Association \& Japan Pancreas Society, Honolulu, USA

4. Kazuichi Okazaki, M-H Kim, Luca Frulloni and Suresch Chari (2009) Putting it All Together: How Do We Diagnose AIP. 40th Anniversary Joint Meeting of the American Pancreatic Association \& Japan Pancreas Society SATELLITE MEETING AIP CONSENSUS MEETING, Honolulu, USA

5. Katsunori Yoshida, Guo-Xiang Yang, Weici Zhang, Masanobu Tsuda, Koichi Tsuneyama, Aftab A. Ansari, Zhe-Xiong Lian, Yuki Moritoki, Kazuichi Okazaki, Ian R. Mackay and M. Eric Gershwin (2009) The modulation of autoimmune cholangitis in murine PBC by deletion of IL12p40. American association for the study of liver dis- ease, Boston, Massachustts, USA

6. Kazuichi Okazaki (2009) The Japanese experience. ANATOMY of a FRIENDSHIP Gunter Kloppel \& the Verona Pancreatic Team, VERONA

7. 岡崎和一 (2009) Autoimmune Pancreatitis: Japanese Experience. The Congress of 3rd Asian-Oceanic Pancreatic Association 2009 Annular Meeting of Taiwan Pancreas Society, 台湾

8. Katsunori Yoshida (2009) IL-12p40 requirement for expression of autoimmue $\mathrm{PBC}$ like cholangitis in genetically modified (dnTGFbRII) mice. Changchun inyernational digestive disease and liver disease peak forum, Changchun

9. Koichi Matsuzaki (2009) Reversible human TGF- $\beta$ signaling between tumor-suppression and carcinogenesis. Changchun inyernational digestive disease and liver disease peak forum, Changchun

10. Kazushige Uchida, Hidekai Miyoshi, Masanori Koyabu, Takeo Kusuda, Norimasa Fukata, Yutaku Sakaguchi, Toshiro Fukui, Motsunobu Matsushita, Makoto Takaoka and Kazuichi Okazkai (2009) Regulatory T cells in patients with autoimmune pancreatitis. European Pancreatic Club Meeting 2009, Szeged, Hungary

11. Masaaki Shimatani, Makoto Takaoka, Mitsunobu Matsushita and Kazuichi Okazaki (2009) Short double balloon enteroscope for ERCP in patients with altered gastrointestinal anatomy. DDW 2009, Chicago

12. Seki T (2009) Clinical application and prospects of microwave. International symposium on update of local ablation therapy for liver tumor, Beijing, China

13. Kazushige Uchida, Hideaki Miyosi, Masanori Koyabu, Takeo Kusuda, Norimasa Fukata, Yutaku Sakaguchi, Toshiro Fukui, Mitsunobu Matsushita, Makoto Takaoka and Kazuichi Okazaki (2009) Analysis of CD4+CD25high regulatory $\mathrm{T}$ cells in patients with autoimmune pancreatitis. International Pancreatic Research Forum, Tokyo

14. Masaaki Shimatani, Makoto Takaoka, Mitsunobu Matsushita, Kota Kato, Yuri Fukui, Masanori Koyabu, Tsukasa Ikeura, Toshiro Fukui, Kazushige Uchida and Kazuichi Okazaki (2009) "Short” double balloon enteroscope for diadnostic and therapeutic ERCP in pataients with altered gastrointestinal annatomy. The 8th KoreaJapan Joint Symposium on Gastrointestinal Endoscopy, Seoul

15. Ikeura T, Takaoka M, Shimatani M, Koyabu M, Kusuda $\mathrm{T}$ and Okazaki K (2009) Evaluation of the international consensus guidelines for management of branch-duct intraductal papillary mucinous neoplasm. The International Pancreatic Research Forum 2009, Tokyo

16. 吉田勝紀, 松崎恒一, 田橋賢也, 森 茂生, 山縣英生, 関本 剛, 関 寿人, 岡崎和一 (2009) 急性肝障害時 
の活性化星細胞における Smad を介したシグナル伝達 機構の解析. 肝類洞壁細胞研究会学術集会, 大阪

17. 松崎恒一 (2009) ヒト癌化過程におけるリン酸化 Smad を介する病的シグナル伝達. 大阪大学大学院セミ ナ一, 大阪

18. 是枝ちづ，関 寿人，岡崎和一（2009）シンポジウム NASHの最前線 : 核医学検査（アシアロシンチ／コロ イドシンチ), レボビスト造影エコーによる NASH の 診断経過観察の意義. 第38回日本肝蔵学会西部会, 鳥 取

19. 池田耕造, 関 寿人, 井口亮輔, 川村梨那子, 朝山俊 樹, 岡崎和一, 北出浩章, 横井川規巨, 權 雅憲, 鷹 巣晃昌, 四方伸朗（2009）肝原発が示唆されたカルチ ノイドの 1 例. 第 38 回日本肝蔵学会西部会, 鳥取県米 子市

20. 田中敏宏, 川股聖二, 加藤孝太, 大宮美香, 松下光伸, 關 壽人, 岡崎和一 (2009) 進行十二指腸癌を合併し た家族性大腸腺腫症（Familial adenomatous polyposis: FAP) の1例. 第190回日本内科学会近畿地方会, 神戸

21. 松崎恒一（2009）リン酸化 Smadを介する TGF-b シグ ナル伝達の解析. 第 23 回肝類洞壁細胞研究会学術集 会, 大阪

22. 川村梨那子, 関 寿人, 朝山俊樹, 井口亮輔, 梅原秀 人, 池田耕造, 西尾彰功, 岡崎和一, 横井川規巨, 北 出浩章, 權 雅憲, 建部 敦, 四方伸明 (2009) 先天 性肝線維症の1例。第38回肝臓学会西部会, 鳥取

23. 岡島 愛, 是枝ちづ, 吉川恵史, 池田耕造, 関 寿人, 岡崎和一，北出浩章，四方伸明（2009）14年間の経過 観察にて進行が緩徐であったPBCの1例. 第38回日本 肝臓学会西部会, 鳥取県

24. 池田広記, 中村尚広, 加藤孝太, 中橋佳嗣, 廣原淳子, 関 寿人，岡崎和一 (2009) 結婚 43 年後の配偶者性行 為が考えられた慢性C型肝炎の1例。第38回日本肝臓 学会西部会, 鳥取

25. 池田広記, 中村尚広, 加藤孝太, 中橋佳嗣, 廣原淳子, 関 寿人，岡崎和一 (2009) 当科における急性 B型肝 炎の特徵とインターフェロン $\alpha+$ 核酸アナログ治療介 入に関する検討. 第38回日本肝臓学会西部会, 鳥取

26. 岡崎和一 (2009) 自己免疫性膵炎の最近の話題〜 IgG4 関連膵疾患として〜．第 1 回消化器病学の最前線懇話 会, 富山

27. 島谷昌明（2009）すべて見せます胆膵内視鏡 治療・ 介助のポイント“従来のERCPからバルーン式内視鏡 を用いたERCP”。第8回プラクティスセミナー（近畿 消化器内視鏡技師会) , 大阪

28. 是枝ちづ, 関 寿人, 岡崎和一 (2009) コロイドシン チノアシアロシンチによる NAFLD の評価一肝集積, 脾集積による検討一。第 13 回日本肝臓学会大会, 京都

29. 島谷昌明, 高岡 亮, 岡崎和一（2009）パネルディス カッション $2:$ ダブルバルーン内視鏡を応用した胆膵 内視鏡治療の現状と新たなる試み. 第17回日本消化器
関連学会 (JDDW 2009), 京都

30. 島谷昌明（2009） サテライトシンポジウム 6 : 術後再 建腸管を有する胆膵疾患症例に対する内視鏡的アプ ローチ。第 17 回日本消化器関連学会（JDDW 2009）, 京都

31. 島谷昌明（2009）術後再建腸管を有する胆膵疾患症例 におけるダブルバルーン内視鏡を用いた内視鏡的ア プローチ．第3回長野県カプセル・バルーン内視鏡研 究会, 長野

32. 池浦 司, 高岡 亮, 島谷昌明, 小薮雅紀, 楠田武生, 中島 淳, 住本貴美, 関 寿人, 岡崎和一 (2009) 検 査処置後アミラーゼ值上昇からみた ERCP後膵炎危険 因子の検討. 第51回日本消化器病学会大会, 京都

33. 深田憲将, 内田一茂, 岡崎和一（2009）実験腸炎にお けるシクロスポリン封入マイクロスフェアーの治療. 第51回日本消化器病学会大会, 京都

34. 柳川雅人，大宮美香，川股聖二，松下光伸，岡崎和一 （2009）ノロウイルス感染合併潰瘍性大腸炎の2例. 第 19 回北河内炎症性腸疾患カンファレンス, 大阪

35. 松崎恒一，関 寿人，岡崎和一（2009）ウイルス性慢 性肝疾患において肝炎ウイルスと慢性炎症は『相加的 に』癌抑制シグナルを癌化シグナルに転換させる. 第 51 回日本消化器病学会大会, 京都

36. 松崎恒一, 関 寿人, 岡崎和一（2009）ウイルス性慢 性肝疾患における癌抑制・線維化シグナルの変遷. 第 51 回日本消化器病学会大会, 京都

37. 内田一茂, 楠田武生, 岡崎和一（2009）自己免疫性膵 炎における制御性 T細胞に関する検討. 第51回日本消 化器病学会大会, 京都

38. 松崎恒一 (2009) ヒト癌化過程におけるリン酸化 Smad を介する病的シグナル伝達. 第 82 回日本生化学会大 会, 神戸

39. 池田耕造, 関 寿人, 梅原秀人, 井口亮輔, 岡崎和一, 米虫 敦, 谷川 昇, 北出浩章, 高田秀穂（2009）転 移性肝癌に対する血流遮断下経皮的局所治療の有用 性の検討.JDDW2009, 京都

40. 井口亮輔，梅原秀人，池田耕造，関 寿人，岡崎和一 （2009）水冷式マイクロ波電極による組織凝固の基礎 的検討. Microwave Surgery研究会, 福岡県久留米市

41. 内田一茂（2009）自己免疫性膵炎における制御性 $\mathrm{T}$ 細 胞の役割. 大阪膵炎フォーラム, 大阪

42. 池宗真美, 福井寿朗, 柳川雅人, 坂口雄沢, 鉢嶺大作, 内田一茂, 松崎恒一, 西尾彰功, 關 壽人, 岡崎和一 （2009）特発性上腸間膜静脈・門脈血栓症の 1 例. 第 189 回日本内科学会近畿地方会, 日本

43. 島谷昌明, 高岡 亮, 岡崎和一 (2009) ワークショッ プ 3 : 術後再建腸管を有する胆道疾患に対する内視鏡 診断・治療における細径内視鏡併用ダブルバルーン $\mathrm{ERC}$ の有用性. 第 45 回日本胆道学会学術集会, 千葉

44. 岡崎和一 (2009) 自己免疫性膵炎の病態・診断におけ る最近の話題. 第 5 回血液免疫ネットワーク in 金沢, 
金沢

45. 池浦 司, 島谷昌明, 高岡 亮 (2009) 術後再建腸管 を有する胆膵疾患に対してダブルバルーン内視鏡を 用いた内視鏡的アプローチの有用性. 第83回日本消化 器内視鏡学会近畿地方会, 京都

46. 島谷昌明（2009）ダブルバルーン内視鏡におけるトラ ブルシューティング一偶発症の検討一. 第 8 回関西 ESD 研究会, 大阪

47. 加藤孝太, 島谷昌明, 松下光伸, 宮本早知, 田中敏宏, 中村尚広, 宮坂将光, 高岡 亮, 岡崎和一 (2009) 原 因不明の消化管出血（OGIB）に対し国産カプセル内 視鏡とダブルバルーン内視鏡が診断および治療に有 用であった小腸Angioectasiaの一例. 第91回消化器病 学会 近畿支部例会, 京都

48. 宮本早知, 島谷昌明, 松下光伸, 加藤孝太, 中村尚広, 宮坂将光, 田中敏広, 高岡 亮, 岡崎和一, 井上健太 郎, 權 雅憲, 大江知里, 植村芳子 (2009) 小腸イレ ウスを契機に発見された虚血性小腸炎の一例. 第91回 消化器病学会 近畿支部例会, 京都

49. 岸本真房, 若松隆宏, 宮坂将光, 宮本早知, 加藤孝太, 田中敏宏, 安藤祐吾, 森 茂生, 田橋賢也, 岡崎和一 （2009）経皮内視鏡的胃瘻造設術後に腹膜膿瘍, 敗血 症性ショックを来たした 1 例. 第83回日本消化器内視 鏡学会近畿地方会, 大阪

50. 池浦 司, 高岡 亮, 岡崎和一 (2009) 分枝型膵管内 乳頭粘液性腫瘍（IPMN）に合併した悪性腫瘍に関す る検討. 第91回日本消化器病学会近畿支部例会, 京都

51. 田中敏宏, 池田広記, 大宮美香, 中村尚広, 加藤孝太, 宮本早知, 宮坂将光, 中橋佳嗣, 廣原淳子, 関 寿人, 岡崎和一 (2009) シェーグレン症候群経過中に重症化 した自己免疫性肝炎と特発性血小板減少性紫斑病の 合併を認めた 1 例. 日本消化器病学会近畿支部第 91 回 例会, 大阪

52. 川村梨那子, 関 寿人, 古川富紀子, 井口亮輔, 梅原 秀人, 池田耕造, 是枝ちづ, 西尾彰功, 岡崎和一 (2009) FNH により Budd-Chiari 症候群様の血流異常を認めた 一例. 北大阪消化器病研究会, 大阪

53. 岡崎和一（2009）診療ガイドラインに基く自己免疫性 膵炎に打ける診断と治療. 京都消化器病医会定例学術 講演会, 京都

54. 島谷昌明 $(2009)$ 当院におけるカプセル内視鏡の実際 一小腸病変の診断・治療へのアプローチ一. 第 1 回近 畿カプセル内視鏡影セミナー, 大阪

55. 松崎恒一 (2009) Reversible human TGF- $\beta$ signaling between tumor-suppression and carcinogenesis. 慶応大 学大学院セミナー, 東京

56. 岡崎和一, 島谷昌明, 松下光伸 (2009) 単純性潰瘍 • 腸管型ベーチェット病の診断. 厚生労働科学研究難治 性疾患克服研究事業「原因不明小腸潰瘍症の実態把 握, 疾患概念, 疫学, 治療体系の確立に関する研究」 平成 21 年度第 1 回総会, 東京
57. 深田憲将, 岡崎和一, 内田一茂, 松下光伸, 西尾彰功 （2009）炎症性腸炎に対するシクロスポリン封入ポリ 乳酸マイクロカプセルを用いた新規治療の開発: 実験 腸炎に打ける治療効果の検討. 厚生労働科学研究難治 性疾患克服研究事業「難治性炎症性腸管障害に関する 調査研究」平成 21 年度第 1 回総会, 東京

58. 若松隆宏, 島谷昌明, 加藤孝太, 山縣英生, 松下光伸, 高岡 亮, 岡崎和一 (2009) カプセル内視鏡胃停滞を 上部消化管内視鏡下に十二指腸へ誘導した一例. 第 2 回日本カプセル内視鏡研究会 総会 - 学術集会, 東京 59. 山木 壮, 里井壯平, 豊川秀吉, 柳本泰明, 山本智久, 由井倫太郎, 高岡 亮, 岡㠃和一, 大江千里, 植村芳 子, 坂井田紀子, 權 雅憲 (2009) 当院における局所 進行ならびに切除可能膵癌症例の術前診断の現状. 第 40 回日本膵臓学会大会, 東京

60. 池浦 司, 岡崎和一 (2009) 慢性膵炎モデルラットに おけるカプサイシン徐神経の効果. 第 40 回日本膵蔵学 会大会, 東京

61. 柳本泰明, 里井壯平, 豊川秀吉, 山本智久, 山木 壮, 由井倫太郎, 廣岡 智, 高岡 亮, 岡㟝和一, 權 雅 憲（2009）当科における膵癌の進展度診断一MDCT と staging laparoscopy の有用性. 第 40 回日本膵臓学会大 会, 東京

62. 井口亮輔, 朝山俊樹, 柳川雅人, 川村梨那子, 梅原秀 人, 池田耕造, 関 寿人, 岡崎和一 (2009) 肝癌に対 する多方向展開型注入針を用いた経皮的エタノール 注入療法の成績. 第 45 回日本肝癌研究会, 福岡

63. 池田耕造, 梅原秀人, 井口亮輔, 川股聖二, 福島慎太 郎, 関 寿人, 岡崎和一, 辻 勝成, 北出浩章, 權 雅憲, 鷹巣晃昌, 四方伸明 (2009) 問題症例検討会一 症例6-1. 第45回日本肝癌研究会, 福岡県福岡市

64. 島谷昌明, 松下光伸, 加藤孝太, 宮本早知, 若松隆宏, 山縣英雄, 高岡 亮, 岡崎和一 (2009) 原因不明の消 化管出血 (OGIB) に対するカプセル内視鏡にて診断・ ダブルバルーン内視鏡にて治療し得た一例一当院に 抢ける OGIB の治療戦略一. 第 6 回関西消化器内視鏡 懇話会, 大阪

65. 内田一茂, 高岡 亮, 岡崎和一（2009） ワークショッ プ 自己免疫性萃炎診断基準 2006 の再評価 診断基 準の国際化にむけて 自験例における自己免疫性膵 炎臨床診断基準 2006 と海外診断基準との前向き比較 検討. 第 40 回日本膵臓学会大会, 東京

66. 内田一茂, 小薮雅紀, 楠田武夫, 三好秀明, 坂口雄沢, 西尾彰功, 岡崎和一（2009）自己免疫性膵炎における 制御性 T 細胞と IgG4 に関する検討. 日本消化器免疫学 会, 松山

67. 深田憲将, 内田一茂, 岡崎和一（2009）ドラッグデリ バリーシステムを用いたシクロスポリンによる実験 腸炎の治療. 日本消化器免疫学会, 松山

68. 若松隆宏, 加藤孝太, 青井一憲, 中村尚広, 川股聖二, 大宮美香, 松下光伸, 廣原淳子, 關 壽人, 岡崎和一 
（2009）予防的抗菌薬投与によって発症した再発性偽 膜性腸炎の 1 例. 第 188 回日本内科学会近畿地方会, 大 阪

69. 井口亮輔, 関 寿人, 池田耕造, 梅原秀人, 岡崎和一 （2009）摘出肝，生体肝を用いた水冷式マイクロ波電 極の凝固能評価：Cool-tip 電極との対比. 第 45 回日本 肝臟学会総会, 神戸

70. 井口亮輔, 関 寿人, 池田耕造, 梅原秀人, 岡崎和一, 北出浩章, 海堀昌樹, 權 雅憲 (2009) C 型慢性肝炎 に対するインターフェロン治療著効後に発症した肝 細胞癌症例 6 例の検討. 第 45 回日本肝臟学会総会, 神戸

71. 池田耕造, 関 寿人, 梅原秀人, 井口亮輔, 是枝ちづ, 岡崎和一, 河 相吉, 鷹巣晃昌, 四方伸明 (2009) コ ロイドシンチグラフィとCD 68染色を用いたNASHに 打ける肝網内系評価. 第 45 回日本肝臓学会総会, 兵庫 県神戸市

72. 岡崎和一 (2009) 自己免疫性膵炎の最近の話題. 第 54 回神奈川県消化器病研究会, 神奈川

73. 是枝ちづ, 谷野朋子, 村田美紀, 武田聖子, 梅原秀人, 池田耕造, 関 寿人, 岡崎和一, 河 相吉 (2009) BMI 変化とレボビスト造影エコー肝シンチグラフィによ るNASHの経過観察. 第 17 回肝病態生理研究会, 兵庫

74. 田中敏宏, 大宮美香, 松下光伸, 岡崎和一 (2009) 潰 瘍性大腸炎に抢ける血中アンチゲネミア陰性・大腸組 織 PCR 陽性 CMV 感染症に対する抗ウイルス治療につ いての検討. 第18回北河内炎症性腸疾患カンファレン ス, 大阪

75. 守時由起, Weici Zhang, 常山幸一, 吉田勝紀, 若林寛 二, Guo-Xiang Yang, 上野義之, M. Eric Gershwin, ZheXiong Lian（2009）PBCモデルdnTGF-bRII マウスにお けるB細胞の肝臟炎症抑制機能について. 第45回日本 肝臓学会総会, 神戸

76. 坂口雄沢（2009）B 型肝炎キャリアに合併した急性 E 型肝炎の一例. 大阪ウィルス性肝炎治療症例検討会, 大阪

77. 若松隆宏, 島谷昌明, 松下光伸, 山縣英生, 加藤孝太, 吉川恵史, 青井一憲, 中村尚広, 福井由理, 高岡 亮, 岡崎和一（2009）診断に苦渋した原因不明の消化管出 血に対してカプセル内視鏡が出血源同定に有用で あった 1 例. 第 4 回カプセル内視鏡の臨床応用に関す る研究会, 名古屋

78. 島谷昌明, 高岡 亮, 岡崎和一 (2009) シンポジウ ム: 術後再建腸管を有する胆膵疾患に対するダブルバ ルーン内視鏡の有用性と細径内視鏡を併用した内視 鏡治療の新展開. 第 77 回日本消化器内視鏡学会総会, 名古屋

79. 島谷昌明, 松下光伸, 岡崎和一（2009）シンポジウ ム : 2 種類のダブルバルーン内視鏡を用いた内視鏡治 療の工夫. 第 77 回日本消化器内視鏡学会総会, 名古屋

80. 島谷昌明, 高岡 亮, 岡崎和一 (2009) 術後再建腸管 を有する胆膵疾患に対してダブルバルーン内視鏡と
細径内視鏡を用いた新しい診断・治療. 第95回日本消 化器病学会総会, 札幌

81. 若松隆宏, 森 茂生, 岸本真房, 段原直行, 田橋賢也, 仲野俊成, 岡崎和一 (2009) Helicobacter pylori 除菌に おける抗菌剤感受性測定の意義. 第95回日本消化器病 学会総会, 札幌

82. 池浦 司, 高岡 亮, 島谷昌明, 内田一茂, 小薮雅紀, 楠田武生, 関 寿人, 岡崎和一 (2009) 分枝型 IPMN の経過観察に関する検討. 第95回日本消化器病学会総 会, 札幌

83. 内田一茂, 小藪雅紀, 岡崎和一 (2009) 自己免疫性膵 炎患者における制御性T細胞とIgG4陽性細胞に関する 検討. 第95回日本消化器病学会総会, 札幌

84. 鈴木聡史, 谷川 昇, 岸本真房, 富野敦稔, 山本 透, 北澤康秀, 小島博之, 狩谷秀治, 庄村裕三, 澤田 敏 （2009）膵局所動注療法における biapenemの有用性に ついて. 第68回日本医学放射線学会総会, 横浜

85. 是枝ちづ（2009）診断困難であった肝腫瘍の一例. 第 9回北河内疾患剆話会, 大阪

86. 田橋賢也（2009）食道胃静脈瘤および消化管血管性病 変に対する内視鏡治療. 第9 回北河内肝臓疾患懇話会, 大阪

87. 廣原淳子（2009）肝蔵の働きと肝臓の病気について 市民公開講座「肝臟病を治すには」, 大阪

88. 島谷昌明, 高岡 亮, 岡崎和一 (2009) 術後再建腸管 を有する胆膵疾患に対するダブルバルーン内視鏡を 用いた内視鏡治療の新展開. 第17回クリニカルビデオ フォーラム, 東京

89. 加藤孝太, 島谷昌明, 高岡 亮, 福井由理, 朝山俊樹, 吉川恵史, 小藪雅紀, 松下光伸, 岡崎和一 (2009) 複 雑な再建腸管を有する悪性胆道狭窄に対しダブルバ ルーン内視鏡を用いて metallic stent留置に成功した一 例. 第 82 回日本消化器内視鏡学会近畿地方会, 大阪

90. 中島 淳, 高岡 亮, 島谷昌明, 星野勝一, 小薮雅紀, 楠田武生, 若松隆宏, 朝山俊樹, 吉川恵史, 加藤孝太, 池浦 司, 関 壽人, 岡崎和一 (2009) 経鼻脺管ドレ ナージが有効であった閉塞性化膿性膵管炎の 1 例. 第 82 回日本消化器内視鏡学会近畿地方会, 大阪

91. 島谷昌明, 福井寿朗, 岡崎和一 (2009) シンポジウ ム: 小腸疾患の診断におけるダブルバルーン小腸内視 鏡と放射線的画像診断の比較検討. 第 82 回日本消化器 内視鏡学会近畿地方会, 大阪

92. 福井由理, 島谷昌明, 岡崎和一 (2009) シンポジウ ム: 当院でのダブルバルーン内視鏡検査における偶発 症の検討. 第 82 回日本消化器内視鏡学会近畿地方会, 大阪

93. 若松隆宏 (2009) 当院における小腸疾患の治療方針〜 カプセル内視鏡を中心に〜. 第6 回枚方エリア消化器 留話会, 大阪

94. 田橋賢也, 若松隆宏, 岡崎和一 (2009) ワークショッ プ 1 : 食道静脈瘤治療における地固め療法および消化 
管血管性病変に対する APCの有用性に関する検討. 第 82 回日本消化器内視鏡学会近畿地方会, 大阪

95. 松下光伸, 岡崎和一, 西尾彰功, 内田一茂, 大宮美香, 福井寿朗, 川股聖二, 安藤祐吾, 深田憲将 (2009) 難 治性炎症性腸疾患に対するステロイドを用いたド ラッグデリバリーシステム治療の臨床試験（I. ポリ 乳酸マイクロカプセルを用いたステロイド封入カプ セルによる難治性潰瘍性大腸炎治療の臨床試験. II. リポ化ステロイドを用いたドラッグデリバリーシス テムによる炎症性腸疾患の治療 : 多施設共同による無 作為化並行群間試験）。厚生労働科学研究難治性疾患 克服研究事業「炎症性腸疾患の画期的治療法に関する 臨床研究」平成 20 年度第 2 回総会, 東京

96. 深田憲将, 岡崎和一, 西尾彰功, 松下光伸, 内田一茂, 大宮美香, 福井寿朗, 川股聖二, 安藤祐吾, 廣田育彦, 田畑泰彦, 仲瀬裕志, 千葉 勉 (2009) サイクロスポ リン封入ポリ乳酸マイクロカプセルを用いた実験腸 炎治療の検討. 厚生労働科学研究難治性疾患克服研究 事業「炎症性腸疾患の画期的治療法に関する臨床研 究」平成 20 年度第 2 回総会, 東京

97. 大宮美香, 松下光伸, 岡崎和一 (2009) 大腸組織 CMV PCR 法陽性潰瘍性大腸炎における抗ウイルス治療の 意義についての前向き検討. 厚生労働科学研究難治性 疾患克服研究事業「難治性炎症性腸管障害に関する調 査研究」平成 20 年度第 2 回総会, 東京

98. 岡崎和一（2009）炎症性腸疾患に対する新しい治療戦 略. 厚生労働科学研究費補助金 難治性疾患克服研究 推進事業研究成果発表会 難治性疾患克服研究の成 果と今後, 東京

99. 岡崎和一 (2009) 自己免疫性膵炎の最近の話題. 第 15 回Pancreatic-Biliary Research Forum, 札幌

100. 島谷昌明, 高岡 亮, 松下光伸, 岡崎和一 (2009) 術 後再建腸管を有する胆膵疾患に対するダブルバルー ン内視鏡を用いた内視鏡治療の新展開. 第 4 回 Bay Area Gut Clib, 大阪

101.島谷昌明, 松下光伸, 岡崎和一（2009）シンポジウ 厶：原因不明の消化管出血の診断に打けるダブルバ ルーン小腸内視鏡と従来の放射線的画像診断の比較. 第5回日本消化管学会総会, 東京

102.関 寿人（2009）肝臓病の基礎知識: 肝がんにならな いために．第11回関西医科大学市民公開講座, 大阪

103. 吉川恵史, 若松隆宏, 朝山俊樹, 加藤孝太, 池田広 記, 中橋佳嗣, 高岡 亮, 廣原淳子, 関 寿人, 岡崎 和一, 斎藤隆道, 海堀昌樹, 權 雅憲 (2009) 胆道出 血による閉塞性黄疸を来たした肝細胞癌の一例. 日本 消化器病学界近畿支部第90回例会, 大阪

104. 廣原淳子, 仲野俊成, 関 寿人, 岡崎和一（2009）原 発性胆汁性肝硬変全国調査第29報. 厚生労働科学研究

難治性疾患克服研究事業「難治性の肝・胆道疾患に 関する調査研究」平成 20 年度第 2 回総会, 東京 105. 岡崎和一, 内田一茂, 西森 功, 下瀬川徹（2009）自
己免疫性膵炎の活動性評価. 厚生労働科学研究費補助 金難治性疾患克服研究事業 難治性脺疾患に関する 調查研究班 第2回総会, 東京

106. 岡崎和一 (2009) 病態に基づいた炎症性疾患の治療戦 略. 第89回京都胃腸勉強会, 京都

107.廣原淳子，池田広記，中橋佳嗣，関 寿人，岡崎和 一, 木村 穣, 海堀昌樹, 斎藤隆道, 松井康輔, 石崎 守彦, 權 雅憲 (2009) 脂肪肝ドナーに対するチーム 医療としての取り組み. 第26回近畿肝移植検討会, 大 阪

108.Kazuichi Okazaki and Guenter Kloppel (2009) Subtypes of AIP (LPSP AND IDCP). 40th Anniversary Joint Meeting of the American Pancreatic Association \& Japan Pancreas Society AUTOIMMUNE PANCREATITIS: EASTERN \& WESTERN PERSPECTIVES, Honolulu, USA

109.松崎恒一, 関 寿人, 岡崎和一 (2009) ウイルス性慢 性肝疾患において肝炎ウイルスと慢性炎症は『相加的 に』癌抑制シグナルを癌化シグナルに転換させる. JDDW 2009 KYOTO, 京都

110.島谷昌明, 高岡 亮, 岡崎和一 (2009) ダブルバルー ン内視鏡を応用した胆膵内視鏡治療の現状と新たな る試み. JDDW 2009 KYOTO, 京都

111. 岡崎和一, 内田一茂, 小藪雅紀, 楠田武夫, 吉田勝 紀, 坂口雄沢, 福井寿朗, 西尾彰功（2009）自己免疫 性膵炎における制御性T細胞の役割. 厚生労働科学研 究費補助金難治性疾患克服研究事業 IgG4 関連全身 疾患の病態解明と疾患概念確立のための臨床研究 第1回総会, 京都

112. 岡崎和一, 内田一茂, 西森 功, 川茂幸, 神沢輝 美, 下瀬川徹（2009）自己免疫性膵炎の活動性評価法 の作成. 厚生労働科学研究費補助金難治性疾患克服研 究事業 難治性膵疾患に関する調査研究班 第 1 回総 会, 東京

113. 岡崎和一, 富山 尚, 内田一茂, 池浦 司, 松下光 伸, 高岡 亮 (2009) 自己免疫性膵炎の初期治療にお ける経ロステロイドとステロイドパルス療法との検 討. 厚生労働科学研究費補助金難治性疾患克服研究事 業 難治性脺疾患に関する調査研究班 第 1 回総会, 東京

114.朝山俊樹, 池田耕造, 関 寿人, 梅原秀人, 井口亮 輔, 岡崎和一, 山田正法, 北出浩章, 權 雅憲, 鷹巣 晃昌, 四方伸明 (2009) 問題症例検討会一症例 1-6. 第 45 回日本肝癌研究会, 福岡県福岡市

115. 坂口雄沢, 深田憲将, 三好秀明, 楠田武生, 福井寿 朗, 内田一茂, 西尾彰功, 岡崎和一 (2009) WBN/Kob ラットの慢性膵炎・膵外病変における自己免疫性機序 の関与及び制御性 T 細胞の免疫応答. 第95回日本消化 器病学会総会, 札幌

116. 井口亮輔, 関 寿人, 池田耕造, 梅原秀人, 岡崎和一 (2009) 肝癌に対する多方向展開型注入針を用いた経 皮的エタノール注入療法（PEIT）の臨床成績. 第 11 
回関西肝癌局所治療研究会, 大阪

著 書

1. Seki T (2009) Microwave ablation and RFA. Radiofrequency ablation of liver tumor. Basic and Clinical studies 1 (Chen MinHua, S. Nahum Goldberg eds) pp 493-502, People's Medical Publishing House, Beijing, China

2. 林 紀夫, 今井康陽, 加藤道夫, 関 寿人, 吉原治正, 片山和宏, 竹原徹郎, 木岡清英, 廣田良夫, 朝野和典, 後藤和彦, 福島若葉（2009）ウイルス性肝炎診療マ ニュアル. ウイルス性肝炎診療マニュアル 1 (今井 康陽編）2-72 頁，大阪府医師会，大阪

3. 岡崎和一 (2009) 炎症性腸疾患の画期的治療法に関す る臨床研究. 炎症性腸疾患の画期的治療法に関する臨 床研究 平成 18-20年度 総合研究報告書3-10頁, 炎 症性腸疾患の画期的治療法に関する臨床研究班, 東京

4. 岡崎和一, 内田一茂, 深田憲将, 松下光伸, 西尾彰功, 安藤祐吾, 田畑泰彦, 玉置敬之, 仲瀬裕志, 千葉 勉, 淀井淳二 (2009) 炎症性腸疾患の画期的治療法に関す る臨床研究 薬剤封入マイクロカプセルを用いたド ラッグデリバリーシステムによる炎症性腸疾患に対 する新しい治療の検討. 炎症性腸疾患の画期的治療法 に関する臨床研究 平成 18-20年度 総合研究報告書 52-56 頁, 炎症性腸疾患の画期的治療法に関する臨床 研究班, 東京

5. 岡崎和一 (2009) 炎症性腸疾患の画期的治療法に関す る臨床研究. 炎症性腸疾患の画期的治療法に関する臨 床研究 平成 20 年度 総括 - 分担研究報告書 3-6 頁, 厚生労働省, 東京

6. 岡崎和一, 安藤祐吾, 坂口雄沢, 内田一茂, 松下光伸, 稲葉宗夫，池原 進（2009）炎症性腸疾患の画期的治 療法に関する臨床研究 ラット皮下脂肪組織由来幹 細胞の粘膜下局所注入法による腸管粘膜再生. 炎症性 腸疾患の画期的治療法に関する臨床研究 平成 20 年 度 総括-分担研究報告書36-38頁, 厚生労働省, 東京

7. 岡崎和一, 内田一茂, 深田憲将, 安藤祐吾, 松下光伸, 西尾彰功, 田畑泰彦, 玉置敬之, 仲瀬裕志, 千葉 勉 （2009）炎症性腸疾患の画期的治療法に関する臨床研 究 シクロスポリン封入ポリ乳酸マイクロカプセル を用いた実験腸炎治療の検討．炎症性腸疾患の画期的 治療法に関する臨床研究 平成 20 年度 総括・分担研 究報告書39-41頁, 厚生労働省, 東京

8. 岡崎和一, 内田一茂, 深田憲将, 安藤祐吾, 松下光伸, 田畑泰彦, 淀井淳二, 玉置敬之, 仲瀬裕志, 西尾彰功 （2009）炎症性腸疾患の画期的治療法に関する臨床研 究 ヒト組み換えチオレドキシンを用いた炎症性腸 疾患に対する新しい治療の検討. 炎症性腸疾患の画期 的治療法に関する臨床研究 平成 20 年度 総括 - 分担 研究報告書42-46頁, 厚生労働省, 東京

9. 岡崎和一, 松下光伸, 西尾彰功, 内田一茂, 大宮美香, 福井寿朗, 川股聖二, 安藤祐吾, 深田憲将, 大植謙一,
廣田育彦, 田畑泰彦, 仲瀬裕志, 千葉 勉（2009）炎 症性腸疾患の画期的治療法に関する臨床研究 ポリ 乳酸マイクロカプセルを用いたステロイド封入カプ セルによる難治性潰瘍性大腸炎治療の臨床試験. 炎症 性腸疾患の画期的治療法に関する臨床研究 平成 20 年度 総括 - 分担研究報告書 47-50 頁, 厚生労働省, 東京

10. 岡崎和一, 松下光伸, 西尾彰功, 内田一茂, 大宮美香, 福井寿朗, 川股聖二, 安藤祐吾, 深田憲将 (2009) 炎 症性腸疾患の画期的治療法に関する臨床研究 リポ 化ステロイドを用いたドラッグデリバリーシステム による炎症性腸疾患の治療多施設共同による無作為 化並行群間試験. 炎症性腸疾患の画期的治療法に関す る臨床研究 平成 20 年度 総括 - 分担研究報告書 $51-$ 54 頁, 厚生労働省, 東京

11. 岡崎和一, 内田一茂, 福井寿朗 (2009) 自己免疫性膵 炎 4. 治療と画像診断. 見て診て学ぶ膵腫瘍の画 像診断 (大友 邦, 木村 理編) 336-342 頁, 永井書 店, 大阪

12. 廣原淳子, 仲野俊成, 関 寿人, 岡崎和一（2009）原 発性胆汁性肝硬変全国調査 (第29報)。厚生労働科学 研究費補助金（難治性疾患克服研究事業）難治性の 肝・胆道疾患に関する調査研究平成 20 年度総括・分担 研究報告書 53-55頁, 厚生労働科学研究費補助金（難 治性疾患克服研究事業）難治性の肝・胆道疾患に関す る調査研究班, 東京

13. 内田一茂, 坂口雄沢, 岡崎和一（2009）動物モデルに よる解析. 自己免疫性膵炎 (岡崎和一, 川茂幸, 神 澤輝実編）56-59頁, 診断と治療社, 東京

14. 関 寿人 (2009) 炎症性疾患: 腸管吻合部潰瘍. 消化 管症候群（第2版）下一その他の消化管疾患を含めて - (浅香正博編) 318-320頁, 日本臨床社, 大阪

15. 島谷昌明, 松下光伸, 岡崎和一（2009） ダブルバルー ン内視鏡における偶発症対策. 消化管内視鏡のリスク マネージメント (五十嵐正広編) 167-172 頁, 中外医 学社, 東京

16. 岡崎和一, 内田一茂（2009）13 自己免疫性膵炎. 消 化器研修ノート（白鳥敬子, 菅野健太郎, 坪内博仁, 日比紀文編）558-562頁, 診断と治療社, 東京

17. 島谷昌明, 高岡 亮, 松下光伸, 池浦 司, 小藪雅紀, 加藤孝太, 岡崎和一（2009）消化管再建術後例でのダ ブルバルーン内視鏡を用いた内視鏡的乳頭括約筋切 開術. 消化器内視鏡 21(6)（藤田直孝編）896-902頁, 東京医学社, 東京

18. 島谷昌明（2009）当院におけるダブルバルーン小腸内 視鏡検査のクリニカルパス. 消化器病学の進歩一原点 から未来への情報発信一第 94 回日本消化器病学会総 会記念誌（飯田三雄編）229-235 頁, 財団法人 日本 消化器病学会, 東京

19. 廣原淳子, 仲野俊成, 関 寿人, 岡崎和一, 大西三朗 （2009）合併する自己免疫疾患別にみた原発性胆汁性 
肝硬変 $(\mathrm{PBC})$ の病態の相違一 $\mathrm{PBC}$ 全国調査結果から 一. 消化器病学の進歩一原点から未来への情報発信一 第 94 回日本消化器病学会総会記念誌（飯田三雄編） 251-254頁, 財団法人 日本消化器病学会, 東京

20. 岡崎和一, 内田一茂 (2009) 1章 疾患概念 1. 自己 免疫性膵炎の疾患概念. 新版 自己免疫性膵炎一病態 から診断・治療まで一（岡崎和一, 川茂幸, 神澤輝 実編） 1-3頁，診断と治療社，東京

21. 岡崎和一（2009）6章 診断と鑑別診断 1 . 診断基準 b 海外の診断基準. 新版 自己免疫性膵炎一病態 から診断・治療まで一（岡崎和一, 川茂幸, 神澤輝 実編）103-106頁，診断と治療社，東京

22 . 岡崎和一 (2009) 6 章 診断と鑑別診断 2 . 膵外病変 f 腎病変. 新版 自己免疫性膵炎一病態から診断・ 治療まで一（岡崎和一，川茂幸，神澤輝実編）132133 頁, 診断と治療社, 東京

23. 岡崎和一, 内田一茂 (2009) 4章 病因 ・病態 2 . 自 己免疫異常 a 体液性免疫. 新版 自己免疫性膵炎 一病態から診断・治療まで一（岡崎和一, 川茂幸, 神澤輝実編）37-40頁，診断と治療社，東京

24. 岡崎和一, 内田一茂（2009）4章病因・病態 2 . 自 己免疫異常 d 細胞性免疫. 新版 自己免疫性膵炎 一病態から診断・治療まで一（岡崎和一, 川茂幸, 神澤輝実編） 52-55頁，診断と治療社，東京

25. 岡崎和一, 内田一茂 (2009) 6 章 診断と鑑別診断 1. 診断基準 $\mathrm{b}$ 日本の診断基準. 新版 自己免疫性 脺炎一病態から診断・治療まで一（岡崎和一, 川茂 幸，神澤輝実編）99-102頁，診断と治療社，東京

26. 島谷昌明, 高岡 亮, 松下光伸, 池浦 司, 小藪雅紀, 宮本 早知, 加藤孝太, 岡崎和一 (2009) 術後再建腸 管を有する胆膵疾患例に対するダブルバルーン内視 鏡を用いた ERCP. 胆と膵 30 (臨時増刊特大号)（系 井 隆夫編）1213-1219 頁, 医学図書出版株式会社, 東京

27. 廣原淳子, 関 寿人, 岡崎和一（2009）原発性胆汁性 肝硬変. 内科学症例図説 (杉本恒明, 小俣政男編) $252-$ 255 頁, 朝倉書店, 東京

28. 廣原淳子, 関 寿人, 岡崎和一（2009）自己免疫性肝 炎. 内科学症例図説（杉本恒明, 小俣政男編) 255-256 頁, 朝倉書店, 東京

29. 西森 功, 岡崎和一, 神澤輝実, 川茂幸, 須田耕一, 能登原憲司，杉山政則，白鳥敬子，菊田和宏，下瀬川
徹（2009）難治性膵疾患に関する調査研究 III. 自己 免疫性膵炎 自己免疫性膵炎の実態調査（第2回全国 調査)。難治性膵疾患に関する調査研究 平成 20 年度

総括 - 分担研究報告書201-203頁, 東北大学大学院 医学系研究科, 仙台

30. 岡崎和一, 川茂幸, 神澤輝実, 伊藤鉄英, 乾 和郎, 入江裕之, 西野隆義, 能登原憲司, 久保惠嗣, 大原弘 隆, 入澤篤志, 藤永康成, 長谷部修, 西森 功, 田中 滋城, 田中雅夫, 白鳥敬子, 須田耕一, 西山利正, 下 瀬川徹（2009）難治性膵疾患に関する調査研究 III. 自己免疫性萃炎 自己免疫性膵炎の診療ガイドライ ンの作成にむけて，難治性膵疾患に関する調査研究 平成 20 年度 総括 ・分担研究報告書 204-208頁, 東北 大学大学院医学系研究科, 仙台

31. 岡崎和一, 内田一茂, 西森 功, 下瀬川徹 (2009) 難 治性膵疾患に関する調査研究 III. 自己免疫性萃炎 自己免疫性脺炎の治療適応と再発に関する検討活動 評価法に対する治療効果の検討. 難治性膵疾患に関す る調査研究 平成 20 年度 総括・分担研究報告書 209211頁, 東北大学大学院医学系研究科, 仙台

32. 西森 功, 水野伸匡, 山雄健次, 飯山達雄, 伊藤鉄英, 岡崎和一, 大原弘隆, 神澤輝実, 木原康之, 川茂幸, 桐山勢生, 白鳥敬子, 吉田 仁, 杉山政則, 下瀬川徹 （2009）難治性膵疾患に関する調査研究 III. 自己免 疫性膵炎 自己免疫性萃炎に打けるステロイド治療 の最適化の検討 (ステロイド維持療法の有用性に関す る多施設共同ランダム化介入試験）。難治性膵疾患に 関する調查研究 平成 20 年度 総括・分担研究報告書 212-217頁, 東北大学大学院医学系研究科, 仙台

33. 岡崎和一, 西尾彰功, 内田一茂, 福井寿朗 (2009) 難 治性萃疾患に関する調査研究 III. 自己免疫性膵炎 マウス自己免疫性膵炎における液性免疫反応の解析. 難治性膵疾患に関する調査研究 平成 20 年度 総括・ 分担研究報告書 221-223 頁, 東北大学大学院医学系研 究科, 仙台

34. 神澤輝実, 岡崎和一, 川 茂幸, 下瀬川徹, 大槻 眞 （2009）6章 1. 診断基準 c アジア診断基準 (Asian diagnostic criteria for autoimmune pancreatitis) . 新版 自己免疫性膵炎一病態から診断・治療まで一（岡崎和 一, 川 茂幸, 神澤輝実編）107-110 頁, 診断と治療 社, 東京

\section{心療内科学講座}

\section{〈研究概要〉}

心身医学の臨床研究では, 「心身症」を対象として, 多岐に渡る検討が求められています，具体的には，消化管運動機 能など各疾患別病態の評価, 自律神経系や内分泌系など中枢と末梢をつなぐシステムに関する検討，心理社会的因子の 検討, 心身相関の評価, 治療者 - 患者関係の評価, 心身医学的治療の効果の評価などが挙げられます。特に, 心身相関 は他分野の研究では見られない, 心身医学特有の重要なテーマです。しかし, 心身医学の研究には次のような独自の困 
難性があるために, 立ち遅れているのが現状です，

1）対象である「心身症」が多様な疾患群であり, 研究の対象として扱うことが容易でない.

2) 一般の医学的検査で評価が困難であり，定量的にとらえにくい事象が多い.

3）多要因で複雑な系であり, 評価が難しい.

このような課題を踏まえ，当科では機能性身体疾患，消化器心身症，慢性疼痛，バイオフィードバックなどの分野で 研究の取組みをしています. 研究手法としては, 一般的な解析に加えて, 質的研究, 精神生理学的手法などを試みてい ます。

\section{○消化器疾患に関する心身医学的研究}

Functional Dyspepsia（FD）患者の胃機能測定に動的上部消化管透視や胃内圧 $\mathrm{pH}$ センーを用い，さまざまなストレス を負荷することによって，情動と胃運動機能との関係を研究している.

\section{○慢性疼痛に関する心身医学的研究}

厚生省班会議の一員として, 多元的病態把握を中心に慢性疼痛の研究を行っている. 心理面からは, ロールシャッハ テストを用いて疼痛慢性化の人格的な要因について検討．また異なる疼痛神経伝達路を刺激する知覚神経検查装置を用 い，慢性疼痛患者の知覚関連間值を指標に，慢性疼痛の治療的な分類を試みている.

\section{○代替医療に関する心身医学的研究}

米国では西洋医学理論に基づいた治療以外はすべて代替医療とされ，わ孙机心療内科領域の治療の多くが代替医療 の範疇ということになる. その中の 1 つであるバイオフィードバック（BF）については, 従来のオペラント条件付け学 習モデルである疾患（書痤，斜䫋など）から, より広くさまざまな疾患を対象とするようになり, 研究対象も広がった. 現在は, 過敏性腸症候群, 線維筋痛症といった機能性身体症候群（functional somatic syndrome）に属する患者に対して, 多チャンネル精神生理指標測定法を用いて，バイオフィードバック治療効果の検討を行っている.

\section{〈研究業績〉}

原 著

1. Mutsuura H, Kanbara K, Fukunaga M, Yamamoto K, Ban I, Kitamura K and Nakai Y (2009) Depression and Anxiety Correlate Differently with Salivary Free Cortisol in the Morning in Patients with Functional Somatic Syndrome. Appl Psychophysiol Biofeedback 34(4): 291-298

2. Imanishi J, Kuriyama $\mathrm{H}$, Shigemori I, Watanabe $\mathrm{S}$, Aihara Y, Kita M, Sawai K, Nakajima H, Yoshida N, Kunisawa M, Kawase M and Fukui K (2009) Anxiolytic effect of aromatherapy massage in patients with breast cancer. Evid Based Complement Alternat Med 6(1): 123-128

3. 首藤由江, 水野泰行, 阿部哲也, 福永幹彦, 中井吉英 （2009）【神経障害性疼痛】治療 心理療法. Clin Neurosci 27(5): 573-575

4. 三宅眞理, Anne Rock, 田近亜蘭, 保津真一郎, 仁木 稔，平木宏児，西山利正 (2009) オーストラリアと 日本の高齢者介護施設におけるケアについての研究. オーストラリア研究 (22): 73-75

5. 水野泰行, 福永幹彦 (2009) Functional somatic syndromeの改善に伴うストレスコーピングの変化. 心療 内科 13(4): 337-342

6. 水野泰行, 福永幹彦, 中井吉英（2009）パニック障害 に対する苓桂术甘湯使用例の検討。日東洋心身医研 23(1-2): 37-41
総 説

1. 相原由花 (2009) 医療現場でのホリスティックケア 8）不妊専門クリニックでのアロマセラピーの役割. aromatopia 18(6): $72-75$

2. 相原由花 (2009) 医療現場でのホリスティックケア 5 臨床アロマセラピーでエビデンス（論拠）を活用 するとき. aromatopia 18(3): 58-61

3. 相原由花 (2009) 医療現場でのホリスティックケア クライアントを理解すること. aromatopia 18(1): 7981

4. 中井吉英 (2009) 身の概念一からだとこころの声を聞 く. バイオフィードバック研 36(1): 11-15

5. 水野泰行，福永幹彦，中井吉英（2009）【ストレス関 連疾患 患者背景にある，隠れたストレスを見過ごし ていませんか?】ストレス関連疾患の診断と治療 慢 性疼痛。治療 91(1): 115-118

6. 神原憲治, 福永幹彦, 阿部哲也, 水野泰行, 首藤由江, 堀 裕典, 中井吉英 (2009) 教育研修委員会から 心 身医学教育研修コース紹介 関西医科大学心療内科 学講座における教育研修の実際。心身医 49(5): 385390

7. 堀 裕典, 福永幹彦（2009）【いま話題の機能性消化 管障害】機能性消化管障害の心身医学的側面. 成人病 と生活習慣病 39(1): 18-21

8. 阿部哲也, 福永幹彦, 中井吉英（2009）胃 胃神経症. 日臨 別冊 (新領域別症候群シリーズ11 消化管症候 群（第2版）上）:362-364 
9. 阿部哲也, 神原憲治, 水野泰行, 福永幹彦 (2009) 機 能性身体症状の心身医療の実際一症例提示を含めて 一腹痛の治療。日臨 67(9): 1773-1777

10. 神原憲治, 福永幹彦（2009）【特集：機能性身体症候 群 (FSS)】FSSの病態. 日臨 67(9): 1669-1675

11. 福永幹彦（2009）FSS (functional somatic syndromes) の概念. 日臨 67(9): 1644-1645

12. 阿部哲也, 福永幹彦, 中井吉英 (2009) 精神科 - 心療 内科領域と消化管疾患 1 . 心療内科で治療を行う消 化管疾患. 臨消内科 24(7): 779-784

\section{症例報告}

1. Mutsuura H, Fukunaga M, Kanbara K, Yagyu T, Yamamoto K, Kitamura K, Ban I and Nakai Y (2009) Biopsychosocial approaches to a patient with vomiting of 10 years' duration-A case of temporal lobe epilepsy. Biopsychosoc Med. 3(Article No. 2): 1-11

2. 蓮尾英明, 山下直人, 本多啓介, 楠 裕明, 神原憲治, 福永幹彦, 中井吉英 (2009) 身体感覚の気づきの回復 過程にて前兆を認めるようになった難治性片頭痛の 一症例．バイオフィードバック研 36(1): 63-68

3. 土井麻里, 福永幹彦, 阿部哲也, 水野泰行, 首藤由江, 神原憲治, 伴 郁美, 中井吉英 (2009) 心身医学的ア プローチが奏功した眼瞼痤攣と顔面痤攣の 2 症例。 心 療内科 13(2): 135-140

その他

1. 中井吉英 (2009) 痛みの臨床 痛みと心理療法. 日医 師会誌 138(9): 1808-1809

2. 福永幹彦, 中井吉英 (2009) FSSの歴史, 概念の解説. 日臨 67(9): 1647-1651

3. 後山尚久, 土井麻里, 岸原千雅子, 金山由美, 村本邦 子（2009）女性のライフサイクルと統合医療, 第2回 21 世紀統合医療フォーラム「心理療法と統合医療的ラ イフスタイル」より 11: 1-25

\section{学会発表}

1. 神原憲治（2009）バイオフィードバック（BF）によ り身体感覚の気づきが高まり, ソマグラムに興味深い 変化がみられた一症例. 日本心理医療諸学会連合 (UPM）第22回大会, 東京

2. 杉本貴美子（2009）心療内科外来での催眠療法の利用 〜効果的な変化をもたらすために〜.日本臨床催眠学 会第11回学術大会, 東京

3. 福永幹彦（2009）患者と医師の関係一治癒を導くもの 一. 第21回皮膚科心身医学療法研究会, 大阪

4. 水野泰行 (2009) 心理面と痛みの関係性. 第7回理学 療法学生交流会, 奈良

5. 杉本貴美子（2009）喪失をめぐる EMDR の適応一不 妊, 流産, 死産のケアを通して一. 日本EMDR学会第 4 回学術大会, 名古屋
6. 山村 綾, 土井麻里, 永岡三穂, 首藤由江, 水野泰行, 神原憲治, 阿部哲也, 植木佐緒里, 福永幹彦（2009） 頻回の救急受診を繰り返していた機能性嘔吐／過敏 性腸症候群の一例. 第 48 回日本心身医学会近畿地方 会, 京都

7. 福永幹彦 (2009) 総合診療医に有用な心療内科の知識 と心療のコツ。第8回奈良総合診療研究会, 奈良

8. 福永幹彦 (2009) 慢性疼痛治療における抗うつ薬, 心 身医学からみた多面的な役割. 名古屋ペイン 2009 日 本ペインクリニック学会第43回大会/第31回日本疼痛 学会, 名古屋

9. 水野泰行 (2009) バイオフィードバックと認知行動療 法. 第37回日本バイオフィードバック学会学術総会, 大阪

10. 阿部哲也, 福永幹彦, 中井吉英 (2009) 知覚閾值検査 装置を用いた慢性疼痛の病態の検討。第 1 回日本心身 医学 5 学会合同集会, 東京

11. 水野泰行, 福永幹彦, 中井吉英 (2009) 疼痛患者にお ける「改善度予測」を用いた心理的重篤度評価の可能 性について. 第 1 回日本心身医学 5 学会合同集会, 東京

12. 福永幹彦（2009）心身医学における過敏性腸症候群の 治療アプローチ〜患者のニーズに応える薬の使い方, 薬物による心身医学的アプローチ〜。第1回日本心身 医学 5 学会合同集会, 東京

13. 神原憲治, 六浦裕美, 伴 郁美, 福永幹彦, 中井吉英 （2009）心身症患者に打ける精神生理学的指標のゆら ぎーストレスに対する反応と安静時のゆらぎについ ての検討一. 第 1 回日本心身医学 5 学会合同集会, 東京

14. 杉本貴美子, 竹林直紀, 福永幹彦, 中井吉英 (2009) 女性心療内科に打けるテーラーメイド治療〜流産, 死 産後の喪の作業〜。第 1 回日本心身医学 5 学会合同集 会, 東京

15. 水野泰行（2009）慢性痛に対する集学的アプローチを 考える〜各診療科がどのように貢献できるか一心療 内科の観点から一. 第 2 回学際的に痛みを考える会, 名古屋

16. 阿部哲也，福永幹彦，中井吉英（2009）機能性胃腸症 における症状と自律神経機能の関連について. 第 47 回 日本心身医学会近畿地方会, 京都

17. 永岡三穂，島津由美，村上典子（2009）当院における 看護師へのメンタルケアの試み. 第 47 回日本心身医学 会近畿地方会, 京都

18. 山村 綾, 堀 裕典, 植木佐緒里, 福永幹彦, 中井吉 英（2009）神経性大食症による急性膵炎の一例．第47 回日本心身医学会近畿地方会, 京都

19. 植木佐緒里, 蓮尾英明, 水野泰行, 福永幹彦, 中井吉 英（2009）患者のニーズにそったカウンセリングが奏 功した一症例. 第47回日本心身医学会近畿地方会, 京 都

20. 水野泰行, 福永幹彦, 中井吉英 (2009) ストレスコー ピング類型化の試み一家族関係ストレスを誘因とし 
た functional somatic syndromeの症例を通して一.第 47

回日本心身医学会近畿地方会, 京都
著 書

1. 福永幹彦 (2009) 老年期の心身症. 心身医学標準テキ スト 3 (久保千春編）207-214頁, 医学書院, 東京

\section{神経内科学講座}

\section{〈研究概要〉}

運動ニューロン病の神経変性に関する研究としては, これまで核細胞質間移送の障害, smad3 と TGF-beta シグナル伝 達の障害等の観点から検討してきた。 そして 2009 年度は核細胞質間移送の異常に関連すると考えられる核膜孔蛋白に注 目して検討し，運動ニューロンにおいて特徵的な変化を初めて見いだすことができた（Nuclear Contour Irregularity and Abnormal Transporter Protein Distribution in Anterior Horn Cells in Amyotrophic Lateral Sclerosis). 遺伝性ALSに関しては 近年目覚ましい展開があるが, 本学でも広島大学と共同でTARDBP 変異の解析を行い一定の成果を得た（Screening for TARDBP mutations in Japanese familial amyotrophic lateral sclerosis). 治療については, SOD-1 変異 transgenic mouseにて 骨髄内骨髄移植を行い脊髄への移植細胞の生着と予後の改善を認めた. こうした基礎的研究に加えて, 従来から重視し ている臨床病理学的検討としては, TDP-43 N352S ミスセンス変異を認めた家族性 ALSの一例, I113T変異を持つ家族性 ALS の剖検例, 長期の臨床経過を示した弧発性筋萎縮性側索硬化症の一剖検例を報告した. さらに当教室の重要なテー マである, 好塩基性封入体を伴う運動ニューロン病については, 好塩基性封入体がmRNA 由来であること, stress granule 由来の可能性を指摘きたが, 2009年度は, autophagy関連蛋白の解析を行い, stress granulesの凝集とそのautophagy処理 の破綻がその形成過程に深く関わることを示した. 一方, Tronto大学Dr. Muznoz との共同研究で, 好塩基性封入体がTDP43 陰性であるが, もう一つのRNA 結合蛋白である FUS/TLS 陽性であることを初めて示した（FUS pathology in basophilic inclusion body disease).

他の変性疾患における検討としては, レボドパ反応性でパーキンソン病様の経過をたどった進行性核上性麻痺の 1 剖検 例, 優性遺伝性家族性SCA8について報告した.

神経感染症の分野では，variant CJD 症例の臨床病理学的所見の詳細を報告した。これは長期の潜伏期間後に発症した 症例と考えられ, 我が国最初の報告である. HIV 感染症では, 認知症を示さず覀急性小脳失調のみを呈したHIV脳症患者 が，AIDS治療で軽快することを詳細に報告した．治療できる失調症として臨床上重要と考えられる，

封入体筋炎も当教室の重要なテーマであるが, この疾患みられる細胞質内縁取り空胞が核膜由来かどうかを精力的に 検討してきた. 2009 年度はその関連で DNA二本鎖切断修復酵素, 核たんぱく質の分布異常を検討し, さらに核膜の OGlcNAc修飾蛋白の分布について検討を加えて, さらに縁取り空胞の生成過程について検討を続けた。

\section{〈研究業績〉}

原 著

1. Munoz DG, Neumann M, Kusaka H, Yokota O, Ishihara K, Terada S, Kuroda S and Mackenzie IR (2009) FUS pathology in basophilic inclusion body disease. Acta Neuropathol 118(5): 617-627

2. Kanazawa S, Kinoshita Y, Yamaguchi K and Nomura S (2009) Gefitinib-induced autologous antitumor immunity. Asia Pac J Clin Oncol 5(2): 119-122

3. Ohnishi S, Ito H, Suzuki Y, Adachi Y, Wate R, Zhang J, Nakano S, Kusaka H and Ikehara S (2009) Intra-bone marrow-bone marrow transplantation slows disease progression and prolongs survival in G93A mutant SOD1 transgenic mice, an animal model mouse for amyotrophic lateral sclerosis. Brain Res 1296: 216-224

4. Kanazawa S, Yamaguchi K, Kinoshita Y, Nakagawa Y, Akai M, Ookura M, Uemura S and Nomura S (2009) Pneumothorax Associated with $\alpha 1$-Antitrypsin Deficiency. Intern Med 48(5): 387-388
5. Kinoshita Y, Ito H, Hirano A, Fujita K, Wate R, Nakamura M, Kaneko S, Nakano S and Kusaka H (2009) Nuclear Contour Irregularity and Abnormal Transporter Protein Distribution in Anterior Horn Cells in Amyotrophic Lateral Sclerosis. J Neuropathol Exp Neurol 68(11): 1184-1192

6. Kamada M, Maruyama H, Tanaka E, Morino H, Wate R, Ito H, Kusaka H, Kawano Y, Miki T, Nodera H, Izumi Y, Kaji R and Kawakami H (2009) Screening for TARDBP mutations in Japanese familial amyotrophic lateral sclerosis. J Neurol Sci 284(1-2): 69-71

7. Shinde A, Kunieda T, Kinoshita Y, Wate R, Nakano S, Ito H, Yamada M, Kitamoto T, Nakamura Y, Matsumoto S and Kusaka H (2009) The first Japanese patient with variant Creutzfeldt-Jakob disease (vCJD). Neuropathology 29(6): 713-719

総 説

1. 伊東秀文 (2009) 優性遺伝性家族性SCA8. Clin Neurosci 27(1): 63-65 
その他

1. Kanazawa S, Yamaguchi K, Kinoshita Y, Siomi K, Tujimoto M, Hanayama K, Sasada S, Hirashima T, Imamura F and Nomura S (2009) Effect of low-dose aspirin for skin rash associated with erlotinib therapy in patients with lung cancer. Platelets 20(1): 70-71

2. 金子 鋭（2009）脳梗塞患者に打けるクロピドグレル の PWV 改善効果に関する検討. 新薬と臨 58(6): 1068-1071

3. 景山 卓, 守田純一, 未長敏彦, 守田純一, 宮西節子 (2009) 抗Aquaporin-4抗体の蛍光顕微鏡による検出に ついて-2症例の検討一. 天理医紀 12(1): 42-51

4. 中村聖香, 和手麗香, 新出明代, 朝山真哉, 中野 智, 日下博文 (2009) HIV 感染症に関連した小脳性運動失 調症の1例．臨神経 49(10): 651-655

\section{学会発表}

1. 藤田賢吾, 長島正人, 柘植彩子, 守田純一, 和手麗香, 齋藤朱実, 金子 鋭, 中野 智, 日下博文 (2009) TolosaHunt 症候群で発症した B 細胞性悪性リンパ腫の一例. 日本神経学会第91回近畿地方会, 京都

2. 和手麗香, 西井 誠, 朝山知子, 中村正孝, 伊東秀文, 金子 鋭, 中野 智, 鎌田正紀, 丸山博文, 川上秀史, 日下博文（2009）TDP-43 N352S ミスセンス変異を認 めた家族性ALSの一例. 日本神経学会第 91 回近畿地方 会, 京都

3. 中野 智, 中村聖香, 西井 誠, 金子 鋭, 日下博文 （2009）コルヒチンミオパチーの1例. 第1回日本神経 病理学会近畿地方会, 京都

4. 中村聖香, 伊東秀文, 朝山真哉, 中村正孝, 西井 誠, 藤田賢吾, 和手麗香, 金子 鋭, 中野 智, 丸山博文, 川上秀史, 日下博文（2009）I113T 変異を持つ家族性 ALSの剖検例. 第37回臨床神経病理懇話会, 姫路市

5. 西井 誠, 中野 智, 中村聖香, 和手麗香, 新出明代, 金子 鋭, 日下博文（2009）封入体筋炎におけるDNA
二本鎖切断修復酵素の検討. 第 41 回日本臨床分子形態 学会総会・学術集会, 神戸

6. 西井 誠, 伊東秀文, 木下芳美, 中村聖香, 朝山知子, 朝山真哉, 中村正孝, 藤田賢吾, 和手麗香, 新出明代, 中野 智, 日下博文 (2009) 長期の臨床経過を示した 弧発性筋萎縮性側索硬化症の一剖検例. 第50回日本神 経病理学会総会学術研究会, 高松市

7. 中村聖香, 伊東秀文, 新出明代, 朝山真哉, 中村正孝, 西井 誠, 木下芳美, 藤田賢吾, 朝山知子, 和手麗香, 中野 智, 日下博文 (2009) レボドパ反応性でパーキ ンソン病様の経過をたどった進行性核上性麻痺の1剖 検例. 第50回日本神経病理学会総会学術研究会, 高松 市

8. 柘植彩子, 和手麗香, 朝山知子, 齋藤朱実, 新出明代, 金子 鋭, 中野 智, 日下博文 (2009) 発熱 - 眼球運 動障害・構音障害にて発症した感染症心内膜炎の一 例. 日本神経学会第 90 回近畿地方会, 大阪市

9. 西井 誠, 中野 智, 中村聖香, 和手麗香, 新出明代, 金子 鋭, 日下博文（2009）封入体筋炎における核蛋 白質の分布異常一免疫電顕による検討. 第50回日本神 経学会総会, 仙台

10. 中村聖香, 中野 智, 西井 誠, 和手麗香, 新出明代, 金子 鋭, 日下博文（2009）筋疾患筋組織における OGlcNAc 修飾蛋白の分布. 第 50 回日本神経学会総会, 仙台

11. 中野 智, 齋藤朱実, 迫田俊一, 新出明代, 金子 鋭, 日下博文（2009）骨格筋 channelopathy の運動負荷試 験. 第50回日本神経学会総会, 仙台

12. 藤田賢吾，金子 鋭，伊東秀文，木下芳美，中村正孝， 西井 誠, 和手麗香, 中野 智, 日下博文 (2009) 好 塩基性封入体を伴う成人発症運動ニューロン病での autophagy 関連蛋白の免疫組織化学. 第 50 回日本神経 学会総会, 仙台

13. 日下博文 (2009) パーキンソン病の初期症状. 第11回 市民公開講座，守口市

\section{精神神経科学講座}

\section{〈研究概要〉}

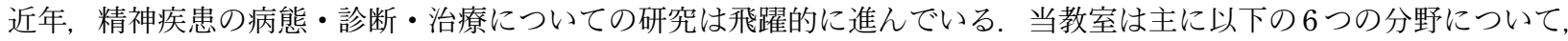
それぞれのグループが研究を行っている.

定量脳波研究グループ:

頭皮上から測定した脳波は精神活動の変化や薬物などの物質が脳に及ぼす影響を敏感に反映する. 定量脳波学とはそ のような脳が受ける影響を定量的に評価するものである. 解析手法には様々なものがあり，その一つに，時々刻々と変 化する脳電場活動を示す microstate analysis がある. これは脳活動を 4 枚の電位マップで表し，それぞれのマップの持続 時間が患者と健常者でどれぐらい異なるかを測定し，それが精神症状にどのように影響しているか脳内電気活動の側面 から病態の解明を行うものである。そもそもは向精神薬が脳波に及ぼす微細な変化を定量化することに始まったが，最 近はその手法を統合失調症やアルツハイマー病の病態生理の解明に応用している。例えば，統合失調症ではそれぞれの 持続時間が健常者に比べて短縮していることが判ってきた。 その時間が短縮するということは, 情報処理が不十分な状 
態で次の異なる情報処理に移行しているものと考えられ，それが幻覚・妄想などの精神症状を産生と関係しているもの と我々は考えている.

神経画像研究グループ:

精神疾患を対象として脳の形態学的研究を行なうため, 三次元大脳容量測定システム（BRAINS II）を用いた研究を 行っている. 統合失調症患者の尾状核容積について検討したところ, 健常者に比して統合失調症患者の白質容積が有意 に減少していることを見出し, その減少が認知機能低下に関連している可能性を報告した. また, 統合失調症患者を対象 とした拡散テンソル画像を用いた研究では, 統合失調症患者の前頭部, 側頭部, 頭頂部, 後頭部の広範囲にわたって Fractional Anisotropy（FA）が有意に低下しており，これらの領域での神経線維走行が健常者と異なることを見出した. 今後は, MRIによる構造画像解析と拡散テンソル解析から得られる結果を統合させることによって, 統合失調症の病態 解明や早期診断に結びつけていきたい.

薬理遺伝研究グループ:

薬理遺伝研究チームでは, 治療選択肢が多様化しているうつ病, 統合失調症治療において, 以下の検討課題を解明す る事により, 患者背景, 疾病のサブタイプや遺伝子多型に基づく各個人に適した治療法, すなわち“うつ病・統合失調 症個別化治療アルゴリズム”を作成する事を目的とする．検討課題として(1)第 1 選択薬としてふさわしい治療薬の検出, (2)補充療法としてふさわしい薬剤と, 補充する時期などをふくめた補充療法の適否の検討, (3)これらの治療に拈いて個 人差をもって認められる治療効果, 副作用が予測できる遺伝子多型, 疾病のサブタイプ, 患者背景を解明する. 我々は 遺伝因子と, 抗うつ薬の臨床効果の関連性を継続して検討しており, 無作為比較試験において, Serotonin transporter gene promoter polymorphism（5-HTTLPR）やセロトニン受容体遺伝子をはじめ, いくつかの遺伝因子が治療効果を予測でき る可能性を報告している. 無作為比較試験で遺伝子多型の影響を検討している研究はほとんど無く, そういった観点か ら我々の研究結果はとても興味深く重要であるものと考えられる. さらに我々は2つの大規模なメタ解析を行い, 抗うつ 薬の臨床効果に関連するとされる遺伝子因子を再確認している.

老年精神医学研究グループ:

認知症を中心として, 老年期に起こり得るあらゆる精神疾患, 精神症状を対象として, 臨床技術の開発, 応用, 研究 を行っている. 平成 12 年から“物忘れ外来”を開設し, 認知症の中でもアルツハイマー病の早期診断, 早期治療に力を 入れている. 最近の画像技術の進歩はめまぐるしく, 脳血流SPECTの他にも, MRIを含めた, 最新の統計画像解析を臨 床に取り込み応用している，更に，家族に対する心理教育にも力を注いでおり，「患者と家族の会」を立ち上げ，家族の 介護負担に関する研究も行っている. このように老年精神医学研究グループは, 老年期の精神障害を総合的に取り扱う ことを目標とし，この分野での中核機関として，地域との連携を強め，指導的な立場を担っていく予定である.

性同一性障害臨床研究グループ：

1999 年から性同一性障害の治療を行い, 2003 年には精神神経科, 形成外科, 産婦人科, 泌尿器科と合同でジェンダー クリニックを設置し, 本障害に関する治療を本格化させた。同年 12 月, 「性同一性障害に対する包括的治療」が本学医学 倫理委員会で承認され，2004年10月には性別適合手術を行い，日本精神神経学会のガイドラインに沿った包括的な治療 を行うことができる本邦で 3 番目の施設となった．精神療法と並行してバウムテスト，ロールシャッハテスト，MMPI (Minnesota Multiphasic Personality Inventory)，SCT (Sentence Completion Test)，WAIS-R（Weschsler Adult Intelligence Scale Revised）などの心理検査を施行し, 本障害の診断の補助と今後の治療に対する適応力を評価している. 現在まで に, 本障害患者の心理特性やMTF (male to female) とFTM (female to male) における心理特性の比較, ホルモン療法に よる変化などについて検討し，報告を重ねている.

薬剤性ジストニア研究グループ:

抗精神病薬の副作用によって生じる遅発性ジストニアに対して鍼治療を行い，その効果を検討している．この鍼治療 は, ジストニアによって生じた異常姿勢の原因を動作分析手法により解析し, 原因となる罹患筋やその他の二次的障害 に対して循経取穴（じゅんけいしゅけつ）という理論を用いて行っている. 精神疾患の既往がある症例のジストニアに 対する鍼治療効果は, 鍼治療回数10回目で約 70\%の症例に臨床症状の改善を認めている．また，最も難治である統合失 調症治療中に発症した頸部，体幹に不随意運動と異常姿勢を認める重度の軸性ジストニア症例に対しても，本法を用い た鍼治療によって改善を認めている.

本治療法の効果機序に関して, 放射線科学講座と共同研究を行っている. 鍼治療後の脳血流SPECTでは大脳基底核周 辺領域の脳血流が増加し，ジストニアの病態是正と関連した鍼治療の作用機序を考えている. 


\section{〈研究業績〉}

原 著

1. Kato M, Fukuda T, Wakeno M, Okugawa G, Takekita Y, Watanabe S, Yamashita M, Hosoi Y, Azuma J, Kinoshita T and Serretti A (2009) Effect of 5-HT1A gene polymorphisms on antidepressant response in major depressive disorder. Am J Med Genet B Neuropsychiatr Genet 150B(1): 115-123

2. Lawyer G, Nesva ${ }^{\circ}$, R, Varna“s K, Okugawa G and Agartz I (2009) Grey and white matter proportional relationships in the cerebellar vermis altered in schizophrenia. Cerebellum 8(1): 52-60

3. Kato M, Okugawa G, Wakeno M, Takekita Y, Nonen S, Tetsuo S, Nishida K, Azuma J, Kinoshita T and Serretti A (2009) Effect of basic fibroblast growth factor (FGF2) gene polymorphisms on SSRIs treatment response and side effects. Eur Neuropsychopharmacol 19(10): 718-25

4. Tsutsumi A, Kanazawa T, Kikuyama H, Okugawa G, Uenishi H, Miyamoto T, Matsumoto N, Koh J, Shinosaki K, Kishimoto T, Yoneda H and Kinoshita T (2009) Genetic polymorphisms in dopamine- and serotoninrelated genes and treatment responses to risperidone and perospirone. Psychiatry Invest 6(3): 222-225

5. Okugawa G, Kato M, Wakeno M, Koh J, Morikawa M, Matsumoto N, Shinosaki K, Yoneda H, Kishimoto T and Kinoshita T (2009) Randomized clinical comparison of perospirone and risperidone in patients with schizophrenia: Kansai psychiatric multicenter study. Psychiatry Clin Neurosci 63(3): 322-328

6. Kato M, Zanardi R, Rossini D, De Ronchi D, Okugawa G, Kinoshita T, Colombo C and Serretti A (2009) 5-HT2A gene variants influence specific and different aspects of antidepressant response in Japanese and Italian mood disorder patients. Psychiatry Res 167(1-2): 97-105

7. Morishita S, Kinoshita T (2009) Gender differences in response to antidepressants. Current topics in pharmacology 13(2): 51-64

8. 三宅眞理, Anne Rock, 田近亜蘭, 保津真一郎, 仁木 稔, 平木宏児, 西山利正 (2009) オーストラリアと 日本の高齢者介護施設におけるケアについての研究. オーストラリア研究 22: 73-75

9. 西村栄津子, 三井 浩, 谷万喜子, 高田あや, 鈴木俊 明, 木下利彦, 柳生隆視（2009）双極性障害の加療中 に生じた遅発性ジストニアに対する鍼治療. 関西医療 大紀 3: 115-120

10. 上田照子, 三宅真理, 西山利正, 田近亜蘭, 荒井由美 子（2009）要介護高齢者の息子による虐待の要因と多 発の背景. 厚生の指標 55(6): 19-26

11. 吉村匡史, 織田裕行, 杉本達哉, 西田圭一郎, 田近亜 蘭, 猋北佳輝, 鈴木美佐, 木下利彦 (2009) 認知症医 療において総合病院精神科病棟が果たす役割. 総病精
医 21(3): 243-250

12. 田近亜蘭, 阿部 尚, 坂井志帆, 分野正貴, 上野千穂, 吉村匡史, 木下利彦 (2009) エトサクシミドにより脳 波の強制正常化を来たし緘黙状態を呈した一例. 大阪 てんかん研会誌 20(1):3-8

13. 上野千穂, 木下利彦, 山本幸良（2009）精神科医が出 会う発達障害者の臨床的問題点一とくに広汎性発達 障害を中心に. 日精協誌 8: 51-55

14. 鈴木美佐（2009）大学病院における精神保健福祉士の 役割. 日精協誌 28(9): 40-45

15. 西田圭一郎, 吉村匡史, 吉田常孝, 入澤 聡, 森田紗 千, 磯谷俊明, 木下利彦 (2009) FTD (frontotemporal dementia）患者の周波数解析を用いた研究. 日薬物脳 波会誌 10(1): 63-66

16. 吉村匡史, 磯谷俊明, 入澤 聡, 西田圭一郎, 山田圭 造, 森田紗千, 获北佳輝, 北浦祐一, 諏訪 梓, 柳生 隆視，木下利彦 (2009) 抗精神病薬単回投与が健常者 の脳電場に及ぼす影響 包括的指標を用いて. 日薬物 脳波会誌 10(1): 43-48

17. 木下利彦 (2009) 新規抗うつ薬 mirtazapineのうつ病及 びうつ状態の患者を対象とした長期投与試験. 臨精薬 理 12(3): 503-520

18. 木下利彦 (2009) 新規抗うつ薬 mirtazapineのうつ病及 びうつ状態の患者を対象としたプラセボ対照二重盲 検比較試験. 臨精薬理 12(2): 289-306

19. 吉村匡史, 齋藤幸子, 延原健二, 磯谷俊明, 菊池 充, 奥川 学, 入澤 聡, 西田圭一郎, 森田紗千, 北浦祐 一, Koeenig Thomas, 木下利彦 (2009) 脳波 - 筋電図 の臨床 強迫性障害の空間的脳機能研究 症状誘発 による変化. 臨脳波 51(9): 560-567

総 説

1. Kinoshita T (2009) Epigenetics in Psychiatry. Neuropsychobiology 60(1): 1

2. 加藤正樹（2009）ファーマコゲノミクス一個別化医療 と薬剤感受性 精神科領域の個別化医療の現状と今 後. 医のあゆみ 230(6-7): 458-462

3. 加藤正樹，木下利彦 (2009)【特集 抗てんかん薬】将 来, どんなてんかん治療が期待されるか一pharmacogenetics と個別化治療の可能性一. 最新精神医 14(4): 361-368

4. 鈴木朋子, 岡村宏美, 木下利彦（2009）三田谷啓によ るビネ式知能検査の改訂. 心理学史・ 心理学論 10 ・ 11: $1-10$

5. 奥川 学, 高瀬勝教, 齊藤幸子, 木下利彦 (2009) MRI 一おさえておきたいポイント 拡散テンソル画像. 精 神 14(4): 312-315

6. 加藤正樹, 福田剛史, 分野正貴, 奥川 学, 获北佳輝, Alessandro Serretti, 東 純一, 木下利彦 (2009) 大う つ病性障害患者に打ける抗うつ薬の治療反応に対す る 5-HT1A 受容体遺伝子多型の影響. 日神精薬理誌 
29(1): 23-31

7. 获北佳輝, 木下利彦（2009）【最新の向精神薬の使い 方うつ・不安・睡眠障害】SSRIの適応の拡大と今後 の展望. 臨床と研究 86(8): 949-953

8. 加藤正樹, 奥川 学, 木下利彦 (2009) 新規抗てんか ん薬lamotrigine気分安定薬としてのlamotrigine一双極 性障害治療における有効性一。臨精薬理 12(5): 903912

9. 木下利彦 (2009) Blonanserinの使い方 Blonanserinの 基礎と臨床. 臨精薬理 12(3): 547-555

10. 获北佳輝 (2009) 統合失調症に対する perospirone と aripiprazole の無作為割付比較試験〜使用の適正化を 目指して〜 12(12):2630-2633

\section{症例報告}

1. 片上哲也, 織田裕行, 北元 健, 入澤 聡, 木下利彦 （2009）初老期にみられる抑うつ症状に対してリチウ ムが奏効した 2 症例. Bipolar disorder 7: 13-19

\section{学会発表}

1. 加藤正樹, Serretti A (2009) Meta-Analysis of Antidepressant Pharmacogenetic Findings in Major Depressive Disorder. 第30回日本臨床薬理学会年会, 横浜

2. 加藤正樹, 南㽞晋平, 鉄尾真司, 分野正貴, 奥川 学, 获北佳輝, 西田圭一郎, 木下利彦 (2009) Basic fibroblast growth factor (FGF2) gene polymorphisms could contribute to SSRIs treatment response and tolerability. 第 30 回日本臨床薬理学会年会, 横浜

3. Takekita Y, Kato M, Sakai S, Suwa A, Wakeno M, Okugawa G and Kinoshita T (2009) Perospirone and Aripiprazole Showed Equal Efficacy for Japanese Schizophrenia-A Randomized Clinical Trial-. The 1st Meeting of the Asian College of Neuropsychophamacology, Kyoto

4. 加藤正樹, Serretti A（2009）ポールヤンセン賞受賞講 演 Review and meta-analysis of antidepressant pharmacogenetic findings in major depressive disorder. 第 19 回 日本臨床精神神経薬理学会-第39回日本神経精神薬理 学会合同年会, 京都

5. Nishida K, Yoshimura M, Suwa A, Kitaura Y, Kono S, Isotani T and Kinoshita T (2009) A Case Report: The Change of EEG Findings in General Paresis before and after Penicillin-G Treatment. 18 th International Congress on Brain Electomagnetic Topography, Kyoto

6. Kato M, Okugawa G, Wakeno M, Takekita Y, Nishida K, Serretti A and Kinoshita T (2009) Basic fibroblast growth factor (FGF2) gene polymorphisms could contribute to SSRIs treatment response and tolerability. 22nd European College of Neuropsychopharmacolgy Congress, Istanbul

7. Suwa A, Wakeno M, Kato M, Sugimoto T, Sakai S,
Nishida K, Takekita Y, Tajika A and Kinoshita T (2009) Syndrome of inappropriate secretion of Anti-Diuretic Hormone in an Elderly Depressive Patient receving Paroxetine: a case report. 22nd European College of Neuropsychopharmacology Congress, Istanbul

8. Kato M, Wakeno M, Okugawa G, Takekita Y, Serretti A and Kinoshita T (2009) 5-HT1A gene polymorphisms contributed to antidepressant response in major depressive disorder. 9th World Congress of Biological Psychiatry, Paris

9. Nishida K, Yoshimura M, Yoshida T, Irisawa S, Kitaura Y, Isotani T and Kinoshita T (2009) Comparison of frontotemporal dementia and healthy volunteers. 9th World Congress of Biological Psychiatry, Paris

10. Takekita Y, Kato M, Tajika A, Sakai S, Suzuki A, Suwa A, Nishida K, Wakeno M, Okugawa $G$ and Kinoshita $T$ (2009) Risk factors of aripiprazole treatment discontinuation in Japanese schizophrenia patients. 9th World Congress of Biological Psychiatry, Paris

11. Nishida K, Yoshimura M, Yoshida T, Irisawa S, Kitaura Y, Isotani T and Kinoshita T (2009) Comparison of frontotemporal dementia and healthy volunteers using quantitative EEG. 2009 Asian and Oceanian Congress of Clinical Neurophysiology (AOCCN), Seoul

12. Yoshimura M, Isotani T, Nishida K, Yamada K, Morita S, Saito A, Irisawa S and Kinoshita T (2009) Global EEG descriptors for changes induced by antipsychotics. 2009 Asian and Oceanian Congress of Clinical Neurophysio$\operatorname{logy}(\mathrm{AOCCN})$, Seoul

13. Kato M, Wakeno M, Okugawa G, Takekita Y, Serretti A and Kinoshita T (2009) Ethnic difference in pharmacogenetic result in major depression. The result of meta-analysis. 9th World Congress of Biological Psychiatry, Paris

14. Kato M, Wakeno M, Okugawa G, Takekita Y, Serretti A and Kinoshita T (2009) Effect of 5-HT1A gene polymorphisms on antidepressant response in major depressive disorder. VIIth Pharmacogenetics in Psychiatry meeting, New York

15. 鈴木美佐 (2009) 日常生活で出来る認知症予防の習得. 守口市第五地域包括支援センター認知症予防教室, 守 口

16. 吉村匡史 (2009) 認知症について一認知症の早期発見 のポイントー。守口市明るい選挙啓発講演会, 守口

17. 岡村宏美, 吉野真紀, 木下利彦, 近松典子（2009）周 囲を気にしすぎる事, 他者への評価が両極的で変り易 い事を主訴として来談した青年との面接過程. 第25回 日本ストレス学会総会・第27回日本青年期精神療法学 会総会, 横浜

18. 山崎久美子, 岡村宏美，矢野裕子，中平暁子，西村美 登利, 西峯貴子, 兵頭紀子, 中務由香, 福永千佳子, 澤谷佳美，阪口博保，河野えみ子，木下利彦（2009） 
精神科における被験者スクリーニングの際の留意点. 第30回日本臨床薬理学会年会, 横浜

19. 鉄尾真司, 加藤正樹, 分野正貴, 奥川 学, 南㽞晋平, 猋北佳輝, 藤尾 慈, 木下利彦, 東 純一 (2009) 抗 うつ薬 SSRI の臨床効果に及ぼすセロトニントランス ポーター遺伝子多型の影響〜 $\mathrm{La} / \mathrm{Lg}$ 多型を考慮した検 討～。第30回日本臨床薬理学会年会, 横浜

20. 加藤正樹 (2009) 向精神薬の反応予測一薬理遺伝学的 アプローチの可能性一. 2009 年度薬物動態談話会 特 別例会, 浜松

21. 鈴木美佐（2009）「健康講座」認知症の介護について. 財団法人加多乃会講演会, 守口

22. 鈴木美佐（2009）認知症予防のための基本的な知識の 普及啓発. 守口市第五地域包括支援センター認知症予 防教室，守口

23. 获北佳輝 (2009) 統合失調症の理解と治療. 守口保健 所精神障がい疾病教室, 守口

24. 阿部 尚（2009）へルパーさんが知っておきたい精神 医学の基礎知識. 寝屋川市保健センター ヘルパー研 修，寝屋川

25. 井上雅晴（2009）虚言について. 心の健康相談支援教 職員研修, 大阪

26. 村上貴栄 (2009) 家族の役割〜本人と心を通わす接し 方〜。精神障がい者家族教室，四条畦

27. 田近亜蘭（2009）病気（統合失調症）の理解。精神障 がい者家族教室，四条畷

28. 村上貴栄 (2009) 精神保健福祉と医療ソーシャルワー ク．大阪医療ソーシャルワーカー協会初任者研修，大 阪

29. 西田圭一郎, 吉村匡史, 北元 健，木下利彦（2009） 不安障害にパロキセチンと不安階層表の併用が有効 であった思春期症例. 第 10 回関西精神医学交流会, 大 阪

30. 加藤正樹（2009）向精神薬の反応予測は可能か？ 第 13 回日本精神保健・予防学会, 東京

31. 諏訪 梓, 分野正貴, 加藤正樹, 杉本達哉, 坂井志帆, 西田圭一郎，訔北佳輝，田近亜蘭，木下利彦（2009） Paroxetine 内服中に Syndoreme of inappropriate secretion of Anti-Diuretic Hormoneをきたした老年期うつ病 患者：症例報告．第19回日本臨床精神神経薬理学会・ 第39回日本神経精神薬理学会, 京都

32. 加藤正樹（2009）うつ病治療における薬理遺伝と個別 化医療の可能性. 第19回日本臨床精神神経薬理学会・ 第39回日本神経精神薬理学会合同年会, 京都

33. 吉村匡史, 杉本達哉, 織田裕行, 鈴木美佐, 田近亜蘭, 获北佳輝，西田圭一郎，佐藤幸代，増本和美，木下利 彦（2009）大学病院精神科病棟における高齢患者群と 非高齢患者群との比較. 第22回日本総合病院精神医学 会総会, 大阪

34. 高野悟史, 吉村匡史, 西田圭一郎, 諏訪 梓, 北浦祐 一，磯谷俊明，木下利彦 (2009) 進行麻痺の一例にお
ける治療経過とその脳波変化. 第39回日本臨床神経生 理学会学術大会, 小倉

35. 板東宏樹, 入澤 聡, 山田妃沙子, 杉本達哉, 織田裕 行, 平川昭彦, 岩瀬正顕, 村尾佳則, 中谷壽男, 木下 利彦（2009）自殺企画にて救急搬送された双極性障害 の2症例．第8回Bipolar Disorder研究会，東京

36. 織田裕行（2009）双極性障害の診断と治療について。 平成 21 年度 第 1 回大阪府病院薬剂師会精神科病院委 員会研修会, 大阪

37. 三井 浩 (2009) 事例検討会（保育所での対応困難の 症例)。保育所運営事例検討会, 守口

38. 鈴木美佐（2009）気付いていますか? 生活習慣から しのびよる認知症の影. 門真第二地域包括支援セン タ一認知症予防講座, 門真

39. 鈴木美佐 (2009) 動き盛りにある認知症の話にふれて. 門真第二地域包括支援センター認知症予防講座, 門真

40. 吉村匡史（2009） The PEACE Project. がん診療に携 わる医師に対する緩和ケア研修会 (松下記念病院), 守 口

41. 織田裕行（2009）The Peace Project. がん診療に携わ る医師に対する緩和ケア研修会 (松下記念病院), 守口

42. 吉村匡史（2009）「健康講座」介護不要の健康管理一 認知症にならないために一. 財団法人加多乃会講演 会, 守口

43. 西田圭一郎 (2009) 認知症について. 財団法人加多乃 会講演会, 守口

44. 守田 稔（2009）性同一性障害について．城東区人権 啓発推進員研修, 大阪

45. 鈴木美佐 (2009) 平成 21 年度課題別研修: 認知症. 大 阪府地域包括支援センタ一職員研修，大阪

46. 田近亜蘭 (2009) こころの病気一統合失調症とは? 大東市精神障がい者理解促進講座, 大東

47. 木下利彦 (2009) うつ病のはなし 変遷と抗うつ薬の 動向. 第16回日本身病システム学会総会, 豊中

48. 峯岸由紀子, 木下利彦，木原 裕 (2009) 気功。第 25 回日本催眠学会学術大会, 枚方

49. 板東宏樹, 村尾佳則, 山田妃沙子, 杉本達哉, 織田裕 行，齊藤福樹，平川昭彦，中谷壽男（2009）当救命救 急センターにおける自殺企図患者の検討. 第37回日本 救急医学会, 盛岡

50. 織田裕行（2009）ミルタザピンの臨床的有用性. 第 3 回兵庫県精神神経科診療所協会学術講演会, 神戸

51. 三宅眞理，上田照子，渡邊完児，田近亜蘭，西山利正 （2009）介護老人福祉の介護作業における就業時間別 の身体活動の比較. 第68回日本公衆衛生学会総会, 奈 良

52. 鈴木美佐（2009）安心して継続した施設ケアが受けら れるために考えること. 認知症の人と家族への援助を すすめる第25回全国研究集会, 佐賀

53. 井上雅晴（2009）「ひきこもり」の理解. ひきこもり 家族セミナ一, 四条畷 
54. 鈴木美佐（2009）認知症疾患医療センターの役割につ いて，交野市介護支援専門員連絡会，交野

55. 鈴木美佐（2009）認知症のサイン. 寝屋川市介護予防 教室, 寝屋川

56. 井上雅晴（2009）自傷について. 心の健康相談支援教 職員研修, 大阪

57. 高野 隼, 杉山祐夫, 村上貴栄, 柿永佳代子, 木下利 彦（2009）地域プログラムへの参加に伴うメンバーの 変化. 日本デイケア学会第 14 回年次大会, 宜野湾

58. 村上貴栄, 杉山祐夫, 高野 隼, 柿永佳良子, 木下利 彦（2009）落語グループから精神障がいの理解促進へ の取り組み. 日本デイケア学会第 14 回年次大会, 宜野 湾

59. 吉野真紀, 鈴木朋子, 堀内麻美（2009）高校を二度中 退した思春期男子の短期心理面接一 10 回限定セッ ションの試み一. 日本心理臨床学会第 28 回秋季大会, 東京

60. 木下利彦 (2009) うつ病の変遷と最近の抗うつ薬の動 向. 兵庫うつ病フォーラム 2009 , 神戸

61. 高野 隼, 杉山祐夫, 村上貴栄, 柿永佳代子, 木下利 彦（2009）運動が効果的であった統合失調症患者の 1 例. 2 大学精神神経科フォーラム, 大阪

62. 鈴木美佐（2009）どうしてなるのかな認知症. 守口第 4地域包括支援センター認知症見守り教室, 守口

63. 西村栄津子, 谷万喜子, 三井 浩, 高田あや, 吉野真 紀, 鈴木俊明, 柳生隆視, 吉田宗平, 木下利彦 (2009) 双極性障害の加療中に生じた薬剂性ジストニア 3 症例 に対する鍼治療. 第105回日本精神神経学会学術総会, 神戸

64. 板東宏樹, 杉本達哉, 山田妃沙子, 加藤正樹, 織田裕 行, 平川昭彦, 岩瀬正顕, 村尾佳則, 中谷壽男, 木下 利彦（2009）自殺企図にて救急搬送となった躁うつ病 の3例. 第 10 回KMUリエゾン研究会, 守口

65. 村上貴栄, 杉山祐夫, 高野 隼, 柿永佳良子, 木下利 彦（2009）デイケアプログラムとしての落語の活用. 第9回外来精神医療学会, 大阪

66. 井上雅晴（2009）ひきこもりの理解. ひきこもり家族 セミナー, 守口

67. 嶽北佳輝 (2009) 認知症の理解と対応上の工夫. 寝屋 川市福祉公社ヘルパー研修会, 寝屋川

68. 鈴木美佐 (2009) 意思決定と権利擁護. 神戸市認知症 介護実践研修実践者研修，神戸

69. 高野悟史, 諏訪 梓, 坂井志帆, 藤山佳子, 西田圭一 郎, 分野正貴, 加藤正樹, 杉本達哉, 吉村匡史, 木下 利彦（2009）行動異常で発症し精神科受診に至った神 経梅毒の一例. 第105回近畿精神神経学会, 大阪

70. 西田圭一郎, 吉村匡史, 諏訪 梓, 高野悟史, 北浦祐 一, 磯谷俊明, 木下利彦 (2009) 進行麻痺に対してぺ ニシリン大量投与を行い症状が改善した一例〜脳波 による検討〜。第 12 回日本薬物脳波学会, 釧路

71. 木下利彦 (2009) 最近のうつ病の動向. 第22回近畿地
区精神科合同卒後研修講座，大阪

72. 織田裕行 (2009) 適応障害. 第4 回関西GIDネットワー ク, 大阪

73. 吉村匡史（2009）The Peace Project. がん診療に携わ る医師に対する 緩和ケア研修会 (大阪市立総合医療 センター), 大阪

74. 板東宏樹, 村尾佳則, 杉本達哉, 織田裕行, 平川昭彦, 岩瀬正顕, 中谷壽男（2009）ICUに打けるせん妄患者 に対しデクスメデトミジンを使用した症例の報告. 第 12 回日本臨床救急医学会, 大阪

75. 加藤正樹 (2009) 再発予防を重視した統合失調症の治 療戦略. 第5 回河内地区精神医療研究会, 大阪

76. 吉村匡史 (2009) The Peace Project. がん診療に携わ る医師に対する緩和ヶア研修会（星ヶ丘厚生年金病 院)，枚方

77. 获北佳輝, 田近亜蘭, 織田裕行, 坂井志帆, 吉村匡史, 木下利彦（2009）首都圏ECT ネットワーク参加報告. 第7回近畿 ECT 連絡会議, 大阪

78. 織田裕行 (2009) The Peace Project. 北河内医療圏が ん診療に携わる医師に対する緩和ヶア研修会（星ヶ丘 厚生年金病院)，枚方

79. 杉本達哉，板東宏樹（2009）リエゾン活動報告．第 9 回KMUリエゾン研究会, 守口

80. 猋北佳輝, 北浦祐一（2009）当院における緩和ケア医 療の現状と今後. 第9回KMUリエゾン研究会, 守口

81. 加藤正樹（2009）日本人のうつ病一原因と治療一. 在 ニューヨーク日本総領事館後援による講演, New York

82. 吉村匡史, 西田圭一郎, 北浦祐一，木下利彦（2009） 薬物脳波学を精神科臨床に生かす. 第31回日本生物学 的精神医学会, 京都

83. 板東宏樹, 杉本達哉, 山田妃沙子, 織田裕行, 平川昭 彦, 岩瀬正顕, 村尾佳則, 木下利彦, 中谷壽男 (2009) 自殺企図にて救急搬送となった躁うつ病の 3 症例. 第 33 回日本自殺予防学会, 大阪

84. 池田耕士, 谷川 昇, 杉本達哉, 米虫 敦, 播磨洋子, 前原 稔, 大村直人, 黒川弘晶, 池田茂樹, 澤田敏 （2009）拡散強調画像による経皮的椎体形成術後の新 たな圧迫骨折の予測. 第 68 回日本医学放射線学会総 会, 横浜

85. 織田裕行 (2009) The peace Project. 第 1 回京都市立 病院緩和ケア研修会, 京都

86. 加藤正樹（2009）うつ病のはなし． 邦人医療ネット ワーク共催, 在ニューヨーク日本総領事館後援による 講演, New York

87. 山田妃沙子, 鈴木美佐, 織田裕行, 片上哲也, 山田圭 造, 守田 稔, 枷場美穂, 岡村宏美, 中平暁子, 吉野 真紀，鈴木朋子，木下利彦（2009）性同一性障害外来 を受診した未成年患者についての検討. GID学会第 11 回研究大会, 長崎

88. 获北佳輝, 坂井志帆, 分野正貴, 加藤正樹, 木下利彦 (2009) 統合失調症に対するペロスピロンとアリピプ 
ラゾールの無作為割付比較試験〜使用の適正化を目 指して〜. ドパミンセロトニン (DS) フォーラム 2009 , 東京

89. 鈴木美佐（2009）認知症と上手につきあおう．家族介 護教室講座, 枚方

90 . 鈴木美佐 $(2009)$ 平成 21 年度課題別研修: 認知症. 大 阪府地域包括支援センター職員研修, 大阪

91. 木下利彦 (2009) 統合失調症の世界. 第7回滋賀臨床 行動科学研究会, 大津

92. 板東宏樹, 村尾佳則, 山田妃沙子, 杉本達哉, 織田裕 行, 平川昭彦, 岩瀬正顕, 中谷壽男 (2009) 当救命救 急センターに打ける急性薬物中毒患者の検討. 第99回 近畿救急医学研究会, 尼崎

93. 黒瀬光一, 石渡和也, 平塚一幸, 南畧晋平, 東 純一, 奥川 学, 加藤正樹, 木下利彦, 黒沢 亨, 長谷川隆 一 (2009) 抗うつ薬SSRI（serotonin selective reuptake inhibitor）による性機能障害の発現に関する遺伝子 マーカーの探索. 日本薬学会 129 年会, 京都

94. 石渡和也, 平塚一幸, 南畧晋平, 東 純一, 奥川 学, 加藤正樹, 木下利彦, 長谷川隆一, 黒沢 亨, 黒瀬光 一(2009) 抗うつ薬SSRI（serotonin selective reuptake inhibiyor）による嘔気の発現に関する遺伝子マーカー の探索. 日本薬学会 129 年会, 京都

95. 平塚一幸, 石渡和也, 南畧晋平, 東 純一, 奥川 学, 加藤正樹, 木下利彦, 長谷川隆一, 黒沢 亨, 黒瀬光 一 (2009) 抗うつ薬SSRI（serotonin selective reuptake inhibitor）の有効性の指標となる遺伝子マーカーの探 索. 日本薬学会 129 年会, 京都

96. 織田裕行, 片上哲也, 山田圭造, 守田 稔, 枷場美穂, 岡村宏美，中平暁子，吉野真紀，鈴木朋子，山田妃沙 子，鈴木美佐，木下利彦（2009）関西医大病院ジェン ダークリニックの現状に関する検討. GID学会第 11 回 研究大会, 長崎

97. 三井 浩 (2009) ひきこもりの青年と家族に関わって 〜医師の立場から〜。「社会的ひきこもり」守口・門 真地域ネットワーク会議, 守口

98. 鈴木美佐 (2009) 認知症の理解と対応. 守口市医師会 職員研修, 守口

99. 上野千穂（2009）精神疾患について 統合失調症を中 心に. 守口門真保健所 守口市精神障がい者理解促進 事業梶地区研修会, 守口

100. 井上雅晴, 今村容子, 入澤 聡, 村田知康, 阿部 尚, 藤山佳子, 获北佳輝, 三井 浩, 片上哲也, 吉田 常孝, 吉村匡史, 堀内麻美, 木下利彦 (2009) 出産後 多発性硬化症を併発した非定型精神病の一症例。第 104 回近畿精神神経学会, 高槻

101.諏訪 梓, 分野正貴, 吉村匡史, 田近亜蘭, 木下利彦 (2009) Paroxetine内服中にSyndoreme of inappropriate secretion of Anti-Diuretic Hormone をきたした老年期 うつ病患者 (症例報告). 第 104 回近畿精神神経学会, 大阪
102.鈴木 歩, 片上哲也, 三井 浩, 訔北佳輝, 織田裕 行, 吉村匡史, 木下利彦 (2009) 軽度認知症を併発し たうつ病にm-ECTが著効した 1 例. 第 104 回近畿精神 神経学会, 高槻

103.吉村匡史，織田裕行，田近覀蘭，杉本達哉，鈴木美 佐，増本和美，小田昌子，木下利彦（2009）関西医大 附属滝井病院精神神経科病棟入院患者の入院前の場 所と退院後の行き先. 第28回日本社会精神医学会, 宇 都宮

104.織田裕行, 片上哲也, 山田圭造, 守田 稔, 枷場美 穂, 岡村宏美, 中平暁子, 吉野真紀, 鈴木朋子, 山田 妃沙子, 鈴木美佐, 木下利彦（2009）性同一性障害専 門外来における初診時のホルモン值とWAIS-R, MMPI に関する検討. 第28回日本社会精神医学会, 宇都宮

105. 田近西蘭, 吉村匡史, 杉本達哉, 西田圭一郎, 获北佳 輝，鈴木美佐，木下利彦（2009）もの忘れ初診外来を 設置する前後における診療サービス内容の比較. 第 28 回日本社会精神医学会, 宇都宮

106. 井上雅晴（2009）広汎性発達障害. 自閉症講演会, 泉 佐野

107.田近亜蘭, 阿部 尚, 坂井志帆, 分野正貴, 上野千 穂, 吉村匡史, 木下利彦 (2009) エクサクシミドによ り脳波の強制正常化をきたし緘黙状態を呈した一例. 第38回大阪てんかん研究会, 大阪

著 書

1. Nishida K, Yoshimura M, Suwa A, Kitaura Y, Kono S, Isotani T, Kinoshita T (2009) A Case Report: The Change of EEG Findings in General Paresis before and after Penicillin-G Treatment. Brain Topography and multimodal imaging 253-255頁, 京都大学学術出版会, 京都

2. 杉本達哉 (2009) 抗うつ薬中毒 (三環系, 四環系), 炭 酸リチウム中毒. 今日の治療指針 2009 年版（Vol. 51） (山口徹, 北原光夫, 福井次矢編) 115-116頁, 医学書 院, 東京

3. 黒瀬光一, 斎藤嘉朗, 佐井君江, 森 篤雄, 丹羽卓朗, 東 純一, 埴岡伸光, 奥川 学, 平塚一幸, 伊藤継孝, 佐藤正宏（2009）医薬品開発のための評価科学に関す る研究 ファーマコゲノミクス情報に基づいた医薬 品の有効性及び安全性評価系の開発と医薬品開発へ の応用. 政策創薬総合研究研究報告書 平成 20 年度 79-90頁，ヒューマンサイエンス振興財団，東京

4. 木下利彦, 西田圭一郎, 吉村匡史（2009） I. 診断を つけるために F. 検査 1 . 神経生理検査. 精神科専門 医のためのプラクティカル精神医学 177-186 頁, 中 山出版, 東京

5. 平安良雄, 有賀 徹, 三村 將, 河西千秋, 田中克明, 加藤大慈, 佐藤玲子, 山田朋樹, 酒井明夫, 大塚耕太 郎, 智田文徳, 廣常秀人, 小川朝生, 宮岡 等, 山本 賢司，上條吉人，朝田 隆，太刀川弘和，岸本年史， 井上 眞, 池下克実, 大久保善朗, 坂本博子, 伊藤敬 
雄, 横田裕行, 䅖吉條太郎, 杉本達哉, 人見佳枝, 黒 木則臣, 堀川直史, 岩熊昭洋, 衞藤暢明, 岩田仲生, 河野元嗣, 川野健治, 松岡 豊, 石塚直樹, 酒井弘憲, 米本直裕（2009）「自殺対策のための戦略研究」自殺
企図の再発防止に対する複合的ケース・マネジメント の効果 : 多施設共同による無作為化比較試験. 自殺対 策のための戦略研究 平成 20 年度 総括 - 分担研究報告 書 20-27頁, 厚生労働省, 東京

\section{小児科学講座}

\section{〈研究概要〉}

小児科学講座では, その対象疾患の多様性から, 幅広い分野において基礎研究, 臨床研究を活発に行っているが, 教 室全体のメインテーマは「小児疾患に打ける活性酸素の病態への関与」である.

このテーマに沿って，2009 年は「腎性低尿酸血症が急性腎不全を合併する際の酸化ストレスの関与」を報告し，日本 小児腎臓病学会学術集会の優秀賞を受賞した。また「特発性ネフローゼ症候群における活性酸素の病因への関与」を明 らかにした，さらに川崎病では，「入院時に酸化ストレスの強い患者ほど，ガンマグロブリン療法が奏功しにくい」こと も示した。 また基礎研究としては, 「好酸球が好中球に比較して弱いながらも領食能（活性酸素産生能）を有しているこ と，そしてそれはCR-1を介した経路で活性化されること」を報告した.

そのほか, 各臨床班が研究成果報告を行っているが, 以下に代表的なものを示す.

・腎泌尿器班：(1)難治性夜尿症の治療法の模索（酶酸デスモプレッシン治療抵抗性夜尿症に対するフロセミド併用療法, 仙骨部表面治療的電気刺激療法)，(2)急性発熱性疾患に打ける低ナトリウム血症の疫学的検討

・代謝・内分泌班 : (1)細胞内カルシウム動態から見たダウン症児の免疫機能低下の成因解明, (2)母体のマグネシウム欠乏 が胎児の各種代謝機構に及ぼす影響の検討

・循環器班 : (1)川崎病の初期治療の歴史的変遷の検証, (2)川崎病における酸化ストレスの程度とガンマグロブリン療法の 反応性に関する検討, (3)マルチスライスCTの小児循環器疾患における有用性についての検討（川崎病の冠動脈病変の検 出や総肺静脈還流異常の診断)

・未熟児新生児班：(1)血中 BNP を指標とした未熟児動脈管開存症の管理法の検討，(2)レーザードップラー法を用いた仮 死新生児の中枢神経機能予後評価法の確立に関する研究，(3)新生児高カリウム血症に対するサルブタモール吸入療法

・神経班：(1)小児てんかんに対する新しい抗てんかん薬の薬物相互作用に関する研究，(2)熱性けいれんと貧血の関連に関 する研究

・免疫・アレルギー班：(1)食物アレルギー患児に対する急速経口減感作療法の有用性に関する検討, (2)自己免疫性好中球 減少症に打ける抗好中球付着性抗体の診断的意義に関する検討，(3)腹部症状のない慢性肉芽腫症腸炎の臨床的検討，(4) 好酸球の領食能（活性酸素産生能）に関する研究

・血液腫瘍班：(1)乳児型大理石病男児例の臨床的検討

・心身症班 : (1)小児心身症外来を受診する患者における発達障害の合併率とその対策, (2)摂食障害を発達障害児が呈する 心身症状の一つの表現形としてとらえた場合の対処法の検討, (2)心身症児の自律神経機能の評価（血圧・心電図・腹部 超音波検査の包括的評価)，(3)巟科における心身症児のスクリーニング方法の確立

上記にあげた研究以外で現在進行中の研究プロジェクトとしては, (1)遺伝性腎炎ラットにおける骨䯣内骨䯣移植法を 用いた腎再生の試み, (2)小児のネフローゼ症候群における酸化ストレスの検討, (3)母体の健康状態が胎児に及ぼすエピ ジェネティックな影響に関する研究, (4)新生児呼吸障害・腸管機能障害とアクアポリンとの関連性に関する研究, (5)未 熟児の副腎機能から見た未熟児晚期循環不全の成因に関する研究，などがあげられる.

\section{〈研究業績〉}

原 著

1. Hatano Y, Taniuchi S, Masuda M, Tsuji S, Ito T, Hasui M, Kobayashi Y and Kaneko K (2009) Phagocytosis of heat-killed Staphylococcus aureus by eosinophils: comparison with neutrophils. APMIS 117(2): 115-123

2. Ishizaki Y, Fukuoka H, Tanaka H, Ishizaki T, Fujii $\mathrm{Y}$, Hattori-Uchida Y, Nakamura M, Ohkawa K, Kobayashi H, Taniuchi S and Kaneko K (2009) Executive function on the 16-day of bed rest in young healthy men. Acta
Astronaut 64(9-10): 864-868

3. Tokuyama Y, Adachi Y, Minamino K, Shintaku H, Okigaki M, Hayashi K, Kitajima A, Takaki T, Koike N, Shima C, Imai Y, Shi M, Yanai S and Ikehara S (2009) Abnormal distribution of dendritic cells in (NZW x BXSB)F1 mice. Autoimmunity 42(5): 399-405

4. Shima C, Adachi Y, Shi M, Imai Y, Okigaki M, Yanai S, Minamino K, Takahashi K and Ikehara S (2009) The combination method using magnetic beads and a magnet helps sustain the number of donor BM cells after intra- 
$\mathrm{BM}$ injection, resulting in rapid hematopoietic recovery. Bone Marrow Transplant Oct 5. [Epub ahead of print]

5. Saito T, Matsumura K, Tsubota Y, Maniwa T, Kaneda H, Minami K, Sakaida N, Uemura Y, Kawa G, Yamamoto N, Fujii Y, Isobe K, Kawakami Y, Matsuda T, Saito Y and Takekoshi K (2009) Novel mutation (L157X) in the succinate dehydrogenase B gene (SDHB) in a Japanese family with abdominal paraganglioma following lung metastasis. Endocr J 56(3): 451-458

6. Yoshimura K, Tatsumi K, Iharada A, Tsuji S, Tateiwa A, Teraguchi M, Ogino H and Kaneko K (2009) Increased nitric oxide production by neutrophils in early stage of Kawasaki disease. Eur J Pediatr 168(9): 1037-1041

7. Tatsumi K, Tsuji S, Miwa H, Morisaku T, Nuriya M, Orihara M, Kaneko K, Okano H and Yasui M (2009) Drosophila big brain does not act as a water channel, but mediates cell adhesion. FEBS Lett 583(12): 2077-2082

8. Yanai S, Adachi Y, Fuijisawa J, Jiang S, Okigaki M, Shi M, Shima C, Imai Y, Kwon AH and Ikehara S (2009) Antitumor effects of fusion cells of type 1 dendritic cells and Meth A tumor cells using hemagglutinating virus of Japan-envelope. Int J Oncol 35(2): 249-255

9. Sasaki Y, Matsuoka Y, Hase M, Toyohara T, Murakami M, Takahashi M, Nakatsuka R, Uemura Y and Sonoda Y (2009) Marginal expression of CXCR4 on c-kit+Sca$1+$ Lineage- hematopoietic stem/progenitor cells. Int J Hematol 90(5): 553-560

10. Taniuchi S, Tanabe S, Fujii Y, Okamoto S, Kojima T, Kurosaka F, Sasai M, Nishino M, Noriyuki I and Kaneko K (2009) Oral desensitization therapy using hypoallergenic wheat for children with wheat allergy. J Appl Res 9(4): $132-138$

11. Kaneko K, Hasui M, Hatae K, So H and Katafuchi R (2009) Change in C1q deposition in C1q nephropathy. Pediatr Nephrol 24(9): 1775

12. Kaneko K and Kaneko K (2009) Hyponatremia in children with respiratory tract infection. Pediatr Nephrol 24(8): 1595, 1597-1598

13. Fujinaga S, Kaneko K, Ohtomo Y, Hirano D, Nishizaki N, Someya T, Ohtsuka Y and Shimizu T (2009) Is continuous antibiotic prophylaxis in children with vesicoureteral reflux really ineffective in preventing pyelonephritis? Pediatr Nephrol 24(7): 1431-1432

14. Fujinaga S, Ohtomo Y, Hirano D, Nishizaki N, Someya T, Ohtsuka Y, Kaneko K and Shimizu T (2009) Relapsing peritonitis with Corynebacterium aquaticum in a boy receiving automated peritoneal dialysis. Pediatr Nephrol 24(6): 1253-1254

15. Iharada A, Kaneko K, Tsuji S, Hasui M, Kanda S and Nishiyama T (2009) Increased nitric oxide production by $\mathrm{T}$ - and B-cells in idiopathic nephrotic syndrome. Pediatr
Nephrol 24(5): 1033-1038

16. Kaneko K (2009) Cerebrovascular lesion in idiopathic midaortic syndrome in children. Pediatr Nephrol 24(2): 419

17. Ohashi A, Kuroyanagi Y, Kitamura N, Kinoshita Y, Kaneko K and Yabuta K (2009) Cerebral blood flow monitoring using a novel laser Doppler flowmeter in asphyxiated infants. Pediatr Int 51(5): 715-719

18. Kitamura N, Nagahama T, Ishizaki Y, Kinoshita Y and Kaneko K (2009) Effects of interview on mood status of pregnant women with high-risk delivery. Pediatr Int 51(4): 498-501

19. Yamato F, Takaya J, Yasuhara A, Teraguchi M, Ikemoto $\mathrm{Y}$ and Kaneko K (2009) Elevated intracellular calcium in neutrophils in patients with Down syndrome. Pediatr Int 51(4): 474-477

20. Nishizaki N, Someya T, Hirano D, Fujinaga S, Ohtomo Y, Shimizu T and Kaneko K (2009) Can cranberry juice be a substitute for cefaclor prophylaxis in children with vesicoureteral reflux?: Rapid Communication. Pediatr Int 51(3): 433-434

21. Fujinaga S, Ohtomo Y, Mochizuki H, Murakami H, Shimizu T, Yamashiro Y and Kaneko K (2009) Rapidly progressive acute post-streptococcal glomerulonephritis in a child with IgA nephropathy. Pediatr Int 51(3): 425428

22. Tanaka H, Fujita Y, Takenaka Y, Kajiwara S, Masutani S, Ishizaki Y, Matsushima R, Shiokawa H, Shiota M, Ishitani N, Kajiura M and Honda K (2009) Japanese clinical guidelines for juvenile orthostatic dysregulation version 1. Pediatr Int 51(1): 169-179

23. Imai Y, Adachi Y, Shi M, Shima C, Yanai S, Okigaki M, Yamashima T, Kaneko K and Ikehara S (2009) Caspase inhibitor, ZVAD-fmk, facilitates engraftment of donor hematopoietic stem cells in intra-bone marrow-bone marrow transplantation. Stem Cells Dev 19(4): 461-468

24. 佐藤正人, 宮内雄也, 園田真理, 棚野晃秀, 高田晃平, 浜田吉則（2009）小児内視鏡手術の適応拡大: 安全な 術式と従来法との比較検討胆道拡張症に対する補助 下手術. 小児外科 41(9): 966-971

25. 谷内昇一郎, 岡本真道, 畑埜泰子, 小島崇嗣, 須藤京 子，金子一成（2009）食物アレルギー患者（卵・小麦） における経口減感作療法の試み. 食物アレルギー研究 会雑誌 9:55-56

26. 石崎優子, 丸光 惠, 東野博彦 (2009) 思春期以降の 小児心身症・発達障害患者を何科がフォローするの か? 一大学病院小児科心身症外来患者の中学卒業後 のフォロー状況からの考察—. 心療内科 13(2): 153156

27. 藤井喜充, 木野 稔 (2009) 肝外胆管径における経口 摂取の影響の検討. 日小児栄消肝会誌 23(1): 8-15 
28. 藤丸季可, 稲田 浩, 木野 稔, 里村憲一, 塩見正司, 鈴木美智子, 高田慶応, 田川哲三, 田辺卓也, 永井利 三郎（2009）学校医・園医の現状と問題点に関する意 識調査. 日児誌 113(9): 1431-1435

29. 木全貴久, 木野 稔, 磯崎夕佳, 金子一成（2009）膿 尿を認めない上部尿路感染症患者の臨床的特徵に関 する検討。 日児腎誌 22(2): 91-96

30. 下智比古, 蓮井正史, 金子一成, 寺西顕司, 原田佳明 （2009）小児の夜尿症に打ける尿中カルシウム排泄量 と病型に関する検討．夜尿症研究会誌 14: 17-21

総 説

1. Kaneko K (2009) Pathogenesis in childhood idiopathic nephrotic syndrome: An update of patchwork. Curr Pediatr $\operatorname{Rev} 5(1): 56-64$

2. 金子一成 (2009) 血清シスタチンC. Med Technol 37(9): 905-906

3. 荻野廣太郎, 佐地 勉, 佐地 勉, 濱岡建城, 薗部友 良, 太田八千雄, 大島美保, 長谷山圭司, 大久保淳, 梶野真弓, 田村英一郎, 相原真樹子, 大山昇一, 監物

靖, 松原知代, 福永英生, 今川智之, 緒方昌平, 木 村光明, 喜瀬広亮, 渡部綾佳, 廣野恵一, 吉林宗夫, 白石泰資, 橋本邦生, 岸本小百合 (2009) 我が国にお ける難治性急性期川崎病に対する infliximab 療法の現 状一3 回の使用実態調査結果から一. Prog Med 29(7): 1722-1727

4. 藤井喜充, 木野 稔 (2009) 肝 - 胆道 - 膵疾患一萃胆 管合流異常, 胆道閉鎖症などの診断法. 外来小児 12(1): 44-52

5. 金子一成 (2009) 小児の夜尿症に対する理論的アプ ローチ．滋賀小児科医会ニュース 22:2-11

6. 金子一成 (2009) 夜尿症の診断治療概論. 小児の精神 と神経 49(4): 274-279

7. 藤井由里, 石崎優子, 金子一成 (2009) 反復性腹痛と 過敏性腸症候群への対応. 小児科 50(2): 237-242

8. 河崎裕英, 野田幸弘, 中野崇秀 (2009) 分子標的治療 5 分子標的治療薬を用いた治療法の現状と問題点小 児 $\mathrm{Ph} 1$ 染色体陽性急性リンパ性白血病. 小児科 50(12): 2015-2019

9. 金子一成（2009）【小児の症候群】循環器 血管炎症候 群. 小児科診療 72 (増刊): 228

10. 河崎裕英, 野田幸弘, 中野崇秀 (2009) 血液 - 腫瘍性 疾患一17 フィラデルフィア染色体陽性急性白血病. 小児内科 41 (増刊) : 1165-1168

11. 村上貴孝 (2009) 救急外来受診時にけいれんが止まっ ている場合の処置. 小児内科 41(4): 625-627

12. 村上貴孝 (2009) 抗てんかん薬の薬剤相互作用. 小児 内科 41(3): 375-377

13. 金子一成（2009）【小児腎疾患の診断・治療戦略】ど のような時に腎疾患を疑い, どのような検査をすべき か?. 小巟内科 41(2): 161-169
14. 荻野廣太郎（2009）【川崎病 最近の進歩と課題】初 期治療の歴史的変遷. 小児内科 41(1): 41-56

15. 金子一成（2009）川崎病急性期の低ナトリウム血症と ガンマグロブリン製剤の影響. 新薬と臨床 58(12): 2079-2084

16. 蓮井正史，金子一成（2009）【注意すべきウイルス感 染症】見逃される感染症 口内疹を起こすウイルス感 染症. 診断と治療 97(3): 518-523

17. 寺口正之 (2009) リレーエッセイ : 小児科医による禁 煙支援. 大阪小児科医会会報 148: 30-32

18. 金子一成 (2009) 大学の空 日本の臨床研究と科研費. 大阪小児科医会会報 148: 16-17

19. 谷内昇一郎 (2009) 食物アレルギ-についてーアトピー 性皮膚炎との関わり. 奈良県小児科医会報 10:12-13

20. 武輪鈴子, 谷口奈穂, 田中幸代, 中野崇秀, 蓮井正史, 金子一成, 野津寛大（2009）腎性低尿酸血症における 運動後急性腎不全の発症機序の関する考察. 日児腎誌 22(2): $147-151$

21. 金子一成（2009）新生児の電解質異常に関する最近の 話題 母乳性高ナトリウム血症と早産児の急性期離 脱後循環不全. 日本小児体液研究会誌 1:3-8

症例報告

1. Takaya J, Fujii Y, Higashino H, Taniuchi S, Nakamura M and Kaneko K (2009) A case of WHIM syndrome associated with diabetes and hypothyroidism. Pediatr Diabetes 10(7): 484-486

2. Kaneko K, Taniguchi N, Tanabe Y, Nakano T, Hasui M and Nozu K (2009) Oxidative imbalance in idiopathic renal hypouricemia. Pediatr Nephrol 24(4): 869-871

3. Noda R, Takaya J, Hasui M, Araki A and Kaneko K (2009) Severe concurrent lung infection caused by legionella and mycoplasma in a 3-year-old patient with Down syndrome and tuberous sclerosis. Pediatr Int 51(3): 413-414

4. 藤井喜充, 木野 稔 (2009) 小児急性胃粘膜病変の超 音波像. 日腹部救急医会誌 29(1): 99-102

5. 舘野寛子, 高橋寛二, 松村美代, 坂井田紀子, 中野崇 秀 (2009) 眼窩内視神経全長に浸潤した年長児の網膜 芽細胞腫の 1 例. 臨床眼科 63(1): 43-49

その他

1. Fujinaga S, Ohtomo Y, Hirano D, Nishizaki N, Someya T, Ohtsuka Y, Kaneko K and Shimizu T. (2009) Mycophenolate mofetil therapy for childhood onset steroid dependent nephrotic syndrome after long-term cyclosporine: Extended experience in a single center. Clin Nephrol 72(4): 268-273

2. Ohashi A and Kaneko K (2009) Serum brain natriuretic peptide for prediction of successful medical treatment of patent ductus arteriosus in premature infants. J Thorac 
Cardiovasc Surg 138(1): 261-262

3. 金子一成（2009）腎疾患の子どものケア．チャイルド ヘルス 12(11): 758-789

4. 石崎優子 (2009) 昨日の常識 思春期の頭痛にはエル ゴタミン製剤 今日の常識 エルゴタミン製剂処方 時は, 薬物乱用頭痛を念頭におく. 治療 91(12): 28002801

5. 森 伸生, 岡部信彦 (2009) 特集 見直してみよう！麻 疹・風疹・水痘・ムンプス 広域での麻疹流行予防 （1）－茨城県．小児内科 41(7): 1022-1025

6. 小野 厚 (2009) 口腔アレルギー症候群. 泉尾だより 198: 2

7. 谷内昇一郎 (2009) 地域研究会の紹介 守口門真小児 科勉強会. 大阪小児科医会会報 149: 27

8. 船戸正久, 根岸宏邦, 小川晴幾, 齋田幸次, 北村直行, 白石 淳, 中平公士，早田賢司，依岡寛和，田中祥介， 西田 勝, 児玉和夫, 野田哲朗, 松下彰宏, 東 隆司, 加美敏隆, 今井龍也, 川崎忠男, 井藤尚之, 大笹幸伸, 杉本 壽, 酒井國男，大阪府医師会周産期医療委員会 （2009）NICU長期入院児の在宅ケア促進に向けた地域 の取り組み 大阪府医師会周産期医療委員会 NICU 長 期入院者対策小委員会の活動と提言. 日本未熟児新生 児学会雑誌 21(3): 464

9. 藤永周一郎, 大友義之, 金子一成, 赤司俊二（2009） 夜尿症，昼間尿失禁の患児に対するコハク酸ソリフェ ナシンの有用性についての検討。夜尿症研究会誌 14: 35-39

10. 木野 稔 (2009) 子どもの救急, 発疹・紫斑. 月刊レ ジデント 2(10): 75-82

学会発表

1. 黒柳裕一, 高屋淳二, 東野博彦, 金子一成 (2009) a case report: Septo-Optic Dysplasia. 10th Henning Andersen Educational Program, Copenhagen, Denmark

2. Takaya J, Fujii Y, Higashino H, Taniuchi S and Kaneko K (2009) A case of WHIM syndrome associated with diabetes and hypothyroidism. LWPES/ESPE 8th Joint Meeting, New York, 米国

3. Takaya J, Yamato F, Higashino H and Kaneko K (2009) Intracellular magnesium of obese and type 2 diabetes mellitus children: the change of magnesium after treatment. LWPES/ESPE 8th Joint Meeting, New York, 米国

4. 金子一成（2009）小児のメタボリックシンドロームと Barker仮説. ノボ・ノルディスクファーマ特別講演会, 大阪

5. 木下 洋 (2009) 新生児蘇生のアルゴリズム。 大阪府 医師会新生児の蘇生講習会平成 21 年度第 3 回, 大阪

6. 寺口正之，田邊裕子，村上貴孝，图府寺美，木野 稔 （2009）RSウイルス感染から惹起された脳症の治療経 験. 大阪臨床小児科セミナー, 大阪

7. 伊藤太一，谷内昇一郎，蓮井正志，居原田安奈，金子
一成（2009）自己免疫性好中球減少症における抗好中 球付着性抗体の診断的意義. 第 17 回食細胞機能異常研 究会, 東京

8. 辰巳貴美子, 原田佳明, 伊藤太一, 中村眞紀子, 内山 敬達，井上岳司，外川正生，塩見正司，平瀬敏志，橋 本直樹，起塚 庸，西野昌光，金子一成（2009）維持 輸液製剤による初期輸液が誘因になったと思われる 低ナトリウム血症性脳症の 3 例。第 184 回大阪小児科 学会, 大阪

9. 黒柳裕一, 大町太一，野田幸弘，金子一成，道上敏美， 大薗惠一 (2009) 乳児型大理石病の1男児例. 第27回 小览代謝性骨疾患研究会, 東京

10. 岡本真道, 谷内昇一郎, 畑埜泰子, 金子一成 (2009) 急速減感作療法を試みた重症牛乳アレルギーの 3 症 例. 第46回日本小児アレルギー学会, 福岡

11. 中島純一, 寺西顕司, 峰 研治, 黒柳裕一, 辻 章志, 大橋 敦, 木下 洋, 金子一成（2009）当院 NICUに おける過去 3 年間の死亡例の検討. 第 54 回日本未熟児 新生児学会, 横浜

12. 金子一成（2009）関西医科大学附属病院初期臨床研修 における小児科研修システム。第 7 回順天堂大学医学 部初期臨床研修指導医講習会, 東京

13. 谷内昇一郎 (2009) 気道感染（RS 感染）と気管支喘 息. 第 2 回大阪臨床小児科セミナー, 大阪

14. 村上貴孝（2009）けいれんについての最新情報. 住吉 区医師会勉強会, 大阪

15. 藤井喜充, 木野 稔 (2009) 急性虫垂炎の小児科的視 点. 第 24 回大阪小児栄養消化器病懇話会, 大阪

16. 高屋淳二, 居原田安奈, 沖花裕行, 金子一成（2009） マグネシウム欠乏ラットの肝臓におけるグルココル チコイド関連遺伝子の発現. 第29回日本マグネシウム 学会総会, 鹿児島

17. 石崎優子, 宮島 祐, 大塚頌子（2009）小児心身医学 会員の 18 歳以上の発達障害患者に対する薬物療法に 関する意識調査. 第36回日本小児臨床薬理学会, 高松 18. 高屋淳二 (2009) 子どもの糖尿病. 第 3 回滝井セミ ナー, 大阪

19. 伊藤正寛，图府寺美，庵原俊昭（2009）麻しんの遺伝 子検査診断法に関する検討. 第 41 回日本小児感染症学 会, 福井

20. 居原田安奈, 谷内昇一郎, 岡本真道, 蓮井正史, 金子 一成（2009）腹部症状のない慢性肉芽腫症腸炎の2例. 第41回日本小児感染症学会, 福井

21. 田邊裕子, 图府寺美, 笠原道雄, 木全貴久, 藤井喜充 目黒敬章，寺口正之，村上貴孝，木野 稔 (2009) 当 院で経験した下気道感染症の原因ウイルスによる臨 床的特徵. 第 41 回日本小児感染症学会, 福井

22. 藤原 亨, 舟木克枝, 辻美代子 (2009) 内耳奇形によ る化膿性髄膜炎に硬膜下膿瘍を伴った 1 例。第 41 回日 本小児感染症学会, 福井

23. 石原重彦，寺田春郎，蘆野伸彦（2009）1 歳時の麻し 
んワクチン接種が primary vaccine failureにならないた めに-母親の麻疹ウイルス抗体測定の意義-. 第41回日 本小児感染症学会, 福井

24. 蓮井正史，辻 章志，谷内昇一郎，，金子一成 (2009) 縦隔肉芽腫を認めた慢性肉芽腫症の一例. 第 41 回日本 小児感染症学会, 福井

25. 岡本一章, 須藤京子, 須藤博明 (2009) クラミジア肺 炎の2例. 第49回伊賀地区小児懇話会, 伊賀

26. 辻 章志, 木下 洋, 北村直行, 大橋 敦, 竹安晶子, 黒柳裕一, 松倉良香, 峰 研治, 中島純一, 寺西顕司, 金子一成（2009）母体に投与されたマグネシウムが胎 児の動脈管に及ぼす影響に関する検討. 第54回日本未 熟児新生児学会, 横浜

27. 北村直行, 船戸正久, 市場博幸, 北島博之, 木下 洋, 白石 淳, 田中真也, 南 宏尚, 吉井勝彦, 李 容桂, 和田 浩, 藤村正哲, 根岸宏邦（2009） NICU の病床 不足と長期入院対策～新生児医療施設からの問題提 起. 第54回日本未熟児新生児学会, 横浜

28. 村上貴孝, 豆板律子（2009）小児の発達障害 基礎知 識と具体的な対応. 日総研セミナー, 大阪

29. 金子一成（2009）経口補水療法の実際. 札幌市小児科 医会, 札幌

30. 小林穂高, 石崎優子，金子一成（2009）アスペルガー 症候群と摄食障害の 2 例〜発達障害児が呈する心身症 状の一つの表現形としての摂食障害という視点〜。第 102 回日本小児精神神経学会, 名古屋

31. 金子一成 (2009) 小览の血管炎症候群 : 最近の考え方. 第19回 日本小児リウマチ学会, 京都

32. 谷内昇一郎, 岡本真道, 畑埜泰子, 金子一成 (2009) 急速減感作療法を試みた重症牛乳アレルギーの 3 症 例. 第19回大阪食物アレルギー懇話会, 大阪

33. 岡本真道, 谷内昇一郎（2009）食物負荷試験でのアナ フィラキー症状への対応. 第34回 KMU小児臨床研究 会, 大阪

34. 谷内昇一郎（2009）学校生活に打ける食物アレルギ の管理と指導. 第34回 KMU小児臨床研究会, 大阪

35. 藤井喜充，木野 稔（2009） 5 年間 200 例の便秘症に おけるステップダウン式 disimpaction 療法の試み。第 36 回日本小児栄養消化器肝臓学会, 札幌

36. 村上貴孝（2009）小児脳波検査の情報量についての評 価. 第43回日本てんかん学会, 弘前

37. 图府寺美（2009）インフルエンザの話題〜入院症例か ら. 第 47 回守口門真小児科勉強会, 守口

38. 图府寺美, 神田雅代，小谷由香，豆板律子，今西美澄， 木野 稔 (2009) 医療機関と行政機関との連携〜虐待 の発見と防止のために. 第5 6 回日本小児保健学会, 大 阪

39. 岡本真道, 谷内昇一郎, 畑埜泰子, 小島崇嗣, 須藤京 子，金子一成（2009）卵食物負荷試験における特異的 卵白 IgG4 抗体の意義 (第2 報). 第59回日本アレルギー 学会秋季大会, 秋田
40. 木野 稔（2009）少子時代の小児医療と育児支援. 病 児保育協議会鹿児島支部総会, 鹿児島

41. 小野 厚 (2009) 小児アレルギー疾患, 最近の動向一 特に食物アレルギーについて一（テーマ：小児疾患, 最近の動向）。平成 21 年度日本医師会生涯教育講座, 大阪市

42. 中野景司（2009）小児夜尿症の診断と治療（テーマ： 小児疾患, 最近の動向)。平成 21 年度日本医師会生涯 教育講座, 大阪

43. 高屋淳二（2009）子どもの生活習慣病・食育. 加多乃 会「講演会」, 大阪

44. 木下 洋（2009）新生児蘇生のアルゴリズム. 大阪府 医師会新生児の蘇生講習会平成 21 年度第 2 回, 大阪

45. 鈴川純子, 田中智子, 中野崇秀, 荒木 敦, 谷内昇一 郎，金子一成，山内康雄（2009）血友病 A と脊髄性筋 萎縮症 1 型を合併した 1 男児例. 第 183 回大阪小児科学 会, 大阪

46. 黒柳裕一，高屋淳二，東野博彦，荒木 敦，金子一成 （2009）脳波異常を伴う中枢性思春期早発症を発症し た先天性ミオパチーの1症例. 第33回近畿小児内分泌 研究会, 大阪

47. 高屋淳二（2009）生活習慣病の予防は，小児から．第 3 回八尾市小児健康フォーラム, 大阪

48. 大林奈穂, 藤原 亨, 辻美代子 (2009) 最近経験した 出血性膀胱炎の 1 例. 第 40 回大阪市東部小児談話会, 大阪

49. 稲垣詔子, 吉村 健, 野田幸弘, 内山敬達, 中野崇秀, 河崎裕英，蓮井正史，木下 洋，金子一成，中嶋 洋 （2009）川崎病を疑ったエルシニア感染症の 1 症例. 第 49 回枚方・交野小児懇話会, 大阪

50. 小林穂高 (2009) 症例提示（プライバシー保護のため 発表タイトルは記載しない)。第11回小児精神医学教 育セミナー,つくば

51. 藤田 位, 日野利治, 木下 洋（2009）診察技法を見 直そう。第19回日本外来小児科学会年次集会, 大宮

52. 金子一成（2009）経口補水療法の実際. 第21回寝屋川 小児科懇話会, 枚方

53. 野田幸弘（2009）サケの生食による日本海裂頭条虫 （サナダムシ）の1症例. 第7回京阪こどもカンファレ ンス, 大阪

54. 鈴川純子, 田中智子, 中野崇秀, 荒木 敦, 谷内昇一 郎，金子一成（2009）発達の遅れから見つかった血友 病の1例．第7回京阪こどもカンファレンス，大阪

55. 谷内昇一郎（2009）病気をもつ子どもの元気を育む 2一地域で安全で楽しい学校生活や日常生活が出来る ため（喘息の場合）。特別支援教育セミナー（関西） 2009 カリキュラム, 大阪

56. 笠松 敦, 依岡寛和, 椹木 晋, 神崎秀陽, 峰 研治, 辻 章志，大橋 敦，木下 洋，金子一成（2009）妊 娠 10 週で診断した結合体を伴った一䄉毛膜性二羊膜 性品胎を周産期管理した 1 症例. 第 45 回日本周産期 • 
新生児医学会, 名古屋

57. 黒柳裕一, 峰 研治, 辻 章志, 中島純一, 寺西顕司, 松倉良香, 大橋 敦, 木下 洋, 金子一成（2009）新 生児高カリウム血症に対するサルブタモール吸入療 法. 第45回日本周産期・新生児医学会, 名古屋

58. 大橋 敦, 峰 研治, 辻 章志, 黒柳裕一, 松倉良香, 中島純一，寺西顕司，木下 洋，金子一成（2009）血 中 BNP 值を指標とした症候性動脈管開存症の治療戦 略. 第 45 回日本周産期・新生児医学会, 名古屋

59. 立岩 愛, 吉村 健, 峰 研治, 内山敬達, 寺口正之, 金子一成 (2009) 川崎病 $(\mathrm{KD})$ の冠動脈病変 $(\mathrm{CAL})$ 検出におけるマルチスライス CT (MSCT) の有用性. 第45回日本小児循環器学会, 神戸

60. 岡本一章, 須藤京子, 須藤博明（2009）化膿性股関節 炎, 化膿性膝関節炎の一例. 第48回伊賀地区小児懇話 会, 名張

61. 谷口奈穂, 吉村 健, 金子一成（2009）マルチスライ スCTが診断に有用であった先天性喘鳴の 1 症例. 第 5 回 OK小児救急症例検討会, 大阪

62. 金子一成（2009）低 $\mathrm{Na}$ 血症と高 $\mathrm{Na}$ 血症に関する最近 の話題 : 医原性低 $\mathrm{Na}$ 血症と母乳性高 $\mathrm{Na}$ 血症. 第 6 回 山形こどもの腎研究会, 山形

63. 金子一成（2009）小児の脱水とその治療. 第8回東京 小児科医会セミナー, 東京

64. 木野 稔（2009）少子時代の小児医療と育児支援. 日 本幼年教育会夏季研修会, 東京

65. 須藤京子, 岡本一章, 須藤博明 (2009) アレルギーの 免疫療法: 誘発中和法とは. 平成 21 年度病診連携懇話 会, 名張

66. 木下 洋 (2009) 新生児蘇生のアルゴリズム. 大阪府 医師会新生児の蘇生講習会平成 21 年度第 1 回, 大阪

67. 福井聖子, 木野 稔, 小林久和, 蔭山尚正 (2009) 大 阪府小児救急電話相談（\# 8000）の役割について．第 12 回日本臨床救急医学会, 大阪

68. 高橋雅也, 吉村 健, 内山敬達, 金子一成, 角田智彦 （2009）血管輪 ( 重複大動脈弓 ) による先天性喘鳴の 1 例. 第 182 回大阪小児科学会, 大阪

69. 平林雅人, 田邊裕子, 笠原道雄, 木全貴久, 目黒敬章, 藤井喜充, 图府寺美, 木野 稔 (2009) 特発性脊髄硬 膜外血腫の 1 乳児例. 第 182 回大阪小児科学会, 大阪

70. 黒柳裕一, 笠原道雄, 大橋 敦, 河崎裕英, 中野崇秀, 野田幸弘, 木下 洋, 金子一成, 矢部普正, 矢部みは る, 加藤俊一 (2009) 臍帯血移植により治療したReticular dysgenesis の 1 例. 第 19 回日本産婦人科・新生児 血液学会, 札幌

71. 小林穂高, 藤井由里, 大川 薰, 内田祐子, 石崎優子 （2009）心身症外来を受診する子どもと発達障害. 第 1 回日本心身医学 5 学会合同集会（第 27 回日本小児心 身医学会学術集会), 東京

72. 田中幸代, 武輪鈴子, 下智比古, 蓮井正史, 金子一成 （2009）昼間遺尿を伴う夜尿症に対する仙骨部表面治
療的電気刺激療法の試み. 第20回日本夜尿症学会, 栃 木

73. 武輪鈴子, 下智比古, 田中幸代, 蓮井正史, 金子一成 （2009）フロセミドを併用した酢酸デスモプレッシン 治療抵抗性夜尿症の 3 例. 第 20 回日本夜尿症学会, 栃木

74. 岡本真道, 谷内昇一郎, 畑埜泰子, 小島崇嗣, 須藤京 子，金子一成（2009）卵食物負荷試験における特異的 卵白 IgG4 抗体の意義. 第 21 回日本アレルギー学会春 季大会, 岐阜

75. 藤井喜充, 木野 稔 (2009) 超音波ハンズオンセミ ナ一、第23回日本小児救急医学会, 熊本

76. 石崎優子 (2009) 私の心身医学一小児心身医学（成長 と発達とを支援する医学) から成人の心身医学への メッセージ一. 第27回日本小児心身医学会, 東京

77. 金子一成（2009）外来で役立つ経口補水療法の実際. 第3回仙台外来小児科懇話会学術講演会, 仙台

78. 金子一成 (2009) 水・電解質を克服する【スーパー ホットトピックスへのお誘い】. 第44回 日本小児腎 臓病学会, 東京

79. 居原田安奈, 辻 章志, 蓮井正史, 今井雄一郎, 磯崎 夕佳, 金子一成 (2009) 小児の特発性ネフローゼ症候 群における一酸化窒素の関与. 第 44 回日本小児腎蔵病 学会, 東京

80. 田中幸代, 平林雅人, 田邊裕子, 木野 稔, 寺西顕司, 原田佳明, 下智比古, 岡崎仁志, 立岩 愛, 吉村 健, 磯崎夕佳, 蓮井正史, 金子一成 (2009) ガンマグロブ リン療法が川崎病患者の血清ナトリウム濃度に及ぼ す影響. 第44回日本小児腎臓病学会, 東京

81. 武輪鈴子, 谷口奈穂, 田辺裕子, 田中幸代, 中野崇秀, 磯崎由佳, 蓮井正史, 金子一成, 野津寬大（2009）腎 性低尿酸血症における運動後急性腎不全の病因に関 する検討 : 運動負荷時の酸化ストレス度と抗酸化力の 不均衡. 第44回日本小児腎臓病学会, 東京

82. 谷口奈穂, 中嶋純一, 吉村 健, 大橋 敦, 木下 洋, 金子一成, 津川二郎, 石井智裕 (2009) マルチスライ ス CT が診断に有用であった先天性喘鳴の 3 症例。第 45 回日本小児放射線学会, 高松

83. 藤井喜充, 木野 稔, 青木良純 (2009) 小児急性虫垂 炎に打ける粪石・腹膜炎の超音波所見. 第45回日本小 览放射線学会, 香川

84. 立岩 愛, 吉村 健, 田邊裕子, 峰 研治, 松倉良香, 大橋 敦, 木下 洋, 金子一成 (2009) 総肺静脈還流 異常における64列マルチスライスCTの有用性. 第 45 回日本小児放射線学会, 高松

85. 米虫 敦, 谷内昇一郎, 谷川 昇, 狩谷秀治, 徳田貴 則, 佐野 明, 鈴川純子, 黒田友顕, 池田耕士, 宇都 宮啓太, 播磨洋子, 金子一成（2009）13歳女児の特発 性卵巣出血に対する TAE. 第 47 回関西 INTERVENTIONAL RADIOLOGY 研究会, 大阪

86. 平林雅人, 森 伸生, 图府寺美, 木野 稔 (2009) 当 院で経験した Human Bocavirus 感染症の 19 症例. 第 50 
回日本臨床ウイルス学会, 高知

87. 图府寺美（2009）かかりつけ医に役立つ診療のポイン 卜～小児科診療・小児救急の現場から. 東淀川医師会 講演会, 大阪

88. 木野 稔 (2009) 小児のプライマリ・ケア 〜知って おくべき知識と考え方〜。守口市医師会学術講演会, 守口

89. 木下 洋 (2009) 大阪での周産期救急体制の現状と新 生児蘇生法普及事業. 第 147 回大阪小児科医会学術集 会, 大阪

90. 藤井喜充，木野 稔（2009）急性虫垂炎の画像診断. 第2 回研修医のための小児救急・新生児勉強会，大阪

91. 平林雅人, 田邊裕子, 木全貴久, 森 伸生, 目黒敬章, 藤井喜充, 图府寺美, 木野 稔 (2009) 非典型的な経 過をとった細菌性髄膜炎の 2 例. 第 2 回研修医のため の小児救急・新生児勉強会, 大阪

92. 藤井喜充, 木野 稔, 青木良純, 佐藤正人（2009）小 児急性虫垂炎における糞石の超音波像と CT 值. 第 82 回日本超音波医学会, 東京

93. 足立 靖, 石 明, 矢内勢司, 嶋千絵子, 今井雄一 郎, 池原 進 (2009) Tie2 発現細胞特異的にFGFレセ プター 2 を発現させたトランスジェニックマウスにお ける造血系細胞の解析. 第98回 日本病理学会総会, 京 都

94. 矢内勢司, 足立 靖, 石 明, 嶋千絵子, 今井雄一 郎, 池原 進 (2009) 樹状細胞とマウス線維肉腫との 融合細胞を用いた抗腫瘍効果の検討. 第 98 回 日本病 理学会総会, 京都

95. 今井雄一郎, 足立 靖, 比舎弘子, 石 明, 矢内勢 司，嶋千絵子，金子一成，池原 進（2009）骨髄移植 後のマウスに発生したドナ一由来未熟白血病細胞株 の樹立とその解析. 第98回 日本病理学会総会, 京都

96. 石 明, 足立 靖, 矢内勢司, 嶋千絵子, 今井雄一 郎，池原進 (2009) 骨髄内骨髄移植法に打けるコ ラーゲン・ゲルの有用性. 第 98 回 日本病理学会総 会, 京都

97. 嶋千絵子，足立 靖，石 明，矢内勢司，今井雄一 郎，高橋寛二，池原 進（2009）骨髄由来樹状細胞の 骨髄内投与による抗腫瘍効果の検討. 第98回 日本病 理学会総会, 京都

98. 图府寺美，木野 稔，伊藤正寛（2009）インフルエン ザにおける鼻腔中ウイルスと臨床的重症度との関連 性. 大阪小児感染症研究会, 大阪

99. 伊藤太一, 谷内昇一郎, 蓮井正志, 居原田安奈, 金子 一成（2009）自己免疫性好中球減少症における抗好中 球付着性抗体の診断的意義. 第 112 回 日本小児科学 会，奈良

100. 岡本真道, 谷内昇一郎, 畑埜泰子, 金子一成（2009） 急速減感作療法を試みた重症牛乳アレルギーの1男児 例. 第 112 回 日本小児科学会, 奈良

101. 寺口正之, 田邊裕子, 平林雅人, 木全貴久, 森 伸
生, 目黒敬章, 藤井喜充, 村上貴孝, 图府寺美, 木野

稔（2009）小児救急病院に打ける観察入院の臨床的 特徵と意義. 第 112 回日本小児科学会, 奈良

102. 吉村 健, 辻 章志, 居原田安奈, 立岩 愛, 辰巳貴 美子，寺口正之，荻野廣太郎，金子一成（2009）川崎 病 $(\mathrm{KD})$ 急性期における一酸化窒素 $(\mathrm{NO})$ の関与に関す る検討一第 2 報一，第 112 回日本小児科学会，奈良

103. 高屋淳二, 東野博彦，山戸史子，黒柳裕一，武輪鈴 子，金子一成 (2009) 肥満症および 2 型糖尿病患児の 細胞内マグネシウム：治療前後の検討. 第 112 回日本 小児科学会, 奈良

104.山戸史子, 高屋淳二, 安原昭博, 寺口正之, 池本裕実 子，金子一成（2009）ダウン症小児における好中球細 胞内カルシウムの動態. 第 112 回日本小児科学会, 奈良 105.大橋 敦, 峰 研治, 辻 章志, 黒柳裕一, 中島純 一, 寺西顕司，木下 洋，金子一成 (2009) 症候性動 脈管開存症を有する極低出生体重児における血中 BNPの臨床的意義. 第 112 回日本小児科学会, 奈良

106.中島純一, 寺西顕司, 峰 研治, 松倉良香, 黒柳裕 一, 大橋 敦, 木下 洋, 金子一成（2009）当院で経 験した新生児脳梗塞の 3 例. 第 112 回日本小児科学会, 奈良

107.辻 章志, 木下 洋, 大橋 敦, 北村直行, 黒柳裕 一, 松倉良香, 峰 研治, 中島純一, 寺西顕司, 金子 一成（2009）当院NICUに打ける過去 10 年間の新生児 敗血症の起炎菌に関する検討。第 112 回日本小児科学 会, 奈良

108. 平林雅人, 田邊裕子, 木全貴久, 森 伸生, 目黒敬 章, 藤井喜充, 图府寺美, 木野 稔, 荒木 敦, 金子 一成（2009）本邦における熱性けいれんと鉄欠乏性貧 血の関連に関する検討. 第 112 回日本小児科学会, 奈良

109.峰 研治, 大橋 敦, 立岩 愛, 吉村 健, 金子一 成, 角田智彦, 服部玲治（2009）極低出生体重児の大 動脈縮窄症 (CoA) に対するバルーン血管形成術 (PTA) の経験. 第 112 回日本小児科学会, 奈良

110.木下 洋, 金子一成（2009）国民に信頼される小児科 医の育成を目指して 単科医科大学における小児医学 教育の現状．第112回日本小児科学会，奈良

111.中野崇秀，野田幸弘，河崎裕英，金子一成（2009）小 児がん患者における活性酸素代謝産物と抗酸化力の 検討．第 112 回日本小児科学会，奈良

112.山本知恵, 松島貴志, 楠本健司, 稲垣隆介, 濱田吉 則, 高田晃平, 大橋 敦 (2009) 腰部結合双胎分離症 例の経験. 第 52 回日本形成外科学会, 横浜

113.金子一成（2009）小児の輸液療法の最近のトピック ス: 経口補液と経静脈輸液. 都北小児科医会学術講演 会, 都城

114.金子一成（2009）枚方病院が目指している病院とは. 平成 21 年度関西医科大学付属病院採用臨床研修医 ワークショップ, 神戸

115.谷内昇一郎 (2009) 小児喘息の最近の話題. 北河内小 
児喘息勉強会, 枚方

116.金子一成（2009）小児の輸液療法の最近のトピック ス: 経口補液と経静脈輸液. 堺市小児科医会, 堺

117.木下 洋（2009）新生児蘇生のアルゴリズム. 大阪府 医師会新生児の蘇生講習会平成 20 年度第 4 回, 大阪

118. 谷内昇一郎, 岡本真道, 藤井泰子, 小島崇嗣, 須藤京 子, 金子一成 (2009) 食物アレルギ一患者（卵・小麦） における経口減感作療法の試み. 第 22 回近畿小児科学 会, 西宮

119.藤井喜充, 寺口正之, 平林雅人, 木全貴久, 森 伸 生，目黒敬章，村上貴孝，圆府寺美，木野 稔 (2009) 心不全を呈した川崎病不全型の一例. 第22回近畿小児 科学会, 西宮

120. 平林雅人, 田邊裕子, 木全貴久, 森 伸生, 目黒敬 章, 藤井喜充, 图府寺美, 木野 稔 (2009) 初回髄液 検査が正常であった化膿性髄膜炎の 1 例. 第 22 回近畿 小児科学会, 西宮

121. 村上貴孝, 田邊裕子, 平林雅人, 木全貴久, 森 伸 生, 目黒敬章, 藤井喜充, 寺口正之, 图府寺美, 木野 稔，中野博光 (2009) 脳波異常が診断のきっかけと なった副腎白質ジストロフィーの 1 例. 第 2 回近畿小 児科学会, 西宮

122. 黒柳裕一，谷口奈穂，田邊裕子，高屋淳二，東野博 彦，金子一成（2009）重症アトピー性皮膚炎に対する 食餌制限によりビタミン D 欠乏性くる病を発症した 1 男児例. 第32回近畿小児内分泌研究会, 大阪

123.山内壮作，藤原 亨，舟木克枝，辻美代子（2009） PFAPA 症候群の 1 症例. 第 39 回大阪市東部小児談話 会, 大阪

124.藤井喜充，木野 稔（2009）腹部 CT 検査と腹部超音 波検査での小児急性虫垂炎における粪石描出能の検 討. 第 45 回日本腹部救急医学会, 東京

125. 谷内昇一郎（2009）食べてなおす，食物アレルギ 第 46 回守口・門真外来小児科勉強会, 守口

126. 岡本一章, 須藤京子, 須藤博明 (2009) ギランバレー 症候群の一例。第 47 回伊賀地区小児懇話会, 伊賀

127. 金子一成（2009）小児の脱水症とその管理. 兵庫県小 児科医会, 神戸

128. 高屋淳二（2009）肥満と喘息. 第 15 回大阪小児科医 会 病診連携懇談会, 大阪

129.内山敬達，黒嵩健一，杉山 央，北野正尚，池田智明 （2009）重度の心収縮力低下を示し出生当日に死亡し た完全大血管転位. 第 15 回日本胎児心臓病研究会, 埼 玉

130.高屋淳二（2009）生活習慣病の予防は小児から，第 51 回尼崎市学校保健大会, 大阪

131. 谷内昇一郎, 岡本真道, 藤井泰子, 小島崇嗣, 須藤京 子，金子一成 (2009) 食物アレルギ一患者（卵・小麦） における経口減感作療法の試み. 第 9 回食物アレル ギ一研究会, 東京

132. 小野 厚, 奥田浩人, 大川 董, 畑中武志 (2009) Drug
Combination による固定薬疹の 1 症例. 平成 21 年度温 仁会総会, 守口

133. 奥野晴久，井辻泰子，大倉ひろ枝，植村芳子，金子一 成, 高橋伯夫 (2009) ASTの異常高値を認めたAST結 合免疫グロブリン症例の HPLCを用いた詳細解析．第 19 回日本臨床化学会近畿支部総会, 大阪

134. 内山敬達, 北野正尚, 矢崎 諭, 杉山 央, 吉沢弘 行, 高田秀美, 山田修 (2009) 経食道心エコー検査よ る肺体血流比の推定. 第20回JPIC 研究会, 東京

135.三浦健一郎, 関根孝司, 五十嵐隆, 田中基嗣, 関 常 司，石澤健一，平橋淳一，藤田敏郎，染谷朋之介，大 友義之, 金子一成, 幡谷浩史（2009）後天性 IgA 欠損 症を発症し, 組織像の改善をみた紫斑病性腎炎の1例. 第75回 関東小児腎臓研究会, 東京

136.依岡寛和, 笠松 敦, 椹木 晋, 神崎秀陽, 峰 研 治，大橋 敦，木下 洋，金子一成，高田晃平，濱田 吉則（2009）出生前診断した胎児肺分画症の 2 症例. 第45回日本周産期・新生児医学会, 名古屋

著 書

1. 金子一成（2009）脱水症. ナースのための小児の病態 生理事典（山城雄一郎編）22-29頁, へるす出版, 東京

2. 木下 洋 (2009) 新生児肝炎, 新生児感染症, 新生児 寒冷障害, 新生児偽性腸閉塞, 新生児機能性イレウス, 新生児筋緊張症, 新生児クラミジア感染症, 新生児痤 攣. 医学書院 医学大辞典 第2 版 (伊藤正男, 井村 裕夫，高久史麿編）1428-1429頁，医学書院，東京

3. 荒木 敦 (2009) 体のしくみ：のみこむ, むせる, う んちする，扎っこする. 医療的ケアはじめの一歩 1 (杉本健郎編) 31-37頁, クリエイツかもがわ, 京都

4. 荒木 敦 (2009) ミトコンドリア病, リソソーム病. 看護のための最新医学講座 2(中尾一和編) 97-101 頁, 中山書店, 東京

5. 奥山眞紀子, 田中英高, 小柳憲司, 村上佳津美, 宮本 信也, 石崎優子, 宮島 祐, 神原雪子, 梶浦 貢 (2009) 子どもの心の診療に関する診療体制確保, 専門的人材 育成に関する研究 子どもの心身医学的診療（含リエ ゾン）の標準化に関する研究. 子どもの心の診療に関 する診療体制確保, 専門的人材育成に関する研究 平 成 20 年度 総括 - 分担研究報告書 293-296頁, 厚生労 働省, 東京

6. 深井善光 (2009) 子どもの身体の発達. 子どもの心の 診療シリーズ 1 子どもの心の診療入門 1（齊藤万 比古編) 38-43頁, 中山書店, 東京

7. 渡辺 新, 河崎裕英（2009）小児がんに対する標準治 療・診断確立のための研究 小児急性リンパ性白血病 の標準的治療法の確立に関する研究. 小児がんに対す る標準治療・診断確立のための研究 平成 20 年度 総 括 - 分担研究報告書 12-17 頁, 国立病院機構名古屋医 療センタ一臨床研究センター, 名古屋

8. 图府寺美（2009）ターミナルケアと臨終にあたっての 
注意. 小児科研修ノート（五十嵐隆編）129-133 頁, 診断と治療社, 東京

9. 木野 稔 (2009) 当直の業務. 小児科研修ノート（五 十嵐隆編）143-144頁, 診断と治療社, 東京

10. 木下 洋 (2009) 研修医の到達目標 - 手技. 小児科研 修ノ一ト（五十嵐隆, 金子一成, 田原卓浩, 渡辺 博 編）17-20頁，診断と治療社，東京

11. 石崎優子（2009）こころのケア．小肾科研修ノート （永井良三，五十嵐隆編）209-211 頁, 診断と治療社, 東京

12. 金子一成（2009）学校検診一腎臓. 小児科研修ノ一ト （永井良三，五十嵐隆編）217-220 頁, 診断と治療社, 東京

13. 高屋淳二 (2009) 糖尿病. 小児科研修ノート（永井良 三，五十嵐隆編）310-311頁，診断と治療社，東京

14. 金子一成（2009）Henoch-Schönlein紫斑病. 小児科研 修ノート（永井良三，五十嵐隆編）364-365 頁, 診断 と治療社, 東京

15. 荒木 敦（2009）小児科医と特別支援学校教諭. 小児 科研修ノート 1 (永井良三, 五十嵐隆編) 64-65 頁, 診断と治療社, 東京

16. 木野 稔 (2009) 急性腎孟腎炎・急性巣状細菌性腎炎. 小児科疾患アルゴリズム（市川光太郎編） 70-71 頁, 中山書店, 東京

17. 木野 稔 (2009) 尿路感染症. 小児科疾患アルゴリズ 厶 (市川光太郎編) 72-73頁, 中山書店, 東京

18. 金子一成（2009）へノッホ・シェーンライン紫斑病. 小児救急アトラス（内山 聖, 安次嶺編） 177 頁, 西 村書店, 東京

19. 木野 稔 (2009) 胃洗浄. 小児救急アトラス（内山 聖, 安次嶺馨編）23-24頁，西村書店，東京

20. 石崎優子, 深井善光 $(2009)<り$ く返す子どもの痛みの
理解と対応ガイドライン. 小児心身医学会ガイドライ ン集 (日本小児心身医学会編) 121-177頁, 南江堂, 東京 21. 深井善光 (2009) 小児科医のための不登校ガイドライ ン. 小児心身医学会ガイドライン集（日本小児心身医 学会編） 55-84頁, 南光堂, 東京

22. 小野厚（2009）52. 果物の加熱, 加工による抗原性の 変化. 食物アレルギー 外来診療のポイント 571 (小林陽之助, 金子一成編) 144 頁, 診断と治療社, 東京

23. 小野 厚 (2009) 38. ピーナッツ・ソバアレルギー. 食物アレルギー 外来診療のポイント 57 1（小林 陽之助, 金子一成編) 87-88頁, 診断と治療社, 東京

24. 金子一成（2009）はじめに。食物アレルギー 外来診 療のポイント 571 (小林陽之助, 金子一成編), 診 断と治療社, 東京

25. 谷内昇一郎 (2009) 食物依存性運動誘発アナフィラキ シ一. 食物アレルギー外来診療のポイント 1 (小林 陽之助, 金子一成編) 115-117頁, 診断と治療社, 東京 26. 谷内昇一郎 (2009) 食物アレルギーの予後. 食物アレ ルギー外来診療のポイント 1 (小林陽之助, 金子一 成編）15-17頁, 診断と治療社, 東京

27. 谷内昇一郎 (2009) 食物アレルギーにおける日常生活. 食物アレルギー外来診療のポイント 1 (小林陽之助, 金子一成編）60-61頁，診断と治療社，東京

28. 谷内昇一郎 (2009) 小麦アレルギーの米パン。食物ア レルギー外来診療のポイント 1 (小林陽之助, 金子 一成編）63-85頁，診断と治療社，東京

29. 金子一成（2009）小児科の視点. 専門医のための腎蔵 病学（内山 聖, 富野康日己, 今井裕一編) 428-432 頁, 医学書院, 東京

30. 金子一成 (2009) 急性期の電解質. 川崎病のすべて （五十嵐隆，石井正浩編）80-81頁, 中山書店, 東京

\section{皮膚科学講座}

\section{〈研究概要〉}

皮膚科学講座における研究の重要な事項と研究の方向性

難治性免疫アレルギ一疾患に対する紫外線療法と, 肉芽腫疾患の診断・治療に関して日本で屈指の施設と評価され, ま た，悪性黒色腫などの皮膚覀性腫瘍に対する外科的，化学的治療にも豊富な経験があり，研究成果がそれらの診療に還 元できることを目標に，下記のような紫外線，肉芽腫，皮膚免疫アレルギー，発癌を主な研究テーマとしている.

1）紫外線は皮膚構成細胞に作用し種々の疾患や老化を誘発する一方，病的皮膚に有効に作用することによって炎症性疾 患や悪性リンパ腫の治療に用いられている. その奏効機序は, 紫外線が表皮細胞や免疫担当細胞に作用し, 免疫反応を 抑制することが大きな要因と考えられている。 これまで，紫外線は接触アレルギ一反応を抑制し，皮膚の抗原提示細胞 として重要な表皮 Langerhans 細胞や，主要な皮膚炎症細胞である $\mathrm{T}$ 細胞に多大な影響を及ぼすことを報告してきた。現 在, 紫外線による免疫抑制の誘導機構のさらなる解明と, それに関連した皮膚局所免疫に拈ける Langerhans 細胞の役割 を検討している．また，DANCEを中心に弾性線維に対する紫外線の作用の解析を通して光老化に関する研究も行ってい る.

2）紫外線DNA傷害修復能を欠き, 表皮メラノサイトを有するマウスを作成し, 表皮内メラニンが紫外線による炎症反応 や免疫抑制, 発癌の抑制に重要であることを明らかにした。そして，本マウスが悪性黒色腫の紫外線誘発モデルになる ことを報告した，昨年，よりヒト皮膚色に近い色素性マウスを作成し，特許（4406696）を取得したが，本マウスを用い 
て紫外線皮膚傷害や紫外線発癌における表皮メラノサイトの役割を検討している.とくに，より優れた紫外線誘発悪性 黒色腫のモデルの確立に取り組んでいる.

3）肉芽腫の形成機序およびその構成細胞である単球・マクロファージ系細胞の解析を行っている. 同細胞系由来で肉芽 腫に特徵的な多核巨細胞は, in vitroでCD14++CD16-単球から直接誘導されマクロファージに分化した細胞からは誘導 されないことを報告した。 また，アジュバント活性を有する細菌の最小構成蛋白のムラミルジペプタイドが，サルコイ ドーシス，結核で優位となるLanghans型多核巨細胞の形成に重要であることを発表した。本研究のin vitroでのヒト末梢 血単球由来多核巨細胞形成モデルはサルコイドーシスに奏効するトラニラストなどの既存の薬剤の有効性の判定に有用

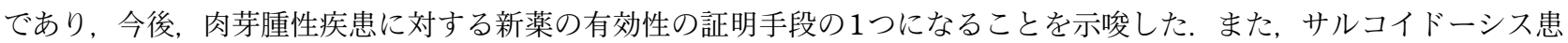
者末梢血の CD14+CD16+ 単球が血清 ACE 值と有意な相関をもって増加することから, CD14++CD16- 単球, $\mathrm{CD} 14+\mathrm{CD} 16+$ 単球はともにサルコイドーシスの病態に関与することを報告した，現在，両単球における ACE，PGE，Ctype レクチン, P2X7レセプター, Notch シグナルなどについて検討し, 肉芽腫形成における両単球の意義をさらに検討 している. そして, 肉芽腫の主要細胞である類上皮細胞の細胞生物学的解析を行い, 解明されていない本態や誘導機構 を明らかにすることを目標としている.

このような基礎的研究と, 臨床での知見を通じて, 皮膚における紫外線の功罪, 発癌機序, 肉芽腫の病態についての 有用な情報を発信したいと考えている.

\section{〈研究業績〉}

原 著

1. Mugii N, Hasegawa M, Hamaguchi Y, Tanaka C, Kaji K, Komura K, Ueda-Hayakawa I, Horie S, Ikuta M, Tachino K, Ogawa F, Sato S, Fujimoto M and Takehara K (2009) Reduced red blood cell velocity in nail-fold capillaries as a sensitive and specific indicator of microcirculation injury in systemic sclerosis. Rheumatology 48(6): 696-703

2. Ueda-Hayakawa I, Malios J and Zhuang Y (2009) Id3 restricts the developmental potential of $\gamma \delta$ lineage during thymopoiesis. Journal of Immunology 182: 5306-5316

3. 濱口儒人, 藤本 学, 長谷川稔, 小村一浩, 松下 隆, 加治賢三，植田郁子，佐藤伸一，桑名正隆，竹原和彦 （2009）抗 U3RNP抗体陽性全身性強皮症 8 例の臨床的 特徵について．日皮会誌 119(9): 1837-1843

4. 水野可魚 (2009) サルコイドーシスの皮膚病変. 日皮 会誌 119(13): 2726-2729

総 説

1. 岡本祐之 (2009) サルコイドーシス. Visual Dermatol 8(2): 1254-1261

2. 岡本祐之 (2009) PART 4 スキンケアと病気の予防 光線過敏症の予防。 からだの科学 (262): 133-136

3. 岡本祐之 (2009) 糖尿病専門医のための皮膚病変講座 汎発性環状肉芽腫. 月刊糖尿病 1(4): 112-118

4. 爲政大幾 (2009) 糖尿病性皮膚潰瘍（糖尿病性足病変） の診断・治療．日皮会誌１19(13): 2584-2586

5. 爲政大幾（2009）日常診療に役立つ皮膚科最新情報一 患者さんへの説明を含めて一16 糖尿病性潰瘍・壊 疽. 皮膚臨床 51(11): 1484-1493

6. 岡本祐之, 上津直子 (2009)【最近のトピックス 2009 Clinical Dermatology 2009】皮膚疾患治療のポイント 難治性萇麻疹とレセルピン治療. 臨皮 63(5): 78-81
症例報告

1. 植田郁子, 白崎文朗, 齋藤 敦, 稲沖 真, 竹原和彦 (2009) 確定診断7年前から経過を追うことができた菌 状息肉症の1例。日皮会誌 119(5): 893-898

2. 松尾智央, 堀尾 武, 足立由香, 岡本祐之, 長澤智彦 （2009）内服 PUVA 療法が著効したリンパ腫様丘疹症 の2例. 皮の科 8(2): 232-237

3. 太田安紀, 杉原 昭, 水野可魚, 堀尾 武, 岡本祐之, 森 茂生 (2009) 食道粘膜の剥離と吐出を伴った水疮 性類天疮瘡の1例。皮の科 8(2): 168-172

4. 太田安紀, 水野可魚, 岡本祐之 (2009) 皮膚コレステ リン肉芽腫の1例. 皮の科 8(3): 336-339

5. 大橋苑子, 荒井利恵, 政次朝子, 太田深雪, 堀口裕治 （2009）自家感作性皮膚炎様の症状を示した類天疮瘡 の1例. 皮膚の科学 8(2): 164-167

6. 光井千慧, 爲政大幾, 岡本祐之 (2009) 在日ナイジェ リア人に生じた acne keloidalis の 1 例. 皮の科 8(1): $58-61$

7. 大江秀一, 爲政大幾, 山崎文和, 梅原真紀子, 岡本祐 之，遠藤由紀子（2009）頭部に生じた巨大な隆起性皮 膚線維肉腫の1例。皮の科 8(1): 54-57

8. 太田安紀, 水野可魚, 大江秀一, 為政大幾, 岡本祐之 (2009) Persistent serpentine supravenous hyperpigmented eruptionの 2 例. 皮の科 8(1): 36-39

9. 松尾智央, 速水淳史, 爲政大幾, 植村芳子, 寺嶋 亨, 岡本祐之（2009） Angiomatoid Fibrous Histiocytomaの 1例。皮膚臨床 51(8): 1051-1053

10. 植田郁子，中野由美子，大石直人，森田礼時，白崎文 朗，竹原和彦，千代恵理子（2009）巨大な Malignant Nodular Hidradenomaの1例。皮膚臨床５1(13): 1899_ 1902

11. 速水真理子, 速水淳史, 速水 誠 (2009) 森永砒素 ミ ルク被害者に認めた異型細胞を伴う色素斑. 皮膚臨床 51(1): 1112-113

12. 大澤 学, 大江秀一, 岡本祐之（2009）【䦈麻疹とそ 
の類症】臨床例 黄桃による食物依存性運動誘発性ア ナフィラキシー。皮病診療 31(1): 81-84

13. 山崎文和, 上津直子, 的場容子, 土井理左, 岡本祐之, 嶋本哲也（2009）潰瘍性大腸炎を合併した pyodermatitis-pyostomatitis vegetans $の 1$ 例. 臨皮 63(9): 685689

14. 岩阪浩志, 水野可魚, 岡本祐之（2009）圧迫にて顎下 腺導管開口部より自然排泄した唾石症の 1 例. 臨皮 63(11): 834-836

その他

1. 水野可魚, 岡本祐之 (2009) サルコイドーシス. Visual Dermatol 9(1): 60-61

2. 松尾智央, 爲政大幾, 岡本祐之, 多田正知 (2009) 結 節性黄色腫. 皮の科 8(3): 267-268

3. 谷村裕嗣, 水野可魚, 岡本祐之, 立花暉夫 (2009) 尋 常性乾癬とサルコイドーシスを併発した 2 例. 皮膚臨 床５1(10): 1267-1271

学会発表

1. F. Yamazaki, S. Ohe, H. Iwasaka, T. Kunisada, M. Inui, H. Matsunaka and H, Okamoto (2009) Brown skin seem cell factor-transgenic(SCF-Tg) mice are useful for the research of DNA damage by ultraviolet radiation. 第34回 日本研究皮膚科学会, 福岡

2. 爲政大幾, 岡本祐之 (2009) Heterotopic nenral nodules of the scalp. 11th World Congress of Pediatril Dermatology, バンコク

3. H. Iwasaka, K. Mizuno and H. Okamoto (2009) Induction of Multi nucleated Giant cells In Vitro by High Dose Glucose Density of Conditionated Medium. 39th Annual ESDR Meeting, ブダペスト（ハンガリー）

4. Kana Mizuno, hiroshi Iwasaka, Shuichi Oe and Hiroyuki Okamoto (2009) Effects of T cells activated by varioous stimuli on multinucleated giant cells. 39th European Society for Dermatological Research Meeting, ブダペス ト（ハンガリー）

5. Kaoru Ota, Taiki Isei, Shuichi Oe and Hiroyuki Okamoto (2009) A Case of Atypical Glomus Tumor Associated with Neurofibromatosis Type 1. 第4回日本・豪州合同皮 膚科学会, 札幌

6. Wakako Inoue, Chiori Murata, Tomoo Matsuo, Fumikazu Yamazaki, Kana Mizuno and Hiroyuki Okamoto (2009) Two cases of cutaneous type pemphigus vulgaris. 第 4 回 日本・豪州合同皮膚科学会, 札幌

7. 山㟝文和, 大江秀一, 岩阪浩志, 國貞隆弘, 岡本祐之 （2009）表皮内メラノサイトを有する seem cell factortransgenic(SCF-Tg) マウスを用いた色調の違いによる 紫外線皮膚障害の比較検討. 第 22 回日本色素細胞学 会, 福岡

8. 大澤 学, 植田郁子, 岡本裕之 (2009) 多発型若年性
黄色肉芽腫の 1 例. 内 416 回日本皮膚科学会大阪地方 会, 大阪

9. 越生佳世, 南部裕之, 城 信雄, 舘野寛子, 高橋寛二, 爲政大幾（2009）色素血管母斑症に合併した早発型発 達緑内障の1例。第20回日本緑内障学会, 沖縄

10. 野田佳織, 植田郁子, 爲政大幾, 幾岡本祐之（2009） 多発性指端壊疽の急速な進行とともに筋原酵素の上 昇を認めた全身性強皮症の 1 例. 第39回日本皮膚アレ ルギー学会総会, 京都

11. 岩阪浩志, 上津直子, 岡本祐之 (2009) 抑制波長と増 強波長がみられた日光莖麻疹の一例. 第39回日本皮膚 アレルギー接触皮膚炎学会総会, 京都

12. 水野可魚, 岡本祐之 (2009) 結節性紅斑を繰り返し発 症したサルコイドーシス. 第29回日本サルコイドーシ 又肉芽腫性疾患学会総会, 宇都宮

13. 豊永三恵子, 山㠃文和, 谷村裕嗣, 岩阪浩志, 太田安 紀, 大江秀一, 加藤典子, 水野可魚, 岡本祐之, 大山 文悟, 橋本 隆 (2009) IgA抗表皮基底膜部抗体を伴っ た抗ラミニンガンマ 1 類天疮瘡の 1 例. 第 31 回水疮症 研究会, 松山

14. 越生佳世, 南部裕之, 城 信雄, 舘野寛子, 高橋寛二, 爲政大幾（2009）色素血管母斑症に合併した早期型発 達緑内障の 1 例. 第 372 回大阪眼科集談会, 大阪

15. 太田 馨, 岡本祐之 (2009) 四肢に多発性病変を生じ たサルコイドーシスの 1 例. 第 415 回日本皮膚科学会 大阪地方会, 大阪

16. 谷村裕嗣, 太田 馨, 爲政大幾, 岡本祐之 (2009) Dac Tam 療法著効後の subtotal integnentectoay を行った足 底原発のstage IV 悪性黒色腫. 第60回日本皮膚科学会 中部支部総会, 京都市

17. 豊永三恵子, 水野可魚, 岡本祐之, 中嶋直子（2009） リポイド類壊死症を併発したサルコイドーシス. 第 60 回日本皮膚科学会中部支部総会, 京都

18. 木下美奈子, 植田郁子, 爲政大幾, 岡本祐之（2009） 乳房萎縮をきたした斑状強皮症. 第60回日本皮膚科学 会中部支部総会, 京都

19. 井上和加子, 村田知織, 山㠃文和, 水野可魚, 岡本祐 之（2009）背部の微細な皮疹より確定診断したサルコ イドーシス. 第61会に本皮膚科学会西部支部総会, 別 府

20. 大橋苑子, 爲政大幾, 松尾智央, 岡本祐之（2009）先 天性頝部遺残軟骨の 1 例. 日本皮膚科学会西武支部総 会, 別府

21. 楠山太郎, 太田安紀, 水野可魚, 岡本祐之 (2009) 乳 児に発症した水疮性類天疮瘡の 1 例. 日本皮膚科学会 大阪地方会, 大阪

22. 楠山太郎, 山崎文和, 水野可魚, 岡本祐之（2009）男 性にみられた色素分界線条の 1 例. 日本皮膚科学会中 部支部総会, 京都

23. 木下美奈子, 爲政大幾, 岡本祐之（2009）塩酸チアラ ミドによる萇麻疹型薬疹. 第39回日本皮膚アレルギー 
接触皮膚炎学会総会, 京都

24. 楠山太郎, 水野可魚, 前田成美, 岡本祐之（2009）肺 および腸管への浸潤を認め治療中に癌性骨直膜炎を 生じた成人 T細胞白血病リンパ腫 (ATLL). 日本皮膚 科学会東部支部総会, 甲府

25. 高畑千絵, 大江秀一, 水野可魚, 岡本祐之, 覚道奈津 子（2009）先天性三角脱毛症の 1 例. 第 102 回近畿集 談会, 京都

26. 松尾智央, 岡本祐之 (2009) 固定性地図状紅斑. 第 102 回近畿皮膚科近畿集談会, 京都市

27. 山㠃文和, 大江秀一, 岩阪浩志, 國貞隆弘, 岡本祐之 （2009）茶色の色調を有する seem cell factor-transgenic (SCF-Tg) マウスは紫外線による皮膚障害の検討に有 用である. 第31回日本光医学光生物学会, 大阪

28. 太田 馨, 爲政大幾, 加藤りか, 北條友里子, 岡本祐 之, 近野哲史, 湯川尚哉, 前川直輝（2009）下口唇に 生じた悪性黒色腫の1例. 第24回日本皮膚外科学会総 会, 犬山

29. 光井千慧, 為政大幾, 岡本祐之（2009）腋窩Paget病. 第24回日本皮膚悪性腫瘍学会, 大阪

30. 大江秀一, 爲政大幾, 藤川彩香, 北條友里子, 山嵪文 和, 水野可魚, 岡本祐之, 大江知里, 植村芳子 (2009) 躯幹ノ表皮? 腫より発生した有棘細胞癌の 2 例。第 25 回日本皮膚悪性腫瘍学会, 岡山

31. 大江秀一, 為政大幾, 藤川彩香, 北條友里子, 山嵪文 和, 水野可魚, 岡本祐之, 大江知里, 植村芳子 (2009) 躯幹の表皮襄腫より発生した有棘細胞癌の 2 例。第 25 回日本皮膚悪性腫瘍学会, 岡山

32. 爲政大幾（2009）ICG 蛍光法によるセンチネルリンパ 節生検. 第25回日本皮膚悪性腫瘍学会総会, 岡山

33. 岩阪浩志, 大江秀一, 水野可魚, 岡本祐之 (2009) 肝 細胞癌に対する肝動脈化学塞栓療法後に生じた上腹 部皮下腫瘤の 1 例. 第 413 回日本皮膚科学会大阪地方 会, 大阪

34. 野田佳織, 松尾智央, 岡本祐之 (2009) Piezogenic pedal papules. 第 413 回日本皮膚科学会大阪地方会, 大阪

35. 岡本祐之 (2009) サルコイドーシスの診断と診断の手 引き。第108回日本皮膚科学会総会, 博多

36. 岩阪浩志, 山嵪文和, 岡本祐之（2009）電子顕微鏡に て汗腺の萎縮と構造異常を認めた特発性分節性無汗 症の1例. 第108回日本皮膚科学会総会, 福岡

37. 水野可魚, 岡本祐之 (2009) サルコイドーシスの皮膚 病変. 第 108 回日本皮膚科学会総会, 博多

38. 村田知織, 水野可魚, 岡本祐之（2009）妊娠を契機に 発見されたサルコイドーシスの 2 例. 第 108 回日本皮 膚科学会総会, 博多
39. 大江秀一, 加藤典子, 石黒亜紀子, 村田知織, 山㠃文 和, 水野可魚, 岡本祐之 (2009) ソラフェニブによる 手足皮膚反応，第108回日本皮膚科学会総会, 福岡

40. 大澤 学, 松尾智央, 爲政大幾, 岡本裕之（2009）? 骨神経及び神経障害を伴ったChurg-strauss 症候群の 1 例. 第108回日本皮膚科学会総会, 博多

41. 豊嶋友里子, 爲政大幾, 岡本祐之（2009）陰茎切断を 要した外陰部乳房外Paget病の1例. 第108回日本皮膚 科学会総会, 京都

42. 爲政大幾（2009）糖尿病性潰瘍 - 壊疽（糖尿病性足病 变）の診断・治療. 第108回日本皮膚科学会総会, 福岡

43. 大江秀一, 水野可魚, 加藤典子, 石黒亜紀子, 村田知 織, 山㠃文和, 岡本祐之（2009）ソラフェニブによる 手足皮膚反応. 第108回日本皮膚科学会総会学術大会, 博多

44. 岡本祐之 (2009) 紫外線と樹状細胞. 第19回太陽紫外 線防御研究委員会シンポジウム, 京都

45. 光井千慧, 爲政大幾, 岡本祐之（2009）正常腎機能患 者のアシクロビル腎症, 脳症. 第 412 回日本皮膚科学 会大阪地方会, 大阪

46. 山㟝文和, 大江秀一, 岩阪浩志, 國貞隆弘, 岡本祐之 （2009）茶色の色調を有する seem cell factor-transgenic （SCF-Tg）マウスは紫外線による皮膚障害の検討に有 用である. 第38回UVAB-Club, 愛知

47. 速 水淳 史, 岡本祐之 (2009) Desmoplastic trichoepithelioma. 第 411 回日本皮膚科学会大阪地方 会, 大阪

48. 太田安紀, 水野可魚, 岡本祐之 (2009) コレステリン 肉芽腫の 1 例. 第 411 回日本皮膚科学会大阪地方会, 大 阪

49. 大橋苑子, 新井利恵, 政次朝子, 太田深雪, 堀口裕治 （2009）自家感作性皮膚炎様の症状を示した類天疮瘡 の 1 例. 第 411 回日本皮膚科学会大阪地方会, 大阪

50. 谷村裕嗣, 太田 馨, 太田安紀, 爲政大幾, 岡本祐之 （2009）悪性末梢神経鞘腫瘍の1例. 日本臨床皮膚外科 学会, 大阪

\section{著 書}

1. 山口哲生，杉崎勝教，千田金吾，石原麻美，森本紳一 郎, 岡本祐之, 折津 愈, 四十坊典晴, 立花暉夫 (2009) びまん性肺疾患に関する調査研究班 II. サルコイ ドーシスサルコイドーシスの新診断基準による臨床 調査個人票(案)の作成. びまん性肺疾患に関する調査 研究班平成 20 年度研究報告書 89-92 頁, 自治医科大 学, 下野 


\section{放射線科学講座}

\section{〈研究概要〉}

画像診断部門

CT 分野では，造影 MD-CT を用いた胃癌深達度の評価，MRI 分野では心臓用コイルを用いた前立腺癌の描出能，ガド リニウム造影剤を用いた股関節造影 MRIの検討，拡散テンソルを用いた強迫神経症の重症度との対比，MRSを用いた大 脳白質病変の検討などについて臨床研究を行っている.

\section{核医学部門}

標識アネキシンによる放射線誘発アポトーシスの検出とその臨床応用の可能性についての研究が主要テーマである. アネキシン V はホスファチジルセリン（PS）に対して高い親和性を持つ蛋白質であり，アポトーシスを起こした細胞で はPSが発現する事が知られている.アネキシンVはこのPSと結合することにより細胞のアポトーシスを検出するプロー ブとして使用することができる. 培養腫瘍細胞, 担癌モデル動物に放射線治療を行い, その際に惹起されるアポトーシ スを集積画像として検出することにより, 臨床応用の可能性を検討している.

\section{血管造影IVR部門}

現在進行中の臨床研究には経皮的椎体形成術, 骨, 肺, 腎・副腎腫瘍に対するラジオ波凝固療法, 中心静脈力テーテ ル留置, 透析シャント不全に対する IVR, CT ガイド下肺生検の臨床成績, 産科出血に対する動脈塞栓術の有用性の検討 などがあり, 基礎研究は経皮的椎体形成術の除痛機序の解明, 管腔臓器バイパス術, マイクロバブル化炭酸ガスを使用 したエックス線診断用造影剤の開発, CT透視下インターベンション時に術者の被曝を低減するシールドの開発, および 複合材料によるステント, ナノファイバーコーティング人工血管の開発などについて行っている.

\section{放射線治療部門}

放射線治療部門の臨床研究は, 進行食道がん・進行頭䅡部がん・進行子宮頸がんに対する化学放射線療法の新規治療 レジメンの研究, 頭䅡部がん化学放射線療法患者に抢ける鱟下機能評価抢よびリハビリーテーションの介入の有用性の 評価, 入院患者における化学療法および放射線療法中のせん妄の実態調査およびその予防対策, がん性疼痛に対するフェ ンタニル貼付剤使用による薬物血中濃度動態に関する研究, 白金製剤使用の化学療法における制吐剤の至適投与法の研 究, ならびに小線源治療におけるオンライン・フィルムレス運用のための撮影系システムの開発など多岐にわたってい る. さらに滝井病院では放射線治療予後予測因子を同定するために，子宮頸癌の初診時に採取した血清を用いて，バイ オマーカーの探索を行い, アポリポ蛋白C-II (ApoC-II) を同定した. ApoC-IIモノクロナール抗体Elisa-Kitを作成し，子 宮頸癌 65 例の予後との相関を解析した結果, ApoC-II は放射線治療後の原病生存率に関与した. ApoC-II は放射線治療予 後予測因子として有用なバイオマーカーの可能性があることを見出した.

\section{〈研究業績〉}

\section{原 著}

1. Tanigawa N, Kariya S, Komemushi A, Tokuda T, Nakatani M, Yagi R and Sawada S (2009) Cement leakage in percutaneous vertebroplasty for osteoporotic compression fractures with or without intravertebral clefts. AJR Am J Roentgenol 193(5): W442-W445

2. Shomura Y, Tanigawa N, Tokuda T, Kariya S, Kojima H, Komemushi A and Sawada S (2009) Composite material stent comprising metallic wire and polylactic acid fibers, and its mechanical strength and retrievability. Acta Radiol 50(4): 355-359

3. Kariya S, Tanigawa N, Kojima H, Komemushi A, Shomura Y, Shiraishi T, Kawanaka T and Sawada S (2009) Transcatheter coil embolization for steal syndrome in patients with hemodialysis access. Acta Radiol 50(1): 2833

4. Kouda K, Kohno H, Nakamura H, Ha-Kawa SK, Sonoda
Y and Iki M (2009) Technetium-99m-GSA clearance in mice under long-term dietary restriction. Ann Nucl Med 23(2): 123-129

5. Kobayashi T, Arai Y, Takeuchi Y, Nakajima Y, Shioyama Y, Sone M, Tanigawa N, Matsui O, Kadoya M, Inaba Y; Japan Interventional Radiology in Oncology Study Group (JIVROSG). (2009) Phase I/II clinical study of percutaneous vertebroplasty (PVP) as palliation for painful malignant vertebral compression fractures (PMVCF): JIVROSG-0202. Ann Oncol 20(12): 1943-1947

6. Tanigawa N, Kariya S, Kojima H, Komemushi A, Shomura Y, Ikeda K, Omura N, Tokuda T, Maehara M, Terada J and Sawada S (2009) Cerebral microembolisation during radiofrequency ablation of lung tumours: detection by carotid duplex ultrasound. Br J Radiol 82(975): 249-253

7. Kariya S, Tanigawa N, Kojima H, Komemushi A, Shomura Y, Shiraishi T, Kawanaka T and Sawada S (2009) 
Peripheral Stent Placement in Hemodialysis Grafts. Cardiovasc Intervent Radiol 32(5): 960-966

8. Tokuda T, Shomura Y, Tanigawa N, Kariya S, Komemushi A, Kojima H and Sawada S (2009) Mechanical Characteristics of Composite Knitted Stents. Cardiovasc Intervent Radiol 32(5): 1028-1032

9. Satoi S, Yanagimoto $H$, Toyokawa $H$, Tanigawa N, Komemushi A, Matsui Y, Mergental H, Araki H, Takai S and Kamiyama Y (2009) Pre-operative patient selection of pancreatic cancer patients by multi-detector row CT. Hepatogastroenterology 56(90): 529-534

10. Aota Y, Morimoto S, Sakuma T, Morita T, Jo F, Takahashi N, Maehara M, Ikeda K, Sawada S and Iwasaka T (2009) Efficacy of an L- and N-type calcium channel blocker in hypertensive patients with neurovascular compression of the rostral ventrolateral medulla. Hypertens Res 32(8): 700-705

11. Morimoto S, Aota Y, Sakuma T, Ichibangase A, Ikeda K, Sawada S and Iwasaka T (2009) Efficacy of clonidine in a patient with refractory hypertension and chronic renal failure exhibiting neurovascular compression of the rostral ventrolateral medulla. Hypertens Res 32(3): 227-228

12. Harima Y and Sawada S (2009) Hyperthermia classic commentary: 'A randomized clinical trial of radiation therapy versus thermoradiotherapy in stage IIIB cervical carcinoma' by Yoko Harima, International Journal of Hyperthermia 2001;17: 97-105. Int J Hyperthermia 25(5): 344-346

13. Harima Y, Nagata K, Harima K, Ostapenko VV, Tanaka Y and Sawada S (2009) Hyperthermia Classic Article: A randomized clinical trial of radiation therapy versusthermoradiotherapy in stage IIIB cervical carcinoma. 2001. Int J Hyperthermia 25(5): 338-343

14. Harima Y, Ikeda K, Utsunomiya K, Shiga T, Komemushi A, Kojima H, Nomura M, Kamata M and Sawada S. (2009) Identification of genes associated with progression and metastasis of advanced cervical cancers after radiotherapy by cDNA microarray analysis. Int J Radiat Oncol Biol Phys 75(4): 1232-1239

15. Kariya S, Tanigawa N, Kojima H, Komemushi A, Shomura Y, Ha-Kawa SK, Tokuda T, Kamata M and Sawada S (2009) Percutaneous translumbar inferior vena cava cannulation under computed tomography guidance. Jpn J Radiol 27(4): 176-179

16. Tokuda T, Tanigawa N, Shomura Y, Kariya S, Kojima H, Komemushi A, Shiraishi T and Sawada S (2009) Transcatheter embolization for peripheral pseudoaneurysms with n-butyl cyanoacrylate. Minim Invasive Ther Allied Technol 18(6): 361-365

17. Kojima H, Tanigawa N, Kariya S, Komemushi A, Shomura Y, Yanishi M, Murota T and Sawada S (2009) High- flow priapism undergoing arterial embolization: Review of literature following American Urological Association guideline on the management of priapism. Minim Invasive Ther Allied Technol 18(1): 1-5

18. Tenjin H, Mandai A, Umebayashi D, Yamamoto S, Osaka Y, Nakahara Y and Tanigawa N (2009) Percutaneous Vertebroplasty Under Three-Dimensional Radiography Guidance-Technical Note-. Neurol Med Chir 49(4): 179-183

19. 津島寿一, 日野一郎, 成松芳明, 林 信成, 天野 泉, 内藤 晃, 貞岡俊一, 黒木一典, 後藤靖雄, 松浦克彦, 高瀬 圭, 狩谷秀治, 佐藤 隆 (2009) 透析シャント 機能不全に対する画像ガイド下血管内治療の成績に 関する調査一前向き多施設共同研究—. IVR 24(4): 368-383

20. 河 相吉 (2009) 胸部単純写真から見る肺癌. 守口市 医師会会報 93: 143-151

21. 中野隆史, 桜井英幸, 鈴木義行, 大野達也, 加藤真吾, 坂田耕一, 戸板孝文, 片岡正樹, 田中栄一, 兼安祐子, 宇野 隆, 播磨洋子 (2009) 子宮頸癌の放射線単独療 法, 同時化学放射線療法に対するJROSG婦人科腫瘍委 員会調査報告一 2001 年から 2003 年における子宮頸癌 の同時化学放射線療法の実態調査一. 日本放射線学会 第21回学術大会調査報告集 19-25

22. 里井壯平, 柳本泰明, 豊川秀吉, 高橋完治, 松井陽一, 北出浩章, Hynek Mergental, 谷川 昇, 高井惣一郎, 權 雅憲 (2009) 膵管癌に対する術前放射線化学療法 後外科的治療成績. 膵臓 $24(5): 630 \times 631$

総 説

1. 谷川 昇, 狩谷秀治, 徳田貴則, 中谷 幸, 八木理絵, 澤田 敏, 米虫 敦 (2009) 経皮的椎体形成術 (vertebroplasty）経皮的椎体形成術の現況と将来性. INNERVISION 24(12): 39-41

2. 池田耕士, 前原 稔, 播磨洋子, 澤田 敏 (2009) CTMRI アトラス Update 正常解剖と読影のポイント 頭 頸部 咽頭・喉頭. Medicina 46(12): 129-135

3. 徳田貴則, 谷川 昇, 狩谷秀治, 米虫 敦, 澤田 敏 (2009) Sawadaカテーテルの特徵と使用経験. Rad Fan 7(13): 64-66

4. 米虫 敦 (2009) 経皮的椎体形成術は今後どこへ向 かっていくのだろうか?〜我々は医者か?医学者 か?. RadFan 7(9): 119-120

5. 米虫 敦 (2009) 基本に立ち戻って親カテーテル / ガ イディングシステムを考える Part2 : 企画. RadFan 7(13): 47-77

6. 米虫 敦 (2009) 基本に立ち戻って親カテーテル / ガ イディングシステムを考える:企画. RadFan 7(11): 72102.

7. 播磨洋子 (2009) 癌放射線治療の基礎理論. Urol View 7(6): 10-14 
8. 小島博之, 岩瀬 哲, 中川恵一 (2009) 放射線治療 緩 和医療における放射線治療の意義. 治療学 43(7): $725-730$

9. 宇都宮啓太 (2009) 最新核医学事情一その可能性と課 題 進展への具体的動向を探る RI 内用療法 がん治 療の中での RI内用療法の位置付けと展開予測. 新医療 36(3): 73-76

10. 米虫 敦, 谷川 昇, 狩谷秀治, 小島博之, 庄村裕三, 徳田貴則, 野村基雄, 池田耕士, 播磨洋子, 澤田 敏 （2009）【IVR の画像評価】経皮的椎体形成術の画像評 価. 断層映像研究会雑誌 35(3): 161-166

11. 米虫 敦, 谷川 昇, 狩谷秀治, 小島博之, 徳田貴則, 野村基雄, 池田耕士, 宇都宮啓太, 播磨洋子, 左野 明, 澤田 敏 (2009)【骨粗鬆症と圧迫骨折】経皮的椎 体形成術とその画像診断. 臨画像 25(8): 864-871

12. 米虫 敦（2009）基本に立ち戻って親カテーテル/ガ イディングシステムを考える : 序文. RadFan 7(11): 73

その他

1. Tanigawa N, Kariya S, Kojima H, Tokuda T, Komemushi A and Sawada S (2009) Transcatheter coil embolization of an aneurysm of an anomalous splenic artery: Usefulness of double microcatheter method. Minim Invasive Ther Allied Technol 18(5): 311-314

2. 谷川 昇, 狩谷秀治, 庄村裕三, 徳田貴則, 小島博之, 米虫 敦, 澤田 敏 (2009) 気道. IVR 24(Supplement): 38-39

3. 米虫 敦 (2009) コダックトラベルフェローシップ報 告SIR2009印象記. JCR News 171: 21-23

4. 米虫 敦, 渡邊 環, 林 信成（2009）SIR 2009を振 り返る世界的なりセッション, 日米医療費の現状, 米 国IVR事情など．RadFan 7(6): 104-113

5. 河 相吉, 上埜泰寛, 澤田 敏 (2009) 99mTc-GSA と 18 F-FDGが興味ある所見を呈した門脈血栓の1例。核 医学症例検討会症例集 30: 21-22

6. 河 相吉, 岩田亮一, 河本圭司, 上埜泰寛, 澤田 敏 （2009）FDG の大脸皮質所見を認めた Fahr 病の一例. 核医症例検討会症例集 29(2): 38-39

7. 播磨洋子 (2009) 放射線腫瘍医のためのPETの基礎知 識と子宮頸癌への臨床応用. 日放線腫瘍会誌 21(34): $103-107$

8. 是枝ちづ, 谷野朋子, 村田美樹, 武田聖子, 梅原秀人, 池田耕造, 関 寿人, 岡崎和一, 河 相吉 (2009) BMI 変化とレボビスト造影エコー/肝シンチグラフィによ るNASHの経過観察. 薬理と治療３7(Suppl.1): S139S145

9. 米虫 敦 (2009) JRC\&ITEM2009 徹底解剖! JRC\&ITEM2009 スペシャリストからのベストアン サー. RadFan 7(6): 91
学会発表

1. Harima Y, Ikeda K, Utsunomiya K, Komemushi A, Kamata M and Sawada S (2009) Prediction of Prognosis of Advanced Cervical Cancers after Radiotherapy by Real-time PCR. Radiological Society of North America, Chicago

2. Utsunomiya K, Sugiyama T, Ikeda T, Akagi H, Narumi Y, Harima Y, Ikeda K, Komemushi A, Kawa S and Sawada S (2009) Iodine-123-IMP brain perfusion SPECT investigation of the relationship between Alzheimer's disease and normal-tension glaucoma. Annual congress of European Nuclear Medicine Association 2009, Barcelona, Spain

3. Nomura M, Kamata M, Kojima H and Sawada S (2009) Short-term versus standard-term conversion from intravenous to transdermal fentanyl in chronic cancer pain: randomized study. ECCO15\&ESMO34 (the European Cancer Organisation and the European Society for Medical Oncology) (第15回欧州癌学会・第34回欧州臨床腫 瘍学会, Berlin, Germany

4. Tanigawa N (2009) Radiofrequency ablation for painful metastatic bone rumors. 2009 World Conference on Interventional Oncology, China

5. Harima Y (2009) Predictive assays for response to radiotherapy and thermoradiotherapy for the patients with advanced cervical cancers. 2th Asian Congress of Radiation Research (ACCR), Soul, South Korea

6. Kashima M, Yamakado K, Nakatsuka A, Takaki H, Uraki J, Kaminou T, Tanigawa N and Takeda K (2009) Prognostic factors of $\mathrm{RF}$ ablation for bone metastases from HCC: a multicenter study in Japan. SIR (34nd Annual Scientific Meeting of The Society of International Radiology), San Diego, CA, U.S.A.

7. Tanigawa N, Kariya S, Shomura Y, Tokuda T, Sawada S and Komemushi A (2009) Percutaneous vertebroplasty for osteoporotic compression fracture, First 500 levels of a single center: Long term evaluation of the technical and clinical outcomes. SIR 2009, San Diego, CA, U.S.A.

8. Aota Y, Morimoto S, Sakuma T, Maehara M, Ikeda K, Sawada S and Iwasaka T (2009) Hypertensive Organ Damages in Essential Hypertension with Neurovascular Compression of the Rostral Ventrolateral Medulla. The 73th Annual Scientific Meeting of the Japanese Circulation Socity, Osaka

9. Sakuma T, Morimoto S, Aota Y, Maehara M, Ikeda K, Sawada S and Iwasaka T (2009) Incidnece of Neurovascular Compression of the Rostral Ventrolateral Medulla in Refractory Essential Hypertensive Patients. The 73th Annual Scientific Meeting of the Japanese Circulation Socity, Osaka

10. Ikeda K, Sang Kil Ha-Kawa, Utsunomiya K, Harima Y and Sawada S (2009) "Clinical significance of incidental 
fluorodeoxyglucose uptake in the parotid glands". Radiological Society of North America, Chicago

11. 播磨洋子（2009）遺伝子解析による子宮頸癌の放射線 感受性予測. 第 52 回日本放射線影響学会学術総会, 広 島

12. 香西雅介, 大村直人, 黒川弘晶, 池田茂樹, 広川雄三, 前原 稔, 田中聖道, 澤田 敏, 坂井田紀子, 池田耕 士 (2009) 前立腺 seminomaの1例. 第293回日本医学 放射線学会 関西地方会, 大阪

13. 前原 稔, 池田耕士, 黒川弘晶, 大村直人, 池田茂樹, 広川雄三，川口あすか, 米田昌則, 片上和敏, 澤田 敏（2009）頭頸部領域における拡散強調画像での Sat $\operatorname{Pad}$ の有用性について. 第37回日本磁気共鳴医学会大 会, 横浜

14. 池田耕士, 前原 稔, 大村直人, 池田茂樹, 黒川弘晶, 米虫 敦, 宇都宮啓太, 播磨洋子, 澤田 敏 (2009) マイラゲルを用いた網膜剥離術後合併症の MRI 所見. 第37回日本磁気共鳴医学会大会, 横浜

15. 瀧本秀一, 清水 洋, 宇田光伸, 平原稔大, 家治祥一, 渡海 絢, 奥土仁孝, 砂川豊彰, 北野大作, 岡 知彦, 打越将人, 澤田 敏 (2009) Reference scanのSeparated mode を用いて総胆管及び主膵管を撮像した際の blurring 低減の検討〜 Integrated mode との比較〜. 第37回 日本磁気共鳴医学大会, 横浜

16. 清水 洋, 宇田光伸, 奥田康登, 山本 豊, 梶川博司, 澤田 敏 (2009) 膀胱小細胞癌の1例. 第45回日本医 学放射線学会秋季臨床大会, 和歌山

17. 谷川 昇 (2009)「IVR のエビデンスを求めて」腫瘍 IVRのエビデンス：骨（骨セメント・RFA）。第 45 回 日本医学放射線学会秋季臨床大会, 和歌山

18. 播磨洋子, 池田耕士, 宇都宮啓太, 米虫 敦, 志賀淑 子, 澤田 敏 (2009) 子宮頸癌の放射線治療効果予測 因子としてのバイオマーカー探索. 第47回日本癌治療 学会, 横浜

19. 河 相吉, 上埜泰寛, 宇都宮啓太, 澤田 敏 (2009) 肺硬化性血管腫の $18 \mathrm{~F}-\mathrm{FDG}-\mathrm{PET}$ と画像所見. 第 49 回日本核医学会学術総会, 旭川

20. 河 相吉, 上埜泰寛, 宇都宮啓太, 澤田 敏 (2009) 肺 硬化性血管腫の 18 F-FDG PET と画像所見. 第49回日 本核医学会総会, 旭川

21. 播磨洋子 (2009) Apolipoprotein C-II could be a potential biomarker as a prognostic factor of locally advanced cervical cancer after radiotherapy. 第68回日本癌学会学術 総会, 横浜

22. 野村基雄（2009）フェンタニル持続静注から経皮吸収 剂へ短時間・ 2 段階減量を用いた移行法. 第 2 回 名 古屋緩和ケア講演会, 名古屋

23. 米虫 敦（2009）テーマレクチャー：仮性動脈瘤に対 するIVR. 第 52 回救急放射線画像研究会, 大阪

24. 米虫 敦 (2009) 骨粗鬆症性圧迫骨折に対する経皮的 椎体形成術。第9回富山IVR研究会, 富山
25. 播磨洋子, 志賀淑子, 池田耕士, 宇都宮啓太, 米虫 敦, 河 相吉, 澤田 敏 (2009) 進行期子宮頸癌に対 する無作為比較試験の登録: リンパ節転移検出におけ るPET-CT検査の有用性. 日本ハイパーサーミア学会 第26回大会, 千葉

26. 香西雅介, 鎌田 実, 小島博之, 野村基雄, 林 謙治, 澤田 敏 (2009) 食道がん化学療法後の救済手術例の 検討. 日本放射線腫瘍学会第22回学術大会, 京都

27. 野村基雄, 鎌田 実, 小島博之, 林 謙治, 香西雅介, 古平 毅（2009）胸部食道癌化学放射線治療後におけ る心筋への FDG-PET 集積の経時的变化に関する検 討. 日本放射線腫瘍学会第 22 回学術大会, 京都

28. 林 謙治, 鎌田 実, 小島博之, 野村基雄, 香西雅介, 澤田 敏（2009）当院におけるIV B期食道がんの治療 成績. 日本放射線腫瘍学会第 22 回学術大会, 京都

29. 播磨洋子, 池田耕士, 宇都宮啓太, 米虫 敦, 志賀淑 子, 鎌田 実, 澤田 敏（2009）進行期子宮頸癌の放 射線治療抵抗性に関与するTTK遺伝子. 日本放射線腫 瘍学会第22回大会, 京都

30. 谷川 昇, 狩谷秀治, 米虫 敦, 徳田貴則, 中谷 幸, 八木理絵, 澤田 敏 (2009) 骨粗鬆症性圧迫骨折 500 椎体に対する経皮的椎体形成術の臨床成績: 長期成績 を中心に. 第5 回椎体形成術研究会, 京都

31. 米虫 敦, 谷川 昇, 狩谷秀治, 徳田貴則, 中谷 幸, 池田耕士，宇都宮啓太，播磨洋子，澤田 敏 (2009) 骨粗鬆症性圧迫骨折に対する経皮的椎体形成術にお けるSF-36を用いた健康関連QOL評価. 第5 回椎体形 成術研究会, 京都

32. 谷川 昇（2009）スペシャルセッション：ステント治 療のEBM 気道. 第27回日本Metallic Stents \& Grafts 研究会, 大阪

33. 谷川 昇, 狩谷秀治, 米虫 敦, 徳田貴則, 中谷 幸, 八木理絵, 澤田 敏 (2009) スペシャルセッション： ステント治療のEBM: 気道. 第27回日本Metallic Stents \& Grafts 研究会, 大阪

34. 狩谷秀治, 谷川 昇, 小島博之, 米虫 敦, 庄村裕三, 鎌田 実, 徳田貴則, 中谷 幸, 八木理絵, 白石友邦, 澤田 敏（2009）IVR部で悪性腫瘍患者に留置した卜 ンネル型中心静脈カテーテルの成績. 第38回日本IVR 学会総会, 大阪

35. 狩谷秀治, 谷川 昇, 小島博之, 米虫 敦, 庄村裕三, 鎌田 実, 徳田貴則, 中谷 幸, 八木理絵, 白石友邦, 澤田 敏 (2009) 化学療法のため IVR 部で留置した中 心静脈リザーバーの成績. 第 38 回日本IVR学会総会, 大阪

36. 谷川 昇 (2009) 経皮的穿刺治療の新しい試み一 IVR が生き残るために骨粗鬆症性圧迫骨折 500 椎体に対す る経皮的椎体形成術 : 長期成績を中心に. 第38回日本 IVR学会総会, 大阪

37. 谷川 昇, 狩谷秀治, 庄村裕三, 小島博之, 徳田貴則, 中谷 幸, 八木理絵, 米虫 敦, 澤田 敏 (2009) 骨 
粗鬆症性圧迫骨折 500 椎体に対する経皮的椎体形成 術: 長期成績を中心に. 第38回日本IVR学会総会, 大阪

38. 谷川 昇, 狩谷秀治, 米虫 敦, 徳田貴則, 中谷 幸, 八木理絵, 澤田 敏 (2009) PVP の有用性と合併症. 第38回日本IVR学会総会, 大阪

39. 徳田貴則, 谷川 昇, 米虫 敦, 狩谷秀治, 庄村裕三, 白石友邦, 澤田 敏 (2009) 末梢動脈真性動脈瘤に対 する経カテーテル的塞栓術の臨床成績. 第 38 回日本 IVR学会総会, 大阪

40. 米虫 敦（2009）イブニングセミナー：IVRの新旧言 いたい放談：演者 6 . 第38回日本IVR学会総会, 大阪

41. 米虫 敦, 谷川 昇, 狩谷秀治, 小島博之, 庄村裕三, 徳田貴則，野村基雄，池田耕士，宇都宮啓太，播磨洋 子, 八木理絵, 左野 明, 澤田 敏 (2009) 骨粗鬆症 性圧迫骨折に対する経皮的椎体形成術における SF-36 を用いた健康関連 QOL 評価．第 38 回日本 IVR学会総 会, 大阪

42. 谷川 昇, 狩谷秀治, 徳田貴則, 中谷 幸, 八木理絵, 澤田 敏, 米虫 敦（2009）骨粗鬆症性圧迫骨折 500 椎体に対する経皮的椎体形成術：長期成績を中心に. 第5回椎体形成術研究会, 京都

43. 米虫 敦, 谷川 昇, 狩谷秀治, 徳田貴則, 中谷 幸, 池田耕士，宇都宮啓太，播磨洋子，澤田 敏 (2009) 骨粗鬆症性圧迫骨折に対する経皮的椎体形成術にお けるSF-36を用いた健康関連QOL評価．第5回椎体形 成術研究会, 京都

44. 左野 明 (2009) 多列検出器 CT の進歩と腹部画像診 断. 第15回済生会泉尾病院病診連携研修会, 大阪

45. 澤田 敏 (2009) “最近の放射線科領域の話題”. 大正 区臨床画像研究会, 大阪

46. 隠岐光涁, 下戸 学, 前田裕仁, 安藤祐吾, 土屋洋之, 板東宏樹, 宮崎秀行, 藤原弘佳, 平川昭彦, 岩瀬正顕, 村尾佳則, 中谷壽男, 米虫 敦, 澤田 敏 (2009) 経 カテーテル的血栓溶解療法にて良好な経過を辿った 上腸間膜動脈塞栓症の一例. 第 100 回近畿救急医学研 究会, 大阪

47. 広川雄三, 黒川弘晶, 池田耕士, 池田茂樹, 大村直人, 前原 稔, 川口あすか, 田中聖道, 寺田次郎, 布施香 織，林 謙治，大江千里，植村芳子，坂井田紀子，澤 田 敏 (2009) コレステロール結晶塞栓症により多発 性に小腸狭窄をきたした一例．第292回日本医学放射 線学会 関西地方会, 大阪

48. 谷川 昇 (2009）血管造影・IVRの現況. 第 3 回関西 医科大学寝屋川会, 大阪

49. 上埜泰寛，河 相吉，宇都宮啓太，澤田 敏（2009） 硬化性血管腫のFDG-PET所見．第42回日本核医学会 近畿地方会, 奈良

50. 谷川 昇 (2009) ワークショップ 肝外性再発 (転移) の診断と治療肝細胞癌骨転移に対するRFA治療. 第45 回 日本肝癌研究会, 福岡

51. 谷川 昇, 狩谷秀治, 米虫 敦, 徳田貴則, 鈴木聡司,
中谷 幸, 八木理絵, 澤田 敏 (2009) 肝細胞癌肝外 転移に対するIVR. 第 45 回日本肝癌研究会, 福岡

52. 播磨洋子, 池田耕士, 宇都宮啓太, 米虫 敦, 志賀淑 子, 澤田 敏 (2009) 遺伝子解析による子宮頸癌の放 射線感受性予測. 第48回日本医学放射線学会生物部会 学術大会, および第39回放射線による制癌シンポジウ 么, 富山

53. 米虫 敦（2009）経皮的椎体形成術：効果と合併症. 第7回日本IVR学会夏季学術セミナー, 神奈川

54. 米虫 敦 (2009) 経皮的椎体形成術：最近のトピック ス. 第7回日本IVR学会夏季学術セミナー, 神奈川

55. 播磨洋子（2009）子宮頸癌の放射線温熱療法. 東海・ 北陸ハイパーサーミア研究会, 富山

56. 池田耕士（2009）苦手な頭頸部を極める Part II一耳下 腺. 日本医学放射線科専門医会 2009 年度ミッドサマー セミナー, 神戸

57. 播磨洋子（2009）診断医が知っておくべき放射線治療 Part II一子宮. 日本医学放射線科専門医会 2009 年度 ミッドサマーセミナー, 神戸

58. 澤田＼cjkstart敏 (2009)「インターベンショナルラジオロジー の最近の進歩」. 2009年春季合同学会・第45回日本獣 医画像診断学会, さいたま

59. 播磨洋子（2009）子宮頸癌の放射線治療効果予測因子 としてのバイオマーカーの再現性評価子宮頸癌の放 射線治療効果予測因子としてのバイオマーカーの再 現性評価. 第13回がん分子標的治療学会総会, 徳島

60. 野村基雄, 鎌田 実, 小島博之, 澤田 敏 (2009) フェ ンタニル製剂の持続静注から経皮吸収剂への短時間・ 2 段階減量を用いた移行法についての検討. 第14回日 本緩和医療学会学術大会, 大阪

61. 播磨洋子, 池田耕士，宇都宮 啓太，米虫 敦，志賀 淑子，鎌田 実，澤田 敏（2009）進行期子宮頸癌の 放射線治療抵抗性に関与する TTK 遺伝子．第 15 回癌 治療増感研究会, 京都

62. 米虫 敦 (2009) 研修医のためのガイドワイヤー講座. 第16回放射線診療安全向上研究会 $<$ IVR と画像診断の ヒヤリ・ハット研究会 $>$, 京都

63. 海堀昌樹, 松井康輔, 斎藤隆道, 石崎守彦, 北出浩章, 松井陽一, 河 相吉, 權 雅憲 (2009) 肝細胞癌に対 する肝予備能評価の新たな指標. 第21回日本肝胆膵外 科学会・学術集会, 名古屋

64. 狩谷秀治, 谷川 昇, 徳田貴則, 中谷 幸, 鎌田 実, 小島博之, 野村基雄, 鈴木聡史, 澤田 敏（2009）中 心静脈カテーテル留置中に大動脈内に空気の混入を 認めた一例. 第26回日本IVR学会関西地方会, 大阪

65. 青木厚子, 米虫 敦, 宮本牧子, 菊川裕子, 徳田貴則, 左野 明，青木和子，金 呂淑，松岡美恵子，谷川 昇，狩谷秀治，池田耕士，宇都宮啓太，播磨洋子，松 岡花子，澤田 敏 (2009) IVRにおける看護師被曝量 第26回日本IVR学会関西地方会, 大阪

66. 米虫 敦, 谷内昇一郎, 谷川 昇, 狩谷秀治, 徳田貴 
則, 左野 明, 鈴川純子, 黒田友顯, 池田耕士, 宇都 宮啓太, 播磨洋子, 金子一成, 澤田 敏（2009）13歳 女児の特発性卵巣出血に対するTAE. 第26回日本IVR 学会関西地方会, 大阪

67. 山道啓吾, 田中義人, 道浦 拓, 岩井愛子, 桜本和人, 中井宏治, 井上健太郎, 中根恭司, 權 雅憲, 谷川 昇 (2009) 食道癌周術期管理の up to date : 術後乳糜胸 の管理，特にリンパ管造影の有用性について. 第63会 日本食道学会学術集会, 横浜

68. 谷川 昇 (2009) IVRの最新の話題. 第 8 回但馬画像 診断研究会, 豊岡市

69. 池田耕士, 前原 稔, 米虫 敦, 宇都宮啓太, 播磨洋 子, 澤田 敏（2009）マイラゲルを用いた網膜剥離術 後合併症. 第38回頭䅡部・胸部画像研究会, 東京

70. 谷川 昇 (2009) シンポジウム輝く放射線医療 今 そして未来 “人と技術のハーモニ一” 塞栓材料と塞 栓技術. 第68回日本医学放射線学会・総会, 横浜

71. 河 相吉，上埜泰寛，宇都宮啓太，澤田 敏 (2009) FDG-PET/CT にて診断された脊椎領域における神経 周囲進展症例の検討. 第 68 回日本医学放射線学会総 会, 横浜

72. 狩谷秀治, 谷川 昇, 小島博之, 米虫 敦, 庄村裕三, 中谷 幸, 徳田貴則, 八木理絵, 白石友邦, 澤田 敏, （2009）悪性腫瘍患者に対する画像ガイド下トンネル 型中心静脈カテーテル留置. 第68回日本医学放射線学 会総会, 横浜

73. 上埜泰寛，河 相吉，宇都宮啓太，澤田 敏 (2009) FDG-PETによる胃癌遠隔転移診断の有用性. 第 68 回 日本医学放射線学会総会, 横浜

74. 前原 稔, 池田耕士, 黒川弘晶, 大村直人, 池田茂樹, 米田昌則, 片上和敏, 澤田 敏（2009）頭頸部領域に おける拡散強調画像での Twin Gradient（Zoom mode） の有用性について. 第68回日本医学放射線学会総会, 横浜

75. 谷川 昇, 狩谷秀治, 小島博之, 庄村裕三, 徳田貴則, 中谷 幸, 八木理絵, 米虫 敦, 左野 明, 澤田 敏 (2009) 骨粗鬆症性圧迫骨折 500 椎体に対する経皮的椎 体形成術 : 長期成績を中心に. 第68回日本医学放射線 学会総会, 横浜

76. 池田耕士, 河 相吉, 前原 稔, 大村直人, 池田茂樹, 黒川弘晶, 米虫 敦, 宇都宮啓太, 播磨洋子, 澤田 敏（2009）FDG-PET 検査で偶然認められた耳下腺集 積の臨床的意義. 第68回日本医学放射線学会総会, 横 浜

77. 池田耕士, 谷川 昇, 杉本達哉, 米虫 敦, 播磨洋子, 前原 稔, 大村直人, 黒川弘晶, 池田茂樹, 澤田 敏 （2009）拡散強調画像による経皮的椎体形成術後の新 たな圧迫骨折の予測. 第 68 回日本医学放射線学会総 会, 横浜

78. 徳田貴則, 谷川 昇, 米虫 敦, 庄村裕三, 狩谷秀治, 澤田 敏（2009） NBCAを用いた抹消動脈仮性動脈瘤
に対する経カテーテル的塞栓術. 第68回日本医学放射 線学会総会, 横浜

79. 播磨洋子, 池田耕士，宇都宮啓太，米虫 敦，志賀淑 子, 鎌田 実, 澤田 敏（2009）子宮頸癌の放射線治 療効果予測因子としてのバイオマーカーの再現性評 価. 第68回日本医学放射線学会総会, 横浜

80. 米虫 敦, 谷川 昇, 狩谷秀治, 小島博之, 庄村裕三, 徳田貴則, 野村基雄, 中谷 幸, 八木理絵, 澤田 敏 （2009）骨粗鬆症性圧迫骨折に対する経皮的椎体形成 術におけるSF-36を用いた健康関連QOL評価. 第68回 日本医学放射線学会総会, 横浜

81. 鈴木聡史, 谷川 昇, 岸本真房, 富野敦稔, 山本 透, 北澤康秀, 小島博之, 狩谷秀治, 庄村裕三, 澤田 敏 （2009）膵局所動注療法における biapenemの有用性に ついて，第68回日本医学放射線学会総会, 横浜

82. 黒川弘晶, 川口あすか, 池田茂樹, 大村直人, 池田耕 士, 澤田 敏, 井上健太郎, 坂井田紀子, 大江知里, 植村芳子（2009）MDCTを用いた胃癌深達度診断 病 理組織との比較検討. 第 68 回日本医学放射線学会総 会, 横浜

83. 狩谷秀治, 谷川 昇, 小島博之, 米虫 敦, 庄村裕三, 中谷 幸, 徳田貴則, 八木理絵, 白石友邦, 澤田 敏 （2009）化学療法を目的とした画像ガイド下中心静脈 リザーバー留置. 第68回日本医学放射線学会総会, 横 浜

84. Aota Y, Morimoto S, Sakuma T, Maehara M, Ikeda K, Sawada S and Iwasaka T (2009) Efficacy of L-and N-type Calcium Blocker in Essential Hypertension with Neurovascular Compression of the Rostral Ventrolateral Medulla. The 73th Annual Scientific Meeting of the Japanese Circulation Socity, Osaka

85. 狩谷秀治（2009）透析シャントに関する話題. 住友別 子病院放射線部院内勉強会, 愛媛

86. 池田耕士（2009）3DCT が診断に有用であった一例. 第16回関西循環器イメージング談話会, 大阪

87. 狩谷秀治 (2009) 透析患者対するバスキュラー・アク セス・インターベンション. 第4回愛媛IVR研究会, 愛媛

88. 播磨洋子, 志賀淑子, 池田耕士, 米虫 敦, 宇都宮啓 太，澤田 敏（2009）子宮頸癌160例に対する根治的 放射線治療成績. 第 11 回癌治療増感研究シンポジウ 厶, 奈良

89. 米虫 敦, 谷川 昇, 狩谷秀治, 小島博之, 庄村裕三, 徳田貴則, 野村基雄, 池田耕士, 宇都宮啓太, 播磨洋 子, 八木理絵, 澤田 敏 (2009) 骨粗鬆症性圧迫骨折 に対する経皮的椎体形成術におけるSF-36 を用いた健 康関連QOL評価. 第25回日本IVR学会関西地方会, 大阪

90. 鈴木聡史, 谷川 昇, 狩谷秀治, 庄村裕三, 徳田貴則, 米虫 敦, 左野 明, 澤田 敏 (2009) 転移性腰椎腫 瘍に伴う臨床症状の改善に経皮的椎体形成術とラジ 才波凝固療法の併用療法が有用であった 1 例. 第 25 回 日本IVR学会関西地方会, 大阪 
91. 黒川弘晶, 寺田次郎, 前原 稔, 大村直人, 池田茂樹, 池田耕士, 澤田 敏（2009）MDCTを用いた胃癌深達 度 病理組織との比較. 第28回日本画像医学会, 東京 92. 前原 稔 (2009) 3T MRI 拡散強調画像の画質向上を 目指して。第28回日本画像医学会, 東京

93. 大村直人, 前原 稔, 田中聖道, 黒川弘晶, 池田茂樹, 池田耕士, 上埜康寛, 河 相吉, 澤田 敏 (2009) 腎 カルチノイドの 1 例. 第 28 回日本画像医学会, 東京

94. 谷川 昇, 狩谷秀治, 米虫 敦, 庄村裕三, 徳田貴則, 鈴木聡史，澤田 敏（2009）澤田 敏骨粗鬆症性圧迫 骨折 500 椎体に対する経皮的椎体形成術．第28回日本 画像医学会, 東京

95. 米虫 敦, 谷川 昇, 狩谷秀治, 小島博之, 庄村裕三, 徳田貴則，野村基雄，池田耕士，宇都宮啓太，播磨洋 子，八木理恵，澤田 敏 (2009) 骨粗鬆症性圧迫骨折に 対する経皮的椎体形成術の QOL 評価. 第 28 回日本画 像医学会, 東京

96. 池田茂樹, 黒川弘晶, 大村直人, 前原 稔, 池田耕士, 前原さ抢り, 川口あすか, 田中聖道, 寺田次郎, 澤田 敏（2009）精巣悪性中皮腫の一症例. 第291回日本 医学放射線学会 関西地方会, 大阪

97. 河 相吉，上埜泰寛，宇都宮啓太，澤田 敏（2009） Neurolymphomatosis の FDG-PET/CT 所見．第29回日 本画像医学会, 東京

98. 池田耕士 (2009) 頭頸部唾液腺疾患のMRI. 第29回北 大阪放射線ミーティング，大阪

99. 上埜泰寛，河 相吉，宇都宮啓太，澤田 敏（2009）
FDG-PET/CTが胃癌診療に及ぼした影響. 第49回日本 核医学会学術総会, 旭川

100.米田昌則，中村剛，片上和敏，西村茂樹，前原＼cjkstart稔， 澤田 敏, 木村元一（2009）3.0T装置の頝部拡散強調 画像を用いた脂肪抑制法の検討. 第52回日本放射線技 術学会近畿部会学術大会, 神戸

101. 谷川 昇, 米虫 敦, 狩谷秀治, 庄村裕三, 徳田貴 則, 小島博之, 中谷 幸, 八木理絵, 澤田 敏 (2009) 骨粗鬆症性圧迫骨折 500 椎体に対する経皮的椎体形成 術の臨床成績. 第2 回脊椎IVRフォーラム, 東京

102. 谷川 昇, 米虫 敦, 狩谷秀治, 庄村裕三, 徳田貴 則, 小島博之, 中谷 幸, 八木理絵, 澤田 敏 (2009) 骨粗鬆症性圧迫骨折 500 椎体に対する経皮的椎体形成 術の臨床成績. 第2 回脊椎IVRフォーラム, 東京

103. 米虫 敦, 谷川 昇, 狩谷秀治, 小島博之, 庄村裕 三，徳田貴則，野村基雄，池田耕士，宇都宮啓太，播 磨洋子, 八木理絵, 澤田 敏 (2009) 骨粗鬆症性圧迫 骨折に対する経皮的椎体形成術におけるSF-36を用い た健康関連QOL評価. 第2 回脊椎IVRフォーラム, 東京 104. 米虫 敦, 谷川 昇, 狩谷秀治, 小島博之, 庄村裕 三，徳田貴則，野村基雄，池田耕士，宇都宮啓太，播 磨洋子, 八木理絵, 澤田 敏 (2009) 骨粗鬆症性圧迫 骨折に対する経皮的椎体形成術におけるSF-36を用い た健康関連QOL評価. 第2 回脊椎IVRフォーラム, 東京 105.上埜泰寛，河 相吉，宇都宮啓太，澤田 敏 (2009) FDG-PET/CTが胃癌診療に及ぼした影響. 第49回日本 核医学会総会, 旭川

\section{臨床検査医学講座}

\section{〈研究概要〉}

臨床検査医学分野では，基本的に循環器・腎臓領域での脈管作動性物質に関する研究に重点を置いている。高橋伯夫 は小宮山豊講師，吉賀正亨助教などと内因性ジギタリスの研究を継続して実施している．ヒトが，ガマ蛙の持つ一種の ジギタリスであるガマ毒（bufadienolide）を生体内で合成している可能性をつきとめて，その合成が副腎皮質でなされて いることを明らかにした。これまで知られた marinobufagenin (MBG) とは別に, それに水素原子が2個付いたtelocinobufagin （TCB）の存在を世界で初めて明らかにし，前者にくらべて後者の方がヒトの血中濃度として約 2 倍高值であった。ささ に，TCB に対するモノクローナル抗体を作成してELISAを作成したが，抗体の特異性が高くなく，実際には構造が類似 しているMBGとの交差性の方が高い結果となった，そこで, 残念ながら ODSカラムを用いた高速液体クロマトグラフィ と組み合わせて測定しないと特異物質の推移を測定することが不可能であった。 しかし，実際には，このことが幸いし て新発見につながった.つまり，このELISA系を用いて副腎皮質細胞培養系で, 培養上清中の成分を分析したところMBG と同じ溶出部位に ELISA 陽性ピークがあるが，これとは別の部位にも同じく陽性ピークがあり，後者の方が濃度が著し く高いことが判明した。このピークを液体クロマトグラフィ／質量分析系で詳細に分析したところ，主成分は marinobufotoxin（MBT）であることが明らかになった. MBT は MBG と同様に Na, K-ATPase 抑制活性を示すことが知ら れているので，その生理活性について詳細な検討をした結果，昇圧作用があることが判明し，高血圧の成因として関係 する可能性がクローズアップされた。ささに，最近では脳内で内因性ジギタリスが脳内アルドステロンと上皮型 Naチャ ンネルと密接に関連して電解質代謝と血圧調節に関与する可能性が指摘されており，我々もアルドステロン受容体遮断 薬, エプレレノンの作用を検討した。 その結果, エプレレノンの経口投与が血中 MBG様免疫活性物質濃度を減少させる ことを明らかにした。 臨床研究では, NT-proBNP の臨床検査としての特徵の把握とその臨床応用の可能性, レプチンや 高分子アディポネクチンの臨床検査としての応用に向けた研究, 高感度 CRP や高感度トロポニン測定の臨床的意義など についても研究している. 
小宮山講師と吉賀助教は, ヘパリン起因性血小板減少症についての症例研究や血栓性血小板減少性紫斑病と ADAMTS13 との関連を検討し，これらの検査所見による積極的な情報提供の有用性を発信している. さらに病院での薬 毒物検査普及に努めている.

正木浩哉准教授は，慢性腎不全の病態と治療に関する臨床的な研究および動脈硬化症の骨䯣単核球細胞移植による血 管再生療法の研究と臨床にも取り組んでいる。

桝田綠講師は，一貫して immunoglobulin 受容体に関する研究を続けていて，他の診療部門などとの共同研究を実施し ている. IgGレセプターIII（FcyRIII: CD16）には，NK細胞とマクロファージ（M $\phi)$ に発現しているIIIa型と好中球に発

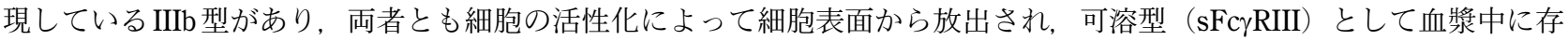
在している。 すなわち，これら可溶型を個々に測定することにより生体内での好中球， NK 細胞あるいは $\mathrm{M} \phi$ の活性化を

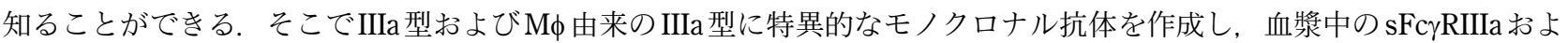
びsFc $\gamma R I I I a M \phi$ 測定法を構築し sFc $\gamma$ RIIIs 測定の臨床検査としての応用を目指している. 関節りウマチ（RA）患者血漿中 の3種の sFcrRIIIsではすべて健常者に比して明らかに増加したが, sFc $\gamma$ RIIIaの值が最もよく病態を反映していた．また， 現在主流になりつつある抗TNF $\alpha$ 抗体療法時の若年性関節りウマチ患者での可溶性F c rRIIIaの変化を測定したところ, 抗 体投与後経日的に低下し, 全ての検查值の内で最もよく病態を反映していた， $\mathrm{M} \phi$ が動脈硬化発症において重要な役割を 果たしていることから, sFc $\gamma R$ RIIIaM $\phi$ の動脈硬化診断法としての可能性も検討している. 血漿 $\mathrm{sF} c \gamma R I I I a M \phi$ は健常者では 加齢とともに増加し, 成人病検診症例では動脈硬化の危険因子数が増すに従い増加し, 頸動脈エコー検查の結果と有意 に相関した，また，虚血性心疾患症例では明らかな高値を示し，冠動脈の有意狭窄数が増すに従い増加した，今後，本 検査法が不安定プラークの検出に応用できないか検討したいと考えている.

腎疾患に扔いては系球体や尿細管, 間質の炎症により同部位に単球／M $\mathrm{M}$ の湿潤が認められ, その発症や進展に関与す ると報告されている．実際，尿中の M $\phi$ 数およびF F $\gamma$ RIIIa陽性 M $\phi$ の有無で腎症の活動性を評価することができるとされ ている. そこで, 血漿および尿中の 3 種の sFcrRIIIs を測定し, それらと腎症の重症度, 活動性を比較検討したところ, 病 態の活動性と関係することが明らかにされた。

病理部では，特異的な症例に関する研究および特殊免疫染色を試みている.

\section{〈研究業績〉}

原 著

1. Nishimura M, Tokoro T, Nishida M, Hashimoto T, Kobayashi H, Imai R, Yamazaki S, Okino K, Iwamoto N, Takahashi H and Ono T (2009) Oral Nicorandil to Reduce Cardiac Death After Coronary Revascularization in Hemodialysis Patients: A Randomized Trial. Am J Kidney Dis 54(2): 307-317

2. Saito T, Matsumura K, Tsubota Y, Maniwa T, Kaneda H, Minami K, Sakaida N, Uemura Y, Kawa G, Yamamoto N, Fujii Y, Isobe K, Kawakami Y, Matsuda T, Saito Y and Takekoshi K (2009) Novel Mutation (L157X) in the Succinate Dehydrogenase B Gene (SDHB) in a Japanese Family with Abdominal Paraganglioma Following Lung Metastasis.. Endocr J 56(3): 451-458

3. Sanada F, Taniyama Y, Azuma J, Iekushi K, Dosaka N, Yokoi T, Koibuchi N, Kusunoki H, Aizawa Y and Morishita R (2009) Hepatocyte growth factor, but not vascular endothelial growth factor, attenuates angiotensin IIinduced endothelial progenitor cell senescence. Hypertension 53(1): 77-82

4. Nishimura M, Tokoro T, Nishida M, Hashimoto T, Kobayashi H, Yamazaki S, Imai R, Okino K, Iwamoto N, Takahashi H and Ono T (2009) Sympathetic overactivity and sudden cardiac death among hemodialysis patients with left ventricular hypertrophy.. Int J Cardiol Jan 23. [Epub ahead of print]
5. Nakamura T, Shimizu C, Kasahara M, Okuda K, Nakata C, Fujimoto H, Okura H, Komatsu M, Shimakawa K, Sueyoshi N, Ura T, Satoh K, Toyokawa M, Wada Y, Orita T, Kofuku T, Yamasaki K, Sakamoto M, Nishio H, Kinoshita S and Takahashi H (2009) Monte Carlo simulation for evaluation of the efficacy of carbapenems and new quinolones against ESBL-producing Escherichia coli.. J Infect Chemother 15(1): 13-17

6. Kuroda N, Michal M, Hes O, Taguchi T, Tominaga A, Mizobuchi K, Ohe C, Sakaida N, Uemura Y, Shuin T and Lee GH (2009) Renal angiomyoadenomatous tumor: fluorescence in situ hybridization.. Pathol Int 59(9): 689691

7. Michal M, Hes O, Nemcova J, Sima R, Kuroda N, Bulimbasic S, Franco M, Sakaida N, Danis D, Kazakov DV, Ohe $\mathrm{C}$ and Hora M (2009) Renal angiomyoadenomatous tumor: morphologic, immunohistochemical, and molecular genetic study of a distinct entity.. Virchows Arch 454(1): 89-99

8. 中村竜也, 清水千裕, 平川 要, 乾佐知子, 奥田和之, 中田千代, 藤本弘子, 大倉ひろ枝, 植村芳子, 高橋伯 夫（2009）キノロン系抗菌薬の各種臨床分離株に対す る抗菌力と PK-PD 理論を用いたその有効性について。 Jpn J Antibiot 62(3): 194-202

9. 吉賀正亨, 小宮山豊, 高橋伯夫 (2009) 自然発症高血 圧ラットに打りる内因性ジギタリス様物質, マリノブ フォトキシンの動態一血圧調節におけるレニン・アン 
ジオテンシン系の関与について. 心臟 41(4): 401-404

10. 小宮山豊, 吉賀正亭, 正木浩哉, 高橋伯夫 (2009)【臨 床検査コンサルテーション／診療支援】分野別のコン サルテーション／診療支援 凝固検査. 臨検 53(3): 285-288

総 説

1. 中村竜也（2009）最前線！ICTが注意すべき微生物対 策10 6 基質拡張型 $\beta$ ラクタマーゼ産生菌. INFECT CONTROL 18(10): 1020-1025

2. 中村竜也 (2009) 微生物検查 3. 迅速検査. Med Technol (別冊) : 55-62

3. 高橋伯夫（2009）薬物による測定値の変動 7. 生理 機能検查. Med Technol 37(8): 837-842

4. 原島典子, 矢澤 直, 友田雅己, 竹島秀美, 原 克子, 朴 幸男, 高橋伯夫, 上野 剛, 平山 哲, 三井田孝 （2009）生化学検查. Med Technol 37(13): 1422-1483

5. 小宮山豊, 正木浩哉, 高橋伯夫, 原 克子 (2009) 乱 用薬物抢よび薬毒物の簡易スクリーニング検查の取 り扱い2. 日本におけるDOA（drug of abuse）のPOCT の現状・測定原理・技術一高度および 3 次救命の経験 を中心．医療と検機器・試薬 32(4): 471-478

6. 高橋伯夫 (2009) 新しい臨床検査 心・腎領域高感度 CRP．診断と治療 97(9): 1796-1801

7. 小宮山豊, 原 克子, 平城 均, 正木浩哉, 高橋伯夫 (2009) 分析ラボ紹介-12- 関西医科大学附属滝井病院 臨床検査部 薬毒物検査室. 中毒研究 22(4): 343345

8. 小宮山豊, 原 克子, 高橋伯夫, 津田紀子, 石部玩也, 丸山克之, 穂坂直美, 八尋美保子, 秀島里沙, 眞名子 順一（2009）【集団中毒に対する危機管理体制】西日 本 3 施設に打ける薬毒物分析機器稼働の現状と課題. 中毒研究 22(1): 12-18

9. 塚口裕康（2009）【ネフローゼ症候群 診断と治療の 進歩】ネフローゼ症候群と遺伝子異常. 日内会誌 98(5): 1076-1083

10. 高橋伯夫 (2009) 循環生理活性物質の最新知見 血管作 動性物質一生合成, 分泌, 生理作用一内因性ジギタリ 又様物質. 日臨 67（増刊6）：272-277

11. 高橋伯夫 (2009) 血圧調節系と高血圧成因論 自律神経 系. 日臨 67(増刊6): 129-133

12. 吉賀正亨（2009）【こんな検査異常をみつけたら考 える臨床検査】採血部位に気をつけよう，臨研プラク ティス 6(3): 88-89

13. 小宮山豊 (2009) トピックス: 凝固検査の進歩一クロ スミキシング試験を中心に一，臨床病理５7(10): 987 $-989$

14. 小宮山豊, 林 伸英 (2009) シンポジウム：医師と技 師のより良いコミュニケーションに向けて一Beyond the Team医療一。臨床病理 57(2): 161-162
症例報告

1. Kaneda H, Sakaida N, Saito T, Maniwa T, Uemura Y and Saito Y (2009) Appearance of bronchioloalveolar carcinoma and the rapid progression into invasive papillary adenocarcinoma.. Gen Thorac Cardiovasc Surg 57(4): 224-227

2. 荒木吉朗, 吉岡和彦, 由井倫太郎, 岩本慈能, 中根恭 司，坂井田紀子（2009）潰瘍性大腸炎に対する回腸囊 肛門管吻合術後に腹痛と頻便にて著しい QOL の低下 を来した症例．Prog Med 29(7): 1866-1868

3. 舘野寛子, 星野健, 高橋寛二, 松村美代, 坂井田紀子, 大江知里 (2009) 急速に進行した肝細胞癌からの転移 性脈絡膜腫瘍の1例。日眼会誌 113(2): 107-111

4. 荒木吉朗, 吉岡和彦, 岩本慈能, 山木 壮, 岩井愛子, 中根恭司, 權雅憲, 松下光伸, 岡崎和一, 植村芳子 (2009) 極めて短い病悩期間で発症した Crohn 病に合 併した colitic cancerの1例. 日消器外誌 42(10): 15971602

5. 大石賢玄, 中井宏治, 川口雄才, 岩井 大, 四方伸明, 權 雅憲 (2009) 中咽頭, 食道, 胃, 盲腸同時性 4 重 複癌の1例. 日臨外会誌 70(12): 3745-3750

6. 木下勇一, 山口直則, 有馬良一, 中山啓三, 安田迪之, 足立靖, 鷹巣晃昌, 四方伸明 (2009) 子宮体部原発神 経内分泌癌の一例。 日臨細胞誌 48(3): 114-118

7. 島田 治, 福井勝也, 矢西正明, 川喜多繁誠, 杉 素 彦, 芦田 眞, 室田卓之, 四方伸明, 松田公志 (2009) FMD(fibromuscular dysplasia) に起因した腎動脈瘤破裂 の1例．泌紀 55(1): 19-22

8. 中本博之, 箕浦俊之, 向出裕美, 四方伸明 (2009) 胃 癌胃全摘術後 5 年目の挙上腸管再発に対して再切除を 施行した1例. 臨外 64(1): 119-123

9. 舘野寛子, 高橋寛二, 松村美代, 坂井田紀子, 中野崇 秀（2009）眼窩内視神経全長に浸潤した年長児の網膜 芽細胞腫の1例．臨眼 63(1): 43-49

その他

1. Qin XS, Tsukaguchi H, Shono A, Yamamoto A, Kurihara H and Doi T. (2009) Phosphorylation of nephrin triggers its internalization by raft-mediated endocytosis.. J Am Soc Nephrol 20(12): 2534-2545

2. 吉岡秀樹, 大倉ひろ枝, 植村芳子, 高橋伯夫, 西田憲 正, 西 保寿, 本鄉義清, 杉江久和（2009）血中アン モニア測定装置, ポケットケムBA PA-4140の基礎検 討. 医療と検機器・試薬 32(2): 201-206

3. 小宮山豊 (2009) ラボクイズ 風邪症状半日後に救急 外来に来院した 36 歳の男性. 検査と技術 37(13): 1470

4. 中村竜也, 清水千裕, 乾佐知子, 奥田和之, 中田千代, 藤本弘子, 大倉ひろ枝, 植村芳子, 高橋伯夫（2009） 肺炎球菌に対する levofloxacin 打よび garenoxacin の抗 菌力と PK-PD 理論による有効性と耐性化抑制に関す る検討. 新薬と臨 58(8): 1376-1383 
5. 伊藤寛子, 大倉ひろ枝, 吉岡秀樹, 鈴木玲子, 吉賀正 享, 高橋伯夫 (2009) 心機能マーカー $「 \mathrm{~N}$ 末端-proBNP」 測定試薬の基礎的検討. 日臨検自動化会誌 34(2): 242-247

\section{学会発表}

1. Midori MASUDA and Hakuo TAKAHASHI (2009) Increase of soluble FcrRIIIs levels in urine from patients with nephritis第39回日本免疫学会総会・学術集会. 第 39 回日本免疫学会総会・学術集会, 大阪

2. Hakuo Takahashi (2009) Current sttus of laboratoy physicians in Japan. Annual meeting of the Chinese Medical Asocation i Taiwan, Taipei, Taiwn

3. Hakuo Takahashi (2009) High-sensitive assay of biomarkers opens a new field of diagnosis in the cardiovascular diseases. 第10回アジア臨床病理・臨床検査医学会 (The 10th Asian Society of Clinical Patholoy and Laboratory Medicine), ウランバートル，モンゴル共和国

4. Toyohiko Yokoi, Yoshiharu Wada, Fumihiro Sanada, Kazuma Iekushi, Masamichi Yoshika, Midori Masuda, Yutaka Komiyama, Yoshiaki Taniyama, Hiroya Masaki, Ryuichi Morishita, Hiroyuki Koshiyama and Hakuo Takahashi (2009) Ursodeoxycholic acid inhibits endothelial cell plasminogen activator inhibitor-1 expression induced by high glucose depend on transforming growth factor signalling. 69th Scientific Sessions, American Diabetes Association, New Orleans, USA

5. Masamichi Yoshika, Yutaka Komiyama, Akihiko Hirakawa, Toshio Nakatan and Hakuo Takahashi (2009) A case of useful measurement of heparin-induced thrombocytopenia antibody during the disseminated intravascular coagulation. XXIInd International Symposium on Technological Innovations in Laboratory Hematology, Nevada, USA

6. 福井淳一, 西憲一郎, 濱野宣行, 山道啓吾, 道浦 拓, 中尾慎一, 大倉ひろ枝, 高橋伯夫, 新宮 興, 權 雅 憲（2009）食道癌周術期におけるシベレスタットナト リウム投与の有効性についての検討. 第71回日本臨床 外科学会総会, 京都

7. 奥野晴久, 吉岡秀樹, 鈴木玲子, 大倉ひろ枝, 植村芳 子, 高橋伯夫 (2009) CK-MB MtO試薬を用いた CK 值 と CK-MB 值逆転検体の詳細解析. 第 20 回日本臨床化 学会近畿支部総会, 大阪

8. 小宮山豊 (2009) 止血系検査は情報提供材料としてお もしろい一TTPやHITの検査と症例を中心に一. 京都 府臨床検查技師会 血液講演会, 京都

9. 林 佳子, 土井田瞳, 中元 剛, 中嶋達也, 松原高史, 斉藤淳子, 椹木 晋, 神崎秀陽, 田所知佳, 植村芳子 （2009）若年者の卵巣粘液性腫瘍の1例. 第 1 回関西婦 人科腫瘍・病理懇話会, 京都市

10. 野村明代, 寺内里恵, 平井雅美, 部谷晃子, 西山弥生,
大倉ひろ枝, 高橋伯夫（2009）悪性リンパ腫の病型, 病期に関する予後マーカーの動態について. 第49回近 畿医学検査学会, 京都

11. 乾佐知子, 中村竜也, 清水千裕, 高橋伯夫（2009）肺 炎球菌に対する levofloxacin (LVFX), garenoxacin (GRNX), moxifloxacin (MFLX) の抗菌力と PK-PD理 論による有効性および耐性化抑制. 第57回日本化学療 法学会西日本支部総会, 名古屋

12. 高橋伯夫, 藤田誠一 (2009) 大阪府医師会臨床検查精 度管理員会報告. 平成 21 年度府医医学会総会, 大阪市

13. 柳田英佐, 北出浩章, 横井川規巨, 尾崎 岳, 辻 勝 成, 高田秀穂, 權 雅憲, 四方伸明 (2009) 肝原発力 ルチノイドの 1 切除例. 北河内肝臟疾患懇話会, 大阪

14. 岩井 大, 池上智子, 坂口麻理子, 正木浩哉 (2009) 術中副甲状腺ホルモン (iPTH) 測定下に施行された副 甲状腺手術症例に打ける術後再発の検討. 第 1 回二次 性副甲状腺機能九進症に対する PTx 研究会学術集会, 名古屋

15. 平川昭彦, 泉野浩生, 土屋洋之, 波柴尉充, 宮崎秀行, 齊藤福樹, 原 克子, 小宮山豊, 岩瀬正顕, 村尾佳則, 中谷壽男 (2009) 血液浄化法施行時に抢けるメシル酸 ナファモスタット後発品の使用状況. 第20回日本急性 血液浄化学会, 札幌

16. 香西雅介, 大村直人, 黒川弘晶, 池田茂樹, 広川雄三, 前原 稔, 田中聖道, 澤田 敏, 坂井田紀子, 池田耕 士 (2009) 前立腺 seminomaの 1 例. 第293回日本医学 放射線学会 関西地方会, 大阪

17. 小宮山豊, 正木浩哉, 高橋伯夫 (2009) 凝固線溶検査 の標準化 : クロスミキシング試験の標準化と利用 原因不明の出血や血栓を解明するために一. 第41回日 本臨床検査自動化学会大会, 横浜

18. 木内絢子, 高橋寬二, 西川真生, 植村芳子, 岩下憲四 郎（2009）著明な白板症と白色眼脂を来した角膜扁平 上皮癌の進展例. 第63回日本臨床眼科学会, 福岡

19. 清水導臣, 石井一慶, 伊藤量基, 小宮山豊, 浦瀬文明, 前田裕弘, 野村昌作 (2009) 造血器腫瘍患者の DIC に 打けるケモカイン・可溶性分子の測定とトロンボモ ジュリンの治療効果. 第71回日本血液学会, 京都

20. 中山英恵, 木村 譲, 高橋伯夫, 大倉ひろ枝, 岡下さ やか, 宮内卓史, 上田加奈子, 岩坂壽二 (2009) 減量 時の内藏脂肪に及ぼす対組成及び運動耐容能の評価. 第30回日本肥満学会, 浜松

21. 高橋伯夫 (2009) 動脈硬化と炎症. 第59回日本アレル ギー学会秋季学術大会, 秋田

22. 奥野晴久, 吉岡秀樹，鈴木玲子，大倉ひろ枝，植村芳 子, 高橋伯夫 (2009) オリンパスAU5421を用いたCK$\mathrm{MB} \mathrm{MtO}$ 試薬の基礎的検討. 日本臨床検査自動化学会, 横浜

23. 大倉ひろ枝，鈴木玲子，奥野晴久，井辻泰子，吉岡秀 樹, 植村芳子, 高橋伯夫 (2009) CRP 測定試薬 CRPラテックスX2「生研」NXの評価一精密さとラテック 
ス粒子に対する非特異的反応改善について一. 日本臨 床検査自動化学会 第41回大会, 横浜

24. 鈴木玲子, 大倉ひろ枝, 植村芳子, 高橋伯夫, 吉岡秀 樹（2009）汎用自動分析装置オリンパスAU2700を用 いたエミットメトトレキサートアッセイ測定法の評 価. 日本臨床検査自動化学会 第 41 回大会, 横浜

25. 吉賀正亨, 小宮山豊, 高橋伯夫（2009）高速液体クロ マトグラフィーを用いた内因性ジギタリス様物質マ リノブフォトキシンの存在様式の検討. 第 45 回 高血 圧関連疾患モデル学会学術総会, 東京

26. 高橋伯夫, 原 克子, 小宮山豊, 平川昭彦, 正木浩哉, (2009) 重症感染症に打けるSAA とCRPの関係（強い 侵襲症例でのリアルタイムマーカー, SAAの評価). 第 49 回臨床化学会, 長崎

27. 小宮山豊（2009）HIT検査など止血系臨床検査による 情報発信の基礎と応用 一現場の実情に即した問題 解決による情報提供一. 第 4 回北陸血栓止血検査懇話 会, 金沢

28. 高橋伯夫 (2009) テーラーメードの人間ドッグ健診を 目指して一臨床検査専門医の立場からの提言一A proposal from a laboratory physician on the tailor-made Ningen Dock. 日本人間ドッグ学会, 東京

29. 高橋伯夫（2009）「循環器診療における臨床検査の役 割」一NT-proBNP と高感度トロポニンTを中心に一. 日本臨床化学会年次学術集会, 長崎

30. 木内絢子, 高橋寛二, 西川真生, 植村芳子, 岩下憲四 郎（2009）著明な白板症と白色眼脂を来した角結膜扁 平上皮癌の進展例. 第371回大阪眼科集談会, 大阪

31. 横井豊彦, 正木浩哉, 清水俊宏, 岡本恵, 吉賀正亨, 桝田緑，小宮山豊，高橋伯夫（2009）本学付属病院に おける下肢動脈エコー検査の症例検討. 第56回日本臨 床検査医学会学術集会, 札幌

32. 吉賀正亨，鈴木玲子，大倉ひろ枝，高橋伯夫（2009） 冠動脈造影検查および冠動脈ステント留置術前後に おける高感度卜ロポニンTの変動. 第56回日本臨床検 査医学会学術集会, 北海道

33. 吉賀正亨，鈴木玲子，大倉ひろ枝，高橋伯夫（2009） 高感度卜ロポニンTの経時的変化を追えた急性心筋梗 塞症例. 第56回日本臨床検査医学会学術集会, 北海道

34. 小宮山豊, 生田明子, 尾崎貴恵, 宗像眞知子, 吉賀正 亨, 横井豊彦, 桝田緑, 正木浩哉, 堀越順彦, 高橋伯 夫 (2009) SCC 偽高值患者の1例 分子量による解析. 第56回日本臨床検査医学会学術集会, 札幌市

35. 正木浩哉, 岩井 大, 尾崎貴恵, 日高典子, 渡辺和子, 塚口裕康，吉賀正亨，横井豊彦，栘田緑，小宮山豊， 宗像眞智子，高橋伯夫（2009）副甲状腺摘除術におけ る術中迅速 intact-PTH測定の有用性の検討. 第56回日 本臨床検査医学会学術集会, 札幌

36. 栘田緑，正木浩哉，高橋伯夫（2009）腎生検施行患者 における 3 種の尿中可溶性 F c $\gamma$ RIIIs の増加. 第5 6 回日 本臨床検査医学会学術集会, 札幌
37. 角坂芳彦, 吉賀正亨, 大倉ひろ枝, 植村芳子, 高橋伯 夫 (2009) 手術直後の血糖濃度と在院日数の関連性に ついて（第二報）。第 56 回日本臨床検査医学会総会, 北海道

38. 大倉ひろ枝，鈴木玲子，伊藤寛子，東 良子，杉林幸 代，吉賀正亨，植村芳子，高橋伯夫（2009）新たに開 発された高感度トロポニン $\mathrm{T}$ 測定試薬の基礎的検討と 臨床的有用性について. 第56回日本臨床検査医学会総 会, 北海道

39. 小宮山豊, 平川昭彦, 下戸 学, 中谷壽男, 五十嵐裕 子, 藤原通恵, 佐藤幸枝, 吉賀正亨, 正木浩哉, 高橋 伯夫（2009）長期に抗へパリン・血小板第 4 因子抗体 (HIT 抗体) を追跡しえた 1 例. 第 10 回日本検査血液学 会学術集会, 甲府

40. 広川雄三, 黒川弘晶, 池田耕士, 池田茂樹, 大村直人, 前原 稔, 川口あすか, 田中聖道, 寺田次郎, 布施香 織, 林謙治, 大江千里, 植村芳子, 坂井田紀子, 澤田

敏（2009）コレステロール結晶塞栓症により多発性 に小腸狭窄をきたした一例。第292回日本医学放射線 学会 関西地方会, 大阪

41. 原 克子, 小宮山豊, 宗像眞智子, 正木浩哉, 高橋伯 夫（2009）新規カラムを用いた HPLC試料直接分析に よる中毒症例の迅速対応法. 第 31 回日本中毒学会総 会・学術集会, 東京

42. 山木 壮, 里井壯平, 豊川秀吉, 柳本泰明, 山本智久, 由井倫太郎, 高岡 亮, 岡㟝和一, 大江千里, 植村芳 子, 坂井田紀子, 權 雅憲 (2009) 当院における局所 進行ならびに切除可能膵癌症例の術前診断の現状. 第 40 回日本膵蔵学会大会, 東京

43. 池上智子, 岩井 大, 坂口麻理子, 金子敏彦, 北尻雅 則, 友田幸一, 正木浩哉（2009）術中迅速副甲状腺木 ルモン（iPTH）測定を用いた副甲状腺手術後の再発 例の検討. 第71回日本耳鼻咽喉科臨床学会, 旭川

44. 高橋敦子，大倉ひろ枝，植村芳子，高橋伯夫（2009） イムノクロマト法を用いたアレルギー迅速検査キッ ト（イムファストチェック J1, J2) の評価. 第58回日 本医学検査学会, 横浜

45. 高橋伯夫（2009）食塩と高血圧：中枢神経系の役割. 第8回九州脳と高血圧研究会, 福岡

46. 高橋伯夫（2009）NT-proBNPの臨床的有用性. 日本医 学検査学会, 横浜市

47. 小宮山豊（2009）多発外傷によるDICに合併したへパ リン起因性血小板减少症の一例. HIT 情報センター幹 事会 講演, 小倉

48. 小宮山豊 (2009) へパリン起因性血小板減少症 (HIT) の検査と病態について 透析症例やICUの症例にHIT 抗体検查実施は有用. 西三河地区透析領域における HIT 研究会, 三河安城

49. 平林篤志, 富野敦稔, 岸本真房, 櫻本和人, 山本透, 浅井悌，小宮山豊，北澤康秀（2009）多発外傷に合併 したへパリン起因性血小板減少症(HIT)の一例。第 12 
回日本臨床救急医学会総会・学術集会, 大阪

50. 平川昭彦, 下戸 学, 前田裕仁, 小宮山豊, 岩瀬正顕, 村尾佳則，中谷壽男 (2009) 救急・集中治療領域にお けるへパリン起因性血小板減少症 (Heparin Induced Thrombocytopenia; HIT) の診断と治療. 第 32 回日本 血栓止血学会, 小倉

51. 小宮山豊, 吉賀正亨, 平林篤志, 北澤康秀, 高橋伯夫 （2009）多発外傷による DIC に合併したへパリン起因 性血小板減少症の一例. 第32回日本血栓止血学会学術 集会, 小倉

52. 正木浩哉, 原 克子, 小宮山豊, 菊池早苗, 山原英樹, 今田崇裕, 河野啓子, 平川昭彦, 中谷壽男 (2009) 注 射用メシル酸ナファモスタット製剂における先発医 薬品と後発医薬品の比較分析. 第5 4 回日本透析医学会 学術集会・総会, 横浜

53. 中村竜也, 清水千裕, 高橋伯夫 (2009) 血液由来 MRSA の薬剂感受性と抗 MRSA 薬の治療効果に関する検討. 第57回日本化学療法学会総会, 東京

54. 木下勇一, 松永志保, 高畠 希, 市邊和夫, 生田明子, 植村芳子, 坂井田紀子, 足立 靖, 圦貴司, 鷹巣晃 昌, 四方伸明 (2009）悪性胸膜 - 腹膜中皮腫が疑われ た 1例. 第十五回大阪病理研究会, 大阪

55. 大西修司, 山岡学, 市邉明美, 有元美代子, 徳永裕彦, 中矢桂子, 藤原通恵, 小宮山豊, 福原資郎 (2009) ADAMTS13 活性とそのインヒビター力価測定が血漿 交換療法に有用であった血栓性血小板減少性紫斑病 の 1 症例．第 57 回日本輸血・細胞治療学会総会, 埼玉

56. 小宮山豊 (2009) 我々が遭遇する凝固異常と検査一現 場の実情に応じた日常的に遭遇する問題とその解決 による情報提供一. 東京都臨床検査委技師会 組織部 勉強会, 東京

57. 吉賀正亨, 中矢秀雄, 小宮山豊, 正木浩哉, 高橋伯夫 （2009）迅速に検査診断しえた基礎疾患を有しないク リプトコッカス髄膜炎の 1 例. 第 83 回日本感染症学会 総会, 東京

58. 黒川弘晶, 川口あすか, 池田茂樹, 大村直人, 池田耕 士，澤田 敏, 井上健太郎, 坂井田紀子, 大江知里, 植村芳子（2009）MDCTを用いた胃癌深達度診断 病 理組織との比較検討. 第 68 回日本医学放射線学会総 会, 横浜

59. 中村竜也, 清水千裕, 奥田和之, 中田千代, 藤本弘子, 宮崎浩彰, 高橋伯夫（2009）POT法によるMRSA迅速 疫学解析の効果について. 日本感染症学会総会, 東京 60. 木下勇一, 濱口記久子, 松永志保, 市邊和男, 李 重 煥, 鷹巣晃昌, 四方伸明, 足立 靖, 圦 貴司, 生田 明子（2009）子宮体部原発明細胞腺癌の一例．第34回

日本臨床細胞学会大阪府支部 学術集会, 大阪

61. 小宮山豊 (2009) 我々が遭遇する凝固異常と検査一現 場の実情に応じた日常的に遭遇する問題の解決によ る情報提供一。第10回中国凝固線溶研究会, 岡山

62. 平川昭彦, 下戸 学, 宮崎秀行, 小宮山豊, 村尾佳則,
中谷壽男（2009）少量ヘパリン投与でヘパリン起因性 血小板減少症を生じた9例の検討. 第36回日本集中治 療医学会, 大阪

63. 小宮山豊 (2009)「血小板減少から見えること」一TTP の診断一院内での ADAMTS13 活性のと破砕赤血球鏡 検は血栓性血小板減少性紫斑病に有用である。第3回 神戸CFMフォーラム，神戸

64. 中村竜也, 清水千裕, 平川 要, 奥田和之, 中田千代, 藤本弘子, 大倉ひろ枝, 植村芳子, 高橋 伯夫 (2009) 百日咳感染症の早期診断における real-time PCR 法の 有用性. 第24回日本環境感染学会総会, 東京

65. 奥野晴久, 井辻泰子, 大倉ひろ枝, 植村芳子, 金子一 成, 高橋伯夫（2009）ASTの異常高值を認めたAST 結 合免疫グロブリン症例の HPLCを用いた詳細解析．第 19 回日本臨床化学会近畿支部総会, 大阪

66. 中村竜也, 清水千裕, 平川 要, 奥田和之, 中田千代, 藤本弘子，大倉ひろ枝，植村芳子，高橋伯夫（2009） OXA型Carbapenemaseを産生するMulti-Drug Resistant A baumannii の検出について. 第 21 回日本臨床微生物 学会総会, 仙台

67. 清水千裕, 中村竜也, 平川 要, 乾佐知子, 奥田和之, 中田千代, 藤本弘子, 大倉ひろ枝, 植村芳子, 高橋伯 夫（2009）輸送スワブの違いと時間経過のよる百日咳 菌の生菌数変動についての検討. 日本臨床微生物学会 総会, 仙台

68. 佐藤麻友美, 井辻泰子, 大倉ひろ枝, 植村芳子, 高橋 伯夫（2009）「ブラームス PCT-Q」による PCT 測定 の有用性の検討. 第49回近畿医学検査学会, 京都

69. Toyohiko Yokoi, Kazuma Iekushi, Masamichi Yoshika, Fumihiro Sanada, Midori Masuda, Yutaka Komiyama, Yoshiaki Taniyama, Hiroya Masaki, Ryuichi Morishita, Hakuo Takahashi (2009) URSODEOXYCHOLIC ACID SUPPRESSES ENDOTHELIAL CELL PLASMINONEN ACTIVATOR INHIBITOR-1 EXPRESSION INDUCED BY HIGH GLUCOSE DEPEND ON TRANSFORMING GROWTH FACTOR SIGNALING, 19th European Meeting on Hypertension, Milan, Italy

著 書

1. 高橋伯夫 他（2009）中枢性交感神経抑制薬. 高血圧 治療薬ハンドブック〜様々な病態に応じた, エビデン スに基づく薬の選び方・使い方〜 (浦信行編) 134-140 頁, 羊土社, 東京

2. 高橋伯夫（2009）あなたもメタボ? 健診チェック「眼 底検查」. 笑顔 40 版 2 巻 24 頁, 保健同人社, 東京

3. 高橋伯夫（2009）あなたもメタボ? 健診チェック「貧 血検査」. 笑顔 40 版 3 巻 24 頁, 保健同人社, 東京

4. 高橋伯夫（2009）あなたもメタボ? 健診チェック「心 電図検查 $」$. 笑顔 40 版 1 巻 24 頁, 保健同人社, 東京

5. 高橋伯夫 (2009) 新しい臨床検査 心・腎領域 高感 度CRP. 診断と治療 97 版 9 巻 $1796-1801$ 頁, 診断 
と治療社, 東京

6. 飯島一誠, 亀井宏一, 佐藤秀則, 鳥山紗由美, 塚口裕 康，仲里仁史 (2009) 稀少疾病治療薬の開発に関する 研究 難治性てんかん・ネフローゼを合併する新たな症 候群の病態解明と診断システム及び治療法の開発に 関する研究. 政策創薬総合研究研究報告書 平成 20 年 度 1-9頁, ヒューマンサイエンス振興財団, 東京

7. 高橋伯夫 他 (2009) 内皮障害に関連するバイオマー カー $「 1$. 高感度 CRPの活用」. 生活習慣病診療に基
づくCVD予防ハンドブック (山岸昌一編) 166-172頁, 羊土社, 東京

8. 高橋伯夫 他 (2009) 循環器疾患. 薬学コアカリ対応 病態・薬物治療概論 40-91頁, 丸善, 東京

9. 高橋伯夫 (2009) 高血圧性疾患. 臨床検査のガイドラ イン JSLM2009（日本臨床検査医学会ガイドライン 作成委員会編）2009 年度版 183-186 頁, 株式会社 宇宙堂八木書店, 東京

\section{外科学講座}

\section{〈研究概要〉 \\ 基礎研究}

消化管分野では，1）胃癌，大腸癌などにおけるiNOS誘導のシグナル伝達機構の解析とiNOS誘導抑制による発癌や進 展の抑止を研究している. 我々はiNOS遺伝子から mRNA安定化を促進するアンチセンス転写物が発現することを報告し た. 今後, 癌の悪性度や予後との関連を検討し, 癌治療に対する新薬の開発を目標としている. 2) 病理学, 医化学教室 とも共同研究を行っており, 後者とは術後疼痛管理における革新的な術後鎮痛法の基礎的, 臨床的研究を行っている.

肝胆膵・移植分野では，1）肝障害因子の1つである誘導型一酸化窒素合成酵素（iNOS）の発現抑制を目的とした，漢 方薬剂や食品による肝保護効果の解析．2）肝臓手術後肝不全を回避するため, 間葉系骨䯣細胞を用いた障害肝，肝切除 後や移植肝の肝再生促進効果の検討. 3) 衛生学との共同研究では, 末期肝不全患者救命のための幹細胞を用いた肝再生 治療の基礎的研究. 4）肝癌における transforming growth factor- $\beta$ シグナル伝達と予後との関係の解析. 5）膵癌患者の免 疫状態に合わせた治療戦略の開発. 6) 膵癌動物モデルを用いた新しい膵癌治療の研究を進めている.

\section{臨床研究}

消化管外科では，1）噴門側胃切除後の残胃運動機能に関する臨床研究，2）胃全摘後の空腸パウチ間置再建術式の有 用性に関する臨床試験，3）胃癌手術の創閉鎖におけるBest Practiceの検討，4）胃癌における，安全で有用な術後腹腔鏡 検査の確立，5）早期胃癌に対する ICG を用いたセンチネルナビゲーションサージェリーの可能性の検討，6）有茥薄筋 移植による肛門機能の改善に関する研究，7）直腸脱に対する腹腔鏡下直腸固定術の臨床的検討を行っている.

肝胆萃外科では，1）肝細胞癌に対する肝切除後肝不全症例の予測と対策，2）当科における高齢者肝細胞癌肝切除症 例の検討，3）進行肝癌術後早期再発死亡の予後因子と治療戦略，4）小肝細胞癌に対する外科的治療方針の検討，5）当 科における肝細胞癌肝切除症例における輸血療法の検討，6）GSA シンチによる生体肝移植ドナ一残肝の肝再生の検討， 7）腹腔鏡下胆囊摘出術に打ける抗生剂投与の必要性についての研究，8）腹腔鏡手術に使用する，磁石を用いた新しい デバイスの開発とその実用化の研究, 9) 切除可能ならびに局所進行膵癌に対する術前放射線化学療法の治療効果の検討, 10）膵頭十二指腸切除術の吻合法（PD）と周術期管理の变更による合併症低減策の検討，11）PDにおけるOSATSを応 用した教育プログラムの導入，12）PDに対する自己血輸血の導入，13）MDCTによる膵癌の術前進展度診断，14）機能 性食品AHCC による免疫機能増強効果に関する健常者を用いたA double-blind, placebo control試験，15）切除不能胆道癌 および多発転移性肝癌における腹腔鏡下マイクロターゼ凝固とサイトカイン局所注入による癌ワクチン療法における第 I 相臨床試験を遂行している.

小児外科では，極・超低出生体重児における臍部人工肛門造設術の臨床研究をおこない，乳腺外科では，乳癌術前化 学療法, エコーガイドおよびステレオガイド下マンモトーム生検, 乳管内視鏡検査, 術後リンパ浮腫の予防, 再発転移 治療の臨床研究を行っている.

\section{〈研究業績〉}

原 著

1. Kaibori M, Ishizaki M, Saito T, Matsui K, Kwon AH and Kamiyama Y (2009) Risk factors and outcome of early recurrence after resection of small hepatocellular carcinomas. Am J Surg 198(1): 39-45

2. Kwon AH, Qiu Z, Hashimoto M, Yamamoto $\mathrm{K}$ and
Kimura T (2009) Effects of medicinal mushroom (Sparassis crispa) on wound healing in streptozotocin-induced diabetic rats. Am J Surg 197(4): 503-509

3. Tokuyama Y, Adachi Y, Minamino K, Shintaku H, Okigaki M, Hayashi K, Kitajima A, Takaki T, Koike N, Shima C, Imai Y, Shi M, Yanai S and Ikehara S (2009) Abnormal distribution of dendritic cells in (NZW x BXSB)F1 mice. 
Autoimmunity 42(5): 399-405

4. Shima C, Adachi Y, Shi M, Imai Y, Okigaki M, Yanai S, Minamino K, Takahashi K and Ikehara S (2009) The combination method using magnetic beads and a magnet helps sustain the number of donor BM cells after intra$\mathrm{BM}$ injection, resulting in rapid hematopoietic recovery. Bone Marrow Transplant Oct 5. [Epub ahead of print]

5. Uchida Y, Sakamoto S, Egawa H, Ogawa K, Ogura Y, Taira K, Kasahara M, Uryuhara K, Takada Y, Kamiyama Y, Tanaka K and Uemoto S (2009) The impact of meticulous management for hepatic artery thrombosis on longterm outcome after pediatric living donor liver transplantation. Clin Transplant 23(3): 392-399

6. Saito T, Matsumura K, Tsubota Y, Maniwa T, Kaneda H, Minami K, Sakaida N, Uemura Y, Kawa G, Yamamoto N, Fujii Y, Isobe K, Kawakami Y, Matsuda T, Saito Y and Takekoshi K (2009) Novel Mutation (L157X) in the Succinate Dehydrogenase B Gene (SDHB) in a Japanese Family with Abdominal Paraganglioma Following Lung Metastasis. Endocr J 56(3): 451-458

7. Wang X, Hisha H, Mizokami T, Cui W, Cui Y, Shi A, Song C, Okazaki S, Li Q, Feng W, Kato J and Ikehara S (2009) Mouse Mesenchymal Stem Cells Can Support Human Hemopoiesis both In Vitro and In Vivo: Crucial Role of Neural Cell Adhesion Molecule (NCAM). Haematologica Dec 16. [Epub ahead of print]

8. Mizokami T, Hisha H, Okazaki S, Takaki T, Wang XL, Song CY, Li Q, Kato J, Hosaka N, Inaba M, Kanzaki H and Ikehara S (2009) Preferential expansion of human umbilical cord blood-derived CD34-positive cells on major histocompatibility complex-matched amnionderived mesenchymal stem cells. Haematologica 94(5): 618-628

9. Satoi S, Yanagimoto $\mathrm{H}$, Toyokawa $\mathrm{H}$, Tanigawa $\mathrm{N}$, Komemushi A, Matsui Y, Mergental H, Araki H, Takai S and Kamiyama Y (2009) Pre-operative patient selection of pancreatic cancer patients by multi-detector row CT. Hepatogastroenterology 56(90): 529-534

10. Miyake T, Hosaka N, Cui W, Nishida T, Takaki T, Inaba M, Kamiyama Y and Ikehara S (2009) Adult Thymus Transplantation with Allogeneic Intra-Bone MarrowBone Marrow Transplantation from Same Donor Induces High Thymopoiesis, Mild Graft-Versus-Host Reaction and Strong Graft-Versus-Tumor Effects. Immunology 126(4): 552-564

11. Yanai S, Adachi Y, Fuijisawa J, Jiang S, Okigaki M, Shi M, Shima C, Imai Y, Kwon AH and Ikehara S (2009) Antitumor effects of fusion cells of type 1 dendritic cells and Meth A tumor cells using hemagglutinating virus of Japan-envelope. Int J Oncol 35(2): 249-255

12. Kaibori M, Matsui K, Ishizaki M, Saito T, Kitade H, Mat- sui Y and Kwon AH (2009) Hepatic resection for hepatocellular carcinoma in the elderly. J Surg Oncol 99(3): 154-160

13. Satoi S, Yanagimoto H, Toyokawa H, Takahashi K, Matsui Y, Kitade H, Mergental H, Tanigawa $\mathrm{N}$ and Takai S, Kwon AH (2009) Surgical results after preoperativechemoradiation therapy for patients with pancreatic cancer. Pancreas 38(3): 282-288

14. Iwai A, Hamada Y, Takada K, Inagaki N, Nakatake R, Yanai H, Miki H, Araki Y, Sato M, Ono S, Iwai N and Kwon AH (2009) Choledochal cyst associated with duodenal atresia: case report and review of the literature. Pediatr Surg Int 25(11): 995-998

15. Inoue K, Nakane Y, Michiura T, Yamaki S, Yui R, Sakuramoto K, Iwai A, Tokuhara K, Araki Y, Kim S, Nakai K, Sato M, Yamamichi K and Kwon AH (2009) Feasibility and accuracy of second-look laparoscopy after gastrectomy for gastric cancer. Surg Endosc 23(10): 2307-2313

16. 吉岡和彦 (2009) 排泄障害の治療・ケア 排便障害 生活指導. Mod Physician 29(11): 1591-1593

17. 石原久美子, 北村 臣, 夜野敏明, 西村泰典, 仲野俊 成, 井上健太郎, 中根恭司, 今村洋二 (2009) 院内が 儿登録症例の予後調査の試み. 医療情報学 29(Suppl.): 886-888

18. 三島崇生，松田公志（2009）マスターしておきたい標 準的内視鏡外科手術 標準的腹腔鏡下副腎摘除術. 外科 治療 100 (増刊) : 630-635

19. 佐藤正人, 園田真理, 宮内雄也, 棚野晃秀, 高田晃平, 濱田吉則 (2009) 内視鏡手術 胸腔鏡下横隔膜縫縮術. 外科治療 100(6): 801-805

20. 里井壯平, 豊川秀吉, 柳本泰明, 北出浩章, 金 成泰, 權 雅憲, 山尾 順, 山本智久, 廣岡 智, 松井陽一 （2009）膵癌術後長期生存を得るための集学的治療戦 略. 癌の臨 55(8): 601-605

21. 佐藤正人, 園田真理, 高田晃平, 濱田吉則, 棚野晃秀 （2009）小児内視鏡手術の技術審査 : 私の術式 私の噴 門形成術. 小児外科 41(1): 54-58

22. 北村公美, 乾万記子, 中万里子, 杉本ももこ, 佐伯久 美子, 藤井由美子, 谷川良子, 岡崎 智, 高田秀穂 （2009）開腹手術患者における腹帯の使用は有用では ない. 消外Nurs 14(1): 117-120

23. 北村 臣, 石原久美子, 西村泰典, 仲野俊成, 里井壯 平, 宮崎浩彰（2009）電子カルテシステムにおけるク リニカルパス管理とその運用一診療情報管理士と医 療情報技師による医師・看護師のパスへの業務負担軽 減の試み一。 日クリニカルパス会誌 11(2): 213-216

24. 里井壯平, 豊川秀吉, 柳本泰明, 道浦 拓, 井上健太 郎, 松井陽一, 中根恭司, 權 雅憲, 宮崎浩彰, 北村

臣（2009）関西医科大学附属枚方病院に打ける消化 器癌診療と地域連携. 日クリニカルパス会誌 11(1): 85-87 
25. 海堀昌樹, 松井康輔, 石崎守彦, 斎藤隆道, 權 雅憲 （2009）C 型肝炎関連肝細胞癌に対する系統的および 非系統的肝切除の検討. 日外科系連会誌 34(5): 743751

26. 吉田 良, 岡崎 智, 高田秀穂, 權 雅憲 (2009) 腹 腔鏡下に修復した再発上腰ヘルニアの 1 例. 日臨外会 誌 70(9): 2889-2892

27. 中根恭司, 道浦 拓, 山田正法, 中井宏治, 井上健太 郎（2009）胃全摘後の空腸パウチの縫合・吻合. 臨外

$$
\text { 64(11): 118-121 }
$$

28. 里井壯平, 柳本泰明, 豊川秀吉, 高橋完治, 松井陽一, 北出浩章, Hynek Mergental, 谷川 昇, 高井惣一郎, 權 雅憲 (2009) 膵管癌に対する術前放射線化学療法 後外科的治療成績. 膵臓 24(5): 630-631

29. 廣岡 智, 里井壯平, 柳本泰明, 豊川秀吉, 山本智久, 山尾 順, 金 成泰, 松井陽一, 權 雅憲 (2009) 悪 性腫瘍に対する膵頭十二指腸切除術における自己血 輸血導入の有用性について。膵臓 24(4): 485-492

30. Yamamoto D, Hamada Y, Okazaki S, Kawakami K, Kanzaki S, Yamamoto C and Yamamoto M. (2009) Metastatic gastric tumor from renal cell carcinoma. Gastric Cancer 12(3): $170-173$

31. 里井壯平, 豊川秀吉, 柳本泰明, 山本智久, 山尾 順, 金 成泰, 松井陽一, 高井惣一郎, Hynek Mergental, 上山泰男（2009）膵頭十二指腸切除術後合併症を低減 させるための新指針．膵臓 24(1): 126-128

32. Matsui Y, Kamiyama Y (2009) Retrospective study in breast cancer patients supplemented with AHCC. International Journal of integrative oncology 3(2): 12-16

33. 佐藤正人, 宮内雄也, 園田真理, 棚野晃秀, 高田晃平 （2009）特集：小児内視鏡手術の適応拡大：安全な術 式と従来法との比較検討 胆道拡張症に対する補助 下手術. 小児外科 41(9): 966-971

34. Mari Sonoda, Masahito Sato, Yuya Miyauchi, Shujiro Yazumi, Makiko Nakamura (2009) A rare case of choledochocele associated with pancreas divism. Pediatr Surg Int 25(11): 991-994

35. 中田昌利, 宮内雄也, 園田真理, 佐藤正人（2009） Extended-spectrum beta-lactamase産生大腸菌のため術 後治療に難渋した急性虫垂炎の1例. 小児外科 41(7): $762-766$

総 説

1. 吉岡和彦, 徳原克治, 岩本慈能, 中根恭司, 權 雅憲 （2009）【外科における先進医療と高度医療】腹腔鏡下 直腸固定術. 外科 71(6): 619-623

2. Tsubura A, Yuri T, Yoshizawa K, Uehara N, Takada H. (2009) Role of fatty acids in malignancy and visual impairment: Epidemiological evidence and experimental studies. Histol Histopathol 24(2): 223-234

3. 吉岡和彦, 徳原克治, 岩本慈能, 中根恭司, 權 雅憲
（2009）手術手技 先進医療としての腹腔鏡下直腸固 定術の検討。手術 63(9): 1333-1337

4. 中根恭司 (2009) 術中偶発症への対応 器械吻合器を用 いた食道空腸吻合の偶発症に対する対策と予防. 手術 63(2): 243-247

5. 豊川秀吉, 里井壯平, 柳本泰明, 權 雅憲 (2009) 消 化器外科手術アトラス 膵頭部癌に対する膵頭十二指 腸切除術. 消外 32(9): 1399-1409

6. 道浦 拓, 中根恭司 (2009) 噴門側胃切除術 - 幽門保 存胃切除. 消外Nurs 14(11): 1105-1111

7. 道浦 拓, 井上健太郎, 岩井愛子, 中井宏治, 山道啓 吾, 中根恭司 (2009)【オーダーメイド医療を可能に する胃癌診断】この症例をどうする 機能温存手術の 有用性 選択基準とその内視鏡診断は? 消内視鏡 21(5): 801-806

8. 豊川秀吉, 權 雅憲（2009）黄色肉芽腫性胆囊炎の診 断と治療. 胆道 23(4): 649-653

9. 中根恭司, 道浦 拓, 井上健太郎, 山道啓吾 (2009) 胃迷入膵. 日臨 別冊（新領域別症候群シリーズ 11 消化管症候群（第2版）上）: 437-440

10. 吉岡和彦, 中根恭司, 權 雅憲 (2009) 肛門機能障害, 不全肛門括約筋不全. 日臨 別冊 (消化管症候群 (下)) : 865-868

11. 中根恭司, 道浦 拓, 岩井愛子, 桜本和人, KIM Songtae, 井上健太郎 (2009) 胃切除後の諸問題 2 胃切除後障害 (4) 逆流性食道炎の病態と対策. 臨消 内科 24(11): 1471-1476

12. 山中英治 (2009) からだのはたらき・消化, 吸収. Nutrition Care 2: 298-271

13. 山道啓吾, 元廣高之, 道浦 拓, 井上健太郎, 中根恭 司（2009）縫合不全ゼロをめざす消化管吻合術一ここ がポイント一胃全摘後の吻合術 (器械吻合)。手術 63(9): 1281-1287

14. 山中英治（2009）チーム医療各論一クリニカルパス. 臨病理レビュー 144: 223-227

15. 山中英治（2009）臓器別に学ぶがんの知識・治療・栄 養療法，食道がん．Nutrition Care 2: 366-370

16. 山中英治（2009）上部消化管外科の栄養管理と NST. 外科治療 100: 15-21

17. 山中英治（2009）DPC 時代におけるクリニカルパス. 看きろく看過程 19: 4-12

18. 山中英治（2009）がん地域連携クリティカルパスの意 義. 消外Nurs 14: 383-385

症例報告

1. 荒木吉朗, 吉岡和彦, 由井倫太郎, 岩本慈能, 中根恭 司，坂井田紀子（2009）潰瘍性大腸炎に対する回腸囊 肛門管吻合術後に腹痛と頻便にて著しい QOL の低下 を来した症例. Prog Med 29(7): 1866-1868

2. 荒木吉朗, 濱田吉則, 高田晃平, 岩井愛子, 中竹利知, 三木博和, 矢内洋次, 佐藤正人 (2009)【出生前診断 
の倫理と実際】出生前の胆道評価. 小児外科 41(5): 505-508

3. 荒木吉朗, 吉岡和彦, 岩本慈能, 山木 壮, 岩井愛子, 中根恭司, 權 雅憲, 松下光伸, 岡崎和一, 植村芳子 (2009) 極めて短い病悩期間で発症した Crohn 病に合 併した colitic cancerの1例. 日消器外誌４2(10): 15971602

4. 矢内勢司, 中井宏治, 徳原克治, 山道啓吾, 中根恭司, 權 雅憲 (2009) 肺病変で発見された胃MALTリンパ 腫の1例. 日臨外会誌 70(7): 1970-1974

5. 吉田 良, 北出浩章, 横井川規巨, 高田秀穂, 權 雅 憲（2009）腹腔鏡で切除した, 上行結腸癌術後異時性 孤立性脾転移の1例。日臨外会誌 70(6): 1831-1835

6. 吉田 良, 横井川規巨, 高田秀穂, 權 雅憲 (2009) 孤立性肝膿瘍を併発し，2期的手術により根治切除が 可能であった直腸癌の1例. 日臨外会誌 70(5): 14491453

7. 大石賢玄, 中井宏治, 川口雄才, 岩井 大, 四方伸明, 權 雅憲 (2009) 中咽頭, 食道, 胃, 盲腸同時性 4 重 複癌の 1 例。 日臨外会誌 70(12): 3745-3750

8. 中本博之, 箕浦俊之, 向出裕美, 四方伸明（2009）胃 癌胃全摘術後 5 年目の挙上腸管再発に対して再切除を 施行した1例。臨外 64(1): 119-123

9. 石崎守彦, 海堀昌樹, 斎藤隆道, 松井康輔, 權 雅憲 (2009) 自己免疫性肝炎に合併した非B非 C 型肝細胞癌 の1切除例. 日臨外会誌 70(12): 3628-3633

その他

1. 海堀昌樹, 岩本慈能, 石崎守彦, 松井康輔, 斎藤隆道, 吉岡和彦，權 雅憲（2009）大腸癌肝転移 H3(Grade C) 初回切除不能多発症例に対する術前補助化学療法 後肝切除術の成績. 癌と化療 36(13): 2579-2582

2. 山岡 学, 大西修司, 有元美代子, 市邊明美, 阿部 操, 館農美香, 大谷哲司, 森眞一郎, 福原資郎, 海堀 昌樹（2009）HLA抗体保有患者の生体肝移植症例。日 輸血細胞治療会誌５5(6): 711-716

\section{学会発表}

1. Satoi S, Yanagimoto H, Toyokawa H, Yui R, Yamamoto T, Hirooka S, Yamaki S, Takahashi K and Kwon AH (2009) Pre-Operative Chemoradiation Therapy for Patients with Pancreatic Cancer. 40th Anniversary Joint Meeting of the American Pancreatic Association \& Japan Pancreas Society, Honolulu, USA

2. Shimatani M, Takaoka M, Matsushita M, Satoi S and Okazaki K (2009) Effective Shot Double Balloon Enteroscope for Diagnostic and Therapeutic ERCP in Patients with Aletered Gastrointestinal Anatomy for Pancreatic Diseases. 40th Anniversary Joint Meeting of the American Pancreatic Association \& Japan Pancreas Society, Honolulu, USA
3. Yanagimoto H, Satoi S, Toyokawa H, Yamamoto T, Hirooka S, Yamao J, Araki H, Matsui Y and Kwon AH (2009) The Benefical Effect of Active Hexose Correlated Compound(AHCC), a Health Food Component, in Patients With Pancreatic or Biliary Tract Cancer Who Underwent Chemotherapy. 40th Anniversary Joint Meeting of the American Pancreatic Association \& Japan Pancreas Society, Honolulu, USA

4. Yui R, Satoi S, Yanagimoto H, Toyokawa H, Yamamoto T, Hirooka S, Yamaki S, Takahashi K, Matsui Y and Kwon AH (2009) A Non-Stented Duct-to-Mucosa Anstomosis Following Oancreaticoduodenectomy. 40th Anniversary Joint Meeting of the American Pancreatic Association \& Japan Pancreas Society, Honolulu, USA

5. Tomohito Saito,Takahito Nakano, Yosuke Ueyama, Hiroyuki Kaneda, Ken-ichiro Minami, Toshifumi Konobu and Yukihito Saito (2009) Spontaneous Pneumothorax in Women Refeffered for Surgery; A 19-year Experience in A Single Institute. CHEST2009, San Diego, United States

6. Tomohito Saito,Takahito Nakano, Yosuke Ueyama, Hiroyuki Kaneda, Ken-ichiro Minami, Toshifumi Konobu and Yukihito Saito (2009) A New Bioabsorbable CAPE Method for Prevention of Persistent Air Leaks and Recurrences after Video-Assisted Thoracoscopic Surgery for Spontaneous Pneumothorax; Report of Clinical Experience with Three Cases. CHEST2009, San Diego, United States

7. 高田晃平, 矢内洋次, 中竹利知, 三木博和, 浜田吉則 （2009）臀結合体の 1 例. 第 71 回日本臨床外科学会総 会, 京都

8. Imamura A, Miyaso T, Yamao J, Hijikawa T, Yamada M, Tsuji K, Yokoigawa N, Yanagida H, Takada H and Kwon AH (2009) Endovascular repair of a traumatic arteriovenous fistula at 20 years after lumbar disc surgery. The 10th Annual Congress of Asian Society for Vascular Surgery, Busan, Korea

9. Nakai K, Yamao J, Yamada M, Kitade H, Takada H and Kwon AH (2009) A case report of 3drugs combination chemotherapy. The 26th Congress of Pan-Pacific Surgical Association, Hong Kong

10. Yanagimoto H, Satoi S, Toyokawa H, Yamamoto T, Hirooka S, Yamao J, Matsui Y and Kwon AH (2009) The beneficial effect of active hexose correlated component, in patients with pancreatic or biliary tract cancer who underwent chemotherapy. 31st ESPEN Congress, Vienna, Austria

11. Matsumiya M, Arak Y, Matsuura T, Kaibori M, Okumura T, Nishizawa M and Kwon AH (2009) Kampo(Hochuekkito, TJ-41)inhibits the induction of iNOS gene expression in pro-inflammatory cytokine-stimulated hepato- 
cytes. 31th ESPEN Congress, Vienna, Austria

12. Yoshioka K, Hata Y, Tokuhara K, Iwamoto S, Nakane Y and Kwon AH (2009) Reconstruction or preservation of anus?: Comparison of functional results between graciloplasty after abdominoperineal resection and intersphicteric resection for lower rectal cancer. 第14回大腸肛門機 能カンファレンス The XIVth Conference on Colorectal and Anal Function, 東京

13. Kwon AH, Matsui Y, Toyokawa H, Tokuhara K and Inoue K (2009) Management of laparoscopic cholecyatectomy in patients with porcelain gallbladder. 17th International Congress of the European Association for Endoscopic Surgery, Prague, Czech Pepublic

14. Michiura T, Nakane Y, Iwai A, Nakai K, Yamamichi and Kwon AH (2009) Assessment of the preserved function of the remnant stomach in pylorus-preserving gastrectomy using gastric emptying scintigraphy. 8th International Gastric Cancer Congress, Krakow,Poland

15. Nakai K, Yamada M, Iwai A, Michiura T, Inoue K, Yamamichi K, Nakane Y and Kwon AH (2009) A case of advanced gastric cancer with cervical lymph node metastasis successfully treated with combined neo-adjuvant chemotherapy of TS-1,paclitaxel and lentinan. 8th International Gastric Cancer Congress, Krakow,Poland

16. Kuwata M, Yoshizawa K, Matsumura M, Takahashi K and Tsubura A. (2009) Ocular toxicity caused by paclitaxel in neonatal Sprague-Dowley rats. The 28 th Soc Toxicol Pathol Annual Symp, Washington DC

17. Iwai A, Nakane Y, Nakai K, Michiura T, Inoue K, Yamamichi K and Kwon AH (2009) Study for sentinel node biopsy with early gastric cancer. The 8th International Gastric Cancer Congress, Krakow, Poland

18. Yamada M, Nakai K, Michiura T, Inoue K and Nakane Y (2009) Two Patients of liver resection for metastatic gastric cancer. The 8th International Gastric Cancer Congress, ポーランド

19. Yoshioka K (2009) Persistent constipation after conservative management fails. 4th Colorectal Disease Symposium, 東京

20. Inoue K, Imamura H, Kimura Y, Fujitani K, Miyake Y, Matuyama J, Tatsumi M, Shimokawa T, Kurokawa Y and Furukawa H, (2009) A randomized phase III trial to determine the efficacy of postoperative antimicrobial prophylaxis in gastric cancer surgery (OGSG0501). ASCO Annual Meeting, Orlando,

21. Yamamoto D, Yoshida H, Iwase S, Odagiri H and Kitamura K (2009) TS-1 in patients with capecitabine-resistant breast cancer. ASCO, USA

22. Kaibori M, Ishizaki M, Matsui K, Saito T and Kwon AH (2009) Impact of fresh frozen plasma on hepatectomy for hepatocellular carcinoma. 19th APASL Conference,
Hong-Kong, China

23. Kaibori M, Ishizaki M, Matsui K, Saito T and Kwon AH (2009) HA/GSA-Rmax ratio as a predictor of postoperative liver failure. 19th APASL Conference, Hong-Kong, China

24. Masaki Kaibori, Morihiko Ishizaki, Kosuke Matsui, Takamichi Saito and A-Hon Kwon (2009) Hepatic resection for hepatocellular carcinoma in the elderly. 19th APASL Conference, Hong-Kong, China

25. 由井倫太郎, 里井壯平, 豊川秀吉, 柳本泰明, 山本智 久, 山木 壮, 廣岡 智, 松井陽一, 權 雅憲 (2009) 当院における膵体尾部切除術クリニカルパスの現況 第 10 回日本クリニカルパス学会学術集会. 第 10 回日 本クリニカルパス学会学術集会, 岐阜

26. 里井壯平, 由井倫太郎, 豊川秀吉, 柳本泰明, 荒木 浩, 栗本修次, 山本智久, 山木 壮, 廣岡 智, 權 雅憲（2009）当院における膵胆道癌切除例に対する地 域連携クリニカルパスの現況. 第10回日本クリニカル パス学会学術集会, 岐阜

27. 山木 壮, 豊川秀吉, 里井壯平, 柳本泰明, 山本智久, 松井陽一, 權 雅憲 (2009) 動脈浸潤膵癌に対して TS-1 による放射線化学療法と維持療法により腫瘍縮 小後に 根治切除となった 1 例. 第186回近畿外科学会, 大阪

28. 斎藤隆道, 海堀昌樹, 松井康輔, 石崎守彦, 中村竜也, 權 雅憲 (2009) 周術期における cefotiamの体内動態 解析と予防的投与に関する検討. 第 22 回日本外科感染 症学会総会学術集会, 山口

29. 佐藤正人, 園田真理, 宮内雄也（2009）小児外科領域 に打ける腹腔鏡下癒着剥離術の経験. 第 22 回日本内視 鏡外科学会総会, 東京

30. 山道啓吾, 大石賢玄, 岩城隆二, 元廣高之 (2009) 単 孔式腹腔鏡下胆囊摘出術における術式の工夫. 第22回 日本内視鏡外科学会総会, 東京

31. 福井淳一, 西憲一郎, 濱野宣行, 山道啓吾, 道浦 拓, 中尾慎一, 大倉ひろ枝, 高橋伯夫, 新宮 興, 權 雅 憲（2009）食道癌周術期におけるシベレスタットナト リウム投与の有効性についての検討. 第71回日本臨床 外科学会総会, 京都

32. 園田真理, 佐藤正人, 宮内雄也（2009）重症心身障害 児に対する腹腔鏡下噴門形成術における learinhg curveの検討. 第22 回日本内視鏡外科学会総会, 東京

33. 宮内雄也，佐藤正人，園田真理（2009）腹腔鏡下虫垂 切除術は赤字手術か? 当院での診療報酬改定前後の 比較検討. 第22回日本内視鏡外科学会総会, 東京

34. 橋田裕毅, 吉田昌弘, 佐藤正人, 中西保貴, 園田真理, 吉村弥緒, 高橋英雄, 吉富摩美, 多田正晴, 上田修吾, 寺嶋宏明, 尾崎信弘 (2009) 完全直腸脱に対する腹腔 鏡下Ripstein法直腸固定術の検討. 第22 回日本内視鏡 外科学会総会, 東京

35. 中西保貴, 橋田裕毅, 佐藤正人, 園田真理, 吉村弥緒, 
高橋英雄, 吉田昌弘, 吉富摩美, 多田正晴, 上田修吾, 寺嶋宏明, 尾崎信弘 (2009) 腹腔鏡下に摘出し得た人 工股関節置換術後 Kirschner wire骨盤内迷入の1例. 第 22 回日本内視鏡外科学会総会, 東京

36. 岡島 愛, 是枝ちづ, 吉川恵史, 池田耕造, 関 寿人, 岡崎和一, 北出浩章, 四方伸明（2009）14年間の経過 観察にて進行が緩徐であったPBCの1例. 第38回日本 肝臓学会西部会, 鳥取県

37. 山中英治（2009）NSTが目指す新たな栄養サポートシ ステム. 日本医療マネジメント学会 第 5 回和歌山支 部学術集会, 和歌山

38. 山中英治 (2009) 栄養管理の標準化とチーム医療連携. 第 12 回長崎県NST研究会, 長崎

39. 岩井愛子, 海堀昌樹, 中竹利知, 石崎守彦, 斎藤隆道, 松井康輔, 權 雅憲 (2009) 肝癌右葉切除術後に良性 胆管狭窄を来した 1 例. 第186回近畿外科学会, 大阪

40. 矢内洋次, 高田晃平, 中竹利知, 浜田吉則, 權 雅憲 (2009) 膵 solid and cystic tumor の 1 例. 第 186 回近畿 外科学会, 大阪

41. 吉田秀行, 山本大悟, 權 雅憲 (2009) 当院における 超音波ガイド下マンモトーム生検の検討. 第19回日本 乳癌検診学会総会, 札幌

42. 石原久美子, 北村 臣, 夜野敏明, 西村泰典, 仲野俊 成, 井上健太郎, 中根恭司, 今村洋二（2009）院内が 儿登録症例の予後調査の試み. 第29回医療情報学連合 大会 (第10回日本医療情報学会学術大会), 広島

43. 山道啓吾, 河野由美子, 大石賢玄, 岩城隆二, 元廣高 之 (2009) 腹腔鏡補助下幽門側胃切除術後, 残胃壊死 を来した 1 例. 第39回胃外科・術後障害研究会, 仙台

44. 岩本慈能, 海堀昌樹, 吉岡和彦, 徳原克治, 岡㟝 智, 向出裕美, 松井康輔, 斎藤隆道, 中根恭司, 權 雅憲 （2009）術前化学療法を行い肝切除したGradeB, C大 腸癌肝転移症例の検討. 第47回日本癌治療学会学術集 会, 横浜

45. 岩本慈能, 吉岡和彦, 岡㠃 智, 徳原克治, 向出裕美, 中根恭司, 權 雅憲 (2009) 進行・再発大腸癌に対す るCetuximabの使用経験. 第47回日本癌治療学会学術 集会, 横浜

46. 笠原憲子, 上山庸佑, 高田晃平, 浜田吉則, 權 雅憲 （2009）反復性腸重積の 1 例. 第5 72 回大阪外科集談会, 大阪

47. 林佑伊子, 岩井愛子, 山尾 順, 宮宗武史, 尾崎 岳, 山田正法, 肱川 健, 辻 勝成, 横井川規巨, 柳田英 佐, 中井宏治, 吉田 良, 北出浩章, 今村 敦, 高田 秀穂（2009）偽還納ヘルニアの 1例. 第 572 回大阪外 科集談会, 大阪

48. 柳本泰明, 里井壯平, 豊川秀吉, 山本智久, 廣岡 智, 山木 壮, 由井倫太郎, 權 雅憲 (2009) 膵癌の術前 進展度診断における staging laparoscopy の有用性. 第 58 回近畿膵疾患談話会, 大阪

49. 吉田 良, 高田秀穂, 中万里子, 大枝由紀 (2009) 終
末期大腸癌における緩和的外科手術の有効性と問題 点. 第64回日本大腸肛門病学会学術集会, 福岡

50. 大石賢玄, 川口雄才, 上山庸佑, 岡崎 智, 宮宗武史, 尾崎 岳, 山田正法, 横井川規巨, 中井宏治, 今田世 紀, 吉田 良, 北出浩章, 今村 敦, 高田秀穂, 權 雅憲（2009）腹膜悪性中皮腫の1例. 第70回日本臨床 外科学会総会, 東京

51. 河野由美子, 大石賢玄, 岩城隆二, 元廣高之, 山道啓 吾（2009）幽門側胃切除後残胃壊死の1例. 第71回日 本臨床外科学会総会, 京都

52. 海堀昌樹, 斎藤隆道, 松井康輔, 石崎守彦, 北出浩章, 松井陽一, 權 雅憲 (2009) 肝細胞癌肝切除合併症ゼ 口を目指した我々の工夫. 第71回日本臨床外科学会総 会, 京都

53. 岩井愛子, 斎藤隆道, 石崎守彦, 松井康輔, 海堀昌樹, 中村竜也, 權 雅憲（2009）周術期における cefotiam の体内動態解析と予防的投与に関する検討. 第71回日 本臨床外科学会総会, 京都

54. 岩本慈能, 吉岡和彦, 徳原克治, 岡㟝 智, 向出裕美, 中根恭司, 權 雅憲 (2009) 外科医が行うがん化学療 法はいかにあるべきか? 一大腸がん外来化学療法で の効率化と工夫一. 第71回日本臨床外科学会総会, 京 都

55. 吉田 良, 高田秀穂, 權 雅憲 (2009) 終末期に打け る緩和的外科手術の有効性と問題点. 第 71回日本臨床 外科学会総会, 京都

56. 向出裕美, 井上健太郎, 道浦 拓, 徳原克治, 高橋完 治, 福井淳一, 藤田洋子, 中根恭司, 權 雅憲 (2009) P0Cy1 胃癌に対する second-look laparoscopy に基づい た化学療法. 第71回日本臨床外科学会総会, 京都

57. 山道啓吾, 道浦 拓, 桜本和人, 金 成泰, 中井宏治, 井上健太郎，元廣高之，中根恭司，權 雅憲 (2009) cT4進行食道癌に対する治療戦略. 第71回日本臨床外 科学会総会, 京都

58. 山本智久, 柳本泰明, 里井壯平, 豊川秀吉, 荒木 浩, 栗本修次, 由井倫太郎, 廣岡 智, 權 雅憲 (2009) 大学病院胆膵外科チームにおける外来化学療法. 第 71 回日本臨床外科学会総会, 京都

59. 松井康輔, 海堀昌樹, 斎藤隆道, 石崎守彦, 岩本慈能, 吉岡和彦, 浜田吉則, 高田秀穂, 權 雅憲 (2009) 大 腸癌転移性肝癌における肝切除後早期再発に対する 治療戦略. 第71回日本臨床外科学会総会, 京都

60. 真鍋和代, 豊川秀吉, 里井壯平, 柳本泰明, 山本智久, 由井倫太郎, 山木 壮, 廣岡 智, 松井陽一, 權 雅 憲（2009）膵囊胞性腫瘍と鑑別が困難であった後腹膜 Cystic Lymphanginomaの1例. 第71回日本臨床外科学 会総会, 京都

61. 石崎守彦, 海堀昌樹, 松井康輔, 斎藤隆道, 岩本慈能, 吉岡和彦, 權 雅憲 (2009) 大腸癌肝転移 H3(Grade C) 症例に対する術前補助化学療法後肝切除術の成績. 第71回日本臨床外科学会総会, 京都 
62. 菱川秀彦, 斎藤隆道, 岩井愛子, 石崎守彦, 松井康輔, 海堀昌樹, 權 雅憲 (2009) 集学的治療により著名な 縮小を認めた巨大肝海綿状血管腫の1例．第71回日本 臨床外科学会総会, 京都

63. 豊川秀吉, 里井壯平, 柳本泰明, 山木 壮, 由井倫太 郎, 廣岡 智, 高橋完治, 松井陽一, 權 雅憲 (2009) 膵管径 $3 \mathrm{~mm}$ 以下の症例における膵頭十二指腸切除術 後膵腸吻合法の工夫とその治療成績. 第71回日本臨床 外科学会総会, 京都

64. 矢内勢司, 今田世紀, 權 雅憲 (2009) 肝膿瘍を契機 に発見された直腸癌の一例. 第71回日本臨床外科学会 総会, 京都

65. 柳本泰明, 里井壯平, 豊川秀吉, 山本智久, 高橋完治, 由井倫太郎, 山木 壮, 廣岡 智, 金 成泰, 山尾 順，權 雅憲 (2009) 大学病院における緩和ケアチー 厶活動一その現状と問題点一. 第71回日本臨床外科学 会総会, 京都

66. 由井倫太郎, 豊川秀吉, 里井壯平, 柳本泰明, 山木 壮, 廣岡 智, 山本智久, 高橋完治, 松井陽一, 權 雅憲（2009）膵頭部癌に対する術前放射線化学療法後 の膵頭十二指腸切除術. 第 71 回日本臨床外科学会総 会, 京都

67. 里井壯平, 岩本慈能, 井上健太郎, 道浦 拓, 豊川秀 吉, 柳本泰明, 吉岡和彦, 中根恭司, 權 雅憲 (2009) 大学病院に打けるがん診療地域連携クリティカルパ 又導入のための取り組み. 第71回日本臨床外科学会総 会, 京都

68. 權 雅憲, 里井壯平, 豊川秀吉, 柳本泰明, 由井倫太 郎, 山本智久, 道浦 拓, 井上健太郎, 廣岡 智, 松 井陽一 (2009) 当科に打ける膵頭十二指腸切除術の教 育プログラム。第71回日本臨床外科学会総会, 京都

69. 園田真理，佐藤正人（2009） delayed appendectomy. 第 24 回大阪小児栄養消化器病懇話会, 大阪

70. 岩本慈能, 吉岡和彦, 徳原克治, 向出裕美, 岡謧 智, 中根恭司 (2009) 進行・再発大腸癌に対する Bevacizymb, Cetuximabの使用経験. 日本大腸肛門病 学会学術集会, 福岡

71. 桜本和人, 向出裕美, 岡㠃 智, 徳原克治, 岩本慈能, 吉岡和彦（2009）当施設に打ける大腸㕷室炎の検討. 日本大腸肛門病学会学術集会, 福岡

72. 徳原克治, 吉岡和彦, 岩本慈能, 中根恭司 (2009) EMR 後に外科的追加切除を要した大腸癌の検討. 日本大腸 肛門病学会学術集会, 福岡

73. 福井淳一，岩本慈能，徳原克治，吉岡和彦，中根恭司 （2009）機能的端々吻合（FEEA）の吻合線で局所再発 をきたした結腸癌の 2 例. 日本大腸肛門病学会学術集 会, 福岡

74. 柳田英佐，北出浩章，横井川規巨，尾崎 岳，辻 勝 成, 高田秀穂, 權 雅憲 四方伸明 (2009) 肝原発力 ルチノイドの 1 切除例. 北河内肝臓疾患懇話会, 大阪

75. 里井壯平, 豊川秀吉, 柳本泰明, 山本智久, 廣岡 智,
由井倫太郎, 山木 壮, 高橋完治, 權 雅憲 (2009) 術前保護化学放射線療法の成績と課題. 厚生労働科学 研究 (がん臨床研究) 推進事業 局所進行膵癌に対す る集学的治療セミナー, 大阪

76. 棚野晃秀（2009） IntervalAppendectomy ができなかっ た Dropout症例の検討. 第 29 回日本小児内視鏡外科・ 手術手技研究会, 鹿児島

77. 高田晃平, 佐藤正人, 岩井愛子, 中竹利知, 上山庸佑, 三木博和，矢内洋次，荒木吉朗，浜田吉則 (2009) 先 天性横隔膜以上に対する治療戦略. 第29回日本小児内 視鏡外科・手術手技研究会 (第25回日本小児外科学会 秋季シンポジウム)，鹿児島

78. 佐藤正人 (2009) 腹腔鏡下癒着剥離術の経験. 第29回 日本小児内視鏡外科・手術手技研究会（第25回日本小 児外科学会秋季シンポジウム)，鹿児島

79. 中井宏治, 山田正法, 岩井愛子, 道浦 拓, 井上健太 郎，中根恭司，權 雅憲（2009）胃切除後早期の上部 消化管内視鏡検査 poor studyの検討。第 39 回胃外科・ 術後障害研究会, 仙台

80. 岩井愛子, 道浦 拓, 向出裕美, 福井淳一, 高橋完治, 井上健太郎，中根恭司，權 雅憲（2009）当施設にお ける胃癌術後早期合併症の検討. 第39回胃外科 - 術後 霜害研究会, 仙台

81. 吉田 良, 三頭佐知子, 佐伯久美子, 脇口智香, 高岡 千晶, 高田秀穂, 權 雅憲 (2009) 外科主導の緩和ケ アの問題と今後の取り組み. 第 47 回日本癌治療学会学 術集会, 横浜

82. 吉田秀行, 山本大悟, 田中完児, 權 雅憲 (2009) 乳 癌術前化学療法としての AC followed by paclitaxelの検 討. 第 47 回日本癌治療学会学術集会, 横浜

83. 向出裕美, 岩本慈能, 岡崎 智, 徳原克治, 吉岡和彦, 中根恭司, 權 雅憲 (2009) Bevacizumab 併用化学療 法を施行し重篤な有害事象をきたした 2 例。第47回日 本癌治療学会学術集会, 横浜

84. 中井宏治, 岡㟝 智, 山田正法, 尾崎 岳, 柳田英佐, 横井川規巨，道浦 拓，井上健太郎，中根恭司，權 雅憲（2009）Stage IV 胃癌症例に対し，DCS療法を施 行した 1 例. 第 47 回日本癌治療学会学術集会, 横浜

85. 尾崎 岳, 岡㠃 智, 宮宗武史, 山田正法, 肱川 健, 过 勝成, 横井川規巨, 柳田英佐, 中井宏治, 吉田 良, 北出浩章, 今村 敦, 高田秀穂, 權 雅憲 (2009) 膵管癌に対する膵頭十二指腸切除後に左心房転移が 疑われた 1 例. 第 47 回日本癌治療学会学術集会, 横浜 86. 豊川秀吉, 里井壯平, 柳本泰明, 山本智久, 廣岡 智, 山木 壮, 由井倫太郎，權 雅憲 (2009) 術前放射線 化学療法後に上腸間静脈血栓症を併発し根治切除を 施行した切除可能膵癌の一例. 第58回近畿膵疾患談話 会, 大阪

87. 里井壯平, 豊川秀吉, 柳本泰明, 山本智久, 廣岡 智, 山木 壮, 由井倫太郎, 權 雅憲 (2009) 膵癌に対す る術前放射線化学療法の成績とその課題. 第58回近畿 
膵疾患談話会, 大阪

88. 石田侑子, 井上健太郎, 古村洋子, 畑井陽二, 福永千 佳子, 梅木若葉, 角森恭子, 勝田麻衣子, 北村 臣, 篠原良実, 小松千紘, 斯波幸絵, 宮垣美和, 大枝由紀, 加藤知子, 西辻知恵美, 南嶋明日香, 横出多美, 高岡 千晶, 道浦 拓, 中井宏治, 中根恭司 (2009) がん チーム医療に打ける患者会の役割。第 5 回関西がん チーム医療研究会, 大阪

89. 柳本泰明, 北浦祐一, 中村桐子, 松森恵理, 打谷和記, 仲村明美，竹中てる子，小島博之，富永敦子，高瀬勝 教, 權 雅憲, 中根恭司 (2009) 大学病院における緩 和ケアチームの立ち上げの現状と問題点. 第 5 回関西 がんチーム医療研究会, 大阪

90. 佐藤正人, 薗田真理, 宮内雄也, 高田晃平, 浜田吉則 （2009）高位鎖肛に対する腹腔鏡補助下鎖肛根治術. 第 66 回直腸肛門奇形研究会 (第 25 回日本小児外科学会 秋季シンポジウム)，鹿児島

91. 尾崎岳, 海堀昌樹, 權 雅憲, 西澤幹雄, 奥村忠芳 （2009）炎症性サイトカインの肝iNOS誘導とグルココ ルチコイドによる iNOS アンチセンス転写物を介した 阻害機構. 第 82 回日本生化学会, 神戸

92. 園田真理, 佐藤正人, 宮内雄也（2009）当院における Interval appendectomy症例の検討．第29回日本小児内 視鏡外科・手術手技研究会, 鹿児島

93. 宮内雄也, 園田真理, 佐藤正人（2009）鎖肛を伴わな い直腸腔瘦の 1 例. 第 29 回日本小巟内視鏡外科 - 手術 手技研究会, 鹿児島

94. 宮内雄也, 佐藤正人, 園田真理（2009）脳腫瘍治療中 に中心静脈カテーテル周囲に血栓形成を起こした一 例. 第 62 回小児外科わからん会, 大阪

95. 溝上智英子, 松本真由美（2009）裖瘡患者に対する NST介入や地域連携を含めた当院での取り組み. 第 11 回日本䙏瘡学会学術集会, 大阪

96. 齊藤 朋人, 笠原 憲子, 馬庭 知弘, 金田 浩由紀, 南 健一郎, 齊藤 幸人 (2009) ブラ新生から気胸発 症までの経時的画像変化が追跡できた 1 例，第 13 回 日本気胸・囊胞性肺疾患学会総会, 大阪

97. 齊藤 朋人, 笠原 憲子, 馬庭 知弘, 金田 浩由紀, 南 健一郎, 齊藤 幸人（2009）当院における女性気 胸症例の臨床病理学的検討. 第13回 日本気胸 - 異胞 性肺疾患学会総会, 大阪

98. 笠原憲子, 金田浩由紀, 齊藤朋人, 南 健一郎, 齊藤 幸人（2009）急性骨髄性白血病後の慢性GVHDに合併 した難治性気胸の一例. 第13回日本気胸・囊胞性肺疾 患学会, 大阪

99. 山中英治（2009）緩和医療における栄養管理. 第22回 阪神緩和医療研究会, 西宮

100. 里井壯平, 岩本慈能, 井上健太郎, 道浦 拓, 豊川秀 吉, 柳本泰明, 吉岡和彦, 中根恭司, 權 雅憲 (2009) 大学病院におけるがん診療地域連携クリティカルパ ス. 第 31 回日本臨床栄養学会総会 第 30 回日本臨床
栄養協会総会 第7回大連合大会, 神戸

101.圦貴司, 大石賢玄, 横井川規巨，兼松清果，頼 彦 長, 三城弥範, 高田秀穂, 螺良愛郎. (2009) 脾横行 結腸間膜巨大腫瘍の 1 例.. 第 41 回日本臨床分子形態学 会, 神戸

102.矢内洋次, 高田晃平, 石井紘介, 岩井愛子, 中竹利 知，浜田吉則（2009）小児臍ヘルニア嵌頓の1例．第 45 回日本小児外科学会近畿地方会, 神戸

103.豊川秀吉, 里井壯平, 柳本泰明, 山尾 順, 金 成 泰, 廣岡 智, 山本智久, 山木 壮, 由井倫太郎, 松 井陽一, 權 雅憲 (2009) 切除不能胆囊癌におけるマ イクロターゼ凝固とサイトカイン局所注入による免 疫療法. 第45回日本胆道学会学術集会, 千葉

104.里井壯平, 豊川秀吉, 柳本泰明, 山本智久, 廣岡 智, 由井倫太郎, 山木 壮, 松井陽一, 權 雅憲 (2009) 十二指腸乳頭部癌と十二指腸癌切除例における背景 因子の比較. 第 45 回日本胆道学会学術集会, 千葉

105. 安藤奈央美, 中竹利知, 海堀昌樹, 岩本慈能, 石㠃守 彦, 斎藤隆道, 松井康輔, 吉岡和彦, 權 雅憲 (2009) 術前化学療法による画像上 CR 症例に対し肝切除した 大腸癌肝転移の 1 例. 第 571 回大阪外科集談会, 大阪

106. 黒田友顯, 山尾 順, 宮宗武史, 尾崎 岳, 山田正 法, 肱川 健, 辻 勝成, 横井川規巨, 柳田英佐, 中 井宏治, 吉田 良, 北出浩章, 今村 敦, 高田秀穂 （2009）腸管気腫性のう胞症の一例. 第571回大阪外科 集談会, 大阪

107.山中英治（2009）地域全体の医療を良くするクリニカ ルパス. 第15回道南パス研究会, 函館

108. 岩井愛子, 中竹利知, 矢内洋次, 三木博和, 荒木吉 朗, 高田晃平, 演田吉則（2009）先天性十二指腸閉鎖 症に合併した先天性胆道拡張症の 1 例. 第 32 回日本 膵・胆管合流異常研究会, 東京

109. 山本智久, 里井壯平, 豊川秀吉, 柳本泰明, 由井倫太 郎, 山木 壮, 廣岡 智, 松井陽一, 權 雅憲 (2009) 当科に打ける過去 5 年間の膵頭十二指腸切除術クリニ カルパス. 第36回日本膵切研究会, 和歌山

110.豊川秀吉, 里井壯平, 柳本泰明, 山本智久, 由井倫太 郎, 廣岡 智, 高橋完治, 山木 壮, 權 雅憲 (2009) 当科に打ける膵液漏低減策としての膵腸吻合部補強 方法. 第36回日本膵切研究会, 和歌山

111.柳本泰明, 里井壯平, 豊川秀吉, 由井倫太郎, 山木 壮, 山本智久, 高橋完治, 廣岡 智, 松井陽一, 權 雅憲（2009）膵頭十二指腸切除術における大網被覆の 意義. 第36回日本膵切研究会, 和歌山

112.里井壯平, 柳本泰明, 豊川秀吉, 由井倫太郎, 山木 壮, 山本智久, 高橋完治, 廣岡 智, 松井陽一, 權 雅憲（2009）膵頭十二指腸切除術における no stent法 の功罪. 第36回日本膵切研究会, 和歌山

113.上山庸佑, 高田晃平, 岡㠃 智, 真鍋和代, 岩井愛 子, 中竹利知, 矢内洋次, 浜田吉則 (2009) 卵巣の一 部から発生し茎捻転で発症した卵巣腫瘍の1例。第 45 
回日本小児外科学会近畿地方会, 神戸

114. 園田真理, 佐藤正人, 宮内雄也（2009）当院における Interval appendectomyの検討. 第 45 回日本小児外科学 会近畿地方会, 神戸

115.坪田 優 (2009) 特異な進展形式で大胸筋浸潤を呈し た浸潤性小葉癌の一例。第 17 回 日本乳癌学会学術総 会, 東京

116. 新崎孝夫, 弥山秀芳, 米田篤司, 茨木隆宏, 北中直 子, 阪口博保, 高橋伯夫, 柳田英佐, 横井川規巨, 高 田秀穂 (2009) 抗精神薬による重篤な低血糖. 第17回 クリニカルファーマシーシンポジウム, 京都

117. 石崎守彦, 吉田秀行, 山本大悟, 權 雅憲 (2009) 乳 癌再発患者の癌性疼痛に対する病棟での取り組み. 第 17 回日本乳癌学会学術集会, 東京

118. 岩井愛子, 吉田秀行, 兼松清果, 山本大悟, 田中完 児, 權 雅憲 (2009) 乳癌術後放射線治療中にイレウ スを景気に発見した大腸癌の 1 例. 第 17 回日本乳癌学 会学術総会, 東京

119. 吉田秀行, 山本大悟, 兼松清果, 矢内洋次, 小路徹 二, 田中完児, 權 雅憲 (2009) 当院におけるステレ オガイド下マンモトーム生検例の検討. 第17回日本乳 癌学会学術総会, 東京

120. 矢内洋次, 山本大悟, 吉田秀行, 兼松清果, 小路徹 二, 田中完児, 權 雅憲（2009）S-1 投与により間質 性肺炎を来たした転移性乳癌の1例。第17回日本乳癌 学会学術総会, 東京

121. 里井壯平 (2009) がん連携パスから「関西医科大学附 属枚方病院における消化器がん地域連携パスの取り 組み」. 第2回合同クリニカルパス大会, 大阪

122.伊藤昭宏, 里井壯平, 豊川秀吉, 柳本泰明, 山本智 久, 由井倫太郎, 山木 壮, 大江千里, 植村芳子, 坂 井田紀子, 權 雅憲 (2009) 術前診断に難渋した solid serous adenomaの 1 切除例. 第 40 回日本膵蔵学会大会, 東京

123.山本智久, 柳本泰明, 里井壯平, 豊川秀吉, 廣岡 智, 山尾 順, 金 成泰, 權 雅憲 (2009) 膵癌患者 末梢血における CD4 + CD25+CD127－制御性 T細胞 の検討. 第 40 回日本膵臓学会大会, 東京

124. 山木 壮, 里井壯平, 豊川秀吉, 柳本泰明, 山本智 久, 由井倫太郎, 高岡 亮, 岡㠃和一, 大江千里, 植 村芳子, 坂井田紀子, 權 雅憲（2009）当院における 局所進行ならびに切除可能膵癌症例の術前診断の現 状. 第 40 回日本膵臓学会大会, 東京

125. 豊川秀吉, 里井壯平, 柳本泰明, 荒木 浩, 栗本修 次, 山本智久, 由井倫太郎, 山木 壮, 廣岡 智, 松 井陽一, 權 雅憲 (2009) 膵胆道癌切除例に対する地 域連携クリティカルパス導入のための取り組み. 第 40 回日本膵蔵学会大会, 東京

126.柳本泰明, 里井壯平, 豊川秀吉, 山本智久, 山木 壮, 由井倫太郎, 廣岡 智, 高岡 亮, 岡﨑和一, 權 雅憲（2009）当科における膵癌の進展度診断一
MDCT と staging laparoscopyの有用性. 第40回日本脺 蔵学会大会, 東京

127.柳本泰明, 里井壯平, 豊川秀吉, 山本智久, 山木 壮, 由井倫太郎, 廣岡 智, 高岡 亮, 岡㠃和一, 權 雅憲（2009）当科に打ける膵癌の進展度診断一 MDCT と staging laparoscopyの有用性. 第 40 回日本膵 臓学会大会, 東京

128. 里井壯平, 豊川秀吉, 柳本泰明, 山本智久, 由井倫太 郎, 山木 壮, 廣岡 智, 松井陽一, 權 雅憲 (2009) 脺癌切除可能例に対する術前進展度診断と術前化学 放射線治療の実績. 第40回日本膵蔵学会大会, 東京

129. 木畑智哲, 豊川秀吉, 里井壯平, 柳本泰明, 山本智 久, 由井倫太郎, 山木 壮, 廣岡 智, 松井陽一, 權 雅憲（2009）膵囊胞性腫瘍と鑑別が困難であった巨大 後腹膜海綿状血管腫の 1 例. 第 40 回日本膵蔵学会大会, 東京

130. 井上健太郎, 中根恭司, 道浦 拓, 山木 壮, 由井倫 太郎, 荒木吉朗, 桜本和人, 山道啓吾, 權 雅憲 (2009) 胃 GIST に対する腹腔鏡下胃局所切除術. 第63 回日本 消化器外科学会総会, 札幌

131.海堀昌樹, 松井康輔, 斎藤隆道, 石崎守彦, 權 雅憲 （2009）ICG 赤外観察カメラシステムを用いた肝切除 後難治性胆汁漏の防止対策. 第64回日本消化器外科学 会, 大阪

132.徳原克治, 吉岡和彦, 岩本慈能, 中根恭司, 權 雅憲 （2009）右側結腸癌に対する腹腔鏡下手術の医療経済 的検討. 第 64 回日本消化器外科学会, 大阪

133. 井上健太郎, 中根恭司, 道浦 拓, 徳原克治, 三木博 和, 石㠃守彦, 山道啓吾, 權 雅憲 (2009) Second Look Laparoscopyの結果からみた, P0Cy1症例に対する胃癌 手術の位置づけ. 第64回日本消化器外科学会総会, 大 阪

134. 吉岡和彦, 畑 嘉高, 徳原克治, 岩本慈能, 中根恭 司, 權 雅憲 (2009) 直腸癌での有茎薄筋移植肛門再 建術と内括約筋切除肛門温存術の術後排便機能の比 較検討. 第64回日本消化器外科学会総会, 大阪

135. 荒木吉朗，松宮美保，松浦 節，海堀昌樹，奥村忠 芳, 西澤幹雄, 權 雅憲 (2009) 好中球エラスターゼ 阻害薬 sivelestatによる肝のiNOS誘導阻害. 第64回日 本消化器外科学会総会, 大阪

136. 山道啓吾, 道浦 拓, 桜本和人, 岩井愛子, 金 成 泰, 中井宏治, 井上健太郎, 中根恭司, 權 雅憲 (2009) Non-T4 StageII/III 食道癌に対する治療戦略, 特にT3症 例に対する治療法について. 第64回日本消化器外科学 会総会, 大阪

137. 山本智久, 柳本泰明, 里井壯平, 豊川秀吉, 廣岡 智, 山尾 順, 金 成泰, 高橋完治, 權 雅憲 (2009) 脺癌患者における末梢血制御性 $\mathrm{T}$ 細胞 (Treg) 測定の 意義. 第64回日本消化器外科学会総会, 大阪

138. 石崎守彦, 海堀昌樹, 松井康輔, 斎藤隆道, 北出浩 章, 松井陽一, 權 雅憲 (2009) 当科に打ける高齢者 
155例に対する肝細胞癌切除症例の問題点第64回日本 消化器外科学会総会, 大阪

139.中根恭司（2009）残胃癌に対する治療戦略第 64 回日 本消化器外科学会総会, 大阪

140.豊川秀吉, 里井壯平, 柳本泰明, 山本智久, 由井倫太 郎, 高橋完治, 金 成泰, 山尾 順, 松井陽一, 權 雅憲（2009）高齢者における膵頭十二指腸切除術後肺 合併症対策. 第64回日本消化器外科学会総会, 大阪

141.柳本泰明, 里井壯平, 峯 孝志, 豊川秀吉, 山本智 久, 塩見尚礼, 山田 亮, 岡 正朗, 伊東恭悟, 權 雅憲 (2009) 膵癌における免疫化学療法の新展開. 第 64 回日本消化器外科学会総会, 京都

142. 里井壯平, 柳本泰明, 豊川秀吉, 山木 壮, 由井倫太 郎, 廣岡 智, 山本智久, 高橋完治, 松井陽一, 權 雅憲（2009）膵頭十二指腸切除術における膵腸吻合の no stent法の治療成績. 第64回日本消化器外科学会総 会, 大阪

143. 岩本慈能, 吉岡和彦, 徳原克治, 岡㠃 智, 向出裕 美, 中根恭司, 權 雅憲 (2009) pStage2 症例に対す る補助化学療法. 第71回大腸癌研究会, 埼玉

144. 松本真由美, 山本大悟, 兼松清果, 吉田秀行, 奥川帆 麻, 小路徹二, 田中完児, 權 雅憲 (2009) 異常乳頭 分泌症例の検討. 第17回日本乳癌学会学術総会, 東京

145. 吉田昌弘, 佐藤正人, 中西保貴, 小山幸法, 郡司周太 郎，多田正晴，上田修吾，橋田裕毅，寺嶋宏明，尾崎 信弘（2009）完全直腸脱に対する腹腔鏡下 Ripstein 法 直腸固定術の有用性の検討. 第64回日本消化器外科学 会総会, 大阪

146. 山中英治, 池田幸子, 川辺文恵（2009）地域医療支援 病院を中心とした中核市に打ける医療安全対策推進 活動. 第11回日本医療マネジメント学会学術総会, 長 崎

147.久松洋司, 安田勝彦, 溝上友美, 中元 剛, 生田明 子，杉本久秀，堀越順彦，横井川規巨，北出秀章，高 田秀穂，神崎秀陽（2009）診断に苦慮した子宮体癌術 後の上行結腸転移の 1 症例。第 120 回近畿産科婦人科 学会学術集会, 神戸市

148. 荒木吉朗, 松宮美保, 松浦 節, 海堀昌樹, 奥村忠 芳, 西澤幹雄, 權 雅憲 (2009) 好中球エラスターゼ 阻害薬 sivelestatによる肝細胞のiNOS誘導阻害. 第 16 回肝細胞研究会, 山形

149. 向出裕美, 岩本慈能, 岡崎 智, 徳原克治, 吉岡和 彦, 中根恭司, 權 雅憲 (2009) Bevacizumab 併用化 学療法施行し重篤な有害事象をきたした 2 例. 第 185 回近畿外科学会, 神戸

150.山木 壮, 里井壯平, 柳本泰明, 豊川秀吉, 北出浩 章, 金 成泰, 山尾 順, 山本智久, 廣岡 智, 松井 陽一, 權 雅憲（2009）膵頭十二指腸切除後膵液漏の 予測因子とドレーン管理. 第185回近畿外科学会, 神戸 151.木畑智哲, 豊川秀吉, 里井壯平, 柳本泰明, 山本智 久, 由井倫太郎, 山木 壮, 廣岡 智, 松井陽一, 權
雅憲（2009）膵囊胞性腫瘍と鑑別が困難であった巨大 後腹膜海綿状血管腫の 1 例. 第 185 回近畿外科学会, 神 戸

152. 矢内洋次, 吉田秀行, 石崎守彦, 山本大悟, 權 雅憲 （2009）ビスフォスフォネート製剤（BP）投与中に顎 骨壊死 $(\mathrm{ONJ})$ を発症した乳癌骨転移の 2 症例。第 185 回近畿外科学会, 大阪

153.柳本泰明, 里井壯平, 塩見尚礼, 豊川秀吉, 山本智 久, 廣岡智, 山田亮, 岡 正朗, 伊藤恭悟, 權 雅憲（2009）進行膵癌における化学療法併用癌ペプチ ドワクチンの開発. 第18回日本癌病態治療研究会, 福 島

154.海堀昌樹, 藤田洋子, 松井康輔, 斎藤隆道, 石㠃守 彦, 岩本慈能, 吉岡和彦, 權 雅憲 (2009) 大腸癌肝 転移に対する切除時期と術前化学療法を考慮した集 学的治療戦略. 第 21 回日本肝胆膵外科学会 - 学術集 会, 名古屋

155.海堀昌樹, 松井康輔, 斎藤隆道, 石崎守彦, 北出浩 章, 松井陽一, 河 相吉, 權 雅憲 (2009) 肝細胞癌 に対する肝予備能評価の新たな指標. 第21回日本肝胆 膵外科学会・学術集会, 名古屋

156.山木 壮, 里井壯平, 豊川秀吉, 柳本泰明, 由井倫太 郎, 道浦 拓, 山本智久, 廣岡 智, 松井陽一, 權 雅憲（2009）卒後6年時外科医師からみた当科におけ る膵頭十二指腸切除後の教育体制と高度技能医への 道. 第21回日本肝胆膵外科学会・学術集会, 名古屋

157.松井康輔, 海堀昌樹, 斎藤隆道, 石崎守彦, 狩谷秀 治, 谷川 昇, 權 雅憲（2009）生体肝移植術後門脈 閉塞症に対する予測と対策. 第21回日本肝胆膵外科学 会・学術集会, 名古屋

158. 斉藤隆道, 海堀昌樹, 松井康輔, 石㠃守彦, 權 雅憲 （2009） ICG 赤外観察カメラシステムを用いた肝切除 後胆汁瘦の防止対策. 第 21 回日本肝胆膵外科学会 - 学 術集会, 名古屋

159. 菱川秀彦, 里井壯平, 内田一茂, 豊川秀吉, 柳本泰 明, 山本智久, 山木 壮, 由井倫太郎, 高岡 亮, 植 村芳子, 坂井田紀子, 岡㠃和一, 權 雅憲 (2009) 長 期観察を行った肝と膵の炎症性偽腫瘍の1例. 第21回 日本肝胆膵外科学会・学術集会, 名古屋

160.豊川秀吉, 里井壯平, 柳本泰明, 山木 壮, 山本智 久, 由井倫太郎, 山尾 順, 金 成泰, 松井陽一, 權 雅憲（2009）当科における膵頭部癌に対する膵頭十二 指腸切除術. 第2 2 回日本肝胆膵外科学会 - 学術集会, 名古屋

161.木畑智哲, 里井壯平, 山木 壮, 柳本泰明, 豊川秀 吉, 由井倫太郎, 松井陽一, 權 雅憲, 坂井田紀子, 大江千里, 植村芳子（2009）十二指腸狭窄をきたした 急性膵炎を伴う粘膜非高産生性IPMCの 1 例。第 21 回 日本肝胆膵外科学会・学術集会, 第21回日本肝胆膵外 科学会・学術集会

162.由井倫太郎, 里井壯平, 豊川秀吉, 柳本泰明, 山木 
壮, 廣岡 智, 山本智久, 高橋完治, 松井陽一, 權 雅憲（2009）膵体尾部切除後クリニカルパスの導入効 果. 第21回日本肝胆膵外科学会・学術集会, 名古屋 163. 里井壯平, 柳本泰明, 豊川秀吉, 山木 壮, 由井倫太 郎, 廣岡 智, 山本智久, 高橋完治, 松井陽一, 權 雅憲（2009）膵頭十二指腸切除術に打ける膵管チュー ブと術後合併症の関連一ロストチューブvs 体外ドレ ナージ一. 第 21 回日本肝胆膵外科学会・学術集会, 名 古屋

164. 完山理咲, 松井康輔, 岩本慈能, 海堀昌樹, 斎藤隆 道, 石崎守彦, 吉岡和彦, 權 雅憲 (2009) 術前補助 化学療法を行い肝切除した大腸癌肝転移症例の検討. 第21回日本肝胆膵外科学会学術集会, 名古屋

165. 石崎守彦, 海堀昌樹, 斎藤隆道, 松井康輔, 權 雅憲 （2009）当科に打ける肝硬変合併小肝細胞癌に対する 肝部分切除手技. 第 21 回日本肝胆膵外科学会学術集 会, 名古屋

166. 柳本泰明, 里井壯平, 豊川秀吉, 山本智久, 由井倫太 郎, 山木 壮, 廣岡 智, 山尾 順, 權 雅憲 (2009) 進行膵癌における癌ペプチドワクチン開発. 第21回日 本肝胆膵外科学会学術集会, 名古屋

167. 吉田 良, 岡㟝 智, 宮宗武史, 室田卓之, 高田秀 穂, 權 雅憲 (2009) 腹腔鏡下に修復した, 再発上腰 ヘルニアの1例. 第34回日本外科系連合学会学術集会, 東京

168.吉田 良, 大石賢玄, 岡㠃 智, 杉素彦, 高田秀穂, 權 雅憲 (2009) 腹腔鏡に膀胱鏡を併用して手術を施 行した, S 状結腸膀胱瘦の 1 例. 第 34 回日本外科系連 合学術集会, 東京

169. 高田晃平, 中竹利知, 三木博和, 矢内洋次, 荒木吉 朗, 佐藤正人, 浜田吉則 (2009) 臍部人工肛門造設術 の検討．第46回日本小児外科学会学術集会，大阪

170. 高田晃平, 中竹利知, 三木博和, 矢内洋次, 荒木吉 朗, 浜田吉則 (2009) 腸管部分拡張症の 1 例. 第46回 日本小児外科学会学術集会, 大阪

171. 矢内洋次, 高田晃平, 中竹利知, 三木博和, 浜田吉則 （2009）先天性恥骨前瘦孔の 1 例。第 46 回日本小児外 科学会学術集会, 大阪

172. 山道啓吾, 道浦 拓, 岩井愛子, 櫻本和人, 金 成 泰, 中井宏治, 井上健太郎, 中根恭司, 權 雅憲 (2009) cT4 食道癌の治療方針. 第 52 回関西胸部外科学会学術 集会, 岡山

173. 山道啓吾, 田中義人, 道浦 拓, 岩井愛子, 桜本和 人, 中井宏治, 井上健太郎, 中根恭司，權 雅憲，谷 川 昇 (2009) 食道癌周術期管理の up to date : 術後乳 糜胸の管理，特にリンパ管造影の有用性について．第 63 会日本食道学会学術集会, 横浜

174. 道浦 拓, 山道啓吾, 岩井愛子, 桜本和人, 金 成 泰, 中井宏治, 井上健太郎, 柴田斉子, 中根恭司, 權 雅憲 (2009) 当科における周術期リハビリテーション. 第63会日本食道学会学術集会, 横浜
175. 岩井愛子, 山道啓吾, 道浦 拓, 中井宏治, 金 成 泰, 中根恭司, 權 雅憲, 森 茂生 (2009) 食道癌術 後吻合部狭窄に対する Radial Incision and Cutting(RIC) 法が有効であった2例. 第63回日本食道学会学術集会, 横浜

176. 宮内雄也, 園田真理, 佐藤正人（2009）急性腹症にて 発症した大網囊腫の 1 例. 第 185 回近畿外科学会, 神戸

177. 園田真理, 宮内雄也, 佐藤正人（2009）特異な経過を たどった choledochoceleの 1 例. 第 23 回大阪小児栄養 消化器病懇話会, 大阪

178. 園田真理, 佐藤正人, 宮内雄也（2009）臍ヘルニア嵌 頓の 1 例. 第 23 回日本小児救急医学会, 熊本

179. 宮内雄也, 佐藤正人, 園田真理（2009）自然破裂をき たした腎孟尿管移行部狭窄症の 1 例. 第 46 回日本小児 外科学会総会, 大阪

180.佐藤正人, 園田真理, 宮内雄也（2009）反復性腹痛に 対する腹腔鏡手術の経験. 第 46 回日本小児外科学会総 会, 大阪

181.海堀昌樹, 松井康輔, 斎藤隆道, 石崎守彦, 北出浩 章，松井陽一，權 雅憲（2009）C型肝炎関連肝細胞 癌に対する系統的および非系統的肝切除の検討. 日本 外科系連合学会, 東京

182.柳本泰明, 里井壯平, 峯 孝志, 塩見尚礼, 豊川秀 吉, 山本智久, 廣岡 智, 山田 亮, 岡 正朗, 伊東 恭悟, 權 雅憲 (2009) 進行膵癌における癌ペプチド ワクチン開発. 第 30 回癌免疫外科研究会, 久留米

183.稲垣詔子, 岩本慈能, 岩井愛子, 徳原克治, 吉岡和 彦, 中根恭司, 權 雅憲 (2009) 機能的端々吻合 (FEEA) の吻合線で局所再発をきたした結腸癌の 2 例。第 568 回大阪外科集談会, 大阪

184.中川 桂, 里井壮平, 内田一茂, 豊川秀吉, 柳本泰 明, 山本智久, 山木 壮, 由井倫太郎, 高岡 亮, 植 村芳子, 坂井田紀子, 岡崎和一, 權 雅憲 (2009) 長 期観察を行った肝と膵の炎症性偽腫瘍の 1 例。第 569 回大阪外科集談会, 大阪

185.足立 靖, 石 明, 矢内勢司, 嶋 千絵子, 今井雄一 郎, 池原 進 (2009) Tie2 発現細胞特異的にFGFレセ プター 2 を発現させたトランスジェニックマウスにお ける造血系細胞の解析. 第98回 日本病理学会総会, 京 都

186. 矢内勢司, 足立 靖, 石 明, 嶋 千絵子, 今井雄一 郎, 池原 進 (2009) 樹状細胞とマウス線維肉腫との 融合細胞を用いた抗腫瘍効果の検討. 第 98 回 日本病 理学会総会, 京都

187.今井雄一郎, 足立 靖, 比舎弘子, 石 明, 矢内勢 司，嶋 千絵子，金子一成，池原 進（2009）骨䯣移 植後のマウスに発生したドナ一由来未熟白血病細胞 株の樹立とその解析. 第98回 日本病理学会総会, 京 都

188. 石 明, 足立 靖, 矢内勢司, 嶋 千絵子, 今井雄一 郎，池原 進（2009）骨髄内骨髄移植法に打けるコ 
ラーゲン・ゲルの有用性. 第 98 回 日本病理学会総

会, 京都

189.嶋千絵子, 足立 靖, 石 明, 矢内勢司, 今井雄一 郎, 高橋寛二, 池原 進 (2009) 骨髄由来樹状細胞の 骨䯣内投与による抗腫瘍効果の検討. 第98回 日本病 理学会総会, 京都

190.佐藤正人（2009）安全に楽しく食べる. 医療的ケアの 会, 和歌山

191. 井上健太郎, 中根恭司, 道浦 拓, 徳原克治, 石崎守 彦, 中竹利知, 三木博和, 矢内洋次, 岩井愛子, 山道 啓吾, 權 雅憲 (2009) 胃癌集学的治療におけるSecond Look Laparoscopy の役割. 第 109 回日本外科学会定期 学術集会, 福岡

192.海堀昌樹, 松井康輔, 石崎守彦, 斎藤隆道, 岩本慈 能, 北出浩章, 松井陽一, 山道啓吾, 吉岡和彦, 浜田 吉則, 高田秀穂, 權 雅憲 (2009) 大腸癌肝転移に対 する切除時期を考慮した外科治療成績. 第109回日本 外科学会定期学術集会, 福岡

193. 岩井愛子, 中井宏治, 櫻本和人, 山木 壮, 由井倫太 郎, 道浦 拓, 井上健太郎, 山道啓吾, 中根恭司, 權 雅憲（2009）胃癌に対するICG試薬を用いたセンチネ ルリンパ節生検の問題点. 第 109 回日本外科学会定期 学術集会, 福岡

194. 岩本慈能, 吉岡和彦, 向出裕美, 岡㟝 智, 徳原克 治, 中根恭司, 權 雅憲 (2009) 進行 - 再発大腸癌に 対する bevacizumabの使用経験. 第109回日本外科学会 定期学術集会, 福岡

195. 吉岡和彦, 畑 嘉高, 徳原克治, 岩本慈能, 中根恭 司, 權 雅憲 (2009) 肛門温存か新肛門再建か? 下部 直腸癌に対する腹会陰式直腸切断術後有茎薄筋移植 とISRの術後排便機能の比較検討. 第 109 回日本外科 学会定期学術集会, 福岡

196. 高田晃平, 三木博和, 矢内洋次, 中竹利知, 佐藤正 人, 浜田吉則 (2009) 臍部人工肛門造設術の検討. 第 109 回日本外科学会定期学術集会, 福岡

197. 山道啓吾, 道浦 拓, 浅井 晃, 岩井愛子, 中竹利 知, 石崎守彦, 金 成泰, 中井宏治, 井上健太郎, 中 根恭司, 權 雅憲 (2009) 局所高度進行食道癌の治療 方針 : 術前科学放射線+手術 vs 根治的化学放射線 療法. 第109回日本外科学会定期学術集会, 福岡

198. 山尾 順, 豊川秀吉, 金 成泰, 里井壯平, 山本智 久, 廣岡 智, 柳本泰明, 松井陽一, 權 雅憲 (2009) 著名な繊維化を伴うラット膵癌モデルの作成. 第 109 回日本外科学会定期学術集会, 福岡

199. 山本智久, 柳本泰明, 里井壯平, 豊川秀吉, 廣岡 智, 山尾 順, 金 成泰, 高橋完治, 寺川直良, 權 雅憲（2009）膵癌患者における制御性 T 細胞（Treg） 評価の意義. 第109回日本外科学会定期学術集会, 福岡 200. 山木 壮, 里井壯平, 柳本泰明, 豊川秀吉, 北出浩 章, 金 成泰, 山尾 順, 山本智久, 廣岡 智, 松井 陽一, 權 雅憲 (2009) 膵頭十二指腸切除術後膵液漏
の予測因子とドレーン管理. 第 109 回日本外科学会定 期学術集会, 福岡

201.浜田吉則（2009）小児胆管径の基準值に関する検討一 日本膵・胆管合流異常研究会診断基準検討委員会報告 第一報一。第109回日本外科学会定期学術集会, 福岡 202.豊川秀吉, 里井壯平, 柳本泰明, 山尾 順, 金 成 泰, 廣岡 智, 山本智久, 山木 壮, 松井陽一, 權 雅憲（2009）切除不能胆囊癌におけるマイクロターゼ 凝固とサイトカイン局所注入による免疫療法（臨床試 験)。第109回日本外科学会定期学術集会, 福岡

203. 北出浩章, 辻 勝成, 宮宗武史, 横井川規巨, 大石賢 玄, 里井壯平, 豊川秀吉, 海堀昌樹, 尾崎 岳, 松井 陽一, 權 雅憲 (2009) ICGR15 不良症例に対する肝 右葉切除術一残存肝のアシアロ糖蛋白受容体量測定 の有用性一.第109回日本外科学会定期学術集会, 福岡 204. 矢内勢司, 足立 靖, 權 雅憲, 池原 進 (2009) マ ウス線維肉腫に対する樹状細胞と腫瘍細胞との融合 細胞による抗腫瘍効果の検討. 第109回日本外科学会 定期学術集会, 福岡

205. 由井倫太郎, 里井壯平, 豊川秀吉, 柳本泰明, 山木 壮, 廣岡 智, 松井陽一, 權 雅憲 (2009) 膵体尾部 切除術クリニカルパスが定着したか?.第109回日本 外科学会定期学術集会, 福岡

206.里井壯平，豊川秀吉，柳本泰明，北出浩章，金 成 泰, 山尾 順, 山本智久, 廣岡 智, 松井陽一, 權 雅憲（2009）膵癌術後長期生存を得るための集学的治 療戦略. 第109回日本外科学会定期学術集会, 福岡

207. 山本知恵, 松島貴志, 楠本健司, 稲垣隆介, 濱田吉 則, 高田晃平, 大橋 敦 (2009) 腰部結合双胎分離症 例の経験. 第 52 回日本形成外科学会総会・学術集会, 横浜市

208. 吉田昌弘, 佐藤正人, 園田真理, 中西保貴, 小山幸 法, 郡司周太郎, 多田正晴, 上田修吾, 橋田裕毅 (2009) 骨盤内臓臓器脱を考慮した完全直腸脱に対する Ripstein法直腸固定術. 第109回日本外科学会総会, 福岡 209. 佐藤正人, 園田真理, 棚野晃秀, 高田晃平, 演田吉則 （2009）腹腔鏡下脾臓摘出術一年齢別に見た術式の相 違一自験例からの検討. 第 109 回日本外科学会総会, 福岡

210.豊川秀吉, 里井壯平, 柳本泰明, 山尾 順, 金 成 泰, 廣岡 智, 山本智久, 山木 壮, 由井倫太郎, 松 井陽一, 權 雅憲 (2009) 切除不能癌におけるマイク ロターゼ凝固とサイトカイン局所注入による免疫療 法 (臨床試験)。第102回大阪胆道疾患研究会, 大阪

211.Inoue K, Sato M, Hirooka S, Matsumoto M, Iwai A, Miki $\mathrm{H}$, Michiura T, Yamamichi K, Nakane Y and Kwon AH (2009) Hospital corporation in staging laparoscopy. 第81 回日本胃癌学会総会, 東京

212. 三木博和, 井上健太郎, 岩井愛子, 中竹利知, 石崎守 彦, 山木 壮, 徳原克治, 道浦 拓, 中井宏治, 山道 啓吾, 中根恭司, 權 雅憲 (2009) 当施設に打ける最 
近の胃癌化学療法の生存期間. 第81回日本胃癌学会総 会, 東京

213. 中井宏治, 山田正法, 上山庸佑, 岩井愛子, 道浦 拓, 井上健太郎, 山道啓吾, 川口雄才, 中根恭司, 權 雅憲（2009）TS-1を2年間継続使用している POCY1 胃 癌の 2 症例. 第 81 回日本胃癌学会総会, 東京

214. 中井宏治, 山田正法, 上山庸佑, 岩井愛子, 道浦 拓, 井上健太郎, 山道啓吾, 川口雄才, 中根恭司, 權 雅憲（2009）TS-1を2年間継続使用している P0CY1胃 癌の 2 症例. 第 81 回日本胃癌学会総会, 東京

215.中島 淳, 高岡 亮, 島谷 昌明, 星野 勝一, 小薮 雅紀, 楠田 武生, 若松 隆宏, 朝山 俊樹, 吉川 恵史, 加藤 孝太, 池浦 司, 関 壽人, 岡崎 和一 （2009）経鼻膵管ドレナージが有効であった

閉塞性化膿性膵管炎の 1 例. 第 82 回日本消化器内視鏡 学会近畿地方会, 大阪

216. 園田真理, 佐藤正人, 宮内雄也, 高田晃平, 演田吉則 （2009）小児腸重積に対する腹腔鏡下手術の検討．第 45 回日本腹部救急医学会総会, 東京

217.園田真理, 佐藤正人, 宮内雄也（2009）診断に難渋し た反復性腹痛の 1 例. 第 61 回小肾外科加から几会, 大阪

218. 荒木吉朗, 松宮美保, 松浦 節, 里井壮平, 邱澤雨, 海堀昌樹, 權 雅憲, 奥村忠芳, 西澤幹雄 (2009) 肝 蔵における好中球エラスターゼ阻害薬 sivelestat (ELASPOL) による一酸化窒素合成酵素 (iNOS) の誘 導阻害. 立命館大学R-GIROシンポジウム, 滋賀

219.柳田英佐, 北出浩章, 横井川規巨, 宮宗武史, 尾崎 岳, 辻 勝成 (2009) 術中下静脈損傷から大量出血し た肝細胞癌の 2 症例. 近畿外科研究会, 大阪

220. 矢内洋次, 金田浩由紀, 馬庭知弘, 齊藤幸人（2009） 前緃隔腫瘍に対する術前ステロイドパルス治療の経 験. 第22回LKカンファレンス特別講演会, 大阪

221.山中英治 (2009) 患者も医療者も満足できる周術期管 理のベストプラクティス. 第 8 回周術期ケア研究会, 大阪

222.中井宏治 (2009) 本院における緩和医療への取り組み $\sim$ 大学病院 . 第 1 回北河内緩和医療研究会, 大阪

223. 山中英治, 前田泰孝, 野口佳奈子, 山脇あやめ, 新田 勉（2009）脳卒中連携パスの推進と栄養療法クリニカ ルパス．第24回日本静脈経腸栄養学会, 鹿児島

224. 野口薰, 弥山秀芳, 北中直子, 米田篤司, 茨木隆 宏, 坂口博保, 大田由子, 横井川規巨, 高田秀穂 (2009) 化学療法終了後 1 ケ月程度経過してから発症した手足 症候群. 第 30 回日本病院薬剂師会-近畿学術大会, 大阪 225.藤田洋子, 山道啓吾, 道浦 拓, 岩井愛子, 荒木吉 朗, 石㠃守彦, 徳原克治, 井上健太郎, 中根恭司, 權 雅憲（2009）アカラシア合併食道悡室の 2 例. 第 567 回大阪外科集談会, 大阪

226.徳原克治, 吉岡和彦, 岩本慈能, 中根恭司, 權 雅憲 （2009）直腸癌に対する腹腔鏡下手術の医療経済的検 討. 第70回大腸癌研究会, 東京
227.佐藤正人，園田真理，宮内雄也，浜田吉則（2009）小 児横隔膜疾患に対する鏡視下手術一機能温存と低侵 襲の追求. 第 22 回日本内視鏡外科学会総会, 東京

228. 向出裕美, 岩本慈能, 吉岡和彦, 徳原克治, 岡崎 智, 中根恭司, 權 雅憲 (2009) Bevacizumab 併用化 学療法に原発巣切除は必要か?.第64回日本大腸肛門 病学会学術集会, 福岡

229. 山本大悟, 吉田秀行, 山本智寿子, 權 雅憲 (2009) 乳がん多発転移に新規分子標的薬剤 Lapatinib が奏効 した 1 例. 第 47 回日本癌治療学会学術集会, 横浜

230. 井上健太郎, 里井壯平, 海堀昌樹, 岩本慈能, 山本大 悟, 道浦 拓, 中根恭司, 權 雅憲 (2009) 当院に打 けるキャンサーボードの現況. 第5 回関西がんチーム 医療研究会, 大阪

231. 山本大悟, 岩瀬 哲, 北村 薰, 小田桐弘毅, 山本智 寿子, 南雲吉則 (2009) 切除不能または再発乳癌の1st ラインに対するXeloda/TS-1 療法の比較試験（多施設 共同臨床第II相試験). 第17回日本乳癌学会学術集会, 東京

232.植野啓介, 中竹利知, 井上健太郎, 福井淳一, 島谷昌 明, 岡崎和一, 大江知里, 植村芳子, 中根恭司, 權 雅憲（2009）小腸内視鏡点墨後に腹腔鏡補助下に切除 したコレステリン塞栓による多発小腸狭窄の 1 例. 第 570 回大阪外科集談会, 大阪

233. 由井倫太郎, 里井壯平, 豊川秀吉, 柳本泰明, 山木 壮, 廣岡 智, 山本智久, 高橋完治, 松井陽一, 權 雅憲（2009）膵体尾部切除術クリニカルパスの導入効 果. 第36回日本膵切研究会, 和歌山

234.稲垣詔子, 高田晃平, 岩井愛子, 中竹利知, 矢内洋 次, 浜田吉則 (2009) 頭蓋骨内出血を合併した胆道閉 鎖症の 1 例. 第 45 回日本小児外科学会近畿地方会, 神戸 235. 宮内雄也, 園田真理, 佐藤正人, 飯田ちひろ, 水本 洋，秦 大資 (2009) 小腸閉鎖術後に増悪した一過性 高インスリン性低血糖の 1 例. 第 45 回日本小児外科学 会近畿地方会, 神戸

236.今村 敦 (2009) 動脈疾患に対する血管内治療. 都島 $\mathrm{PAD}$ カンフレンス, 大阪

237. 寺川直良, 北川克彦, 小田道夫, 山中英治（2009）保 存的に治癒した大腸 ESDによる気胸の1例. 第 13 回中 河内消化器病研究会, 大阪

238. 由井倫太郎, 里井壯平, 豊川秀吉, 柳本泰明, 山本智 久, 山木 壮, 廣岡 智, 松井陽一, 權 雅憲 (2009) ドレーン管理の変更が膵体尾部切除術後合併症に与 元る臨床的影響. 第 40 回日本膵㵴学会大会, 東京

239.池田耕造, 梅原秀人, 井口亮輔, 川股聖二, 福島慎太 郎, 関 寿人, 岡㠃和一, 辻 勝成, 北出浩章, 權 雅憲, 鷹巣晃昌, 四方伸明 (2009) 問題症例検討会 6 病理診断困難症例 3 . 第 45 回日本肝癌研究会, 福岡 240.依岡寬和, 笠松 敦, 椹木 晋, 神崎秀陽, 峰研治, 大橋敦, 木下洋, 金子一成, 高田晃平, 濱田吉則 (2009) 出生前診断した胎児肺分画症の 2 症例. 第 45 回日本周 
産期・新生児医学会学術集会, 名古屋市

241.Hamada Y, Takada K, Sato M (2009) Transumbilical stoma for very low birth weight infants. 10th European Congress of Peadiatric surgery, 56th Annual International Congress of the BAPS, Graz, Austria

242. 金 成泰, 豊川秀吉, 山尾 順, 里井壯平, 柳本泰 明, 山本智久, 廣岡 智, 松井陽一, 權 雅憲 (2009) Gemcitabine 感受性細胞株を用いたラット膵癌モデル に対する抗繊維化学法併用した化学療法. 第21回日本 肝胆膵外科学会・学術集会, 名古屋

243. 山本智久, 柳本泰明, 里井壯平, 豊川秀吉, 廣岡 智, 山尾 順, 金 成泰, 高橋完治, 寺川直良, 權 雅憲（2009）CD127抗体を用いた膵癌患者末梢血にお ける制御性 T 細胞の検討. 第 21 回日本肝胆膵外科学 会・学術集会, 名古屋

244. 園田真理, 佐藤正人, 宮内雄也 (2009) 診断に難渋し た choledochoceleの 1 例. 第 46 回日本小児外科学会総 会, 大阪

245. 道浦 拓, 山道啓吾, 岩井愛子, 徳原克治, 三木博 和，井上健太郎，中根恭司，權 雅憲 (2009) 食道非 上皮性腫瘍の悪性度診断. 第52回関西胸部外科学会学 術集会, 岡山

246. 岩井愛子, 中竹利知, 矢内洋次, 三木博和, 荒木吉 朗, 高田晃平, 浜田吉則 (2009) 先天性十二指腸閉鎖 症の術後に発症した膵・胆管合流異常の 1 例. 日本小 児外科学会学術集会, 大阪

247.今村 敦 (2009) 椎間板ヘルニア術後に生じた外傷性 動静脈瘻に対してステントグラフト留置を行った 1 例. 日本血管外科学会, ?

248. 寺川直良, 山中英治, 北川克彦, 小田道夫（2009）地 域医療支援救急病院における後期高齢者の消化器癌
手術症例の検討。第109回日本外科学会, 福岡 249. 山田正法, 中井宏治, 上山庸佑, 道浦 拓, 井上健太 郎, 海堀昌樹, 北出浩章, 山道啓吾, 川口雄才, 中根 恭司, 權 雅憲 (2009) 胃癌肝転移に対して肝切除施 行した2例. 第81回日本胃癌学会総会, 福岡

250. 岩井愛子, 井上健太郎, 道浦 拓, 石崎守彦, 三木博 和，中井宏治，金 成泰，山道啓吾，中根恭司，權 雅憲（2009）術後腹腔鏡検査施行症例からみた癒着防 止フィルムの有効性について. 第81回日本胃癌学会総 会, 東京

251. 米田篤司, 弥山秀芳, 北中直子, 茨木隆宏, 阪口博 保, 太田由子, 大石賢玄, 北出浩章, 高田秀穂 (2009) 急性腹症を契機に敗血症を発症し, 長期間集中治療を 要した蛋白漏出性胃腸症の一例. 日本薬学会第 129 年 会, 京都

\section{著 書}

1. 中根恭司, 道浦 拓, 井上健太郎 (2009) 噴門側胃切 除術. Digestive Surgery 食道 - 胃外科手術 6 標準手 術からのステップアップ 6 (上西紀夫, 後藤満一, 杉 山政則，渡邊昌彦編), Medical View

2. 山中英治（2009）症例でみるNSTの実際. NST完全ガ イド改訂版 79-80頁, 照林社, 東京

3. 中根恭司 (2009) パウチ法. 胃外科の要点と盲点 2 (荒井邦佳編）353-355頁，文光堂

4. 山中英治 (2009) 栄養療法の適応. 胃瘻ケアと栄養剤 投与法（西口幸雄編） 5-8頁，照林社，東京

5. 山中英治 (2009) 症例で学ぶ栄養アセスメントと栄養 療法一裖瘡. 栄養アセスメント\&ケアプラン（山中英 治編）151-160頁，メディカ出版，大阪

\section{胸部心臓血管外科学講座}

\section{〈研究概要〉}

[概要]

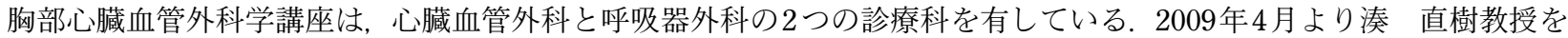
迎え, 臨床, 研究, 教育の面で, 新たな展開と講座の発展が期待される。心臓血管外科は循環器内科や小児科循環器グ ループとともに, 先天性心疾患, 虚血性心疾患, 弁膜症, 大動脈疾患等の疾患に対し, 内科と外科が一体となって臨床・ 研究活動を行っている. また, 呼吸器外科は, 肺癌, 転移性肺腫瘍, 悪性縦隔腫瘍, 重症筇無力症の外科治療を行い, 第 一内科呼吸器グループ, 放射線科治療部門, 病態検査科病理部門, 神経内科と研究グループを作り協力して臨床・研究 活動を行っている.

[臨床研究 $]$

心臓血管外科部門では，手術件数約 250 例である，臨床では，循環器グループ，小児循環器グループとも密接な関係を 保ち，術前より互いに協力して治療を行って抢り，成績向上のため，きめ細かい術前術後管理に努めている。虚血性心 疾患では, いわゆるオフポンプ冠動脈バイパス術を基本とし, さらに，バイパス困難症例に対しても，「内膜摘除＋onlay grafting」等の冠動脈形成術を駆使して動脈グラフトを用いた完全血行再建をめざしている．この際に，動脈グラフトを 使用した冠動脈形成術では，遠隔期に冠動脈の remodelling が起こり，冠動脈が一見正常化するような現象がある。この 好都合な現象に関する臨床研究を行っている，また，僧帽弁膜症においては，自己弁温存をはかる「弁形成術」を第一 選択とし，形成不可能な例に人工弁置換術を行う方針である。大血管疾患は，定期手術に加え，大動脈瘤破裂や急性大 
動脈解離などの超救急疾患も積極的に外科治療している. 大動脈弓部全置換は, 超低体温循環停止法と選択的脳潅流法 の併用により, 安全な手術が可能になった. また, 胸腹部大動脈置換時の大動脈遮断に伴う脊䯣麻痺の問題は世界的に も極めて重要であり, その予防法の研究をすすめている. これから開始する大動脈疾患の低侵襲治療としての「ステント グラフト治療」は今後の大動脈外科の主流となる可能性が高く, これらを含めた臨床, 研究いずれの分野も若手の活躍 の場としたい.

呼吸器外科は, 年間約 170 例の手術症例があり，その多くは原発性肺癌，悪性縦隔腫瘍，転移性腫瘍である，肺癌は， 地域医師会と協力し市民検診を積極的に行っており早期発見例が増加しており，治療成績は向上し，その成績を逐次公 表している．これら早期肺癌の外科手術にあたっては胸腔鏡を補助とした低侵襲手術を行うことを原則としている。し かし, 依然減少しない進行肺癌などに対しては呼吸器内科, 放射線科と協力し集学的治療を積極的に行い予後の改善に 努めている．自然気胸も数多い疾患であり，若年者が多い本疾患には胸腔鏡手術を多用している.

[研究]

平成21年度も，心臓血管外科，呼吸器外科ともに，これらの臨床経験に基づいた研究発表を行った。

心臓血管分野では，1）組織培養装置の導入による分子生物学的側面からの研究に基づいた心筋保護に関する臨床的, 基礎的研究 (心筀細胞特異的心筋保護法に関する研究, 統合的薬理学Preconditioningに関する研究), 2) 冠動脈形成術に おける冠動脈 remodelling，3）虚血性心疾患に対する骨髄幹細胞移殖による再生医療の研究などを行った。 また，4）大 阪工業大学生体システム研究室とともに生体流体力学の共同研究も進めている.

呼吸器外科分野では，1）肺癌に関する細胞免疫学的研究，2）全摘術後の対側肺嚢胞の予防的処理に関する検討，3） 肺切除術後のドレーン管理に関する臨床的評価，4）複数の腫瘍マーカーを統合的に用いた肺癌の診断の検討を行った. 実験的研究では，5）生体吸収性気管支ステントの開発とその臨床応用の研究を続け，6）ラット肺移植モデルにおける 移植後再還流障害の予防，7）肺腺癌における癌幹細胞の同定とその臨床的意義の検討にも19年度から取り組んでいる.

\section{〈研究業績〉}

原 著

1. Minato N, Katayama Y, Yunoki J, Kawasaki H and Satou $\mathrm{H}$ (2009) Hemostatic effectiveness of a new application method for fibrin glue, the "rub-and-spray method", in emergency aortic surgery for acute aortic dissection. Ann Thorac Cardiovasc Surg 15(4): 265-271

2. Nomura S, Shouzu A, Omoto S, Inami N, Shimazu T, Satoh D, Kajiura T, Yamada K, Urase F, Maeda Y and Iwasaka T (2009) Effects of pitavastatin on monocyte chemoattractant protein-1 in hyperlipidemic patients. Blood Coagulation and Fibrinolysis 20(6): 440-447

3. Saito T, Matsumura K, Tsubota Y, Maniwa T, Kaneda H, Minami K, Sakaida N, Uemura Y, Kawa G, Yamamoto N, Fujii Y, Isobe K, Kawakami Y, Matsuda T, Saito Y and Takekoshi K (2009) Novel Mutation (L157X) in the Succinate Dehydrogenase B Gene (SDHB) in a Japanese Family with Abdominal Paraganglioma Following Lung Metastasis. Endocr J 56(3): 451-458

4. Maniwa T, Saito Y, Saito T, Kaneda H and Imamura H (2009) Ossification does not cause any complication when a bronchial stump is reinforced with an intercostal muscle flap. Eur J Cardiothorac Surg 35(3): 435-438

5. Maniwa T, Saito Y, Saito T, Kaneda H and Imamura H (2009) Evaluation of chest computed tomography in patients after pneumonectomy to predict contralateral pneumothorax. Gen Thorac Cardiovasc Surg 57(1): 2832

6. Saito T, Shime N, Itoh K, Fujita N, Saito Y, Shinozaki M, Shibuya K, Makimura K and Hashimoto S (2009) Dis- seminated Aspergillosis Following Resolution of Pneumocystis Pneumonia with Sustained Elevation of BetaGlucan in an Intensive Care Unit: a Case Report. Infection 37(6): 547-550

7. Maniwa T, Kaneda H and Saito Y (2009) Management of a complicated pulmonary fistula caused by lung cancer using a fibrin glue-soaked polyglycolic acid sheet covered with an intercostal muscle flap. Interact Cardiovasc Thorac Surg 8(6): 697-698

8. Yunoki J, Minato N, Katayama Y and Sato H (2009) Mitral valve stenosis caused by abnormal pannus extension over the prosthetic ring and leaflets after Duran ring mitral annuloplasty. Journal of Cardiac Surgery 24(2): 143-145

9. Hattori R, Nakao Y, Okada T, Johno H, Enoki C, Sumida $\mathrm{T}$ and Imamura H. (2009) Repair of a recurrent pseudoaneurysm of the ascending aorta in an atomic bomb survivor with myelodysplastic syndrome. J Card Surg 24(4): 433-434

10. Hattori R, Oishi C, Iwasaka J, Iwasaka T, Okada T, Johno H, Enoki C, Sumida T, Nakao Y and Imamura H (2009) Multiple papillary fibroelastoma with quadricuspid aortic valve. J Thorac Cardiovasc Surg 137(5): 1280-1282

11. Shimazu T, Inami N, Satoh D, Kajiura T, Yamada K, Iwasaka T and Nomura S (2009) Effect of acarbose on platelet-derived microparticles, soluble selectins, andadiponectin in diabetic patients. $\mathrm{J}$ Thromb Thrombolysis 28(4): 429-435

12. Tatsuya Nakamura, Kazuo Okuchi, Takeshi Matsuyama, Hidetada Fukushima, Tadahiko Seki, Toshifumi Konobu 
and Kenji Nishio (2009) Clinical Significance of Elevated Natriuretic Peptide Levels and Cardiopulmonary Parameters after Subarachnoid Hemorrhage. Neurologia medico-chirurgica 49(5): 185-192

13. 朴 幸男, 岩坂壽二, 湯浅文雄, 大石千尋, 佐藤大祐, 岩坂潤二，大谷 肇（2009）この心電図から何が読み 取れるか？ HEART nursing 22(9): 86-89

14. 岩坂潤二, 山本克浩, 眞鍋憲市, 前羽宏史, 妹尾 健, 大石千尋, 吉田 進, 森口 暁, 佐藤大祐, 山本哲史, 湯浅文雄, 大谷 肇，岩坂壽二（2009）この心電図は 数時間後の突然死を予測できるか? HEART nursing 22(1): 69-72

15. 柚木純二, 湊 直樹, 片山雄二, 蒲原啓司, 佐藤 久 （2009）胸腔外鎖骨下動脈瘤切迫破裂の1例. 胸部外科 62(12): 1085-88

16. 小延俊文, 奥地一夫, 関 匡彦, 渡辺知朗, 伊藤真吾, 中村達也 (2009) 特殊病態下での緊急時外科的気道確 保. 奈良県医師会年報 22(1): 39-43

総 説

1. 竹原有史, 服部玲治, 松原弘明, 王 英正 (2009) 循 環器の生物学 2.cardiosphere による心筋再生. Annu Rev循環器２009: 10-17

2. 齊藤幸人, 金田浩由紀, 馬庭知弘, 齊藤朋人, 南健一 郎 (2009)【胸腔鏡補助下肺癌肺切除の適応, アプロー チとその成績】器具の工夫 胸腔鏡補助下肺癌肺切除 のアプローチと工夫. 胸部外科 62(4): 289-294

3．齊藤幸人，齊藤朋人，馬庭知弘，金田浩由紀 (2009) 【呼吸器症候群 ( 第 2 版) その他の呼吸器疾患を含め て】縱隔疾患 縦隔腫瘍 縦隔囊胞. 日臨 別冊呼吸 器症候群 III: 499-502

4. 齊藤幸人, 齊藤朋人, 馬庭知弘, 金田浩由紀 (2009) 【呼吸器症候群 (第 2 版) その他の呼吸器疾患を含め て】縦隔疾患 縦隔腫瘍 縦隔絨毛癌. 日臨 別冊呼 吸器症候群III: 473-475

\section{症例報告}

1. Hattori R, Sumida T, Okada T, Johno H, Enoki C, Nakao Y, Miyasaka Y, Haiden M, Dote K, Seno K, Iwasaka T and Imamura H. (2009) Surgical treatment for right sided infective endocarditis with recurrent pulmonary infarction concurrent with a ventricular septal defect. CHIRURG 21: 339-342

2. Kaneda H, Sakaida N, Saito T, Maniwa T, Uemura Y and Saito Y (2009) Appearance of bronchioloalveolar carcinoma and the rapid progression into invasive papillary adenocarcinoma. Gen Thorac Cardiovasc Surg 57(4): 224-227

3. 川井康之, 中村達也, 浅井英樹, 小延俊文, 奥地一夫 （2009）頸部ドレナージにて救命しえた降下性壊死性 縦隔炎の1例。手術 63(4): 527-530
4. 岩村あさみ, 福島英賢, 北岡寛教, 浅井英樹, 渡邊知 朗, 川井廉之, 西口貴司, 畑 倫明, 中村達也, 小延 俊文, 西尾健治, 奥地一夫（2009）破傷風に対するマ グネシウム大量療法についての一考察. 日本外傷学会 雑誌 23(3): 284-287

その他

1. 小延俊文, 畑 倫明, 河野安宣, 今西正巳, 西尾健治, 奥地一夫（2009）外傷初期診療コースJATECTM奈良 開催報告. 奈良県医師会年報 22(1): 62-65

2. 齊藤幸人, 齊藤朋人, 馬庭知弘, 金田浩由紀, 南健一 郎（2009）標準的気胸治療の確立に向けて. 日気胸囊 胞性肺会誌 $9(2): 111-116$

3. 馬庭知弘, 齊藤朋人, 金田浩由紀, 南健一郎, 齊藤幸 人（2009）呼吸不全を呈した左膿胸に対して右下葉巨 大肺囊胞を切除し救命しえた1例. 日呼外会誌 23(7): 977-980

\section{学会発表}

1. Tomohito Saito,Takahito Nakano, Yosuke Ueyama, Hiroyuki Kaneda, Ken-ichiro Minami, Toshifumi Konobu and Yukihito Saito (2009) Spontaneous Pneumothorax in Women Refeffered for Surgery; A 19-year Experience in A Single Institute. CHEST2009, San Diego, United States

2. Tomohito Saito,Takahito Nakano, Yosuke Ueyama, Hiroyuki Kaneda, Ken-ichiro Minami, Toshifumi Konobu and Yukihito Saito (2009) A New Bioabsorbable CAPE Method for Prevention of Persistent Air Leaks and Recurrences after Video-Assisted Thoracoscopic Surgery for Spontaneous Pneumothorax; Report of Clinical Experience with Three Cases. CHEST2009, San Diego, United States

3. Takayuki Okada ,Naoki Minato, Yoshihisa Nakao, Tomohiko Sumida and Chiharu Enoki (2009) ' Do you still prefer to use Papaverine in CABG?' Pharmacological preparations with Olprinone hydrochloride for human arterial conduits in coronary surgery. the 19th Biennial Congress Association of Thoracic and Cardiovascular Surgeons of Asia, Seoul, Korea

4. Takayuki Okada,Reiji Hattori, Yoshihisa Nakao, Tomohiko Sumida, Chiharu Enoki, Hiroyuki Jono and Takanori Oka (2009) Do you still prefer to use Papaverine in CABG? Pharmacological preparations with PDEIII inhibitor for human arterial conduits in coronary surgery. The 17th Annual Meeting of the Asian Society for Cardiovascular and Thoracic Surgery, Taipei,Taiwan

5. Takayuki Okada,Reiji Hattori, Yoshihisa Nakao, Tomohiko Sumida, Chiharu Enoki, Hiroyuki Jono and Takanori Oka (2009) Do you still prefer to use Papaverine in CABG? Pharmacological preparations with PDEIII inhib- 
itor for human arterial conduits in coronary surgery. マ レーシア国立循環器病センター国際招請講演, クアラ ルンプール, マレーシア

6. 中尾佳永, 湊 直樹, 岡田隆之, 榎木千春, 角田智彦 （2009）心・大血管手術患者の手術部位感染に対する 術前鼻前庭培養検査およびその治療の有効性につい ての検討。第 22 回日本外科感染症学会, 山口

7. 金田浩由紀, 齊藤朋人, 南健一郎, 齊藤幸人 (2009) 多発肺癌手術症例における病変の局在に関する検討. 第50回日本肺癌学会総会, 東京

8. 湊 直樹 (2009) 複雑冠動脈病変に対する心拍動下冠 動脈形成術. 守口市医師会懇話会, 大阪

9. 小延俊文, 奥地一夫, 齊藤幸人（2009）日本のガイド ラインを取り入れた医学生への外傷初期診療教育の 導入. 第 13 回 日本気胸・震胞性肺疾患学会総会, 大阪 10. 小延俊文, 中村達也, 奥地一夫, 伊藤真吾, 岩村あさ み, 浅井英樹（2009）遅発性に両側気胸を合併した鈍 的外傷による頸部気管損傷. 第13回 日本気胸・囊胞 性肺疾患学会総会, 大阪

11. 齊藤朋人, 笠原憲子, 馬庭知弘, 金田浩由紀, 南健一 郎, 齊藤幸人（2009）ブラ新生から気胸発症までの経 時的画像変化が追跡できた 1 例. 第 13 回 日本気胸・ 囊胞性肺疾患学会総会, 大阪

12. 齊藤朋人, 笠原憲子, 馬庭知弘, 金田浩由紀, 南健一 郎, 齊藤幸人 (2009) 当院における女性気胸症例の臨 床病理学的検討. 第 13 回 日本気胸 - 異胞性肺疾患学 会総会, 大阪

13. 笠原憲子, 金田浩由紀, 齊藤朋人, 南健一郎, 齊藤幸 人（2009）急性骨髄性白血病後の慢性GVHDに合併し た難治性気胸の一例. 第13回日本気胸・囊胞性肺疾患 学会, 大阪

14. 金田浩由紀, 笠原憲子, 齊藤朋人, 南健一郎, 齊藤幸 人（2009）初期診療の標準化への課題 一自験例とメ 夕解析による検討一. 第 13 回日本気胸・囊胞性肺疾患 学会総会, 大阪

15. 湊 直樹（2009）吻合部針穴出欠をいかに止めるか! Fibrin glueの有効な使い方 : Rub-and-Spray法. 第57回 日本心蔵学会学術集会, 札幌

16. 金田浩由紀（2009）肺がんの外科的療法および化学療 法の最前線. 2009 年度摂南大学薬学部公開講座, 大阪

17. 小延俊文, 浅井英樹, 岩村あさみ, 伊藤真吾, 渡邊知 朗, 関 匡彦, 植山 徹, 福島英賢, 瓜園泰之, 中村 達也, 西尾健治, 奥地一夫, 今西正巳 (2009) へビ咬 傷小児入院例の検討. 第 100 回 日本救急医学会 近 畿地方会, 大阪

18. 岩村あさみ, 瓜園泰之, 浅井英樹, 伊藤真吾, 渡辺知 郎, 植山 徹, 福島英賢, 中村達也, 小延俊文, 西尾 健治, 奥地一夫, 吉川公彦, 東浦 渉, 多林伸起 (2009) 孤立性上腸間膜動脈解離の 1 例. 第 185 回近畿外科学 会, 大阪

19. 奥地一夫, 西尾健治, 小延俊文, 中村達也, 福島英賢,
朴 永銖, 中瀬裕之 (2009) 神経学的症状を訴え救急 搬送された妊産婦の救急医療. 第 12 回日本臨床救急医 学会, 大阪

20. 今西正巳, 奥地一夫, 西尾健治, 小延俊文, 平林秀裕 （2009）奈良県にPSLSを導入して. 第12 回日本臨床救 急医学会, 大阪

21. 小延俊文, 奥地一夫, 岩村あさみ, 渡邊知朗, 伊藤真 吾, 西口貴司, 河村健二, 植山 徹, 西尾健治, 関 匡彦（2009）看護学生に対する病院前外傷救護・外傷 初期診療教育の導入 第二報. 第 12 回日本臨床救急医 学会, 大阪

22. 小延俊文, 今西正巳, 奥地一夫, 西尾健治, 福島英賢, 瓜園泰之, 中村達也, 河野安宣, 西尾博至 (2009) 発 足よりの奈良県 MC 協議会における検証結果の検討. 第 12 回日本臨床救急医学会, 大阪

23. 湊 直樹（2009）DES 全盛時代のCABG：複雑冠動脈 病変に対する心拍動下冠動脈形成術. 関西心力テ研究 会, 大阪

24. 奥地一夫, 伊藤真吾, 小延俊文, 福島英賢, 中村達也, 西尾健治（2009）神経外傷を伴う多発外傷の現状と対 応. 第23回日本外傷学会, 大阪

25. 小延俊文，奥地一夫，岩村あさみ，関 匡彦，渡邊知 朗, 伊藤真吾, 西口貴司, 植山 徹, 福島英賢, 瓜園 泰之, 中村達也, 西尾健治 (2009) 最近 8 年間に入院 となったへビ咬傷 30 例の検討. 第23回日本外傷学会, 大阪

26. 中尾佳永, 角田智彦, 榎木千春, 佐藤 正 (2009) 当 院におけるペースメーカー電池交換手術での短期間 入院についての検討. 第 109 回日本外科学会, 福岡

27. 齊藤幸人 (2009) 自然気胸治療ガイドラインと内視鏡 外科手術. 東北内視鏡外科フォーラム, 仙台

28. 湊 直樹, 蒲原啓司, 峰松紀年, 諸隈宏之 (2009) 胸 腹部大動脈手術時の選択的肋間腰動脈灌流, 灌流力 ニューラ固定器具の工夫. 日本大動脈外科研究会, 福 岡

29. 小延俊文, 奥地一夫, 岩村あさみ, 伊藤真吾, 渡邊知 朗, 西口貴司, 河村健二, 植山 徹, 福島英賢, 瓜園 泰之, 中村達也, 西尾健治, 関 匡彦, 畑 倫明, 今 西正巳（2009）外傷トレーニングコースの概念を取り 入れた学生教育. 第 99 回日本救急医学会 近畿地方 会, 尼崎市

30. 矢内洋次，金田浩由紀，馬庭知弘，齊藤幸人（2009） 前縦隔腫瘍に対する術前ステロイドパルス治療の経 験. 第22回LKカンファレンス特別講演会, 大阪

31. 中島慎吾, 野口明則, 齊藤朋人, 生駒大登, 清水 健, 伊藤忠雄, 谷 直樹, 山口正秀, 岡野晋治, 山根哲郎 （2009）結腸癌術後カペシタビンにより生じた壊死性 腸炎の1例. 第 2 回 京都消化器外科臨床検討会, 京都

32. 湊 直樹（2009）DES 全盛時代のCABG：複雑冠動脈 病変に対する心拍動下冠動脈形成術. Sky View循環器 フォーラム, 大阪 


\section{脳神経外科学講座}

\section{〈研究概要〉}

・脳腫瘍の分子生物学的研究

当教室では1978年フローサイトメトリーを用いた脳腫瘍のcell kineticsを日本で初めて導入し, 長年研究を続け, また, FISHによる遺伝子解析も行い, Stem cellの解析によるMolecular targeting の治療を進めている. 癌治療研究全般に抢いて 分子生物学的研究が進展しているが, 脳腫瘍についても分子標的治療の有用性が認識されており, 特に, 特定の分子・ シグナル伝達経路を標的とする阻害剤をスクリーニングによって同定する試みを進め, 最近重要性が提唱されている「脳 腫瘍幹細胞を標的とする新規治療法開発」にも関与している.

・電子顕微鏡を用いた脳腫瘍の微細構造の研究

電子顕微鏡的解析は，従来から脳腫瘍の診断や新しい腫瘍概念の確立に重要な役割を果たしてきており，当教室には 長年の成果がある. 免疫組織化学の導入以来, 電顕検索の頻度は減少しているが依然として重要な研究手段である. 脳 動静脈奇形は血管が動脈・毛細血管・静脈に分かれる胎生早期に起こる異常な血管形成の結果である. 成因・増大機序 についての詳細は不明であるが, 小児と成人例のAVMの組織について, 免疫組織学的電顕的手法を用い比較検討を行う など，その微細構造を探ることにより成因について研究中である.

・頭蓋底外科の手術的アプローチと治療法の開発

頭蓋底腫瘍疾患の治癒とは患部の摘出にあるのではなく，どうすれば治療後の障害・後遺症を小さくできるか，また いかに早い回復と社会復帰を目的にしており, 耳鼻科, 形成外科との共同研究を継続することにより部署の壁をなくし, 更に治療の開発を，様々な専門分野のスタッフによるチーム診療で，より良い医療を提供できるように努めている.

\section{・脊䯣損傷患者の骨䯣細胞移植による珍しい治療法の開発}

救命センターと当教室において世界に先駆けて, 脊損患者に対して, 患者の骨髄細胞を培養し, mesenchymal cell を取 り出し, 患者のくも膜下腔に移植する新しい治療法（患者自身の骨髄液中に含まれる骨䯣間質細胞を，患者自身の脳脊 䯣液中に投与する方法を用いるため, 拒絶反応の心配が無く，免疫抑制剂も不要である．また，細胞を直接損傷部位に 注入するのではなく，脳脊䯣液中に投与するので，患者への負担が非常に少ないという利点がある，骨䯣間質細胞は神 経細胞や, 骨の細胞, 心臓の笳肉の細胞など, 種々の細胞に分化する能力があるが, 骨䯣間質細胞を神経細胞に分化さ せることを意図したものではなく，骨䯣間質細胞の作用により，中枢神経系に残っている神経幹細胞の再生を促すこと を目的としている.）を共同開発中である.

\section{・脳死判定における脳波解析測定の開発}

長年, 法医学教室, 救命センターと当教室において, 脳死診断における脳波判読を客観的に行う目的で, 脳波検査を 定量的に行い，脳死診断の脳波判読に利用できるATMAP II for Windows解析システム（キッセイコムテック侏）の簡便 な実用化を進めてきた，本システムにより平坦脳波が確認できれば等価電位解析による脳死補助診断が一般に広く応用 でき, 脳死判定にも有用と考えられるため, 脳死患者から誘導された脳波の平坦化を確認する目的で脳波の解析を行い, 臨床応用を可能にしている.

\section{〈研究業績〉}

原 著

1. Li Q, Oshige H, Zhen Y, Yamahara T, Oishi T, Seno T, Kawaguchi T, Numa Y and Kawamoto K (2009) Interleukin-5 and interleukin-10 are produced in central nervous system tumor cysts. J Clin Neurosci 16(3): 437-440

2. Oi S, Nomura S, Nagasaka M, Arai H, Shirane R, Yamanouchi Y, Nishimoto H and Date H (2009) Embryopathogenetic surgicoanatomical classification of dysraphism and surgical outcome of spinal lipoma: A nationwide multicenter cooperative study in Japan-Clinical article. J Neurosurg Pediatrics 3(5): 412-419

3. Kunizawa A, Fujioka M, Suzuki S, Ryu T, Asai A, Kawa- moto K and Kitazawa Y (2009) Spontaneous spinal epidural hematoma inducing acute anterior spinal cord syndrome. J Neurosurg Spine 10(6): 574-577

4. Okii Y, Akane A, Kawamoto K, Iwase M, Yoshida M, Mitani T, Yoshimura S, Tokiyasu T and Kobayashi T (2009) The proof of flat-line scalp EEGs of brain dead patients by an automatic EEG analysis system. Leg Med 11(Supplement 1): S401-S403

5. Kinoshita M, Asai A, Komeda S, Yoshimura K, Takeda J, Uesaka T, Yamanouchi Y, Kanzaki H and Kawamoto K (2009) Spontaneous regression of a spinal extradural arteriovenous fistula after delivery by cesarean section. Neurol Med Chir 49(7): 313-315 
6. 河本圭司, 瀬野敏孝, 川口㻟也, 大重英行, 大石哲也, 山原崇弘, 甄 云波, 李 一, 龍 新兵, 沼 義博, 淺井昭雄（2009）【悪性腫瘍と DNA aneuploidy DA研 究の過去と未来】サイトメトリーを用いた脳腫瘍の DNA ploidy の解析 過去から未来へ. Cytometry Res 19(1): 23-29

7. 李一, 沼 義博, 大石哲也, 山原崇弘, 甄 雲波, 桜井靖夫, 山内康雄, 浅井昭雄, 河本圭司 (2009) 腫 瘍内出血を来たした PNET の 2 例. Neuro-Oncol 進歩 18(1): 11-14

8. 大重英行, 大石哲也, 櫻井靖夫, 沼 義博, 河本圭司, 田中一穂, 横山明嗣（2009）急性硬膜下血腫で発症し た頭蓋内 dural AVF の一例. Neurosurg Emerg 14(1): 79-85

9. 福井英人, 朝子幹也, 友田幸一, 上坂達郎, 浅井昭雄 （2009）脳外科用ナビゲーションシステムのみ利用可 能な状況下で施行した鼻内内視鏡手術の経験. 耳鼻展 望 52(5): 331-333

10. 野村貞宏, 鈴木倫保, 大井静雄, 新井 一, 長坂昌登, 白根礼造, 稲垣隆介, 西本 博, 伊達裕昭 (2009) 晚 期発症型脊髄脂肪腫の特徵一脊髄脂肪腫の自然歴と 治療に関する前方視的多施設共同調査より一. 小児の 脳神 34(5): 369-373

11. 稲垣隆介, 河本圭司, 大井静雄（2009）発達期におけ る骨格系と脳脊髄液循環動態の発生学的特性に基づ く高次脳脊髄機能障害の治療および総合医療に関す る研究胎児診断の現状，アンケート結果から．小児の 脳神 34(1): 61-62

12. 稲垣隆介, 久徳茂雄, 河本圭司（2009）発達期におけ る骨格系と脳脊髄液循環動態の発生学的特性に基づ く高次脳脊髄機能障害の治療および総合医療に関す る研究】稀な頭蓋形態を示した頭蓋縫合早期癒合症症 例の検討．小児の脳神 34(1): 56-60

13. 大井静雄, 下地武義, 宮嶋雅一, 稲垣隆介, 高橋里史 （2009）発達期における骨格系と脳脊髄液循環動態の 発生学的特性に基づく高次脳脊髄機能障害の治療お よび総合医療に関する研究 前頭縫合早期癒合症(三角 頭蓋)の自然歴と手術適応に関する前方視的多施設共 同調查. 小児の脳神 34(4): 320-327

14. 稲垣隆介（2009）二分脊椎への取り組み 二分脊椎の 発生と予防対策。小児外科 41(7): 651-657

15. 山内康雄（2009）神経疾患 頭部外傷. 小児内科 41 (増刊) : 659-663

\section{症例報告}

1. 鈴木倫保, 野村貞宏, 大井静雄, 新井 一, 長坂昌登, 白根礼造, 稲垣隆介, 西本 博, 伊達裕昭 (2009) 発 達期における骨格系と脳脊髄液循環動態の発生学的 特性に基づく高次脳脊髄機能障害の治療および総合 医療に関する研究 脊髄脂肪腫の自然歴と治療方針 に関する前方視的多施設共同調査一2006-2007 年度登
録症例の経過報告一．小児の脳神 34(1): 38-41

2. 谷口久哲, 河 源, 木下秀文, 松田公志, 浅井昭雄 （2009）男性更年期症状を呈し低ゴナドトロピン性性 腺機能低下症と診断された1例．泌紀５5(2): 107-109

その他

1. 河 相吉, 岩田亮一, 河本圭司, 上埜泰寛, 澤田 敏 （2009）FDG の大脳皮質所見を認めた Fahr 病の一例. 核医症例検討会症例集 29(2): 38-39

2. 稲垣隆介, 河本圭司（2009）グラフィックと図表でみ る小览脳神経外科の “Emergency” と専門医の対応 小児の頭部外傷一特に虐待が疑われたときの注意点 一。 小览の脳神 34(6): 477-481

学会発表

1. 李強, 甄 雲波, 李 一, 龍 新兵, 川口㻟 也, 沼 義博, 河本 圭司（2009）脳腫瘍シスト液か ら検出したサイトカイン. 第19回日本サイトメトリー 学会, 鳥取

2. Akio Asai, Hideyuki Oshige, Hirokazu Takami, Tatsuro Uesaka, Jun-ichi Takeda, Kunikazu Yoshimura and Keiji Kawamoto (2009) CLINICAL TRIAL WITH TEMOZOLOMIDE IN AN ALTERNATING WEEKLY REGIMEN AGAINST RECURRENT MALIGNANT GLIOMAS-A PRELIMINARY REPORT. The 3rd Quadrennial Meeting of the World Federation of Neuro-Oncology/The 6th Meeting of the Asian Society for Neuro-Oncology(ASNO), 横浜

3. Numa Yoshihiro, Takahiro Yamahara, Tetsuya Oishi, Takuya Kawaguchi, Toshitaka Seno, Yasuo Sakurai, Yasuo Yamauchi, Akio Asai and Keiji Kawamoto (2009) Is it Total removal of glioblastoma possible?-tumor cell infiltration from autopsy brain. The 3rd Quadrennial Meeting of the World Federation of Neuro-Oncology/The 6th Meeting of the Asian Society for Neuro-Oncology(ASNO), 横浜

4. Takami H (2009) Inspection about recurrence and progressing dementia after WBRT to metastatic brain tumor-Problem presentation against WBRT. The 3rd Quadrennial Meeting of the World Federation of NeuroOncology/The 6th Meeting of the Asian Society for Neuro-Oncology(ASNO), 横浜

5. Takayuki Inagaki and Keiji Kawamoto (2009) The fifth congress of the internationl federation of neuroendoscopy. The 5th World Congress of Neuroendoscopy, Athens

6. Yamamoto D, Yoshida H, Iwase S, Odagiri H and Kitamura K, (2009) TS-1 in patients with capecitabine-resistant breast cancer. ASCO, USA

7. 龍 新兵, 甄 云波, 李 一, 大石哲也, 瀬野敏孝, 大重英行，河本圭司（2009）Immunohistochemical and 
electron microscopic study on primary hematopoetic tumors of the skull. 第27回日本脳腫瘍病理学会, 福岡

8. 大重英行 (2009) Case prasentation (Dept of neurosurgery in KMU)/Purpose: final pathological diagnosis/Case: 48 y.o female. 第96回近畿脳腫瘍病理検討会, 大阪

9. Takayuki Inagaki and Oi Shizuo (2009) The national survey of in utero diagnosis forcentral nervous anomaly in Japan. First world congress of spina bifida research and care, Florida

10. 大重英行, 淺井昭雄, 高見浩数, 上坂達郎, 武田純一, 吉村晋一, 河本圭司（2009）粘稠性の下垂体病変へ Flexible nozzle を用いた灌流法の有用性. 第 22 回日本 内視鏡外科学会総会, 東京

11. 大重英行, 淺井昭雄, 高見浩数, 上坂達郎, 武田純一, 吉村晋一, 河本圭司 (2009) 雷鳴性頭痛を伴ったbasal ncephaloceleの 1 成人例. 第37回日本頭痛学会総会, 宇 都宮

12. 岩瀬正顕, 中谷壽男, 齊藤福樹, 前田裕仁, 河本圭司 （2009）蘇生後昏睡患者の脳機能予後予測における体 性感覚誘発電位の役割. 第39回日本臨床神経生理学学 会, 小倉

13. 岩瀬正顕, 平川昭彦, 波柴尉充, 中谷壽男, 河本圭司 （2009）頭部電撃症の 1 例. 第 57 回日本職業 - 災害医 学会, 高槻

14. 沖井 裕, 赤根 敦, 河本圭司, 岩瀬正顕, 時安太久 磨, 吉村澄孝, 吉田 学 (2009) 脳波解析用ソフト ウェア(ATAMAP II for Windows)の脳死判定への応用. 日本法医学会学術近畿地方集会, 高槻

15. 岩瀬正顕, 前田裕仁, 平川昭彦, 齊藤福樹, 中谷壽男, 河本圭司 (2009) 骨折を伴う頸椎片側脱臼に対する治 療. 第37回日本救急医学会, 盛岡

16. 岩瀬正顕, 前田裕仁, 中谷壽男, 河本圭司 (2009) 頝 椎損傷に伴う椎骨動脈損傷の治療戦略 3 症例の経験. 第68回日本脳神経外科学会学術総会, 東京

17. 山原崇弘, 川口㻟也, 甄 雲波, 李 一, 李 強, 沼 義博, 山内康雄, 淺井昭雄, 河本圭司 (2009) Glioblastomaの剖検脳における細胞浸潤の検討一画像と形 態とDNA 量の対比. 第 68 回日本脳神経外科学会学術 総会, 東京

18. 沼 義博, 山原崇弘, 櫻井靖男, 大石哲也, 川口玩哉, 山内康雄, 河本圭司（2009）頭蓋内伸展のある鼻腔神 経芽腫の治療. 第68回日本脳神経外科学会学術総会, 東京

19. 前田裕仁, 岩瀬正顕, 池堂太一, 河本圭司, 中谷壽男 （2009）頚椎化膿性脊椎炎の 3 例の検討. 第 68 回日本 脳神経外科学会学術総会, 東京

20. 大重英行, 淺井昭雄, 吉村晋一, 高見浩数, 上坂達郎, 武田純一, 河本圭司 (2009) 劣位半球補足運動野 (SMA) 近傍の神経膠腫の手術, 経過の特徵. 第68回日本脳神 経外科学会学術総会, 東京

21. 大石哲也, 沼 義博, 櫻井靖夫, 山原崇弘, 山内康雄,
淺井昭雄，河本圭司（2009）転移性眼窩内腫瘍の外科 手術. 第68回日本脳神経外科学会学術総会, 東京

22. 淺井昭雄, 大重英行, 高見浩数, 上坂達郎, 武田純一, 吉村晋一, 河本圭司（2009）再発悪性グリオーマに対 するテモゾロミド隔週投与の試み. 第68回日本脳神経 外科学会学術総会, 東京

23. 李強, 甄 雲波, 李一, 龍 新兵, 川口玩也, 沼 義博, 河本圭司 (2009) 脳腫瘍シスト液から検出 したサイトカイン. 第10回分子脳神経外科学会, 岡山

24. 大重英行, 淺井昭雄, 高見浩数, 上坂達郎, 武田純一, 吉村晋一, 河本圭司 (2009) 小脳出血の今後の課題に ついて (当院での 19 例の検討から). 第 14 回日本脳腫 瘍の外科学会, 東京

25. 李強, 甄 雲波, 李一, 龍 新兵, 川口㙇 也, 沼 義博, 河本 圭司 (2009) 脳腫瘍シスト液か ら検出したサイトカイン. 第41回日本臨床分子形態学 会総会・学術集会, 神戸

26. 大重英行, 淺井昭雄, 吉村晋一, 高見浩数, 上坂達郎, 武田純一, 沼 義博, 河本圭司（2009）小脳虫部充実 性血管芽腫の一例. 第 70 回近畿脳腫瘍研究会 /第 58 回日本脳神経下学会 近畿支部学術集会, 大阪

27. 河本圭司, 山原崇弘, 沼 義博, 大石哲也, 川口㻟也, 瀬野敏孝, 山内康雄, 淺井昭雄（2009）培検脳からみ た脳腫瘍細胞の浸潤. 第27回日本ヒト細胞学会大会, 東京

28. 李一, 沼 義博, 大石哲也, 山原崇弘, 甄 雲波, 李 強, 桜井靖夫, 山内康雄, 浅井昭雄, 河本圭司 （2009）細胞培養にてPNETの分化能を検索した一例. 第27回日本ヒト細胞学会大会, 東京

29. 李強, 甄 雲波, 李一, 大石哲也, 瀬野敏孝, 沼 義博, 河本圭司 (2009) フローサイトメトリーを 用いて脳腫瘍細胞における緑色蛍光核酸色素の発現 の検討. 第27回日本ヒト細胞学会大会, 東京

30. 大重英行, 淺井昭雄, 高見浩数, 上坂達郎, 武田純一, 吉村晋一, 河本圭司 (2009) 小脳出血の今後の課題に ついて（当院での 19 例の検討から）. 第 28 回 Mt.Fuji Workshop on CVD, 東京

31. 沼 義博, 山原崇弘, 櫻井靖夫, 大石哲也, 川口琢也, 山内康雄, 河本圭司 (2009) 頭蓋内伸展のある鼻腔神 経芽腫の手術. 第21回日本頭蓋底外科学会, 福岡

32. 大重英行, 淺井昭雄, 高見浩数, 上坂達郎, 武田純一, 吉村晋一, 河本圭司 (2009) Cystic Vestibular Schwannoma 2 例の検討. 第 21 回日本頭蓋底外科学会, 福岡

33. 岩瀬正顕, 前田裕仁, 齊藤福樹, 平川昭彦, 中谷壽男, 河本圭司（2009）墜落による頭蓋底顔面骨骨折に伴う 外傷性視神経症の 1 例. 第 12 回日本臨床救急医学会, 大阪

34. 山原崇弘, 川口玩也, 甄 雲波, 李 一, 李強, 龍 新兵, 沼 義博, 河本圭司（2009） FCM を用い て膠芽腫の剖検脳における細胞浸潤の検討. 第19回日 本サイトメトリー学会, 鳥取 
35. 前田裕仁, 岩瀬正顕, 中谷壽男, 河本圭司, 赤根 敦, 池堂太一 (2009) 頭部打撲後 12 日目に急激な意識低下 をきたし 14 日目に死亡した外傷性脳腫脹の一剖検例. 第23回日本神経救急学会, 栃木

36. 山原崇弘, 大石哲也, 櫻井靖夫, 沼 義博, 山内康雄, 甄 云波, 李 一, 龍 新兵, 河本圭司 (2009) 原 発巣不明の amelanotic melanomaの一例. 第27 回日本 脳腫瘍病理学会, 福岡

37. 瀬野敏孝, 山原崇弘, 沼 義博, 大重英行, 甄 云波, 李 一, 淺井昭雄, 河本圭司 (2009) 悪性グリオー マの部位別術中病理診断とDNA 量の解析. 第 27 回日 本脳腫瘍病理学会, 福岡

38. 李一, 沼 義博, 大石哲也, 山原崇弘, 櫻井靖夫, 甄 云波, 山内康雄, 淺井昭雄, 河本圭司 (2009) 腫 瘍内出血を来したPNETの 2 例. 第27回日本脳腫瘍病 理学会, 福岡

39. 前田裕仁, 岩瀬正顕, 中谷壽男, 河本圭司, 山内康雄, 山原崇弘（2009）中脳水道狭窄と孤立性第四脳室に対 し神経内視鏡の支援下に第四脳室一脳槽シャント術 を施行した 1 例. 第 12 回関西脳神経外科臨床カンファ レンス, 大阪

40. 岩瀬正顕, 前田裕仁, 中谷壽男, 河本圭司 (2009) 神 経内視鏡支援による孤立性第 4 脳室の後頭窩開頭手 術. 第18回脳神経外科と機器学会, 秋田

41. 山本知恵, 松島貴志, 楠本健司, 稲垣隆介, 濱田吉則, 高田晃平, 大橋 敦 (2009) 腰部結合双胎分離症例の 経験. 第52回日本形成外科学会総会・学術集会, 横浜市

42. 大重英行, 淺井昭雄, 吉村晋一, 高見浩数, 上坂達郎, 武田純一，河本圭司（2009）Giant Cystic Vestibular Schwannomaの 1 例. 第 57 回日本脳神経下学会 近畿 支部学術集会, 大阪

43. 山原崇弘, 沼 義博, 川口玩也, 大石哲也, 櫻井靖夫, 李一, 山内康雄, 河本圭司 (2009) Leukopathiaに 合併した頭蓋内 amelanotic melanoma の一例. 第 69 回 近畿脳腫瘍研究会 /第 57 回日本脳神経下学会 近畿 支部学術集会, 大阪

44. 大重英行, 淺井昭雄, 吉村晋一, 高見浩数, 上坂達郎, 武田純一, 河本圭司 (2009) Giant Cystic Vestibular Schwannomaの 1 例. 第 69 回近畿脳腫瘍研究会 $/$ 第 57 回日本脳神経下学会 近畿支部学術集会, 大阪

45. 大石哲也, 沼 義博, 山原崇弘, 櫻井靖夫, 李 一, 山内康雄，河本圭司（2009）高齡で発症したPNETの 稀な症例. 第 69 回近畿脳腫瘍研究会 /第 57 回日本脳 神経下学会 近畿支部学術集会, 大阪

46. 櫻井靖夫, 大石哲也, 山原崇弘, 沼 義博, 山内康雄, 河本圭司 (2009) 脊髄空洞症を伴う後頭蓋窩囊胞に対 して後頭蓋窩減圧術を行った 1 成人例. 第69回近畿脳 腫瘍研究会/第 57 回日本脳神経下学会近畿支部学 術集会, 大阪

47. 沼 義博, 大重英行, 山原崇弘, 淺井昭雄, 河本圭司 （2009）悪性神経膠腫に対するテモゾロミド (TMZ) 治
療一Pseudo-progressionの画像所見を中心に。第32回 日本脳神経 CI学会総会, 京都

48. 川口㻟也, 沼 義博, 山原崇弘, 櫻井靖夫, 稲垣隆介, 山内康雄, 河本圭司（2009）特異な画像所見を呈した 視神経膠腫の 2 例. 第32回日本脳神経CI学会総会, 京都

49. 前田裕仁, 岩瀬正顕, 中谷壽男, 河本圭司, 山内康雄, 山原崇弘（2009）中脳水道狭窄と孤立性第四脳室に対 し神経内視鏡の支援下に第四脳質一脳槽シャント術 を施行した1例. 第34回日本脳卒中学会, 松江

50. 大重英行, 高見浩数, 上坂達郎, 武田純一, 吉村晋一, 淺井昭雄，河本圭司（2009）当院における小脳出血 19 例の検討. 第34回日本脸卒中学会, 出雲

51. 沼 義博, 山原崇弘, 川口㻟也, 櫻井靖夫, 山内康雄, 河本圭司（2009）特異な画像所見を呈した視神経膠腫 の2例. 第19回日本間脳下垂体腫瘍学会, 東京

52. 大重英行, 淺井昭雄, 高見浩数, 上坂達郎, 武田純一, 吉村晋一, 河本圭司 (2009) 下垂体腫瘍術後腫瘍内出 血に関する検討. 第19回日本間脳下垂体腫瘍学会, 東 京

53. 岩瀬正顕, 前田裕仁, 中谷壽男, 河本圭司（2009）脳 神経外科救急領域における高齡者脊椎・脊髄損傷一三 次救命センターでの現状一. 第14回日本脳神経外科救 急学会, さいたま

54. 山原崇弘, 沼 義博, 大石哲也, 山内康雄, 河本圭司 （2009）脳動脈瘤破裂を合併した特発性血小板減少性 紫斑病 (ITP) の一例. 第14回日本脳神経外科救急学 会,さいたま

55. 沼 義博, 山原崇弘, 大石哲也, 櫻井靖夫, 山内康雄, 河本圭司 (2009) 放射線照射中に腫瘍内出血で緊急手 術を要した悪性脳腫瘍の 2 例. 第14回日本脳神経外科 救急学会, さいたま

56. 大重英行, 吉村晋一, 高見浩数, 上坂達郎, 武田純一, 淺井昭雄, 河本圭司（2009）急性期手術を行い比較的 良好に経過した感染性動脈瘤破裂くも膜下出血の一 例. 第 14 回日本脳神経外科救急学会, さいたま

57. 山原崇弘, 瀬野敏孝, 久徳茂雄, 笠井千尋, 大谷一弘, 稲垣隆介, 山内康雄, 河本圭司 (2009) 頭蓋縫合早期 癒合症の治療予後? 形態面を中心に?.第 36 回日本小 児神経外科学会, 大阪

58. Long X, Li Q, Zhen Y,Li Y, Oishi T, Seno T, Numa Y,Kawamoto K (2009) Flow cytometric Analyses of Green-fluorescent Nuceic Acid Stains in Brain Tumor Cell. 第19回日本サイトメトリー学会, 鳥取

59. 大重英行, 高見浩数, 上坂達郎, 武田純一, 吉村晋一, 淺井昭雄, 河本圭司（2009）生検目的にて入院した basal encephalocele の成人例 /比較的特徵的な画像パ ターンを呈し眼窩内外傷性脂肪壊死と診断された一 例. 第32回日本脳神経 CI学会, 京都

60. 前田裕仁, 岩瀬正顕, 中谷壽男, 河本圭司（2009）複 数診療科の連携を要した眼窩異物杙創による頭部顔面 外傷の 1 例. 第 14 回日本脳神経外科救急学会, さいたま 
著 書

1. 山内康雄 (2009) 頭部外傷. 小児疾患診察のための病 理生理 2一第4版一 659-673頁, 東京医学社, 日本

2. 高見浩数, 淺井昭雄, 上坂達郎, 武田純一, 大重英行, 吉村晋一, 河本圭司 (2009) One-Piece Orbitozygomatic Approachによる脳腫瘍摘出 7 症例の検討. 脳腫瘍の外 科一-multimodality 時代の脳腫瘍の外科一 203-209 頁, メディカ出版, 日本

3. 山原崇弘, 沼 義博, 大石哲也, 川口㻟哉, 瀬野敏孝, 櫻井靖男, 山内康雄, 淺井昭雄, 河本圭司 (2009) Glioblastomaは全摘できるか一剖検脳から細胞浸潤の検討 一. 脳腫瘍の外科一 multimodality時代の脳腫瘍の外科 - 45-49頁, メディカ出版, 日本

4. 大重英行, 淺井昭雄, 高見浩数, 上坂達郎, 武田純一, 吉村晋一, 河本圭司（2009）下垂体腺腫における mul- tiple staged operation に関する考察．（巨大下垂体腫瘍 術後腫瘍内出血 2 例の経験から ). 脳腫瘍の外科 multimodality時代の脳腫瘍の外科一 (河本圭司編) 8892頁, メディカ出版, 日本

5. 監修: 河本圭司 他, 編集 : 奥寺 敬 他（2009）徹底 マスター!トレーニングシナリオ 20 Case 8 痤攣 発作で発見された脳腫瘍例, 徹底マスター! トレーニ ングシナリオ 20 Case 9 脳出血をきたした脳腫瘍 例，徹底マスター！トレーニングシナリオ 20 Case 10 水頭症をきたした脳腫瘍例. 脳神経外科救急基礎 コースガイドブック（日本脳神経外科救急学会編） 126-128，130-133頁, メディカ出版, 日本

6. 監修: 河本圭司 他（2009）スタンダードフローサイ トメトリー（日本サイトメトリー技術者認定協議会 編）1-343頁，医歯薬出版，日本

\section{整形外科学講座}

基礎研究一骨䯣細胞を用いた再生医療一

整形外科 串田剛俊, 飯田寛和

\section{〈研究概要〉}

緒 言

骨䯣細胞は造血系幹細胞と間葉系幹細胞からなり，さまざまな分野に応用されるようになってきた．整形外科分野に おいても骨䯣細胞を用いた再生医療の基礎研究が盛んに行われ, 一部, 臨床応用も行われている. 当講座に打いても骨 䯣細胞を用いた再生医療についての基礎研究を積極的に行っている. 今回, 近年の業績を踏まえ, テーマ別に概要を述 ベる.

研究内容

1. 椎間板組織に対する研究

椎間板組織の変性は様々な脊椎性疾患を発症する，我々は椎間板組織の変性を抑制する治療として間葉系幹細胞と造 血系幹細胞を含む新鮮全骨䯣細胞とラット椎間板䯣核細胞を共培養し，椎間板䯣核細胞への影響を検討した。 その結果， 新鮮全骨䯣細胞は, 椎間板䯣核細胞の細胞増殖能力と細胞外器質の合成能力を元進させることが可能であった．また，椎 間板髄核細胞から TGF- $\beta$ の産生量が光進しており, 椎間板細胞の増殖と細胞外器質の活性化に関与していると考元ら水 $た^{11}$.

2. 勒帯・腱組織に対する研究

アキレス腱損傷はスポーツ中のみならず日常性活でも生じやすい腱損傷の一つである. 保存的加療では固定期間が長 く, 強度にも問題があるため手術加療が選択されることが多い. 我々はラットのアキレス腱断裂部に骨髄移植を行い, 損 傷部位の再生のメカニズムを解析した，その結果，骨䯣移植部位の腱組織は速やかに再生さ，約 4 週でほぼ正常と同等の 強度となっていた，骨䯣移植部位のTGF- $\beta$, VEGF は著しく増加しており, 腱組織の再生促進に関与していることが推察 された2).

3. 骨壊死疾患に対する研究

ステロイド剤は様々な治療で必要な薬剤であるが, 合併症の一つである大腿骨頭壊死は大きな問題である. 今回, 我々 はステロイド誘発家兔骨壞死に対する骨䯣細胞移植を用いた新しい治療法を開発した．ステロイド剤投与前の骨䯣細胞 を採取し，ステロイド誘発家兔骨壊死モデル（MPSL: $20 \mathrm{mg} / \mathrm{kg}$ 筋注）の大腿骨骨䯣内に注入した。その結果，大腿骨骨 壊死発生率を抑制することが可能であった。これは，骨䯣細胞を直接骨髄内に投与することにより骨髄内局所の活性化， 骨䯣細胞の脂肪変性抑制, さらに髄内圧の抑制が得られためと考えられた。 さらに血中止血・凝固系も改善しており，又 テロイド剤に暴露されていない骨䯣細胞が血管内皮細胞に作用した可能性も考えられた

さらに, 我々はステロイド剂投与後の骨髄細胞を用いてステロイド誘発家兔骨壊死モデルの治療を行った。これは骨 髄細胞を 1 週間培養し, 骨䯣細胞の活性化させた後に, 家免大腿骨に注入した。 その結果, 大腿骨骨壊死発生率を抑制す 
ることが可能であった，ステロイド剂投与後においても骨䯣細胞をリフレッシュすることにより十分な治療効果が期待 され，ステロイド性骨壊死の臨床応用が可能であると考えられた4).

4. 自己免疫疾患に対する研究

自己免疫疾患の多くは「stem cell disorder」，すなわち，異常幹細胞から分化する細胞やサイトカインなどが自己の臓 器を攻撃する疾患と考えられている. 我々は骨粗鬆症モデルマウスであるSAMP6マウスに正常マウスであるB6マウスの 骨䯣細胞を移植し，骨粗鬆症の進行を抑制するメカニズムを解明した ${ }^{5)}$ ままた，逆に SAMP6 マウスの骨䯣細胞を正常マ ウスに骨髄移植することにより，骨粗鬆症を促進させることに成功した6).

また，関節りウマチモデルマウスである SKG/Jcl マウスに正常 B6 マウスの骨䯣細胞を骨髄移植することにより関節破 壞の予防が可能であることを証明した ${ }^{7)}$.

結 語

骨髄細胞を用いた再生医療は整形外科分野においても多岐にわたり，臨床応用への期待も高い. しかしながら，現在 も未知の発展途上であり，今後も基礎研究を重悋る必要がある。

参考文献

1) Umeda M, Kudhida T, et al. Activation of rat nucleus pulposus cells by coculture with whole bone marrow cells collected by the perfusion method. J Orthop Res. 222228. 2008.

2) Okamoto N, Kushida T, et al. New Strategy for Treating Achilles Tendon Rupture in Rats using Bone Marrow Cell Transplantation Therapy. JBJS: 2010, in press.

3) Asada T, Kushida T, et al. Prevention of corticosteroidinduced osteonecrosis in rabbits by intra-bone marrow injection of autologous bone marrow cells. Rheumatology. 47: 591-596. 2008.

4) Matsuya H, Kushida T, et al. Regenerative effects of transplanting autologous mesenchymal stem cells on corticosteroid-induced osteonecrosis in rabbits. Mod Rheumatol. 18: 132-139. 2008.

5) Takada K, Inaba M, et al. Treatment of senile osteoporosis in SAMP6 mice by intra-bone marrow injection of allogeneic bone marrow cells. Stem Cells. 24: 399-405. 2006.

6) Ueda $\mathrm{Y}$, Inaba M, et al. Induction of senile osteoporosis in normal mice by intra-bone marrow-bone marrow transplantation from osteoporosis-prone mice. Stem Cells. 25: 1356-1363. 2007.

7) Kushida T, Ueda $Y$, et al. Allogeneic intra-bone marrow transplantation prevents rheumatoid arthritis in SKG/Jcl mice. J Autoimmun. 32: 216-222. 2009.

\section{〈研究業績〉}

原 著

1. Akiyama H, Kawanabe K, Iida H, Haile P, Goto K and Nakamura T (2009) Long-Term Results of Cemented Total Hip Arthroplasty in Developmental Dysplasia With Acetabular Bulk Bone Grafts After Improving Operative Techniques. J Arthroplasty Jul 3. [Epub ahead of print]

2. Kushida T, Ueda $Y$, Umeda M, Oe K, Okamoto N, Iida $H$, Abraham NG, Gershwin ME and Ikehara S (2009) Allo- geneic intra-bone marrow transplantation prevents rheumatoidarthritis in SKG/Jcl mice. J Autoimmun 32(3-4): 216-222

3. Ichikawa H, Yamada T, Taniguchi S, Hara M, Fujisawa R, Shimizu H and Kimura J (2009) Changes of Recovery Function in Median Nerve Somatosensory Evoked Potentials From Awake to Sleep. J Clin Neurophysiol 26(3): 183-191

4. Umeda M, Kushida T, Sasai K, Asada T, Oe K, Sakai D, Mochida J, Ikehara S and Iida H (2009) Activation of rat nucleus pulposus cells by coculture with whole bone marrow cells collected by the perfusion method. J Orthop Res 27(2): 222-228

5. 岡本尚史, 串田剛俊, 打抢え賢一, 中村知寿, 和田孝 彦，飯田寛和（2009）強直股関節に合併した大腿骨転 子下骨折の1例. Hip Joint 35: 857-860

6. 上田祐輔, 徳永裕彦, 松矢浩暉 (2009) 肥満男性に生 じた特発性一過性大腿骨頭萎縮症の3 例. Hip Joint 35: 813-815

7. 小室 元 (2009) 転倒恐怖とヒッププロテクター 高 齢者大腿骨頸部骨折を予防する新しいヒッププロテ クターの開発. Osteoporo Jpn 17(3): 546-548

8. 若林 英, 三浦慎之介 (2009) 術野の変化から予測し て動こう！整形外科手術の器械出し 6 術野から予 測しよう! 腰椎後方進入椎体間固定術の器械出しポ イント．オペナーシング２4(1): 95-101

9. 大野博史, 高橋正子 (2009) 術野の変化から予測して 動こう! 整形外科手術の器械出し 5 術野から予測 しょう! 前十字䩲帯再建術の器械出しポイント.オぺ ナーシング２4(1): 87-94

10. 大野博史, 高橋正子（2009）術野の変化から予測して 動こう！整形外科手術の器械出し 4 術野から予測 しょう! 膝関節人工関節置換術の器械出しポイント. オペナーシング 24(1): 78-86

11. 和田孝彦, 飯田寛和 (2009) 術野の变化から予測して 動こう! 整形外科手術の器械出し 3 術野から予測 しょう! 股関節人工関節置換術の器械出しポイント. 
オペナーシング２4(1): 69-77

12. 飯田寛和（2009）術野の変化から予測して動こう！整 形外科手術の器械出し 1 整形外科手術だからこそ 押さえるべきポイント.オペナーシング２4(1): 60-63

13. 加茂智裕, 浅田 卓, 児島 新, 飯田寬和 (2009) チ タンプレート骨接合を伴いインプラントの部分破損 を生じた4例。骨折 31(1): 204-207

14. 和田孝彦, 尾崎吉郎, 小室 元, 孫 瑛洙, 飯田寬和 （2009）ロキソプロフェンナトリウム水和物含有貼付 剤（ロキソニンパップ）の使用感に関する患者調査一 アンケート調査に打ける他剂貼付剤との比較検討一。 新薬と臨 58(7): 1250-1257

15. 井上 豪, 徳永裕彦, 上田祐輔, 松矢浩喗, 斉藤貴徳, 飯田寬和（2009）アルコール多飲歴を有する多発性骨 壊死に対して両側大腿骨頭回転骨切り術および両側 脛骨高位骨切り術を行った1例. 整・災外 52(6): 803807

16. 打打元賢一, 飯田宽和, 和田孝彦，井上 豪（2009） 臂筋内脱臼性股関節症に対する大腿骨転子下短縮骨 切り術併用セメント人工股関節置換術. 整 - 災外 52(3): 293-298

17. 齋藤貴徳, 串田剛俊, 松矢浩喗, 足立 崇, 石原昌幸, 谷 陽一 (2009) N16遠隔電場電位の起源と至適記録 部位に関する検討。脊髄機能診断 30(1): 104-108

18. 岡本尚史, 串田剛俊, 抢抗賢一, 飯田寬和 (2009) 発症後 SKG/Jcl マウスの骨䯣内骨髅移植による治療効 果の検討。中部整災誌 52(6): 1369-1370

19. 徳永裕彦, 松矢浩暉, 上田祐輔（2009）高位脱臼股に 対する転子下短縮骨切り術併用人工股関節置換術の 術後成績. 中部整災誌 52(5): 1237-1238

20. 加藤充孝, 飯田寛和, 和田孝彦，お打元賢一（2009） 当科での改良臼蓋側セメントテクニックによるセメ ント侵入の評価. 中部整災誌 52(5): 1207-1208

21. 加藤充孝, 飯田寬和, 和田孝彦, 打打元賢一 (2009) アンケートによる THA 後の ADL 調査. 中部整災誌 52(5): 1197-1198

22. 守屋 円, 児島 新, 飯田寛和 (2009) RS3PEに対す る外科的治療を行った1例. 中部整災誌 52(5): 10711074

23. 石原昌幸, 齋藤貴徳, 串田剛俊, 足立 崇, 谷 陽一, 飯田寬和（2009）高齢者の骨粗鬆症性椎体圧潰に対す る後方固定術の検討. 中部整災誌 52(4): 885-886

24. 串田剛俊, 齋藤貴徳, 足立 崇, 石原昌幸, 谷 陽一, 飯田寬和（2009） Reduction 用 SEXTANT system を用 いた腰椎変性迄り症に対する使用経験. 中部整災誌 52(4): 879-880

25. 谷川暢之, 齋藤貴徳, 飯田寛和 (2009) 不安定型骨盤 輪骨折に対する早期整復の必要性. 中部整災誌 52(4): 1029-1030

26. 石原昌幸, 串田剛俊, 足立 崇, 谷 陽一, 齋藤貴徳, 飯田寬和（2009）再発により再手術を施行した胸椎部
脊䯣ヘルニアの1例．中部整災誌 52(3): 703-704

27. 足立 崇, 串田剛俊, 斎藤貴徳, 石原昌幸, 谷 陽一, 飯田寛和（2009）腰椎術後神経症状を呈した硬膜外血 腫4例の治療経験. 中部整災誌 52(2): 395-396

28. 谷 陽一, 斎藤貴徳, 串田剛俊, 足立 崇, 石原昌幸, 飯田寛和（2009）手術を施行した平山病の 1 例. 中部 整災誌 52(2): 365-366

29. 岡本尚史, 串田剛俊, 打抢賢一, 飯田寬和 (2009) アキレス腱断裂ラットモデルに打ける局所骨䯣移植 による再生治療の効果. 中部整災誌 52(2): 301-302

30. 打打元賢一, 大野博史, 小室 元, 飯田寬和 (2009) 人工滕関節術における深屈曲縫合後の膝蓋骨アライ メントと術後可動域の関係. 中部整災誌 52(1): 95-96

31. 串田剛俊, 齋藤貴徳, 松矢浩睴, 足立 崇, 石原昌幸, 飯田寛和（2009）高齢者の腰椎変性すべり症に対する SEXTANT system を用いた TLIF の有効性. 中部整災 誌 52(1): 43-44

32. 松矢浩暉，徳永裕彦，上田祐輔，飯田寛和（2009）当 科における S-ROM セメントレスステムを用いた人工 股関節再置換術の成績. 中部整災誌 52(1): 29-30

33. 市川宜弘, 串田剛俊, 足立 崇, 石原昌幸, 斎藤貴徳, 飯田寛和（2009）胸椎黄色靱帯骨化症に対する片側進 入両側除圧術の術後成績. 中部整災誌 52(1): 133-134

34. 谷川暢之, 齋藤貴徳, 中村誠也, 飯田寬和（2009）中 手骨䅡部骨折に対する経皮的ピンニング法の工夫. 日 手の外科会誌 25(6): 876-878

35. 児島 新, 飯田寛和, 吉川尚孝, 菅 俊光, 中村誠也 （2009）外力による爪の変形観察—Kleinert法改善への 基礎研究一. 日手の外科会誌 25(4): 478-481

36. 児島 新, 飯田寛和, 森 裕之, 中村誠也, 岡村泰三 （2009）マレット骨折の治療経験（閉鎖的骨螺子固定 法). 日手の外科会誌 25(4): 474-477

37. 串田剛俊, 齋藤貴徳, 松矢浩睴, 浅田 卓, 飯田寛和 （2009）ステロイド剤が女性関節リウマチ患者の骨型 アルカリホスファターゼ(BAP)に与える影響. 臨整外 44(5): 465-471

38. 正岡利紀, 山本謙吾, 今給黎篤弘, 石井良章, 里見和 彦, 飯田寬和，松野丈夫，豊島良太，鳥巣岳彦，宮岡 英世, 勝呂徹, 早乙女紘一, 四宮謙一, 河原和夫 (2009) 整形外科術後感染の実態と予防対策 整形外科領域に おける術後感染の疫学 日本整形外科学会学術研究プ ロジェクト調査より。臨整外 44(10): 975-980

総 説

1. 吉田清和, 柴田斉子（2009）私が経験した日米におけ るがん治療の違い. J Clin Rehabil 18(10): 911-915

2. 小室 元 (2009) 人工股関節置換術後の合併症 メカ ニズムを知って予防・早期発見・患者指導につなげよ う! 術後合併症 骨折．整外看 14(7): 682-689

3. 飯田宽和 (2009) 人工股関節置換術後の合併症 メカ ニズムを知って予防・早期発見・患者指導につなげよ 
う! 人工股関節置換術の基礎知識 人工股関節置換 術とは. 整外看 14(7): 650-656

4. 和田孝彦, 諏訪照美, 松井菜津子, 岡田 修, 浦香世 子（2009）パスで流れがわかる! 整形外科の周術期ケ ア人工骨頭置換術. 整外看 14(4): 390-395

5. 飯田寛和（2009）臼蓋形成術による臼蓋形成不全の治 療. 日関節病会誌 28(2): 141-146

6. 吉田清和 (2009) 米国リハビリテーションと日米格差 日本の理学療法の将来のために. 理療京都 (38): 24

7. 齋藤貴徳, 今田直紀, 小串むつみ, 小川浩司, 谷川暢 之, 梅田眞志 (2009)【脊髄モニタリング】体性感覚 誘発電位と経頭蓋電気刺激筋誘発電位を用いた術中 脊髄機能モニタリング。臨脳波 51(5): 270-285

\section{症例報告}

1. おおえ賢一, 飯田寛和, 和田孝彦, 徳永裕彦, 加藤充 孝（2009）股関節強直に対する人工関節置換術．整・ 災外 52(8): 1005-1010

2. お抢え賢一, 和田孝彦, 飯田寛和 (2009) 感染人工関 節に対する人工股関節置換術の治療成績. 整 - 災外 52(1): 75-81

その他

1. 菅 俊光 (2009) リハビリテーション科医が育つため に必要なシステムは何か地方会からのリハビリテー ション科医育成サポート. Jpn J Rehabil Med 46(11): 696-700

学会発表

1. Kushida T, Saito T, Umeda M, Oe K, Okamoto N, Iida H and Ikehara S (2009) Prevention of autoimmune diseases in SKG/Jcl Mice using Intra-Bone Marrow-Bone Marrow Transplantation. 55th Annual Meetting of the Orthopaedic Research Society（米国整形外科学基礎学術集 会), ラスベガス

2. Oe K, Kushida T, Okamoto N, Umeda M, Sasai K and Iida H (2009) Next Generation Treatment for Anterior Cruciate Ligament Partial Rupture by Bone Marrow Transplantation in Rats. 55th Annual Meetting of the Orthopaedic Research Society（米国整形外科学基礎学 術集会)，ラスベガス

3. Umeda M (2009) Treatment of Degenerated Intervertebral Disc Using Whole Bone Marrow Cells Collected by the Perfusion Method. 55th Annual Meetting of the Orthopaedic Research Society（米国整形外科学基礎学 術集会)，ラスベガス

4. 飯田寛和 (2009) 股関節外科 40 年の進歩と課題. 第 11 回Macnab Memorial Lecture 郡山市

5. Takanori Saito, T. Kushida, M. Ishihara and Y.Tani (2009) MRI and electrophysiological evaluations of the damage to paraspinal muscles caused by MIS-TLIF. 第 18 回日本脊椎インストゥルメンテーション学会, 東京

6. 串田剛俊, 齋藤貴徳, 石原昌幸, 谷 陽一, 飯田寛和 （2009）SEXTANT systemを用いた二椎間TLIFの有効 性. 第 18 回日本脊椎インストゥルメンテーション学 会, 東京

7. 石原昌幸，齋藤貴徳，串田剛俊，谷 陽一，飯田寛和 （2009）高齢者の骨粗鬆症性椎体圧潰に対する Indirect claw 固定を併用した後方固定術の検討. 第18回日本脊 椎インストゥルメンテーション学会, 東京

8. 打抗賢一, 神宮司誠也, 飯田寛和, 富田直秀 (2009) 超高分子量ポリエチレン製ケーブルの骨との生体反 応性について. 第 24 回日本整形外科学会基礎学術集 会, 横浜

9. 岡本尚史, 串田剛俊, 打抗え賢一, 飯田寛和 (2009) アキレス腱断裂ラットモデルを用いた全骨髄細胞移 植の軟部組織治癒への影響の評価. 第24回日本整形外 科学会基礎学術集会, 横浜

10. 串田剛俊, 岡本尚史, おおえ賢一, 齋藤貴徳, 飯田寛 和（2009）骨髄内骨髄移植を用いた SKG/Jcl マウスの 関節炎および関節破壊の治療効果. 第24回日本整形外 科学会基礎学術集会, 横浜

11. 井上 豪, 徳永裕彦, 上田祐輔, 松矢浩暉, 齊藤貴徳, 濱田 彰（2009）アルコール多飲が誘因の多発性骨壊 死を発症した 2 例。第37回日本関節病学会, 横浜

12. 上田祐輔, 徳永裕彦, 松矢浩暉, 市川宜弘, 井上 豪, 齋藤貴徳（2009）７0歳以上の高齢者に対し S-ROM ス テムを用いたセメントレス人工股関節置換術の短期 成績. 第37回日本関節病学会, 横浜

13. 徳永裕彦, 松矢浩暉, 上田祐輔, 飯田寛和 (2009) 若 年者の特発性大腿骨頭壊死症に対する大腿骨頭回転 骨切り術の治療成績. 第37回日本関節病学会, 横浜

14. 石原昌幸, 齋藤貴徳, 串田剛俊, 谷 陽一, 飯田寛和 （2009）THA術後に発症した両側梨状筋症候群の1例. 第 427 回整形外科集談会京阪神地方会, 大阪

15. 齋藤貴徳, 串田剛俊, 石原昌幸, 谷 陽一, 谷川暢之 （2009）術中モニタリングに用いる経頭蓋電気刺激筋 記録運動誘発電位の刺激法の工夫による振幅増大効 果. 日本臨床神経生理学会, 北九州

16. 岡本尚史, 串田剛俊, おおえ賢一, 飯田寛和 (2009) 全骨髄細胞移植を用いたアキレス腱断裂治療の評価. 第113回中部日本整形外科災害外科学会, 神戸

17. 岩宮裕章，打抗賢一，和田孝彦，飯田寛和（2009） 人工股関節置換術における術中回収式自己血輸血の 有用性. 第113回中部日本整形外科災害外科学会, 神戸 18. 串田剛俊, 齋藤貴徳, 石原昌幸, 谷 陽一, 飯田寛和 （2009）腰椎固定術後に合併した早期深部感染に対す る治療経験. 第 113 回中部日本整形外科災害外科学会, 神戸

19. 松矢浩暉, 徳永裕彦, 上田祐輔, 飯田寛和 (2009) 当 科における Pinnacle Aアセタブラーカップシステムの 
使用経験. 第 113 回中部日本整形外科災害外科学会, 神戸

20. 石原昌幸, 齋藤貴徳, 串田剛俊, 谷 陽一, 飯田寛和 （2009）高齢者の骨粗鬆症性椎体圧潰に対し indirect claw 固定を併用した後方固定術の検討. 第 113 回中部 日本整形外科災害外科学会, 神戸

21. 石田 響, 齋藤貴徳, 徳永裕彦, 串田剛俊, 松矢浩暉, 飯田寛和（2009）80歳以上の高齢者に対する人工膝関 節全置換術の検討。第 113 回中部日本整形外科災害外 科学会, 神戸

22. 谷 陽一, 齋藤貴徳, 串田剛俊, 足立 崇, 石原昌幸, 飯田寛和（2009）脊椎難治性MRSA感染症に対するリ ファンピシンと ST 合剤の多剤併用療法の有効性につ いて．第113回中部日本整形外科災害外科学会，神戸

23. 谷川暢之, 齋藤貴徳, 飯田寛和（2009）尺側手根屈筋 副腱断裂による腱鞘炎の治療経験. 第 113 回中部日本 整形外科災害外科学会, 神戸

24. 齋藤貴徳, 串田剛俊, 石原昌幸, 谷 陽一, 松矢浩暉, 飯田寛和（2009）頝椎椎弓形成術後に生じる軸性疼痛 に対する早期リハビリテーションの効果. 第 113 回中 部日本整形外科災害外科学会, 神戸

25. 打抗賢一，岩宮裕章，和田孝彦，飯田寛和（2009） 人工股関節置換術における肥満と出血量の関係. 第 36 回日本股関節学会, 京都

26. 松矢浩睴, 徳永裕彦, 上田祐輔, 飯田寛和 (2009) 当 科における Pinnacle Aアセタブラーカップシステムの 使用経験. 第36回日本股関節学会, 京都

27. 上田祐輔, 徳永裕彦, 松矢浩暉, 市川宜弘, 串田剛俊 (2009) 当科に打ける感染性人工股関節の治療経験. 第 36 回日本股関節学会, 京都

28. 中村知寿, 和田 孝彦, お抢え賢一, 浅田 卓, 飯田 寛和（2009）当院におけるタナ形成術の短期成績. 第 36 回日本股関節学会, 京都

29. 徳永裕彦, 松矢浩暉, 上田祐輔, 飯田寛和 (2009) 大 腿骨頭壊死症に対する大腿骨骨切り術の治療成績. 第 36 回日本股関節学会, 京都

30. 和田孝彦，お颃賢一，中村知寿，飯田寛和（2009） Triple taper polished stem 周囲の骨量変化の検討. 第36 回日本股関節学会, 京都

31. 飯田寛和（2009） 股関節外科 40 年の進歩と課題. 第 7 回鹿児島 骨・関節フォーラム, 鹿児島市

32. Ishihara M, Saito T, Kushida T, Tani Y, Iida H (2009) Two cases with Retro-odontoid pseudotumor-successful resection without dural incision一. 第 16 回日本脊椎 脊髄神経手術手技学会, 東京

33. Takanori Saito, T. Kushida, M. Ishihara and Y. Tani (2009) MRI and electrophysiological evaluations of the damage to paraspinal muscles caused by MIS-TLIF. 第 16 回日本脊椎脊髄神経手術手技学会, 東京

34. Taketoshi Kushida, Takanori Saito, Astuyoshi Yakushiji, Masayuki Ishihara, Yoichi Tani and Hirokazu Iida (2009)
The Minimally Invasive TLIF with Reduction of Degenerative Lumber Slpondylolisthesis using SEXTANT System. 第 16 回日本脊椎脊髄神経手術手技学会, 東京

35. 勝本桂史，お抢え賢一，田島剛史，和田孝彦，飯田寛 和（2009）両股関節内転拘縮による下肢交差位歩行患 者に対し両人工股関節置換術を施行した 1 例。第 426 回整形外科集談会京阪神地方会, 大阪

36. 児島 新 (2009) 日常診療で遭遇する手の疾患と治療. 第4回整形外科ビジュアルフォーラム, 大阪

37. T. Saito, T. Kushida, T. Adachi, M. Ishihara, Y. Tani, K. Sasai and H. Iida (2009) Clinical characteristics of cervical myelopathy complicated with diabetic neuropathy. Spine acrros the cea，ハワイ マウイ島

38. 谷川暢之，中村誠也，飯田寛和（2009）尺骨近位端粉 砕骨折に対するLCP Olecranon Plateの使用経験. 第35 回日本骨折治療学会, 横浜

39. Oe K, Iida H, Wad a T, Saito T, Kushida T and Okamoto N (2009) Acetabular reconstruction using a KerboullType acetabular reinforcement device in total hip arthroplasty. 第10回日仏整形外科合同会議, 沖縄

40. 打抗え賢一，大野博史，小室 元，飯田寛和（2009） 膝蓋骨非置換人工膝関節置換術における膝蓋大腿関 節の適合性. 第 1 回日本関節鏡・膝・スポーツ整形外 科学会, 札幌

41. 大野博史，小津 敏，おおえ賢一，小室 元，飯田寛 和（2009）膝関節後外側支持機構（PLS）損傷に対す る膝窩筋角再建術の治療成績. 第1回日本関節鏡・膝・ スポーツ整形外科学会, 札幌

42. 打打賢一, 和田孝彦, 加藤充孝, 岡本尚史, 中村知 寿，飯田寛和 (2009) 人工関節置換術後感染予防にお ける抗菌薬含有セメントの有用性. 第32回日本骨・関 節感染症学会, 札幌

43. 岡本尚史, 飯田寛和, 和田孝彦, 加藤充孝, 串田剛俊, 打抢え賢一, 中村知寿 (2009) 人工股関節置換術にお ける術後感染および皮下膿瘍の経験. 第32回日本骨・ 関節感染症学会, 札幌

44. 串田剛俊, 齋藤貴徳, 石原昌幸, 谷 陽一, 飯田寛和 （2009）胸椎 - 腰椎後方固定術後早期深部 感染に対 する治療経験. 第32回日本骨・関節感染症学会, 札幌

45. 矢倉拓磨, 齋藤貴徳, 串田剛俊, 石原昌幸, 谷 陽一, 飯田寛和（2009）Indirect claw 法を用い後方固定術 を施行した胸腰椎移行部破裂骨折の 1 例. 第 425 回整 形外科集談会京阪神地方会, 大阪

46. 飯田寛和（2009）人工股関節 40 年の進歩と課題. 第 8 回中信整形外科医会学術講演会, 松本

47. Kushida T, Saito T, Adachi T, Ishihara M, Tani Y and Iida H (2009) Minimally invasive TLIF for degenerative lumbar spondylolisthesis in elderly patientsere. 第10回日仏 整形外科合同会議, 沖縄

48. Okamoto N, Kushida T, Oe K, Ikehara S and Iida H (2009) Allogenic bone marrow cells influence tendon- 
healing in a rat Achilles tendon model. 第 10 回日仏整形 外科合同会議, 沖縄

49. T. Saito, T. Kushida, T. Adachi, M. Ishihara Y. Tani, K. Sasai and H. Iida (2009) Clinical characteristics of cervical myelopathy complicated with diabetic neuropathy. 第 10 回日仏整形外科合同会議, 沖縄

50. 打抢え賢一, 和田孝彦, 加藤充孝, 岡本尚史, 中村知 寿，飯田寛和 (2009) 人工関節置換術後感染予防にお ける抗菌薬含有セメントの有用性. 第 82 回日本整形外 科学会学術総会, 福岡

51. 打抗賢一, 和田孝彦, 加藤充孝, 岡本尚史, 中村知 寿, 飯田寛和（2009）KT プレート併用人工股関節置 換術の経験. 第 82 回日本整形外科学会学術総会, 福岡 52. 岡本尚史, 飯田寛和, 和田孝彦, 加藤充孝, 串田剛俊, お打え賢一 (2009) セメント人工股関節置換術におけ る modified transgluteal approach（Dall）の短期臨床的 評価. 第 82 回日本整形外科学会学術総会, 福岡

53. 佐々木万弓, 小室 元, 藤本宗徳, 中尾光孝, 沖井 明，柴田斉子，菅 俊光，飯田寛和，吉田清和 (2009) 次世代義足の外観研究. 第 82 回日本整形外科学会学術 総会, 福岡

54. 佐々木万弓, 小室 元, 菅 俊光, 柴田斉子, 吉田清 和, 飯田寛和 (2009) 義足の新しい外観カバーの研究 開発. 第 82 回日本整形外科学会学術総会, 福岡

55. 斎藤明義, 布袋屋浩, 大野博史, 成瀬克弘 (2009) 中 高年のスポーツ障害に対する予防・治療 ーゴルフ 一. 第 82 回日本整形外科学会学術総会, 福岡

56. 小室 元, 諏訪照美, 大森美和子, 林えりか, 清水由 紀子, 飯田寛和（2009）新しい転倒リスクスケールを 使用した高齢者転倒骨折予防の条件の検討. 第 82 回日 本整形外科学会学術総会, 福岡

57. 小室 元, 飯田寛和, 大森美和子, 㴊上 望, 林えり か, 諏訪照美, 清水由紀子 (2009) 新しい転倒リスク スケールを使用した高齢者転倒骨折予防の条件の検 討. 第 82 回日本整形外科学会学術総会, 福岡

58. 梅田眞志, 笹井邦彦, 若林 英, 丸山東勲, 飯田寛和 (2009) 頝椎椎弓形成術に使用したHA スペーサー周囲 の骨癒合一追跡 2 年間の前向き検討一. 第 82 回日本整 形外科学会学術総会, 福岡

59. 飯田寛和（2009）臼蓋コンポーネント設置の基本コン セプト (原臼位設置). 第 82 回日本整形外科学会学術 総会, 福岡

60. 飯田寛和（2009）人工股関節のサルベージ手術. 第 82 回日本整形外科学会学術総会, 福岡

61. 和田孝彦, お括賢一, 加藤充孝, 中村知寿, 飯田寛 和（2009）人工股関節置換術々後感染の予防と治療. 第 82 回日本整形外科学会学術総会, 福岡

62. 打打え賢一, 和田孝彦, 加藤充孝, 中村知寿, 飯田寛 和（2009）大腿骨転子下骨切り術併用セメント人工股 関節置換術の短期成績. 第 112 回中部日本整形外科災 害外科学会, 京都
63. 岡本尚史, 串田剛俊，おおえ賢一，飯田寛和（2009） 発症後 SKG/Jc1 マウスの骨䯣内骨髄移植による治療効 果の検討. 第 112 回中部日本整形外科災害外科学会, 京都

64. 加藤充孝, 飯田寛和, 和田孝彦，打抗え賢一，中村知 寿（2009）アンケートによる THA後の ADL 調查. 第 112 回中部日本整形外科災害外科学会, 京都

65. 加藤充孝, 飯田寛和, 和田孝彦, おおえ賢一, 中村知 寿 (2009) 臼蓋側改良セメントテクニックとその評価. 第112回中部日本整形外科災害外科学会, 京都

66. 串田剛俊, 齋藤貴徳, 足立 崇, 石原昌幸, 谷 陽一, 飯田寛和（2009） Reduction 用 SEXTANT system を用 いた腰椎変性沪り症に対する使用経験. 第 112 回中部 日本整形外科災害外科学会, 京都

67. 松矢浩暉, 徳永裕彦, 上田祐輔, 和田孝彦, 飯田寛和 （2009）アナトミック人工股関節置換術における osteolysisの検討. 第 112 回中部日本整形外科災害外科 学会, 京都

68. 石原昌幸, 齋藤貴徳, 串田剛俊, 足立 崇, 谷 陽一, 飯田寛和（2009）高齡者の骨粗鬆症性椎体圧潰に対す る後方固定術の検討. 第 112 回中部日本整形外科災害 外科学会, 京都

69. 徳永裕彦，松矢浩暉，上田祐輔（2009）金属対金属の セメントレスTHAの中期成績. 第 112 回中部日本整形 外科災害外科学会, 京都

70. 徳永裕彦, 松矢浩暉, 上田祐輔（2009）高位脱臼股に 対する大腿骨転子下短縮骨切り術併用セメントレス 人工股関節置換術の成績. 第 112 回中部日本整形外科 災害外科学会, 京都

71. 齋藤貴徳, 串田剛俊, 足立 崇, 石原昌幸, 谷 陽一, 飯田寛和（2009）小侵襲腰椎固定術の背筋に対する侵 襲度の検討. 第 112 回中部日本整形外科災害外科学会, 京都

72. 齋藤貴徳, 串田剛俊, 足立 崇, 石原昌幸, 谷 陽一, 飯田寛和（2009）梨状筋症候群の診断と術後成績. 第 112 回中部日本整形外科災害外科学会, 京都

73. 笹井邦彦, 若林 英, 梅田眞志, 丸山東勲, 飯田寛和 （2009）頚椎症脊髄症に対する頝半棘筋とC7 棘突起を 温存した低侵襲椎弓形成術一 2 年間の前向き追跡研究 一. 第38回日本脊椎脊髄病学会, 神戸

74. 足立 崇, 齋藤貴徳, 串田剛俊, 石原昌幸, 谷 陽一, 飯田寛和（2009）高齢発症䅡髅症の手術適応決定因子 の解析. 第38回日本脊椎脊髄病学会, 神戸

75. 谷 陽一, 齋藤貴徳, 串田剛俊, 石原昌幸, 足立 崇, 飯田寛和 (2009) 手術例から見た平山病の病態と治療 成績. 第38回日本脊椎脊髄病学会, 神戸

76. 梅田眞志, 笹井邦彦, 若林 英, 丸山東勲, 飯田寛和 （2009）低侵襲 en-bloc 頚椎椎弓形成術に使用した HA スペーサー周囲の骨癒合一 2 年間の前向き検討一。第 38 回日本脊椎脊髄病学会, 神戸

77. 齋藤貴徳, 串田剛俊, 石原昌幸, 足立 崇, 谷 陽一, 
飯田寛和（2009）小侵襲腰椎固定術の背筋に対する侵 襲度の検討. 第38回日本脊椎脊髄病学会, 神戸

78. 齋藤貴徳, 串田剛俊, 石原昌幸, 足立 崇, 谷 陽一, 飯田寛和（2009）Dynamyzation rodを用いた脊椎固定 術と隣接椎間障害. 第3 8 回日本脊椎脊髄病学会, 神戸

79. 齋藤貴徳, 串田剛俊, 石原昌幸, 足立 崇, 谷陽一, 飯田寛和（2009）頸椎手術後 C5 麻痺に対する椎間孔 部除圧術による予防. 第38回日本脊椎脊髄病学会, 神 戸

80. 児島 新, 漆㠃亜弥, 飯田寛和, 吉田清和, 中村誠也 （2009）Kleinert 法に関する実験的工夫. 第 52 回日本 手の外科学会, 東京

81. 串田剛俊, 上田祐輔, 市川宜弘, 齋藤貴徳, 飯田寛和 （2009）ステロイド剤投与によるリウマチ患者の血中 BAPに与える影響. 第53回日本リウマチ学会総会, 東 京

82. 市川宜弘, 串田剛俊, 上田祐輔, 齋藤貴徳, 宮島茂夫, 飯田寛和（2009）関節リウマチ患者に打けるタクロリ ムスの治療経験. 第53回日本リウマチ学会総会, 東京

83. 小室 元, 尾崎吉郎, 孫 瑛洙, 和田孝彦（2009）非 定型抗酸菌症による膝関節炎をきたした 1 例. 第 53 回 日本リウマチ学会総会, 東京

84. 上田祐輔, 串田剛俊, 市川宜弘, 齋藤貴徳, 飯田寛和 （2009）当科におけるトシリズマブの使用経験. 第 53 回日本リウマチ学会総会, 東京

85. 上田祐輔, 徳永裕彦, 串田剛俊, 松矢浩暉, 市川宜弘, 飯田寛和（2009）関節リウマチに対する S-ROM を用 いたセメントレス人工股関節置換術の中期成績. 第5 3 回日本リウマチ学会総会, 東京

86. 和田孝彦，小室 元，尾崎吉郎，孫 瑛洙 (2009) 当 院での関節リウマチに対するタクロリムスの効果検 討。第53回日本リウマチ学会総会, 東京

87. 和田孝彦，小室 元，尾崎吉郎，孫 瑛洙（2009） 口 キソプロフェン貼付剤(ロキソニンパップ)の使用感に 関する患者調査. 第53回日本リウマチ学会総会, 東京 88. 徳永裕彦, 大西修司, 市辺明美, 山岡 学, 有本美代 子（2009）両側同時セメントレス人工股関節置換術 (THA)の周術期の検討. 第22回日本自己血輸血学会, 福島

89. 浅田 卓, 大野博史, 小室 元, 中村知寿, 飯田寛和 （2009）結核性膝関節炎の治療経験. 第 424 回整形外科 集談会京阪神地方会，大阪

90. 打抗賢一, 和田孝彦, 加藤充孝, 岡本尚史, 中村知 寿，飯田寛和（2009）KT プレートを用いた臼蓋再建 術の成績．第39回日本人工関節学会, 東京
91. 岡本尚史, 飯田寛和, 和田孝彦, 加藤充孝, 串田剛俊, おおえ賢一（2009）セメント人工股関節置換術におけ る Modi-fied Transgluteal Approach(Dall) の短期臨床的 評価. 第39回日本人工関節学会, 東京

92. 加藤充孝，飯田寛和，和田孝彦，おおえ賢一，中村知 寿, 浅田 卓 (2009) 外側方向への軟部組織緊張不良 が人工股関節置換術後脱臼の原因と思われた 3 例。第 39 回日本人工関節学会, 東京

93. 加藤充孝, 飯田寛和, 和田孝彦, 打抢え賢一, 中村知 寿, 浅田 卓 (2009) Aseptic loosening に対する cement 使用 stem 再置換術の成績. 第39回日本人工関節学会, 東京

94. 小室 元, 大野博史, 中村知寿, お抗え賢一, 飯田寬 和（2009）高齢者への最小侵襲手術とは? - UKA 手術 適応再検討。第39回日本人工関節学会, 東京

95. 小津 敏, 和田孝彦, 加藤充孝, お抗え賢一, 中村知 寿, 飯田寛和 (2009) Triple taper polished stem (C-stem) と curved triple taper polished stem（SC-stem）の比較 検討一短期成績. 第 39 回日本人工関節学会, 東京

96. 松矢浩暉, 徳永裕彦, 上田祐輔, 飯田寛和 (2009) 当 科における S-ROM セメントレスステムを用いた両側 同時人工股関節置換術の成績. 第 39 回日本人工関節学 会, 東京

97. 大野博史, 吉川尚孝, 小室 元, 飯田寛和（2009）難 治性感染 TKA に対する治療経験. 第 39 回日本人工関 節学会, 東京

98. 徳永裕彦，松矢浩暉，上田祐輔，飯田寛和（2009）脱 臼股に対する転子下短縮骨切り術併用人工股関節置 換術の術後成績. 第39回日本人工関節学会, 東京

99. 飯田寛和, 和田孝彦, 加藤充孝, 打打え賢一, 浅田 卓, 中村知寿 (2009) THAにおけるセメント手技の要 点. 第39回日本人工関節学会, 東京

100.和田孝彦，加藤充孝，お打え賢一，中村知寿，飯田寛 和 (2009) アミカシンの粉末性状の変化に伴う混入骨 セメントへの影響一力学的強度と気孔率の検討一. 第 39 回日本人工関節学会, 東京

101.和田孝彦，加藤充孝，おおえ賢一，中村知寿，飯田寛 和（2009）V Vacuum mixing system での吸引時間の骨セ メントへの影響. 第39回日本人工関節学会, 東京

102.飯田寛和（2009）感染人工関節に対する治療．第2回 東海人工関節研究会, 名古屋

103. 石原昌幸, 串田剛俊, 足立 崇, 谷 陽一, 齋藤貴 徳, 飯田寛和 (2009) 環椎外側塊一軸椎椎弓根スク リューによる環軸椎後方固定術後に小脳梗塞を合併 した 1 例. 第 423 回整形外科集談会京阪神地方会, 大阪 


\section{形成外科学講座}

\section{〈研究概要〉}

当講座では, 基礎研究では創傷治癒と再生医学を柱にし，その他形成外科臨床を支える多くの臨床研究を進めている. 以下に，主な項目を挙げる.

I. 基礎研究 :

A. 創傷治癒

1. 皮膚・軟部組織創傷治癒：肉芽形成，血管新生，上皮化が具体的目標となる．これらに対して体性幹細胞である脂肪 組織由来幹細胞（ASCs: Adipose-derived Stem Cells），局所サイトカイン療法でTGF- $\beta$, PDGF, VEGF, EGFなどのサイ トカインを高濃度に含む多血小板血漿 (PRP: Platelet-Rich Plasma), 肉芽増生や血管新生を増進させる線維芽細胞增殖因 子 (bFGF: basic Fibroblast Growth Factor) を主な検討対象として, 種々の条件設定を行い創傷治癒における有効性の検討 を進めている，基礎的検討から一部臨床的検討に進み，既に PRP など大いなる成果を挙げている. 次の再生医療とも密 接に関係している.

また, 皮膚の瘢痕治癒過程の瘢痕拘縮, 肥厚性瘢痕, 真性ケロイドといった病的治癒過程を解明し, これらの改善へ の系口を明らかにすべく検討をしている，すでにPRPやbFGFによる瘢痕拘縮の軽減が $\alpha$ SMA（ $\alpha$ smooth muscle action） の検出やコラーゲンゲル収縮などにより明らかにされつつある.

2. 骨・軟骨創傷治癒：骨の再生として骨形性タンパク（BMP: Bone Morphogenetic Protein）による骨誘導，骨形成を応 用した骨・軟骨創傷治癒の検討している，種々の担体，至適濃度，不利な条件下での骨誘導，遺伝子誘導などを検討し 詳細なデータを検証，蓄積中である。

B. 再生医学

1. 骨再生 : BMPによる骨誘導，骨形成につき骨再建への応用を目指した検討を進めている.さらに種々の人工骨の検討 や, BMP との併用の検討も行っている.

2. 軟骨再生：GDF-5による骨・軟骨誘導を検討し，軟骨再建への応用を検討している.

3. 皮膚再生 : bFGF, PRP, 人工真皮, 培養表皮を単体, 複合で種々の条件下での適用を検討し応用を目指した検討をし ている.

4. 軟部組織再生：bFGF，PRP，ASCsによる肉芽増生，脂肪組織移植を検討している.

II. 臨床研究 :

1. 皮膚軟部組織潰瘍・裖瘡の新規治療法

2. 熱傷の新規治療の検討

3. 各種創傷被覆材の検討

4. ケロイド・肥厚性痏痕の病態と治療法の検討

5. 皮膚腫瘍の手術再建治療法の検討

6. 皮膚レーザーによる皮膚への侵襲と色素改善

7. 皮膚・軟部組織の加齢現象と抗加齢治療の検討

8. 新規皮弁の開発

9. 育毛促進の検討

10. 加電圧水点下保存庫（水感庫）による組織・臟器の保存の検討

11. マイクロサージャリーを応用した遊離組織移植の検討

12. 唇裂・ 口蓋裂の発生原因解明と集学的治療の検討

13. 構音・音声障害の構造的, 機能的検討

14. 顔面骨骨折・骨切り術における人工骨, 吸収性固定材料の検討

15. 頭蓋顎顔面の骨軟部組織の計測と 3 次元表示

16. リンパ浮腫モデル作成と治療の検討

17. 手術シミュレーション, バーチャルリアリティの研究

\section{〈研究業績〉}

原 著

1. Kakudo N, Ogawa Y, Suzuki K, Kushida S and Kusumoto K (2009) Clinical Outcome of Surgical Treatment for
Periorbital Basal Cell Carcinoma. Ann Plast Surg 65(5): 531-535

2. Kakudo N, Kushida S and Kusumoto K (2009) Plateletrich plasma: the importance of platelet separation and 
concentration. Plast Reconstr Surg 123(3): 1135-1136

3. Kakudo N, Ogawa Y and Kusumoto K (2009) Success of the orbicularis oculi myocutaneous vertical v-y advancement flap for upper eyelid reconstruction. Plast Reconstr Surg 123(1): 423-424

4. Horiguchi M, Inoue T, Ohbayashi T, Hirai M, Noda K, Marmorstein LY, Yabe D, Takagi K, Akama TO, Kita T, Kimura T and Nakamura T (2009) Fibulin-4 conducts proper elastogenesis via interaction with cross-linking enzyme lysyl oxidase. Proc Natl Acad Sci USA 45: 19029-19034

5. 覚道奈津子, 南方竜也, 鈴木健司, 楠本健司 (2009) 関西医科大学附属滝井病院におけるスキンケア外来. Cosmetic Stage 3(4): 45-49

6. 日野沙衣子, 竹本剛司, 楠本健司 (2009) 足底に発生 した腱鞘巨細胞腫の1例. 形成外科 52(12): 1481-1487

7. 藤本明久, 内田茂樹, 篠置 哲, 後藤研三, 鈴木健司, 山本 純 (2009) コンポジックスメッシュ感染後に components separation法にて修復した腹壁痕痕へルニ アの1例. 手術 63(10): 1597-1600

8. 森 雄大, 堀尾 修, 楠本健司 (2009) 㚘骨骨折に合 併する顎関節窩骨折についての検討. 日形会誌 29(6): 347-352

9. 三宅ヨシカズ, 福田 智, 井口有子, 大西早百合, 楠 本健司（2009）PRP（platelet-rich plasma；多血小板血 漿）を使用した皮膚潰瘍治療の検討. 日形会誌 29(2): 65-72

10. 南方竜也, 覚道奈津子, 鈴木健司, 楠本健司（2009） 弾性ストッキング着用による足部裖瘡についての検 討. 裖瘡会誌 11(4): 502-509

11. 三宅ヨシカズ，楠本健司（2009）裖瘡ポケットに対す る多血小板血漿を使用した治療. 裖瘡会誌 11(1): 5560

12. 光井俊人, 下間覀由子, 三宅省吾, 覚道奈津子, 堀尾 修, 中谷壽男 (2009) 当院における過去 5 年間の 60 歳以上の重症熱傷の検討. 熱傷 35(1): 15-20

総 説

1. 楠本健司 (2009) 耳鼻咽喉科の外傷に強くなる下顎骨 折. JOHNS 25(9): 1273-1277

2. 楠本健司 (2009)【頭部・顔面の画像診断と手術シミュ レーション】セファログラムを用いた顎顔面変形の治 療計画. PEPARS (29): 18-25

3. 楠本健司, 鈴木健司, 竹本剛司 (2009) 頭部・顔面の 形成外科 6. 顔面骨欠損の再建法. 形成外科 52 (増 刊): S41-S48

4. 楠本健司 (2009) 私の手術と合併症回避のコツ 下顎 枝矢状分割法と合併症回避のコツ。形成外科 52(3): 297-303
症例報告

1. 三島伸介, 天野博之, 鈴木裕子, 神田靖士, 石田高明, 西山利正, 堀尾 修, 伊藤誠, 木村英作 (2009) 末梢 血厚層塗抹法にてミクロフィラリアを検出したロア 糸状虫症の1例．Clinical Parasitology 19(1): 136-139

その他

1. 田中保子, 光井俊人, 鈴木健司, 楠本健司 (2009) 過 去 10 年間の当院における小児熱傷患者についての検 討. 熱傷 35(5): 253-257

学会発表

1. Fredeirk Zefanya Notodihardjo, Henry Wijono Notodihardjo, Kenji Kusumoto and Yutaka Ogawa (2009) Treatment of Hygroma Colli with OK-432. The 10th Congress of the international Confederation for Plastic Reconstructive and Aesthetic Surgery-Asian Pacific Section, 東 京

2. Henry Wijono Notodihardjo, Frederik Zefanya Notodihardjo, Kenji Kusumoto and Yutaka Ogawa (2009) Treatment of lymphangioma with $\mathrm{OK} 432$, Triamcinolon and Operation. The 10th Congress of the international Confederation for Plastic Reconstructive and Aesthetic Surgery-Asian Pacific Section, 東京

3. Natsuko Kakudo, Yutaka Ogawa, Kenji Suzuki, Satoshi Kushida and Kenji Kusumoto (2009) Clinical outcome of surgical treatment for periorbital basal cell carcinoma. The 10th Congress of the international Confederation for Plastic Reconstructive and Aesthetic Surgery-Asian Pacific Section, 東京

4. Satoshi Kushida, Takashi Takemoto, Osamu Horio, Natsuko Kakudo, Kenji Suzuki and Kenji Kusumoto (2009) Statistical analysis of maxillofacial fractures for 3 years in Kansai Medical University. The 10th Congress of the international Confederation for Plastic Reconstructive and Aesthetic Surgery-Asian Pacific Section, 東京

5. Natsuko Kakudo, Satoshi Kushida and Kenji Kusumoto (2009) Possibility of myofibroblast differentiation of human adipose-derived stem cell. The 7th Annual Meeting of the International Federation for Adipose Therapeutics and Science, Daegu, Korea

6. Satoshi Kushida, Natsuko Kakudo and Kenji Kusumoto (2009) Effects of collagen gel contraction with TGF- $\beta 1$ and PRP in embedded culture of adipose-derived stem cells of dermal fibroblasts. The 7th Annual Meeting of the International Federation for Adipose Therapeutics and Science, Daegu, Korea

7. Atsuko Tanabe, Nobuko Tanaka, Kikuo Oku and Kenji Kusumoto (2009) Reconstruction of postoperative oronasal fistula in 3 patients. the 10th Congress of the international Confederation for Plastic Reconstructive and Aes- 
thetic Surgery-Asian Pacific Section, 東京

8. Takashi Takemoto, Yasuko Tanaka, Tomoe Yamamoto and Kenji Kusumoto (2009) Effects of early treatment for strawberry hemangioma with pulsed dye laser. the 10th Congress of the international Confederation for Plastic Reconstructive and Aesthetic Surgery-Asian Pacific Section, 東京

9. Horiguchi, M., Inoue, T., Ohbayashi, T., Hirai, M., Noda, K., Marmorstein, L.Y., Akama, T.O., Kita, T., Kimura, T. and Nakamura, T. (2009) The role of FIBULINs in elastogenesis. Gordon Research Conference on Elastin and Elastic Fiber, Biddeford, USA

10. Horiguchi M, Inoue T, Noda K and Nakamura T (2009) The role of fibulins in elastic fiber assembly of mouse aorta. 8th Pan Pacific Connective Tissue Societies Symposium, 横須賀

11. 櫛田哲史，覚道奈津子，鈴木健司，楠本健司（2009） 多血小板血漿（PRP）添加によるコラーゲンゲル真皮 創傷モデルの収縮効果の検討. 第39回日本創傷治癒学 会, 東京

12. 伊藤文人, 井口有子, 三宅良平 (2009) 下眼瞼内反症 治療におけるJones法の選択と効果. 第93回日本形成 外科学会関西支部学術集会, 西宮市

13. 光井俊人, 久徳美樹, 櫛田哲史 (2009) 背部に発生し た巨大悪性石乍化上皮腫の一例. 第93回日本形成外科 学会関西支部学術集会, 西宮市

14. 黒川憲史, 久徳茂雄, 笠井千尋, 川島正裕, 高橋 豊, 浜川博司（2009）Pectus bar が術後早期に回転した Marfan症候群漏斗胸の一例. 第93回日本形成外科学会 関西支部学術集会, 西宮市

15. 大西早百合，日原正勝，楠本健司，松島貴志 (2009) 大阪府内の切断指 - 挫滅創患者救急搬送件数の推移の 調査と検討. 第93回日本形成外科学会関西支部学術集 会, 西宮市

16. 田中寧子, 竹本剛司, 松島貴志, 楠本健司 (2009) NUSS 法におけるバー抜去時，肋骨仮骨化を認めた一例．第 93 回日本形成外科学会関西支部学術集会, 西宮市

17. 日原正勝, 小倉常敬, 楠本健司, 富野敦稔, 三家 泉, 北澤康秀（2009）超早期手術後に自家培養表皮移植を 併用した広範囲熱傷の一例. 第93回日本形成外科学会 関西支部学術集会, 西宮市

18. 日野沙衣子, 笹尾卓史, 森 雄大（2009）大腿骨骨頭 切除および笳皮弁による再建にて治癒し得た右大転 子部裖瘡の化膿性股関節炎合併例. 第93回日本形成外 科学会関西支部学術集会, 西宮市

19. 尾崎裕次郎，南方竜也，鈴木健司，楠本健司（2009） 眼窩異物除去後に突発性眼窩炎症の発症が疑われた 一例. 第93回日本形成外科学会関西支部学術集会, 西 宮市

20. 櫛田哲史，鈴木健司，覚道奈津子，楠本健司（2009） 当科に打ける Pletelet-Rich Plasma（多血小板血漿）の
基礎的研究成果. 第 1 回 PRP（多血小板血漿）療法研 究会, 大阪市

21. 笹尾卓史, 高山沙衣子，森 雄大（2009）指骨骨癒合 不全にPRPを併用した 1 例. 第 1 回 PRP（多血小板血 漿）療法研究会, 大阪市

22. 山本知恵, 田辺敦子, 田中伸子, 奥きくお, 大前和人, 荻野真由, 小川 豊 (2009) 当院におけるPRP治療の 経験. 第 1 回PRP (多血小板血漿) 療法研究会, 大阪市 23. 仲野雅之, 竹本剛司, 日原正勝, 三宅省吾, 山本 純, 楠本健司 (2009) 囊胞腔へのPRP注入療法による治療 経験. 第1回PRP (多血小板血漿) 療法研究会, 大阪市

24. 南方竜也, 鈴木健司, 堀尾 修, 覚道奈津子, 畔 熱 行, 尾崎裕次郎, 楠本健司 (2009) 様々な疾患に対す るPRP（多血小板血漿）の使用経験. 第 1 回 PRP（多 血小板血漿) 療法研究会, 大阪市

25. 福田 智, 三宅ヨシカズ（2009）PRP療法の適応と限 界. 第 1 回 PRP (多血小板血漿) 療法研究会, 大阪市 26. 三宅ヨシカズ, 福田 智 (2009) 多血小板血漿 (Plateletrich plasma;PRP) を使用した形成外科・美容外科領域 の治療. 第 1 回 PRP (多血小板血漿) 療法研究会, 大阪市

27. 覚道奈津子, （2009） ヒト脂肪組織由来幹細胞と増殖 因子を用いた組織再生と展望. 第18回日本形成外科学 会基礎学術集会, 東京

28. 櫛田哲史（2009）多血小板血漿（PRP）添加によるコ ラーゲンゲル真皮創傷モデルの収縮効果の検討. 第 18 回日本形成外科学会基礎学術集会, 東京

29. 南方竜也（2009）電圧負荷による氷点下非凍結組織保 存の有用性 : 筋組織について (第 1 報)。第 18 回日本 形成外科学会基礎学術集会, 東京

30. 三宅ヨシカズ, 福田 智 (2009) 医誠会病院 創傷治 療センターにおけるフットケアの現状と難治例への 対応. 第31回大阪形成外科医会, 大阪

31. 國吉京子, 楠本健司（2009）鰓弓由来症候群の構音指 導. 第54回日本音声言語医学会総会・学術集会, 福島市

32. 井上唯史, 大林徹也, 赤間智也, 中邨智之 (2009) LTBP2 遺伝子欠損マウスは緑内障を発症する. 第 82 回日本 生化学会, 神戸

33. 堀口真仁, 井上唯史, 野田和男, 中邨智之（2009） マ ウス大動脈の弾性線維形成における Fibulinの役割. 第 82 回日本生化学会, 神戸

34. 南方竜也, 鈴木健司, 覚道奈津子, 振角明恵, 大枝由 紀（2009）当院で経験した医原性裖瘡について．第11 回日本裖瘡学会, 大阪市

35. 覚道奈津子，櫛田哲史，楠本健司（2009）線維芽細 胞・脂肪組織細胞に対する多血小板血漿および線維芽 細胞増殖因子による増殖効果. 第 41 回日本臨床分子形 態学会総会・学術集会, 神戸市

36. 尾崎裕次郎，覚道奈津子，南方竜也，鈴木健司，楠本 健司（2009）当院における耳部ケロイドの放射線療法 と再発率の検討. 第 4 回痒痕・ケロイド治療研究会, 東京 
37. 久徳茂雄, 笠井千尋, 奥野涼子, 黒川憲史, 大谷一弘 （2009）頭蓋顔面領域における fibrous dysplasiaの外科 的治療について. 第 21 回日本頭蓋底外科学会, 福岡市

38. 畔 熱行, 鈴木健司, 堀尾 修, 南方竜也, 覚道奈津 子, 尾崎裕次郎 (2009) 組織拡張器を用いて行った遊 離広背筋皮弁による足部再建. 第 28 回大阪マイクロ サージャリー研究会, 大阪

39. 山本知恵, 大西早百合, 楠本健司（2009）虐待による 熱傷の一例. 第35回日本熱傷学会総会・学術集会, 東京 40. 大谷一弘, 久徳茂雄, 笠井千尋, 奥野涼子 (2009) 手 指電撃傷の一治療例. 第35回日本熱傷学会総会・学術 集会, 東京

41. 畔 熱行, 鈴木健司, 堀尾 修, 南方竜也, 覚道奈津 子, 櫛田哲史, 仲野雅之, 楠本健司（2009）熱傷創お よび分層採皮創にモイスキンパッド ; を用いた湿潤療 法の検討. 第35回日本熱傷学会総会・学術集会, 東京

42. 笠井千尋, 久徳茂雄, 奥野涼子, 黒川憲史, 大谷一弘 （2009）治療中の顔面非対称の 3 例について．第 92 回 日本形成外科学会関西支部学術集会, 大阪市

43. 三宅ヨシカズ, 福田 智, 富野祐里, 楠本健司 (2009) 膠原病の血管病変による進行性足趾壊死にシルデナ フィルが著効した 1 例. 第92回日本形成外科学会関西 支部学術集会, 大阪市

44. 仲野雅之, 畔 熱行, 覚道奈津子, 南方竜也, 堀尾 修, 鈴木健司, 楠本健司（2009）当院で経験した陰茎 内異物の症例. 第92 回日本形成外科学会関西支部学術 集会, 大阪市

45. 田中伸子, 田辺敦子, 奥喜久雄, 山本知恵, 楠本健司, 小川 豊（2009）削皮術後の治療について一考. 第92 回日本形成外科学会関西支部学術集会, 大阪市

46. 田中保子, 山本知恵, 小倉常敬, 楠本健司 (2009) 慰 部に生じた Nevus Lipomatosus Cutaneous Superficialis の一例. 第92 回日本形成外科学会関西支部学術集会, 大阪市

47. 土井秀明（2009）眼輪筋弁を用いて重瞼高を下げる術 式. 第92 回日本形成外科学会関西支部学術集会, 大阪 市

48. 楠本健司, 竹本剛司, 山本知恵 (2009) 老人性眼瞼下 垂症例の手術治療について. 第9 回日本抗加齢医学会 総会, 東京

49. 和氣家彩果, 楠本健司, 山本一郎, 萩尾藤江 (2009) 口唇裂・口唇裂児の母親の育児ストレスと子どもへの 情緒的きずな：一般乳幼児の母親と比較して. 第33回 日本口蓋裂学会, 東京

50. 國吉京子, 楠本健司, 山本一郎, 西村朱美（2009）顎 裂骨移植術前後の言語の変化の検討. 第33回日本口蓋 裂学会, 東京

51. 井口有子, 鈴木健司, 堀尾 修, 南方竜也, 三宅良平,
楠本健司（2009）慰部慢性膿皮症の治療法における検 討一慢性膿皮症に合併した有棘細胞癌の経験例を加 えて一. 第 52 回日本形成外科学会総会 - 学術集会, 横 浜市

52. 覚道奈津子, 小川 豊, 鈴木健司, 楠本健司（2009） 眼瞼部基底細胞癌とその再建法の検討. 第52回日本形 成外科学会総会・学術集会, 横浜市

53. 久徳茂雄（2009）頭蓋顔面，頭蓋底，唇裂手術への思 い入れ, 使命感とその継続. 第5 2 回日本形成外科学会 総会・学術集会, 横浜市

54. 光井俊人, 久徳美樹 (2009) 皮膚 - 軟部腫瘍における 臨床診断一病理診断の不一致例に関する検討一. 第 52 回日本形成外科学会総会・学術集会, 横浜市

55. 三宅ヨシカズ, 福田 智, 楠本健司, 大西早百合, 井 口有子, 鈴木健司, 覚道奈津子, 森 雄大 (2009) 多 血小板血漿（platelet-rich plasma;PRP）を使用した形 成外科 - 美容外科領域の治療. 第52回日本形成外科学 会総会・学術集会, 横浜市

56. 山本知恵, 松島貴志, 楠本健司, 稲垣隆介, 濱田吉則, 高田晃平, 大橋 敦（2009）腰部結合双胎分離症例の 経験. 第52回日本形成外科学会総会・学術集会, 横浜市

57. 楠本健司，鈴木健司，竹本剛司，堀尾 修（2009）島 状皮弁による鼻と口囲の軟部組織再建. 第52回日本形 成外科学会総会・学術集会, 横浜市

58. 福田 智, 三宅ヨシカズ, 楠本健司, 富野祐里 (2009) 虚血性下腿潰瘍の血行再建不適例に対する治療戦略. 第52回日本形成外科学会総会・学術集会, 横浜市

59. 鈴木健司, 堀尾 修, 覚道奈津子, 畔 熱行, 楠本健 司（2009）超音波キューサーを使用した腋臭症治療の 一工夫. 第52 回日本形成外科学会総会 - 学術集会, 横 浜市

60. 鈴木健司（2009）足底部 Pincer flap（仮称）を使用し た合趾症例. 第14回形成外科手術手技研究会, 大阪

61. 覚道奈津子, 畔 熱行, 鈴木健司, 楠本健司 (2009) 前額部知覚神経障害を併発した, 眼窩切痕領域の外傷 性三叉神経痛の1例. 第 20 回眼瞼・義眼床手術研究会, 岡山

62. 小川 豊, 竹本剛司（2009）瞼裂高は立位（坐位）よ り仰臥位のほうが小さい. 第20回眼瞼・義眼床手術研 究会, 岡山

63. 仲野雅之, 小倉常敬, 南方竜也, 堀尾 修, 竹本剛司, 松島貴志, 鈴木健司, 楠本健司 (2009) 当院で経験し た医原性創傷について. 第1回日本創傷外科学会総会・ 学術集会, 東京

64. 南方竜也，鈴木健司，堀尾 修，覚道奈津子，畔 熱 行, 小倉常敬, 楠本健司（2009）四肢外傷患者に対す る PRP（多血小板血漿）の使用経験. 第 1 回日本創傷 外科学会総会・学術集会, 東京 


\section{泌尿器科学講座}

\section{〈研究概要〉}

当教室の最も大きな研究テーマは, 基礎, 臨床ともに低侵襲治療, 特に腹腔鏡手術の技術評価, 治療成績と, 教育に 関するものである.

基礎研究では従来困難と思われていた，手術手技の客観的な評価を行うために，手術操作時の器具にかかる圧，方向 性などをりアルタイムに計測できるシステムを開発し，手技の各パラメーターをもとに，初心者に対してょり科学的な 手術技術の教育を行えるような基礎的データを蓄積している. また，手術（手術手技）シミュレーターを通して，初心 者がいかに効率よくラーニングカーブを克服できるのか検討を行っている.

臨床研究では, 主に泌尿器生殖器癌の治療成績, 術後の機能温存などに関わる, または, 男性更年期障害, 女性の骨 盤臟器脱と治療, 間質性膀胱炎に関する研究を行っている.

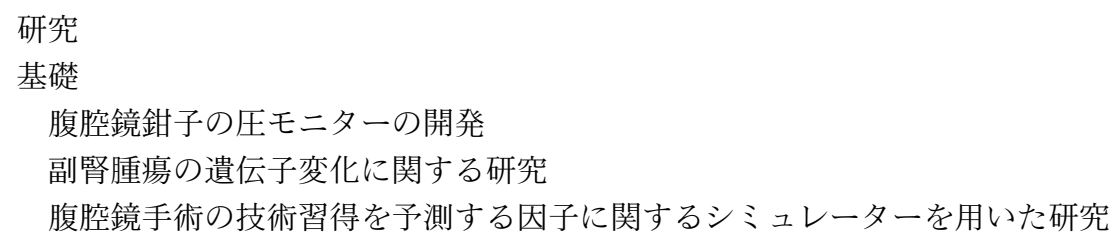

\section{臨床}

腹腔鏡手術のラーニングカーブの短期化に関する研究

腹腔鏡手術の合併症に関する研究

筋層浸潤性膀脱癌の予後予測因子に関する研究

腹腔鏡下腎部分切除術の阻血時間と術後の腎機能に関する研究

前立腺生検の最適化に関する研究

早期前立腺癌に対する手術療法の予後予測因子に関する研究

早期前立腺癌に対する手術療法後の勃起能に関する研究

前立腺癌に対する内分泌療法の方法と効果に関する無作為比較試験

再燃前立腺癌に対する抗癌剤の有効性に関する研究

腎外傷に対する腎温存治療のリスクと臨床的意義に関する研究

男性更年期の治療と QOLに関する研究

女性の尿失禁に対する手術療法とアウトカムに関する研究

間質性膀胱炎における潰瘍の有無と臨床症状に関する研究

\section{〈研究業績〉}

\section{原 著}

1. Nishida T, Hosaka N, Takaki T, Miyake T, Cui W, Inaba M, Kinoshita H, Matsuda T and Ikehara S (2009) Allogeneic intra-BM-BMT plus adult thymus transplantation from same donor has benefits for long-term survival even after sublethal irradiation or low-dose BM cell injection. Bone Marrow Transplant 43(11): 829-837

2. Saito T, Matsumura K, Tsubota Y, Maniwa T, Kaneda H, Minami K, Sakaida N, Uemura Y, Kawa G, Yamamoto N, Fujii Y, Isobe K, Kawakami Y, Matsuda T, Saito Y and Takekoshi K (2009) Novel Mutation (L157X) in the Succinate Dehydrogenase B Gene (SDHB) in a Japanese Family with Abdominal Paraganglioma Following Lung Metastasis. Endocr J 56(3): 451-458

3. Kamihira O, Hattori R, Yamaguchi A, Kawa G, Ogawa O, Habuchi T, Kawauchi A, Uozumi J, Yokoi S, Tsujihata M, Hasui Y, Miyakoda K, Tada H, Ono Y and Naito S (2009)
Laparoscopic Radical Nephroureterectomy: A Multicenter Analysis in Japan. Eur Urol 55(6): 1397-1409

4. Nishida S, Utsunomiya N, Nishiyama H, Kamoto T, Ogawa O and Kinoshita H (2009) Urethral mobility at catheter removal predicts early recovery of urinary continence after radical prostatectomy. Int J Urol 16(4): 375378

5. Arai Y, Kaiho Y, Takei M, Nonomura K, Baba S, Habuchi T, Matsuda T, Takahashi S, Igawa M and Nakagawa $\mathrm{H}$ (2009) Burden of male stress urinary incontinence: A survey among urologists in Japan: Short Communication. Int J Urol 16(11): 915-917

6. Arai Y, Takei M, Nonomura K, Baba S, Habuchi T, Matsuda T, Takahashi S, Igawa M, Kaiho Y and Nakagawa $\mathrm{H}$ (2009) Current use of the artificial urinary sphincter and its long-term durability: A nationwide survey in Japan. Int J Urol 16(1): 101-104

7. 河 源, 松田公志 (2009) 後腹膜的アプローチによ 
る腹腔鏡下腎孟形成術の長期予後の検討. Jpn J Endourol ESWL 22(2): 204-207

8. 吉田健志, 西山博之, 木下秀文, 渡部 淳, 三富陽子, 松田公志，小川 修（2009）回腸新膀胼増設術後の男 性患者に打ける排尿習慣の横断的実態調査. 泌尿器科 紀要 55(7): 389-393

9. 谷口久哲, 河 源, 木下秀文, 松田公志 (2009) LOH 症候群患者に対するアンドロゲン補充療法が QOL に 及ぼす影響に関する検討。泌紀 55(12): 741-744

10. 小角幸人, 高原史郎, 奥山明彦, 勝岡洋治, 東 治人, 仲谷達也，山口誓司，江左篤信，金卓，植村天受， 石井徳味, 西岡 伯, 松田公志, 坂口勝彦, 客野宮治, 原 恒男 (2009) 大阪府で行われた腎移植に関する実 態調査. 大阪透析研会誌 27(2): 213-224

11. 谷口久哲, 日浦義仁, 河 源, 木下秀文, 松田公志 （2009）当科における後天性低ゴナドトロピン性男子 性腺機能低下症の検討. 日性機能会誌 24(3): 377-382

12. 木村美穂, 足立清美, 富田麻里子, 日下美保子, 川喜 多繁誠, 福井勝也, 杉 素彦, 室田卓之 (2009) 前立 腺密封小線源永久挿入療法を受けた患者と家族の意 識調査 日常生活上の被曝に対する患者・家族の不安 の相違について．泌ケア 14(2): 192-199

13. 河 源, 谷口久哲, 木下秀文，松田公志（2009）男 性更年期専門外来の受診患者像に関する検討 : 5 年間 の臨床統計と年次における変遷. 泌紀 55(2): 87-92

総 説

1. Tanaka M, Ono Y, Matsuda T, Terachi T, Suzuki K, Baba S, Hara I, Hirao Y; Urological Laparoscopic Surgery Guideline Committee, Japanese Society of Endourology and ESWL (2009) Guidelines for urological laparoscopic surgery. Int J Urol 16(2): 115-125

2. 木下秀文, 井上貴明, 松田公志 (2009) 陰茎海綿体神 経温存腹腔鏡下前立腺全摘除術のコツ. Jpn J Endourol ESWL 22(2): 173-178

3. 小野佳成, 松田公志 (2009) 第26回世界泌尿器内視鏡 学会議（WCE2008）と The Endourological Society. Jpn J Endourol ESWL 22(1): 50-52

4. 日浦義仁, 松田公志, 森本義晴（2009）【生殖医療最 前線】男性不妊症への対応. Pharm Med 27(5): 27-30

5. 木下秀文，松田公志 (2009）骨転移巣に対する姑息的 放射線療法の適応と効果, 限界. Urol View 7(6): 72-75

6. 矢西正明，松田公志 (2009)【副腎腫瘍の診断と治療 の最近の動向】副腎腫瘍の診断と治療Update 腹腔鏡 による副腎摘除術の進歩. カレントテラピー 27(3): $244-248$

7. 滝澤奈恵, 松田公志 (2009) 原発性アルドステロン症 の外科治療の現状. 血圧 16(11): 948-951

8. 河 源（2009）男性ホルモンの臨床 男性更年期障 害の症状と診断．治療 91(9): 2201-2205

9. 木下秀文 (2009)【腹腔鏡手術での血管処理について】
副腎摘除術における経腹膜到達法. 腎移植・血管外 20(2): 96-101

10. 藤本直浩，松本哲朗，鈴木啓悦，市川智彦，沖原宏治， 三木恒治，三宅秀明，藤澤正人，植村元秀，三好進， 田丁貴俊, 矢野 明, 藤井元廣, 滝花義男, 武田正之, 石光 広, 松原昭郎, 碓井 亞, 木下秀文, 松田公志, 麦谷荘一, 大園誠一郎, 那須保友, 雑賀隆史, 公文裕 巳 (2009) Maximum androgen blockade 中の PSA 再燃 に対する非ステロイド性抗アンドロゲン剂交替療法 一NASA-PC 研究会報告を中心に一. 西日泌 71(1):310

11. 大口尚基（2009）女性泌尿器外来における過活動膀胱 の診療のコツ。大阪内科医会誌 18(2): 172-176

12. 三島崇生, 滝澤奈恵, 松田公志 (2009)【クッシング 症候群 新しい展開】クッシング症候群に対する腹腔 鏡下副腎摘除術。内分泌外科 26(2): 87-93

13. 木下秀文，松田公志（2009）【前立腺疾患の実地診療 と最近の動向】前立腺がんに対する根治的手術 腹腔 鏡下前立腺全摘除術．日医師会誌１38(2): 265-269

14. 河源（2009）【内分泌疾患を診るこつ】よく出遭 う内分泌疾患【性腺機能低下】男性性腺機能低下 (LOH 症候群)．Medicina 46(6): 958-961

15. 三島崇生，松田公志（2009）標準的腹腔鏡下副腎摘除 術. 外科治療 100 (増刊) : 202-207

16. 木下秀文 (2009) 経過がわかれば異常に気づける 新 人ナースのための術前・術後ケアの $\mathrm{ABC}$ 腹腔鏡下副腎 摘出術. 泌ケア 14(5): 442-445

症例報告

1. Iida T, Kawa G and Matsuda T (2009) A case of preserving renal function by renal autotransplantation for bilateral urothelial carcinoma of the ureter. Int J Urol 16(6): 587

2. 安田鐘樹, 河 源, 木下秀文, 松田公志 (2009) 腹 腔鏡下腎尿管摘除術後にトロカーポート部再発が疑 われた尿管腫瘍の1例。泌紀 55(3): 141-144

3. 谷口久哲, 河 源, 木下秀文, 松田公志, 浅井昭雄 （2009）男性更年期症状を呈し低ゴナドトロピン性性 腺機能低下症と診断された1例．泌紀 55(2): 107-109

4. 島田 治, 福井勝也, 矢西正明, 川喜多繁誠, 杉 素 彦, 芦田 眞, 室田卓之, 四方伸明, 松田公志 (2009) FMD(fibromuscular dysplasia) に起因した腎動脈瘤破裂 の1例．泌紀 55(1): 19-22

5. 山本 梓, 豊田長與, 山本奈恵, 浮田千津子, 野村惠 巳子，小崎篤志，坂井田紀子，植村芳子，岩坂壽二, 廣川満良, 宮内 昭, 松田公志, 西川光重 (2009) 副 腎偶発腫瘍が診断の契機となった多発内分泌腺腫症 (MEN) 2Aの1例. 日本内分泌学会雑誌 85(1): 389

その他

1. Matsuda T (2009) Varicocelectomy for male infertility: A 
comparative study of open, laparoscopic and microsurgical approaches-Commentary. J Endourol 23(2): 211212

2. Matsuda T (2009) Surgical renal ischemia: A contemporary overview—Commentary. J Endourol 23(1): 212-213

3. Mishima T, Matsuda T, Masuda T, Watanabe M, Kawa G, Kinoshita H and Sekino N (2009) Development of a Multifunctional Footswitch Controller. Recent Advances in Endourology 11: 93-97

4. 松田公志 (2009) 停留精巣, 精索静脈瘤患者に対する 治療効果. 日本IVF学会誌 12: 18-19

5. 松田公志 (2009) 男性不妊症の治療. 医事新報 (4457): 78-79

6. 松田公志, 今村洋二 (2009) 関西医科大学付属枚方病 院手術部の内視鏡外科手術室. 日内視鏡外会誌 14(1): 117-119

\section{学会発表}

1. Katsuya Fukui, Hidefumi Kinoshita, Gen Kawa and Tadashi Matsuda (2009) Outcomes of Laparoscopic Radical Prostatectomy in our hospital. The 6th East Asian Society of Endourology 2009, マニラ, フィリピン

2. Tadashi Matsuda (2009) Asian Symposium 「Present Status and Future Development of Endourology in Asia $」$. 第 23 回日本Endrology $・$ ESWL学会総会, 東京都

3. Matsuda T (2009) Managing intraoperative tumor violation/positive margin-My tips and tricks for LPN. 27th World Congress of Endourology \& SWL 2009, Munich,Germany

4. H. Taniguchi, G. Kawa, H. Kinoshita and T. Matsuda (2009) Health related quality of life in Japanese late onset hypogonadism patients administered androgen replacement therapy in past years. the 5th Congress of Asia Pacific Society for the Study of Aging Male(APSSAM), Osaka,Japan

5. 松田公志 (2009) Panel Discussion: Minimally invasivenephron sparing surgery.Ways to shorten the warm ischemic time and to achieve the oncological goal. 1. Japnanese experience: retroperitoneal. 26th Korea-Japan Urological Congress, ソウル, 韓国

6. Tadashi Matsuda (2009) Laparoscopic urological surgery in Japan. The 7th Severance Urological Symposium, Seoul, Korea

7. Kawa G, Masuda T, Oguchi N, Kinoshita H and Matsuda $\mathrm{T}$ (2009) Uninterrupted suture for renal parenchyma in laparoscopic partial nephrectomy decreases renal ischemic time and intraoperative blood loss. Annual Meeting American Urological Assosiation, America

8. 堀越幹人, 矢西正明, 秦健一郎, 大口尚基, 河 源, 木下秀文, 松田公志, 日野沙衣子, 三宅省吾, 楠本健 司（2009）尿道摘除・虫垂を用いた Mitrofanoff法尿路
変更を行った外陰部Paget病の1例. 第209回日本泌尿 器科学会関西地方会, 京都市

9. 河源 (2009) 後腹腔的アプローチによる腹腔鏡下 腎孟形成術の長期予後. 第22回日本内視鏡外科学会総 会, 東京

10. 吉田健志，大口尚基，河源，木下秀文，松田公志 （2009）腹腔鏡用鉗子先端作用力の計測による剥離操 作の技能分析. 第 22 回日本内視鏡外科学会総会, 東京

11. 駒井資弘, 河 源, 滝澤奈恵, 大口尚基, 木下秀文, 松田公志 (2009) 腎阻血による腹腔鏡下腎部分切除術 後の腎機能の評価. 第 22 回日本内視鏡外科学会総会, 東京

12. 松田公志 (2009)（特別講演）副腎腫瘍の診断と治療： 最近の話題を含めて. 第 26 回神戸 Urogenital Tumor Conference, 神戸市

13. 河源 (2009) サンゴ状結石に対する PNLは有効か つ低侵襲か？：難治症例の経験からの検討. 大阪泌尿 器科臨床医会第 56 回学術集会, 大阪市

14. 谷口久哲, 日浦義仁, 河源, 木下秀文, 松田公志 （2009）当科に打ける後天性低ゴナドトロピン性男子 性腺機能低下症の検討. 第14回日本生殖内分泌学会学 術集会, 東京都

15. 松田公志 (2009) 腹腔鏡下腎部分切除術 : 断端陰性と 腎機能保持を目指して. 第15回みなと泌尿器カンファ レンス, 東京都港区

16. 海法康裕, 荒井陽一, 住吉義光, 副島秀久, 田中良典, 内藤誠二, 長谷川友紀, 服部良平, 松田公志, 岡村菊 夫（2009）開腹前立腺全摘除術における周術期管理の 全国調査開腹前立腺全摘除術における周術期管理の 全国調査：設定基準とその実態. 第 23 回 日本 Enourology・ESWL学会総会, 東京都

17. 駒井資弘, 松田公志, 荒井陽一, 佐々直人, 副島秀久, 津島知靖, 内藤誠二, 長谷川友紀, 服部良平, 岡村菊 夫 (2009) 術経験症例数が前立腺ぜん摘除術のアウト カムに与える影響. 第23回 日本Enourology ・ ESWL 学会総会, 東京都

18. 佐々直人, 荒井陽一, 川喜田睦司, 津島知靖, 内藤誠 二, 野尻佳克, 長谷川友紀, 服部良平, 松田公志, 岡 村菊夫（2009）全国調査を基とした経尿道的前立腺全 摘除術における術式 (TURP, TURis, HoLAP, HoLEP, PVP）による周術期成績, 合併症の検討. 第23回 日 本Enourology ・ESWL学会総会, 東京都

19. 志賀健一郎, 関 成人, 荒井陽一, 住吉義光, 田中良 典, 長谷川友紀, 服部良平, 松田公志, 内藤誠二, 岡 村菊夫 (2009) BOHの経尿道的手術における術式別の 周術期管理. 第23回 日本Enourology $-\mathrm{ESWL}$ 学会総 会, 東京都

20. 川喜田睦司, 荒井陽一, 関 成人, 内藤誠二, 永江浩 史, 長谷川友紀, 服部良平, 松田公志, 矢内原仁, 岡 村菊夫（2009）術式による前立腺全摘除術の周術期管 理の違いに関する検討. 第 23 回 日本 Enourology・ 
ESWL学会総会, 東京都

21. 津島知靖, 新 良治, 荒井陽一, 佐々直人, 内藤誠二, 野尻佳克, 長谷川友紀, 服部良平, 松田公志, 岡村菊 夫（2009）術式による前立腺全摘除術の周術期成績の 違いに関する検討．第23回 日本Enourology・ESWL 学会総会, 東京都

22. 野尻佳克, 荒井陽一, 関 成人, 内藤誠二, 永江浩史, 長谷川友紀，服部良平，松田公志，矢内原仁，岡村菊 夫（2009） TURP周術期管理の全国調査. 第23回 日 本Enourology ・ESWL学会総会, 東京都

23. 矢内原仁, 荒井陽一, 川喜田睦司, 津島知靖, 内藤誠 二, 長谷川友紀, 服部良平, 松田公志, 岡村菊夫 (2009) TURP 周術期管理の全国調査データを用いた術者の経 験に基づく様々なアウトカムの解析. 第 23 回 日本 Enourology・ESWL学会総会, 東京都

24. 井上貴昭, 木下秀文, 三島崇生, 谷口久哲, 増田朋子, 大口尚基, 河 源, 室田卓之, 松田公志 (2009) 当 院での腹腔鏡下腎盂尿管全摘術における合併症の臨 床的検討. 第23回日本Endrology $\cdot$ ESWL学会総会, 東 京都

25. 杉 素彦, 原田二郎, 乾 秀和, 西田晃久, 川喜多繁 誠, 佐藤尚, 室田卓之, 松田公志 (2009) 高齢癌患者 における腹腔鏡手術の検討．第 23 回日本 Endrology・ ESWL学会総会, 東京都

26. 川喜多繁誠，杉 素彦，乾 秀和，原田二郎，西田晃 久，佐藤 尚，室田卓之，志賀淑子，播磨洋子，松田 公志 (2009) 前立腺癌密封小線源永久挿入治療におけ る治療計画法の比較検討。第 23 回日本 Endrology • ESWL学会総会, 東京都

27. 増田朋子，西田幸代，安田鐘樹，木下秀文，松田公志 （2009）HoLEP初期の経験〜 $100 \mathrm{ml}$ 以上の前立腺に対 する安全性の検討。第 23 回日本 Endrology・ESWL学 会総会, 東京都

28. 木下秀文, 河 源, 安田鐘樹, 増田朋子, 西田幸代, 三島崇生，谷口久哲，矢西正明，大口尚基，松田公志 （2009）Intrafascial Nerve Sparing techniqueによる腹腔 鏡下前立腺全摘出術の oncological outcome. 第23回日 本Endrology・ESWL学会総会, 東京都

29. 馬場真有美, 岡田英孝, 川畑仁美，下井華代，宮城博 恵, 小野淑子, 岡田園子, 松原高史, 安田勝彦, 谷口 久哲，松田公志，神崎秀陽（2009）体外受精説明会に おける患者の意識調査とその後の治療経過について. 第54回日本生殖医学会・学術講演会, 金沢市

30. 馬場真有美, 岡田英孝, 川畑仁美, 下井華代, 宮城博 恵，小野淑子，岡田園子，松原高史，安田勝彦，谷口 久哲，松田公志，神崎秀陽（2009）体外受精説明会に おける患者の意識調査とその後の治療経過について. 第54回日本生殖医学会総会学術講演会, 金沢市

31. 増田朋子（2009）HoLEP 初期の経験〜 $100 \mathrm{ml}$ 以上の 前立腺に対する安全性の検討．第 5 回内視鏡的前立腺 治療研究会, 東京都
32. 松田公志（2009）腹腔鏡手術の技術評価と認定制度. 第18回秋田県内視鏡外科研究会, 秋田

33. 地崎竜介，松田公志，畧崎佐和子，片野泰代，矢尾育 子, 伊藤誠二（2009）精巣特異的 movo 遺伝子の精子 形成に関する研究. 第39回 関西アンドロロジーカン ファレンス, 大阪市

34. 松田公志 (2009) 各種根治的前立腺摘除術一本邦・米 国の現状と今後一腹腔鏡下アプローチ. 第59回日本泌 尿器科学会中部総会, 金沢

35. 川喜多繁誠, 杉 素彦, 原田二郎, 乾 秀和, 西田晃 久, 佐藤 尚, 室田卓之, 志賀淑子, 播磨洋子, 木下 秀文，松田公志 (2009) 前立腺癌密封小腺源永久挿入 治療後の排尿障害の検討. 第59回日本泌尿器科学会中 部総会, 金沢

36. 大口尚基, 中川雅之, 三島崇生, 河 源, 松田公志 （2009）女性下部尿路症状に対する干渉低周波刺激療 法の carry-over effect の検討. 第59 回日本泌尿器科学 会中部総会, 金沢

37. 中川雅之, 福井勝也, 井上貴昭, 駒井資弘, 川端和史, 河 源，大口尚基，木下秀文，松田公志（2009）当 院における経尿道的バイポーラ前立腺核出術 (TUBE) の初期治療成績. 第59 回日本泌尿器科学会中部総会, 金沢

38. 福井勝也, 杉 素彦, 川喜多繁誠, 河 源, 室田卓 之，木下秀文，松田公志 (2009) 関西医科大学に打け る腎外傷の検討。第59回日本泌尿器科学会中部総会, 金沢

39. 堀越幹人, 木下秀文, 井上貴昭, 増田朋子, 地崎竜介, 安田鐘樹, 大口尚基, 河 源, 松田公志 (2009) MBA 療法再燃前立腺癌に対して antiandrogen withdrawal syndromeが 3 年以上継続している 1 例. 第59回日本泌 尿器科学会中部総会, 金沢

40. 大口尚基, 三島崇生, 河 源, 木下秀文, 松田公志 （2009）前立腺全摘術後の下部尿路症状の検討．第 16 回 日本排尿機能学会, 福岡市

41. 中川晴夫, 武井実根雄, 野々村克也, 馬場志郎, 羽㴊 友則，松田公志，高橋 悟，井川幹夫，海法康裕，荒 井陽一（2009）男性重症尿失禁の実態調査. 第 16 回 日本排尿機能学会, 福岡市

42. 三島崇生，岡田卓也（2009）膀胱 endosalpingiosis の 1 例. 第208回日本泌尿器科学会関西地方会, 大阪市

43. 西田晃久, 杉 素彦, 原田二郎, 乾 秀和, 川喜多繁 誠, 佐藤 尚, 室田卓之 (2009) hCG $\beta$ が正常值を示 さなかった精巣腫瘍セミノーマの 2 例. 第 208 回日本 泌尿器科学会関西地方会, 大阪市

44. 谷口久哲, 日浦義仁, 河 源, 木下秀文, 松田公志 （2009）腹腔鏡下神経温存前立腺全摘除術患者の術前 勃起能に関する客観的評価. 第 20 回 日本性機能学 会, 東京都港区

45. 松田公志 (2009) 泌尿器腹腔鏡手術の技術評価と認定 制度. 第89回北海道医学大会, 札幌市 
46. 木下秀文 (2009) 腎癌に対する腎摘以外の治療（部分 切除, ablation）. 第 4 回 マンスリーミーティング サマーセミナー，京都市

47. 松田公志 (2009) 泌尿器腹腔鏡手術のトレーニング 法 : 前立腺全摘除術をめざして. 富山県泌尿器科木曜 会, 富山市

48. 谷口久哲, 河 源, 日浦義仁, 木下秀文, 松田公志 （2009）当科に打ける低ゴナドトロピン性性腺機能低 下症の検討. 日本アンドロロジー学会第 28 回学術大 会・総会, 富山

49. 松田公志 (2009) 内視鏡手術 : その開発と普及から近 未来まで. 公益社団法人日本動物病院福祉協会 平成 21 年度年次大会, 大阪市

50. 松田公志 (2009) 泌尿器科腹腔鏡手術～技術認定制度 を中心に。第91回千葉泌尿器科集談会, 千葉市

51. 玉木美種子, 高谷明美, 今村理恵, 蔵田佐知子, 大口 尚基，松田公志 (2009) 在宅自己導尿患者管理簿を用 いた指導と経過管理についての検討. 第22回日本老年 泌尿器科学会, 京都

52. 井上貴昭, 木下秀文, 佐藤仁彦, 大口尚基, 河 源, 室田卓之, 松田公志 (2009) 泌尿器腹腔鏡手術の合併 症の検討. 第97回 日本泌尿器科学会, 岡山市

53. 河 源，増田朋子，大口尚基，木下秀文，松田公 志（2009）腎阻血による腹腔鏡下腎部分切除における 腎実質縫合法に関する検討. 第97回 日本泌尿器科学 会, 岡山市

54. 乾 秀和, 堀越幹人, 福井勝也, 駒井資弘, 川喜多繁 誠, 杉 素彦, 室田卓之, 木下秀文, 松田公志 (2009) 膀胱全摘後の上部尿路再発 4 例. 第97回 日本泌尿器 科学会, 岡山市

55. 吉田健志, 井上貴昭, 谷口久哲, 三島崇生, 増田朋子, 矢西正明, 大口尚基, 河 源, 木下秀文, 松田公志 （2009）評価用紙を用いた術者と指導者による腹腔鏡 手術技術評価. 第97回 日本泌尿器科学会, 岡山市

56. 三島崇生, 飯田剛嗣, 秦健一郎, 谷口久哲, 大口尚基, 河源，木下秀文，松田公志（2009）後腹膜鏡下に 施行した精巣腫瘍・後腹膜リンパ節郭清の 2 例. 第 97 回 日本泌尿器科学会, 岡山市

57. 松田公志（2009）腎癌に対する低侵襲手術：腹腔鏡下 腎部分切除術を中心に. 第97回 日本泌尿器科学会, 岡山

58. 西田幸代, 木下秀文, 井上貴昭, 谷口久哲, 三島崇生, 増田朋子, 矢西正明, 大口尚基, 河 源, 松田公志 （2009）前立腺全摘術施行症例の生検前 MRI 所見と全 摘標本の比較検討. 第97回 日本泌尿器科学会, 岡山 市

59. 川喜多繁誠, 杉 素彦, 駒井資弘, 乾 秀和, 福井勝 也, 堀越幹人, 室田卓之, 志賀淑子, 播磨洋子, 木下 秀文, 松田公志 (2009) 前立腺癌密封小線源永久挿入 治療後のEPICを用いたQOL变化の検討。第97回 日 本泌尿器科学会, 岡山市
60. 増田朋子, 松田公志, 三島崇生, 谷口久哲, 大口尚基, 河源, 木下秀文, 関野直美 (2009) 腹腔鏡手術に おける multiple power sources フットスイッチの検討. 第97回 日本泌尿器科学会, 岡山市

61. 大口尚基, 三島崇生, 谷口久哲, 井上貴昭, 増田朋子, 矢西正明，西田幸代，河源，木下秀文，松田公志 （2009）腹腔鏡下前立腺全摘術後の下部尿路症状の検 討. 第97回 日本泌尿器科学会, 岡山市

62. 谷口久哲, 河 源, 木下秀文, 松田公志 (2009) LOH 症候群に対するアンドロゲン補充療法 (ART) 終了後 の予後調査. 第97回 日本泌尿器科学会, 岡山市

63. 木下秀文, 河源, 三島崇生, 谷口久哲, 増田朋子, 矢西正明, 井上貴昭, 西田幸代, 大口尚基, 松田公志 (2009) Intrafascial Nerve Sparing technique による腹腔 鏡下前立腺全摘出術の初期経験. 第97回 日本泌尿器 科学会, 岡山市

64. 矢西正明, 井上貴昭, 谷口久哲, 三島崇生, 増田朋子, 大口尚基, 河 源, 木下秀文, 松田公志 (2009) 転 移性腎癌に対するソラフィニブ初期使用経験. 第97回 日本泌尿器科学会, 岡山市

65. 寺地敏郎, 松田公志 (2009) JUA アップデートセッ ション パネルディスカッション 1 「エンドユロロ ジー, 腹腔鏡領域」 $<\mathrm{I}>$ 座長のことば $</ \mathrm{I}>$. 第97回 日本泌尿器科学会, 岡山市

66. 鈴木啓悦, 藤澤正人, 東原英二, 三好 進, 松本哲朗, 藤井元廣, 武田正之, 大園誠一郎, 碓井 亞, 松田公 志, 公文裕巳, 市川智彦, 三木恒治 (2009) アンチア ンドロゲン交替療法における, セカンドライン・フル タミドの臨床的有用性との予測モノグラムの作成・検 証. 第97回 日本泌尿器科学会, 岡山市

67. 福井勝也, 堀越幹人, 杉 素彦, 川喜多繁誠, 駒井資 弘, 乾 秀和, 室田卓之, 松田公志 (2009) 内視鏡下 小切開前立腺全摘除術の臨床的検討. 第97回日本泌尿 器科学会総会, 岡山市

68. 山内梓, 豊田長興, 山本奈惠, 浮田千津子, 野村恵巳 子, 小崎篤志, 坂井田紀子, 植村芳子, 岩坂壽二, 廣 川満良, 宮内 昭, 松田公志, 西川光重 (2009) 副腎 偶発腫瘍が診断の契機となった多発性内分泌線腫症 (MEN) 2Aの一例. 内分泌学会第82回, 前橋市

69. 松田公志 (2009) 前立腺がん検診の意義と取り組みに ついて. 枚方市医師会講演会「前立腺がんに関する講 演会」, 大阪府枚方市

70. 谷口久哲, 河源, 秦健一郎, 飯田剛嗣, 井上貴昭, 三島崇生，増田朋子，矢西正明，西田幸代，大口尚基， 木下秀文，松田公志（2009）腹腔鏡下前立腺全摘除 術: 勃起神経温存とその短期結果. 第 134 回 日本生 殖医学会関西支部集談会 第 38 回関西アンドロロジー カンファレンス, 大阪市

71. 乾 秀和, 堀越幹人, 福井勝也, 駒井資弘, 川喜多繁 誠, 杉 素彦, 室田卓之 (2009) 同時性両側腎細胞癌 の1例. 第206回日本泌尿器科学会関西地方会, 京都市 
72. 西田幸代, 河 源, 井上貴昭, 大口尚基, 木下秀文, 松田公志（2009）尿管ポリープに合併した尿管重積の 1例. 第206回日本泌尿器科学会関西地方会, 京都市

73. 松田公志（2009）男性更年期障害：何がどこまでわ かったか. 伏見内分泌代謝ネットワーク連携の会・講 演会，京都市

74. 三島崇生，木下秀文（2009）骨盤外傷・尿道断裂後に 骨盤内腫瘍が遷延した 1 例．第28回 泌尿器科手術研 究会 テーマ:「下部尿路手術」, 岡山

75. 矢西正明, 河源, 井辻泰子, 小森敏彦 (2009) 移 植後 BK ウイルス腎症の 3 例。第 42 回日本臨床腎移植 学会, 東京

76. Kawakita M, Kawa G, Kinoshita H, Matsuda T (2009) Extraperitoneal approach following transperitoneal seminal vesicle dissection in laparoscopic radical prostatectomy. 27th World Congress of Endourology \& SWL 2009, Munich,Germany

77. Komai Y, Kawa G, Takizawa N, Oguchi N, Kinoshita H, Matsuda T (2009) Changes in renal function after laparoscopic partial nephrectomy with temporary renal ischemia. 27th World Congress of Endourology \& SWL 2009, Munich,Germany

著 書

1. 松田公志, 中川昌之, 冨田善彦 (2009) 新Urologic Surgeryシリーズ 1 前立腺癌の手術（松田公志, 中川昌
之, 冨田善彦編）1-180頁, メジカルビュー社, 東京

2. 松田公志, 中川昌之, 冨田善彦 (2009) 新Urologic Surgery シリーズ 2 膀胱の手術（松田公志, 中川昌之, 冨田善彦編）1-176頁，メジカルビュー社，東京

3. 木下秀文, 松田公志 (2009) 鏡視下膀胱部分切除術. 新 Urologic Surgery シリーズ 2 膀胱の手術（松田公 志, 中川昌之, 冨田善彦編) 104-109 頁, メジカル ビュー社, 東京

4. 松田公志（2009） I 腎細胞癌に対する手術

腹腔鏡下手術 腎部分切除術一後腹膜到達法 + 冷 却法. 新Urologic Surgery シリーズ 3 腎細胞癌およ び上部尿路癌の手術（松田公志, 中川昌之, 冨田善彦 編）109-115頁，メジカルビュー社，東京

5. 松田公志 (2009) 前立腺全摘除術 膀胱尿道吻合：連 続縫合. 新Urologic Surgery シリーズ 1 前立腺癌の 手術 1 版（松田公志, 中川昌之, 冨田善彦編）145151頁, メジカルビュー社，東京

6. 松田公志 (2009) 経胸経腹膜的副腎摘除術. 新Urologic Surgeryシリーズ 4 良性腎疾患・副腎・後腹膜の手 術（松田公志, 中川昌之, 冨田善彦編) 49-54頁, MEDICAL VIEW，日本

7. 河源, 松田公志 (2009) 腹腔鏡下腎孟形成術： 後腹膜到達法. 新Urologic Surgery シリーズ 4 良 性腎疾患・副腎・後腹膜の手術（松田公志, 中川昌之, 冨田善彦編）66-77頁，MEDICAL VIEW，日本

\section{眼科学講座}

\section{〈研究概要〉}

〈基礎研究〉

1. 眼内血管新生の発生機序とその抑制方法の解明：糖尿病網膜症，加齢黄斑変性をはじとする眼内血管新生には血管 内皮増殖因子 vascular endothelial growth factor（VEGF）が関与すると言われている. 一方最近種々の疾患で細胞の小胞 体ストレスが関与すると言われており，眼特有の細胞である網膜色素上皮における VEGF 発現増加に小胞体ストレスが どのように関与しているかを検討中であり，その抑制実験も行っている.

2. 緑内障の遺伝子治療 : 線維柱帯に選択的に線溶系蛋白の遺伝子導入を行って眼圧下降を図るケミカルトラベクロト ミーを開発すべく基礎実験を行っている.

3. ガレクチンの眼内局在とぶどう膜炎との関連：遺伝子，蛋白質に続く生命第三の鎖といわれる糖鎖ガレクチンの ラット眼内での局在と実験的ぶどう膜炎のモデルラットにおける発現の変化について検討している.

4. 網脈絡膜変性の発生機序とその抑制方法の解明：高オルニチン血症をともなう網脈絡膜変性疾患である脳回転状脈 絡網膜萎縮の in vitro モデルを医化学講座と共同で確立し，アルギナーゼIIの網膜色素上皮細胞傷害への関与を検討した. また，病理学第二講座と共同で網膜変性疾患モデルを用いて網膜変性機序と治療法の解明を行っている.

\section{〈臨床研究〉}

1. 加齢黄斑変性の診断と最適治療法の解明：近年わが国でも急増している加齢黄斑変性には種々の病型, 病態がある ことが明らかになっている，その治療面では, 確立された治療法として光線力学的療法 photodynamic therapy（PDT), 新 しく認可された抗 VEGF 薬である pegaptanib, ranibizumabの硝子体内注入による治療を多数例に行い, 併用療法も含め て, 各病型, 病態に最適な治療法を検討している. また, 各種の抗血管新生薬の臨床試験を積極的に行っている.

2. 糖尿病網膜症におけるサイトカインの動態と抗VEGF薬の奏功機序：教室の従来の研究から, 糖尿病網膜症では眼 内および血中のVEGF，色素上皮由来因子 pigment epithelium-derived factor（PEDF）などの各種サイトカインが大きく変 
動することを明らかになった，近年，糖尿病網膜症に対して抗VEGF中和抗体bevacizumabの硝子体内注入が治療として 用いられるようになったが，それに伴うサイトカインの変動について検討している.

3. 緑内障薬物療法と手術療法の検討：緑内障に対する薬物療法が進歩し, 多種類のプロスタグランジン点眼薬や点眼 合剤が生まれている. 種々の点眼トライアルを行って最適な薬物療法を検討している. 血管新生緑内障に対する bevacizumab硝子体注入の効果と, 最も有効な手術療法の検討を行っている.

4. 網膜血管病变による黄斑浮腫に対する最適治療法の検討 : 糖尿病や網膜静脈閉塞症に伴う黄斑浮腫に対する治療法 として, ステロイドのテノン囊下注射, レーザー光凝固, 硝子体手術, 抗 VEGF 薬の硝子体内注入が行われている. 抗 VEGF薬，ステロイドの臨床試験も含めて最適な治療法の検討を行っている.

5. 低侵襲硝子体手術による網膜硝子体疾患の治療：特発性黄斑円孔, 黄斑上膜, 黄斑浮腫, 裂孔原性網膜剥離に対す る硝子体切除術は近年, 切開創を小さくする小切開化が進んでいる. 小切開硝子体手術を積極的に取り入れ, 従来は 20 ゲージを用いていた手術に打いて，多数例に 23 ゲージ，25ゲージ手術を行い，その成績と合併症について検討している.

\section{〈研究業績〉}

原 著

1. Tokuyama Y, Adachi Y, Minamino K, Shintaku H, Okigaki M, Hayashi K, Kitajima A, Takaki T, Koike N, Shima C, Imai Y, Shi M, Yanai S and Ikehara S (2009) Abnormal distribution of dendritic cells in (NZW x BXSB)F1 mice. Autoimmunity 42(5): 399-405

2. Shima C, Adachi Y, Shi M, Imai Y, Okigaki M, Yanai S, Minamino K, Takahashi K and Ikehara S (2009) The combination method using magnetic beads and a magnet helps sustain the number of donor BM cells after intra$\mathrm{BM}$ injection, resulting in rapid hematopoietic recovery. Bone Marrow Transplant Oct 5. [Epub ahead of print]

3. Kuwata M, Yoshizawa K, Matsumura M, Takahashi K and Tsubura A (2009) Ocular toxicity caused by Paclitaxel in neonatal sprague-dawley rats. In Vivo 23(4): $555-560$

4. Yanai S, Adachi Y, Fuijisawa J, Jiang S, Okigaki M, Shi M, Shima C, Imai Y, Kwon AH and Ikehara S (2009) Antitumor effects of fusion cells of type 1 dendritic cells and Meth A tumor cells using hemagglutinating virus of Japan-envelope. Int J Oncol 35(2): 249-255

5. Matsuyama K, Ogata N, Jo N, Shima C, Matsuoka M and Matsumura M (2009) Levels ofvascular endothelial growth factor and pigment epithelium-derived factor in eyes before and after intravitreal injection of bevacizumab. Jpn J Ophthalmol 53(3): 243-248

6. Tsuda M, Ando A, Matsuyama K, Otsuji T, Fukui C, Maenishi N, Kuwahara A, Nishimura T, Jo N, Nambu H and Matsumura M (2009) Intraocular Pressure (IOP) Reduction by Latanoprost in Japanese Normal Tension Glaucoma Patients Over a Five-Year Period Stratified by Presenting IOP. J Ocul Pharmacol Ther 25(5): 441-445

7. Nishikawa $M$, Matsunaga $H$, Takahashi $K$ and Matsumura M (2009) Indocyanine greenangiography in experimental choroidal circulatory disturbance. Ophthalmic Res 41(1): 53-58

8. Ikeda K, Nakano R, Uraoka M, Nakagawa Y, Koide M, Katsume A, Minamino K, Yamada E, Yamada H, Quer- termous T and Matsubara H. (2009) Identification of ARIA regulating endothelial apoptosis and angiogenesis by modulating proteasomal degradation of cIAP-1 and cIAP-2. Proc Natl Acad Sci USA 106(20): 8227-8232

9. 南野桂三, 松岡雅人, 安藤 彰, 松山加耶子, 嶋千絵 子, 福井智恵子, 桑原敦子, 尾辻 剛, 緒方奈保子, 西村哲哉（2009）選択的レーザー線維柱帯形成術の治 療成績. あたらしい眼科 26(9): 1249-1252

10. 萩原実早子, 寺内博夫, 星野 健, 西川真生, 北川誠 彦, 松岡雅人, 桶口暁子, 松村美代（2009）関西医科 大学における最近の未熟児網膜症管理と治療. 眼臨紀 2(5): 433-437

11. 頼 彦長, 圦 貴司, 兼松清果, 桑田満喜, 螺良愛郎 （2009）若年と高齢での妊娠を模倣する短期エストロ ゲンとプロゲステロン処置による乳癌発生への影響 と乳腺脂肪織の役割。乳癌基礎研 18:23-27

12. 津田メイ, 尾辻 剛, 木村元貴, 中内正志, 木本高志, 西 麗子, 西村哲哉 (2009) 増殖糖尿病網膜症に原田 病が合併した1例。臨眼 63(8): 1359-1363

13. 山田晴彦, 山田英里（2009）同一術者による 20, 23, 25, ゲージ硝子体手術の比較. 臨眼 63(8): 1307-1311

総 説

1. 高橋寛二 (2009) 光線力学的療法 (PDT) ガイドライ ン。あたらしい眼科 26(7): 905-909

2. 尾辻 剛, 高橋寛二 (2009) 黄斑円孔はこう読む. あ たらしい眼科 26(5): 597-603

3. 飯島裕幸, 今澤光宏, 佐藤 拓, 永井由巳 (2009) 私 の経験一ベバシズマブ (アバスチン) 硝子体注射に関 する全国調査. 眼科 51: 927-933

4. 仲村永江, 山田晴彦 (2009) 3 部 眼鏡処方の実務で 困ったら 3 眼鏡処方の流れ. 眼ケア (夏季増刊): 158-162

5. 木本高志, 高橋寛二 (2009) 眼感染症の謎を解く II. 眼感染症事典 6. 網脈絡膜炎 9）オンコセルカ症. 眼科プラクティス 28: 206-207

6. 高橋寛二 (2009) 内科的網膜疾患 内科的網膜レー ザー凝固 12) MPPE. 眼プラクティス 26: 88-94

7. 高橋寛二（2009）加齢黄斑変性の新しい分類と診断基 
準. 眼科手術 22(3): 333-336

8. 高橋寛二 (2009) マクジェンとルセンティス. 眼科手 術 22(2): 183-185

\section{症例報告}

1. Kiuchi K, Miyashiro M, Kitagawa C and Wada S (2009) Linezolid-associated optic neuropathy in a patient with ocular sarcoidosis. Jpn J Ophthalmol 53(4): 420-424

2. Yasuda M, Ando A, Otsuji T, Fukui C and Matsumura M (2009) Improvement of the topographic parameters of the optic discs after trabeculotomy in two patients with developmental glaucoma. J Pediatr Ophthalmol Strabismus 46(6): 372-275

3. 嶋千絵子, 緒方奈保子, 松山加耶子, 松岡雅人, 和田 光正，高橋寛二，松村美代（2009）糖尿病網膜症に高 度な黄斑部滲出性網膜剥離を認めた症例。あたらしい 眼科 26(2): 235-238

4. 舘野寛子, 星野 健, 高橋寛二, 松村美代, 坂井田紀 子, 大江知里 (2009) 急速に進行した肝細胞癌からの 転移性脈絡膜腫瘍の1例。 日眼会誌 113(2): 107-111

5. 杉山千晶, 有澤章子, 久保木香織, 長央由里子, 西川 真生，永井由巳，高橋寛二（2009）小児に認められた 傍中心窩毛細血管拡張症の 2 例. 臨眼 63(7): 11631167

6. 金 熙乾, 星野 健, 山田晴彦, 高橋寛二, 松村美代 (2009) 結核治療直後にみられた網膜静脈周囲炎の 1 例. 臨眼 63(2): 199-203

7. 舘野寛子, 高橋寛二, 松村美代, 坂井田紀子, 中野崇 秀（2009）眼窩内視神経全長に浸潤した年長児の網膜 芽細胞腫の 1 例. 臨眼 63(1): 43-49

その他

1. Goto A, Akahori M, Okamoto H, Minami M, Terauchi N, Haruhata Y, Obazawa M, Noda T, Honda M, Mizota A, Tanaka M, Hayashi T, Tanito M, Ogata N and Iwata T (2009) Genetic analysis of typical wet-type age-related macular degeneration and polypoidal choroidal vasculopathy in Japanese population. J Ocul Biol Dis Infor 2(4): 165-167

2. 高橋寛二（2009）加齢黄斑変性の新しい分類と診断基 準の解説. NANO OPHTHALMOLOGY 37: 5-8

3. 高橋寛二（2009）時の人一高橋寛二先生. あたらしい 眼科 26(6): 775

4. 垰本 慎 (2009) 理に適った網膜復位術 III バックル 手術 1. 裂孔閉鎖 2) ジアテルミー. 眼プラクティ ス 30: 58-62

5. 西村哲哉 (2009) One Point Advice 黄斑㱀譬と黄斑 円孔. 眼プラクティス 30:254-255

6. 西村哲哉 (2009) One Point Advice バックル膨隆（マ イラゲル)。眼プラクティス 30: 252-253

7. 西村哲哉 (2009) 周術管理 術後合併症と対策. 眼プ
ラクティス 30: 249-251

8. 松山加耶子，和田光正，松山英子，西村哲哉（2009） 視神経乳頭に刺入した眼内アルミ片異物の 1 例. 眼科 手術 22(4): 553-556

9. 高橋寛二（2009）論点一いま，なぜPDT一薬剤併用療 法か?一. 眼科手術 22(3): 291

10. 安藤 彰 (2009) 線維柱帯切除術にはマイトマイシン Cがつきものか. 臨眼 63(11): 287

11. 高橋寛二, 小椋祐一郎 (2009) 光干渉断層計（OCT） はこう読む. あたらしい眼科 26(5): 581-582

12. 木内克治, 北川チエミ, 宮代美樹（2009）重篤な視力 障害を生じたインターフェロンによる両眼性前部虚 血性視神経症. 日本眼科学会雑誌 113(1): 16-23

\section{学会発表}

1. Shima C, Adachi Y, Shi Ming,Yanai S, Imai Y, Takahashi K and Ikehara S (2009) Combination Method of Magnetic Beads and Magnet Helps Sustain Number of Donor Bone Marrow Cells after Intra-Bone Marrow Injection, Resulting in Rapid Hemopoietic Recovery マグネットビーズ とマグネットを用いた骨髄内骨髄移植の造血回復に おける効果. Japanese Society for Immunity 第39回日本 免疫学会総会学術集会, 大阪

2. Kuwata M, Yoshizawa K, Matsumura M, Takahashi K and Tsubura A. (2009) Ocular toxicity caused by paclitaxel in neonatal Sprague-Dowley rats. The 28 th Soc Toxicol Pathol Annual Symp, Washington DC

3. 頼 彦長, 圦 貴司, 上原範久, 松岡洋一郎, 兼松清 果, 桑田満喜, 螺良愛郎 (2009) Biphasic effect of shortterm pregnancy hormone in young and old rats in MNUinduced mammary cancers. 第98回日本病理学会, 京都

4. 松岡雅人, 緒方奈保子, 松山加耶子, 和田光正, 高橋 寛二, 西村哲哉 (2009) 糖尿病患者の眼圧. NOW2009( 第15回日本糖尿病眼学会), 名古屋

5. 松山加耶子, 和田光正, 緒方奈保子, 松岡雅人, 西村 哲哉（2009）糖尿病網膜症患者に打ける bevacizumab 投与後の血中 VEGF と血中サイトカインの経過. NOW2009（第15回日本糖尿病眼学会総会), 名古屋

6. 城 信雄, 山田晴彦, 南部裕之, 舘野寛子, 加賀郁子, 高橋寛二, 松山加耶子, 和田光正, 緒方奈保子, 西村 哲哉, 松村美代（2009）血管新生緑内障を伴った増殖 糖尿病網膜症に対する緑内障手術併用硝子体手術. NOW2009（第15回日本糖尿病眼学会総会）, 名古屋

7. 井上千鶴, 有澤章子, 山田晴彦, 二階堂潤, 高橋寛二 （2009）光干渉断層計による原田病の脈絡膜所見. NOW2009（第26回日本眼循環学会 - 第48回日本網膜 硝子体学会), 名古屋

8. 石黒利充, 山田晴彦, 二階堂潤, 高橋寛二 (2009) 黄 斑浮腫を伴う網膜静脈分枝閉塞症の治療成績. NOW2009（第26回日本眼循環学会・第48回日本網膜 硝子体学会), 名古屋 
9. 有澤章子, 永井由巳, 西川真生, 長央由里子, 久保木 香織, 高橋寛二（2009）網膜血管腫状増殖に対する ranibizumab 併用トリプル療法の早期反応. NOW2009 (第 26 回日本眼循環学会 - 第 48 回日本網膜硝子体学 会), 名古屋

10. 正健一郎（2009）加齢黄斑変性治療の current trend抗 VEGF 療法の病態別検討. NOW2009（第26 回日本 眼循環学会総会), 名古屋

11. 永井由巳 (2009) 3学会合同 教育セミナー 眼底画像 診断の進歩 1 OCTを使いこなそう 〜 OCT検査の コツと読み方〜「加齢黄斑变性」.NOW2009（第 48 回 日本網膜硝子体学会総会 -第26回 日本眼循環学 会・第15回 日本糖尿病眼学会), 名古屋

12. 高橋寛二 (2009) 加齢黄斑変性の診断と治療. 守口市 医師会講演会, 守口

13. 安藤 彰, 新井英子, 河合江実, 秋岡真砂子, 小林か おる, 小池直子, 西村哲哉（2009）外傷性のシーソー 眼振の一例. 第373回大阪眼科集談会, 大阪

14. 越生佳世, 南部裕之, 城 信雄, 舘野寛子, 高橋寛二, 爲政大幾（2009）色素血管母斑症に合併した早発型発 達緑内障の1例. 第20回日本緑内障学会, 沖縄

15. 加賀郁子, 南部裕之, 田中春花, 二階堂潤, 西川真生, 城 信雄, 高橋寛二, 安藤 彰, 松村美代 (2009) 早 発型発達緑内障の兄妹発症例. 第 20 回日本緑内障学 会, 沖縄

16. 城 信雄, 南部裕之, 加賀郁子, 高橋寛二, 安藤 彰, 松村美代 (2009) 視野進行例を含む原発閉塞隅角緑内 障に対する隅角癒着解離術の長期成績. 第20回日本緑 内障学会, 沖縄

17. 大山奈美, 南部裕之, 城 信雄, 有澤章子, 高橋寬二 （2009）マイラゲルを用いた網膜剥離術後にみられた 開放隅角緑内障の 1 例一網膜剥離術後にみられた緑内 障一. 第20回日本緑内障学会, 沖縄

18. 南野桂三, 安藤 彰, 竹内正光, 高橋寛二, 小池直子, 小林か扔る, 秋岡真砂子, 河合江実, 西村哲哉 (2009) 診断に苦慮したLeber遺伝性視神経症の1例. 第47回 日本神経眼科学会総会, 東京

19. 山田晴彦 (2009) 高血圧症と眼科疾患一降圧剤の影響 一. 第5回堺高血圧座談会, 堺

20. 山田晴彦 (2009) 若年者における糖尿病網膜症. 平成 21 年度関西医科大学眼科同空会 秋の勉強会, 守口

21. 緒方奈保子 (2009) 最近の網膜光凝固. 平成 21 年度関 西医科大学眼科同空会 秋の勉強会, 守口

22. 松山加耶子（2009）糖尿病網膜症に対するアバスチン 投与症例の基礎的臨床研究. 平成 21 年度関西医科大学 眼科同空会 秋の勉強会, 守口

23. 城 信雄 (2009) 血管新生緑内障に対する最近の治療. 平成 21 年度関西医科大学眼科同空会 秋の勉強会, 守 口

24. 西村哲哉（2009）糖尿病網膜症に対する硝子体手術. 平成 21 年度関西医科大学眼科同空会 秋の勉強会, 守

\section{口}

25. 和田光正 (2009) 糖尿病網膜症に対するアバスチン投 与の代表症例. 平成 21 年度関西医科大学眼科同空会 秋の勉強会, 守口

26. 高橋寛二 (2009) 加齢黄斑変性の病態と診断, 治療の 考え方. 湘西眼科医会学術講演会, 横浜

27. 松山加耶子, 南野桂三, 和田光正, 安藤 彰, 西村哲 哉（2009） soemmering 輪により生じた閉塞隅角緑内 障の 1 例. 第 15 回大阪眼科手術シンポジウム, 大阪

28. 井上千鶴, 有澤章子, 山田晴彦, 二階堂潤, 高橋寛二 （2009）光干渉断層計による原田病の脈絡膜所見. 第 372 回大阪眼科集談会, 大阪

29. 井上千鶴, 有澤章子, 山田晴彦, 二階堂潤, 高橋寛二 （2009）光干渉断層計による原田病の脈絡膜所見. 第 372 回大阪眼科集談会, 大阪

30. 越生佳世, 南部裕之, 城 信雄, 舘野寛子, 高橋寛二, 爲政大幾（2009）色素血管母斑症に合併した早期型発 達緑内障の 1 例. 第 372 回大阪眼科集談会, 大阪

31. 永井由巳 (2009) シンポジウム 7 加齢黄斑変性のトー タルケア 加齢黄斑変性の診断〜 OCT 画像を中心に $\sim$. 第63回日本臨床眼科学会, 福岡

32. 加賀郁子, 南部裕之, 城 信雄, 松原敬忠, 高橋寛二, 安藤 彰, 松村美代 (2009) ビスコカナロストミーと サイヌソトミー併用トラベクロトミーの長期成績の 比較. 第63回日本臨床眼科学会, 福岡

33. 舘野寛子, 城 信雄, 南部裕之, 山田晴彦, 高橋寛二 （2009）血管新生緑内障を合併したEales 病の1例. 第 63 回日本臨床眼科学会, 福岡

34. 久保木香織, 垰本 慎, 石黒利充, 高橋寛二 (2009) 非球面眼内レンズと球面眼内レンズの術後成績の比 較検討. 第63回日本臨床眼科学会, 福岡

35. 小池直子, 尾辻 剛, 木村元貴, 西村哲哉, 高橋寛二 （2009）高齢者の中心性漿液性脈絡網膜症様所見を呈 した原田病の 1 例. 第63回日本臨床眼科学会, 福岡

36. 松岡雅人, 緒方奈保子, 高橋寛二, 足立 靖, 木下勇 一, 西村哲哉 (2009) 硝子体細胞診が診断に有用で あったサルコイドーシスの 2 例

(硝子体細胞診とサルコイドーシス). 第63回日本臨床 眼科学会, 福岡

37. 松山加耶子, 緒方奈保子, 和田光正, 松岡雅人, 西村 哲哉（2009）Bevacizumab 投与眼及びその僚眼の前房 水中血管内皮細胞増殖因子(VEGF)。第 63 回日本臨床 眼科学会, 福岡

38. 木村元貴, 津田メイ, 松山加耶子, 安藤 彰, 西村哲 哉 (2009) 眼内レンズ縫着術後の reverse pupillary block にレーザー虹彩切開術を施行した 3 例. 第63回日本臨 床眼科学会, 福岡

39. 木内絢子, 高橋寛二, 西川真生, 植村芳子, 岩下憲四 郎（2009）著明な白板症と白色眼脂を来した角膜扁平 上皮癌の進展例. 第63回日本臨床眼科学会, 福岡 40. 辻川元一, 沢美喜, 五味文, 生野齋司, 隅野正誉, 永 
井由巳，高橋寛二（2009）加齢黄斑変性に対する HLA+A 拘束性VEGFRワクチン療法の第 I 相試験. 第 63 回日本臨床眼科学会, 福岡

41. 永井由巳, 生野恭司, 松田理, 有澤章子, 正健一郎, 木下貴志，内堀泰孝，五味文，高橋寛二（2009）近視 性脈絡膜新生血管に対する光線力学的療法とべバシ ズマブ硝子体注射の多施設研究. 第63回日本臨床眼科 学会 (専門別研究会 強度近視眼底研究会), 福岡

42. 山田晴彦, 河合江実, 高橋寛二 (2009) 超音波乳化吸 引術での 20 ゲージと 21 ゲージ手術の比較．第 63 回日 本臨床眼科学会総会, 福岡

43. 高橋寛二（2009）加齢黄斑編成正の病態と最近治療. 第6回和歌山眼科フォーラム, 和歌山

44. 大中誠之, 芦高恵美子, 金子志帆, 安藤 彰, 高橋寛 二, 伊藤誠二 (2009) 脳回転状脈絡網膜萎縮症の網膜 色素上皮細胞に打けるアルギナーゼIIの役割. 第82回 日本生化学会大会, 神戸

45. 高橋寛二 (2009) 加齢黄斑変性の病態と最新治療. 兵 庫県眼科医会総会特別講演会, 神戸

46. 高橋寛二 (2009) 眼窩疾患ケーススタディー. 関西医 大耳鼻科同門会講演会，大阪

47. 田中春花，二階堂潤，西川真生，城 信雄，南部裕之, 高橋寛二，安藤 彰，松村美代（2009）早発型発達緑 内障の兄妹発症例。第15回京都眼科学会, 京都

48. 桑田満喜, 義澤克彦, 頼 彦長, 高橋寛二, 螺良愛郎 ・（2009）抗腫瘍薬 Paclitaxel による新生仔ラットへの 眼毒性の検討. 第41回日本臨床分子形態学会, 神戸

49. 兼松清果, 上原範久, 三城弥範, 桑田満喜, 義澤克彦, 川中彩子，圦 貴司，螺良愛郎。(2009) Sulforaphane による乳癌細胞增殖抑制に打けるアポトーシスと オートファジー誘導. 第 41 回日本臨床分子形態学会, 神戸

50. 頼 彦長, 兼松清果, 桑田満喜, 三城弥範, 川中彩子, 義澤克彦, 螺良愛郎. (2009) Short-term pregnancy hormones in young and old rats with MNU-induced mammary cancers. 第 41 回日本臨床分子形態学会, 神戸

51. 城 信雄 (2009) 血管新生緑内障に対する bevacizumab 投与後のトラベクレクトミー併用硝子体手術．第2回 大阪眼科フォーラム, 大阪

52. 高橋宽二 (2009) 加齢黄斑変性. 近眼連 夏季講習会, 大阪

53. 高橋寛二 (2009) 網膜表層に網目状血管を認める網膜 血管腫状増殖．第11回Japan Macula Club，蒲郡

54. 藤田 識人, 岡田由香, 上出利光, 今重之, Susan R. Rittling, David T. Denhardt, 松岡雅人, 緒方奈保子雑 賀司珠也 (2009) 眼組織の血管新生におけるオステオ ポンチンの役割. 第 14 回眼創傷治癒研究会, 仙台

55. 加賀郁子, 南部裕之, 城 信雄, 松原敬忠, 高橋寛二, 安藤 彰, 松村美代（2009）ビスコカナロストミー (VCS) とサイヌソトミー併用トラベクロトミー (LS) の長期成績の比較. 第371回大阪眼科集談会，大阪
56. 木内絢子, 高橋寛二, 西川真生, 植村芳子, 岩下憲四 郎（2009）著明な白板症と白色眼脂を来した角結膜扁 平上皮癌の進展例. 第371回大阪眼科集談会, 大阪

57. 山田晴彦，二階堂潤，星野 健，高橋寛二，尾崎吉郎 （2009）インフリキシマブ投与中の眼ベーチェット病 患者にトラベクレクトミーを施行した 2 例。スリーサ ム・イン なにわ（第 43 回眼炎症学会），大阪

58. 武田信彦，西川真生，岩下憲四郎，高橋寛二（2009） 原因不明のぶどう膜炎に網膜中心動脈閉塞症を合併 した小児例. スリーサム・イン なにわ（第 43 回眼炎 症学会), 大阪

59. 高橋寛二 (2009) 加齢黄斑変性の病態と最新治療. 第 11 回千葉臨床眼科フォーラム,千葉

60. 高橋寬二 (2009) 加齢黄斑変性の診断と新しい治療〜 注意すべき病態と眼底所見を中心に〜。第 4 回神戸山 の手カンファレンス, 神戸

61. 木内克治, 北川チエミ，今井清美，宮代美樹（2009） Linezolid による中毒性視神経症の 1 例。第 8 回すだち の会, 大阪

62. 高橋寛二 (2009) 加齢黄斑変性の病態と最新治療. $3 \mathrm{rd}$ Yokohama Retina Study，横浜

63. 高橋寞二（2009）加齢黄斑変性の診断と治療. 加多乃 会勉強会, 守口

64. 緒方奈保子（2009）糖尿病網膜症の対策（眼科医と内 科医の連携にむけて）。寝屋川女医会（はなみずき会） 勉強会, 寝屋川

65. 小池直子，尾辻 剛，木村元貴，西村哲哉，高橋寞二 （2009）高齢者の中心性漿液性脈絡網膜症様所見を呈 した原田病の 1 例。第 370 回大阪眼科集談会，大阪

66. 有澤章子, 高橋寬二, 西川真生, 長央由里子, 久保木 香織（2009）脈絡膜母斑を伴ったポリープ状脈絡膜血 管症の症例．第370回大阪眼科集談会，大阪

67. 高橋寛二 (2009) スペクトラルドメインOCTによる黄 斑疾患の解析」. 第 38 回関西医科大学眼科同空会 春 の勉強会, 枚方

68. 安藤 彰, 福井智恵子, 嶋千絵子, 南野桂三, 松岡雅 人, 桑原敦子，西村哲哉（2009）浅前房に対する周辺 虹彩切除術後に増悪した虹彩分離症の一例. 第 38 回 関西医科大学眼科同空会 春の勉強会, 枚方

69. 永井由巳（2009）ICG 造影など画像診断の進歩と加齢 黄斑変性(AMD)治療の進歩 (井街賞講演). 第38回関 西医科大学眼科同空会 春の勉強会, 枚方

70. 永井由巳，生野恭司，松田 聡，有澤章子，正健一郎， 尾辻 剛, 大下貴志, 五味文, 内堀恭孝, 高橋寛二, 田野保雄（2009）近視性脈絡膜新生血管の治療. 第38 回関西医科大学眼科同空会 春の勉強会, 枚方

71. 加賀郁子，松村美代，西川真生，高橋寞二，植村芳子 （2009）上眼瞼に認めた神経莢腫 (Cellular neurothekeoma)の 1 例. 第38回関西医科大学眼科同空会 春の勉 強会, 枚方

72. 舘野寛子, 城 信雄, 山田晴彦，松山加耶子，和田光 
正, 緒方奈保子, 西村哲哉, 松村美代, 高橋寛二 (2009) 血管新生緑内障に対する bevacizumab 投与後のトラべ クレクトミー併用硝子体手術. 第38回関西医科大学眼 科同空会 春の勉強会, 枚方

73. 三木弘彦, 三木克朗 (2009) angle hypopyon uveitis 症 例紹介. 第 38 回関西医科大学眼科同空会 春の勉強 会, 枚方

74. 松岡雅人, 緒方奈保子, 高橋寛二, 足立 靖, 西村哲 哉（2009）硝子体生検が診断に有用であったサルコイ ドーシスの 1 例. 第 38 回関西医科大学眼科同空会 春 の勉強会, 枚方

75. 杉山千晶, 有澤章子, 久保木香織, 長央由里子, 西川 真生，永井由巳，高橋寛二（2009）小児に認められた 傍中心窩毛細血管拡張症の 2 例. 第38回関西医科大学 眼科同空会 春の勉強会, 枚方

76. 西川真生, 咔本 慎, 高橋寛二, 山田晴彦, 松村美代 (2009) Group G 溶血連鎖球菌による内因性細菌性眼内 炎の1例. 第38回関西医科大学眼科同空会 春の勉強 会, 枚方

77. 早川公章, 杉山千晶, 佐々木奈々, 山村 匡, 中内正 志, 岡見豊一 (2009) Duane症候群 II 型の 2 例. 第38 回関西医科大学眼科同空会 春の勉強会, 枚方

78. 田中春花, 二階堂潤, 西川真生, 城 信雄, 南部裕之, 高橋寛二, 安藤 彰, 松村美代 (2009) 早発型発達緑内 障の兄妹発症例. 第38回関西医科大学眼科同空会 春 の勉強会, 枚方

79. 内田宣子, 前西尚子, 武田丹音, 寺井実知子, 松永裕 史 (2009) 抗癌薬によって涙点閉鎖をきたした 2 症例. 第38回関西医科大学眼科同空会 春の勉強会, 枚方

80. 有澤章子, 咔本 慎, 杉山千晶, 高橋寛二, 西村哲哉 （2009）術後良好な視力を得た黄斑円孔・網膜下出血 を伴う網膜細動脈瘤の 1 例. 第 38 回関西医科大学眼科 同空会 春の勉強会, 枚方

81. 和田光正 (2009) 近年の糖尿病網膜症治療（井街賞講 演). 第 38 回関西医科大学眼科同空会 春の勉強会, 枚方

82. 高橋寛二 (2009) 加齢黄斑変性の病態と最新治療. 第 79 回九州眼科学会ランチョンセミナー, 福岡

83. 足立 靖, 石 明, 矢内勢司, 嶋千絵子, 今井雄一 郎, 池原 進 (2009) Tie2 発現細胞特異的にFGFレセ プター 2 を発現させたトランスジェニックマウスにお ける造血系細胞の解析. 第98回 日本病理学会総会, 京 都

84. 矢内勢司, 足立 靖, 石 明, 嶋千絵子, 今井雄一 郎, 池原 進 (2009) 樹状細胞とマウス線維肉腫との 融合細胞を用いた抗腫瘍効果の検討. 第 98 回 日本病 理学会総会, 京都

85. 今井雄一郎, 足立 靖, 比舎弘子, 石 明, 矢内勢 司, 嶋千絵子, 金子一成, 池原 進 (2009) 骨髄移植 後のマウスに発生したドナー由来未熟白血病細胞株 の樹立とその解析. 第98回 日本病理学会総会, 京都
86. 石 明, 足立 靖, 矢内勢司, 嶋千絵子, 今井雄一 郎, 池原 進 (2009) 骨髄内骨髄移植法におけるコ ラーゲン・ゲルの有用性. 第98回 日本病理学会総会, 京都

87. 嶋千絵子, 足立 靖, 石 明, 矢内勢司, 今井雄一 郎, 高橋寛二, 池原 進 (2009) 骨髄由来樹状細胞の 骨髄内投与による抗腫瘍効果の検討. 第 98 回 日本病 理学会総会, 京都

88. 桑田満喜, 義澤克彦, 頼 彦長, 螺良愛郎 (2009) 新 生仔ラットに対する Paclitaxel 誘発眼毒性. 第 98 回日 本病理学会, 京都

89. 桑田満喜, 義澤克彦, 頼 彦長, 螺良愛郎 (2009) 新 生仔ラットに対する Paclitaxel 誘発眼毒性. 第 98 回日 本病理学会総会, 京都

90. 高橋寛二 (2009) 教育セミナー 加齢黄斑変性の分類 と診断基準 萎縮型加齢黄斑変性と除外規定. 第 113 回日本眼科学会総会, 東京

91. 高橋寛二（2009）サブスペシャリティーサンデー＼cjkstart網 膜硝子体疾患治療の進歩 加齢黄斑变性. 第 113 回日 本眼科学会総会, 東京

92. 高橋寛二（2009）教育セミナー ここまで組織を再 現！最近の画像診断検査 光干渉断層計による網脈 絡膜疾患の解析. 第113回日本眼科学会総会, 東京

93. 高橋寛二 (2009) ランチョンセミナー 抗VEGF時代 の AMD 診療戦略 AMD 僚眼発症と予防戦略. 第 113 回日本眼科学会総会, 東京

94. 吉川匡宣, 緒方奈保子, 和田光正, 尾辻 剛, 松岡 雅人, 松山 加耶子, 高橋寛二（2009）糖尿病網膜症 に合併した滲出型加齢黄斑変性の臨床経過. 第 113 回 日本眼科学会総会, 東京

95. 桑田満喜, 義澤克彦, 高橋寛二, 螺良愛郎 (2009) Paclitaxelの新生仔ラットに対する眼毒性の検討. 第113回 日本眼科学会総会, 東京

96. 松山加耶子, 緒方奈保子, 松岡雅人, 和田光正, 西村 哲哉, 高橋寛二 (2009) 糖尿病網膜症患者の血清, 前 房水, 硝子体内 PEDF 濃度. 第 113 回日本眼科学会総 会, 東京

97. 山田晴彦，二階堂潤，星野 健，高橋寛二，尾崎吉郎 （2009）インフリキシマブ投与中のベーチェット病患 者に続発性緑内障を生じてトラベクレクトミーを施 行した 2 例. 第369回大阪眼科集談会, 大阪

98. 松岡雅人, 緒方奈保子, 高橋寛二, 足立 靖, 西村哲 哉（2009）硝子体生検が診断に有用であったサルコイ ドーシスの一例. 第369回大阪眼科集談会, 大阪

99. 永井由巳（2009）近視性CNVに対する治療. 近視眼底 研究会 近視病変の新しい展開〜緑内障とのコラボ レーション〜, 大阪

100.垰本 慎 (2009) 網膜分離症と黄斑円孔網膜剥離の手 術術式. 近視眼底研究会 近視病変の新しい展開〜緑 内障とのコラボレーション〜，大阪

101.高橋寛二 (2009) 加齢黄斑変性の病態と治療. 第 97 
回南大阪眼科研究会, 大阪

102.城 信雄 (2009) 糖尿病網膜症診療の現状. 第 3 回 $\mathrm{KKO}$ 会, 大阪

103. 高橋寛二（2009）加歯黄斑変性の診断と治療. 平成 20 年度関西医科大学同空会大阪支部総会, 大阪

104.高橋寛二（2009）国際シンポジウム「加齢黄斑変性の 治療戦略」パネルディスカッション. 東京

105.高橋寛二 (2009) 黄斑治療のすべて一加齢黄斑変性の 鑑別診断を中心に一. 順天堂浦安病院講演会 AMD の治療最前線, 浦安

106. 加賀郁子, 西川真生, 松村美代, 高橋寛二, 植村芳子 (2009) 上眼瞼に生じた神経萊腫 (cellular neurothekeoma)の一例. 第368回大阪眼科集談会, 大阪 107. 吉川匡宣, 緒方奈保子, 和田光正, 尾辻 剛, 松岡雅 人, 松山加耶子, 高橋寛二 (2009) 糖尿病網膜症に合 併した滲出型加齢黄斑変性の臨床経過. 一第368回大 阪眼科集談会, 大阪

108. 平本裕盛, 松原孝, 大津弥生, 小林かおる (2009) 裂 孔原性網膜剥離に対する硝子体術後に内境界膜剥離 を認めた症例。第368回大阪眼科集談会，大阪

109. 高橋寛二 (2009) 加齢黄斑変性 明日から役立つ診断 と治療のポイント. 第3回ひらかた眼疾患フォーラム, 枚方

110.山田晴彦 (2009) 糖尿病網膜症 明日から役立つ診断 と治療のポイント. 第3回ひらかた眼疾患フォーラム, 枚方

111.高橋寛二（2009）加齢黄斑変性の病態と治療. 第 48 回福井県眼科集談会, 福井

112. 高橋寛二 (2009) 加齢黄斑变性治療の新しい流れ。第 6 回神戸市立医療センター西市民病院 眼科オープン カンファレンス, 神戸

113. 高橋寛二 (2009) 加齢黄斑変性の病態と治療. 奈良県 眼科集談会, 奈良

114. 安藤 彰, 大中誠之, 金子志帆, 中内正志, 山田眞 未，伊藤誠二，高橋寛二（2009）網脈絡膜変性疾患の in vitro モデルの確立および細胞変性機構におけるア ミノ酸輸送の関与. 厚生労働省難治性疾患克服研究事 業, 網膜脈絡膜 - 視神経萎縮症調査研究班, 平成 20 年 度班会議, 名古屋

115. 緒方奈保子, 吉川匡宣, 尾辻 剛, 和田光正, 松岡雅 人，松山加耶子，高橋寛二（2009）糖尿病網膜症に合 併した滲出型加齢黄斑変性. 厚生労働省難治性疾患克 服研究事業, 網膜脈絡膜 - 視神経萎縮症調查研究班, 平成 20 年度班会議, 名古屋

116. 松山加耶子, 緒方奈保子, 和田光正, 松岡雅人, 高橋 寛二, 西村哲哉（2009）Bevacizumab 投与後の血中 VEGF 濃度. 厚生労働省難治性疾患克服研究事業, 網 膜脈絡膜 - 視神経萎縮症調査研究班, 平成 20 年度班会 議, 名古屋

117. 正健一郎, 尾辻 剛, 津村晶子, 永井由巳, 有澤章 子，高橋寛二（2009）加齢黄斑変性 occult CNVに対す
る光線力学的療法. 厚生労働省難治性疾患克服研究事 業, 網膜脈絡膜 - 視神経萎縮症調査研究班, 平成 20 年 度班会議, 名古屋

118. 安藤 彰, 大中誠之, 金子志帆, 中内正志, 山田眞 未, 伊藤誠二 (2009) 網脈絡膜変性疾患のin vivo モデ ルの確立および細胞変性機構におけるアミノ酸輸送 の関与. 第 13 回眼科分子生物研究会, 福岡

119.高橋寛二 (2009) 教育セミナー 網膜硝子体一加歯黄 斑変性のレーザー治療一FA-guided PDT : PDTガイド ライン。第32回日本眼科手術学会総会, 神戸

120. 安藤 彰, 南部裕之, 田辺晶代, 尾辻 剛, 松村美代 （2009）教育セミナー 緑内障一原発閉塞隅角緑内障 の治療戦略一隅角癒着解離術のノウハウ. 第32回日本 眼科手術学会総会, 神戸

121.舘野寛子, 城 信雄, 山田晴彦, 松山加耶子, 和田光 正, 緒方奈保子, 西村哲哉, 松村美代, 高橋寛二 (2009) 血管新生緑内障に対する bevacizumab 投与後のトラべ クレクトミー併用硝子体手術. 第32回日本眼科手術学 会総会, 神戸

122.緒方奈保子 (2009) 教育セミナー 網膜硝子体一網膜 光凝固術の適応と限界一糖尿病網膜症に対する光凝 固. 第32回日本眼科手術学会総会, 神戸

123.南部裕之 (2009) 教育セミナー 緑内障一原発閉塞隅 角緑内障の治療戦略一原発閉塞隅角緑内障の治療の 進め方. 第32回日本眼科手術学会総会, 神戸

124. 尾辻 剛 (2009) 教育セミナー 緑内障一原発閉塞隅 角緑内障の治療戦略一隅角癒着解離術の術後管理と 術後成績. 第32回日本眼科手術学会総会, 神戸

125.垰本 慎 (2009) 教育セミナー 網膜硝子体一バック リング手術ージアテルミー凝固を用いたエクソプラ ント。第32回日本眼科手術学会総会, 神戸

126. 尾辻 剛, 正健一郎, 津村晶子, 津田メイ, 高橋寛二 （2009）視神経乳頭周囲病変や大きい病変に対する光 線力学的療法. 第63回日本臨床眼科学会, 福岡

127. 高橋寛二 (2009) 加齢黄斑変性の病態と診断. 講演会 「加齢黄斑变性の診断と治療」, 大阪

128.吉田秀之, 尾辻 剛, 木村元貴, 西村哲哉（2009）若 年者にみられた両眼性乳頭上網膜細動脈瘤の 1 例. 第 38 回関西医科大学眼科同空会 春の勉強会, 枚方

129. 武田信彦, 西川真生 (教室), 岩下憲四郎 (岩下眼科), 高橋寛二（2009）原因不明のぶどう膜炎に網膜中心動 脈閉塞症を合併した小児例. 第38回関西医科大学眼科 同空会 春の勉強会, 枚方

著 書

1. 永井由巳 (2009) メディカルレチナ治療 中心性漿液性 脈絡網膜症一漏出点が中心窩に近い症例は？ 眼科 インストラクションコース 眼科診療のスキルアッ プ 網膜硝子体編 初版 20 (白神史雄編) 86-89 頁, 株式会社 メジカルビュー社, 東京

2. 尾辻 剛, 高橋寛二（2009）加齢黄斑変性一いつ専門 
医に紹介する？ 眼科インストラクションコース 眼科診療のスキルアップ 網膜硝子体編初版 20 （白 神史雄編）90-102 頁, 株式会社 メジカルビュー社, 東京

3. 永井由巳 (2009) 8. 眼底疾患と看護（黄斑疾患 - 網 膜変性疾患・脈絡膜腫瘍）。眼科看護の知識と実際 第4版 (高橋宽二編) 191-206頁, メディカ出版, 大阪

4. 高橋寛二 (2009) 1. 症状からみた眼の機能的解剖学. 眼科看護の知識と実際 第 4 版（高橋寛二編）25-36 頁, メディカ出版, 東京

5. 弓削堅志 (2009) 12 . 眼科救急と看護. 眼科看護の知 識と実際＼cjkstart第 4 版（高橋寛二編）272-293 頁, メディ 力出版, 大阪

6. 小林かおる, 松原孝 (2009) 14 . 点眼薬と点眼指導. 眼科看護の知識と実際 第4版 (高橋寬二編) 310-335 頁, メディカ出版, 大阪

7. 南部裕之 (2009) 4. 緑内障と看護. 眼科看護の知識 と実際 第4版（高橋寛二編）90-117頁，メディカ出 版, 大阪

8. 緒方奈保子 (2009) 3. 診療のための眼科疾患学 $\mathrm{ABC}$ (19)全身疾患と眼障害頭蓋内疾患で起こる眼障害 は? 眼科診療学 $\mathrm{ABC} 1$ (下村嘉一, 松村美代, 三 村治, 池田恒彦編）318-319 頁, 株式会社 メジカル ビュー社, 東京

9. 緒方奈保子 (2009) 3. 診療のための眼科疾患学 $\mathrm{ABC}$ (19)全身疾患と眼障害 自己免疫疾患で起こる眼障害 は? 眼科診療学 $\mathrm{ABC} 1$ (下村嘉一, 松村美代, 三 村治, 池田恒彦編）320-321 頁，株式会社 メジカル ビュー社, 東京

10. 緒方奈保子（2009）3. 診療のための眼科疾患学 $\mathrm{ABC}$ (19)全身疾患と眼障害 血液疾患で起こる眼障害は? 眼科診療学 $\mathrm{ABC} 1$ (下村嘉一, 松村美代, 三村治, 池田恒彦編）322-323 頁，株式会社 メジカルビュー 社, 東京

11. 緒方奈保子（2009）3. 診療のための眼科疾患学 $\mathrm{ABC}$

(19)全身疾患と眼障害免疫不全でみられる眼障害 は? 眼科診療学 $\mathrm{ABC} 1$ (下村嘉一, 松村美代, 三 村治, 池田恒彦編) 324-325 頁, 株式会社 メジカル ビュー社, 東京

12. 緒方奈保子（2009）3. 診療のための眼科疾患学 $\mathrm{ABC}$

(19)全身疾患と眼障害感染症で起こる眼障害は? 眼科診療学 $\mathrm{ABC} 1$ (下村嘉一, 松村美代, 三村治, 池田恒彦編）326-327 頁，株式会社 メジカルビュー 社, 東京

13. 緒方奈保子（2009）3. 診療のための眼科疾患学 $\mathrm{ABC}$ (19)全身疾患と眼障害 悪性腫瘍で起こる眼障害は? 眼科診療学 $\mathrm{ABC} 1$ (下村嘉一, 松村美代, 三村治, 池田恒彦編）328-329 頁，株式会社 メジカルビュー 社, 東京

14. 高橋寛二 (2009) 4. 眼科非観血治療 $\mathrm{ABC} \mathrm{６レーザー}$ 治療, 冷凍凝固 網膜光凝固とはどのような治療か?
眼科診療学 $\mathrm{ABC}$ 第1版（下村嘉一, 松村美代, 三村 治, 池田恒彦編）360-361 頁, 株式会社 メジカル ビュー社, 東京

15. 松村美代（2009）3. 診療のための眼科疾患学 ABC (13)緑内障 発達緑内障とは? 眼科診療学 $\mathrm{ABC}$ 第 1 版（下村嘉一，松村美代，三村治，池田恒彦編）272273頁，株式会社 メジカルビュー社，東京

16. 城 信雄 (2009) 3. 診療のための眼科疾患学 $\mathrm{ABC}$ (13)緑内障 緑内障治療の基本とは? I. 眼科診療学 $\mathrm{ABC}$ 第 1 版（下村嘉一, 松村美代, 三村治, 池田恒 彦編）274-275頁, 株式会社 メジカルビュー社, 東京

17. 城 信雄 (2009) 3. 診療のための眼科疾患学 $\mathrm{ABC}$ (13)緑内障 緑内障治療の基本とは? II. 眼科診療学 $\mathrm{ABC}$ 第1版（下村嘉一, 松村美代, 三村治, 池田恒 彦編) 276-277頁, 株式会社 メジカルビュー社, 東京

18. 松村美代 (2009) 3. 診療のための眼科疾患学 $\mathrm{ABC}$ (13)緑内障 緑内障治療の基本とは? III. 眼科診療学 $\mathrm{ABC}$ 第1版（下村嘉一, 松村美代, 三村治, 池田恒 彦編) 278-279頁, 株式会社 メジカルビュー社, 東京

19. 高橋寛二 (2009) 4. 眼科非観血治療 $\mathrm{ABC}$ 6レーザー 治療, 冷凍凝固 光線力学療法 (PDT) とはどのよう な治療か? 眼科診療学 $\mathrm{ABC}$ 第1版（下村嘉一, 松 村美代，三村治，池田恒彦編）362-363 頁, 株式会社 メジカルビュー社, 東京

20. 松村美代（2009）5. 眼科観血治療 ABC 11術前術後 管理には何があるか? 眼科診療学 $\mathrm{ABC}$ 第1版（下 村嘉一, 松村美代, 三村治, 池田恒彦編）366-367頁, 株式会社 メジカルビュー社，東京

21. 緒方奈保子, 吉川匡宣, 和田光正, 尾辻 剛, 松岡雅 人, 松山加耶子, 高橋寛二 (2009) 糖尿病網膜症に合 併した滲出型加齢黄斑変性. 網膜脈絡膜・視神経萎縮 症に関する研究 平成 20 年度 総括 - 分担研究報告書

117-118頁, 厚生労働省, 東京

22. 安藤 彰, 大中誠之, 金子志帆, 中内正志, 山田眞未, 伊藤誠二, 高橋寛二 (2009) 網脈絡膜変性疾患の in vitro モデルの確立および細胞变性機構におけるアミ ノ酸輸送の関与. 網膜脈絡膜・視神経萎縮症に関する 研究 平成 20 年度 総括・分担研究報告書 146-149 頁, 厚生労働省, 東京

23. 松山加耶子, 緒方奈保子, 和田光正, 松岡雅人, 西村 哲哉, 高橋寛二（2009）Bevacizumab 投与前後の血中 VEGF と PEDF. 網膜脈絡膜・視神経萎縮症に関する研 究 平成 20 年度 総括・分担研究報告書 36-38頁, 厚 生労働省, 東京

24. 正健一郎, 尾辻 剛, 津村晶子, 永井由巳, 有澤章子, 高橋寛二（2009）加齢黄斑変性 occultCNVに対する光 線力学的療法. 網膜脈絡膜・視神経萎縮症に関する研 究 平成 20 年度 総括 - 分担研究報告書 98-100頁, 厚生労働省, 東京

25. 福島伊知郎 (2009) 9. 網膜 - 硝子体疾患の手術看護. 看護の知識と実際 第4版（高橋寛二編）208-222頁, 
メディカ出版，大阪

26. 松永裕史（2009）8. 眼底疾患と看護（眼底の血管病 変・網膜剥離・ぶどう膜炎) 。眼科看護の知識と実際 第4版 (高橋寛二編) 176-190 頁, メディカ出版, 大阪

27. 安藤 彰 (2009) 3. 診療のための眼科疾患学 $\mathrm{ABC}$ (19)全身疾患と眼障害 小览疾患と眼障害とは? 眼科 診療学 $\mathrm{ABC}$ 第 1 版（下村嘉一, 松村美代, 三村治, 池田恒彦編）330-331 頁，株式会社 メジカルビュー 社, 東京

28. 安藤 彰 (2009) 3. 診療のための眼科疾患学 $\mathrm{ABC}$ (19)全身疾患と眼障害 薬物と眼障害とは? 眼科診療 学 $\mathrm{ABC}$ 第1版（下村嘉一, 松村美代, 三村治, 池田 恒彦編）332-333 頁, 株式会社 メジカルビュー社, 東京

29. 西村哲哉（2009）3. 診療のための眼科疾患学 $\mathrm{ABC}$ (6)水晶体 白内障とは? 眼科診療学 $\mathrm{ABC}$ 第 1 版 （下村嘉一, 松村美代, 三村治, 池田恒彦編）184-185 頁, 株式会社 メジカルビュー社, 東京

30. 西村哲哉 (2009) 3. 診療のための眼科疾患学 $\mathrm{ABC}$ (6)水晶体 膨隆白内障, 水晶体起因性眼内炎とは? 眼科診療学 $\mathrm{ABC}$ 第1版（下村嘉一, 松村美代, 三村 治, 池田恒彦編）186-187 頁，株式会社 メジカル ビュー社, 東京

31. 西村哲哉（2009）3. 診療のための眼科疾患学 $\mathrm{ABC}$ (6)水晶体 水晶体亜脱臼, 水晶体脱臼とは? 眼科診 療学 $\mathrm{ABC}$ 第1版（下村嘉一，松村美代，三村治，池田 恒彦編）188-189 頁, 株式会社 メジカルビュー社, 東京

32. 安藤 彰 (2009) 3. 診療のための眼科疾患学 $\mathrm{ABC}$ (13)緑内障 緑内障とは? 眼科診療学 $\mathrm{ABC}$ 第1版（下 村嘉一，松村美代，三村治，池田恒彦編）256-257頁， 株式会社 メジカルビュー社，東京

33. 安藤 彰 (2009) 3. 診療のための眼科疾患学 $\mathrm{ABC}$ (13)緑内障 開放隅角緑内障とは? 眼科診療学 $\mathrm{ABC}$ 第 1 版（下村嘉一，松村美代，三村治，池田恒彦編） 258-259頁, 株式会社 メジカルビュー社, 東京

34. 安藤 彰 (2009) 3. 診療のための眼科疾患学 $\mathrm{ABC}$ (13)緑内障 正常眼圧緑内障とは? 眼科診療学 $\mathrm{ABC}$ 第 1 版（下村嘉一，松村美代，三村治，池田恒彦編） 260-262頁, 株式会社 メジカルビュー社, 東京

35. 安藤 彰 (2009) 3. 診療のための眼科疾患学 $\mathrm{ABC}$ (13)緑内障 高眼圧症とは? 眼科診療学 $\mathrm{ABC}$ 第 1 版 （下村嘉一, 松村美代, 三村治, 池田恒彦編）262-263 頁, 株式会社 メジカルビュー社, 東京

36. 南部裕之 (2009) 3. 診療のための眼科疾患学 $\mathrm{ABC}$ (13)緑内障 閉塞隅角緑内障とは? 眼科診療学 $\mathrm{ABC}$ 第 1 版（下村嘉一，松村美代，三村治，池田恒彦編） 264-265頁, 株式会社 メジカルビュー社, 東京

37. 南部裕之 (2009) 3. 診療のための眼科疾患学 $\mathrm{ABC}$ (13)緑内障 急性緑内障発作とは? 慢性原発閉塞隅角 緑内障とは? 眼科診療学 $\mathrm{ABC}$ 第1版（下村嘉一, 松
村美代，三村治，池田恒彦編）266-267 頁，株式会社 メジカルビュー社, 東京

38. 城 信雄 (2009) 3. 診療のための眼科疾患学 $\mathrm{ABC}$ (13)緑内障 続発緑内障とは? 眼科診療学 $\mathrm{ABC}$ 第1版 （下村嘉一，松村美代，三村治，池田恒彦編）268-269 頁，株式会社 メジカルビュー社，東京

39. 城 信雄 (2009) 3. 診療のための眼科疾患学 $\mathrm{ABC}$ (13)緑内障 血管新生緑内障とは? 眼科診療学 $\mathrm{ABC}$ 第 1 版（下村嘉一，松村美代，三村治，池田恒彦編） 270-271頁，株式会社 メジカルビュー社，東京

40. 西村哲哉（2009）5. 眼科観血治療 $\mathrm{ABC}$ ６水晶体（白 内障) の手術 水晶体囊内摘出術とはどのような手術 か? 眼科診療学 $\mathrm{ABC}$ 第1版 (下村嘉一, 松村美代, 三村治, 池田恒彦編) 382-383 頁, 株式会社 メジカ ルビュー社, 東京

41. 西村哲哉（2009）5. 眼科観血治療 $\mathrm{ABC}$ ６水晶体（白 内障）の手術 水晶体囊外摘出術とはどのような手術 か? 眼科診療学 $\mathrm{ABC}$ 第1版 (下村嘉一, 松村美代, 三村治, 池田恒彦編) 384-3835頁, 株式会社 メジカ ルビュー社, 東京

42. 西村哲哉（2009）5. 眼科観血治療 $\mathrm{ABC}$ ６水晶体（白 内障）の手術 超音波乳化吸引術とはどのような手術 か? 眼科診療学 $\mathrm{ABC}$ 第1版 (下村嘉一, 松村美代, 三村治, 池田恒彦編) 386-387 頁, 株式会社 メジカ ルビュー社, 東京

43. 西村哲哉（2009）5. 眼科観血治療 $\mathrm{ABC}$ ６水晶体（白 内障）の手術 白内障手術トラブルシューティングと は? 眼科診療学 $\mathrm{ABC}$ 第1版 (下村嘉一, 松村美代, 三村治, 池田恒彦編) 388-389 頁, 株式会社 メジカ ルビュー社, 東京

44. 西村哲哉（2009）5. 眼科観血治療 $\mathrm{ABC}$ ６水晶体（白 内障）の手術 眼内レンズ縫着術とはどのような手術 か? 眼科診療学 $\mathrm{ABC}$ 第1版 (下村嘉一, 松村美代, 三村治, 池田恒彦編) 390-391 頁, 株式会社 メジカ ルビュー社, 東京

45. 南部裕之（2009）5. 眼科観血治療 $\mathrm{ABC}$ 9)緑内障手 術 周辺虹彩切除術とはどのような手術か? 眼科 診療学 $\mathrm{ABC}$ 第 1 版（下村嘉一, 松村美代, 三村治, 池田恒彦編）402-403 頁，株式会社 メジカルビュー 社, 東京

46. 南部裕之（2009）5. 眼科観血治療 $\mathrm{ABC}$ 99緑内障手 術 トラベルロトミーとはどのような手術か？ 眼 科診療学 $\mathrm{ABC}$ 第1版 (下村嘉一, 松村美代, 三村治, 池田恒彦編）404-405 頁，株式会社 メジカルビュー 社, 東京

47. 南部裕之（2009）5. 眼科観血治療 $\mathrm{ABC}$ 9)緑内障手 術 トラベルレクトミーとはどのような手術か？ 眼科診療学 $\mathrm{ABC}$ 第1版（下村嘉一, 松村美代, 三村 治, 池田恒彦編）406-407 頁, 株式会社 メジカル ビュー社, 東京

48. 南部裕之（2009）5. 眼科観血治療 $\mathrm{ABC}$ 9)緑内障手 
術＼cjkstart隅角癒着解離術とはどのような手術か？ 眼科 診療学 $\mathrm{ABC}$ 第 1 版（下村嘉一, 松村美代, 三村治,
池田恒彦編）408-409 頁，株式会社メジカルビュー 社, 東京

\section{耳鼻咽喉科学講座}

関西医大耳鼻咽喉科・主任教授・友田幸一

\section{〈研究概要〉}

耳鼻咽喉科学教室の研究主題は, 人間として大切な感覚, 機能を扱う領域であることから,「機能温存・回復医学」を 主眼に, 聴覚, 平衡覚, 嗅覚の基礎・臨床学的研究と呼吸, 嬩下, 音声言語などの臨床学的研究, そして「安全で確実 な医療」を提供する目的から,ナビゲーションシステムで代表される医用工学機器の開発に関する基礎・臨床学的研究 に集約される。

\section{「耳科領域」}

内耳・聴覚中枢関連の基礎的研究は, 米国ミシガン大学の Kresge研究所との共同で, 遺伝子導入と感覚細胞再生に関 する研究, Wayne State大学との共同で聴覚中枢神経の光反応に関する研究. また国内では解剖学教室との共同で, 聴覚 中枢におけるコリン作動性神経の分布に関する研究, 公衆衛生学教室との共同で, 神経幹細胞の局在に関する研究を行 なってきた。一方, 骨䯣移植, 内耳免疫と難聴予防の研究は, 岩井らが継続して行ってきた, 一方, 臨床研究は, 軟骨 接合型人工耳小骨（細田式）による聴覚機能のさらなる改善を目的として研究, 耳鳴に対する TRT 療法（カウンセリン グとサウンドジェネレータを組み合わせた治療）の効果の検討について行ってきた.

\section{「鼻科領域}

鼻アレルギーに関する基礎的研究は，血管内皮細胞を用いて各種サイトカイン負荷による細胞内カルシウム動態の研 究がこれまで行われてきた。また臨床的研究としてアレルギーのレーザー治療に関する基礎・臨床学的研究の成果が発 表されている。一方, 鼻副鼻腔腫瘍へのESSの適応として, 下鼻甲介swing法と medial maxillectomyを組み合わせた手術 手技の確立をめざした臨床研究が行われてきた.

\section{「頭頸部領域」}

最近の頭頸部癌の治療は, 放射線化学同時併用療法（CRT）の進歩によって原発巣のコントロールがかなりできるよ うになり，その結果，局所形態，機能の温存が非常に良くなってきている，その臨床成績と治療内容に関する臨床研究 が行われている.

一方, 基礎研究ではがん免疫・ワクチン療法の基礎と臨床研究を計画し, 耳下腺癌（salivary duct carcinoma）の特異的 蛋白発現とその分子標的治療に関する基礎研究を継続している.

\section{「次世代医療」}

ナビゲーション手術は，「安全で確実な医療」を提供する目的で，これまで 300 例を越える症例を対象に，そのよい適 応, 問題点について検討してきた. また学生や研修医の手術教育への応用として, 手術手技の行動工学的分析と自己 フィードバックを行う新しい教育システムを産総研との共同で開発を進めている.

\section{〈研究業績〉}

原 著

1. Masaki Y, Dong L, Kurose N, Kitagawa K, Morikawa Y, Yamamoto M, Takahashi H, Shinomura Y, Imai K, Saeki T, Azumi A, Nakada S, Sugiyama E, Matsui S, Origuchi T, Nishiyama S, Nishimori I, Nojima T, Yamada K, Kawano M, Zen Y, Kaneko M, Miyazaki K, Tsubota K, Eguchi K, Tomoda K, Sawaki T, Kawanami T, Tanaka M, Fukushima T, Sugai S and Umehara H. (2009) Proposal for a new clinical entity, IgG4-positive multi-organ lymphoproliferative syndrome: Analysis of 64 cases of IgG4- related disorders. Ann Rheum Dis 68(8): 1310-1315

2. Shibata SB, Di Pasquale G, Cortez SR, Chiorini JA and Raphael Y (2009) Gene transfer using bovine adeno-associated virus in the guinea pig cochlea. Gene Ther 16(8): 990-997

3. Kawamoto K, Izumikawa M, Beyer LA, Atkin GM and Raphael Y (2009) Spontaneous hair cell regeneration in the mouse utricle following gentamicin ototoxicity. Hear Res 247(1): 17-26

4. Kanda A, Driss V, Hornez N, Abdallah M, Roumier T, Abboud G, Legrand F, Staumont-Sallé D, Quéant S, 
Bertout J, Fleury S, Rémy P, Papin JP, Julia V, Capron M and Dombrowicz D (2009) Eosinophil-derived IFNgamma induces airway hyperresponsiveness and lung inflammation in the absence of lymphocytes. J Allergy Clin Immunol 124(3): 573-82

5. Abboud G, Staumont-Sallé D, Kanda A, Roumier T, Deruytter N, Lavogiez C, Fleury S, Rémy P, Papin JP, Capron M and Dombrowicz D (2009) Fc(epsilon)RI and FcgammaRIII/CD16 differentially regulate atopic dermatitis in mice. J Immunol 182(10): 6517-26

6. Senda M, Kubo N, Adachi K, Ikari Y, Matsumoto K, Shimizu K and Tominaga H (2009) Cerebral histamine $\mathrm{H} 1$ receptor binding potential measured with PET under a test dose of olopatadine, an antihistamine, is reduced after repeated administration of olopatadine. J Nucl Med 50(6): 887-892

7. Iwai H, Nakamichi N, Nakae K, Konishi M, Inaba M, Hoshino S, Baba S and Amakawa R (2009) Parotid mucosa-associated lymphoid tissue lymphoma regression after Helicobacter pylori eradication. Laryngoscope 119(8): 1491-1494

8. Trifonov S, Houtani T, Hamada S, Kase M, Maruyama M and Sugimoto T (2009) In situ hybridization study of the distribution of choline acetyltransferase mRNA and its splice variants in the mouse brain and spinal cord. Neuroscience 159(1): 344-357

9. Suzuki K, Iwai H, Kaneko T, Sakaguchi M, Hoshino S and Inaba M (2009) Induction of parotitis by fine-needle aspiration in parotid Warthin's tumor. Otolaryngol Head Neck Surg 141(2): 282-284

10. 宮本 真, 楠山敏行, 森 有子, 中川秀樹, 田村悦代, 新美成二, 福田宏之, 宮本 真, 中川秀樹, 田村悦代 （2009）喉頭微細手術による痒痕声帯に対する外科的 治療法の検討一声帯硬化性病変の原因と思われる痏 痕性病変の除去一。喉頭 21(2): 117-122

11. 馬場一泰, 柴田清児ブルース, 古川昌幸, 友田幸一 （2009）手術手技向上のツールとしてのナビゲーショ ンシステムの可能性. 耳鼻展望 52(5): 395-399

12. 朝子幹也, 友田幸一 (2009) 内視鏡下鼻内手術に打け る新しい手術手技一Balloon Sinuplasty一. 耳鼻展望 52(5): 373-376

13. 福井英人, 朝子幹也, 友田幸一, 上坂達郎, 浅井昭雄 （2009）脳外科用ナビゲーションシステムのみ利用可 能な状況下で施行した鼻内内視鏡手術の経験. 耳鼻展 望 52(5): 331-333

14. 竹林慎治, 山西美映, 池田浩己, 芝 埜彰, 三浦 誠 (2009） ガス産生を伴う深頸部膿瘍の 4 例. 耳鼻臨床 102(11): 938-990

15. 福辻賢治, 硲田猛真, 芝 埜彰, 池田浩己, 中原啓, 山西美映, 榎本雅夫, 原田保（2009）巨大耳下腺悪性 腫瘍症例に対する Mohs 軟膏の使用経験. 耳鼻臨床
102(10): 841-845

16. 大迫茂人, 佐野光仁, 愛場庸雅, 近藤千雅, 北尻雅則, 坂下啓史, 東川雅彦, 村本大輔, 奥村隆司, 坂本平守, 浅井英世（2009）大阪府下に抢ける新生児聴覚スク リーニング後の精密聴力検査に関する経年的検討. 小 児耳鼻 30(1): 10-15

17. 岩井 大, 鈴木健介, 星野勝一, 友田幸一, 稲葉宗夫 （2009）耳下腺術後唾液瘦に対する塩酸ミノサイクリ ン局所注入療法. 頭頸部外 19(3): 173-178

18. 井上俊哉, 辻 裕之, 南豊彦, 山下敏夫 (2009) 当科 における遊離移植による頭頸部再建手術の検討. 頭頸 部外 19(1): 55-61

19. 濱田聡子, 宝谷剛志, Trifonov Stefan, 丸山正人, 加 瀬政彦, 堤 俊之, 杉本哲夫, 友田幸一, 山下敏夫 （2009）中枢聴覚路におけるコリン線維とムスカリン 性受容体サブタイプ発現の解析. 頭頸自律神 23: 7273

20. 永田基樹, 井上俊哉, 湯川尚哉, 小椋 学, 八木正夫, 藤澤玩郎, 竹村博一, 近野哲史, 鈴木健介, 友田幸一 （2009）耳下腺腫瘍手術における顔面神経主幹部の見 つけ方一我々が行っている方法一. 南大阪病医誌 57(1): 1-7

21. 山下樹里, 横山和則, 熊谷 徹, 友田幸一, 小西 玩, 村田英之（2009）仮想の鏡「ハイパーミラー」を用い た内視鏡下鼻内手術の遠隔手技指導実験. 日本バー チャルリアリティ学会論文誌１4(4): 445-454

22. 堀口章子, 下出祐造, 山田奏子, 友田幸一（2009）当 科における Provox2 の 2 期的挿入法の工夫. 日気管食 道会報 60(3): 240-246

総 説

1. 岩井 大 (2009) 頸部手術と術中・術後ヒヤリ・ハット 一予防と対策一. ENTONI (109): 69-76

2. 岩井 大 (2009)【耳鼻咽喉科外来 薬の選び方・使 い方・投与期間】急性耳下腺炎. ENTONI (100): 122-128

3. 岩井大 (2009)【放射線治療における有害事象】唾 液分泌機能低下．耳鼻・頭頸外科 81(10): 677-682

4. 友田幸一（2009）耳鼻咽喉・頭頸部領域における最新 の医療手技一鼻科領域の最新医療技術一. 日耳鼻会報 112(12): 777-782

5. 久保伸夫 (2009) アレルギー性鼻炎に対する手術治療. 日鼻科会誌 48(1): 62

症例報告

1. 中出多子, 岩井 大, 金子敏彦, 河本光平, 星野勝一, 稲葉宗夫, 清水俊樹 (2009) 喉頭原発の混合型小細胞 癌例。耳鼻・頭頸外科 81(9): 633-637

2. 河本光平, 岩井 大, 坂口麻理子, 鈴木健介, 泉川雅 彦，金子敏彦，中出多子，北尻雅則（2009）両側頸瘻 摘出術を施行した鰓弓耳症候群の 2 例. 耳鼻臨床 102(4): 279-285 
3. 竹村博一, 永田基樹, 井上俊哉, 湯川尚哉, 藤澤琭郎, 阪上智史, 友田幸一（2009） 口腔内での花火破裂を契 機とした深頸部膿瘍の1例. 頭頸部外 19(2): 125-129

4. 鈴木健介, 岩井 大, 小椋 学, 井上俊哉, 友田幸一 (2009) 頸部に発生した小児神経節芽腫 (ganglioneuroblastoma) の1例. 頭頸部外 19(2): 119124

5. 池田浩己, 島谷美映, 芝 埜彰, 竹林慎治, 三浦 誠, 友田幸一, 福辻賢治, 榎本雅夫（2009）ナビゲーショ ン支援下に鼻内視鏡手術にて摘出し得た若年性血管 線維腫症例。 日鼻科会誌 48(2): 133-137

6. 大石賢玄, 中井宏治, 川口雄才, 岩井 大, 四方伸明, 權 雅憲 (2009) 中咽頭, 食道, 胃, 盲腸同時性 4 重 複癌の1例。 日臨外会誌 70(12): 3745-3750

その他

1. Kanda A, Chihara J, Capron M and Dombrowicz D (2009) What's New About Eosinophil Activation in Asthma and Allergic Disease. Allergy Frontiers: Classification and Pathomechanisms 2: 95-107

2. 友田幸一 (2009) 加多乃会勉強会「今, 外科手術は変 わるーコンピューター外科の世界一」。おとづれ (131): 34-37

3. 朝子幹也 (2009) 花粉症と咳嗽. 千里丘山田臨医会報 27(7): 63-67

4. 岩井 大 (2009) グロニンゲンを用いたシャント発声 法の応用. 第19回日本気管食道科学会認定気管食道科 専門医大会テキスト 37-41

5. 永田基樹 (2009) 耳鼻咽喉科における頭頸部腫瘍（癌） について．布施医師会誌（70号別冊）:25-26

学会発表

1. Takemura H (2009) A Case of Deep Neck Abscess Injured by Accidental. The 26th PPSA-Japan Chapter in Hong Kong, Hong Kong

2. Tomoda K (2009) Recent Advances in Robotic Surgery in Otorhinolaryngology and its Application to surgical Training. The 26th PPSA-Japan Chapter in Hong Kong, Hong Kong

3. Ooka H, Asako M, Hamada S, Kawamoto K and Tomoda K (2009) —Balloon Sinuplasty-The experience of the new sinus surgery technique \& consideration. 第48回日 本鼻科学会, 松江

4. 村田英之, Wolfgang Draf, 三輪高喜, 友田幸一 (2009) Osteoplastic Frontal Sinusotomy and Reconstruction $の$ 一例. 第48回日本鼻科学会, 松江

5. 友田幸一 (2009) The Clinical and Educational Application of Navigation System for Endoscopic Sinus Surgery. 第48回日本鼻科学会, 松江

6. Baba S, Iwai H, Inaba M, Sakaguchi M, Lee S, Ikehara S and Tomoda K (2009) PREVENTIVE EFFECTS OF
THYMUS GRAFT ON AGE-RELATED HEARING LOSS. 46th Inner Ear Biology Workshop, Utrecht, The Netherlands

7. Iwai H, Baba S, Inaba M, Sakaguchi M, Lee S, Ikehara S and Tomoda K (2009) INOCULATION OF HELPER T CELLS AS A STRATEGY FOR THE PREVENTION OF AGERELATED HEARING LOSS IN SAMP1 MICE. 46th Inner Ear Biology Workshop, Utrecht, The Netherlands

8. Trifonov S, Houtani T, Hamada S, Kase M, Maruyama M, Shimizu J and Sugimoto T (2009) Distinct regional differences in the expression pattern of the transcripts of the cholinergic gene locus. 第 32 回日本神経科学大会, 名古 屋

9. Kanda A, Driss V, Hornez N, Abdallah M, Bertout J, Fleury S, Julia V, Capron M and Dombrowicz D (2009) Eosinophil-derived IFN gamma induced airway hyperresponsiveness (AHR) and lung inflammation in the absence of lymphocytes. 6th BIENNIAL INTERNATIONAL SYMPOSIUM. "EOSINOPHILS 2009" of the International Eosinophil Society, Bruges, Belgium

10. Trifonov S, Houtani T, Hamada S, Kase M, Maruyama M and Sugimoto T (2009) Differential expression of ChAT mRNA splice variants in the mouse basal forebrain cholinergic neurons. Alzheimer's Association 2009 International Conference on Alzheimer's Disease, Vienna, Austria

11. Tomoda K (2009) The clinical and educational application of navigation system in otorhinolaryngology. Computer assisted Radiology and Surgery 23rd Internatiomal Congress and Exhibitation, Berlin

12. Shibata SB (2009) Regeneration of Nerve Fibers into the Deaf Ear. The Ninth Charles J. Krause Lectureship, Ann Arbor, USA

13. Eric Mosconi, Rekima Akila, Barbara Seitz, Akira Kanda, Sébastien Fleury, David Dombrowicz, Valérie Julia, Nicolas Glaichenhaus and Valerie Verhasselt. (2009) Breast milk-mediated transfer of an antigen induces tolerance and protection from allergic asthma. allergic mothers do better. BSACI, Nottingham, England.

14. Eric Mosconi, Rekima Akila, Barbara Seitz, Akira Kanda, Sébastien Fleury, David Dombrowicz, Valérie Julia, Nicolas Glaichenhaus and Valerie Verhasselt (2009) Breast milk-mediated transfer of an antigen induces tolerance and protection from allergic asthma: allergic mothers do better. Congress of the Mucosal Immunology Society, Boston, USA

15. Ooka H and Kanda S (2009) Identification of Tissue Specific Stem/ Progenitor Cells in Auditory Pathway. 7departments joint meeting of otolaryngology 2009, hyogoken awajishima 
16. Eric Mosconi, Rekima Akila, Barbara Seitz, Akira Kanda, Sébastien Fleury, David Dombrowicz, Valérie Julia, Nicolas Glaichenhaus and Valerie Verhasselt. (2009) Breast milk-mediated transfer of an antigen induces tolerance and protection from allergic asthma: allergic mothers do better. World Immune regulation meeting III, Davos , Switzerland

17. Hamada S, Asako M, Tomoda K and Sugimoto T (2009) Cholinergic varicose fibers and muscarinic receptor subtypes: regional distribution in the mouse brainstem. 32rd MidWinter Meeting for the Association for Research in Otolaryngology, Baltimore

18. Ooka H, Kanda S, Suzuki H, Nishiyama T and Tomoda K (2009) Identification of Tissue Specific Stem/Progenitor Cells in Auditory Pathway. Association for Research in Otolaryngology, Marylamd,USA

19. Bozena Fyk-Kolodziej,Shimano T and AvrilGenene Holt (2009) Vesicular Glutamate Transporters Are Associated with Specific Cell Types in the Rat Cochlear Nucleus: Deafness Related Changes. Association for Research in Otolaryngology 32nd Midwinter Research Meeting, Baltimore, USA

20. Najab Mirza, Bozena Fyk-Kolodziej, Shimano T, Ian Forsythe and Avril Genene Holt (2009) Localization and Gene Expression Levels of Two Pore Domain Potassium Channels in Sound Activated Cochlear Nucleus Neurons. Association for Research in Otolaryngology 32nd Midwinter Research Meeting, Baltimore, USA

21. Shibata SB, Cortez SR, Beyer LA, Wiler JA and Raphael Y. (2009) Adenovirus vector mediated BDNF expression induces neuronal growth into the flat cochlear epithelium. Association for Research in Otolaryngology 32nd Midwinter Research Meeting, Baltimore, USA

22. Shimano T, Bozena Fyk-Kolodziej, Zhuo-Hua Pan,Asako M and Avril Genene Holt (2009) Histological and Physiological Properties of Channelrhodopsin-2 in the Rat Dorsal Cochlear Nucleus. Association for Research in Otolaryngology 32nd Midwinter Research Meeting, Baltimore, USA

23. Tzy-Wen Gong,Shimano, Sherry Ho, Nadine Bannick and Avril Genene Holt (2009) Tumor Necrosis Factor Signaling in Noise-Induced Trauma. Association for Research in Otolaryngology 32nd Midwinter Research Meeting, Baltimore, USA

24. Batts S, Swiderski D, Shibata SB and Raphael Y (2009) Severity of Cesium Chloride Induced Inner Ear Lesion Depends on Concentration of Mouse Strain. Association for Research in Otolaryngology 32nd Midwinter Research Meeting, Baltimore, USA

25. Shibata SB, Swiderski D, Cortez SR, Skaliter R, Feinstein E and Raphael Y (2009) Cy-3.5 Labeled siRNA
Spreads into Cochlear Epithelium via Transtympanic Inoculation. Association for Research in Otolaryngology 32nd Midwinter Research Meeting, Baltimore, USA

26. Swiderski D, Shibata SB, Basu I and Raphael Y (2009) Ototoxicity of Cesium in Guinea Pigs. Association for Research in Otolaryngology 32nd Midwinter Research Meeting, Baltimore, USA

27. 友田幸一 (2009) 耳鼻咽喉科領域における内視鏡手術 とナビゲーションシステム. 第16回日本神経内視鏡学 会, 富山

28. 高田洋平, 馬場 奨, 河本光平, 井上俊哉, 友田幸一 （2009）耳下腺部に発生した脂腺癌（sebaceous carcinoma）の1例. 第311回日耳鼻大阪地方会, 大阪

29. 朝子幹也, 鈴木健介, 濱田聡子, 大岡久司, 福井英人, 友田幸一（2009）鼻副鼻腔内反性乳頭腫 中鼻道篩骨 洞病変の取り扱い. 第311回日耳鼻大阪地方会, 大阪

30. 藤澤玩郎, 湯川尚哉, 井上俊哉, 永田基樹, 竹村博一, 鈴木健介, 友田幸一（2009）甲状腺癌と術前に診断さ れた胸腺癌の 1 例. 第311回日耳鼻大阪地方会, 大阪

31. 鈴木千晶, 池田浩己, 三好拓志, 竹林慎治, 三浦 誠 （2009）上顎前摘出術・遊離腹直筋皮弁再建を行った 上顎紡錘細胞癌の一例. 第 87 回日本耳鼻咽喉科学会和 歌山県地方部会, 和歌山

32. 朝子幹也（2009）鼻内手術の Up To Date一下鼻甲介手 術を中心として一. 第17回 睡眠学セミナ一, 大津

33. 朝子幹也 (2009) 重症鼻アレルギー対策 〜保存的治 療から手術療法まで〜。 わかはな会, 鹿児島市

34. 友田幸一 (2009) 日常診療に役立つ眩暈の診断と治療. 関西医大同空会・香川県支部学術研修会, 坂出

35. 馬場一泰, 村田英之, 朝子幹也, 友田幸一（2009）ナ ビゲーション手術の有用性に関するエビデンスの検 索・評価. 第11回耳鼻咽喉科手術支援システム・ナビ 研究会, 金沢

36. 福井英人, 井上俊哉, 永田基樹, 朝子幹也, 村田英之, 友田幸一（2009）頸部ナビゲーション手術に打けるレ ジストレーションの創意工夫. 第 11 回耳鼻咽喉科手術 支援システム・ナビ研究会, 金沢

37. 友田幸一, 村田英之, 朝子幹也, 馬場一泰, 福井英人 （2009）ナビゲーション手術の必要性と適応拡大につ いての新たな提言. 第 11 回耳鼻咽喉科手術支援システ ム・ナビ研究会, 金沢

38. 永田基樹, 竹村博一, 井上俊哉, 湯川尚哉, 藤澤㙇郎, 鈴木健介（2009）ドセタキセル（タキソテール）導入 化学療法が著効した下咽頭扁平上皮癌の 1 例. 第 2 回 京阪頭頸部座談会, 大阪

39. 宮本 真, 森 有子, 中川秀樹, 田村悦代, 新美成二, 福田宏之（2009）東京ボイスセンターにおける一側声 帯麻痺症例の検討. 第 61 回日本気管食道科学会, 横浜

40. 森 有子, 宮本 真, 中川秀樹, 田村悦代, 新美成二, 福田宏之（2009）喉頭結核の喉頭ストロボスコピー所 見について。第 61 回日本気管食道科学会, 横浜 
41. 池田浩己, 竹田浩子, 富岡公子, 圓藤陽子, 友田幸一 （2009）いわゆるシックハウス症候群および化学物質 過敏症の経験. 第64回臨床アレルギー研究会 (関西), 大阪

42. 友田幸一（2009）診療参加型実習における耳鼻咽喉科 の取り組み. 平成 21 年度診療参加型臨床実習に関する FDプログラム, 守ロ

43. 友田幸一（2009）耳鼻咽喉科領域に打けるナビゲー ション手術の現状と将来. 平成 21 年度大阪医科大学耳 鼻咽喉科学教室同門会八交会総会・学術講演会, 大阪

44. 岩井 大, 坂口麻理子, 馬場 奨, 李 進隆, 友田幸 一（2009） T細胞機能維持による進行性老人性難聴予 防。第19回日本耳科学会, 東京

45. 金子敏彦, 土井 直, 細田泰男, 泉川雅彦, 北尻雅則, 友田幸一 (2009) 当科の術式における鼓室容積の検討. 第19回日本耳科学会, 東京

46. 泉川雅彦, 土井 直, 金子敏彦, 宗本由美, 米田元胤, 金子明弘, 栗山博道, 古川昌幸, 北尻雅則, 友田幸一 （2009）当科におけるアブミ骨手術症例の検討．第 19 回日本耳科学会, 東京

47. 土井 直, 泉川雅彦, 金子敏彦, 北尻雅則, 友田幸一 （2009）耳小骨再建材料の長さと聴力成績, 鼓膜所見 の検討. 第19回日本耳科学会, 東京

48. 和田忠彦, 岩永迪孝, 平塚康之, 隈部洋平, 小西将矢, 樋渡 直（2009）アブミ骨周囲に硬化性病変を伴った 鼓室硬化症に対する鼓室形成術. 第 19 回日本耳科学 会, 東京

49. 岩井 大, 池上智子, 坂口麻理子, 正木浩哉 (2009) 術中副甲状腺ホルモン（iPTH）測定下に施行された 副甲状腺手術症例における術後再発の検討。第 1 回二 次性副甲状腺機能充進症に対する PTx 研究会学術集 会, 名古屋

50. 友田幸一 (2009) 日常診療に役立つ難聴, 眩暈の診断 と治療. 第2 35 回枚方市医師会 - 交野医師会学術研修 会, 枚方

51. 柴田清児ブルース, Yehoash Raphael, 友田幸一 (2009) BDNF 遺伝子導入による障害コルチ器の神経再生. 第 28 回聴覚生理研究会, 東京

52. 河本光平, 馬場 奨, 高田洋平, 谷原佑子, 朝子幹也, 友田幸一 (2009) 当科における鼻出血症例の検討. 第 48 回日本鼻科学会, 松江

53. 久保伸夫, 大久保公裕, 朝子幹也 (2009) Rhinolight によるアレルギー性鼻炎に対する光線治療. 第48回日 本鼻科学会, 松江

54. 金子敏彦, 朝子幹也, 泉川雅彦, 鈴木健介, 友田幸一 （2009）内視鏡下に摘出し得た若年性血管線維腫の検 討. 第48回日本鼻科学会, 松江

55. 池田浩己, 三好拓志, 竹林慎治, 三浦 誠, 友田幸一 （2009）ESS再手術症例の検討. 第48回日本鼻科学会, 松江

56. 朝子幹也, 河本光平, 濱田聡子, 大岡久司, 福井英人,
村田英之, 友田幸一（2009）アレルギー性鼻炎の外科 的治療 術式の選択と粘膜下下甲介骨後鼻神経合併 切除術. 第48回日本鼻科学会, 松江

57. 朝子幹也, 河本光平, 濱田聡子, 鈴木健介, 大岡久司, 友田幸一（2009）鼻副鼻腔内反性乳頭腫に対する下甲 介Swing 法によるアプローチ. 第 48 回日本鼻科学会, 松江

58. 濱田聡子，朝子幹也，大岡久司，河本光平，友田幸一 (2009) 鼻腔拡張テープ ブリーズライト ${ }^{\circledR} の$ 鼻閉改善 効果の検討. 第48回日本鼻科学会, 松江

59. 宮本 真, 佐藤剛史, 浅香明日美, 早乙女泰伴, 森 有子, 中川秀樹, 田村悦代, 新美成二, 福田宏之 (2009) 一側声帯麻痺に対する音声治療の検討. 第54回日本音 声言語医学会, 福島

60. 浅香明日美, 宮本 真, 佐藤剛史, 早乙女泰伴, 森 有子，新美成二，福田宏之（2009）喉頭外傷に対する 音声治療の有効性. 第54回日本音声言語医学会, 福島

61. 下雅意学, 池田浩己, 伊良波浩, 畑埜義雄, 榎本雅夫 (2009) OAS患者でのラテックス特異的 IgE抗体価の測 定法の比較. 第 59 回日本アレルギー学会秋季学術大 会, 秋田

62. 森田恭平，池田浩己，西山秀樹（2009）気管支喘息を 合併する慢性好酸球性副鼻腔炎術後の検討. 第59回日 本アレルギー学会秋季学術大会, 秋田

63. 池田浩己, 森田恭平, 西山秀樹, 友田幸一（2009）副 鼻腔炎手術治療後に好酸球性炎症が続発した 2 症例。 第59回日本アレルギー学会秋季学術大会, 秋田

64. 竹田浩子, 池田浩己, 富岡公子, 圓藤陽子, 久保伸夫, 友田幸一（2009）当科に打けるシックハウス症候群・ 化学物質過敏症の経験 (第 3 報)。第 59 回日本アレル ギー学会秋季学術大会, 秋田

65. 朝子幹也, 河本光平, 濱田聡子, 大岡久司, 友田幸一 （2009）花粉症と咳嗽 スギヒノキ花粉症患者実態調 査とプランルカスト初期療法の有用性について 2 年間 の調査結果より. 第59回日本アレルギー学会秋季学術 大会, 秋田

66. 久保伸夫, 池田浩己, 硲田猛真, 榎本雅夫 (2009) 七 ノキ森林地方地域での小中学校耳鼻咽喉科検診. 第 59 回日本アレルギー学会秋季学術大会, 秋田

67. 朝子幹也（2009）『重症鼻アレルギー対策』〜保存的 治療から手術療法まで〜。鼻・副鼻腔研究会, 那覇

68. 朝子幹也 (2009) 重症アレルギー性鼻炎に対する治療. 耳鼻咽喉科点鼻薬研究会, 堺市

69. 北尻雅則 (2009）難聴・耳鳴・めまい. 第159回加多 乃会「勉強会」, 守口

70. 山原康平, 隈部洋平, 田中信三, 岩永通孝, 平塚康之, 小西将矢, 岡上雄介, 樋渡 直, 和田忠彦 (2009) PCPS 下に手術を行った気管癌の 1 例. 第 310 回日耳鼻大阪 地方会, 大阪

71. 朝子幹也, 片岡大輔, 北原久志, 福井英人, 友田幸一, 濱田聡子 (2009) 鼻腔拡張テープ ブリーズライトは 
鼻閉を改善するか. 第310回日耳鼻大阪地方会, 大阪 72. 鈴木健介, 永田基樹, 友田幸一, 尼川龍一（2009） メ トトレキセートが原因と考えられた上顎歯肉覀性リ ンパ腫の 1 例。第310回日耳鼻大阪地方会, 大阪

73. 阪上智史, 竹村博一, 永田基樹, 友田幸一（2009）縦 隔膿瘍，膿胸を併発した深頸部膿瘍の1例。第39回日 本耳鼻咽喉科感染症研究会, 東京

74. 矢野純也, 友田幸一 (2009) 耳鼻咽喉科領域における $2-5 \mathrm{AS}$ 測定. 第39回日本耳鼻咽喉科感染症研究会, 東京

75. 宮本 真, 佐藤剛史, 浅香明日美, 森 有子, 福田宏 之（2009）下部消化管術後イレウスによる, 長期絶食 患者に対するリハビリテーションの経験. 第 15 回日 本・摂食與下リハビリテーション学会, 豊明

76. 大岡久司, 神田靖士, 岡崎はるか, 鈴木裕子, 西山利 正, 友田幸一 (2009) 聴覚伝導路に打ける組織幹細胞 の同定および特徵付け. 第 27 回頭頸部自律神経研究 会, 大阪

77. 友田幸一（2009） Balloon Sinuplasty の実際と治療成 績. 第 22 回神奈川県耳鼻咽喉科 - 頭頸部外科手術手技 研究会, 横浜

78. 阪上智史（2009）視診上診断に難渋した外耳道腫瘍の 1 例. 第 4 回枚方耳鼻咽喉科臨床懇話会, 枚方

79. 湯川尚哉（2009）当院における頭頸部診療. 第 4 回枚 方耳鼻咽喉科臨床懇話会, 枚方

80. 福井英人（2009）鼻性視神経症の 1 例. 第 4 回枚方耳 鼻咽喉科臨床懇話会，枚方

81. 鈴木健介（2009）滲出性中耳炎として発症した上咽頭 癌の 1 例. 第 4 回枚方耳鼻咽喉科臨床懇話会, 枚方

82. 村田英之, Wolfgang Draf, 三輪高喜, 友田幸一 (2009) Osteoplastic Frontal Sinusotomy and Reconstruction の 1 例. 第57回中部地方部会連合会, 金沢

83. 竹林慎治, 島谷美映, 池田浩己, 芝 埜彰, 三浦 誠 （2009）短期間に経験したガス産生を伴う深頸部膿瘍 の4例。第71回耳鼻咽喉科臨床学会, 旭川

84. 岡崎はるか, 宗本由美, 清水順一, 久保伸夫, 友田幸 一 (2009) 一側性難聴が初発症状であったMPO-ANCA 関連腎炎の1例. 第71回日本耳鼻咽喉科臨床学会, 旭川 85. 高田洋平, 小椋 学, 永田基樹, 井上俊哉, 友田幸一 （2009）舌根部に発生した多形腺腫の一例。第71回日 本耳鼻咽喉科臨床学会, 旭川

86. 阪上智史, 湯川尚哉, 永田基樹, 藤澤㻟郎, 竹村博一, 井上俊哉, 友田幸一, 小椋 学, 八木正夫 (2009) 両 側顎下腺腫大から診断された，自己免疫性膵炎の一 例. 第71回日本耳鼻咽喉科臨床学会, 旭川

87. 池上智子, 岩井 大, 坂口麻理子, 金子敏彦, 北尻雅 則，友田幸一，正木浩哉（2009）術中迅速副甲状腺木 ルモン（iPTH）測定を用いた副甲状腺手術後の再発 例の検討。第71回日本耳鼻咽喉科臨床学会, 旭川

88. 朝子幹也, 友田幸一 (2009) 副鼻腔新手術 balloon sinuplastyの当科における経験と考察. 第 71 回日本耳 鼻咽喉科臨床学会, 旭川
89. 鈴木健介, 朝子幹也, 永田基樹, 友田幸一（2009）当 科に打ける鼻副鼻腔腫瘍症例の検討一鼻内内視鏡手 術の観点から一. 第71回日本耳鼻咽喉科臨床学会, 旭 川

90. 磯貝 豊, 宮本 真, 生野 登, 新美成二 (2009) 扁 桃内〜周囲膿瘍の診断・治療における MRIの有用性に ついて. 第3回東京・埼玉 5 大学頭頸部外科研究会, 東京

91. 宮本 真, 森 有子, 石川カミラクリスティナ, 中川 秀樹, 田村悦代, 福田宏之 (2009) 痽痕声帯に対する ラリンゴマイクロサージャリー（LMS）の有効性. 第 3 回東京・埼玉 5 大学頭頸部外科研究会, 東京

92. 朝子幹也（2009）鼻内前頭洞アプローチの選択一拡大 的手術 vs 低侵襲手術一。第 15 回北東大阪耳鼻咽喉科 臨床懇話会, 大阪

93. 池田浩己, 森田恭平, 渡邊茂樹, 西山秀樹, 友田幸一 (2009）ピークフロー管理からみて奏効した耳鼻科患 者の 2 症例. 第21回日本アレルギー学会春季臨床大会, 岐阜

94. 朝子幹也, 河本光平, 濱田聡子, 大岡久司, 福井英人, 友田幸一（2009）当科に打ける粘膜下下甲介骨切除術 に関する検討一後鼻枝の粘膜下走行と術後成績一. 第 21 回日本アレルギー学会春季臨床大会, 岐阜

95. 太田馨, 爲政大幾, 加藤りか, 北條友里子, 岡本祐之, 近野哲史, 湯川尚哉, 前川直輝（2009）下口唇に生じ た悪性黒色腫の 1 例. 第 24 回日本皮膚外科学会総会, 犬山

96. 池上智子，岩井 大，坂口麻理子，金子敏彦，北尻雅 則, 友田幸一, 正木浩哉（2009）術中迅速副甲状腺木 ルモン（iPTH）測定を用いた副甲状腺術後の検討. 第 309 回日耳鼻大阪地方会, 大阪

97. 藤澤玩郎, 永田基樹, 湯川尚哉, 竹村博一, 鈴木健介, 井上俊哉, 友田幸一 (2009) 当科に打ける上顎癌を除 いた鼻副鼻腔悪性腫瘍症例についての検討. 第309回 日耳鼻大阪地方会，大阪

98. 鈴木健介, 朝子幹也, 永田基樹, 友田幸一（2009）当 科に打ける鼻副鼻腔腫瘍症例の検討一鼻内内視鏡手 術の観点から一. 第309回日耳鼻大阪地方会, 大阪

99. 藤澤玩郎, 永田基樹, 井上俊哉, 湯川尚哉, 小椋 学, 竹村博一, 友田幸一 (2009) 当科における上顎癌を除 いた鼻副鼻腔悪性腫瘍症例についての検討. 第33回日 本頭頝部癌学会, 札幌

100. 井上俊哉，永田基樹，湯川尚哉，藤澤玩郎，竹村博 一, 友田幸一, 辻 裕之（2009）上側壁型中咽頭癌切 除後再建症例に打ける術後機能評価一同一症例にお ける Gehanno法の経時的変化の検討一. 第33回日本頭 頸部癌学会, 札幌

101.朝子幹也（2009）長引く咳と耳鼻科疾患. 垂水区医師 会学術講演会, 神戸

102. 久保伸夫, 朝子幹也, 竹田浩子, 宗本由美, 岡崎はる か, 濱本由記子 (2009) 外鼻鼻中隔形成術 鼻外法と 内視鏡下鼻内法. 第 110 回 日本耳鼻咽喉科学会総会. 
学術講演会, 東京

103. 田村悦代, 飯田政弘, 岡田信也, 渋谷正人, 福田宏 之, 森 有子, 宮本 真 (2009) 片側声帯麻痺に心因 性発声障害を伴った一症例. 第 110 回日本耳鼻咽喉科 学会, 東京

104. 宮本 真, 楠山敏行, 森 有子, 中川秀樹, 田村悦 代，新美成二，福田宏之（2009）瘢痕声帯に対するラ リンゴマイクロサージャリー (LMS) の有効性. 第 110 回日本耳鼻咽喉科学会総会・学術講演会, 東京

105.阪上智史, 八木正夫, 湯川尚哉, 井上俊哉, 永田基 樹, 小椋 学, 藤澤㻟郎, 泉川雅彦, 竹村博一, 近野 哲史, 友田幸一（2009）甲状腺乳頭癌反回神経癒着症 例の検討. 第 110 回日本耳鼻咽喉科学会総会 - 学術講 演会, 東京

106. 山下樹里, 熊谷 徹, 森川 治, 横山和則, 友田幸一 （2009）内視鏡下鼻内手術手法の自習システムの開発. 第 110 回日本耳鼻咽喉科学会総会・学術講演会, 東京 107. 柴田清児ブルース, 泉川雅彦, 河本光平, 八木正夫, 朝子幹也, ラファエルヨアッシュ，友田幸一（2009） Adv.BDNF 遺伝子導入による Neomycin 蝸牛障害モデ ルの神経伸張. 第 110 回日本耳鼻咽喉科学会総会・学 術講演会, 東京

108. 泉川雅彦, 土井 直, 金子敏彦, 友田幸一 (2009) 外 耳道骨部軟骨腫の 1 例. 第 110 回日本耳鼻咽喉科学会 総会・学術講演会, 東京

109.朝子幹也，河本光平，阪上智史，友田幸一（2009）鼻 副鼻腔新手術器具 ballon sinuplastyの経験. 第110回 日本耳鼻咽喉科学会総会・学術講演会, 東京

110.朝子幹也 (2009) 聴覚と嗅覚の老化. 第2回東京アン チエイジングアカデミー, 東京

111.朝子幹也（2009）2009 年花粉症対策. 堺市耳鼻咽喉 科医会，堺市

112. 友田幸一 (2009) 今, 外科手術は変わるーコンピュー ター外科の世界一. 第157回加多乃会「勉強会」, 守口

113. 岩井 大 (2009) 無喉頭者に対する音声再建外科の現 状と問題点「グロニンゲンを用いたシャント発声法の 応用」. 第 19 回日本気管食道科学会認定気管食道科専 門医大会, 米子

114. 堀口章子, 友田幸一 (2009) 無喉頭者に対する音声再 建外科の現状「Provoxレコードマーク 2 を心とした 当科における経験」. 第 19 回日本気管食道科学会認定 気管食道科専門医大会, 米子

115. 宮本 真, 森 有子, 佐藤剛史, 浅香明日美, 中川秀 樹，田村悦代，今川博，新美成二，福田宏之（2009） 発声部位の診断に電気声門図 (EGG) が有効であった 1 症例. 第30回東日本音声外科研究会, 東京

116. 泉川雅彦 (2009) 遺伝子導入による内耳有毛細胞の再 生と機能回復. 学術フロンティア推進事業（ブレイン メディカルリサーチセンター) 中間発表会, 守口

117. 朝子幹也（2009）花粉症と咳嗽. 気道疾患対策セミ ナー, 盛岡
118.小西将矢（2009）AAV ベクターを用いたモルモット 蝸牛内への遺伝子導入. 第 125 回関西医科大学内学術 集談会, 守口

119.永田基樹（2009）耳下腺腫瘍一術前診断と手術手法 一. 第15回関西耳鼻咽喉科臨床懇話会, 大阪

120. 岡崎はるか, 宗本由美, 清水順一, 友田幸一, 久保伸 夫（2009）難聴，めまいが初発症状であったANCA関 連腎炎の 1 例. 第308回日耳鼻大阪地方会, 大阪

121.Trifonov S, Houtani T, Hamada S, Kase M, Maruyama M, Sugimoto T (2009) Choline acetyltransferase mRNA splice variants一マウス脳・脊髄での発現. 第114回日 本解剖学会総会・全国学術集会, 岡山

122.大岡久司，神田靖士，鈴木裕子，美島健二，斉藤一 郎, 西山利正 (2009) 聴覚伝導路（下丘）における組 織幹細胞の同定. 第8回日本再生医療学会総会, 東京

123.朝子幹也（2009）2009年 スギ・ヒノキ花粉症対策. アレルギー講演会 2009 , 宇部

124.朝子幹也（2009）2009 年花粉症対策. 堺市耳鼻咽喉 科医会，堺市

125.朝子幹也（2009）花粉症と咳嗽. 三原市医師会学術講 演会, 三原

126.池田浩己（2009）アレルギー性鼻炎・花粉症の診断と 治療～民間療法から最新手術療法まで〜. 第15回アレ ルギー週間市民講座，和歌山

127. 友田幸一 (2009) 行動工学に基づく鼻科手術の新しい 評価. 第 19 回大阪耳友会学術講演会, 大阪

128. 友田幸一 (2009) 自分の手術はどれくらい正確か? 行動工学に基づく鼻科手術手法の新しい評価一. 第 34 回御茶ノ水耳鼻咽喉頭䅡科治療研究会, 東京

129. 永田基樹（2009）耳下腺腫瘍一術前診断と手術手技 一. 第45回 頭頸部癌治療カンファレンス, 東京

130.山下樹里, 横山和則, 熊谷 徹, 森川 治, 友田幸一 （2009）内視鏡下鼻内手術（蓄膿症手術）手技のトレー ニングシステム. 第一回日本医療教授システム学会総 会, 東京

131.朝子幹也（2009）花粉症と咳嗽。吹田市医師会臨床医 学談話会, 大阪

132.友田幸一（2009）「自分の手術はどれくらい正確か？ 一行動工学に基づく鼻科手術の新しい評価一」. 第 16 回近畿耳鼻頸科集談会, 大阪

133.井上俊哉, 岡崎はるか, 永田基樹, 湯川尚哉, 藤澤环 郎, 友田幸一（2009）ハイリスク下咽頭癌症例に対す る双茎遊離空腸移植の経験. 第19回日本頭頸部外科学 会, 名古屋

134.永田基樹，藤澤㻟郎，竹村博一，湯川尚哉，小椋 学, 近野哲史, 井上俊哉, 友田幸一, 辻 裕之 (2009) Lateral rhinotomy+hemicoronal flap 法による上顎全摘 術一顎動脈結紮について一. 第19回日本頭頸部外科学 会, 名古屋

135. 岩井 大，鈴木健介，友田幸一（2009）耳下腺唾液瘻 に対するミノサイクリン局所注入療法. 第19回日本頭 
頸部外科学会, 名古屋

136. 竹村博一, 永田基樹, 井上俊哉, 湯川尚哉, 小椋 学，藤澤㻟郎，近野哲史，池上智子，友田幸一（2009） 口腔内での花火破裂を契機とした咽頭外傷の1例。第 19 回日本頭頸部外科学会, 名古屋

137.鈴木健介, 岩井 大, 坂口麻理子, 友田幸一（2009） 頸部に発生した小児神経節芽腫 (ganglioneuroblastoma) の1例. 第19回日本頭頸部外 科学会, 名古屋

138.池田浩己（2009）内視鏡鼻内手術の up to date. 第2回 上本町耳鼻咽喉科勉強会, 大阪
139.佐藤剛史, 浅香明日美, 早乙女泰伴, 衛藤りえ, 大塚 まみこ, 宮本 真, 森 有子, 熊田政信, 新美成二, 福田宏之（2009） Tongue Thrust（舌突出症）の 1 例. 第54回日本音声言語医学会, 福島

著 書

1. 永田基樹 (2009) 耳下腺腫瘍. 口腔咽頭の臨床 2 (日 本口腔 - 咽頭科学会編) 170-175頁, 医学書院, 東京

2. 岩井 大 (2009) 唾液腺疾患唾石症. 口腔咽頭の臨床 2 (日本口腔・咽頭科学会編) 68-69頁, 医学書院, 東京

\section{産科学・婦人科学講座}

\section{〈研究概要〉}

子宮内膜機能の制御機構の研究としては, 性ステロイドホルモンによる子宮内膜機能調節機構の一端を解明すること を目指して, ヒト子宮内膜における，1）性ステロイドホルモンによる血管新生因子の制御機構の解明，2)子宮内膜分化 (脱落膜化) においてPが制御する局所因子の網羅的検索，3)PCの一つである PC6の脱落膜化における役割の解明，4)不 妊症例での局所因子発現の解析, の観点から検討を行っている. ヒト子宮内膜細胞を用いて, 増殖・分化に打ける中心 的な役割を担う $\mathrm{E}$ あるいPで制御される局所因子の同定と解析を行なっている. その結果, これらの性ステロイドホル モンはそれぞれの特異的に制御している因子, つまり Eにより誘導されるVEGF, SDF-1, およびPにより誘導されるIL15, Fibulin-1, PC6を介して子宮内膜での血管新生, 着床能, 免疫能, 細胞運動能, 脱落膜化などの機能を調節している ことを明らかとした．IL-15やFibulin-1の発現はPにより誘導されまた分泌期内膜で増強していることから，着床と妊娠 維持との関連が強く示唆された。 さらに，これらの局所因子の発現異常が子宮内膜機能に影響する可能性を，不妊症患 者より採取した子宮内膜を用いて示した．臨床へのフィードバックを考えると，これら因子のモニタリングにより，内 膜増殖不良症例, 内分泌学的に同定できない子宮内膜機能障害, 着床不全症例の診断に新たな展望が開かれるものと期 待される. 我々の研究成果は, 生殖医療のさらなる発展への可能性を秘めており, 臨床応用に向けさらに検討を進めて いる.

子宮平滑筋細胞の収縮調節機構研究では, 妊娠子宮筋の収縮調節機能の解明は, 早産および安全な分娩誘発・促進を 行う観点から産婦人科臨床医にとって重要な研究テーマの一つとして収縮に関与する刺激因子と抑制因子を解明し早産 治療薬の開発に役立てたいと考え, 各種分子特に, 活性脂質の役割を中心に検討している. 活性脂質としては古くから プロスタグランジンが知られ，陣痛促進あるいは腸管運動の促進に用いられている，その後，ロイコトリエン，血小板 活性化因子, ホスファティディールイノシトール代謝関連物質, リゾホスファチジン酸, スフィンゴシン 1 リン酸など 種々の活性脂質が見いだされている. これらについて, 子宮収縮との関連での研究を進める一方, 子宮内膜症, 子宮体 癌, 卵巣癌の発症や進展への脂質の関与についても検討しており, 種々の活性脂質と産婦人科領域の疾患との関係を研 究し, 発症の機序の解明や予防・治療に役立てたい.

子宮がんについての研究では, 若年者に多く発生し, 増加傾向にある子宮頸がんを対象とし, 昨年日本で認可された HPV 予防ワクチンの有用性と問題点を検討している。これまでに細胞診と HPV 感染について検討した結果は, (1) HPV 陽性例では, HPV 関連細胞 (koilocyte, parakeratotic cell, multinucleation, smuded nucleus, giant cell, immature metaplastic cell）の頻度が高かった（2）HPV関連細胞とHPV型別を比較すると, HPV16型で有意に koilocyteの頻度が低かった. 特 にLSIL, ASCUS, AGCではこの傾向が強かった. LSIL, ASCUSでは parakeratotic cell, multinucleationが高頻度で検出さ れ, koilocyte 以外の HPV 感染関連細胞についても注意する必要がある. よって頸がんの早期発見には従来の細胞診だけ でなくHPV検査が必要であると結論された。 今後HPV型別検査と細胞診, 異型成の進展についてさらに検討してゆく予 定である.

\section{〈研究業績〉}

原 著

1. Okada H, Tsutsumi A, Imai M, Nakajima T, Yasuda K and Kanzaki H (2009) Estrogen and selective estrogen receptor modulators regulate vascular endothelial growth factor and soluble vascular endothelial growth fac tor receptor 1 in human endometrial stromal cells. Fertil Steril Oct 12. [Epub ahead of print]

2. Wang X, Hisha H, Mizokami T, Cui W, Cui Y, Shi A, Song C, Okazaki S, Li Q, Feng W, Kato J and Ikehara S (2009) 
Mouse Mesenchymal Stem Cells Can Support Human Hemopoiesis both In Vitro and In Vivo: Crucial Role of Neural Cell Adhesion Molecule (NCAM). Haematologica Dec 16. [Epub ahead of print]

3. Mizokami T, Hisha H, Okazaki S, Takaki T, Wang XL, Song CY, Li Q, Kato J, Hosaka N, Inaba M, Kanzaki H and Ikehara S (2009) Preferential expansion of human umbilical cord blood-derived CD34-positive cells on major histocompatibility complex-matched amnionderived mesenchymal stem cells. Haematologica 94(5): 618-628

4. Kimura T, Matsuoka Y, Murakami M, kimura T, Takahashi Y, Nakamoto T, Yasuda K, Matsui K, Kobayashi K, Imai S, Asano H, Nakatsuka R, Umemura Y, Sasaki Y and Sonoda Y (2009) In vitro dynamics of human cord bloodderived CD34-SCID-repopulating cells(SRCs) in comparison to CD34+CD38+and CD34+CD38-SRCs using intra-bone marrow injection. Leukemia 24: 162-168

5. Tokumura A, Kume T, Taira S, Yasuda K and Kanzaki H (2009) Altered activity of lysophospholipase D, which produces bioactive lysophosphatidic acid and choline, in serum from women with pathological pregnancy. Mol Hum Reprod 15(5): 301-310

6. Kinoshita M, Asai A, Komeda S, Yoshimura K, Takeda J, Uesaka T, Yamanouchi Y, Kanzaki H and Kawamoto K (2009) Spontaneous regression of a spinal extradural arteriovenous fistula after delivery by cesarean section. Neurol Med Chir 49(7): 313-315

7. 辻 祥子, 安田勝彦, 村田紘未, 奥野茜子, 吉田桃子, 笠松 敦, 岡田英孝, 松尾 泉, 松岡 進, 神崎秀陽 （2009）子宮笳腫および卵巣線維腫の摘出後に正常月 経周期となった肥満女性の 1 症例. 産婦の進歩 61(3): $267-270$

8. 中嶋達也, 神崎秀陽 (2009)【子宮疾患 - 子宮内膜症 の臨床 基礎・臨床研究のアップデート】妊娠・産裖 期異常 筋腫分婏. 日臨 67(増刊5): 419-421

総 説

1. 岡田英孝, 神崎秀陽（2009）【着床のメカニズム】着 床における黄体ホルモンの役割. HORM FRONT GYNECOL 16(1): 11-17

2. 中元 剛 (2009) 最近の子宮頸がんスクリーニング検 査について．産婦人科の進歩 61(4): 313

3. 依岡寛和, 神崎秀陽（2009）産科出血一診断・治療の ポイント 前置胎盤. 臨婦産 63(1): 49-51

その他

1. 神崎秀陽（2009） ホルモン $\mathrm{Q} \& \mathrm{~A}$ 子宮筋腫治療にお けるUAE, FUS について教えてください. HORM FRONT GYNECOL 16(2): 160-162

2. 神崎秀陽（2009） ホルモン $\mathrm{Q} \& \mathrm{~A}$ 子宮内膜症にプロ
ゲスチンは有効でしょうか. HORM

FRONT GYNECOL 16(2): 159-160

3. 末原則幸, 杉本 壽, 小倉裕司, 中谷壽男, 鍛治有登, 松岡哲也，木村 正，荻田和秀，依岡寛和，松尾重樹， 塩田 充, 池田智明, 桂木真司, 厚生科学研究班「周 産期医療システムと救命救急システムの協力体制に 関する研究」(2009) 大阪における重症妊娠合併症へ の対応を目指した周産期医療と救急医療との連携. 産 婦人科の進歩 61(2): 208

4. 末原則幸, 光田信明, 松尾重樹, 依岡寛和, 今井史郎, 辻本大治, 中村哲生, 荻田和秀, 志村研太郎, 高木 哲（2009）大阪における周産期緊急搬送コーディネー ター 1 年間の運用結果とその問題点. 産婦人科の進歩 61(2): 191

5. 末原則幸, 杉本 壽, 小倉裕司, 中谷壽男, 鍛治有登, 松岡哲也，木村 正，荻田和秀，依岡寛和，松尾重樹， 塩田 充, 池田智明, 桂木真司, 厚生科学研究班「周 産期医療システムと救命救急システムの協力体制に 関する研究班」（2009）大阪に打ける重症妊娠合併症 への対応に関する実態調査報告（第一報）。産婦人科 の進歩 61(2): 191

6. 船戸正久, 根岸宏邦, 小川晴幾, 齋田幸次, 北村直行, 白石 淳, 中平公士, 早田賢司, 依岡寛和, 田中祥介, 西田 勝, 児玉和夫, 野田哲朗, 松下彰宏, 東 隆司, 加美敏隆, 今井龍也, 川崎忠男, 井藤尚之, 大笹幸伸, 杉本 壽, 酒井國男, 大阪府医師会周産期医療委員会 （2009）NICU長期入院児の在宅ケア促進に向けた地域 の取り組み 大阪府医師会周産期医療委員会 NICU 長 期入院者対策小委員会の活動と提言. 日本未熟児新生 児学会雑誌 21(3): 464

学会発表

1. Sonoda Y, Kimura T, Matsuoka Y, Murakami M, kimura T, Takahashi Y, Nakamoto T, Yasuda K, Nakatsuka R, Matsui K, Umemura Y and Sasaki Y, (2009) In vitro dynamics of human cord blood-derived CD34-SCIDrepopulating cells(SRCs) in comparison to CD34+CD38+and CD34+CD38-SRCs using intra-bone marrow injection. 2nd TERMIS World Congress, Soul

2. 斉藤淳子 (2009) Delivery system of HPV peptide vaccine in mice. The 25th International Papillomavirus Conference(IPC)2009, Sweden

3. 角玄一郎, 中嶋達也, 都築朋子, 溝上友美, 生田明子, 杉本久秀, 安田勝彦, 堀越順彦, 神崎秀陽 (2009) 手 術後急速に増悪した子宮体癌の 1 例. 第 121 回近畿産 科婦人科学会学術集会, 神戸市

4. 江本まゆみ, 中嶋達也, 中村友美, 林 佳子, 山下衣 里子, 吉田 彩, 渡邊 恵, 曺寿勇, 土井田曈, 小野 淑子，中元 剛，岡田英孝，松原高史，斉藤淳子，椹 木 晋, 神崎秀陽（2009）低悪性度子宮内膜間質肉腫 の1例. 第 121 回近畿産科婦人科学会学術集会, 神戸市 
5. 山下衣里子, 依岡寛和, 辻 祥子, 曺寿勇, 土井田瞳, 渡邊 恵, 吉田 彩, 石原美由希, 伊藤亜希子, 都築 朋子, 笠松 敦, 松原高史, 岡田英孝, 椹木 晋, 神 崎秀陽（2009）妊娠 19週で診断した胎児Ebstein 奇形 の1例. 第 121 回近畿産科婦人科学会学術集会, 神戸市

6. 中村友美, 中嶋達也, 伊藤亜希子, 江本まゆみ, 林 佳子, 山下衣里子, 曺寿勇, 土井田瞳, 渡邊 恵, 吉 田 彩, 石原美由希, 小野淑子, 笠松 敦, 中元 剛, 依岡寛和, 松原高史, 斉藤淳子, 岡田英孝, 椹木 晋, 神崎秀陽 (2009) Placental site trophoblastic tumor (PSTT) の 1 例. 第 121 回近畿産科婦人科学会学術集 会, 神戸市

7. 都築朋子, 林 佳子, 角玄一郎, 笠松 敦, 依岡寛和, 中嶋達也, 椹木 晋, 安田勝彦, 堀越順彦, 神崎秀陽 （2009）造影 MRI が診断に有用であった子宮筋腫合併 の胎盤ポリープの 1 例. 第 121 回近畿産科婦人科学会 学術集会, 神戸市

8. 土井田 瞳, 依岡寛和, 吉田 彩, 渡邊 恵, 曺寿勇, 石原美由希，伊藤亜希子，都築朋子，笠松 敦，岡田 園子, 岡田英孝, 松原高史, 中元 剛, 椹木 晋, 神 崎秀陽（2009）五胎妊娠 - 分婏の管理. 第121回近畿 産科婦人科学会学術集会, 神戸市

9. 林 佳子, 依岡寛和, 吉田 彩, 江本まゆみ, 中村友 美, 土井田 瞳, 曺寿勇, 渡邊 恵, 山下衣里子, 伊 藤亜希子, 笠松 敦, 中元 剛, 中嶋達也, 松原高史, 椹木 晋, 神崎秀陽 (2009) 出生前診断された腋窩囊 胞状リンパ管腫の 1 例. 第 121 回近畿産科婦人科学会 学術集会, 神戸市

10. 林 佳子, 土井田 瞳, 中元 剛, 中嶋達也, 松原高 史, 斉藤淳子, 椹木 晋, 神崎秀陽, 田所知佳, 植村 芳子（2009）若年者の卵巣粘液性腫瘍の 1 例. 第 1 回 関西婦人科腫瘍・病理懇話会, 京都市

11. 小野淑子, 岡田英孝, 松岡 進, 神崎秀陽（2009）妊 娠初期に卵巣茎捻転を 2 回発症し両側附属気摘出後に 早産した双胎妊娠の 1 症例. 第5 4 回日本生殖医学会総 会学術講演会, 金沢市

12. 馬場真有美, 岡田英孝, 川畑仁美, 下井華代, 宮城博 恵，小野淑子，岡田園子，松原高史，安田勝彦，谷口 久哲，松田公志，神崎秀陽（2009）体外受精説明会に おける患者の意識調査とその後の治療経過について. 第54回日本生殖医学会総会学術講演会, 金沢市

13. 都築朋子，岡田英孝，小野淑子，岡田英孝，松原高史， 椹木 晋, 安田勝彦, 神崎秀陽 (2009) 不育症に対す る低容量アスピリン・ヘパリン療法の有効性と安全 性. 第54回日本生殖医学会総会総会・学術講演会, 金 沢市

14. 角玄一郎（2009）術後判明した低悪性度子宮内膜間質 肉腫の一例. 第 26 回大阪産婦人科医会（河北地区研修 会）ならびに同門会，守口市

15. 江本まゆみ（2009）低悪性度子宮間質肉腫の1例。第 26 回大阪産婦人科医会（河北地区研修会）ならびに同
門会, 守口市

16. 山下衣里子（2009）出生前診断した胎児 Ebstein 奇形 の 1 例. 第 26 回大阪産婦人科医会（河北地区研修会） ならびに同門会, 守口市

17. 土井田 瞳 (2009) 五胎妊娠を経験して. 第26回大阪 産婦人科医会（河北地区研修会）ならびに同門会，守 口市

18. 林 佳子（2009）胎児腋窩リンパ管腫の1例. 第26回 大阪産婦人科医会 (河北地区研修会) ならびに同門会, 守口市

19. 斉藤淳子, 中元 剛, 神崎秀陽（2009）HPV と子宮頸 部細胞診 形態学的考察を中心に HPV 感染における 細胞形態变化について. 第48回日本臨床細胞学会学術 集会秋期大会, 福岡市

20. 山口昌美, 中元 剛, 斉藤淳子, 神崎秀陽（2009）子 宮内膜細胞診が有用であった正常大卵巣癌の 1 症例. 第48回日本臨床細胞学会秋期大会, 福岡

21. 斉藤淳子（2009）HPV と子宮頸部細胞診一形態学的考 察を中心に一 HPV 感染における細胞形態変化につ いて．第48回日本臨床細胞学会秋期大会, 福岡

22. 木下勇一, 松永志保, 市邊和男, 生田明子, 植村芳子, 坂井田紀子, 足立 靖, 圦貴司, 鷹巣晃昌, 四方伸 明（2009）腹膜に進展した高分化乳頭型胸膜中皮腫の 一例．第48回日本臨床細胞学会秋期大会, 福岡

23. 神崎秀陽（2009）子宮内膜症薬物治療のトピックス. 岐阜県産婦人科研究会 (生殖医学)，岐阜市

24. 岡田英孝（2009）子宮内膜における前駆体蛋白活性化 酵素による脱落膜化調節機構の解明. 第 41 回日本臨床 分子形態学総会ならびに学術講演会, 神戸

25. 斉藤淳子（2009）子宮頸癌 新しい予防. 日本産婦人 科医会和歌山支部研修会, 和歌山

26. 岡田園子, 岡田英孝, 下井華代, 宮城博恵, 小野淑子, 松原高史, 安田勝彦, 神崎秀陽 (2009) 子宮内膜組織 診に打ける内膜採取器具による痛みと組織採取量に 及汭す影響. 第27回日本受精着床学会学術講演会, 京 都市

27. 下井華代，岡田英孝，宮城博恵，石塚文平，市川智彦， 岡田 弘, 京野廣一, 堤 治, 詠田由美, 峯岸 敬, 吉澤 緑, 森本義晴, 神崎秀陽, 佐藤英明（2009）非 配偶者間の生殖補助医療に関する学会会員の意識調 查. 第27回日本受精着床学会学術講演会, 京都市

28. 馬場真有美，岡田英孝，川畑仁美，下井華代，宮城博 恵，小野淑子，岡田園子，松原高史，安田勝彦，神崎 秀陽（2009）生殖医療センターにおける女性患者のア ンケートからみた看護支援のあり方について. 第27回 日本受精着床学会学術講演会, 京都市

29. 小宮山豊, 生田明子, 尾崎貴恵, 宗像眞知子, 吉賀正 亨, 横井豊彦, 桝田 緑, 正木浩哉, 堀越順彦, 高橋 伯夫（2009）SCC 偽高值患者の1例 分子量による解 析. 第56回日本臨床検査医学会学術集会, 札幌市

30. 斉藤淳子 (2009) HPV と尖圭コンジローマ. イボイボ 
ネットフォーラム, 大阪

31. 神崎秀陽（2009）子宮内膜症薬物治療の最新動向. 京 都産婦人科医会 - 保険医協会診療内容向上会, 京都市

32. 笠松 敦, 依岡寛和, 椹木 晋, 神崎秀陽, 峰 研治, 辻 章志, 大橋 敦, 木下 洋, 金子一成 (2009) 妊 娠 10 週で診断した結合体を伴った一絨毛膜性二羊膜 性品胎を周産期管理した 1 症例。第 45 回日本周産期 • 新生児医学会学術集会, 名古屋市

33. 安田勝彦, 神崎秀陽, 岡田英孝, 中嶋達也, 中元 剛 （2009）妊娠時の子宮筋収縮調節機構とそれに及ぼす 契煙の影響. 平成 20 年度喫煙科学研究財団助成研究発 表会, 東京都

34. 斉藤淳子（2009）子宮頸癌と HPV について. GSK 研 修会, 大阪

35. 久松洋司, 安田勝彦, 溝上友美, 中元 剛, 生田明子, 杉本久秀, 堀越順彦, 横井川規巨, 北出秀章, 高田秀 穂, 神崎秀陽（2009）診断に苦慮した子宮体癌術後の 上行結腸転移の 1 症例. 第 120 回近畿産科婦人科学会 学術集会, 神戸市

36. 中元 剛, 生田明子, 分野由佳里, 久松洋司, 溝上友 美, 杉本久秀, 安田勝彦, 堀越順彦, 神崎秀陽 (2009) 子宮頸癌治療のため放射線治療中（腔内照射）子宮小 腸㾇を合併した 1 例. 第 120 回近畿産科婦人科学会学 術集会, 神戸市

37. 土井田 瞳, 吉田 彩, 渡邊 恵, 曺寿勇, 石原美由 希, 角玄一郎, 中嶋達也, 松尾 泉, 松岡 進, 斉藤 淳子, 椹木 晋, 神崎秀陽 (2009) 巨大卵巣腫瘍の 2 症例. 第 120 回近畿産科婦人科学会学術集会, 神戸市

38. 末原則幸, 光田信明, 松尾重樹, 依岡寛和, 今井史郎, 辻本大治, 中村哲生, 荻田和秀, 志村研太郎, 高木哲 (2009) 大阪における周産期緊急搬送コーディネー ター 1 年間の運用結果とその問題点. 第 120 回近畿産 科婦人科学会学術集会, 神戸市

39. 末原則幸, 杉本 壽, 小倉裕司, 中谷壽男, 鍛治有登, 松岡哲也, 木村 正, 荻田和秀, 依岡寛和, 松尾重樹, 塩田 充, 池田智明, 桂木真司 (2009) 大阪における 重症妊娠合併症への対応に関する実態調査報告（第 1 報)。第 120 回近畿産科婦人科学会学術集会, 神戸市

40. 曺 寿勇, 土井田 瞳, 吉田 彩, 渡邊 恵, 笠松 敦, 依岡寛和, 椹木 晋, 神崎秀陽（2009）子宮頸部 前壁に卵膜付着を伴う部分前置胎盤の 1 症例. 第 120 回近畿産科婦人科学会学術集会, 神戸市

41. 神崎秀陽（2009）子宮内膜症薬物治療の現状と展望. 第 46 回日本生殖医学会北陸支部学術集会イブニング セミナー，金沢市

42. 木下勇一, 松永志保, 高畠 希, 市邊和夫, 生田明子,
植村芳子, 坂井田紀子, 足立 靖, 圦 貴司, 鷹巣晃 昌, 四方伸明 (2009) 悪性胸膜 - 腹膜中皮腫が疑われ た 1 例. 第十五回大阪病理研究会, 大阪

43. 岡田英孝, 堤 明裕, 角玄一郎, 中元 剛, 中嶋達也, 安田勝彦, 神崎秀陽（2009） ヒト子宮内膜の血管新生 に関わるVEGF とその遊離型 VEGF 受容体 1 型の発現 制御. 第61回日本産科婦人科学会学術講演会, 京都市

44. 角玄一郎, 笠松 敦, 小野淑子, 中嶋達也, 岡田英孝, 斉藤淳子, 松尾 泉, 松岡 進, 椹木 晋, 安田勝彦, 神崎秀陽（2009）腹式子宮筇腫核出術において手術時 間, 出血量と関係する因子の検討. 第61回日本産科婦 人科学会学術講演会, 京都市

45. 木下勇一, 濱口記久子, 松永志保, 市邊和男, 李 重 煥, 鷹巣晃昌, 四方伸明, 足立 靖, 圦 貴司, 生田 明子（2009）子宮体部原発明細胞腺癌の一例. 第34回

日本臨床細胞学会大阪府支部 学術集会, 大阪

46. 神崎秀陽（2009）子宮内膜症治療の変遷と将来展望. 第22回武庫川婦人科セミナー, 西宮市

47. 斉藤淳子（2009）子宮頸癌と尖圭コンジローマ. 万有 製薬研修セミナー, 大阪

48. 角玄一郎, 中嶋達也, 岡田英孝, 安田勝彦, 神崎秀陽 （2009）卵巣子宮内膜症性囊胞手術時の出血時間，手 術時間に関連する因子の検討. 第30回日本エンドメト リオーシス学会, 仙台

49. 神崎秀陽（2009）子宮内膜症治療の現状と展望. 第 5 回山形県生殖生理研究会, 山形市

50. 中村友美 (2009) Placental site trophoblastic tumor(PSTT)の1例. 第26回大阪産婦人科医会（河北 地区研修会）ならびに同門会，守口市

51. 依岡寛和, 笠松 敦, 椹木 晋, 神崎秀陽, 峰 研治, 大橋 敦, 木下 洋, 金子一成, 高田晃平, 濱田吉則 （2009）出生前診断した胎児肺分画症の 2 症例. 第 45 回日本周産期・新生児医学会学術集会, 名古屋市

著 書

1. 岡田英孝, 神崎秀陽（2009）無月経, 稀発月経, 頻発 月経. 産婦人科研修ノート 2 257-259頁, 診断と治 療社, 東京

2. 末原則幸, 杉本 壽, 中谷寿男, 小倉裕司, 鍛冶有登, 松岡哲也, 木村 正, 荻田和秀, 依岡寛和, 松尾重樹, 塩田 充, 池田智明, 桂木真司 (2009) 乳幼児死亡と 妊産婦死亡の分析と提言に関する研究 周産期医療 システムと救命救急システムの協力体制に関する研 究. 乳幼児死亡と妊産婦死亡の分析と提言に関する研 究 平成 20 年度 総括・分担研究報告書 199-218 頁, 厚生労働省, 東京 


\section{麻酔科学講座}

\section{〈研究概要〉}

麻醉科学講座の現在の研究課題としては脳虚血における白質病変に関する研究, 麻酔関連薬の免疫機能へ及ぼす影響 に関する研究，低酸素誘導因子に関する研究，気道確保器具に関する臨床的研究が挙げられる。

脳虚血における白質病変に関する研究: 従来脳虚血が及ぼす影響については主として灰白質病変が注目されてきた。 し かし，ヒトに抢いては白質の脳の中で占める割合が他動物種に比して大きく, 動物実験で有効とされる脳虚血に対する 予防・治療薬が臨床ではその有効性が明らかとされないことが多かった。この違いが白質の脳虚血による病変に関連し ている可能性が取り上げられ, 最近では白質病変への研究が注目されてきている. ラットにおける心停止・蘇生動物モ デルを使用して, 脳虚血の白質病変に関する研究を進めている. 本年度はフリーラディカルスキャベンジャーとして臨 床で使用されているEdravoneの有效性について本動物モデルを使用して検討し, 灰白質のみならず白質病変に対しても 有効であることを生化学的手法を用いて証明した.

免疫機能への影響に関する研究: 免疫は循環・呼吸・代謝・神経系・内分泌系とともに生体恒常性維持に重要な機能 であり, 手術侵襲・麻酔が及ぼす免疫系への影響も麻醉科学においては重要な課題である. しかし, これまで他の機能 に比して麻酔薬・麻酔関連薬が免疫系へ及ぼす影響については十分な研究が行われてこなかった，本講座では稲田講師 を中心に麻酔薬・麻酔関連薬の免疫系へ及ぼす影響について検討を継続してきている. これまで, 手術侵襲抢よび麻酔 薬がリンパ球分化へ及ぼす検討, 麻酔薬の腫瘍免疫へ及ぼす影響についてその結果を報告している. 本年度は静脈麻醉 薬である propofolがcyclo-oxygenaseへ及ぼす影響について研究を進め, その結果を報告した.

低酸素誘導因子に関する研究: 京都大学麻醉学講座と共同でhypoxia-induced factor 1 亿麻酔薬㧍よび麻酔関連薬が及ぼ す影響について研究を進めてきている。

気道確保器具に関する臨床的研究: 浅井講師を中心に各種 supra-glotic airway securing devicesに関する臨床研究を継続 している. Laryngeal mask airwayに代わる各種器具が改良されてきており, また, 気管挿管に用いる喉頭鏡に関しても新 しい各種喉頭鏡が開発されてきている. 気道確保が臨床麻酔の現場において生命に関わる重要な事項であることから, こ の分野は麻酔科学の重要な臨床課題である.

\section{〈研究業績〉}

原 著

1. Asai T (2009) Tracheal intubation with restricted access: a randomised comparison of the Pentax-Airway Scope and Macintosh laryngoscope in a manikin. Anaesthesia 64(10): 1114-1117

2. Asai T, Liu EH, Matsumoto S, Hirabayashi Y, Seo N, Suzuki A, Toi T, Yasumoto K and Okuda Y (2009) Use of the Pentax-AWS in 293 patients with difficult airways. Anesthesiology 110(4): 898-904

3. Kubo K, Nakao S, Jomura S, Sakamoto S, Miyamoto E, Xu Y, Tomimoto H, Inada T and Shingu K (2009) Edaravone, a free radical scavenger, mitigates both gray and white matter damages after global cerebral ischemia in rats. Brain Res 1279: 139-146

4. Inada T, Kubo K, Kambara T and Shingu K (2009) Propofol inhibits cyclo-oxygenase activity in human monocytic THP-1 cells. Can J Anaesth 56(3): 222-229

5. Wakamatsu T, Tanaka T, Oda S, Nishi K, Harada H, Daijo H, Takabuchi S, Kai S, Fukuda K and Hirota K (2009) The intravenous anesthetics barbiturates inhibit hypoxia-inducible factor 1 activation. Eur J Pharmacol 617(1-3): 17-22

6. Oda S, Oda T, Takabuchi S, Nishi K, Wakamatsu T, Tanaka T, Adachi T, Fukuda K, Nohara R and Hirota K (2009) The calcium channel blocker cilnidipine selec- tively suppresses hypoxia-inducible factor 1 activity in vascular cells. Eur J Pharmacol 606(1-3): 130-136

7. Inada T, Kubo K and Shingu K (2009) Vaccines using dendritic cells, differentiated with propofol, enhance antitumor immunity in mice. Immunopharmacol Immunotoxicol 31(1): 150-157

8. Kambara T, Inada T, Kubo K and Shingu K (2009) Propofol Suppresses Prostaglandin E(2) Production in Human Peripheral Monocytes. Immunopharmacol Immunotoxicol 31(1): 117-126

9. Jiang S, Inada T, Tanaka M, Furuta RA, Shingu K and Fujisawa J-I (2009) Involvement of TORC2, a CREB coactivator, in the in vivo-specific transcriptional control of HTLV-1. Retrovirology 6(ArticleNo. 73): 1-16

10. 森山尚治, 上山精二, 西田吉治, 堀江 剛, 浅井 隆 （2009）救急救命士が使用できる気道確保器具の有用 性について．プレホスピタル・ケア 22(6): 55-57

11. 中本麻衣子, 中尾慎一, 新宮 興, 村尾浩平, 木本倫 代（2009）フェンタニルを添加した脊䯣くも膜下麻酔 においてブピバカインの比重が bispectral index(BIS) 值に与える影響. 麻酔 58(4): 460-462

総 説

1. 松本早苗 (2009) LMA・声門上器具 私の疑問に答え て! LMAで陽圧換気をするときの注意点は? ProSeal を選択，確実に挿入・固定し，患者の傍を離れず，こ 
まめにチェック．LiSA 16(8): 792-793

2. 浅井 隆 (2009) LMA・声門上器具 私の疑問に答え て! 固定する必要はありますか, またバイトブロック のようなものは必要ですか? 必要なものにはバイト ブロックをし， 固定もしっかりとしよう，LiSA 16(8): 784-785

3. 浅井 隆 (2009) LMA・声門上器具 私の疑問に答え て! カフ内圧の調整は必要ですか?まさか, カフに最 大量を注入しておしまいではプロの麻醉科医ではな い. LiSA 16(8): 779-780

4. 狩谷伸享, 浅井 隆 (2009) LMA・声門上器具 私の疑 問に答えて! 挿入時の体位は? 種類によって挿入時 の最適な頭頸位は違う。 LiSA 16(8): 765-767

5. 浅井 隆 (2009) LMA・声門上器具 ラリンジアルマス クは麻酔管理をこう変えた。 LiSA 16(8): 694-698

\section{症例報告}

1. 河嶋 朗, 浅井 隆 (2009) LMA • 声門上器具 最新 のLMA・声門上器具 : i-gel:ぜひ使ってみたい！。LiSA 16(8): 750-752

2. 里井明子, 村尾浩平, 井上昌子, 神原知子, 上村幸子, 中尾みどり，新宮 興（2009）エアウェイスコープと 気管支ファイバースコープを使用し経鼻気管抻管し えた巨大喉頭蓋囊胞の1症例．麻酔５8(8): 1028-1031

3. 岸井 幹, 浅井 隆, 永田 厚, 新宮 興 (2009) ブ ジーを用いて気管チューブ交換が困難な際にエア ウェイスコープが有用であった 1 症例. 麻酔 58(6): 765-767

4. 宮崎秀行, 浅井 隆, 神原知子, 永田 厚, 新宮 興 （2009）気管チューブ周囲からのガス漏れをラリンジ アルマスクにより軽減できた症例。麻酔 58(2): 193194

その他

1. 永田厚 (2009) ここがポイント! 気道確保 $\mathrm{Q} \& \mathrm{~A}$ 事象別 救急現場. 麻酤科学レクチャー 1(3): 777782

2. 浅井 隆 (2009) ここがポイント!気道確保 Q\&A 気 道確保が困難な症例 挿管困難, 換気困難予測症例へ の気道確保計画. 麻酔科学レクチャー 1(3): 699-702

3. 浅井 隆 (2009) 気道確保 ビデオ喉頭鏡, ラリンゴ ビュー． 麻酔科学レクチャー 1(2): 421-425

4. 浅井 隆 (2009) 麻酔の現況と展望 研修医と指導医 のための質問 317 麻酔の技術 気道確保. 麻酔科学レ クチャー 1(1): 65-69

5. 松本早苗 (2009) ここがポイント!気道確保 Q\&A 気 管挿管用器具 非直視下挿管器具 マッキントッ シュ型以外の喉頭鏡（トゥルービュー, ブラード型, ベルスコープ, グライドスコープなど）。麻酔科学レ クチャー 1(3): 619-625
学会発表

1. Kubo K, Joumura S, Miyamoto E, Nakao S and Shingu K. (2009) Edaravone resuces neuronal perikaryal and axonal damage following global cerebral ischemia in rats. American Society of Anesthesiologists 2009 annual meetingm, USA

2. Asai T (2009) Is There Any Supraglottic Airway Superior to The Laryngeal Mask? Excellence in Anesthesia, 台湾

3. 福井淳一, 西憲一郎, 濱野宣行, 山道啓吾, 道浦 拓, 中尾慎一, 大倉ひろ枝, 高橋伯夫, 新宮 興, 權 雅 憲（2009）食道癌周術期におけるシベレスタットナト リウム投与の有効性についての検討. 第71回日本臨床 外科学会総会, 京都

4. 永田 厚, 浅井 隆, 河嶋朗呉, 本善 聡, 伊藤 勲, 新宮 興 (2009) 救急救命士の気管挿管実習における 挿管手技にかかる時間についての考察. 第29回日本臨 床麻酔科学会, 浜松市

5. 松本早苗, 浅井 隆, 名和照晃, 新宮 興 (2009) Glidescope に gum-elastic bougie を用いて気管扦管に成功 した1例. 第29回日本臨床麻酔科学会, 浜松市

6. 上嶋浩順, 吉田光剛, 波多野貴彦, 米井昭智 (2009) 重症筋無力症の拡大胸腺摘出術に対して筋弛緩薬を 用いずレミフェンタニルで管理し得た 5 症例. 第29回 日本臨床麻酔科学会, 浜松市

7. 浅井 隆 (2009) エアウェイスコープの現状と未来一 マッキントッシュ型喉頭鏡は今や無用の長物か? 一 . 第29回日本臨床麻酔科学会, 浜松市

8. 浅井 隆 (2009) 挿管困難症例における気管チューブ の選択一進化したパーカー気管チューブの有用性一. 第29回日本臨床麻酔科学会, 浜松市

9. 波多野貴彦，北野正吾，住吉直秀，新宮 興 (2009) 頸椎手術術後に陰圧性肺水腫を生じたと考えられた 1 例. 第29回日本臨床麻酔科学会, 浜松市

10. 小島研太郎, 永田 厚, 大石敬子, 松本英夫, 中尾みど り，田口仁士（2009）麻酔・手術に関連したニュ - ロ パシックペインの 2 例. 第 8 回難治性疼痛研究会, 大 阪市

11. 岡本明久, 濱野宣行, 山崎悦子, 阪本幸世, 西憲一郎, 中尾慎一, 新宮 興 (2009) 先天性囊胞性腺腫様奇形 (CCAM）の生後 10个月の患児に対する分離肺換気の 麻酔経験. 第55 回日本麻酔科学会関西支部学術集会, 大阪

12. 松本早苗, 名和照晃, 新宮 興（2009）プレフィルド シリンジの組み立ての不具合により麻酔導入に時間 を要した症例. 第55回日本麻酔科学会関西支部学術集 会, 大阪

13. 杉田久美子, 西憲一郎, 北野正吾, 松井博義, 新宮 興（2009）植え込み型除細動器を挿入された Brugada 症候群患者の麻酔. 第55回日本麻酔科学会関西支部学 術集会, 大阪

14. 梅垣岳志, 角 千里, 西憲一郎, 池田栄浩, 新宮 興 
（2009）重複大動脈弓により強度の気管挟窄を有した 乳児の 1 症例. 第 55 回日本麻酔科学会関西支部学術集 会, 大阪市

15. 木本倫代, 村尾浩平 (2009) SMON病患者の麻酔経験. 第55回日本麻酔科学会関西支部学術集会, 大阪

16. 矢倉拓磨, 浅井 隆, 永田 厚, 廣瀬卓治, 新宮 興 （2009）不安定性頸椎疾患患者に対し，エアウェイス コープにより覚醒下経鼻扦管を施行し得た症例. 第5 5 回日本麻酔科学会関西支部学術集会, 大阪

17. 稲田武文, 久保古寿江, 新宮 興 (2009) ヒト単球に おいてプロポフォルがシクロオキシゲナーゼ活性に およぼす影響，第56回日本麻酔科学会，神戸市

18. 新宮 興 (2009) 病院経営における麻酔科の役割。第 56 回日本麻酔科学会, 神戸市

19. 浅井 隆 (2009) Difficult airway への対応に, スタン ダードを示すガイドラインは必要. 第56回日本麻酔科 学会, 神戸市

20. 浅井 隆 (2009) i-gelはラリンジアルマスクを超えら れるか？第56回日本麻酔科学会, 神戸市

21. 久保古寿江，上村幸子，中尾慎一，宮本悦子，阪本幸 世，新宮 興（2009）フリーラジカルスカベンジャー のエダラボンは, ラット全脳虚血後の灰白質, 白質両 者の傷害を軽減させる. 第56回日本麻酔科学会学術集 会，神戸市

22. 小島研太郎, 田口仁士, 増澤宗洋, 永田 厚, 大石敬 子，新宮 興（2009）仙骨硬膜外ブロック治療中に見 られた殿部皮下膿瘍の 1 例. 第 39 回日本ペインクリ ニック学会関西地方会, 高槻市

23. 岡本明久, 三木博和, 竹村博一, 濱野宣行, 山崎悦子,
阪本幸世，西憲一郎，中尾慎一，新宮 興（2009）扁 桃周囲膿瘍から波及した下降性壊死性縦隔炎で救命 し得た症例. 第5 4 回日本集中治療医学会近畿地方会, 和歌山

24. 武田福子, 浅井 隆, 永田 厚, 廣瀬卓治, 新宮 興 （2009）脊髄小脳変性疾患者への麻酔: 精巣挙筋反射 の有用性. 第55回日本麻酔科学会関西支部学術集会, 大阪

25. 西憲一郎（2009）マクロファージにおけるLPS誘導性 低酸素誘導性因子 1 活性化には活性酸素種を介した経 路が関与する. 第 125 回関西医科大学学内学術集談会, 枚方市

26. 久保古寿江, 中尾慎一, 宮本悦子, 上村幸子, 阪本幸 世，新宮 興（2009）ラット心肺停止・再灌流モデル におけるエダラボンのミクログリア活性化と神経細 胞傷害に対する影響. 日本神経麻酔・集中治療研究会, 吹田市

27. 岡田俊裕, 永田 厚, 浅井 隆, 新宮 興 (2009) 術 中にケトアシドーシス状態になった 1 例。 日本麻酔科 学会関西支部症例検討会, 大阪

28. 東山聡子, 廣瀬卓治, 永田 厚, 浅井 隆, 杉田久美 子, 新宮 興（2009）多発性硬化症患者に対する帝王 切開術の麻酔. 日本麻酔科学会関西支部症例検討会, 大阪

著書

1. 浅井 隆 (2009) これでわかった! 図説ラリンジアル マスク。これでわかった! 図説ラリンジアルマスク (安本和正編) 1-186頁, 克誠堂出版, 日本

\section{救急医学科}

\section{〈研究概要〉}

\section{1）急性期脊髄損傷に対する培養自家骨髄間質細胞移植による脊骾再生治療の検討＼cjkstart第 I-II相臨床試験}

急性期脊髄損傷患者を対象にした培養自家骨骾間質細胞移植による脊髄再生治療の臨床効果および安全性を評価す る.

脊髄損傷重症例では，生涯を対麻痺のために車椅子で，あるいは四肢麻痺のためにベッド上での生活が強いられる，さ らに呼吸筋麻疩のために人工呼吸器すら外せない場合もある。脊䯣損傷患者の多くは介護を必要とするため, その治療 法の発展は，当事者のQOL や社会参加を大きく向上させるだけでなく，介護の社会的コストを大きく削減することに繋 がるものと考えられる.

新しい治療法の可能性として，最近，骨髄間質細胞を移植することによって中枢神経の損傷部を修復させようとする 試みが報告された. 共同で研究を行う京都大学の研究グループもラットから採取した骨髄から間質細胞を分離培養し, 胸 髄 Th 8-9 レベルに挫滅損傷を加えた別のラットへ移植する実験を行ってきた。損傷後急性期に損傷部へ直接移植を行っ た群で歩行運動の著明な改善を認めた。しかし，ヒトへの応用を考えた場合には，脊髄の実質内に細胞を注入するのは 危険性が高く, 注入操作そのものにより新たな損傷が発生する可能性がある。一つの解決案として, 細胞を脳脊髄液中 に投与することが考えられる。ラット骨髄間質細胞を第四脳室内に投与する実験で，移植した群では神経学的な回復が 認められて抢り，組織学的にも春髄損傷の程度が軽く損傷部位の空洞の形成が少ない結果が認められた。 この回復は移 植細胞からの活性物質によるものと考えられるが，その詳細は未だ不明である．移植された細胞は，初期には損傷部位 内部に認められるが, 1か月以上生存する細胞はごく少数しか存在せず, 移植された細胞が長期間生着することが神経機 能の回復にとって必須でないことが示唆される.また, 移植された細胞は初期には脊髄の表面に広く分布していたが, そ 
れは時間とともに減少傾向にあったので, ES 細胞移植時に問題となっているような腫瘍化などの危険性もほとんど考え られない。

骨髄間質細胞移植以外の脊䯣損傷治療として, 諸外国においても細胞治療の開発が行われている. 中絶ヒト胎児由来 の幹細胞や胚性幹細胞 (ES cell), 患者自身のマクロファージ, 鼻粘膜より採取し培養した嗅球の神経細胞を取り巻くグ リア細胞（OEG）などが，実際にヒトへの臨床応用として使われている．これらの治療法はまだ実験段階であり，有効 性および安全性が検証されたものではない. 加えて, これらの細胞の移植には, 損傷部位の脊椎の椎弓切除を行って損 傷部の脊髄実質内に直接, 細胞を注入する方法が不可欠である.

一方, われわれが実施している骨髄間質細胞の移植は, 腰椎穿刺の手技を使って脳脊䯣液中に細胞を投与するため, 患 者への侵襲が少なく，より危険性の少ない優れた方法であると考えている. 倫理委員会の承認が2005年7月 1 日に得られ たことから, 患者団体への説明会などを経て, すでに臨床試験を開始している. 本方法による脊髄再生治療の試みは, 世 界初の方法であるが，これまでに 5 例に対して実施した． 3 例は著効， 2 例は無効であった。安全性には全く問題が見ら れていない. 今後も症例を重悋て医療として定着させたい.

\section{出血性ショックにおける高張食塩液蘇生の臓器障害防御効果とアポトーシス発現に関する実験的研究と臨床試験 1）出血性ショックにおける高張食塩液の免疫賦活作用に関する研究}

一アポトーシスとiNOSの関連について—

出血性ショック後の蘇生に成功しても, その後に ARDS（急性呼吸窮迫症候群）やMOF（多藏器不全）が発生し, 死 亡する症例がしばしば見られる，これには，出血性ショック後の免疫抑制状態が深く関与していると考えられ，高張食 塩液の抗アポトーシス作用が免疫抑制状態を回復または回避するメカニズムの解明を行い, 治療に役立てることを目標 とする.

高張食塩液蘇生が免疫担当臓器の胸腺および脾臓の $\mathrm{CD} 4^{+} \mathrm{CD} 25^{+}$制御性 $\mathrm{T}$ 細胞と $\gamma \delta \mathrm{T}$ 細胞にどの程度影響を及ぼし, ま たiNOS とアポトーシスが関与しているかを検討している. wild type としてのC57BL6/JマウスとiNOSノックアウトマウ ス（B6.129P2（NOS2））を用いた. 全身麻酔下に左大腿動脈にPE10のカテーテルを挿入し，へパリン $100 \mathrm{U} / \mathrm{Kg}$ を投与後 脱血し血圧を $40 \pm 5 \mathrm{mmHg}$ に 60 分保つ. 蘇生液として $4 \mathrm{ml} / \mathrm{Kg}$ の $7.5 \% \mathrm{NaCl}$ とB (Shed blood : 脱血血液); HS 群と脱血血 液の 2 倍量のラクテートリンゲル液と脱血血液; $2 \mathrm{LR}$ 群を作製し, 無処置のControl群と HS群と $2 \mathrm{LR}$ 群の蘇生後 $2 \mathrm{~h}, 6 \mathrm{~h}$, $24 \mathrm{~h}, 48 \mathrm{~h}$ の時点での $\mathrm{CD} 4^{+} \mathrm{CD} 25^{+}$制御性 T 細胞と $\gamma \delta \mathrm{T}$ 細胞の脾臓及び胸腺での蘇生後の変化をフローサイトメトリーを用 いて検討している. 出血性ショックは $\mathrm{CD} 4^{+} \mathrm{CD} 25^{+}$制御性 $\mathrm{T}$ 細胞, $\gamma \delta \mathrm{T}$ 細胞を介する免疫抑制に影響を及ぼし, iNOSが関 与していると考えている.

\section{2）臨床試験}

上記研究に関する臨床試験を倫理委員会の承認を得て泌尿器科とともに実施中である.

\section{〈研究業績〉}

原 著

1. Murao Y, Isayama K, Saito F, Hirakawa A and Nakatani T. (2009) Effect of hypertonic saline resuscitation on $\mathrm{CD} 4+\mathrm{CD} 25+$ regulatory $\mathrm{T}$ cells and gammadelta $\mathrm{T}$ cells after hemorrhagic shock and resuscitation in relation to apoptosis and iNOS. J Trauma 67(5): 975-982

2. Kunizawa A, Fujioka M, Suzuki S, Ryu T, Asai A, Kawamoto K and Kitazawa Y (2009) Spontaneous spinal epidural hematoma inducing acute anterior spinal cord syndrome. J Neurosurg Spine 10(6): 574-577

3. Yabuki T, Takeyama N, Tsuda M, Saitoh F, Tanaka T, Noguchi H and Nakatani T (2009) CpG Oligonucleotides Activate the Immune Response in Burned Mice. J Surg Res Feb 21. [Epub ahead of print]

4. Okii Y, Akane A, Kawamoto K, Iwase M, Yoshida M, Mitani T, Yoshimura S, Tokiyasu T and Kobayashi T (2009) The proof of flat-line scalp EEGs of brain dead patients by an automatic EEG analysis system. Leg Med 11(Supplement 1): S401-S403
5. 中谷壽男 (2009) 脊髄損傷に対する自己骨髄間質細胞 の髄液内投与による治療. Clinical Engineering 20: 1926

6. 岸本真房（2009）重症急性膵炎に対する膵局所動注療 法の有効性. 侵襲と免疫 18(3): 55-62

7. 村尾佳則, 諌山憲司, 平川昭彦, 中谷壽男 (2009) 出 血性ショック後に抢いて高張食塩液蘇生が $\mathrm{CD} 4+\mathrm{CD} 25+$ 制御性 $\mathrm{T}$ 細胞と $\gamma \delta \mathrm{T}$ 細胞に及ぼす影響一 iNOS とアポトーシスの関連より一. 日救命医療会誌 23: 9-14

8. 光井俊人, 下間覀由子, 三宅省吾, 覚道奈津子, 堀尾 修, 中谷壽男 (2009) 当院における過去 5 年間の 60 歳以上の重症熱傷の検討. 熱傷 35(1): 15-20

総 説

1. 北澤康秀（2009）【クリティカルケアにおける腎臓管 理 Q\&A】知っておきたい腎臓のメカニズム 腎の水分 の調節 尿量の異常. 救急集中治療 21(1-2): 5-10

2. 齊藤福樹, 泉野浩生, 北澤康秀, 中谷壽男 (2009) 急 性期栄養管理の基本と実際 II 急性期栄養管理の施 
設独自の工夫 関西医科大学における急性期栄養管理 の実際. 救急医 33(13): 1829-1832

3. 平川昭彦 (2009)【心停止に対応する!】知っておくべ き蘇生関連機. 月刊レジデント 2(7): 68-74

4. 北澤康秀 (2009) 病態・疾患別にみるエキスパートの 輸液管理 電解質異常の理解に必須な内分泌代謝の 知識整理. 重症集中ケア 8(4): 9-17

5. 北澤康秀 (2009) 病態・疾患別にみるエキスパートの 輸液管理 伸び悩む重炭酸リンゲル液. 重症集中ケア 8(4): 81-82

6. 北澤康秀 (2009) クリティカルケア領域の輸液管理の ポイント 輸液療法におけるピットフォール. 重症集 中ケア 7(6): 107-113

7. 北澤康秀, 辻佐世里, 徳山博美, 安藤有子 (2009) 末 梢血検査を詳しく読もう。達人ナース: 経験知の伝授 誌 30(7): 7-17

8. 北澤康秀, 辻佐世里, 徳山博美, 安藤有子（2009）電 解質データを読もう. 達人ナース : 経験知の伝授誌 30(7): 54-60

9. 北澤康秀, 辻佐世里, 徳山博美, 安藤有子 (2009) 腎 機能関連データを読もう. 達人ナース: 経験知の伝授 誌 30(7): 48-53

10. 北澤康秀, 辻佐世里, 徳山博美, 安藤有子（2009）肝 機能関連データを読もう。達人ナース: 経験知の伝授 誌 30(7): 37-47

11. 北澤康秀, 辻佐世里, 徳山博美, 安藤有子 (2009) 血 液凝固関連検査データを読もう。達人ナース : 経験知 の伝授誌 30(7): 18-36

12. 中谷壽男 (2009) 神経再生臨床応用 骨髄間質細胞によ る脊髄損傷の治療。脳21 12(3): 322-327

\section{症例報告}

1. 前田敏樹，村尾佳則，下戸 学，平川昭彦，中谷壽男 （2009）外傷性腹壁ヘルニアの1例．日腹部救急医会誌 29(1): 115-119

2. 岸本真房, 鈴木聡史, 富野敦稔, 藤井弘史, 山本 透, 北澤康秀（2009）意識障害をきたした睡眠時無呼吸症 候群の 1 症例一閉塞型睡眠時無呼吸症候群と中枢型睡 眠時無呼吸症候群の両者の発現をみた症例一. 日臨救 急医会誌 12(3): 343-347

3. 宮崎秀行, 浅井 隆, 神原知子, 永田 厚, 新宮 興 （2009）気管チューブ周囲からのガス漏れをラリンジ アルマスクにより軽減できた症例。麻酔 58(2): 193194

その他

1. 村尾佳則, 諌山憲司, 中谷壽男 (2009) ケース別ショッ クへの対応 出血性ショックの病態, 診断と治療戦略 とは? 救急集中治療 21(7-8): 937-942

2. 鈴木聡史, 山本 透 (2009) 内科エマージェンシー 病態生理の理解と診療の基本 VI 内分泌・代謝系疾
患褐色細胞腫．救急医 33(10): 1426-2429

3. 中谷壽男 (2009) 救急隊員の生涯教育・生涯研究につ いて．救急医療ジャーナル 17(6): 8-9

学会発表

1. Nakatani T, Iwase M, Saito F, Maeda Y, Hirakawa A, Murao Y, Suzuki Y and Ide C (2009) Follow-up study of the clinical trial of spinal cord injury treatment with intrathecal autologous bone marrow stromal cell transplantation:report of the first two cases. International Surgical Week ISW 2009, Adelaide, Australia

2. Maeda Y, Nakatani T, Iwase M and Saito F (2009) A report of one year follow up spinal cord injury treatment with intrathecal autologous bone marrow stromal cell transplantation. The fifth Mediterranean Emergency Medicine Congress, Valencia, Spain

3. Nakatani T, Bando H, Tsuchiya H, Shimoto M, Saito F, Tsuda M, Maeda Y, Hirakawa A, Iwase M and Murao Y (2009) Difficulties to find a hospital which accept drug overdose repeaters in metropolitan Japan. 5th Asian Conference on Emergency Medicine, Busan, South Korea

4. Nakatani T, Iwase M, Saito F, Maeda Y, Murao Y, Iiji O, Shigeoka I, Takayama N, Suzuki Y and Ide C (2009) Spinal cord regeneration trial with intrathecal autologous bone marraw stromal cell transplantation:report of the first two cases. 5th Asian Conference on Emergency Medicine, Busan, South Korea

5. Yoshika M, Komiyama Y, Hirakawa A, Nakatani T and Takahashi H (2009) A case of useful measurement of heparin-induced thrombocytopenia antibody during the disseminated intravascular coagulation. XXIInd International Symposium on Technological Innovations in Laboratory Hematology, Nevada, USA

6. 日原正勝, 小倉常敬, 楠本健司, 富野敦稔, 三家 泉, 北澤康秀（2009）超早期手術後に自家培養表皮移植を 併用した広範囲熱傷の一例. 第93回日本形成外科学会 関西支部学術集会, 西宮市

7. 中谷壽男 (2009) 日常臨床において遭遇する中毒と最 近の対処法. 第6回神鋼外科フォーラム, 神戸

8. 岩瀬正顕, 中谷壽男, 齊藤福樹, 前田裕仁, 河本圭司 （2009）蘇生後昏睡患者の脳機能予後予測における体 性感覚誘発電位の役割. 第39回日本臨床神経生理学学 会, 小倉

9. 岩瀬正顕, 平川昭彦, 波柴尉充, 中谷壽男, 河本圭司 （2009）頭部電撃症の 1 例. 第 57 回日本職業・災害医 学会, 高槻

10. 村尾佳則, 土屋洋之, 泉野浩生, 下戸 学, 平川昭彦, 中谷壽男（2009）特発性食道破裂に対する経腹的後縦 隔ドレナージ術. 第71回日本臨床外科学会, 京都

11. 板東宏樹，入澤 聡，山田妃沙子，杉本達哉，織田裕 
行, 平川昭彦, 岩瀬正顕, 村尾佳則, 中谷壽男, 木下 利彦（2009）自殺企画にて救急搬送された双極性障害 の2症例. 第8回Bipolar Disorder研究会, 東京

12. 泉野浩生, 前田裕仁, 宮崎秀行, 土屋洋之, 齊藤福樹, 藤原弘佳，平川昭彦，岩瀬正顕，村尾佳則，中谷壽男 （2009）大阪北河内地区における災害現場での心肺蘇 生 CPRの経験. 日本蘇生学会第28回大会, 佐賀

13. 沖井 裕, 赤根 敦, 河本圭司, 岩瀬正顕, 時安太久 磨, 吉村澄孝, 吉田 学 (2009) 脳波解析用ソフト ウェア（ATAMAP II for Windows）の脳死判定への応 用. 日本法医学会学術近畿地方集会, 高槻

14. 平川昭彦, 泉野浩生, 土屋洋之, 波柴尉充, 宮崎秀行, 齊藤福樹, 原 克子, 小宮山豊, 岩瀬正顕, 村尾佳則, 中谷壽男（2009）血液浄化法施行時に抢けるメシル酸 ナファモスタット後発品の使用状況. 第20回日本急性 血液浄化学会, 札幌

15. 下戸 学, 村尾佳則, 平川昭彦, 宮崎秀行, 金子一郎, 中谷壽男（2009）酸による腐食性食道炎, 胃炎から食 道, 幽門狭窄を来し手術を施行した1例. 第37回日本 救急医学会, 盛岡

16. 諌山憲司, 村尾佳則, 平川昭彦, 中谷壽男 (2009) 出 血性ショック後の高張食塩液蘇生が

CD4 +CD25+Foxp3+ 制御性 T 細胞に及ぼす影響一サイト カインとiNOSとの関連より. 第37回日本救急医学会, 盛岡

17. 諌山憲司, 平川昭彦, 村尾佳則, 中谷壽男（2009）卜 レーニングモデルを用いた救急救命士による骨䯣内 輸液ルート確保に要する時間の検討. 第37回日本救急 医学会, 盛岡

18. 岩瀬正顕, 前田裕仁, 平川昭彦, 齊藤福樹, 中谷壽男, 河本圭司 (2009) 骨折を伴う頸椎片側脱臼に対する治 療. 第37回日本救急医学会, 盛岡

19. 泉野浩生, 村尾佳則, 土屋洋之, 下戸 学, 齊藤福樹, 三好秀明，平川昭彦，中谷壽男（2009）体外式人工呼 吸器と腹臥位療法で改善した重症呼吸不全の 3 例。第 37 回日本救急医学会, 盛岡

20. 前田裕仁, 岩瀬正顕, 齊藤福樹, 中谷壽男, 平川昭彦, 藤原弘佳, 村尾佳則, 宮崎秀行, 下戸 学, 泉野浩生, 土屋洋之（2009）自家骨髄間質細胞移植による脊髄再 生治療の一年後経過. 第37回日本救急医学会, 盛岡

21. 土屋洋之, 泉野浩生, 下戸 学, 波柴尉充, 宮崎秀行, 津田雅庸, 平川昭彦, 岩瀬正顕, 村尾佳則, 中谷壽男 （2009）当センターにおける特発性食道破裂の診断と 治療に関する検討。第37回日本救急医学会, 盛岡

22. 板東宏樹, 村尾佳則, 山田妃沙子, 杉本達哉, 織田裕 行, 齊藤福樹, 平川昭彦, 中谷壽男 (2009) 当救命救 急センターにおける自殺企図患者の検討. 第37回日本 救急医学会, 盛岡

23. 齊藤福樹, 岩瀬正顕, 中谷壽男, 村尾佳則, 平川昭彦, 鈴木義久, 井出千束, 津田雅庸, 前田裕仁, 谷原正夫 （2009）細胞死抑制ペプチド添加コラーゲンを用いた
脊髄再生. 第37回日本救急医学会, 盛岡

24. 富野敦稔, 中嶋麻里, 平林篤志, 高橋弘毅, 櫻本和人, 浅井 悌, 北澤康秀 (2009) 当院におけるARDSに対 するシベレスタット $\mathrm{Na}$ の有効性の検討. 第 37 回日本 救急医学会総会・学術集会, 盛岡

25. 平林篤志, 高橋弘毅, 富野敦稔, 浅井 悌, 鈴木聡史, 北澤康秀（2009）当施設における HIT症例の検討．第 37 回日本救急医学会総会・学術集会, 盛岡

26. 櫻本和人, 高橋弘毅, 中嶋麻里, 平林篤志, 富野敦稔, 山本 透, 北澤康秀 (2009) 当施設に打ける大腸穿孔 例の検討. 第37回日本救急医学会総会・学術集会, 盛岡

27. 岩瀬正顕, 前田裕仁, 中谷壽男, 河本圭司 (2009) 頚 椎損傷に伴う椎骨動脈損傷の治療戦略 3 症例の経 験. 第68回日本脳神経外科学会学術総会, 東京

28. 諌山憲司, 平川昭彦, 村尾佳則, 中谷壽男 (2009) 救 命救急士による静脈路確保の現状と B.I.Gによる骨髄 内輸液路確保の検討. 第2 4 回日本救命医療学会, 東京 29. 板東宏樹, 杉本達哉, 山田妃沙子, 加藤正樹, 織田裕 行, 平川昭彦, 岩瀬正顕, 村尾佳則, 中谷壽男, 木下 利彦（2009）自殺企図にて救急搬送となった躁うつ病 の3例. 第 10 回 KMUリエゾン研究会, 守口

30. 隠岐光涁, 下戸 学, 前田裕仁, 安藤祐吾, 土屋洋之, 板東宏樹, 宮崎秀行, 藤原弘佳, 平川昭彦, 岩瀬正顕, 村尾佳則, 中谷壽男, 米虫 敦, 澤田 敏 (2009) 経 カテーテル的血栓溶解療法にて良好な経過を辿った 上腸間膜動脈塞栓症の一例. 第 100 回近畿救急医学研 究会, 大阪

31. 中嶋麻里, 平林篤志, 高橋弘毅, 櫻本和人, 富野敦稔, 中村知寿, 北澤康秀 (2009) 保存的加療にて軽快した 両側 flail chest の一例. 第 100 回近畿救急医学研究会, 大阪

32. 平林篤志, 富野敦稔, 高橋弘毅, 中嶋麻里, 櫻本和人, 北澤康秀 (2009) 通勤中突然CPA となり現場と病院と の見事な連携で救命し得た一例. 第 100 回近畿救急医 学研究会, 大阪

33. 小宮山豊, 平川昭彦, 下戸 学, 中谷壽男, 五十嵐裕 子, 藤原通恵, 佐藤幸枝, 吉賀正亨, 正木浩哉, 高橋 伯夫（2009）長期に抗へパリン・血小板第 4 因子抗体 (HIT抗体) を追跡しえた 1 例. 第 10 回日本検査血液学 会学術集会, 甲府

34. 中谷壽男 (2009) 外傷死を減らすための日本外傷学会 の取り組み. 湖南救急集中治療セミナー, 草津市, 滋 賀県

35. 下戸 学, 平川昭彦, 土屋洋之, 前田裕仁, 村尾佳則, 中谷壽男（2009）負荷分散バンド式自動胸郭圧迫装置 の有用性と問題点. 第 12 回日本臨床救急医学会, 大阪

36. 諌山憲司, 平川昭彦, 村尾佳則, 中谷壽男 (2009) 救 急救命士による骨髄内輸液ルート確保の必要性. 第 12 回日本臨床救急医学会, 大阪

37. 岩瀬正顕, 前田裕仁, 齊藤福樹, 平川昭彦, 中谷壽男, 河本圭司（2009）墜落による頭蓋底顔面骨骨折に伴う 
外傷性視神経症の 1 例. 第 12 回日本臨床救急医学会, 大阪

38. 板東宏樹, 村尾佳則, 杉本達哉, 織田裕行, 平川昭彦, 岩瀬正顕, 中谷壽男（2009）ICUにおけるせん妄患者 に対しデクスメデトミジンを使用した症例の報告. 第 12 回日本臨床救急医学会, 大阪

39. 前田裕仁, 岩瀬正顕, 中谷壽男, 河本圭司, 赤根 敦, 池堂太一 (2009) 頭部打撲後 12 日目に急激な意識低下 をきたし14日目に死亡した外傷性脳腫脹の一剖検例. 第23回日本神経救急学会, 栃木

40. 泉野浩生, 村尾佳則, 下戸 学, 土屋洋之, 三好秀明, 平川昭彦, 中谷壽男 (2009) APRV, 腹臥位療法と体 外式陰圧人工呼吸器が有効であった重症肺炎の 1 例. 第54回日本集中治療医学会近畿地方会, 和歌山

41. 正木浩哉, 原 克子, 小宮山豊, 菊池早苗, 山原英樹, 今田崇裕, 河野啓子, 平川昭彦, 中谷壽男 (2009) 注 射用メシル酸ナファモスタット製剤における先発医 薬品と後発医薬品の比較分析. 第54回日本透析医学会 学術集会・総会, 横浜

42. 中谷壽男 (2009) 外傷外科学の発展と日本外傷学会の 取り組み。洛友会, 京都市

43. 諌山憲司，村尾佳則，平川昭彦，中谷壽男（2009）出 血性ショック後の蘇生において高張食塩液と iNOS が cytokineの産生に及ぼす影響. 第 23 回日本外傷学会, 大阪

44. 岩瀬正顕，平川昭彦，村尾佳則，中谷壽男，河本圭司 （2009）外傷診療録の入力法・データの質の保全と効 率化についての工夫. 第23回日本外傷学会, 大阪

45. 森 雅美, 宮崎秀行, 平川昭彦, 岩瀬正顕, 村尾佳則, 中谷壽男（2009）診療情報管理士が行う日本外傷デー タバンクへの登録業務. 第23回日本外傷学会, 大阪

46. 土屋洋之, 村尾佳則, 下戸 学, 平川昭彦, 岩瀬正顕, 中谷壽男（2009）外傷性総胆管断裂，十二指腸破裂合 併の 1 例. 第 23 回日本外傷学会, 大阪

47. 土屋洋之, 齊藤福樹, 津田雅庸, 谷川暢之, 平川昭彦, 岩瀬正顕，村尾佳則，中谷壽男（2009）幼小児骨盤輪 不安定型骨折の治療経験. 第23回日本外傷学会, 大阪

48. 岩瀬正顕，前田裕仁，齊藤福樹，中谷壽男，河本圭司 （2009）骨折を伴う頸椎片側脱臼に対するインストル メンテーション手術. 第2 4 回日本脊髄外科学会, 宮崎

49. 横田順一朗，坂本哲也，中谷壽男，山本保博（2009） 外傷標準診療の off-the-job training（JATECコース）へ 学会としての参画を期待する. 第109回日本外科学会, 福岡

50. 村尾佳則, 平川昭彦, 津田雅庸, 前田裕仁, 藤原弘佳, 下戸 学, 土屋洋之, 中谷壽男 (2009) 出血性ショッ ク後免疫抑制状態における高張食塩液蘇生が $\mathrm{CD} 4+\mathrm{CD} 25+$ 制御性 $\mathrm{T}$ 細胞と $\gamma \delta \mathrm{T}$ 細胞に及ぼす影響一 iNOSとアポトーシスの関連より一. 第109回日本外科 学会, 福岡

51. 前田裕仁, 岩瀬正顕, 中谷壽男, 河本圭司, 山内康雄,
山原崇弘（2009）中脳水道狭窄と孤立性第四脳室に対 し神経内視鏡の支援下に第四脳室一脳槽シャント術 を施行した 1 例. 第 12 回関西脳神経外科臨床カンファ レンス, 大阪

52. 岩瀬正顕，前田裕仁，中谷壽男，河本圭司（2009）神 経内視鏡支援による孤立性第 4 脳室の後頭窩開頭手 術. 第18回脳神経外科と機器学会, 秋田

53. 板東宏樹, 杉本達哉, 山田妃沙子, 織田裕行, 平川昭 彦，岩瀬正顕，村尾佳則，木下利彦，中谷壽男（2009） 自殺企画にて救急搬送となった躁うつ病の 3 症例. 第 33 回日本自殺予防学会, 大阪

54. 鈴木聡史, 谷川 昇, 岸本真房, 富野敦稔, 山本 透, 北澤康秀, 小島博之, 狩谷秀治, 庄村裕三, 澤田 敏 （2009）膵局所動注療法における biapenemの有用性に ついて，第68回日本医学放射線学会総会，横浜

55. 岩瀬正顕，前田裕仁，中谷壽男，河本圭司（2009）痤 攣重責で発症した脳出血の 2 例. 第34回日本脳卒中学 会, 松山

56. 前田裕仁, 岩瀬正顕, 中谷壽男, 河本圭司, 山内康雄, 山原崇弘（2009）中脳水道狭窄と孤立性第四脳室に対 し神経内視鏡の支援下に第四脳質一脳槽シャント術 を施行した1例. 第34回日本脳卒中学会, 松江

57. 安藤祐吾 (2009) この症例をどうする？ 第45回日本 腹部救急医学会, 東京

58. 下戸 学, 平川昭彦, 土屋洋之, 津田雅庸, 村尾佳則, 中谷壽男（2009）腐食性胃・食道炎に打ける緊急内視 鏡検査の意義. 第 45 回日本腹部救急医学会, 東京

59. 中谷壽男（2009）1）脳卒中・心筋梗塞ガイドライン の試行. 医療体制に係る指針の追加. 2) アナフィラ キシー患者へのエピネフリン投与. 3) 北河内地域の 再教育の現状について. 第59回北河内救急研究会, 守 口市

60. 岸本真房, 櫻本和人, 武田純一, 小津 敏, 富野敦稔, 山本 透, 北澤康秀 (2009) 関西医科大学附属枚方病 院救命救急センター開設後 3 年間の推移と課題. 第 99 回近畿救急医学研究会, 尼崎

61. 盛 秀嗣, 前田裕仁, 安藤祐吾, 下戸 学, 土屋洋之, 板東宏樹, 宮崎秀行, 藤原弘佳, 平川昭彦, 岩瀬正顕, 村尾佳則，中谷壽男（2009）多彩な病態（慢性硬膜下 血腫, ショック, 敗血症, 急性膵炎）を呈した難治性 低カリウム血症を伴う急性腎不全の1例. 第99回近畿 救急医学研究会, 尼崎

62. 板東宏樹，村尾佳則，山田妃沙子，杉本達哉，織田裕 行, 平川昭彦，岩瀬正顕，中谷壽男 (2009) 当救命救 急センターにおける急性薬物中毒患者の検討. 第99回 近畿救急医学研究会, 尼崎

63. 富野敦稔, 岸本真房, 櫻本和人, 山本 透, 北澤康秀 （2009）鈍的腹部外傷による胃粘膜裂傷の一例．第 99 回近畿救急医学研究会, 尼崎

64. 前田裕仁, 下戸 学, 宮崎秀行, 土屋洋之, 村尾佳則, 中谷壽男, 藤野佑香, 藤田美保, 中尾博之 (2009) 北 
河内地区における災害現場コラボレーションの現状. 第14回日本集団災害医学会, 神戸

65. 板東宏樹, 津田雅庸, 村尾佳則, 岩瀬正顕, 平川昭彦, 中谷壽男（2009）著しい高カリウム血症を呈したグリ ホサート中毒の一例. 第 29 回日本中毒学会西日本部 会, 大阪

66. 平川昭彦, 下戸 学, 宮崎秀行, 小宮山豊, 村尾佳則, 中谷壽男（2009）少量へパリン投与でヘパリン起因性 血小板減少症を生じた 9 例の検討。第36回日本集中治 療医学会, 大阪

67. 岩瀬正顕, 前田裕仁, 中谷壽男, 河本圭司 (2009) 脳 神経外科救急領域における高齢者脊椎・脊髄損傷一三 次救命センターでの現状一. 第14回日本脳神経外科救 急学会, さいたま

68. 前田裕仁, 岩瀬正顕, 中谷壽男, 河本圭司 (2009) 複 数診療科の連携を要した眼窩異物杙創による頭部顔 面外傷の 1 例. 第 14 回日本脳神経外科救急学会, さい たま

著 書

1. 村尾佳則, 諌山憲司, 中谷壽男（2009）出血性ショッ クの病態, 診断と治療戦略とは? 救急・集中治療 第 21 巻 ショック管理 Q \& A（篠澤洋太郎, 岡本和文 編）937-942頁，総合医学社，東京

2. 村尾佳則, 諌山憲司, 中谷壽男 (2009) ハチアレル ギーの病態, 診断と治療戦略とは? 救急・集中治療

第 21 巻 ショック管理 $\mathrm{Q} \& \mathrm{~A}$ （篠澤洋太郎, 岡本和 文編）980-984頁, 総合医学社, 東京

3. 中谷壽男 (2009) 中毒性疾患の治療の動向. 今日の治 療指針 51 (山口 徹, 北原光夫, 福井次矢編) 109 頁, 医学書院，東京

4. 中谷壽男 (2009) メタノール中毒. 今日の治療指針 51 （山口 徹, 北原光夫, 福井次矢編） 123 頁, 医学 書院，東京
5. 中谷壽男, 嶋津岳士 (2009) 急性中毒. 今日の治療指 針 51（山口 徹, 北原光夫, 福井次矢編) 1231-1262 頁, 医学書院, 東京

6. 平川昭彦 (2009) 外傷処置 小手術手技, 皮膚解開放 創の処置. 今日の治療指針 51 (山口 徹, 北原光夫, 福井次矢編) 93-94頁, 医学書院, 東京

7. 北澤康秀, 辻佐世里, 徳山博美, 安藤有子（2009）血 液凝固関連検査データを読もう。達人ナース: 経験知 の伝授誌 特別編集号(1)，30(7)，18-36頁，日総研出 版，東京

8. 北澤康秀, 辻佐世里, 徳山博美, 安藤有子 (2009) 肝 機能関連データを読もう。達人ナース : 経験知の伝授 誌 特別編集号(1),30(7), 37-47頁, 日総研出版, 東京

9. 北澤康秀, 辻佐世里, 徳山博美, 安藤有子 (2009) 腎 機能関連データを読もう。達人ナース : 経験知の伝授 誌 特別編集号(1),30(7), 48-53頁, 日総研出版, 東京 10. 北澤康秀, 辻佐世里, 徳山博美, 安藤有子（2009）電 解質データを読もう。達人ナース：経験知の伝授誌 特別編集号(1)，30(7)，54-60頁，日総研出版，東京

11. 北澤康秀, 辻佐世里, 徳山博美, 安藤有子（2009）末 梢血検査を詳しく読もう. 達人ナース : 経験知の伝授 誌 特別編集号(1)，30(7)，7-17頁, 日総研出版, 東京

12. 末原則幸, 杉本 壽, 中谷寿男, 小倉裕司, 鍛冶有登, 松岡哲也，木村 正，荻田和秀，依岡寛和，松尾重樹， 塩田 充, 池田智明, 桂木真司 (2009) 乳幼児死亡と 妊産婦死亡の分析と提言に関する研究 周産期医療シ ステムと救命救急システムの協力体制に関する研究. 乳幼児死亡と妊産婦死亡の分析と提言に関する研究 平成 20 年度 総括・分担研究報告書 199-218頁, 厚 生労働省, 東京

13. 中谷壽男 (2009) 救急処置 : B. 静脈路の確保, C. 中 心静脈カテーテルの挿入, D. 動脈カニュレーション. 標準救急医学 4, 111-115頁, 医学書院, 東京

\section{滝井輸血部}

\section{〈研究概要〉}

術前貯血式自己血輸血.

自己血輸血は手術時の出血に対して，予め貯めておいた自分の血液を輸血する方法であり，他人の方の血液を輸血し た時にみられる副作用が回避される安全な輸血方法である. 専用ベッドと救急機器を整備した専用採血室で専任スタッ フにより自己血採血を行っている。病状などで安静が必要な患者には出張採血も実施し，また，血液感染症を保有して いる患者の自己血貯血も実施している.

整形外科よりの依頼が多いのが特徵であり，高齢化社会の到来とともに高齢者の自己血貯血が増加している，過去 3 年 間の高齢者に対する自己血貯血の調査を行った結果, 自己血輸血は安全に行われたことを確認した. 今後高齢者に対す る自己血輸血は増加するものと考えられ安全性は最重要課題であり, 症例を増やして調査していきたい.

両側人工股関節置換術は同時に疼痛を除去し歩行能力を短期間に改善しうるが, 片側例に比して合併症の増加及び同 種血輸血の増加が危惧される.片側人工股関節置換術例と両側例とを比較し合併症及び同種血輸血率を調査した。両側 例ではやや同種血輸血率が高くなったが合併症の頻度に差はなく安全に行いうる手術法であると考えられた. 


\section{〈研究業績〉}

原 著

1. Shirasugi $Y$, Ando K, Hashino S, Nagasawa T, Kurata Y, Kishimoto Y, Iwato K, Ohtsu T and Berger DP. (2009) A phase II, open-label, sequential-cohort, dose-escalation study of romiplostim in Japanese patients with chronic immune thrombocytopenic purpura. Int J Hematol 90(2): $157-165$

その他

1. 山岡 学, 大西修司, 有元美代子, 市邊明美, 阿部 操, 館農美香, 大谷哲司, 森眞一郎, 福原資郎, 海堀 昌樹 (2009) HLA 抗体保有患者の生体肝移植症例. 日 輸血細胞治療会誌 55(6): 711-716

学会発表

1. 大西修司, 山岡 学, 市邊明美, 有元美代子, 徳永裕
彦，中矢桂子，藤原通恵，小宮山豊，福原資郎（2009） ADAMTS13 活性とそのインヒビター力価測定が血漿 交換療法に有用であった血栓性血小板減少性紫斑病 の1症例. 第 57 回日本輸血 - 細胞治療学会総会, 埼玉

2. 大西修司, 山岡 学, 市邊明美, 有元美代子, 徳永裕 彦，中矢佳子，藤原通恵，小宮山豊，福原資郎 (2009) ADAMTS13 活性とそのインヒビター力価測定が血漿 交換療法に有用であった血检性血小板減少性紫斑病 の 1 症例. 第 57 回日本輸血・細胞治療学会総会, 埼玉市

3. 大西修司, 市邊明美, 山岡 学, 有元美代子, 徳永裕 彦（2009）当院の貯血式自己血輸血における高齢者採 血の現状について. 第22回日本自己血輸血学会学術総 会, 福島市

4. 徳永裕彦, 大西修司, 大谷哲司, 市邊明美, 山岡 学 （2009）両側同時セメントレス人工股関節置換術 (THA) の周術期の検討. 第 22 回日本自己血輸血学会 学術総会, 福島市

\section{枚方輸血部}

\section{〈研究業績〉}

原 著

1. Shirasugi Y, Ando K, Hashino S, Nagasawa T, Kurata Y, Kishimoto Y, Iwato K, Ohtsu T and Berger DP (2009) A phase II, open-label, sequential-cohort, dose-escalation study of romiplostim in Japanese patients with chronic immune thrombocytopenic purpura. Int J Hematol 90(2):
$157-165$

その他

1. 山岡 学, 大西修司, 有元美代子, 市邊明美, 阿部 操, 館農美香, 大谷哲司, 森眞一郎, 福原資郎, 海堀 昌樹（2009）HLA抗体保有患者の生体肝移植症例. 日 輸血細胞治療会誌５5(6): 711-716

\section{総合診療科}

\section{〈研究業績〉}

原 著

1. Mori Y, Kosaki A, Kishimoto N, Kimura T, Iida K, Fukui M, Nakajima F, Nagahara M, Urakami M, Iwasaka T and
Matsubara H (2009) Increased plasma S100A12 (ENRAGE) levels in hemodialysis patients with atherosclerosis. Am J Nephrol 29(1): 18-24

\section{健康科学センター}

\section{〈研究業績〉}

原 著

1. 田嶋佐和子, 木村 穣, 高尾奈那, 田部浩子, 中村伸 一, 坂根直樹 (2009) 携帯電話を用いた生活習慣病予 防プログラムの検討一福井県抢おい町を大阪から支 援する遠隔プログラムの試み一. 肥満と糖尿病 8 (別 冊8） : 35-43

2. 佐々木弘志, 北川佳奈, 木村 穣 (2009) マラソンの 記録を速度漸増テストの肺換気量応答から予測する. 大阪体育研 (47): 19-25
総 説

1. 木村 穣, 門井文恵 (2009) ナースのための心臓リハ ビリテーション完全ガイド 第 4 章 心蔵リハビリ テーションチームづくり AtoZ 8 関西医科大学健康科 学センター. ハートナーシング (春季増刊) : 213-222

2. 木村 穣 (2009) 生活習慣病対策 保健指導のための 認知行動療法セミナー：第7回 実践編 保健指導に よる認知行動療法の具体的手順. 臨スポーツ医 26(4): 447-451

3. 木村 穣 (2009) 生活習慣病対策 保健指導のための 認知行動療法セミナー：第6回 実践編 運動指導と 
認知行動療法. 臨スポーツ医 26(3): 353-357

4. 木村 穣 (2009) 生活習慣病対策 保健指導のための 認知行動療法セミナー：第5回 実践編 食事指導と 認知行動療法. 臨スポーツ医 26(2): 225-230

学会発表

1. 岡下さやか, 木村 穣, 堤 博美, 岩坂壽二 (2009) 心肺運動負荷試験による加圧効果の検討. 第20回日本 臨床スポーツ医学会, 神戸

2. 堤 博美, 木村 穣, 岡下さやか, 岩坂壽二 (2009) 上肢加圧トレーニングが及ぼす形態, 筋力および生理 学的効果の検討. 第 20 回日本臨床スポーツ医学会, 神 戸
3. 中山英恵, 木村 譲, 高橋伯夫, 大倉ひろ枝, 岡下さ やか, 宮内卓史, 上田加奈子, 岩坂壽二（2009）減量 時の内臓脂肪に及ぼす対組成及び運動耐容能の評価. 第30回日本肥満学会, 浜松

4. 田嶋佐和子, 福田正子, 堤 博美, 浦上昌也, 木村 穣（2009）10代若年者のインスリン抵抗性と体組成と の関係．第30回日本肥満学会，浜松

5. 福田正子, 田嶋佐和子, 堤 博美, 浦上昌也, 木村 穣（2009）若年者のインスリン抵抗性と生活習慣との 関係. 第30回日本肥満学会, 浜松

6. 中山英恵, 木村 穣, 高尾奈那, 宮内拓史, 堤 博美, 岩坂壽二 (2009) 高気圧酸素環境による脂肪燃焼効果 の検討．第23回日本体力医学会近畿地方会, 大阪

\section{医療安全管理センター}

\section{〈研究概要〉}

医療安全管理センターは，平成 18 年 10 月に開設され，附属病院の医療安全計画の策定，実施，及び評価を行うことで 医療安全を推進している. 本センターでは, 以下の研究を行っている.

1. 医療安全のための教育に関する研究

医療の高度化や複雑化が進む中で，医療安全の確保は医療機関にとって重要な課題である. 医療安全教育は医科大学 の一部門のみで行えるものではなく，すべての職種の卒前から必要なものである. 現在，われわれは，インフォームド コンセントに着目し，医学生への講義や職員教育を行い，附属病院の説明同意文書の標準化を進めている．また，卒後 も複数の診療科が行うような侵襲的手技については医療安全の観点から標準的な手技の教育が重要であることから，い くつかの検討を行っている．特に中心静脈穿刺時の超音波装置の使用については，導入時ならびに導入後も定期的な講 習会を開催することで, 穿刺時の合併症が減少したことを報告した. 今後は, 学内の各組織ならびに他の大学や病院と 協力して, 医療安全教育における医療安全管理者業務の標準化や先進的手法などの取り組みについて検討する予定であ る.

2. 医療安全のためのシステムに関する研究

「人間は間違える.」や「医療事故はヒューマンエラーよりもシステムエラーが原因であることが多い.」という視点か ら, 電子カルテや電子クリニカルパスなどを活用した医療の安全や質の向上に資するシステム構築について検討してい る. 特に, 患者のアレルギー情報については, 初診時に患者が申告した内容を電子カルテに記録し, 処方オ一ダ時に自 動的に参照できるシステムを構築することで，アレルギーに関する医療事故が減少したことを報告した。 その他，血液 製剂の患者認証システムの有用性についても報告した。 また，附属病院から報告されるインシデント報告は，年間9,000 件近くに達して抢り，これらのインシデント事例を解析することで，エラーの根本原因を断ち切るシステムについても 検討しており，その成果の一部を報告している。 さらに，大学病院だけではなく，地域の医療機関とも連携を図り，医 療安全に配慮した診療連携の構築についても検討している.

3. 医療安全のための製品開発や改良

医薬品や医療機器については，説明書や使用法が分かりにくいことや製品が人間の特性を理解した仕様になっていな いことがエラーを誘発しているとの報告がある。関西医科大学でのインシデント事例や使用者の改善意見を集約し，人 間工学やデザイン学の観点から，より良い医薬品や医療機器の開発ならびに改良について研究，提言している.

\section{〈研究業績〉}

原 著

1. 北村 臣, 石原久美子, 西村泰典, 仲野俊成, 里井壯 平，宮崎浩彰（2009）電子カルテシステムにおけるク リニカルパス管理とその運用一診療情報管理士と医
療情報技師による医師・看護師のパスへの業務負担軽 減の試み一。 日クリニカルパス会誌 11(2): 213-216

2. 里井壯平, 豊川秀吉, 柳本泰明, 道浦 拓, 井上健太 郎, 松井陽一, 中根恭司, 權 雅憲, 宮崎浩彰, 北村 臣（2009）関西医科大学附属枚方病院における消化器 
癌診療と地域連携. 日クリニカルパス会誌 11(1): 8587

学会発表

1. 北村 臣, 仲野俊成, 石原久美子, 和西晃寛, 夜野敏 明, 西野典宏, 廣田美貴子, 西村泰典, 宮嵪浩彰, 今 村洋二, 堀井俊洋 (2009) 電子クリニカルパスの現状 と課題. 第 13 回日本医療情報学会春季学術大会 (シン ポジウム2009), 長崎
2. 宮崎浩彰, 清水由紀子, 竹内聡史, 川瀬泰裕, 西本英 充, 山城博史, 前田利治, 岡崎和一（2009）中心静脈 穿刺・抜去時に使用する携帯型超音波装置の導入につ いて。 日本医療マネジメント学会, 長崎

3. 宮嶠浩彰, 清水由紀子, 川瀬泰裕, 西本英充, 山城博 史, 前田利治, 岡崎和一（2009）危険薬の誤投与防止 に関する取り組み. 日本医療マネジメント学会大阪支 部第2回学術総会, 大阪 